LA-14420-PR

Progress Report

Approved for public release;

distribution is unlimited.

\title{
Surface Water Data at Los Alamos National Laboratory
}

2009 Water Year 
Edited by Hector Hinojosa, Group IRM-CAS.

The three most recent reports in this unclassified series are LA-14328-PR, LA-14376-PR, and LA-14405-PR.

Los Alamos National Laboratory, an affirmative action/ equal opportunity employer, is operated by Los Alamos National Security, LLC, for the National Nuclear Security Administration of the U.S. Department of Energy under contract DE-AC52-06NA25396.

This report was prepared as an account of work sponsored by an agency of the U.S. Government. Neither Los Alamos National Security, LLC, the U.S. Government nor any agency thereof, nor any of their employees make any warranty, express or implied, or assume any legal liability or responsibility for the accuracy, completeness, or usefulness of any information, apparatus, product, or process disclosed, or represent that its use would not infringe privately owned rights. Reference herein to any specific commercial product, process, or service by trade name, trademark, manufacturer, or otherwise does not necessarily constitute or imply its endorsement, recommendation, or favoring by Los Alamos National Security, LLC, the U.S. Government, or any agency thereof. The views and opinions of authors expressed herein do not necessarily state or reflect those of Los Alamos National Security, LLC, the U.S. Government, or any agency thereof. Los Alamos National Laboratory strongly supports academic freedom and a researcher's right to publish; as an institution, however, the Laboratory does not endorse the viewpoint of a publication or guarantee its technical correctness. 
LA-14420-PR

Progress Report

Issued: May 2010

Surface Water Data at Los Alamos National Laboratory

2009 Water Year

David Ortiz

Betsy McCullough

Los Alamos 



\section{Contents}

Abbreviations, Acronyms, and Glossary ............................................................. viii

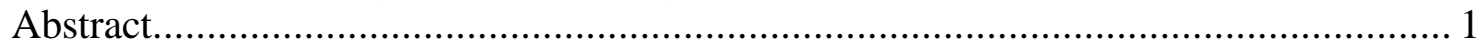

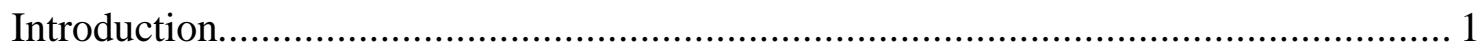

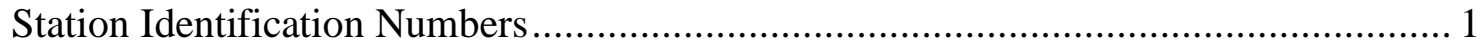

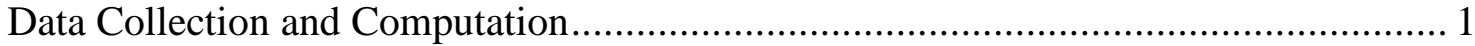

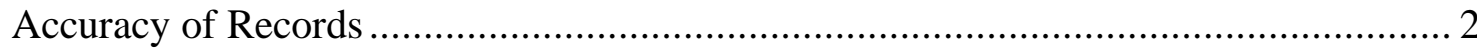

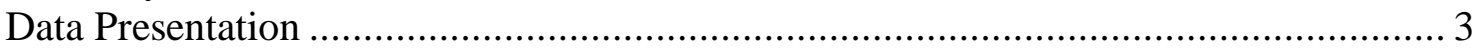

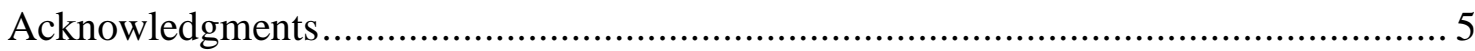

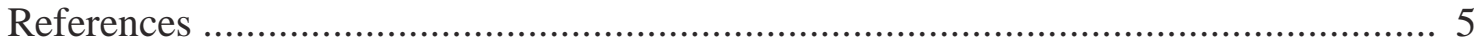

Gage Stations.................................................................................................. 7

Gage Stations at Los Alamos National Laboratory ............................................... 8

Summary of Discharges from Stream Monitoring Stations at Los Alamos

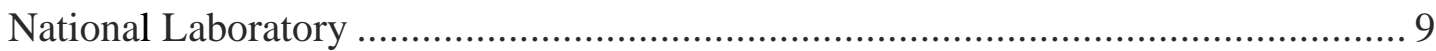

E025 Los Alamos Canyon at Los Alamos........................................................... 11

E026 Los Alamos Canyon below Ice Rink.......................................................... 14

E02685 Los Alamos Canyon at TA-2 .................................................................. 17

E030 Los Alamos Canyon above DP Canyon ....................................................... 20

E038 DP Canyon above TA-21 ........................................................................... 23

E039 DP Canyon below Meadow near TA-21 ................................................... 26

E040 DP Canyon above Los Alamos Canyon .................................................... 29

E042 Los Alamos Canyon above SR 4 _.......................................................... 32

E050 Los Alamos Canyon below Los Alamos Weir ............................................. 35

E055 Pueblo Canyon above Acid Canyon............................................................. 38

E0555 South Fork of Acid Canyon ................................................................ 41

E056 Acid Canyon above Pueblo Canyon........................................................... 44

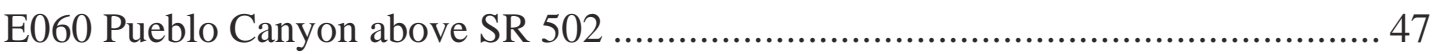

E121 Sandia Canyon Right Fork at Power Plant .............................................. 50

E1219 Sandia Canyon East of Power Plant........................................................ 53

E122 Sandia Canyon near Roads and Grounds at TA-3 .................................... 56

E1222 Sandia Canyon Tributary from Roads and Grounds ................................ 59

E1223 Sandia Canyon Tributary from Sigma Building ..................................... 62

E12235 Sandia Canyon Tributary from MRF .................................................. 65

E1225 Sandia Canyon Tributary at Heavy Equipment ...................................... 68

E123 Sandia Canyon below Wetlands ............................................................ 71 
E1234 Sandia Canyon Roads and Grounds at Sigma ………................................. 74

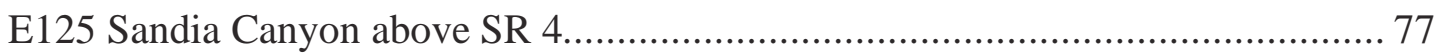

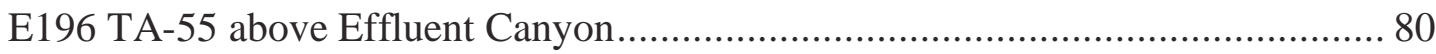

E200 Mortandad Canyon below Effluent Canyon ................................................. 83

E2005 Mortandad Canyon Tributary Batch Plant at Sigma ..................................... 86

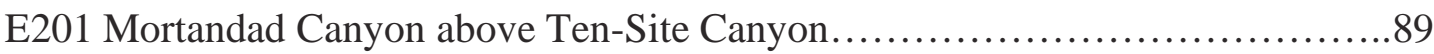

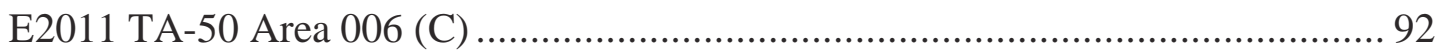

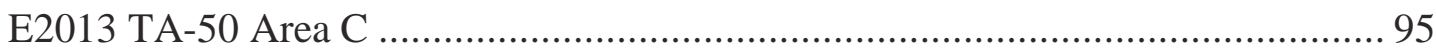

E2015 Ten-Site Canyon above Mortandad Canyon................................................. 98

E202 Mortandad Canyon above Sediment Traps ………….................................... 101

E203 Mortandad Canyon below Sediment Traps .................................................. 104

E204 Mortandad Canyon at LANL Boundary ...................................................... 107

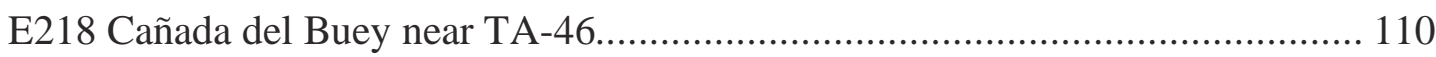

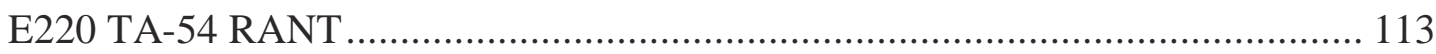

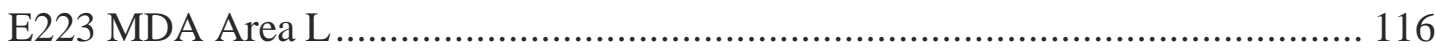

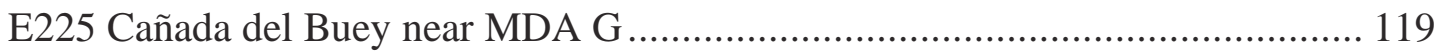

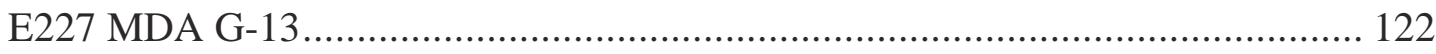

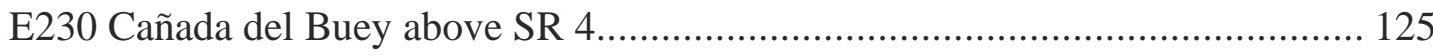

E240 Pajarito Canyon below SR 501 ............................................................. 128

E241 Pajarito Canyon above Starmer's Gulch ........................................................ 131

E242 Starmer's Gulch above Pajarito Canyon ..................................................... 134

E2425 Arroyo de la Delfe above Pajarito Canyon................................................. 137

E243 Pajarito Canyon above Two-Mile Canyon .................................................. 140

E2435 Two Mile Canyon Tributary at TA-3 ..................................................... 143

E244 Two Mile Canyon above Pajarito Canyon …………………………......... 146

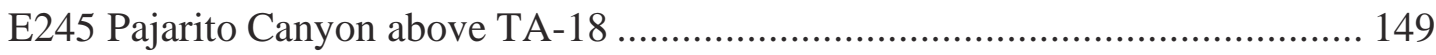

E2455 Pajarito Canyon above Three Mile Canyon................................................ 152

E246 Three Mile Canyon above Pajarito Canyon................................................ 155

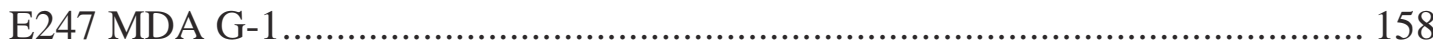

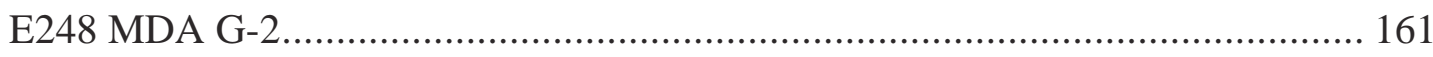

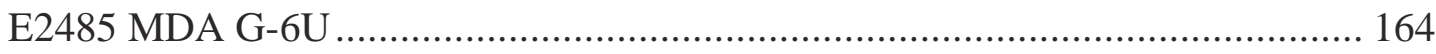

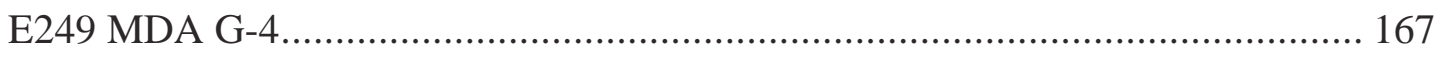

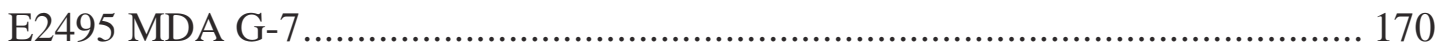

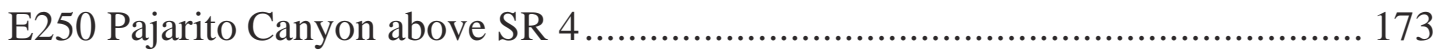




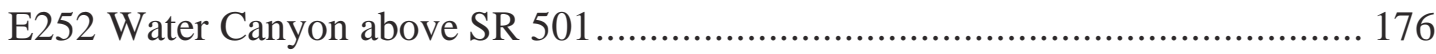

E2525 Water Canyon above S Site Canyon ..................................................... 179

E2528 S Site Canyon above Water Canyon ....................................................... 182

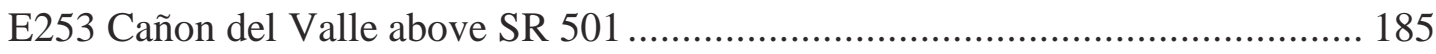

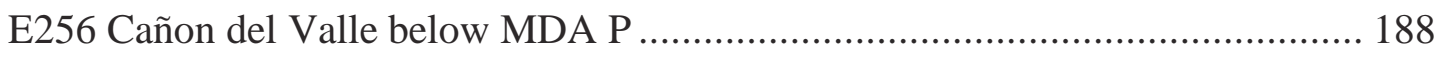

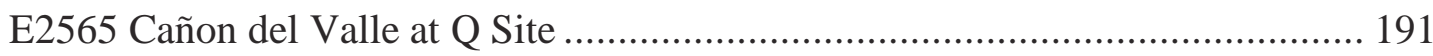

E257 Cañon del Valle Tributary at Burn Grounds.................................................. 194

E262 Cañon del Valle above Water Canyon ....................................................... 197

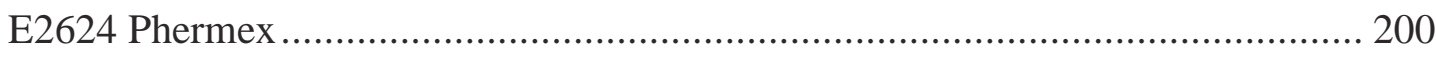

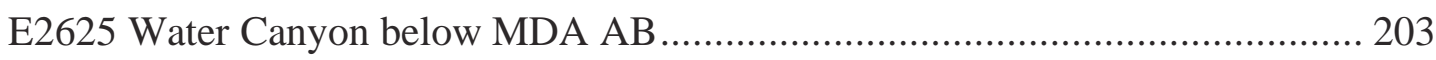

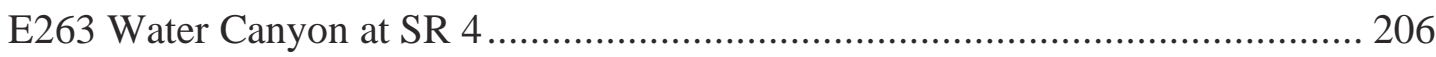

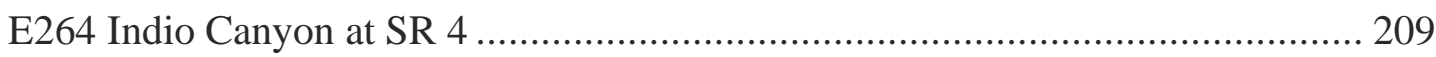

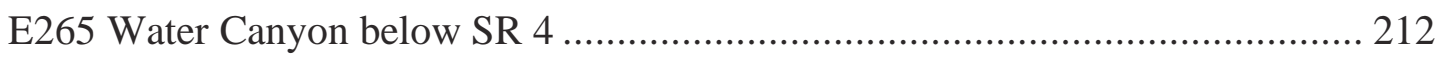

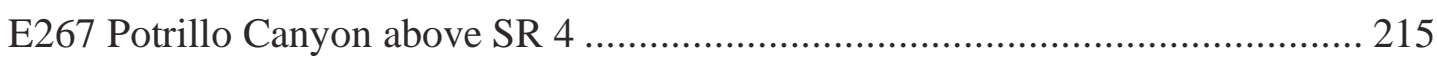

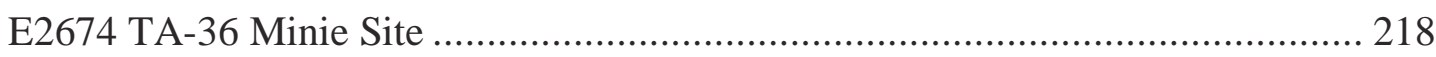

E274 North Fork Ancho Canyon below SR 4 ....................................................... 221

E275 Ancho Canyon below SR 4.................................................................... 224

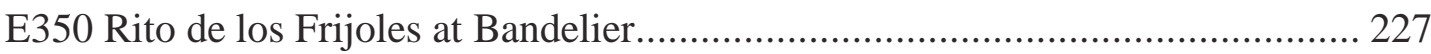

\section{Spring Stations}

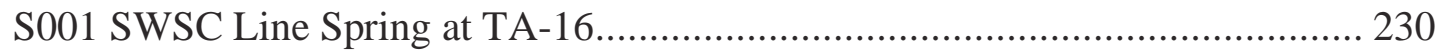

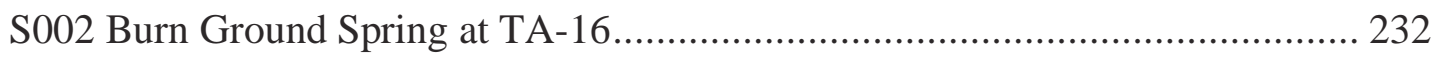

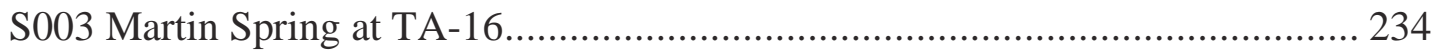

Gage Stations Omitted from this Publication ...................................................... 236

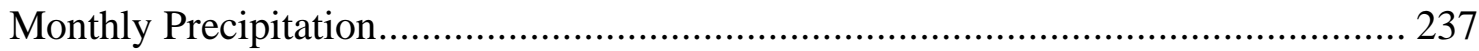




\section{Abbreviations, Acronyms, and Glossary}

Acre-foot (Ac-Ft, acre-ft) is the quantity of water required to cover 1 acre to a depth of 1 foot and is equivalent to 43,560 cubic feet, 325,851 gallons, or 1,233.49 cubic meters.

CFS-day is the volume of water represented by the flow of 1 cubic foot per second for 24 hours. It is equivalent to 86,400 cubic feet, 1.98347 acre-feet, 646,317 gallons, or 2,445 cubic meters.

Control designates a feature downstream from the gage that determines the stagedischarge relation at the gage. This feature may be a natural constriction of the channel, an artificial structure, or a uniform cross section over a long reach of the channel.

Control structure as used in this report is a structure on a stream or canal used to regulate the flow or stage of the stream or to prevent the intrusion of saltwater.

Cubic feet per second per square mile $\left[\left(\mathrm{ft}^{3} / \mathrm{s}\right) / \mathrm{mi}^{2}\right]$ is the average number of cubic feet of water flowing per second from each square mile of area drained, assuming that the runoff is distributed uniformly in time and area.

Cubic foot per second $\left(\mathrm{ft}^{3} / \mathrm{s}\right)$ is the rate of discharge representing a volume of 1 cubic foot passing a given point during 1 second; it is equivalent to 7.48 gallons per second, 448.8 gallons per minute, or 0.02832 cubic meters per second.

Discharge is the volume of water (or more broadly, the volume of fluid, including suspended sediment) that passes a given point within a given period of time.

Drainage area (DA) of a stream at a specified location is that area measured in a horizontal plane and enclosed by a topographic divide from which direct surface runoff from precipitation normally drains by gravity into the stream above the specified point. Figures of DA given herein include all closed basins, or noncontributing areas, within the area, unless otherwise noted.

Drainage basin is a part of the surface of the earth that is occupied by a drainage system, which consists of a surface stream or a body of impounded surface water together with all tributary surface streams and bodies of impounded surface water.

Gage height $(\mathrm{GH})$ is the water-surface elevation referred to in some arbitrary gage data. $\mathrm{GH}$ is often used interchangeably with the more general term "stage," although GH is more appropriate when used with a reading on a gage.

Gage station is a particular site on a stream, canal, lake, or reservoir in which systematic observations of hydrologic data are obtained. 


\section{Abbreviations, Acronyms, and Glossary (continued)}

GPS is an abbreviation for global positioning system.

HWM is an abbreviation for high-water mark.

Instantaneous discharge is the discharge at a particular instant of time.

LANL is the acronym for Los Alamos National Laboratory.

Mean discharge (MEAN) is the arithmetic mean of individual daily mean discharges during a specific period.

National Geodetic Vertical Datum of 1929 (NGVD) is a geodetic datum derived from a general adjustment of the first-order level nets of both the United States and Canada. It was formerly called Sea Level Datum of 1929, or "mean sea level," in this series of reports. Although the datum was derived from the average sea level over a period of many years at 26 tide stations along the Atlantic, Gulf of Mexico, and Pacific coasts, it does not necessarily represent the local mean sea level at any particular place.

NPDES is the abbreviation for National Pollution Discharge Elimination System.

Point of Zero Flow (PZF) is the gage height at which no flow occurs.

SR means "State Road."

Stage see Gage Height.

Stage-discharge relation is the relation between the water-surface elevation, termed "gage height," and the volume of water flowing in a channel per unit of time.

Stream flow is the discharge that occurs in a natural channel.

SWSC is an abbreviation for sanitary wastewater systems consolidation.

USGS is the abbreviation for U.S. Geological Survey.

Water year in reports dealing with surface water supply is the 12-month period, October 1 through September 30. The water year is designated by the calendar year in which it ends and which includes 9 of the 12 months. Thus, the year ending September 30, 1980, is called the "1980 water year."

WDR is an abbreviation for "Water-Data Report" in the "Revised Records" paragraph to refer to annual hydrologic-data reports.

WSP is an abbreviation for "Water-Supply Paper" in references to previously published reports. 


\title{
Surface Water Data at Los Alamos National Laboratory: 2009 Water Year
}

by

David Ortiz and Betsy McCullough

\begin{abstract}
The principal investigators collected and computed surface water discharge data from 73 stream-gage stations that cover most of Los Alamos National Laboratory and one at Bandelier National Monument. Also included are discharge data from three springstwo that flow into Cañon de Valle and one that flows into Water Canyon.
\end{abstract}

\section{Introduction}

This annual water data report from Los Alamos National Laboratory (LANL) contains flow data from 73 stream-gage stations that cover most of the Laboratory's property. Data are collected on the Laboratory's downstream boundary, which approximates New Mexico State Road (SR) 4; the upstream boundary is approximated by New Mexico SR 501. Some gage stations are within Laboratory boundaries and were originally installed to assist groups other than the Water Stewardship Programs, which also conducts site-specific earth science research.

Rainfall/precipitation data collection began at selected stations starting March 2007-July 2007 and continued to the end of the water year. Tipping-bucket rain gages measured precipitation with data recorded every five minutes.

Water chemistry data from selected storm events occurring at some stations will be published in the "Los Alamos National Laboratory Environmental Surveillance Report."

\section{Station Identification Numbers}

The U.S. Geological Survey (USGS), Water Resources Division, assigns a unique identification number to each stream-gage station it establishes. All sites numbered since 1950 are part of the downstream-order system. The downstream-order system increases station numbers in the downstream direction along main streams, and in the case of this report, their respective mouths to the Rio Grande.

This report adheres to the USGS convention of downstream order. Because of the proximity of stations in this network, the first five digits of all station numbers are 08313. We have replaced this number string with the letter $\mathrm{E}$ in the station number partly to abbreviate and also to accommodate instrumentation.

\section{Data Collection and Computation}

A complete record at a gage station gathers records of stage and discharge measurements from 
streams or canals. In addition to gathering these stage and discharge measurements, we directly observe factors affecting the stage/discharge relation, consult weather records, and use other information that supplements base data in determining daily flow. Direct readings on a nonrecording gage or from the data logger provide integrated (five-minute) records of stage. We measure discharge with current meters, using methods the USGS adapted as a result of experience accumulated since 1880. Standard textbooks describe these methods, as do WaterSupply Paper 2175 and the U.S. Geological Survey Technique of Water Resources Investigations, Book 3, Chapter A6.

We use stage/discharge relation curves to prepare rating tables that give the discharge for any stage measured at a stream-gage station. When it is necessary to define discharge extremes outside the range of current meter measurements, we extend the curves using logarithmic plotting; velocity area studies; results of indirect measurements of peak discharge, such as slope area or contracted opening measurements, and computations of flow over dams or weirs; or step backwater techniques.

Daily mean discharges are computed by applying daily mean gage height (stage) to the stage discharge curves or tables. If the stage/discharge relation is subject to change because of frequent or continual change in the physical features that form the control, the daily mean discharge is computed by the shifting-control method. In the shifting-control method, correction factors based on individual discharge measurements and notes by personnel taking the measurements are applied to the gage heights before discharges are determined from the curves or tables.

The shifting-control method is also used if the stage/discharge relation for a station is temporarily changed by the presence of aquatic growth or debris on the control. At some northern stream-gage stations, the stage/discharge relation is affected by ice in the winter, and it becomes impossible to compute discharge in the usual manner. Discharge for the period of ice effect is computed on the basis of gage height record and occasional winter discharge measurements. Consideration is given to the available information about temperature and precipitation, notes of observations, and comparable discharge records for other stations in the same or nearby basins for comparable periods of time.

For some gage stations, periods occur when no gage height record is obtained, or the recorded gage height is so faulty that it cannot be used to compute daily discharge or contents. This happens when the recorder stops or otherwise fails to operate properly, intakes are plugged, the float is frozen in the well, etc. For such periods, the daily discharges are estimated on the basis of recorded range-in-stage, prior and subsequent records, discharge measurements, weather records, and record comparisons made against other stations in the same or nearby basins. Likewise, daily contents may be estimated from operator logs, prior and subsequent records, inflow-outflow studies, and other information.

\section{Accuracy of Records}

The following two factors determine the accuracy of stream flow records:

- stability of the stage-discharge relation or, if the control is unstable, the frequency of discharge measurements and 
- accuracy of measurements or stage, accuracy of discharge measurements, and interpretations of records.

Accuracy attributed to records is noted under "Remarks."

- Excellent-95\% of daily discharges are within 5\% of the true value.

- Good-95\% of daily discharges are within $10 \%$ of the true value.

- Fair- $95 \%$ of daily discharges are within $15 \%$ of the true value.

- Poor-records do not meet the criteria mentioned.

Accuracy determination is only based on days with flow.

The number of significant figures used to report daily mean discharges is based solely on the magnitude of the discharge value:

\begin{tabular}{|l|l|}
\hline If - the value $\left(\mathrm{ft}^{3} / \mathrm{s}\right)$ is & Then-it is reported as \\
\hline less than $1 \mathrm{ft}^{3} / \mathrm{s}$ & nearest hundredth \\
\hline $1-10 \mathrm{ft}^{3} / \mathrm{s}$ & nearest tenth \\
\hline $10-1,000 \mathrm{ft}^{3} / \mathrm{s}$ & whole number \\
\hline above $1,000 \mathrm{ft}^{3} / \mathrm{s}$ & three significant figures \\
\hline
\end{tabular}

\section{Data Presentation}

The records published in this report are for each gage station and consist of three parts:

- station analysis summary,

- station manuscript description with photo, and

- data table for the water year (October 1, 2008, to September 30, 2009).

The station analysis supplements each daily values table and includes a description of monitoring equipment, problems associated with data collection during the water year, and other information used to compute stream flow discharge.

The station manuscript provides data under various headings: station location, period of record, average discharge, historical extremes, record accuracy, and other points pertinent to station operation and regulation. Each continuous record of discharge includes the following categories of descriptions:

Location. The most accurate and available maps, coupled with global positioning system (GPS) technology, provide location information. The location of the gage with respect to the vicinity's cultural and physical features is given, as well as a name that refers to place. For a few stations, the U.S. Army Corps of Engineers or the Water Resources Council (River Mileage Measurement, Bulletin 14, rev. October 1968) provided river mileage. We define left and right banks from the perspective of facing downstream.

Drainage Area. The most accurate and available maps provide drainage area measurements. The 
accuracy of drainage area measurements varies, depending on the type of map available for this purpose.

Revised Records. Because of new information, published records occasionally are found to be incorrect and revisions are printed in later reports. If a revision did not include daily, monthly, or annual figures of discharge, that fact is noted after the year as follows: (M) means that only instantaneous maximum discharge was revised; $(\mathrm{m})$ means that only the instantaneous minimum was revised; and (P) means that only the peak discharge was revised. If the drainage area has been revised, the report in which the most recently revised figure was first published is given.

Period of Record. The period of record is the time during which published records exist for a station or its equivalent station. An equivalent station is one that was in operation when the present station was not in operation and was located so that records from it can be reasonably considered equivalent to records from the present station.

Gage. This section describes the type of gage in current use. The datum of the current gage referred to in the National Geodetic Vertical Datum (NGVD) of 1929 (see Abbreviations, Acronyms, and Glossary) given under this heading are a condensed history of the types, locations, and data of previous gages.

Remarks. The text presents information relative to the accuracy of the records, special methods of computation, conditions that affect natural flow at the station, and other pertinent information.

Average Discharge. The average discharge is the average of the annual mean discharge published after five years of record. Once published, it continues as a moving average.

Extremes for Period of Record. Extremes may include maximum and minimum stages and maximum and minimum discharges or content. Unless otherwise qualified, the maximum discharge or content is the instantaneous maximum corresponding to the highest stage that occurred. The highest stage may have been obtained from a graphic or digital recorder, a crest stage gage, or by direct observation of a non-recording gage.

If the maximum stage did not occur on the same day as the maximum discharge or content, it is given separately. Similarly, the minimum is the instantaneous minimum discharge, unless otherwise qualified, and was determined and is reported in the same manner as the maximum.

Extremes Outside Period of Record. This section contains information concerning major floods or unusually low flows that occurred outside the stated period of record. The information may have been obtained from other agencies, old data files, newspapers, or local citizens.

Extremes for Current Year. Extremes given here are similar to those for the period of record. The time for occurrence of peaks is expressed in 24-h local standard time. For example, 12:30 A.M. is 0030 and 1:30 P.M. is 1330. The minimum for the current water year appears in this section.

Data Table of Daily Mean Values. The daily table of discharge records for stream-gage stations gives the mean discharge for each day of the water year. In the monthly summary for 
the table, the line headed "Total" gives the sum of the daily figures for each month; the line headed "Mean" gives the average flow in cubic feet per second for the month; and the lines headed "Max" and "Min" give the maximum and minimum daily mean discharges for each month and in acre-feet, respectively, in the line headed "Acre-Ft."

\section{Acknowledgments}

The authors thank the following individuals for their contribution to this report: R. Duran, J.L. Martinez, B. McKown, R. Romero, D. Powell (Portage, Inc.) and E. Pulliam (TPMC, Inc.).

\section{References}

Water-Supply Paper 2175 and the U.S. Geological Survey Technique of Water Resources Investigations, Book 3, Chapter A6.

U.S. Army Corps of Engineers, River Mileage Measurement, Bulletin 14, rev. October 1968.

National Geodetic Vertical Datum of 1929.

http://www.esg.montana.edu/gl/glcus.html Used to obtain legal locations.

Previous Los Alamos National Laboratory reports in this series- "Surface Water Data at Los Alamos National Laboratory" for Water Years 1995-2008:

1995: LA-13177-PR (August 1996)

1996: LA-13234-PR (November 1996)

1997: LA-13403-PR (January 1996)

1998: LA-13551-PR (February 1999)

1999: LA-13706-PR (April 2000)

2000: LA-13814-PR (July 2001)

2001: LA-13905-PR (April 2002)

2002: LA-14019-PR (March 2003)

2003: LA-14131-PR (March 2004)

2004: LA-14211-PR (April 2005)

2005: LA-14239-PR (May 2006)

2006: LA-14328-PR (August 2007) 
2007: LA-14376 (October 2008)

2008: LA-14405-PR (September 2009) 
Gage Stations 


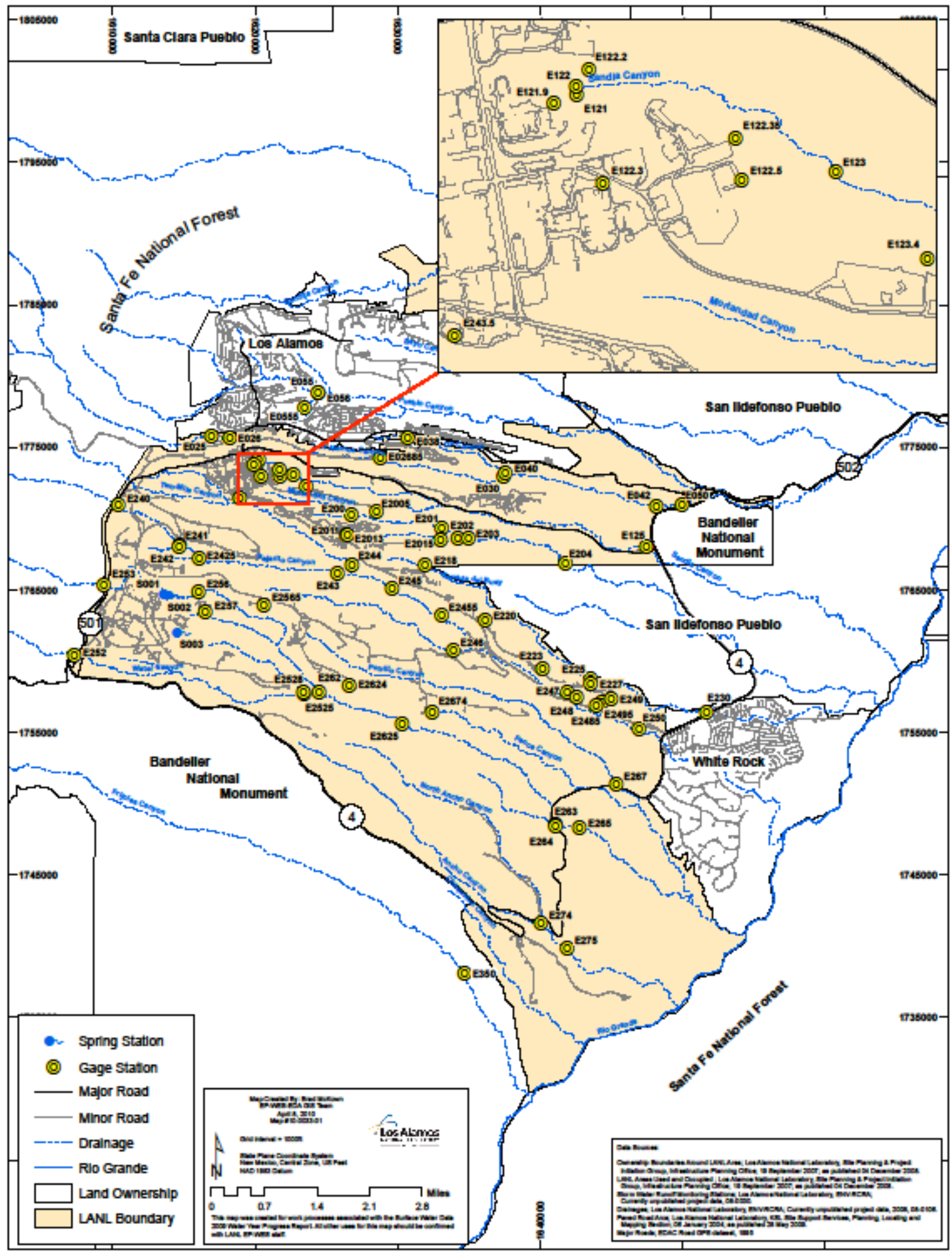




\section{Summary of Discharges from Stream Monitoring Stations at \\ Los Alamos National Laboratory \\ Water Year 2009}

October 1, 2008, to September 30, 2009

\begin{tabular}{|l|c|c|c|}
\hline Canyon Sites & $\begin{array}{c}\text { Days with Mean } \\
\text { Discharge }\end{array}$ & $\begin{array}{c}\text { Volume in } \\
\text { Acre-Ft }\end{array}$ & $\begin{array}{c}\text { Instantaneous Max } \\
\text { in ft }^{\mathbf{3}} \text { /s }\end{array}$ \\
\hline E025 Los Alamos Canyon at Los Alamos & 154 & 70 & 1.86 \\
\hline E026 Los Alamos Canyon below Ice Rink & 123 & 65 & 2.80 \\
\hline E02685 Los Alamos Canyon at TA-2 & 96 & 76 & 34 \\
\hline E030 Los Alamos Canyon above DP Canyon & 26 & 7.50 & 11 \\
\hline E038 DP Canyon above TA-21 & 71 & 107 & 202 \\
\hline E039 DP Canyon below Meadow near TA-21 & 124 & 67 & 123 \\
\hline E040 DP Canyon above Los Alamos Canyon & 36 & 57 & 153 \\
\hline E042 Los Alamos Canyon above SR 4 & 7 & 16 & 53 \\
\hline E050 Los Alamos Canyon below Los Alamos Weir & 5 & 5.30 & 34 \\
\hline E055 Pueblo Canyon above Acid Canyon & 118 & 58 & 34 \\
\hline E0555 South Fork of Acid Canyon & 36 & 3.80 & 31 \\
\hline E056 Acid Canyon above Pueblo Canyon & 153 & 21 & 263 \\
\hline E060 Pueblo Canyon above SR 502 & 155 & 37 & 4.20 \\
\hline E121 Sandia Canyon Right Fork at Power Plant & 365 & 411 & 42 \\
\hline E1219 Sandia Canyon East of Power Plant & 36 & 1.30 & 2.52 \\
\hline E122 Sandia Canyon near Roads and Grounds at TA-3 & 361 & 54 & 15 \\
\hline E1222 Sandia Canyon Tributary from Roads and Grounds & 21 & 0.91 & 1.19 \\
\hline E1223 Sandia Canyon Tributary from Sigma Building & 5 & 0.10 & 1.90 \\
\hline E12235 Sandia Canyon Tributary from MRF & 8 & 0.22 & 1.59 \\
\hline E1225 Sandia Canyon Tributary at Heavy Equipment & 37 & 2.80 & 6.00 \\
\hline E123 Sandia Canyon below Wetlands & 365 & 357 & 54 \\
\hline E1234 Sandia Canyon Roads and Grounds at Sigma & 41 & 4.10 & 2.20 \\
\hline E125 Sandia Canyon above SR 4 & 0 & 0 & 0 \\
\hline E196 TA-55 above Effluent Canyon & 6 & 0.24 & 0.77 \\
\hline E200 Mortandad Canyon below Effluent Canyon & 145 & 41 & 14 \\
\hline E2005 Mortandad Canyon Tributary Batch Plant at Sigma & 3 & 0.24 & 1.10 \\
\hline E201 Mortandad Canyon above Ten Site Canyon & 0 & 0 & 0 \\
\hline E2011 TA-50 Area 006 (C) & 45 & 2.60 & 5.00 \\
\hline E2013 TA-50 Area C & 37 & 1.60 & 7.56 \\
\hline E2015 Ten Site Canyon above Mortandad Canyon & 2 & 0.14 & 2.45 \\
\hline E202 Mortandad Canyon above Sediment Traps & 0 & 0 & 0 \\
\hline E203 Mortandad Canyon below Sediment Traps & 0 & 0 & 0 \\
\hline E204 Mortandad Canyon at LANL Boundry & 0 & 0 & 0 \\
\hline E218 Cañada del Buey near TA-46 & 0 & 0 & 0 \\
\hline E220 TA-54 RANT & 9 & 0.20 & 1.67 \\
\hline E223 MDA Area L & 3 & 0.06 & 1.28 \\
\hline E225 Cañada del Buey near MDA G & 0 & 0 & 0 \\
\hline
\end{tabular}




\section{Summary of Discharges from Stream Monitoring Stations at Los Alamos National Laboratory (continued) \\ Water Year 2009}

October 1, 2008, to September 30, 2009

\begin{tabular}{|l|c|c|c|}
\hline Canyon Sites & $\begin{array}{c}\text { Days with Mean } \\
\text { Discharge }\end{array}$ & $\begin{array}{c}\text { Volume in } \\
\text { Acre-Ft }\end{array}$ & $\begin{array}{c}\text { Instantaneous Max } \\
\text { in ft }\end{array}$ /s \\
\hline E227 MDA G-13 & 0 & 0 & 0 \\
\hline E230 Cañada del Buey above SR 4 & 4 & 1.60 & 12 \\
\hline E240 Pajarito Canyon below SR 501 & 1 & 0.10 & 8.60 \\
\hline E241 Pajarito Canyon above Starmer's Gulch & 362 & 9.2 & 2.20 \\
\hline E242 Starmer's Gulch above Pajarito Canyon & 365 & 107 & 10 \\
\hline E2425 Arroyo de la Delfe above Pajarito Canyon & 365 & 15 & 0.10 \\
\hline E243 Pajarito Canyon above Two Mile Canyon & 190 & 35 & 0.62 \\
\hline E2435 Two Mile Canyon Tributary at TA-3 & 38 & 3.90 & 7.70 \\
\hline E244 Two Mile Canyon above Pajarito Canyon & 70 & 4.70 & 4.00 \\
\hline E245 Pajarito Canyon above TA-18 & 6 & 1.30 & 2.10 \\
\hline E2455 Pajarito Canyon above Three Mile Canyon & 0 & 0 & 0 \\
\hline E246 Three Mile Canyon above Pajarito Canyon & 2 & 0.04 & 0.04 \\
\hline E247 MDA G-1 & 1 & 0.02 & 0.51 \\
\hline E248 MDA G-2 & 1 & 0.02 & 1.40 \\
\hline E2485 MDA G-6U & 4 & 0.22 & 1.40 \\
\hline E249 MDA G-4 & 0 & 0 & 0 \\
\hline E2495 MDA G-7 & 0 & 0 & 0 \\
\hline E250 Pajarito Canyon above SR 4 & 0 & 0 & 0 \\
\hline E252 Water Canyon above SR 501 & 362 & 50 & 0.21 \\
\hline E2525 Water Canyon above S Site Canyon & 219 & 44 & 0.27 \\
\hline E2528 S Site Canyon above Water Canyon & 0 & 0 & 0 \\
\hline E253 Cañon del Valle above SR 501 & 0 & 0 & 0 \\
\hline E256 Cañon del Valle below MDA P & 340 & 21 & 0.19 \\
\hline E2565 Cañon del Valle at Q Site & 25 & 0.67 & 0.87 \\
\hline E257 Cañon del Valle Tributary at TA-16 Burn Grounds & 10 & 0.30 & 0.71 \\
\hline E262 Cañon del Valle above Water Canyon & 0 & 0 & 0 \\
\hline E2624 Phermex & 33 & 1.6 & 0.71 \\
\hline E2625 Water Canyon below MDA AB & 1 & 0.08 & 2.70 \\
\hline E263 Water Canyon at SR 4 & 0 & 0 & 0 \\
\hline E264 Indio Canyon at SR 4 & 4 & 0.08 & 0.01 \\
\hline E265 Water Canyon below SR 4 & 0 & 0 & 0.16 \\
\hline E267 Potrillo Canyon above SR 4 & 3 & 0 & 0.03 \\
\hline E2674 TA-36 Minie Site & 3 & 0.06 & 0.53 \\
\hline E274 North Fork Ancho Canyon below SR 4 & 365 & 5706 & 0.30 \\
\hline E275 Ancho Canyon below SR 4 & & 17 & 414 \\
\hline E350 Rito de los Frijoles at Bandelier & 0 & 5.0 \\
\hline
\end{tabular}




\section{E025 Los Alamos Canyon at Los Alamos}

Location. Lat $35^{\circ}$ 52' 50", long $106^{\circ} 19^{\prime} 45^{\prime \prime}$, NW 1/4, Sec. 17, T. 19 N., R. 6 E., Los Alamos County.

Drainage Area. $6.92 \mathrm{mi}^{2}$.

Period of Record. October 1, 1993, to September 30, 2001; October 2001 to September 2006 (fragmentary). October 1, 2006, to September 30, 2009.

Revised Record. Drainage Area (2007).

Gage. Data logger and 24" Parshall flume. Elevation of gage is 7,237 ft above NGVD.

Remarks. Records are good. Flow is partially regulated by Los Alamos Reservoir about 1.52 mi upstream.

Extremes for Period of Record. Maximum discharge, $185 \mathrm{ft}^{3} / \mathrm{s}$, August 9, 2001, gage height not determined. No flow at times.

Extremes for Current Water Year. Maximum discharge $1.86 \mathrm{ft}^{3} / \mathrm{s}$ at $1015 \mathrm{~h}$, June 11, gage height $0.39 \mathrm{ft}$. No peak above base of $5.0 \mathrm{ft}^{3} / \mathrm{s}$. No flow at times.

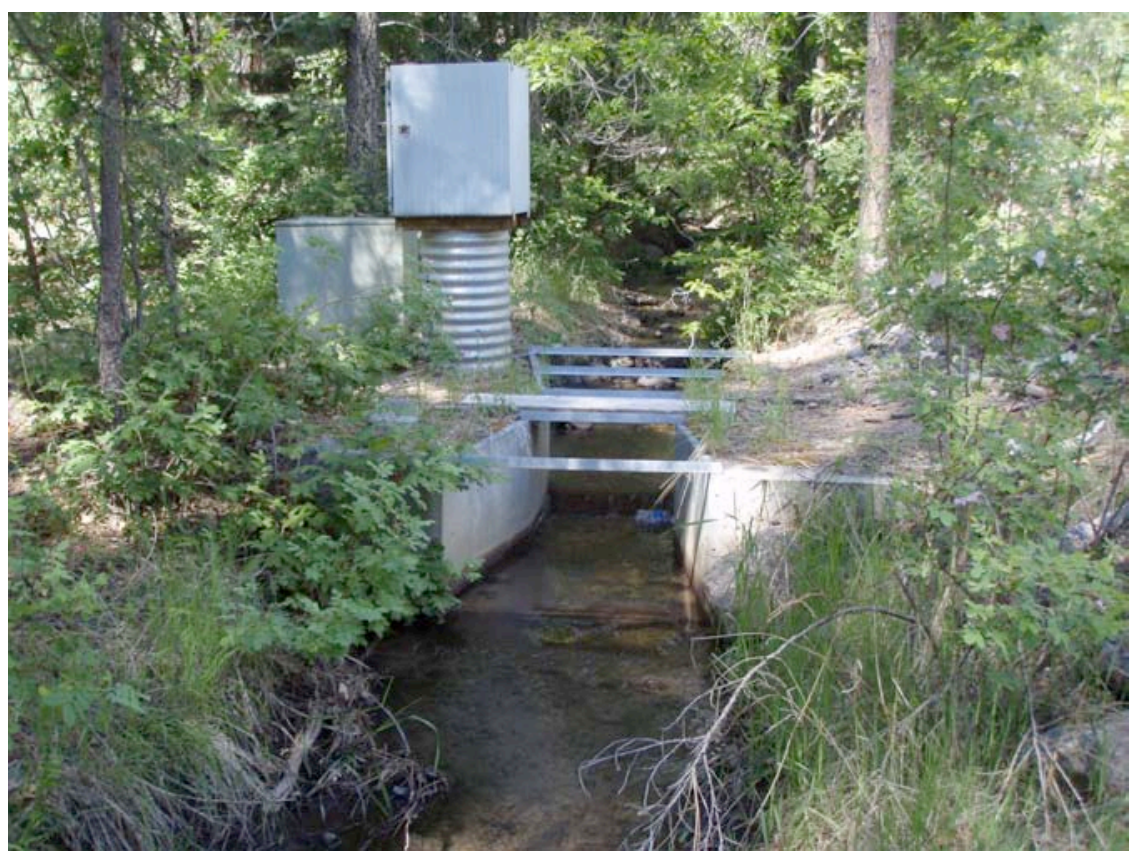




\section{E025 Los Alamos Canyon at Los Alamos}

\section{Station Analysis}

\section{Water Year}

Equipment. Station is equipped with Sutron 8200 data logger (5-min. interval) with a shaft encoder float system. The system is powered by a solar panel battery system housed in a National Electric Manufacturing Association (NEMA) shelter on top of a 18" Corrugated Metal Pipe (CMP) well attached to a 24" Parshall flume on right bank. No provision for measurement above wading stage.

Field Work. The station was visited 18 times to conduct discharge measurements and service the instrumentation. Field inspections for the gage are listed under site history files on the Hydstra database. Discharge measurements for the gage are listed under site gauging files on the Hydstra database.

Datum Correction. None from levels.

Gage-Height Record. The data logger referenced to the outside staff gave a complete and satisfactory record, except during the period from April 1-23 when float was raised during the winter months.

Rating. The low-flow control is a 24" Parshall flume. The medium- to high-flow control becomes the channel. Channel is straight for $100^{\prime}$ above and below gage and is subject to overflow at very high stages. The streambed is gravel and cobbles with grass covering over banks.

One discharge measurement (No. 16) and 18 inspections were made during the year.

Rating No. 1 was developed based on the computation of 24" Parshall flume. Point of zero flow is 0.00 gage height.

Discharge. Discharge was computed by applying Rating No. 1 directly. Estimated discharges were based on precipitation and referenced to E026.

Flow is somewhat controlled by Los Alamos Reservoir about 1 River mi upstream of gage.

Remarks. Records are good.

Peak flow since the Cerro Grande fire has been too high to record at gage. Station E026 has been established $0.1 \mathrm{mi}$ downstream for high flow. E025 will functionally be operated as a low- to medium-flow partial record station. 


\section{E025 Los Alamos Canyon at Los Alamos}

Daily Mean Discharge in Cubic Feet per Second

Water Year October 2008 to September 2009

\begin{tabular}{|c|c|c|c|c|c|c|c|c|c|c|c|c|}
\hline DAY & OCT & NOV & DEC & JAN & FEB & MAR & APR & MAY & JUN & JUL & AUG & SEP \\
\hline 1 & 0 & 0 & 0 & 0 & 0 & 0 & $0^{*}$ & .84 & .32 & .18 & .07 & .08 \\
\hline 2 & 0 & 0 & 0 & 0 & 0 & 0 & $0^{*}$ & .86 & .27 & .18 & .05 & .07 \\
\hline 3 & 0 & 0 & 0 & 0 & 0 & 0 & $0^{*}$ & .82 & .31 & .18 & .03 & .05 \\
\hline 4 & 0 & 0 & 0 & 0 & 0 & 0 & $0^{*}$ & .75 & .27 & .17 & .01 & .03 \\
\hline 5 & 0 & 0 & 0 & 0 & 0 & 0 & $0^{*}$ & .68 & .26 & .21 & 0 & .02 \\
\hline 6 & 0 & 0 & 0 & 0 & 0 & 0 & $0^{*}$ & .64 & .25 & .23 & 0 & 0 \\
\hline 7 & 0 & 0 & 0 & 0 & 0 & 0 & $0^{*}$ & .61 & .22 & .17 & 0 & 0 \\
\hline 8 & 0 & 0 & 0 & 0 & 0 & 0 & $0^{*}$ & .54 & .23 & .14 & 0 & 0 \\
\hline 9 & 0 & 0 & 0 & 0 & 0 & 0 & $0^{*}$ & .53 & .22 & .12 & 0 & 0 \\
\hline 10 & 0 & 0 & 0 & 0 & 0 & 0 & $0^{*}$ & .49 & .29 & .10 & 0 & 0 \\
\hline 11 & .04 & 0 & 0 & 0 & 0 & 0 & $0^{*}$ & .45 & .77 & .09 & 0 & 0 \\
\hline 12 & .06 & 0 & 0 & 0 & 0 & 0 & $0^{*}$ & .38 & .36 & .07 & .02 & 0 \\
\hline 13 & .04 & 0 & 0 & 0 & 0 & 0 & $0^{*}$ & .32 & .23 & .05 & .09 & 0 \\
\hline 14 & .02 & 0 & 0 & 0 & 0 & 0 & $0^{*}$ & .28 & .26 & .03 & .09 & 0 \\
\hline 15 & .01 & 0 & 0 & 0 & 0 & 0 & $0^{*}$ & .26 & .24 & 0 & .09 & 0 \\
\hline 16 & 0 & 0 & 0 & 0 & 0 & 0 & $0^{*}$ & .24 & .22 & 0 & .07 & .09 \\
\hline 17 & 0 & 0 & 0 & 0 & 0 & 0 & $.10^{*}$ & .19 & .19 & 0 & .05 & .09 \\
\hline 18 & 0 & 0 & 0 & 0 & 0 & 0 & $.15^{\star}$ & .19 & .19 & 0 & .02 & .07 \\
\hline 19 & 0 & 0 & 0 & 0 & 0 & 0 & $.40^{\star}$ & .19 & .18 & 0 & 0 & .05 \\
\hline 20 & 0 & 0 & 0 & 0 & 0 & 0 & .83 & .16 & .26 & .04 & 0 & .05 \\
\hline 21 & 0 & 0 & 0 & 0 & 0 & 0 & .89 & .16 & .20 & .09 & 0 & .03 \\
\hline 22 & 0 & 0 & 0 & 0 & 0 & 0 & .94 & .18 & .18 & .09 & 0 & .01 \\
\hline 23 & 0 & 0 & 0 & 0 & 0 & 0 & .97 & .28 & .18 & .07 & 0 & 0 \\
\hline 24 & 0 & 0 & 0 & 0 & 0 & 0 & 1.0 & .26 & .18 & .05 & 0 & 0 \\
\hline 25 & 0 & 0 & 0 & 0 & 0 & 0 & 1.1 & .20 & .18 & .04 & 0 & 0 \\
\hline 26 & 0 & 0 & 0 & 0 & 0 & 0 & 1.1 & .18 & .19 & .06 & 0 & 0 \\
\hline 27 & 0 & 0 & 0 & 0 & 0 & 0 & 1.1 & .21 & .18 & .09 & 0 & 0 \\
\hline 28 & 0 & 0 & 0 & 0 & 0 & 0 & 1.1 & .27 & .18 & .08 & 0 & 0 \\
\hline 29 & 0 & 0 & 0 & 0 & ---- & 0 & .97 & .28 & .18 & .10 & 0 & 0 \\
\hline 30 & 0 & 0 & 0 & 0 & ---- & 0 & .85 & .32 & .18 & .11 & .04 & 0 \\
\hline 31 & 0 & --- & 0 & 0 & ---- & $0^{*}$ & ---- & .33 & ----- & .09 & .09 & ---- \\
\hline Total & 0.17 & 0 & 0 & 0 & 0 & 0 & 11.50 & 12.09 & 7.37 & 2.83 & 0.72 & 0.64 \\
\hline Mean & .006 & 0 & 0 & 0 & 0 & 0 & .38 & .39 & .25 & .091 & .023 & .021 \\
\hline Max & .06 & 0 & 0 & 0 & 0 & 0 & 1.1 & .86 & .77 & .23 & .09 & .09 \\
\hline Min & 0 & 0 & 0 & 0 & 0 & 0 & 0 & .16 & .18 & 0 & 0 & 0 \\
\hline Acre-Ft & .34 & 0 & 0 & 0 & 0 & 0 & 23 & 24 & 15 & 5.6 & 1.4 & 1.3 \\
\hline Wtr Year & 2009 & Total & 35.32 & Mean & & & Max & 1.1 & Min & 0 & Acre-Ft & 70 \\
\hline Cal Year & 2008 & Total & 130.84 & Mean & & 36 & Max & 2.8 & Min & 0 & Acre-Ft & 260 \\
\hline
\end{tabular}




\section{E026 Los Alamos Canyon below Ice Rink}

Location. Lat $35^{\circ} 52^{\prime} 49^{\prime \prime}$ long $106^{\circ} 19^{\prime} 30^{\prime \prime}$, NE 1/4, Sec. 17, T. 19 N., R. 6 E., Los Alamos County.

Drainage Area. $7.07 \mathrm{mi}^{2}$.

Period of Record. February 26, 2001, to September 30, 2009.

Revised Record. Drainage Area (2006); Section (2007).

Average Discharge. $8 \mathrm{yr}, 0.35 \mathrm{ft}^{3} / \mathrm{s}, 250$ acre- $\mathrm{ft} / \mathrm{yr}$.

Gage. Data logger with cellular telemetry. Elevation of gage is 7,183 ft above NGVD.

Remarks. Records are good, except estimated daily discharges, which are fair. Flow partially regulated by Los Alamos Reservoir about $1.55 \mathrm{mi}$ upstream.

Extremes for Period of Record. Maximum discharge, $185 \mathrm{ft}^{3} / \mathrm{s}$, August 9, 2001, gage height $1.52 \mathrm{ft}$. No flow at times.

Extremes for Current Water Year. Maximum discharge, $2.8 \mathrm{ft}^{3} / \mathrm{s}$ at $1030 \mathrm{~h}$, June 11, gage height $0.48 \mathrm{ft}$. No peak above base of $15 \mathrm{ft}^{3} / \mathrm{s}$. No flow at times.

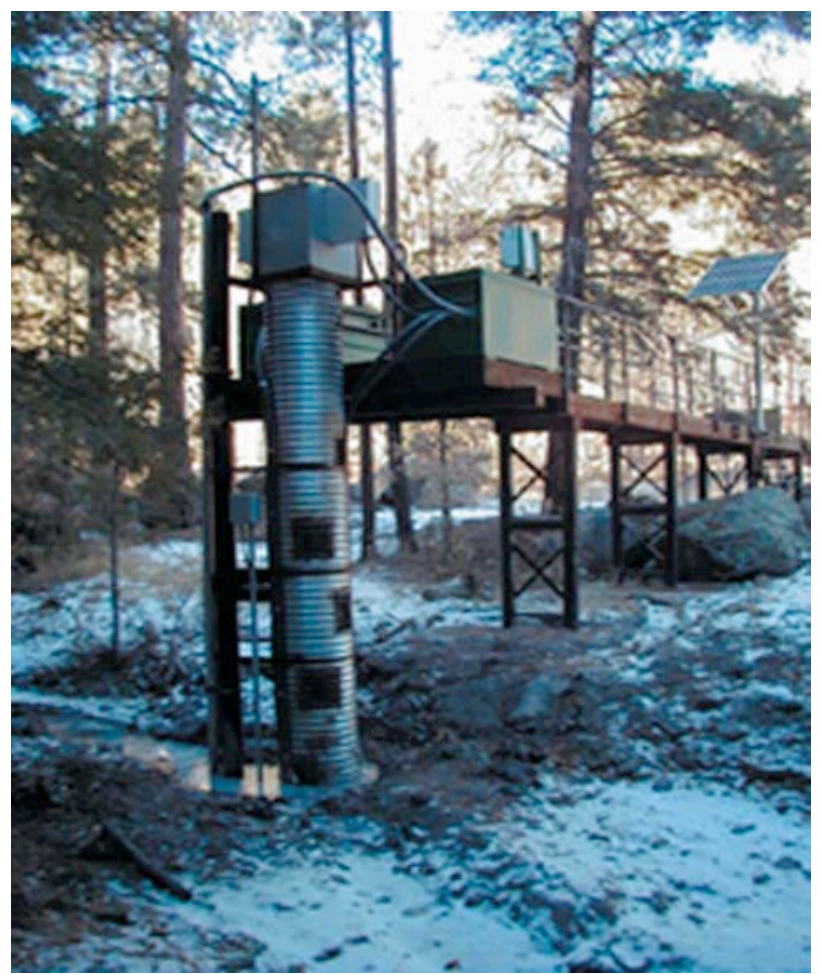




\title{
E026 Los Alamos Canyon below Ice Rink
}

\author{
Station Analysis
}

2009 Water Year

Equipment. Station is equipped with Sutron 8210 data logger (5-min. interval) and shaft encoder float system with cellular phone. The system is powered by a solar panel battery system housed in a NEMA shelter on top of a 24" CMP well. Station is equipped with ISCO samplers for water quality sample collection. ISCO samplers are housed in a separate $3^{\prime} \times 4^{\prime}$ metal box. Samplers are triggered by stage through the data logger. An outside staff is available for reference. No provision for measurement above wading stage. All high-flow measurement will be by slope-area or critical depth computation methods.

Field Work. The station was visited 38 times to conduct discharge measurements and service the instrumentation. Field inspections for the gage are listed under site history files on the Hydstra database. Discharge measurements for the gage are listed under site gauging files on the Hydstra database.

Datum Correction. Levels run November 21, 2001, found gage to be within limits.

Gage-Height Record. The data logger referenced to the inside staff gave a complete and satisfactory record, except for the period from July 6 to September 21 due to data logger malfunction.

Rating. The channel at the gage is about $20^{\prime}$ wide and straight for $20^{\prime}$ upstream where it bends to the left and then straight for about $150^{\prime}$ downstream. The streambed through this reach is primary gravel with cobbles. Low-flow control is rock and gravel riffle 15' downstream from gage. Channel is control for medium and high stages. The build-up and scour of this control leads to changes of shifts during the water year.

Six discharge measurements (Nos. 69-74) and 38 inspections were made during the year.

Rating No. 3 was developed based on measurements made during the period of record.

Flow is partially regulated by Los Alamos Reservoir about $1.5 \mathrm{mi}$ upstream of gage and draining of this reservoir. Gage of reference at this station is the inside reference point (RP measure). Fall exists at all low- to medium-flow regimes between staff and well.

Discharge. Discharges were computed from Rating No. 3 using variable shifts. Estimated discharges were based on precipitation and referenced to E025.

Remarks. Records are good, except for estimated daily discharges, which are fair. 


\section{E026 Los Alamos Canyon below Ice Rink}

Daily Mean Discharge in Cubic Feet per Second

Water Year October 2008 to September 2009

\begin{tabular}{|c|c|c|c|c|c|c|c|c|c|c|c|c|}
\hline DAY & ОСт & NOV & DEC & JAN & FEB & MAR & APR & MAY & JUN & JUL & AUG & SEP \\
\hline 1 & 0 & 0 & 0 & 0 & 0 & 0 & 0 & .80 & .39 & .06 & $.06^{*}$ & $.08^{*}$ \\
\hline 2 & 0 & 0 & 0 & 0 & 0 & 0 & 0 & .88 & .46 & .04 & $.04^{*}$ & $.06^{*}$ \\
\hline 3 & 0 & 0 & 0 & 0 & 0 & 0 & 0 & .88 & .68 & .05 & $.02^{\star}$ & $.03^{*}$ \\
\hline 4 & 0 & 0 & 0 & 0 & 0 & 0 & 0 & .84 & .59 & .03 & $0^{*}$ & $.01^{*}$ \\
\hline 5 & 0 & 0 & 0 & 0 & 0 & 0 & 0 & .77 & .52 & .12 & $0^{*}$ & $0^{*}$ \\
\hline 6 & 0 & 0 & 0 & 0 & 0 & 0 & 0 & .74 & .44 & $.09^{*}$ & $0^{*}$ & $0^{*}$ \\
\hline 7 & 0 & 0 & 0 & 0 & 0 & 0 & 0 & .72 & .36 & $.07^{*}$ & $0^{*}$ & $0^{*}$ \\
\hline 8 & 0 & 0 & 0 & 0 & 0 & 0 & 0 & .64 & .38 & $.05^{*}$ & $0^{*}$ & $0^{*}$ \\
\hline 9 & 0 & 0 & 0 & 0 & 0 & 0 & 0 & .62 & .32 & $.04^{*}$ & $0^{*}$ & $0^{*}$ \\
\hline 10 & 0 & 0 & 0 & 0 & 0 & 0 & 0 & .63 & .57 & $.02^{*}$ & $0^{*}$ & $0^{*}$ \\
\hline 11 & 0 & 0 & 0 & 0 & 0 & 0 & 0 & .48 & 1.3 & $.01^{*}$ & $.01^{*}$ & $0^{*}$ \\
\hline 12 & 0 & 0 & 0 & 0 & 0 & 0 & 0 & .36 & .73 & $0^{*}$ & $.07^{\star}$ & $0^{*}$ \\
\hline 13 & 0 & 0 & 0 & 0 & 0 & 0 & 0 & .22 & .32 & $0^{*}$ & $.05^{\star}$ & $0^{*}$ \\
\hline 14 & 0 & 0 & 0 & 0 & 0 & 0 & 0 & .15 & .32 & $0^{*}$ & $.06^{*}$ & $0^{*}$ \\
\hline 15 & 0 & 0 & 0 & 0 & 0 & 0 & 0 & .14 & .28 & $0^{*}$ & $.05^{\star}$ & $0^{*}$ \\
\hline 16 & 0 & 0 & 0 & 0 & 0 & 0 & 0 & .09 & .20 & $0^{*}$ & $.04^{*}$ & $.08^{*}$ \\
\hline 17 & 0 & 0 & 0 & 0 & 0 & 0 & .01 & .07 & .12 & $0^{*}$ & $.01^{*}$ & $.07^{*}$ \\
\hline 18 & 0 & 0 & 0 & 0 & 0 & 0 & .07 & .06 & .10 & $0^{*}$ & $0^{*}$ & $.06^{*}$ \\
\hline 19 & 0 & 0 & 0 & 0 & 0 & 0 & .30 & .05 & .08 & $0^{*}$ & $0^{*}$ & $.04^{*}$ \\
\hline 20 & 0 & 0 & 0 & 0 & 0 & 0 & .72 & .02 & .47 & $.03^{*}$ & $0^{*}$ & $.03^{*}$ \\
\hline 21 & 0 & 0 & 0 & 0 & 0 & 0 & .64 & .03 & .21 & $.05^{\star}$ & $0^{*}$ & $.02^{*}$ \\
\hline 22 & 0 & 0 & 0 & 0 & 0 & 0 & .66 & .05 & .09 & $.06^{*}$ & $0^{*}$ & $.01^{*}$ \\
\hline 23 & 0 & 0 & 0 & 0 & 0 & 0 & .78 & .29 & .09 & $.05^{\star}$ & $0^{*}$ & 0 \\
\hline 24 & 0 & 0 & 0 & 0 & 0 & 0 & .92 & .21 & .08 & $.04^{*}$ & $0^{*}$ & .04 \\
\hline 25 & 0 & 0 & 0 & 0 & 0 & 0 & .99 & .09 & .09 & $.03^{*}$ & $0^{*}$ & .01 \\
\hline 26 & 0 & 0 & 0 & 0 & 0 & 0 & .99 & .05 & .14 & $.05^{*}$ & $0^{*}$ & 0 \\
\hline 27 & 0 & 0 & 0 & 0 & 0 & 0 & .96 & .10 & .12 & $.08^{*}$ & $0^{*}$ & 0 \\
\hline 28 & 0 & 0 & 0 & 0 & 0 & 0 & .91 & .20 & .13 & $.07^{\star}$ & $0^{*}$ & 0 \\
\hline 29 & 0 & 0 & 0 & 0 & ----- & 0 & .86 & .18 & .11 & $.09^{*}$ & $0^{*}$ & 0 \\
\hline 30 & 0 & 0 & 0 & 0 & --.-- & 0 & .77 & .31 & .09 & $.10^{*}$ & $.03^{*}$ & 0 \\
\hline 31 & 0 & --.- & 0 & 0 & ----- & 0 & ----- & .33 & --.-- & $.08^{*}$ & $.08^{*}$ & ---- \\
\hline Total & 0 & 0 & 0 & 0 & 0 & 0 & 9.58 & 11.00 & 9.78 & 1.31 & 0.52 & 0.54 \\
\hline Mean & 0 & 0 & 0 & 0 & 0 & 0 & .32 & .35 & .33 & .042 & .017 & .018 \\
\hline Max & 0 & 0 & 0 & 0 & 0 & 0 & .99 & .88 & 1.3 & .12 & .08 & .08 \\
\hline Min & 0 & 0 & 0 & 0 & 0 & 0 & 0 & .02 & .08 & 0 & 0 & 0 \\
\hline Acre-Ft & 0 & 0 & 0 & 0 & 0 & 0 & 19 & 22 & 19 & 2.6 & 1.0 & 1.1 \\
\hline Wtr Year & 2009 & Total & 32.73 & Mean & & 90 & $\operatorname{lax}$ & 1.3 & Min & 0 & Acre- $\mathrm{Ft}$ & 65 \\
\hline Cal Year & 2008 & Total & 126.17 & Mean & & 34 & $\operatorname{lax}$ & 2.6 & Min & 0 & Acre-Ft & 250 \\
\hline
\end{tabular}




\section{E02685 Los Alamos Canyon at TA-2}

Location. Lat $35^{\circ}$ 52' 34", long $106^{\circ}$ 17' 21", SE 1/4, Sec. 15, T. 19 N., R. 6 E., Los Alamos County

Drainage Area. $7.97 \mathrm{mi}^{2}$.

Period of Record. March 8, 2006, to September 30, 2009.

Gage. Data logger. Elevation of gage is $6,853 \mathrm{ft}$ above NGVD.

Remarks. Water discharge records are good. Flow partially regulated by Los Alamos Reservoir about $3.0 \mathrm{mi}$ upstream.

Extremes for Period of Record. Maximum discharge $52 \mathrm{ft}^{3} / \mathrm{s}$, September 6, 2007, gage height $1.94 \mathrm{ft}$. No flow most of the time.

Extremes for Current Water Year. Peak discharges above base of $15 \mathrm{ft}^{3} / \mathrm{s}$ and $\operatorname{maximum}(*)$ :

\begin{tabular}{|c|c|c|c|}
\hline Date & Time & Discharge $\left(\mathbf{f t}^{\mathbf{3}} / \mathbf{s}\right)$ & Gage Height $(\mathbf{f t})$ \\
\hline July 5 & 1255 & 24 & 1.53 \\
\hline July 6 & 1300 & $34^{*}$ & $1.75^{*}$ \\
\hline
\end{tabular}

No flow at times.

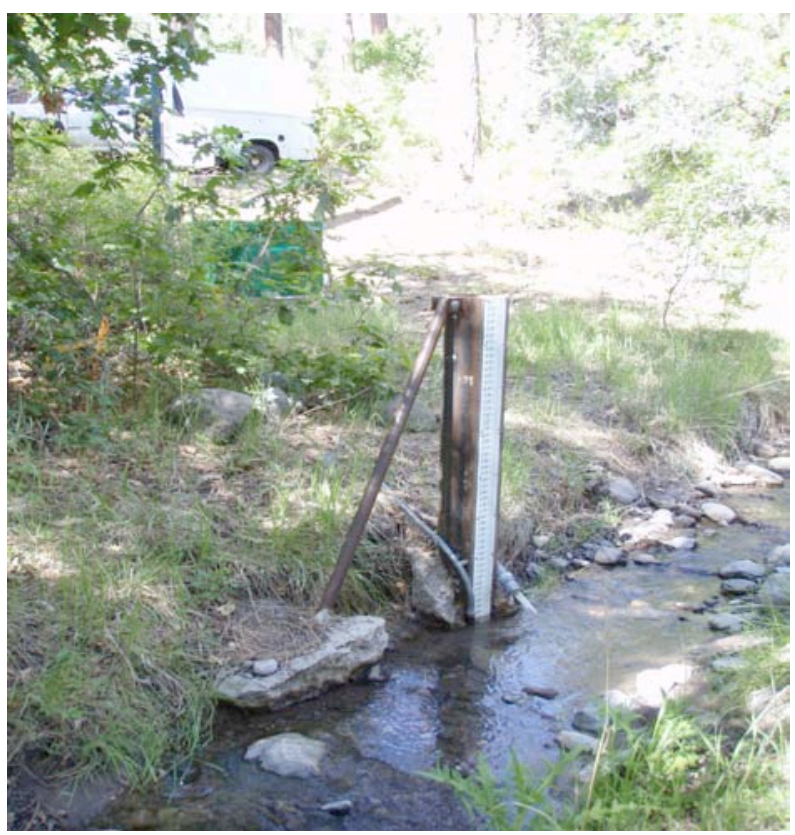




\section{E02685 Los Alamos Canyon at TA-2}

\section{Station Analysis}

\section{Water Year}

Equipment. Station is equipped with Sutron 8210 data logger (5-min. interval) with a Sutron Accubar bubble sensor. System is powered by a solar panel battery system housed in a NEMA shelter. Station is equipped with an ISCO pump sampler for water quality sample collection. ISCO is housed in a separate shelter, a $3^{\prime} \times 4^{\prime}$ metal box. Sampler is triggered by stage through the data logger. An outside staff is available for reference. No provision for direct measurement above wading stage.

Field Work. The station was visited 21 times to conduct discharge measurements and service the instrumentation. Field inspections for the gage are listed under site history files on the Hydstra database. Discharge measurements for the gage are listed under site gauging files on the Hydstra database.

Datum Correction. Levels of March 30, 2006, found gage within limits, no correction needed.

Gage-Height Record. The data logger referenced to the outside staff gave a complete and satisfactory record, except during the period from February 5-8 and February 21, 22 when gage height was affected by ice.

Rating. The channel is straight for 100' upstream and downstream. Bed is large gravel and well armored and should not be subject to much movement. Channel is trapezoidal with some vegetation. Flow is regulated somewhat by Los Alamos Reservoir about 3.0 mi upstream.

Eleven discharge measurements (Nos. 34-44) and 21 inspections were made during the year.

Rating No. 2 was used for part of the year. Rating No. 4 was developed based on measurements made during the year. Shifts are small and variable. Flows are very flashy, less than an hour, so mean daily discharges are very small in relation to the instantaneous peak.

Discharge. Discharge was computed from Ratings No. 4 with shifts applied by stage V diagram.

Remarks. Records are good. 
E02685 Los Alamos Canyon at TA-2

Daily Mean Discharge in Cubic Feet per Second

Water Year October 2008 to September 2009

\begin{tabular}{|c|c|c|c|c|c|c|c|c|c|c|c|c|}
\hline DAY & OCT & NOV & DEC & JAN & FEB & MAR & APR & MAY & JUN & JUL & AUG & SEP \\
\hline 1 & 0 & 0 & 0 & 0 & 0 & 0 & 0 & .95 & .21 & .01 & 0 & 0 \\
\hline 2 & 0 & 0 & 0 & 0 & 0 & 0 & 0 & .95 & .23 & 0 & 0 & 0 \\
\hline 3 & 0 & 0 & 0 & 0 & 0 & 0 & 0 & .96 & .68 & .03 & 0 & 0 \\
\hline 4 & 0 & 0 & 0 & 0 & 0 & 0 & 0 & .89 & .39 & 0 & 0 & 0 \\
\hline 5 & 0 & 0 & 0 & 0 & $0^{*}$ & 0 & 0 & .74 & .31 & 1.2 & 0 & 0 \\
\hline 6 & 0 & 0 & 0 & 0 & $0^{*}$ & 0 & 0 & .64 & .24 & 1.7 & 0 & 0 \\
\hline 7 & 0 & 0 & 0 & 0 & $0^{*}$ & 0 & 0 & .61 & .19 & .25 & 0 & 0 \\
\hline 8 & 0 & 0 & 0 & 0 & $0^{*}$ & 0 & 0 & .56 & .20 & .05 & 0 & 0 \\
\hline 9 & 0 & 0 & 0 & 0 & 0 & 0 & 0 & .53 & .17 & 0 & 0 & 0 \\
\hline 10 & 0 & 0 & 0 & 0 & 0 & 0 & 0 & .53 & .91 & 0 & 0 & 0 \\
\hline 11 & .52 & 0 & 0 & 0 & 0 & 0 & .44 & .46 & .70 & 0 & 0 & 0 \\
\hline 12 & 0 & 0 & 0 & 0 & 0 & 0 & .31 & .39 & .49 & 0 & 0 & 0 \\
\hline 13 & 0 & 0 & 0 & 0 & 0 & 0 & .33 & .32 & .26 & 0 & 0 & 0 \\
\hline 14 & 0 & 0 & 0 & 0 & 0 & 0 & .19 & .22 & .35 & 0 & .02 & 0 \\
\hline 15 & 0 & 0 & 0 & 0 & 0 & 0 & .14 & .18 & .25 & 0 & 0 & 0 \\
\hline 16 & 0 & 0 & 0 & 0 & 0 & 0 & .11 & .16 & .16 & 0 & 0 & 0 \\
\hline 17 & 0 & 0 & 0 & 0 & 0 & 0 & .21 & .14 & .10 & 0 & 0 & 0 \\
\hline 18 & 0 & 0 & 0 & 0 & 0 & 0 & .23 & .09 & .06 & 0 & 0 & 0 \\
\hline 19 & 0 & 0 & 0 & 0 & 0 & 0 & .23 & .08 & .03 & 0 & 0 & 0 \\
\hline 20 & 0 & 0 & 0 & 0 & 0 & 0 & .45 & .03 & .80 & 0 & 0 & 0 \\
\hline 21 & 0 & 0 & 0 & 0 & $0^{*}$ & 0 & .66 & .04 & .35 & .02 & 0 & 0 \\
\hline 22 & 0 & 0 & 0 & 0 & $0^{*}$ & 0 & .89 & .12 & .17 & 0 & 0 & 0 \\
\hline 23 & 0 & 0 & 0 & 0 & 0 & 0 & 1.2 & .79 & .09 & .06 & 0 & 0 \\
\hline 24 & 0 & 0 & 0 & 0 & 0 & 0 & 1.2 & .55 & .05 & 0 & 0 & 0 \\
\hline 25 & 0 & 0 & 0 & 0 & 0 & 0 & 1.2 & .38 & .06 & 0 & 0 & 0 \\
\hline 26 & 0 & 0 & 0 & 0 & 0 & 0 & 1.2 & .20 & .12 & .03 & 0 & 0 \\
\hline 27 & 0 & 0 & 0 & 0 & 0 & 0 & 1.1 & .38 & .07 & 0 & 0 & 0 \\
\hline 28 & 0 & 0 & 0 & 0 & 0 & 0 & 1.1 & .30 & .09 & .03 & 0 & 0 \\
\hline 29 & 0 & 0 & 0 & 0 & ---- & 0 & 1.0 & .21 & .06 & .06 & 0 & 0 \\
\hline 30 & 0 & 0 & 0 & 0 & --- & 0 & .94 & .22 & .03 & .60 & .04 & 0 \\
\hline 31 & 0 & --.- & 0 & 0 & --.-- & 0 & 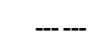 & .22 & ---- & 0 & 0 & ---- \\
\hline Total & 0.52 & 0 & 0 & 0 & 0 & 0 & 13.13 & 12.84 & 7.82 & 4.04 & 0.06 & 0 \\
\hline Mean & .017 & 0 & 0 & 0 & 0 & 0 & .44 & .41 & .26 & .13 & .002 & 0 \\
\hline $\operatorname{Max}$ & .52 & 0 & 0 & 0 & 0 & 0 & 1.2 & .96 & .91 & 1.7 & .04 & 0 \\
\hline Min & 0 & 0 & 0 & 0 & 0 & 0 & 0 & .03 & .03 & 0 & 0 & 0 \\
\hline Acre-Ft & 1.0 & 0 & 0 & 0 & 0 & 0 & 26 & 25 & 16 & 8.0 & .12 & 0 \\
\hline Wtr Year & 2009 & Total & 38.41 & Mean & & 11 & $\operatorname{Max}$ & 1.7 & Min & 0 & Acre- $\mathrm{Ft}$ & 76 \\
\hline Cal Year & 2008 & Total & 148.19 & Mean & & 40 & $\operatorname{Max}$ & 3.1 & Min & 0 & Acre- $\mathrm{Ft}$ & 294 \\
\hline
\end{tabular}

${ }^{*}$ Estimate 


\section{E030 Los Alamos Canyon above DP Canyon}

Location. Lat $35^{\circ}$ 52' 21", long $106^{\circ} 15^{\prime} 36 "$, SW 1/4, sec. 13, T. 19 N., R. 6 E., Los Alamos County.

Drainage Area. $8.57 \mathrm{mi}^{2}$.

Period of Record. July 1994 to September 30, 2009.

Revised Record. Drainage Area (2006); Township (2007).

Gage. Data logger with concrete control. Elevation of gage is $6,621 \mathrm{ft}$ above NGVD from GPS survey.

Remarks. Records are good. Flow partially regulated by Los Alamos Reservoir about 2.5 mi upstream.

Average Discharge. $15 \mathrm{yr}, 0.28 \mathrm{ft}^{3} / \mathrm{s}, 202$ acre- $\mathrm{ft} / \mathrm{yr}$.

Extremes Outside Period of Record. Flood of July 31, 1968, was $329 \mathrm{ft}^{3} / \mathrm{s}$ from slope area determination. Gage height was established later at $3.71 \mathrm{ft}$ present datum.

Extremes for Period of Record. Maximum discharge, $125 \mathrm{ft}^{3} / \mathrm{s}$, June 22, 2002, gage height $2.88 \mathrm{ft}$ from peak flow computation. No flow most of the time.

Extremes for Current Water Year. Peak discharges above base of $10 \mathrm{ft}^{3} / \mathrm{s}$ and $\operatorname{maximum}(*)$ :

\begin{tabular}{|c|c|c|c|}
\hline Date & Time & Discharge $\left(\mathbf{f t}^{\mathbf{3}} / \mathbf{s}\right)$ & Gage Height (ft) \\
\hline July 6 & 1340 & $11^{*}$ & 1.57 \\
\hline
\end{tabular}

No flow at times.

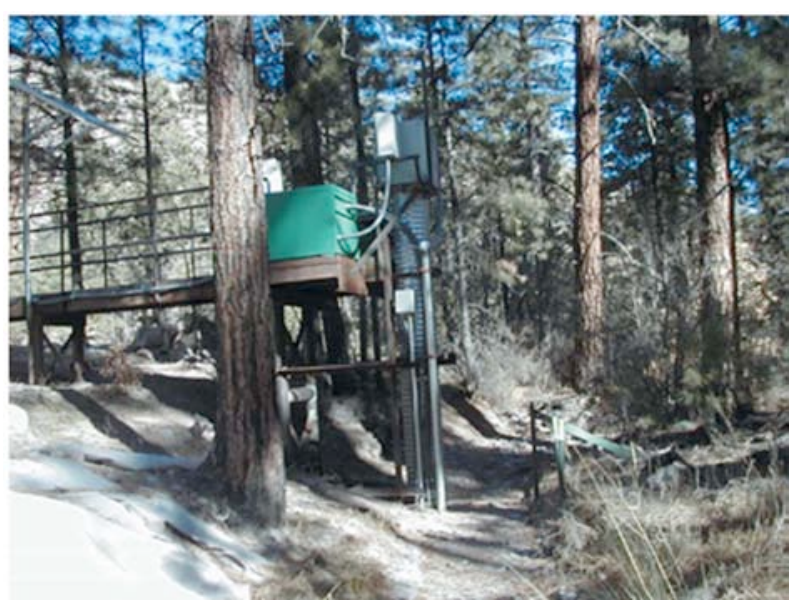




\title{
E030 Los Alamos Canyon above DP Canyon
}

\author{
Station Analysis
}

\section{Water Year}

Equipment. Station is equipped with Sutron 8210 data logger (5-min. interval) with shaft encoder float system (5-min. interval). The system is powered by a solar panel battery system housed in NEMA shelter on 18" CMP well on left bank. Station is equipped with an ISCO pump sampler for water quality sample collection. ISCO is housed in a separate shelter, a $3^{\prime} \times 4^{\prime}$ metal box. Sampler is triggered by stage through the data logger. An outside staff is available for reference. No provision for direct discharge measurements above wading stages.

Field Work. The station was visited 25 times to conduct discharge measurements and service the instrumentation. Field inspections for the gage are listed under site history files on the Hydstra database. Discharge measurements for the gage are listed under site gauging files on the Hydstra database.

Datum Correction. None

Gage-Height Record. The data logger referenced to the outside staff gave a complete and satisfactory record for the year, except during the periods from March 2-5 when gage height was affected by ice and July 7 to August 6 when gage height was affected by silting of stilling well.

Rating. Streambed is sand and gravel and subject to slight movement during flow events. The channel is straight for $300^{\prime}$ above gage and $50^{\prime}$ below. Vegetation on bank is sparse grass.

Two discharge measurement (Nos. 55-56) and 25 inspections were made during the year.

Rating No. 2 was used for the entire water year.

Discharge. Discharge was computed using Rating No. 2.

Remarks. Records are good. 
E030 Los Alamos above DP Canyon

Daily Mean Discharge in Cubic Feet per Second

Water Year October 2008 to September 2009

\begin{tabular}{|c|c|c|c|c|c|c|c|c|c|c|c|c|}
\hline DAY & ОСТ & NOV & DEC & JAN & FEB & MAR & APR & MAY & JUN & JUL & AUG & SEP \\
\hline 1 & 0 & 0 & 0 & 0 & 0 & 0 & 0 & 0 & 0 & 0 & $.04^{\star}$ & 0 \\
\hline 2 & 0 & 0 & 0 & 0 & 0 & $0^{*}$ & 0 & 0 & 0 & 0 & $.03^{\star}$ & 0 \\
\hline 3 & 0 & 0 & 0 & 0 & 0 & $0^{*}$ & 0 & .09 & .20 & 0 & $0^{*}$ & 0 \\
\hline 4 & 0 & 0 & 0 & 0 & 0 & $0^{*}$ & 0 & .11 & 0 & 0 & $0^{*}$ & 0 \\
\hline 5 & 0 & 0 & 0 & 0 & 0 & $0^{*}$ & 0 & .05 & 0 & .53 & $0^{*}$ & 0 \\
\hline 6 & 0 & 0 & 0 & 0 & 0 & 0 & 0 & .06 & 0 & .92 & $0^{*}$ & 0 \\
\hline 7 & 0 & 0 & 0 & 0 & 0 & 0 & 0 & .05 & 0 & $.04^{*}$ & 0 & 0 \\
\hline 8 & 0 & 0 & 0 & 0 & 0 & 0 & 0 & .05 & 0 & $0^{*}$ & 0 & 0 \\
\hline 9 & 0 & 0 & 0 & 0 & 0 & 0 & 0 & .02 & 0 & $0^{*}$ & 0 & 0 \\
\hline 10 & 0 & 0 & 0 & 0 & 0 & 0 & 0 & .02 & .35 & $0^{*}$ & 0 & 0 \\
\hline 11 & .14 & 0 & 0 & 0 & 0 & 0 & 0 & 0 & .18 & $0^{*}$ & 0 & 0 \\
\hline 12 & 0 & 0 & 0 & 0 & 0 & 0 & 0 & 0 & .13 & $0^{*}$ & 0 & 0 \\
\hline 13 & 0 & 0 & 0 & 0 & 0 & 0 & 0 & 0 & 0 & $0^{*}$ & 0 & 0 \\
\hline 14 & 0 & 0 & 0 & 0 & 0 & 0 & 0 & 0 & .01 & $0^{*}$ & 0 & 0 \\
\hline 15 & 0 & 0 & 0 & 0 & 0 & 0 & 0 & 0 & 0 & $0^{*}$ & 0 & 0 \\
\hline 16 & 0 & 0 & 0 & 0 & 0 & 0 & 0 & 0 & 0 & $0^{*}$ & 0 & 0 \\
\hline 17 & 0 & 0 & 0 & 0 & 0 & 0 & 0 & 0 & 0 & $0^{*}$ & 0 & 0 \\
\hline 18 & 0 & 0 & 0 & 0 & 0 & 0 & 0 & 0 & 0 & $0^{*}$ & 0 & 0 \\
\hline 19 & 0 & 0 & 0 & 0 & 0 & 0 & 0 & 0 & 0 & $0^{*}$ & 0 & 0 \\
\hline 20 & 0 & 0 & 0 & 0 & 0 & 0 & 0 & 0 & .17 & $0^{*}$ & 0 & 0 \\
\hline 21 & 0 & 0 & 0 & 0 & 0 & 0 & 0 & 0 & 0 & $0^{*}$ & 0 & 0 \\
\hline 22 & 0 & 0 & 0 & 0 & 0 & 0 & 0 & 0 & 0 & $0^{*}$ & 0 & 0 \\
\hline 23 & 0 & 0 & 0 & 0 & 0 & 0 & 0 & .16 & 0 & $0^{*}$ & 0 & 0 \\
\hline 24 & 0 & 0 & 0 & 0 & 0 & 0 & 0 & .03 & 0 & $0^{*}$ & 0 & 0 \\
\hline 25 & 0 & 0 & 0 & 0 & 0 & 0 & 0 & .02 & 0 & $0^{*}$ & 0 & 0 \\
\hline 26 & 0 & 0 & 0 & 0 & 0 & 0 & 0 & 0 & 0 & $0^{*}$ & 0 & 0 \\
\hline 27 & 0 & 0 & 0 & 0 & 0 & 0 & 0 & .04 & 0 & $0^{*}$ & 0 & 0 \\
\hline 28 & 0 & 0 & 0 & 0 & 0 & 0 & 0 & 0 & 0 & $0^{*}$ & 0 & 0 \\
\hline 29 & 0 & 0 & 0 & 0 & ---- & 0 & 0 & 0 & 0 & $0^{*}$ & 0 & 0 \\
\hline 30 & 0 & 0 & 0 & 0 & --.-- & 0 & 0 & 0 & 0 & $.30^{*}$ & 0 & 0 \\
\hline 31 & 0 & ---- & 0 & 0 & --.-- & 0 & ----- & 0 & -..-- & $.05^{\star}$ & 0 & -..-- \\
\hline Total & 0.14 & 0 & 0 & 0 & 0 & 0 & 0 & 0.70 & 1.04 & 1.84 & 0.07 & 0 \\
\hline Mean & .005 & 0 & 0 & 0 & 0 & 0 & 0 & .023 & .035 & .059 & .002 & 0 \\
\hline Max & .14 & 0 & 0 & 0 & 0 & 0 & 0 & .16 & .35 & .92 & .04 & 0 \\
\hline Min & 0 & 0 & 0 & 0 & 0 & 0 & 0 & 0 & 0 & 0 & 0 & 0 \\
\hline $\begin{array}{r}\text { Acre- } \\
\mathrm{Ft}\end{array}$ & .28 & 0 & 0 & 0 & 0 & 0 & 0 & 1.4 & 2.1 & 3.6 & .14 & 0 \\
\hline Wtr Year & 2009 & Total & 3.79 & Mean & & 10 & Max & .92 & Min & 0 & Acre- $\mathrm{Ft}$ & 7.5 \\
\hline Cal Year & 2008 & Total & 88.21 & Mean & & 24 & $\operatorname{Max}$ & 2.6 & Min & 0 & Acre- $\mathrm{Ft}$ & 175 \\
\hline
\end{tabular}




\section{E038 DP Canyon above TA-21}

Location. Lat $35^{\circ} 52^{\prime} 49^{\prime \prime}$, long $106^{\circ} 16^{\prime}$ 58", SW 1/4, sec. 14, T. 19 N., R. 6 E., Los Alamos County.

Drainage Area. $0.22 \mathrm{mi}^{2}$.

Period of Record. April 26, 2000, to September 30, 2009.

Revised Record. Drainage Area (2006); Section (2007).

Average Discharge. $9 \mathrm{yr}, 0.14 \mathrm{ft}^{3} / \mathrm{s}, 98$ acre- $\mathrm{ft} / \mathrm{yr}$.

Gage. Data logger with cellular telemetry. Elevation of gage is 7,087 ft above NGVD.

Remarks. Records are good.

Extremes for Period of Record. Maximum discharge, $295 \mathrm{ft}^{3} / \mathrm{s}$, July 24, 2004, gage height $4.36 \mathrm{ft}$ from rating curve extended above $10 \mathrm{ft}^{3} / \mathrm{s}$ on basis of peak flow computations. No flow most of the time.

Extremes for Current Water Year. Peak discharges above base of $100 \mathrm{ft}^{3} / \mathrm{s}$ and $\operatorname{maximum}(*)$ :

\begin{tabular}{|c|c|c|c|}
\hline Date & Time & Discharge $\left(\mathbf{f t}^{3} / \mathbf{s}\right)$ & Gage Height (ft) \\
\hline July 30 & 1350 & $202^{*}$ & $3.56^{*}$ \\
\hline
\end{tabular}

No flow at times.

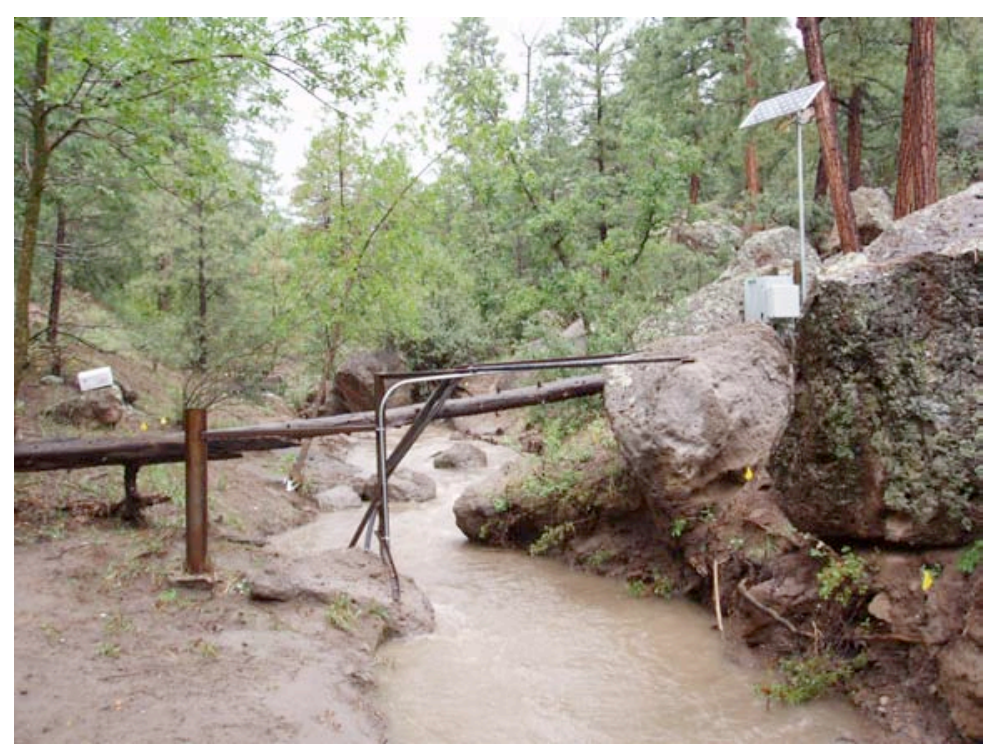




\title{
E038 DP Canyon above TA-21
}

\author{
Station Analysis
}

\section{Water Year}

Equipment. Station is equipped with Sutron 8210 data logger (5-min. interval) with a Sutron accububble self contained bubbler system and cellular telemetry with speech modem. The system is powered by a solar panel battery system housed in a NEMA shelter. Station is equipped with an ISCO pump sampler for water quality sample collection. ISCO is housed in a separate shelter, a $3^{\prime} \times 4^{\prime}$ metal box. Sampler is triggered by stage through the data logger. An outside staff gage is available for reference. No provision for discharge measurements above wading stage. All high-flow measurement will be by slope-area or peak flow computation methods.

Station is also equipped with a tipping bucket rain gage, Rain Collection II. All equipment is powered with a solar panel battery charging system.

Field Work. The station was visited 26 times to conduct discharge measurements and service the instrumentation. Field inspections for the gage are listed under site history files on the Hydstra database. Discharge measurements for the gage are listed under site gauging files on the Hydstra database.

Datum Correction. Levels run July 2005 show gage to be within limits.

Gage-Height Record. The data logger referenced to the outside gage gave a complete and satisfactory record for the year, except for the periods from November 6-8, 11, 12, December 28 to January 24, and February 24 to March 5 when gage height was affected by ice.

Rating. The channel is about $10^{\prime}$ wide and straight for about $30^{\prime}$ upstream and downstream. The streambed through this reach is primarily sand, gravel, and larger boulders. Low-flow control is a rock outcrop downstream from gage about $5^{\prime}$. Channel is control for medium and high stages.

Two discharge measurement (Nos. 10-11) and 26 inspections were made this year. All inspections of no flow used to develop a V diagram shift needed to adjust PZF.

Rating No. 2 was developed using past discharge measurements and verified with current measurements.

Discharge. Rating No. 2 was used with V diagrams to compute this record.

Remarks. Records are good. 
E038 DP C an yon above T A-21

Daily Mean Discharge in Cubic Feet per Second

Water Year October 2008 to September 2009

\begin{tabular}{|c|c|c|c|c|c|c|c|c|c|c|c|c|}
\hline DAY & OCT & NOV & DEC & JAN & FEB & MAR & APR & MAY & JUN & JUL & AUG & SEP \\
\hline 1 & 0 & 0 & 0 & $0^{*}$ & 0 & $0^{*}$ & 0 & .02 & .02 & 0 & 0 & 0 \\
\hline 2 & 0 & 0 & 0 & $0^{*}$ & 0 & $0^{*}$ & 0 & 0 & 0 & 0 & 0 & 0 \\
\hline 3 & 0 & 0 & 0 & $0^{*}$ & 0 & $0^{*}$ & 0 & 0 & 1.7 & 0 & 0 & .14 \\
\hline 4 & .39 & 0 & 0 & $0^{*}$ & 0 & $0^{*}$ & 0 & 0 & .02 & 0 & 0 & .02 \\
\hline 5 & .09 & 0 & 0 & $0^{*}$ & 0 & $0^{*}$ & 0 & 0 & 0 & 1.9 & 0 & 0 \\
\hline 6 & 0 & $0^{*}$ & 0 & $0^{*}$ & 0 & 0 & 0 & 0 & 0 & .05 & 0 & .25 \\
\hline 7 & 0 & $0^{*}$ & 0 & $0^{*}$ & 0 & 0 & 0 & 0 & 0 & 0 & 0 & .28 \\
\hline 8 & 0 & $0^{*}$ & 0 & $0^{*}$ & 0 & 0 & 0 & 0 & 0 & 0 & 0 & .24 \\
\hline 9 & 0 & 0 & 0 & $0^{*}$ & 0 & .09 & 0 & 0 & 0 & 0 & 0 & 0 \\
\hline 10 & 0 & 0 & .02 & $0^{*}$ & 0 & 0 & 0 & 0 & 3.6 & .04 & 0 & .03 \\
\hline 11 & 4.1 & $0^{*}$ & .22 & $0^{*}$ & 0 & 0 & .50 & 0 & 0 & 0 & 0 & .14 \\
\hline 12 & 0 & $0^{*}$ & .20 & $0^{*}$ & 0 & 0 & .29 & 0 & 0 & 0 & .32 & 0 \\
\hline 13 & $0^{*}$ & 0 & .01 & $0^{*}$ & 0 & 2.1 & 0 & 0 & 0 & 0 & .21 & 0 \\
\hline 14 & $0^{*}$ & 0 & 0 & $0^{*}$ & 0 & .14 & 0 & 0 & 2.0 & 0 & 2.2 & .13 \\
\hline 15 & 0 & 0 & 0 & $0^{*}$ & 0 & .01 & 0 & 0 & .05 & 0 & 0 & .05 \\
\hline 16 & 0 & 0 & 0 & $0^{*}$ & 0 & 0 & 0 & 0 & 0 & 0 & 0 & 3.0 \\
\hline 17 & 0 & 0 & 0 & $0^{*}$ & 0 & 0 & .09 & 0 & 0 & 0 & 0 & 1.9 \\
\hline 18 & 0 & 0 & 0 & $0^{*}$ & 0 & 0 & .02 & 0 & 0 & 0 & 0 & .31 \\
\hline 19 & 0 & 0 & 0 & $0^{*}$ & 0 & 0 & 0 & 0 & 0 & 0 & 0 & 0 \\
\hline 20 & 0 & 0 & .03 & $0^{*}$ & 0 & 0 & 0 & 0 & 4.2 & 0 & 0 & 0 \\
\hline 21 & 0 & 0 & .05 & $0^{*}$ & 0 & 0 & 0 & .01 & 0 & 1.5 & 0 & 0 \\
\hline 22 & $0^{*}$ & 0 & 0 & $0^{*}$ & 0 & 0 & 0 & .01 & 0 & 0 & 0 & 0 \\
\hline 23 & $0^{*}$ & 0 & 0 & $0^{*}$ & 0 & 0 & 0 & 2.3 & 0 & 1.0 & 0 & 1.3 \\
\hline 24 & 0 & 0 & .07 & $0^{*}$ & $0^{*}$ & 0 & 0 & 1.9 & 0 & 0 & .17 & 1.6 \\
\hline 25 & 0 & 0 & 0 & 0 & $0^{*}$ & 0 & 0 & .12 & .56 & .03 & 0 & .04 \\
\hline 26 & 0 & 0 & 0 & 0 & $0^{*}$ & 1.5 & 0 & .21 & .01 & .50 & 0 & 0 \\
\hline 27 & 0 & 0 & 0 & 0 & $0^{*}$ & 2.2 & 0 & 1.4 & 0 & 0 & 0 & 0 \\
\hline 28 & 0 & 0 & $0^{*}$ & 0 & $0^{*}$ & .01 & 0 & .19 & .13 & .44 & 0 & 0 \\
\hline 29 & 0 & 0 & $0^{*}$ & 0 & ---- & 0 & 0 & 0 & 0 & .51 & 0 & 0 \\
\hline 30 & 0 & 0 & $0^{*}$ & 0 & ---- & 0 & 0 & 0 & 0 & 2.9 & 1.4 & 0 \\
\hline 31 & 0 & --- & $0^{*}$ & 0 & ---- & 0 & ---- & .79 & ----- & .03 & .05 & ---- \\
\hline Total & 4.58 & 0 & 0.60 & 0 & 0 & 6.05 & 0.90 & 6.95 & 1229 & 8.90 & 4.35 & 9.43 \\
\hline Mean & .15 & 0 & .019 & 0 & 0 & .20 & .030 & .22 & .41 & .29 & .14 & .31 \\
\hline $\operatorname{Max}$ & 4.1 & 0 & .22 & 0 & 0 & 2.2 & .50 & 2.3 & 4.2 & 2.9 & 2.2 & 3.0 \\
\hline Min & 0 & 0 & 0 & 0 & 0 & 0 & 0 & 0 & 0 & 0 & 0 & 0 \\
\hline Acre-F t & 9.1 & 0 & 1.2 & 0 & 0 & 12 & 1.8 & 14 & 24 & 18 & 8.6 & 19 \\
\hline Wtr Year & 2009 & Total & 54.05 & Mean & & 15 & Max & 4.2 & Min & 0 & Acre- $\mathrm{Ft}$ & 107 \\
\hline Cal Year & 2008 & Total & 27.84 & Mean & & 76 & Max & 4.1 & Min & 0 & Acre- $\mathrm{Ft}$ & 55 \\
\hline
\end{tabular}




\section{E039 DP Canyon below Meadow near TA-21}

Location. Lat $35^{\circ} 52^{\prime} 41^{\prime \prime}$, long $106^{\circ} 15^{\prime} 28^{\prime \prime}$, SE 1/4, sec. 14, T. 19 N., R. 6 E., Los Alamos County.

Drainage Area. $0.315 \mathrm{mi}^{2}$.

Period of Record. October 1, 1999, to September 30, 2009.

Revised Record. Section, Township, Range (2007).

Average Discharge. $8 \mathrm{yr}, 0.12 \mathrm{ft}^{3} / \mathrm{s}, 85$ acre-ft/yr.

Gage. Data logger with cellular telemetry. Elevation of gage is 7,010 ft above NGVD from topographic map.

Remarks. Records are good except estimated daily discharges, which are fair.

Extremes for Period of Record. Maximum discharge, $200 \mathrm{ft}^{3} / \mathrm{s}$, July 24, 2004 gage height $2.58 \mathrm{ft}$. No flow most of the time.

Extremes for Current Water Year. Peak discharges above base of $50 \mathrm{ft}^{3} / \mathrm{s}$ and maximum $(*)$ :

\begin{tabular}{|c|c|c|c|}
\hline Date & Time & Discharge $\left(\mathbf{f t}^{\mathbf{3}} / \mathbf{s}\right)$ & Gage Height $(\mathbf{f t})$ \\
\hline July 6 & 1245 & 101 & 1.87 \\
\hline July 30 & 1410 & $123^{*}$ & $2.03^{*}$ \\
\hline
\end{tabular}

No flow at times.

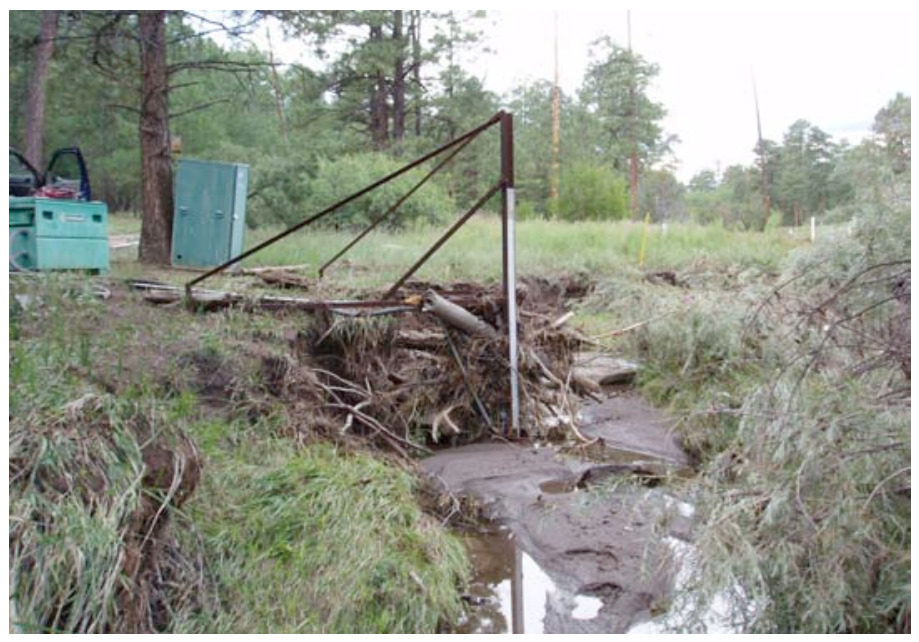




\title{
E039 DP Canyon below Meadow near TA-21
}

\author{
Station Analysis
}

\section{Water Year}

Equipment. Station is equipped with Sutron 8210 data logger (5-min. interval) and Sutron Accubar bubble sensor with cellular phone speech modem. The system is powered by a solar panel battery system housed in a NEMA shelter. Station is equipped with an ISCO pump sampler for water quality sample collection. ISCO is housed in a separate shelter, a $3^{\prime} \times 4^{\prime}$ metal box. Sampler is triggered by stage through the data logger. An outside staff is available for reference. Low to medium flow can be waded. High flow will be measured by indirect methods.

Field Work. The station was visited 20 times to conduct discharge measurements and service the instrumentation. Field inspections for the gage are listed under site history files on the Hydstra database. Discharge measurements for the gage are listed under site gauging files on the Hydstra database.

Datum Correction. Levels run July 14, 2005, found gage within acceptable limits.

Gage-Height Record. The data logger referenced to the outside staff gave a complete and satisfactory for the water year, except during the periods October 12-27 due to data logger malfunction and February 9, 15, 19, 20 when gage height was affected by ice.

Rating. The channel has rock outcrop in bed with pockets of sand mostly from deposition below riffles. Channel is straight for $50^{\prime}$ above and below gage. A slight left bend $50^{\prime}$ below gage also has a $2^{\prime}$ drop and could act as a broad-crested weir at high flow. Banks and canyon bottom are thickly vegetated with grass.

One discharge measurements (No. 17) and 20 inspections were made during the year.

Rating No. 2 was developed from three critical depth computations and a PZF.

Discharge. Discharge was computed by applying gage height directly to Rating No. 2 . The channel in winter is heavily glaciated and choked with ice and snow with flow frozen dry. The winter record is published as zero based on comparison with E038 and E040. Variable shift diagrams were used at lower flows defined by discharge measurements.

Remarks. Records are good, except for estimated daily discharges, which are fair. 
E039 D P Canyon below Meadow near T A-21

Daily Mean Discharge in Cubic Feet per Second

Water Year October 2008 to September 2009

\begin{tabular}{|c|c|c|c|c|c|c|c|c|c|c|c|c|}
\hline DAY & OCT & NOV & DEC & JAN & FE B & MAR & APR & MAY & JUN & JUL & AUG & SEP \\
\hline 1 & .02 & .02 & 0 & 0 & 0 & 0 & .03 & 0 & 0 & .08 & 0 & 0 \\
\hline 2 & .02 & .02 & 0 & 0 & 0 & 0 & .01 & 0 & 0 & .09 & 0 & 0 \\
\hline 3 & .03 & .02 & 0 & 0 & 0 & 0 & 0 & 0 & .68 & .11 & 0 & 0 \\
\hline 4 & .06 & .02 & 0 & 0 & 0 & 0 & 0 & 0 & 0 & .12 & 0 & 0 \\
\hline 5 & .06 & .02 & 0 & 0 & 0 & 0 & 0 & 0 & 0 & 2.6 & 0 & 0 \\
\hline 6 & 0 & .02 & 0 & 0 & 0 & 0 & 0 & 0 & 0 & 3.4 & 0 & 0 \\
\hline 7 & 0 & .02 & 0 & 0 & 0 & 0 & 0 & 0 & .02 & 0 & 0 & 0 \\
\hline 8 & .01 & .02 & 0 & 0 & 0 & 0 & 0 & 0 & .06 & 0 & 0 & 0 \\
\hline 9 & .01 & .03 & 0 & 0 & $0^{*}$ & 0 & 0 & 0 & .05 & 0 & 0 & 0 \\
\hline 10 & .01 & .03 & 0 & 0 & 0 & 0 & 0 & 0 & 1.7 & 0 & 0 & 0 \\
\hline 11 & .03 & .04 & 0 & 0 & 0 & 0 & 2.0 & 0 & 0 & 0 & 0 & 0 \\
\hline 12 & $.02^{*}$ & .04 & 0 & 0 & 0 & 0 & 1.3 & 0 & 0 & 0 & 0 & 0 \\
\hline 13 & $.01^{*}$ & .04 & 0 & 0 & 0 & .02 & 1.2 & 0 & 0 & 0 & 0 & 0 \\
\hline 14 & $.01^{*}$ & .04 & 0 & 0 & 0 & 0 & .58 & 0 & .98 & 0 & .82 & 0 \\
\hline 15 & $.01^{*}$ & .03 & 0 & 0 & $0^{*}$ & 0 & .49 & 0 & 0 & 0 & 0 & 0 \\
\hline 16 & $.02^{*}$ & .03 & 0 & 0 & 0 & 0 & .42 & 0 & 0 & 0 & 0 & .80 \\
\hline 17 & $.01^{*}$ & .03 & .01 & 0 & 0 & 0 & .91 & 0 & 0 & 0 & 0 & .32 \\
\hline 18 & $.01^{*}$ & .03 & .23 & 0 & 0 & 0 & .69 & 0 & 0 & 0 & 0 & .05 \\
\hline 19 & $.01^{*}$ & .03 & .01 & 0 & $0^{*}$ & 0 & .07 & 0 & 0 & 0 & 0 & 0 \\
\hline 20 & $.01^{*}$ & .03 & 0 & 0 & $0^{*}$ & 0 & .03 & 0 & 2.2 & 0 & 0 & 0 \\
\hline 21 & $.02^{*}$ & .03 & 0 & 0 & 0 & 0 & 0 & 0 & .20 & .86 & 0 & 0 \\
\hline 22 & $.01^{*}$ & .02 & 0 & 0 & 0 & 0 & 0 & 0 & .17 & .03 & 0 & 0 \\
\hline 23 & $.01^{*}$ & .02 & 0 & 0 & 0 & 0 & 0 & .98 & .15 & .80 & 0 & .21 \\
\hline 24 & $.01^{*}$ & .02 & 0 & 0 & 0 & 0 & 0 & .36 & .15 & 0 & 0 & .66 \\
\hline 25 & $.01^{*}$ & .02 & 0 & 0 & 0 & 0 & 0 & 0 & .29 & 0 & 0 & 0 \\
\hline 26 & $.01^{*}$ & .02 & 0 & 0 & 0 & .01 & 0 & 0 & .07 & .34 & 0 & 0 \\
\hline 27 & $.01^{*}$ & .49 & 0 & 0 & 0 & .48 & 0 & .20 & .06 & 0 & 0 & 0 \\
\hline 28 & .01 & 0 & 0 & 0 & 0 & .17 & 0 & 0 & .07 & .27 & 0 & 0 \\
\hline 29 & .02 & 0 & 0 & 0 & ---- & .19 & 0 & 0 & .07 & .29 & 0 & 0 \\
\hline 30 & .02 & 0 & 0 & 0 & --.-- & .04 & 0 & 0 & .08 & 2.3 & .37 & 0 \\
\hline 31 & .02 & ----- & 0 & 0 & --.-- & .03 & ----- & .17 & -.--- & .01 & 0 & ----- \\
\hline Total & 0.51 & 1.18 & 0.25 & 0 & 0 & 0.94 & 7.73 & 1.71 & 7.00 & 11.30 & 1.19 & 2.04 \\
\hline Mean & .016 & .039 & .008 & 0 & 0 & .030 & .26 & .055 & .23 & .36 & .038 & .068 \\
\hline $\operatorname{Max}$ & .06 & .49 & .23 & 0 & 0 & .48 & 2.0 & .98 & 2.2 & 3.4 & .82 & .80 \\
\hline Min & 0 & 0 & 0 & 0 & 0 & 0 & 0 & 0 & 0 & 0 & 0 & 0 \\
\hline Acre-Ft & 1.0 & 2.3 & .50 & 0 & 0 & 1.9 & 15 & 3.4 & 14 & 22 & 2.4 & 4.0 \\
\hline Wtr Year & 2009 & Total & 33.85 & Mean & & 93 & Max & 3.4 & Min & 0 & Acre-Ft & 67 \\
\hline Cal Year & 2008 & Total & 43.22 & Mean & & 12 & $\operatorname{Max}$ & 3.0 & Min & 0 & Acre- $\mathrm{Ft}$ & 86 \\
\hline
\end{tabular}

${ }^{\star}$ Estimate 


\section{E040 DP Canyon above Los Alamos Canyon}

Location. Lat $35^{\circ}$ 52' 24", long $106^{\circ} 15^{\prime} 34^{\prime \prime}$, SW 1/4, sec. 13, T. 19 N., R. 6 E., Los Alamos County.

Drainage Area. $0.60 \mathrm{mi}^{2}$.

Period of Record. May 1999 to September 30, 2009.

Revised Record. Drainage Area (2006); Section (2007).

Gage. Data logger and concrete control. Elevation of gage is 6,620 ft above NGVD from GPS survey.

Remarks. Records are good, except estimated daily discharges, which are fair.

Average Discharge. $10 \mathrm{yr}, 0.035 \mathrm{ft}^{3} / \mathrm{s}, 25$ acre-ft/yr.

Extremes for Period of Record. Maximum discharge $452 \mathrm{ft}^{3} / \mathrm{s}$, August 8, 2006, gage height $5.65 \mathrm{ft}$. (from slope area measurement). No flow most of the time.

Extremes for Current Water Year. Peak discharge above base of $30 \mathrm{ft}^{3} / \mathrm{s}$ and $\operatorname{maximum}(*)$.

\begin{tabular}{|c|c|c|c|}
\hline Date & Time & Discharge $\left(\mathbf{f t}^{\mathbf{3}} / \mathbf{s}\right)$ & Gage Height (ft) \\
\hline October 11 & 1600 & 134 & 3.98 \\
\hline June 10 & 0640 & 30 & 3.13 \\
\hline July 5 & 1310 & 78 & 3.62 \\
\hline July 6 & 1310 & $153^{*}$ & $4.10^{*}$ \\
\hline July 30 & 1440 & 140 & 4.02 \\
\hline
\end{tabular}

No flow most of the time.

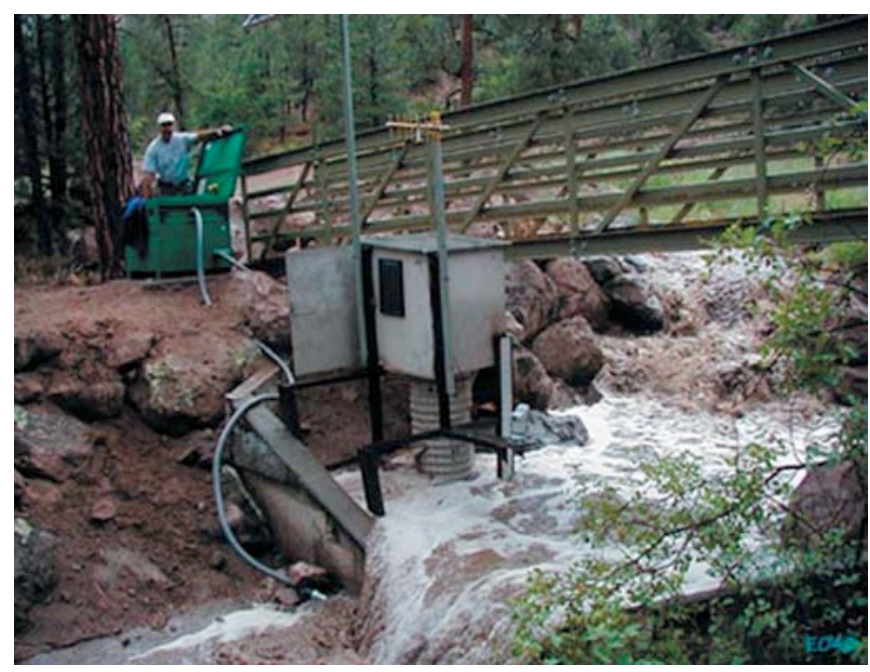




\title{
E040 DP Canyon above Los Alamos Canyon
}

\author{
Station Analysis
}

\section{Water Year}

Equipment. Station is equipped with Sutron 8210 data logger (5-min. interval) with Milltronics sonic probe. The system is powered by a solar panel battery system. All equipment is housed in a NEMA shelter. Station is equipped with an ISCO pump sampler for water quality collection in a $3^{\prime} \times 4^{\prime}$ metal box. Sampler is triggered by stage through the data logger. An outside staff is available for reference. High flow measurements can be made from bridge upstream of gage.

Field Work. The station was visited 29 times to conduct discharge measurements and service the instrumentation. Field inspections for the gage are listed under site history files on the Hydstra database. Discharge measurements for the gage are listed under site gauging files on the Hydstra database.

Datum Corrections. None from levels.

Gage-Height Record. The data logger referenced to the outside staff gave a complete and satisfactory record, except during the periods from November 19-23 and December 9 to January 7 when gage height was affected by ice. Several days throughout the summer were estimated due to silting at control.

Rating. The channel is about $15^{\prime}$ wide and bends to the right above gage and straight for about $100^{\prime}$ downstream. The streambed through this reach is primarily sand with large boulders. The control at this site is a concrete control with a $\mathrm{V}$ notch in the middle for low flow. Channel becomes the control for medium to high flows.

Twenty-nine inspections of no flow were made during the year.

Rating No. 3 is good up to $30 \mathrm{ft}^{3} / \mathrm{s}$ and fair above that.

Discharge. Discharge was computed using Rating No. 3. Those days estimated at zero flow were based on comparison with nearby gage stations and precipitation records. No flow most of the time.

Remarks. Records are good except for estimated daily discharges, which are fair. 


\section{E040 DP Canyon above Los Alamos Canyon}

Daily Mean Discharge in Cubic Feet per Second

Water Year October 2008 to September 2009

\begin{tabular}{|c|c|c|c|c|c|c|c|c|c|c|c|c|}
\hline DAY & ОСТ & NOV & DEC & JAN & FEB & MAR & APR & MAY & JUN & JUL & AUG & SEP \\
\hline 1 & 0 & 0 & 0 & $0^{*}$ & 0 & 0 & 0 & 0 & 0 & 0 & .05 & 0 \\
\hline 2 & 0 & 0 & 0 & $0^{*}$ & 0 & 0 & 0 & 0 & 0 & 0 & 0 & 0 \\
\hline 3 & 0 & 0 & 0 & $0^{*}$ & 0 & 0 & 0 & $0^{*}$ & .68 & 0 & 0 & 0 \\
\hline 4 & 0 & 0 & 0 & $0^{*}$ & 0 & 0 & 0 & $0^{*}$ & .03 & 0 & 0 & 0 \\
\hline 5 & 0 & 0 & 0 & $0^{*}$ & 0 & 0 & 0 & $0^{*}$ & 0 & 3.2 & 0 & 0 \\
\hline 6 & 0 & 0 & 0 & $0^{*}$ & 0 & 0 & 0 & $0^{*}$ & 0 & 5.2 & 0 & 0 \\
\hline 7 & 0 & 0 & 0 & $0^{*}$ & 0 & 0 & 0 & $0^{*}$ & 0 & .06 & 0 & 0 \\
\hline 8 & 0 & 0 & 0 & 0 & 0 & 0 & 0 & $0^{*}$ & 0 & 0 & 0 & 0 \\
\hline 9 & 0 & 0 & $0^{*}$ & 0 & 0 & 0 & 0 & $0^{*}$ & 0 & 0 & 0 & 0 \\
\hline 10 & 0 & 0 & $0^{*}$ & 0 & 0 & 0 & 0 & $0^{*}$ & 2.3 & 0 & 0 & 0 \\
\hline 11 & 7.1 & 0 & $0^{*}$ & 0 & 0 & 0 & .13 & $0^{*}$ & 0 & 0 & 0 & 0 \\
\hline 12 & 0 & 0 & $0^{*}$ & 0 & 0 & 0 & .05 & $0^{*}$ & 0 & 0 & 0 & 0 \\
\hline 13 & 0 & 0 & $0^{*}$ & 0 & 0 & 0 & .15 & $0^{*}$ & 0 & 0 & 0 & 0 \\
\hline 14 & 0 & 0 & $0^{*}$ & 0 & 0 & 0 & 0 & $0^{*}$ & .94 & 0 & .13 & 0 \\
\hline 15 & 0 & 0 & $0^{*}$ & 0 & 0 & 0 & 0 & $0^{*}$ & $0^{*}$ & 0 & 0 & 0 \\
\hline 16 & 0 & 0 & $0^{*}$ & 0 & 0 & 0 & 0 & $0^{*}$ & $0^{*}$ & 0 & 0 & 0 \\
\hline 17 & 0 & 0 & $0^{*}$ & 0 & 0 & 0 & 0 & $0^{*}$ & 0 & 0 & 0 & .02 \\
\hline 18 & 0 & 0 & $0^{*}$ & 0 & 0 & 0 & 0 & $0^{*}$ & 0 & 0 & 0 & 0 \\
\hline 19 & 0 & $0^{*}$ & $0^{*}$ & 0 & 0 & 0 & 0 & $0^{*}$ & 0 & 0 & 0 & 0 \\
\hline 20 & 0 & $0^{*}$ & $0^{*}$ & 0 & 0 & 0 & .01 & $0^{*}$ & 1.5 & 0 & 0 & 0 \\
\hline 21 & 0 & $0^{*}$ & $0^{*}$ & 0 & 0 & 0 & .03 & 0 & $0^{*}$ & .18 & 0 & 0 \\
\hline 22 & 0 & $0^{*}$ & $0^{*}$ & 0 & 0 & 0 & .03 & .01 & $0^{*}$ & .14 & 0 & 0 \\
\hline 23 & 0 & $0^{*}$ & $0^{*}$ & 0 & 0 & 0 & 0 & .69 & 0 & .52 & 0 & 0 \\
\hline 24 & 0 & 0 & $0^{*}$ & 0 & 0 & 0 & 0 & .87 & 0 & .02 & 0 & .15 \\
\hline 25 & 0 & 0 & $0^{*}$ & 0 & 0 & 0 & 0 & .18 & 0 & $0^{*}$ & 0 & $.01^{*}$ \\
\hline 26 & 0 & 0 & $0^{*}$ & 0 & 0 & .01 & 0 & 0 & 0 & $0^{*}$ & 0 & $0^{*}$ \\
\hline 27 & 0 & 0 & $0^{*}$ & 0 & 0 & .14 & 0 & .12 & 0 & $0^{*}$ & 0 & $0^{*}$ \\
\hline 28 & 0 & 0 & $0^{*}$ & 0 & 0 & .01 & 0 & .05 & 0 & $0^{*}$ & 0 & $0^{*}$ \\
\hline 29 & 0 & 0 & $0^{*}$ & 0 & ---- & 0 & 0 & 0 & 0 & .03 & 0 & $0^{*}$ \\
\hline 30 & 0 & 0 & $0^{*}$ & 0 & 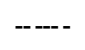 & 0 & 0 & 0 & 0 & 3.6 & 0 & 0 \\
\hline 31 & 0 & 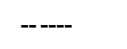 & $0^{*}$ & 0 & ----- & 0 & ---- & 0 & ----- & .31 & 0 & --- \\
\hline Total & 7.1 & 0 & 0 & 0 & 0 & 0.16 & 0.40 & 1.92 & 5.45 & 13.26 & 0.18 & 0.18 \\
\hline Mean & .23 & 0 & 0 & 0 & 0 & .005 & .013 & .062 & .18 & .43 & .006 & .006 \\
\hline Max & 7.1 & 0 & 0 & 0 & 0 & .14 & .15 & .87 & 2.3 & 5.2 & .13 & .15 \\
\hline Min & 0 & 0 & 0 & 0 & 0 & 0 & 0 & 0 & 0 & 0 & 0 & 0 \\
\hline Acre-Ft & 14 & 0 & 0 & 0 & 0 & .32 & .79 & 3.8 & 11 & 26 & .36 & .36 \\
\hline Wtr Year & 2009 & Total & 28.65 & Mean & & & $\operatorname{lax}$ & 7.1 & Min & 0 & Acre-Ft & 57 \\
\hline Cal Year & 2008 & Total & 11.52 & Mean & & 31 & $\operatorname{lax}$ & 7.1 & $\mathrm{Min}$ & 0 & Acre-Ft & 23 \\
\hline
\end{tabular}

${ }^{*}$ Estimate 


\section{E042 Los Alamos Canyon above SR 4}

Location. Lat $35^{\circ} 52^{\prime} 01^{\prime \prime}$, long $106^{\circ} 13^{\prime} 25^{\prime \prime}$, NW 1/4, sec. 20, T. 19 N., R. 7 E., Santa Fe County.

Drainage Area. $10.11 \mathrm{mi}^{2}$.

Period of Record. November 1970 to June 1971, October 1991 to September 30, 2009.

Revised Record. Drainage Area (2006); Quarter (2007); Peak discharges for 2006 (2007).

Gage. Data logger with cellular telemetry and concrete control. Elevation of gage is 6,300 ft above NGVD from GPS survey.

Remarks. Records are good. Flow partially regulated by Los Alamos Reservoir about 7.8 mi upstream.

Average Discharge. $15 \mathrm{yr}, 0.25 \mathrm{ft}^{3} / \mathrm{s}, 181$ acre- $\mathrm{ft} / \mathrm{yr}$.

Extremes for Period of Record. Maximum discharge, $240 \mathrm{ft}^{3} / \mathrm{s}$, August 08, 2006, gage height $3.76 \mathrm{ft}$ (from flood marks). No flow at times.

Extremes for Current Water Year. Peak discharges above base of $40 \mathrm{ft}^{3} / \mathrm{s}$ and maximum $(*)$ :

\begin{tabular}{|c|c|c|c|}
\hline Date & Time & Discharge $\left(\mathbf{f t}^{\mathbf{3}} / \mathbf{s}\right)$ & Gage Height $(\mathbf{f t})$ \\
\hline July 6 & 1410 & $53^{*}$ & $2.36^{*}$ \\
\hline
\end{tabular}

No flow at times.

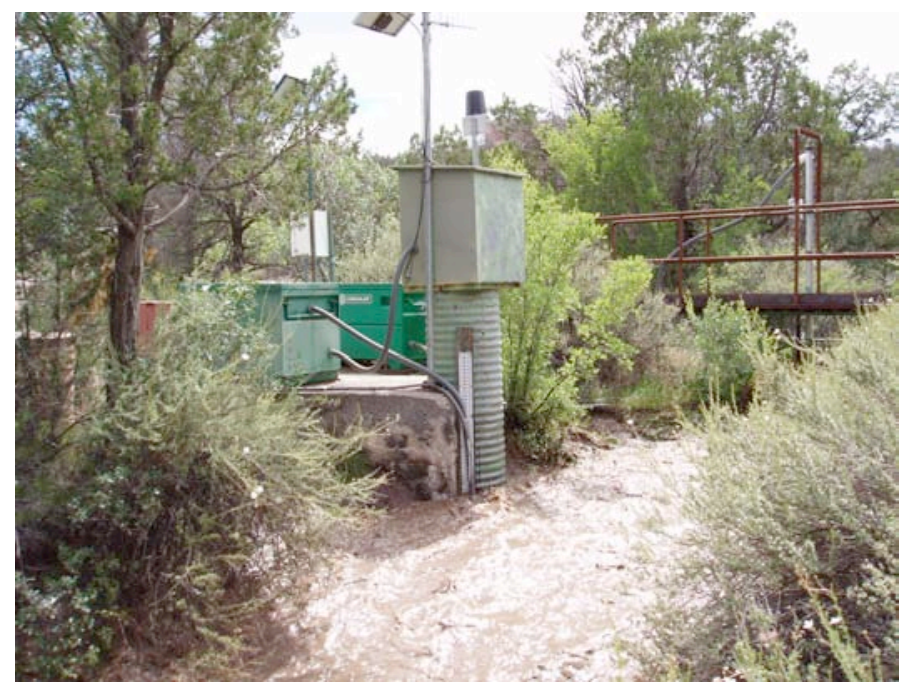




\title{
E042 Los Alamos Canyon above SR 4
}

\author{
Station Analysis
}

\section{Water Year}

Equipment. Station is equipped with Sutron 8210 data logger (5-min. interval) with quadrature encoder driven by float tape in stilling well and cellular telemetry with speech modem. System is powered by a solar panel battery system housed in a NEMA shelter. Station is equipped with an ISCO pump sampler for water quality sample collection. ISCO is housed in a separate shelter, a $3^{\prime} \times 4^{\prime}$ metal box. Sampler is triggered by stage through the data logger. Outside staff available for reference. Control is broad-crested weir that has deteriorated somewhat over the years, but is still fairly stable. Footbridge is available for high-flow discharge measurements.

Station is also equipped with a tipping bucket rain gage, Rain Collection II. All equipment is powered with a solar panel battery charging system.

Field Work. This station was visited 32 times to conduct discharge measurements and service the instrumentation. Field inspections for the gage are listed under site history files on the Hydstra database. Discharge measurements for the gage are listed under site gauging files on the Hydstra database.

Datum Correction. None.

Gage-Height Record. The data logger referenced to the outside staff gave a complete and satisfactory record for the year, except during the periods from May 17-21 when the data logger malfunctioned and July 30, 31 when stilling well became silted.

Rating. Streambed is sand and gravel and channel is straight for over $150^{\prime}$ above and below broad-crested weir. Fill and scour, mostly fill, results in pooling at the gage on most flow events.

Thirty-two inspections of no flow were made.

Rating No. 4 was developed from measurements made in previous years.

Discharge. Discharge computed from Rating No. 4 using V diagrams with no shifts on high flows. Those days estimated were based on precipitation and nearby gage stations for verification.

Remarks. Records are good. Flow partially regulated by Los Alamos Reservoir about 7.8 mi upstream. 
E042 Los Alamos Canyon above SR 4

Daily Mean Discharge in Cubic Feet per Second

Water Year October 2008 to September 2009

\begin{tabular}{|c|c|c|c|c|c|c|c|c|c|c|c|c|}
\hline DAY & OCT & NOV & DEC & JAN & FEB & MAR & APR & MAY & JUN & JUL & AUG & SEP \\
\hline 1 & 0 & 0 & 0 & 0 & 0 & 0 & 0 & 0 & 0 & 0 & 0 & 0 \\
\hline 2 & 0 & 0 & 0 & 0 & 0 & 0 & 0 & 0 & 0 & 0 & 0 & 0 \\
\hline 3 & 0 & 0 & 0 & 0 & 0 & 0 & 0 & 0 & 0 & 0 & 0 & 0 \\
\hline 4 & 0 & 0 & 0 & 0 & 0 & 0 & 0 & 0 & 0 & 0 & 0 & 0 \\
\hline 5 & 0 & 0 & 0 & 0 & 0 & 0 & 0 & 0 & 0 & 1.3 & 0 & 0 \\
\hline 6 & 0 & 0 & 0 & 0 & 0 & 0 & 0 & 0 & 0 & 3.1 & 0 & 0 \\
\hline 7 & 0 & 0 & 0 & 0 & 0 & 0 & 0 & 0 & 0 & 0 & 0 & 0 \\
\hline 8 & 0 & 0 & 0 & 0 & 0 & 0 & 0 & 0 & 0 & 0 & 0 & 0 \\
\hline 9 & 0 & 0 & 0 & 0 & 0 & 0 & 0 & 0 & 0 & 0 & 0 & 0 \\
\hline 10 & 0 & 0 & 0 & 0 & 0 & 0 & 0 & 0 & .54 & 0 & 0 & 0 \\
\hline 11 & 1.1 & 0 & 0 & 0 & 0 & 0 & 0 & 0 & 0 & 0 & 0 & 0 \\
\hline 12 & 0 & 0 & 0 & 0 & 0 & 0 & 0 & 0 & 0 & 0 & 0 & 0 \\
\hline 13 & 0 & 0 & 0 & 0 & 0 & 0 & 0 & 0 & 0 & 0 & 0 & 0 \\
\hline 14 & 0 & 0 & 0 & 0 & 0 & 0 & 0 & 0 & .05 & 0 & 0 & 0 \\
\hline 15 & 0 & 0 & 0 & 0 & 0 & 0 & 0 & 0 & 0 & 0 & 0 & 0 \\
\hline 16 & 0 & 0 & 0 & 0 & 0 & 0 & 0 & 0 & 0 & 0 & 0 & 0 \\
\hline 17 & 0 & 0 & 0 & 0 & 0 & 0 & 0 & $0^{*}$ & 0 & 0 & 0 & 0 \\
\hline 18 & 0 & 0 & 0 & 0 & 0 & 0 & 0 & $0^{*}$ & 0 & 0 & 0 & 0 \\
\hline 19 & 0 & 0 & 0 & 0 & 0 & 0 & 0 & $0^{*}$ & 0 & 0 & 0 & 0 \\
\hline 20 & 0 & 0 & 0 & 0 & 0 & 0 & 0 & $0^{*}$ & .31 & 0 & 0 & 0 \\
\hline 21 & 0 & 0 & 0 & 0 & 0 & 0 & 0 & $0^{*}$ & 0 & 0 & 0 & 0 \\
\hline 22 & 0 & 0 & 0 & 0 & 0 & 0 & 0 & 0 & 0 & 0 & 0 & 0 \\
\hline 23 & 0 & 0 & 0 & 0 & 0 & 0 & 0 & 0 & 0 & 0 & 0 & 0 \\
\hline 24 & 0 & 0 & 0 & 0 & 0 & 0 & 0 & 0 & 0 & 0 & 0 & 0 \\
\hline 25 & 0 & 0 & 0 & 0 & 0 & 0 & 0 & 0 & 0 & 0 & 0 & 0 \\
\hline 26 & 0 & 0 & 0 & 0 & 0 & 0 & 0 & 0 & 0 & 0 & 0 & 0 \\
\hline 27 & 0 & 0 & 0 & 0 & 0 & 0 & 0 & 0 & 0 & 0 & 0 & 0 \\
\hline 28 & 0 & 0 & 0 & 0 & 0 & 0 & 0 & 0 & 0 & 0 & 0 & 0 \\
\hline 29 & 0 & 0 & 0 & 0 & ----- & 0 & 0 & 0 & 0 & 0 & 0 & 0 \\
\hline 30 & 0 & 0 & 0 & 0 & $-\cdots$ & 0 & 0 & 0 & 0 & $1.5^{*}$ & 0 & 0 \\
\hline 31 & 0 & --- & 0 & 0 & ----- & 0 & ----- & 0 & ---- & $0^{*}$ & 0 & $-\cdots$ \\
\hline Total & 1.1 & 0 & 0 & 0 & 0 & 0 & 0 & 0 & 0.90 & 5.9 & 0 & 0 \\
\hline Mean & .035 & 0 & 0 & 0 & 0 & 0 & 0 & 0 & .030 & .19 & 0 & 0 \\
\hline Max & 1.1 & 0 & 0 & 0 & 0 & 0 & 0 & 0 & .54 & 3.1 & 0 & 0 \\
\hline Min & 0 & 0 & 0 & 0 & 0 & 0 & 0 & 0 & 0 & 0 & 0 & 0 \\
\hline Acre-Ft & 22 & 0 & 0 & 0 & 0 & 0 & 0 & 0 & 1.8 & 12 & 0 & 0 \\
\hline Wtr Year & 2009 & Total & 7.90 & Mean & & 22 & $\operatorname{lax}$ & 3.1 & Min & 0 & Acre-Ft & 16 \\
\hline Cal Year & 2008 & Total & 47.48 & Mean & & 13 & $\operatorname{lax}$ & 2.4 & Min & 0 & Acre-Ft & 94 \\
\hline
\end{tabular}

${ }^{*}$ Estimate 


\section{E050 Los Alamos Canyon below Los Alamos Weir}

Location. Lat $35^{\circ}$ 52' 71", long $106^{\circ}$ 13' 0.03", NE 1/4, sec. 20, T. 19N., R. 7E., Los Alamos County.

Drainage Area. $10.42 \mathrm{mi}^{2}$.

Period of Record. May 2001 to September 30, 2009.

Revised Record. Drainage Area (2006).

Gage. Data logger. Elevation of gage is 6,345 ft above NGVD from GPS survey.

Remarks. Records are good. Flows partially regulated by broad-crested weir $200 \mathrm{ft}$ upstream.

Average Discharge. $8 \mathrm{yr}, 0.19 \mathrm{ft}^{3} / \mathrm{s}, 138$ acre-ft/yr.

Extremes for Period of Record. Maximum discharge, $252 \mathrm{ft}^{3} / \mathrm{s}$ August 08, 2006, gage height $3.20 \mathrm{ft}$ (from slope area measurement). No flow most of the time.

Extremes for Current Year. Peak discharge above base of $30 \mathrm{ft}^{3} / \mathrm{s}$ and maximum (*):

\begin{tabular}{|c|c|c|c|}
\hline Date & Time & Discharge $\left(\mathbf{f t}^{\mathbf{3}} / \mathbf{s}\right)$ & Gage Height (ft) \\
\hline July 6 & 1445 & $34^{*}$ & $1.49^{*}$ \\
\hline
\end{tabular}

No flow most of the time.

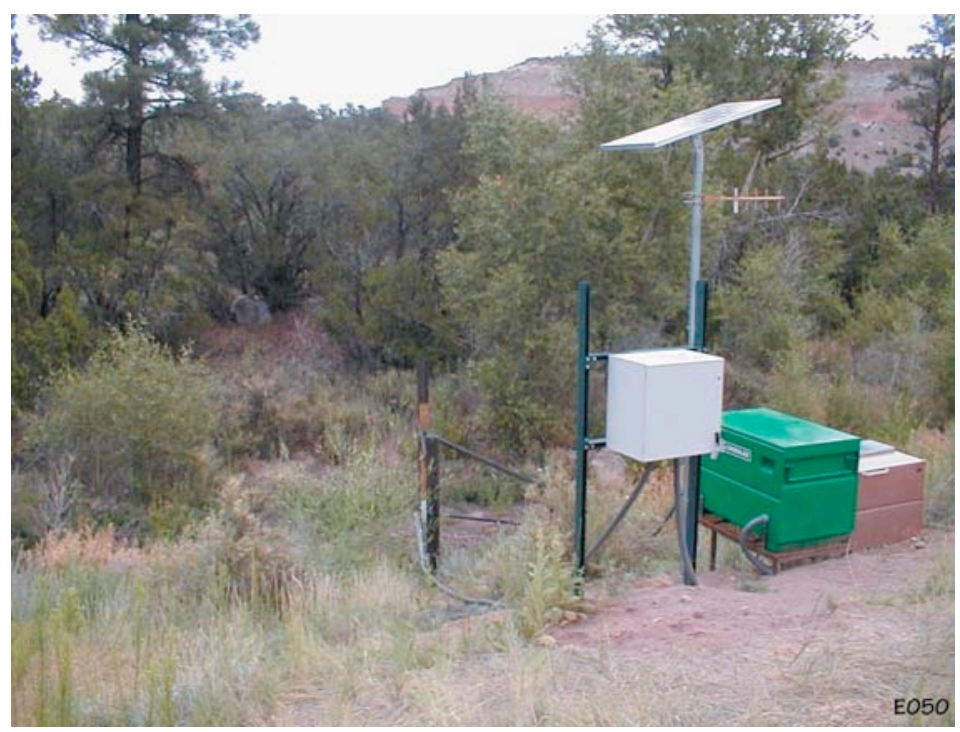




\section{E050 Los Alamos Canyon below Los Alamos Weir

\author{
Station Analysis
}

2009 Water Year

Equipment. Station is equipped with Sutron 8210 data logger (5-min. interval) and Sutron Accubar bubble sensor. Station is equipped with an ISCO pump sampler for water quality sample collection. ISCO is housed in a separate shelter, a $3^{\prime} \times 4^{\prime}$ metal box. Sampler is triggered by stage through the data logger. No provision for discharge measurements above wading stage.

Field Work. The station was visited 23 times to conduct discharge measurements and service the instrumentation. Field inspections for the gage are listed under site history files on the Hydstra database. Discharge measurements for the gage are listed under site gauging files on the Hydstra database.

Datum Correction. Levels of May 31, 2001, found gage within limits; no correction needed.

Gage-Height Record. The data logger referenced to the outside staff gave a complete and satisfactory record.

Rating. The channel is straight for $100^{\prime}$ upstream and downstream. Bed is large gravel and well armored and should not be subject to much movement. Channel is trapezoidal with little or no vegetation. Flow is regulated somewhat by detention weir just upstream.

Twenty-six inspections of no flow were made.

Rating No. 2 was developed based on all measurements made during the period of record. Shifts are small and variable. Flows are very flashy, less than an hour, daily mean discharges are very small in relation to the instantaneous peak.

Discharge. Discharge was computed from Rating No. 2 with shifts applied by stage diagram.

Remarks. Records are good. 


\section{E050 Los Alamos Canyon below Los Alamos Weir}

Daily Mean Discharge in Cubic Feet per Second

Water Year October 2008 to September 2009

\begin{tabular}{|c|c|c|c|c|c|c|c|c|c|c|c|c|}
\hline DAY & OCT & NOV & DEC & JAN & FEB & MAR & APR & MAY & JUN & JUL & AUG & SEP \\
\hline 1 & 0 & 0 & 0 & 0 & 0 & 0 & 0 & 0 & 0 & 0 & 0 & 0 \\
\hline 2 & 0 & 0 & 0 & 0 & 0 & 0 & 0 & 0 & 0 & 0 & 0 & 0 \\
\hline 3 & 0 & 0 & 0 & 0 & 0 & 0 & 0 & 0 & 0 & 0 & 0 & 0 \\
\hline 4 & 0 & 0 & 0 & 0 & 0 & 0 & 0 & 0 & 0 & 0 & 0 & 0 \\
\hline 5 & 0 & 0 & 0 & 0 & 0 & 0 & 0 & 0 & 0 & 0 & 0 & 0 \\
\hline 6 & 0 & 0 & 0 & 0 & 0 & 0 & 0 & 0 & 0 & 2.3 & 0 & 0 \\
\hline 7 & 0 & 0 & 0 & 0 & 0 & 0 & 0 & 0 & 0 & .02 & 0 & 0 \\
\hline 8 & 0 & 0 & 0 & 0 & 0 & 0 & 0 & 0 & 0 & 0 & 0 & 0 \\
\hline 9 & 0 & 0 & 0 & 0 & 0 & 0 & 0 & 0 & 0 & 0 & 0 & 0 \\
\hline 10 & 0 & 0 & 0 & 0 & 0 & 0 & 0 & 0 & 0 & 0 & 0 & 0 \\
\hline 11 & .27 & 0 & 0 & 0 & 0 & 0 & 0 & 0 & 0 & 0 & 0 & 0 \\
\hline 12 & 0 & 0 & 0 & 0 & 0 & 0 & 0 & 0 & 0 & 0 & 0 & 0 \\
\hline 13 & 0 & 0 & 0 & 0 & 0 & 0 & 0 & 0 & 0 & 0 & 0 & 0 \\
\hline 14 & 0 & 0 & 0 & 0 & 0 & 0 & 0 & 0 & 0 & 0 & 0 & 0 \\
\hline 15 & 0 & 0 & 0 & 0 & 0 & 0 & 0 & 0 & 0 & 0 & 0 & 0 \\
\hline 16 & 0 & 0 & 0 & 0 & 0 & 0 & 0 & 0 & 0 & 0 & 0 & 0 \\
\hline 17 & 0 & 0 & 0 & 0 & 0 & 0 & 0 & 0 & 0 & 0 & 0 & 0 \\
\hline 18 & 0 & 0 & 0 & 0 & 0 & 0 & 0 & 0 & 0 & 0 & 0 & 0 \\
\hline 19 & 0 & 0 & 0 & 0 & 0 & 0 & 0 & 0 & 0 & 0 & 0 & 0 \\
\hline 20 & 0 & 0 & 0 & 0 & 0 & 0 & 0 & 0 & 0 & 0 & 0 & 0 \\
\hline 21 & 0 & 0 & 0 & 0 & 0 & 0 & 0 & 0 & 0 & 0 & 0 & 0 \\
\hline 22 & 0 & 0 & 0 & 0 & 0 & 0 & 0 & 0 & 0 & 0 & 0 & 0 \\
\hline 23 & 0 & 0 & 0 & 0 & 0 & 0 & 0 & 0 & 0 & 0 & 0 & 0 \\
\hline 24 & 0 & 0 & 0 & 0 & 0 & 0 & 0 & 0 & 0 & 0 & 0 & 0 \\
\hline 25 & 0 & 0 & 0 & 0 & 0 & 0 & 0 & 0 & 0 & 0 & 0 & 0 \\
\hline 26 & 0 & 0 & 0 & 0 & 0 & 0 & 0 & 0 & 0 & 0 & 0 & 0 \\
\hline 27 & 0 & 0 & 0 & 0 & 0 & 0 & 0 & 0 & 0 & 0 & 0 & 0 \\
\hline 28 & 0 & 0 & 0 & 0 & 0 & 0 & 0 & 0 & 0 & 0 & 0 & 0 \\
\hline 29 & 0 & 0 & 0 & 0 & ---- & 0 & 0 & 0 & 0 & 0 & 0 & 0 \\
\hline 30 & 0 & 0 & 0 & 0 & 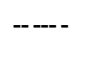 & 0 & 0 & 0 & 0 & .08 & 0 & 0 \\
\hline 31 & 0 & --.- & 0 & 0 & 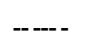 & 0 & 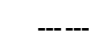 & 0 & ---- & .01 & 0 & ---- \\
\hline Total & 0.27 & 0 & 0 & 0 & 0 & 0 & 0 & 0 & 0 & 2.41 & 0 & 0 \\
\hline Mean & .009 & 0 & 0 & 0 & 0 & 0 & 0 & 0 & 0 & .078 & 0 & 0 \\
\hline Max & .27 & 0 & 0 & 0 & 0 & 0 & 0 & 0 & 0 & 2.3 & 0 & 0 \\
\hline Min & 0 & 0 & 0 & 0 & 0 & 0 & 0 & 0 & 0 & 0 & 0 & 0 \\
\hline Acre-Ft & .54 & 0 & 0 & 0 & 0 & 0 & 0 & 0 & 0 & 4.8 & 0 & 0 \\
\hline Wtr Year & 2009 & Total & 2.68 & Mean & & 07 & $\operatorname{Max}$ & 2.3 & Min & 0 & Acre-Ft & 5.3 \\
\hline Cal Year & 2008 & Total & 10.41 & Mean & & 28 & Max & 1.8 & Min & 0 & Acre- $\mathrm{Ft}$ & 21 \\
\hline
\end{tabular}




\section{E055 Pueblo Canyon above Acid Canyon}

Location. Lat $35^{\circ}$ 53' 20", long $106^{\circ}$ 18' 14", SE 1/4, Sec. 9, T 19 N., R 6 E., Los Alamos County.

Drainage Area. $3.42 \mathrm{mi}^{2}$.

Period of Record. October 1, 2002, to September 30, 2009.

Revised Record. Average discharge (2007, 2008).

Gage. Data logger. Elevation of gage is $6,945 \mathrm{ft}$ above NGVD from topographic map.

Remarks. Records are good to fair.

Average Discharge. $7 \mathrm{yr}, 0.23 \mathrm{ft}^{3} / \mathrm{s}, 167$ acre-ft/yr.

Extremes for Period Outside of Record. Maximum discharge, 1,600 $\mathrm{ft}^{3} / \mathrm{s}$ (from slopearea computation), July 2, 2001, gage height $7.3 \mathrm{ft}$ (from flood mark). No flow most of the time.

Extremes for Period of Record. Maximum discharge, 1,780 $\mathrm{ft}^{3} / \mathrm{s}$, August 8, 2006, gage height $7.50 \mathrm{ft}$ (from critical depth computation). No flow most of the time.

Extremes for Current Year. Peak discharge above base of $20 \mathrm{ft}^{3} / \mathrm{s}$ and maximum (*):

\begin{tabular}{|c|c|c|c|}
\hline Date & Time & Discharge $\left(\mathbf{f t}^{\mathbf{3}} / \mathbf{s}\right)$ & Gage Height $(\mathbf{f t})$ \\
\hline July 5 & 1225 & $34^{*}$ & $3.02^{*}$ \\
\hline
\end{tabular}

No flow most of the time.

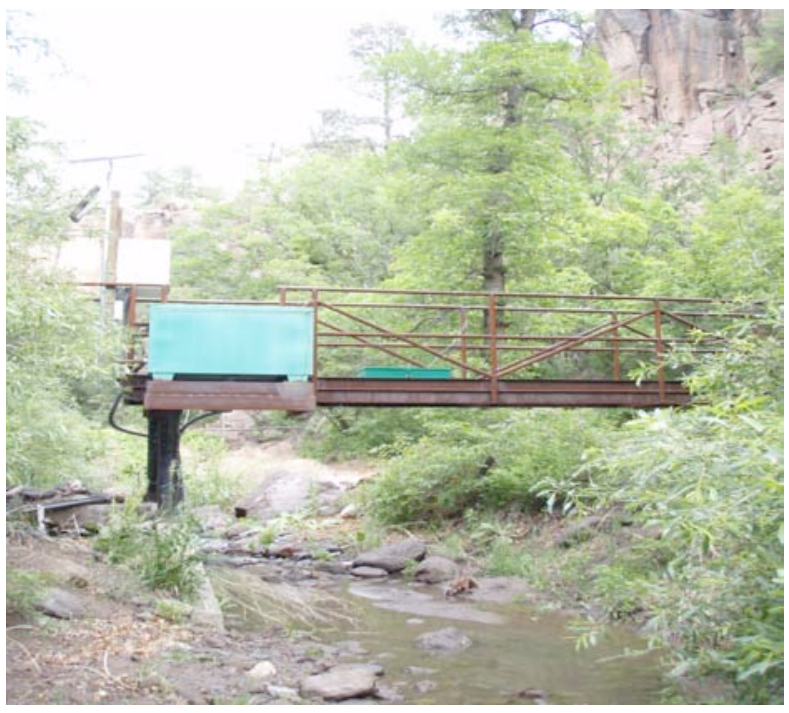




\title{
E055 Pueblo Canyon above Acid Canyon
}

\author{
Station Analysis
}

2009 Water Year

Equipment. Station is equipped with Sutron 8210 data logger (5-min. interval) and Sutron Accubar bubble sensor. System is powered by a solar panel battery system housed in a NEMA shelter. Station is equipped with ISCO pump sampler for water quality sample collection. ISCO is housed in separate shelter, a $3^{\prime} \times 4^{\prime}$ metal box. Sampler is triggered by stage through the data logger. An outside staff is available for reference. No provision for direct discharge measurements above wading stage.

Field Work. The station was visited 31 times to conduct discharge measurements and service the instrumentation. Field inspections for the gage are listed under site history files on the Hydstra database. Discharge measurements for the gage are listed under site gauging files on the Hydstra database.

Datum Correction. None.

Gage-Height Record. The data logger referenced to the outside staff gave a complete and satisfactory record, except during the period of November 30 to March 19 when ice affected gage height.

Rating. Channel comes into gage from a left to right bend and bends hard left about $100^{\prime}$ below gage. Bed consists of unstable sand and gravel with some boulders. The left bank downstream from gage is heavily wooded and that tends to hold the flow to the right, away from the reach of the gage. Lower end of any stage-discharge relation here will be unstable. The upper end could be stable, but floods and construction have enabled the flow to jump channel at the bend above the gage and allow significant flow to go down the road not in accordance with recorded gage heights. This jump out occurs at approximately $500 \mathrm{ft}^{3} / \mathrm{s}$. This channel problem was corrected in March 2007.

Five discharge measurements (Nos. 46-50) and 16 inspections of no flow were made during the year.

Rating No. 2 was developed using the current-year measurements and one critical depth measurement of $850 \mathrm{ft}^{3} / \mathrm{s}$, and various low-flow measurements from previous years. Low water definition is poor, and high end needs to be confirmed. Low end of rating was verified by dye study and used to enhance rating. Rating No. 2 is good.

Discharge. Discharge was computed using Rating No. 2 and a series of V diagrams.

Remarks. Records are good. 
E055 Pueblo Canyon above Acid Canyon

Daily Mean Discharge in Cubic Feet per Second

Water Year October 2008 to September 2009

\begin{tabular}{|c|c|c|c|c|c|c|c|c|c|c|c|c|}
\hline DAY & OCT & NOV & DEC & JAN & FEB & MAR & APR & MAY & JUN & JUL & AUG & SEP \\
\hline 1 & 0 & 0 & 0 & 0 & 0 & 0 & .10 & 0 & .09 & .01 & .08 & 0 \\
\hline 2 & 0 & 0 & 0 & 0 & 0 & 0 & .07 & 0 & .08 & 0 & .03 & $0^{*}$ \\
\hline 3 & 0 & 0 & 0 & 0 & 0 & 0 & .06 & 0 & .90 & .18 & .01 & $0^{*}$ \\
\hline 4 & 0 & .42 & 0 & 0 & 0 & 0 & .02 & 0 & .32 & .04 & 0 & $0^{*}$ \\
\hline 5 & 0 & .07 & 0 & 0 & 0 & 0 & 0 & 0 & .15 & 2.8 & 0 & $0^{*}$ \\
\hline 6 & 0 & .06 & 0 & 0 & 0 & 0 & 0 & 0 & .12 & 3.0 & 0 & $0^{*}$ \\
\hline 7 & 0 & .04 & 0 & 0 & 0 & 0 & 0 & 0 & .09 & .97 & 0 & $0^{*}$ \\
\hline 8 & 0 & 0 & 0 & 0 & 0 & 0 & 0 & 0 & .07 & .56 & 0 & $0^{*}$ \\
\hline 9 & 0 & 0 & 0 & 0 & 0 & 0 & 0 & 0 & .04 & .40 & 0 & $0^{*}$ \\
\hline 10 & 0 & 0 & 0 & 0 & 0 & 0 & 0 & 0 & .97 & .40 & 0 & $0^{*}$ \\
\hline 11 & .80 & 0 & 0 & 0 & 0 & 0 & .40 & 0 & .24 & .31 & 0 & $0^{*}$ \\
\hline 12 & .16 & 0 & 0 & 0 & 0 & 0 & .41 & 0 & .13 & .22 & 0 & $0^{*}$ \\
\hline 13 & .10 & 0 & 0 & 0 & 0 & 0 & .45 & 0 & .09 & .18 & 0 & $0^{*}$ \\
\hline 14 & .17 & 0 & 0 & 0 & 0 & 0 & .17 & 0 & .09 & .14 & .63 & $0^{*}$ \\
\hline 15 & .15 & 0 & 0 & 0 & $0^{*}$ & 0 & .14 & 0 & .10 & .07 & .10 & $0^{*}$ \\
\hline 16 & .10 & 0 & 0 & 0 & $0^{*}$ & 0 & .12 & 0 & .07 & .03 & .01 & $.05^{*}$ \\
\hline 17 & .08 & 0 & 0 & 0 & $0^{*}$ & 0 & .32 & 0 & .05 & 0 & 0 & $.24^{*}$ \\
\hline 18 & .07 & 0 & $0^{*}$ & 0 & $0^{*}$ & 0 & .30 & 0 & .02 & 0 & 0 & .12 \\
\hline 19 & .07 & 0 & $0^{*}$ & 0 & $0^{*}$ & 0 & .20 & 0 & 0 & 0 & 0 & .01 \\
\hline 20 & .06 & 0 & $0^{*}$ & 0 & $0^{*}$ & 0 & .15 & 0 & 1.4 & 0 & 0 & 0 \\
\hline 21 & .05 & 0 & $0^{*}$ & 0 & $0^{*}$ & 0 & .13 & 0 & .33 & .11 & 0 & 0 \\
\hline 22 & 0 & 0 & $0^{*}$ & 0 & $0^{*}$ & 0 & .13 & 0 & .14 & .17 & 0 & 0 \\
\hline 23 & 0 & 0 & $0^{*}$ & 0 & $0^{*}$ & 0 & .12 & .47 & .08 & .06 & 0 & 0 \\
\hline 24 & 0 & 0 & $0^{*}$ & 0 & $0^{*}$ & 0 & .12 & .22 & .06 & .02 & 0 & .34 \\
\hline 25 & 0 & 0 & $0^{*}$ & 0 & 0 & 0 & .12 & .20 & .06 & 0 & 0 & .02 \\
\hline 26 & 0 & 0 & $0^{*}$ & 0 & 0 & 0 & .12 & .12 & .14 & .62 & 0 & 0 \\
\hline 27 & 0 & 0 & $0^{*}$ & 0 & 0 & 0 & .11 & .46 & .07 & .27 & 0 & 0 \\
\hline 28 & 0 & 0 & $0^{*}$ & 0 & 0 & .05 & .10 & .29 & .06 & .23 & 0 & 0 \\
\hline 29 & 0 & 0 & 0 & 0 & ----- & .07 & .05 & .15 & .05 & .25 & 0 & 0 \\
\hline 30 & 0 & 0 & 0 & 0 & -.--- & .10 & 0 & .11 & .02 & 1.4 & .04 & 0 \\
\hline 31 & 0 & --.- & 0 & 0 & 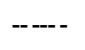 & .10 & ---- & .10 & --- & .26 & 0 & ---- \\
\hline Total & 1.81 & 0.59 & 0 & 0 & 0 & 0.32 & 3.91 & 2.12 & 6.03 & 12.70 & 0.90 & 0.78 \\
\hline Mean & .058 & .020 & 0 & 0 & 0 & .010 & .13 & .068 & .20 & .41 & .029 & .026 \\
\hline Max & .80 & .42 & 0 & 0 & 0 & .10 & .45 & .47 & 1.4 & 3.0 & .63 & .34 \\
\hline M in & 0 & 0 & 0 & 0 & 0 & 0 & 0 & 0 & 0 & 0 & 0 & 0 \\
\hline Acre-Ft & 3.6 & 1.2 & 0 & 0 & 0 & .63 & 7.8 & 4.2 & 12 & 25 & 1.8 & 1.5 \\
\hline Wtr Year & 2009 & Total & 29.16 & Mean & & 80 & $\operatorname{Max}$ & 3.0 & Min & 0 & Acre- $\mathrm{Ft}$ & 58 \\
\hline Cal Year & 2008 & Total & 9.47 & Mean & & 26 & Max & .99 & Min & 0 & Acre- $\mathrm{Ft}$ & 19 \\
\hline
\end{tabular}




\section{E0555 South Fork of Acid Canyon}

Location. Lat $35^{\circ} 53^{\prime} 10^{\prime \prime}$, long $106^{\circ}$ 18' 26", SE 1/4, Sec. 9, T 19 N., R 6 E., Los Alamos County.

Drainage Area. $0.08 \mathrm{mi}^{2}$.

Period of Record. August 18, 2004, to September 30, 2009.

Revised Record. Period of Record (this report).

Gage. Data logger with cellular telemetry. Elevation of gage is $7,100 \mathrm{ft}$ above NGVD from GPS survey.

Remarks. Records are good.

Average Discharge. $5 \mathrm{yr}, 0.03 \mathrm{ft}^{3} / \mathrm{s}, 23$ acre-ft/yr.

Extremes for Period of Record. Maximum discharge, $108 \mathrm{ft}^{3} / \mathrm{s}$, August 08, 2006, gage height $6.22 \mathrm{ft}$ (from critical depth computation). No flow most of the time.

Extremes for Current Year. Peak discharges above base of $20 \mathrm{ft}^{3} / \mathrm{s}$ and maximum (*):

\begin{tabular}{|c|c|c|c|}
\hline Date & Time & Discharge $\left(\mathbf{f t}^{\mathbf{3}} / \mathbf{s}\right)$ & Gage Height (ft) \\
\hline July 5 & 1205 & $31^{*}$ & $5.58^{*}$ \\
\hline
\end{tabular}

No flow most of the time.

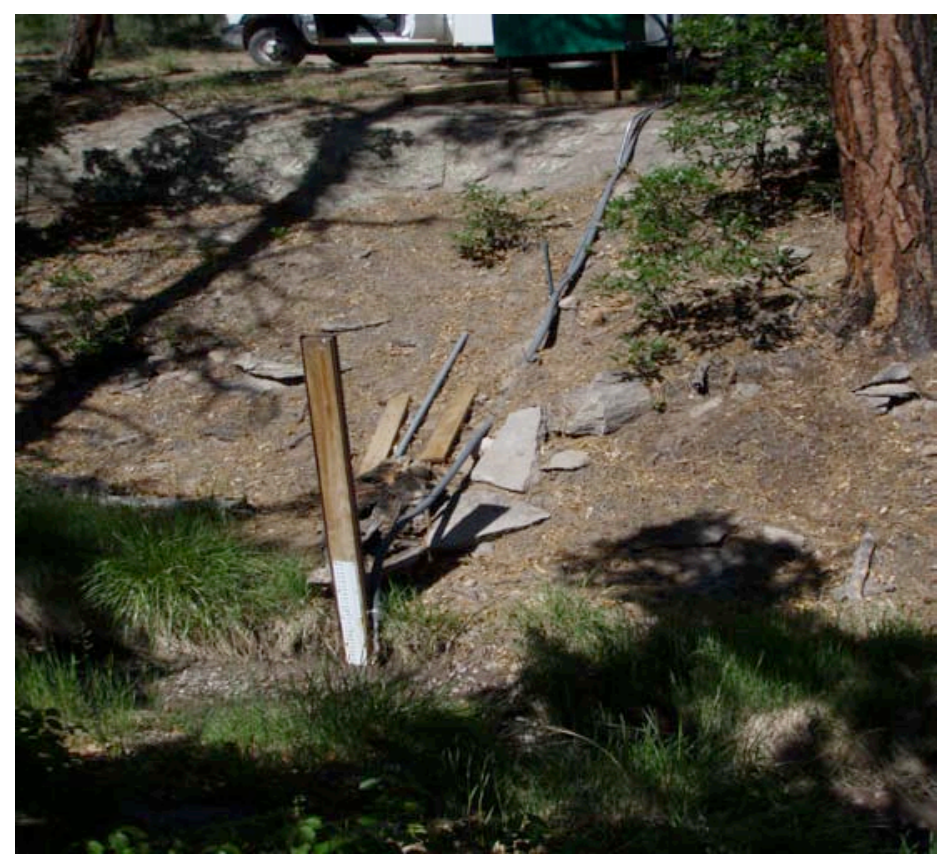




\title{
E0555 South Fork of Acid Canyon
}

\author{
Station Analysis
}

\section{Water Year}

Equipment. Station is equipped with Sutron 8210 data logger (5-min. interval) with a Sutron Accubar bubble sensor and cellular telemetry with speech modem housed in a NEMA shelter on left bank. The system is powered by a solar panel battery system. The station is equipped with ISCO pump samplers for water quality sample collection. Samples are trigged by stage through the data logger. Samplers are housed in a separate shelter, a $3^{\prime} \times 4^{\prime}$ metal box. An outside staff gage is available for reference. No provision for discharge measurements above wading stage.

Station is also equipped with a tipping bucket rain gage, Rain Collection II. All equipment is powered with a solar panel battery charging system.

Field Work. The station was visited 19 times to conduct discharge measurements and service the instrumentation. Field inspections for the gage are listed under site history files on the Hydstra database. Discharge measurements for the gage are listed under site gauging files on the Hydstra database.

Datum Correction. None. Levels from November 8, 2005, found gage within limits. No corrections needed.

Gage-Height Record. The data logger referenced to the outside staff gave a complete and satisfactory record, except for the periods from October 24 to November 18 and July 6 to August 6 when the data logger malfunctioned and December 18 and April 13-15 when gage height was affected by ice.

Rating. The channel is straight for about $75^{\prime}$ upstream and $100^{\prime}$ downstream. The channel is trapezoidal with little vegetation. Bed is rock with gravel and should not be subject to very much movement.

Twelve inspections of no flow and seven inspections of observed flow were made this year.

Rating No. 1 was developed by one discharge measurement of low flow and one slope area measurement of peak flow. Rating curve was extended to 6.22, based on a critical depth computation.

Discharge. Discharge was computed by applying Rating No. 1. Shift was applied with a $\mathrm{V}$ diagram for the entire year.

Remarks. Records are good except for estimated daily discharges, which are fair. 
E0555 South Fork of Acid Can yo n

Daily Mean Discharge in Cubic Feet per Second

Water Year October 2008 to September 2009

\begin{tabular}{|c|c|c|c|c|c|c|c|c|c|c|c|c|}
\hline DAY & OCT & NOV & DEC & JAN & FEB & MAR & APR & MAY & JUN & JUL & AUG & SEP \\
\hline 1 & 0 & $0^{*}$ & 0 & 0 & 0 & 0 & 0 & 0 & 0 & 0 & $0^{*}$ & 0 \\
\hline 2 & 0 & $0^{*}$ & 0 & 0 & 0 & 0 & 0 & 0 & 0 & 0 & $0^{*}$ & 0 \\
\hline 3 & 0 & $0^{*}$ & 0 & 0 & 0 & 0 & 0 & 0 & .02 & 0 & $0^{*}$ & 0 \\
\hline 4 & 0 & $0^{*}$ & 0 & 0 & 0 & 0 & 0 & 0 & 0 & 0 & $0^{*}$ & 0 \\
\hline 5 & .01 & $0^{*}$ & 0 & 0 & 0 & 0 & 0 & 0 & 0 & .59 & $0^{*}$ & 0 \\
\hline 6 & .01 & $0^{*}$ & 0 & 0 & 0 & 0 & 0 & 0 & 0 & $.35^{*}$ & $0^{*}$ & 0 \\
\hline 7 & 0 & $0^{*}$ & 0 & 0 & 0 & 0 & 0 & 0 & 0 & $.20^{*}$ & 0 & 0 \\
\hline 8 & 0 & $0^{*}$ & 0 & 0 & 0 & 0 & 0 & 0 & 0 & $.10^{*}$ & 0 & 0 \\
\hline 9 & 0 & $0^{*}$ & 0 & 0 & 0 & 0 & 0 & 0 & 0 & $.05^{\star}$ & 0 & 0 \\
\hline 10 & 0 & $0^{*}$ & 0 & 0 & 0 & 0 & 0 & 0 & .02 & $.01^{*}$ & 0 & 0 \\
\hline 11 & 0 & $.10^{\star}$ & 0 & 0 & 0 & 0 & .03 & 0 & 0 & $0^{*}$ & 0 & 0 \\
\hline 12 & .02 & $.02^{*}$ & 0 & 0 & 0 & 0 & .01 & 0 & 0 & $0^{*}$ & 0 & 0 \\
\hline 13 & .01 & $.01^{*}$ & 0 & 0 & 0 & 0 & $0^{*}$ & 0 & 0 & $0^{*}$ & 0 & 0 \\
\hline 14 & .01 & $.01^{*}$ & 0 & 0 & 0 & 0 & $0^{*}$ & 0 & .01 & $0^{*}$ & .02 & 0 \\
\hline 15 & .01 & $0^{*}$ & 0 & 0 & 0 & 0 & $0^{*}$ & 0 & 0 & $0^{*}$ & 0 & 0 \\
\hline 16 & 0 & $0^{*}$ & 0 & 0 & 0 & 0 & 0 & 0 & 0 & $0^{*}$ & 0 & .01 \\
\hline 17 & 0 & $0^{*}$ & 0 & 0 & 0 & 0 & 0 & 0 & 0 & $0^{*}$ & 0 & 0 \\
\hline 18 & 0 & $0^{*}$ & $0^{*}$ & 0 & 0 & 0 & 0 & 0 & 0 & $0^{*}$ & 0 & 0 \\
\hline 19 & 0 & 0 & 0 & 0 & 0 & 0 & 0 & 0 & 0 & $0^{*}$ & 0 & 0 \\
\hline 20 & 0 & 0 & 0 & 0 & 0 & 0 & 0 & 0 & .03 & $.01^{*}$ & 0 & 0 \\
\hline 21 & 0 & 0 & 0 & 0 & 0 & 0 & 0 & 0 & 0 & $0^{*}$ & 0 & 0 \\
\hline 22 & 0 & 0 & 0 & 0 & 0 & 0 & 0 & 0 & 0 & $0^{*}$ & 0 & 0 \\
\hline 23 & 0 & 0 & 0 & 0 & 0 & 0 & 0 & .03 & 0 & $0^{*}$ & 0 & .01 \\
\hline 24 & $0^{*}$ & 0 & 0 & 0 & 0 & 0 & 0 & .01 & 0 & $0^{*}$ & 0 & 0 \\
\hline 25 & $0^{*}$ & 0 & 0 & 0 & 0 & 0 & 0 & 0 & .01 & $0^{*}$ & 0 & 0 \\
\hline 26 & $0^{*}$ & 0 & 0 & 0 & 0 & 0 & 0 & 0 & 0 & $.04^{\star}$ & 0 & 0 \\
\hline 27 & $0^{*}$ & .02 & 0 & 0 & 0 & $0^{*}$ & 0 & 0 & 0 & $.03^{*}$ & 0 & 0 \\
\hline 28 & $0^{*}$ & 0 & 0 & 0 & 0 & 0 & 0 & 0 & 0 & $.03^{*}$ & 0 & 0 \\
\hline 29 & $0^{*}$ & 0 & 0 & 0 & -.--- & 0 & 0 & 0 & 0 & $.05^{\star}$ & 0 & 0 \\
\hline 30 & $0^{*}$ & 0 & 0 & 0 & -..-- & 0 & 0 & 0 & 0 & $.01^{*}$ & .03 & 0 \\
\hline 31 & $0^{*}$ & ---- & 0 & 0 & ----- & 0 & ----- & 0 & --- & $0^{*}$ & 0 & ---- \\
\hline Total & 0.07 & 0.16 & 0 & 0 & 0 & 0 & 0.04 & 0.04 & 0.09 & 1.47 & 0.05 & 0.02 \\
\hline Mean & .002 & .005 & 0 & 0 & 0 & 0 & .001 & .001 & .003 & .047 & .002 & .001 \\
\hline $\operatorname{Max}$ & .02 & .10 & 0 & 0 & 0 & 0 & .03 & .03 & .03 & .59 & .03 & .01 \\
\hline M in & 0 & 0 & 0 & 0 & 0 & 0 & 0 & 0 & 0 & 0 & 0 & 0 \\
\hline Acre-F t & .14 & .32 & 0 & 0 & 0 & 0 & .08 & .08 & .18 & 2.9 & .10 & .04 \\
\hline Wtr Year & 2009 & Total & 1.94 & Mean & & 05 & $\operatorname{Max}$ & .59 & Min & 0 & Acre- $\mathrm{Ft}$ & 3.8 \\
\hline Cal Year & 2008 & Total & 0.23 & Mean & & 03 & Max & .10 & Min & 0 & Acre- $\mathrm{Ft}$ & .46 \\
\hline
\end{tabular}




\section{E056 Acid Canyon above Pueblo Canyon}

Location. Lat $35^{\circ} 53^{\prime}$ 19", long $106^{\circ} 18^{\prime} 14^{\prime \prime}$ SE 1/4, Sec. 9, T 19 N., R 6 E., Los Alamos County.

Drainage Area. $0.452 \mathrm{mi}^{2}$.

Period of Record. October 1, 2006, to September 30, 2009.

Revised Record. Period of Record (2008).

Gage. Data logger. Elevation of gage is 6,944 above NGVD.

Remarks. Records are fair to poor. Records for this site existed before period of record but are not reliable.

Extremes for Period of Record. Maximum discharge, $263 \mathrm{ft}^{3} / \mathrm{s}$, July 5, 2009, gage height $3.63 \mathrm{ft}$. No flow most of the time.

Extremes for Current Year. Peak discharges above base of $50 \mathrm{ft}^{3} / \mathrm{s}$ and maximum (*):

\begin{tabular}{|c|c|c|c|}
\hline Date & Time & Discharge $\left(\mathbf{f t}^{\mathbf{3}} / \mathbf{s}\right)$ & Gage Height $(\mathbf{f t})$ \\
\hline July 5 & 1225 & $263^{*}$ & $3.63^{*}$ \\
\hline
\end{tabular}

No flow most of the time.

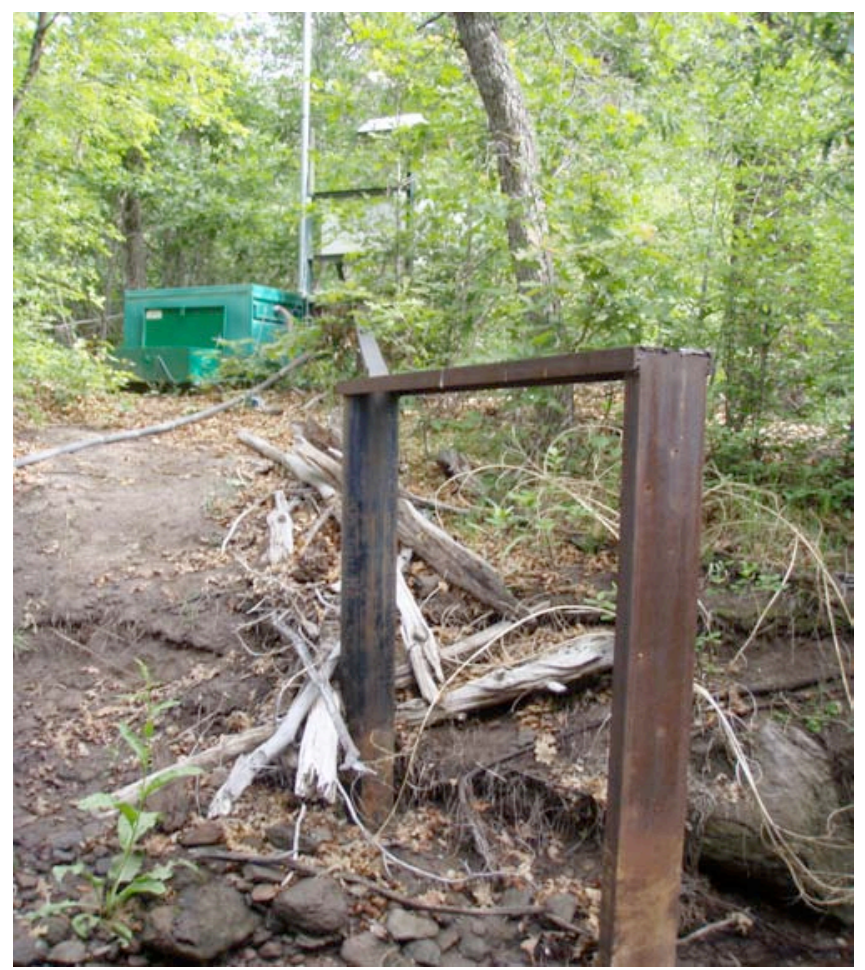




\title{
E056 Acid Canyon above Pueblo Canyon
}

\author{
Station Analysis \\ 2009 Water Year
}

Equipment. Station is equipped with Sutron 8210 data logger (5-min. interval) with a Sutron Accubar bubble sensor mounted on a 6" channel cantilevered over streambed. The system is powered by a solar panel battery system housed in a NEMA shelter. Station is equipped with an ISCO pump sampler for water quality sample collection. ISCO is housed in a separate shelter, a $3^{\prime} \times 4^{\prime}$ metal box. Sampler is triggered by stage through the data logger. Outside staff is available for reference. No provisions for measurements above wading stage.

Field Work. The station was visited 32 times to conduct discharge measurements and service the instrumentation. Field inspections for the gage are listed under site history files on the Hydstra database. Discharge measurements for the gage are listed under site gauging files on the Hydstra database.

Datum Correction. None. Levels from June 6, 2006. Gage is within acceptable limits.

Gage-Height Record. The data logger referenced to the outside staff gave a complete and satisfactory record for the year, except for the period from November 28 to December 2 when gage height was affected by ice.

Rating. The channel is about $20^{\prime}$ wide and straight for about $15^{\prime}$ upstream and about $40^{\prime}$ downstream and 20' above the confluence of Pueblo Canyon. The streambed through this reach is primarily sand and cobbles. The low-water control is a $90^{\circ}$ sharp-crested weir. At high flow, the channel becomes the control.

Ten discharge measurements (Nos. 19-25) and seven visits of no flow. All inspections of no flow were used to develop a V diagram shift needed to adjust for PZF.

Rating No. 2 is based on four discharge measurements and six indirect measurements made by concurrent dye study at site. Shifts were applied to low flow using V diagrams.

Discharge. Discharge was computed by applying gage height to Rating No. 2 through shift adjustment based on $\mathrm{V}$ diagrams. Estimated daily discharges were based on precipitation record, field notes, and some comparison with E0555.

Remarks. Records are fair. 
E056 Acid Canyon above Pueblo Canyon

Daily Mean Discharge in Cubic Feet per Second

Water Year October 2008 to September 2009

\begin{tabular}{|c|c|c|c|c|c|c|c|c|c|c|c|c|}
\hline DAY & ОСТ & NOV & DEC & JAN & FEB & MAR & APR & MAY & JUN & JUL & AUG & SEP \\
\hline 1 & 0 & 0 & $0^{*}$ & 0 & 0 & 0 & 0 & .05 & .06 & 0 & .02 & .04 \\
\hline 2 & 0 & 0 & $0^{*}$ & 0 & 0 & 0 & 0 & .04 & .06 & 0 & .03 & .04 \\
\hline 3 & .01 & 0 & 0 & 0 & 0 & 0 & 0 & .04 & .10 & 0 & .04 & .04 \\
\hline 4 & .01 & 0 & 0 & 0 & 0 & 0 & 0 & .03 & .04 & 0 & .04 & .03 \\
\hline 5 & .01 & 0 & 0 & 0 & 0 & 0 & 0 & .03 & .04 & 5.1 & 0 & .03 \\
\hline 6 & .01 & 0 & 0 & 0 & 0 & 0 & 0 & .01 & .04 & .18 & 0 & .03 \\
\hline 7 & .01 & 0 & 0 & 0 & 0 & 0 & 0 & 0 & .03 & .03 & 0 & .03 \\
\hline 8 & .02 & 0 & 0 & 0 & 0 & 0 & 0 & 0 & .03 & .06 & 0 & .03 \\
\hline 9 & .02 & 0 & 0 & 0 & 0 & 0 & 0 & 0 & .02 & .07 & 0 & .03 \\
\hline 10 & .02 & 0 & 0 & 0 & 0 & 0 & 0 & 0 & .11 & .07 & .03 & .03 \\
\hline 11 & .07 & 0 & 0 & 0 & 0 & 0 & 0 & 0 & .03 & .07 & .08 & .03 \\
\hline 12 & .02 & 0 & 0 & 0 & 0 & 0 & 0 & 0 & .03 & .07 & .08 & .03 \\
\hline 13 & .03 & 0 & 0 & 0 & 0 & 0 & 0 & 0 & .03 & .07 & .07 & .03 \\
\hline 14 & .02 & 0 & 0 & 0 & 0 & 0 & 0 & 0 & .02 & .08 & .10 & .03 \\
\hline 15 & .02 & 0 & 0 & 0 & 0 & 0 & 0 & 0 & .02 & .07 & .06 & .02 \\
\hline 16 & .03 & 0 & 0 & 0 & 0 & 0 & 0 & 0 & .02 & .06 & .06 & .01 \\
\hline 17 & .03 & 0 & 0 & 0 & 0 & 0 & 0 & 0 & .02 & .05 & .05 & 0 \\
\hline 18 & .03 & 0 & 0 & 0 & 0 & 0 & 0 & 0 & .02 & .04 & .05 & .01 \\
\hline 19 & .03 & 0 & 0 & 0 & 0 & 0 & 0 & 0 & .02 & .03 & .04 & .01 \\
\hline 20 & .02 & 0 & 0 & 0 & 0 & 0 & 0 & 0 & .11 & .02 & .04 & .02 \\
\hline 21 & .02 & 0 & 0 & 0 & 0 & 0 & 0 & 0 & .02 & .01 & .04 & .03 \\
\hline 22 & .02 & 0 & 0 & 0 & 0 & 0 & 0 & 0 & .02 & 0 & .04 & .03 \\
\hline 23 & .01 & 0 & 0 & 0 & 0 & 0 & 0 & .05 & .03 & 0 & .04 & .03 \\
\hline 24 & .01 & 0 & 0 & 0 & 0 & 0 & 0 & .03 & .03 & 0 & .04 & .05 \\
\hline 25 & .01 & 0 & 0 & 0 & 0 & 0 & .01 & .03 & .03 & 0 & .04 & .03 \\
\hline 26 & .01 & 0 & 0 & 0 & 0 & 0 & .01 & .03 & .03 & .04 & .04 & .04 \\
\hline 27 & 0 & 0 & 0 & 0 & 0 & 0 & .01 & .05 & .03 & .03 & .04 & .04 \\
\hline 28 & 0 & $0^{*}$ & 0 & 0 & 0 & 0 & .03 & .04 & .03 & .03 & .04 & .04 \\
\hline 29 & 0 & $0^{*}$ & 0 & 0 & --.-- & 0 & .05 & .06 & .03 & .01 & .04 & .04 \\
\hline 30 & 0 & $0^{*}$ & 0 & 0 & --.-- & 0 & .05 & .06 & .02 & .08 & .05 & .04 \\
\hline 31 & 0 & ----- & 0 & 0 & -.--- & 0 & ----- & .06 & --.-- & .01 & .04 & ---- \\
\hline Total & 0.49 & 0 & 0 & 0 & 0 & 0 & 0.16 & 0.61 & 1.12 & 6.28 & 1.24 & 0.89 \\
\hline Mean & .016 & 0 & 0 & 0 & 0 & 0 & .005 & .020 & .037 & .20 & .040 & .030 \\
\hline Max & .07 & 0 & 0 & 0 & 0 & 0 & .05 & .06 & .11 & 5.1 & .10 & .05 \\
\hline Min & 0 & 0 & 0 & 0 & 0 & 0 & 0 & 0 & .02 & 0 & 0 & 0 \\
\hline Acre-Ft & .97 & 0 & 0 & 0 & 0 & 0 & .32 & 1.2 & 2.2 & 12 & 2.5 & 1.8 \\
\hline Wtr Year & 2009 & Total & 10.79 & Mean & & 30 & $\operatorname{lax}$ & 5.1 & Min & 0 & Acre- $\mathrm{Ft}$ & 21 \\
\hline Cal Year & 2008 & Total & 3.42 & Mean & & 09 & $\operatorname{lax}$ & 1.9 & Min & 0 & Acre-Ft & 6.8 \\
\hline
\end{tabular}


Location. Lat $35^{\circ} 52^{\prime} 15^{\prime \prime}$, long $106^{\circ} 13^{\prime}$ 1", NE 1/4, Sec. 20, T. 19 N., R. 7 E., Santa Fe County.

Drainage Area. $8.21 \mathrm{mi}^{2}$.

Period of Record. January 1992 to September 30, 2009.

Revised Record. Drainage area (2006).

Gage. Data logger with cellular telemetry. Elevation of gage is $6,341 \mathrm{ft}$ above NGVD from GPS survey.

Remarks. Records are fair. No diversion above station. Perennial flow is primarily from effluent.

Average Discharge. $15 \mathrm{yr}, 0.051 \mathrm{ft}^{3} / \mathrm{s}, 591$ acre- $\mathrm{ft} / \mathrm{yr}$.

Extremes for Period of Record. Maximum discharge, 1,930 $\mathrm{ft}^{3} / \mathrm{s}$, August 24, 2006, gage height $11.75 \mathrm{ft}$ (from slope area measurement). Rating curve extended above 130 $\mathrm{ft}^{3} / \mathrm{s}$ on basis of slope area measurement. No flow at times.

Extremes for Current Water Year. Maximum discharge $4.2 \mathrm{ft}^{3} / \mathrm{s}$ at $2050 \mathrm{~h}$, July 6 , gage height $7.89 \mathrm{ft}$. No peak above base of $75 \mathrm{ft}^{3} / \mathrm{s}$. No flow at times.

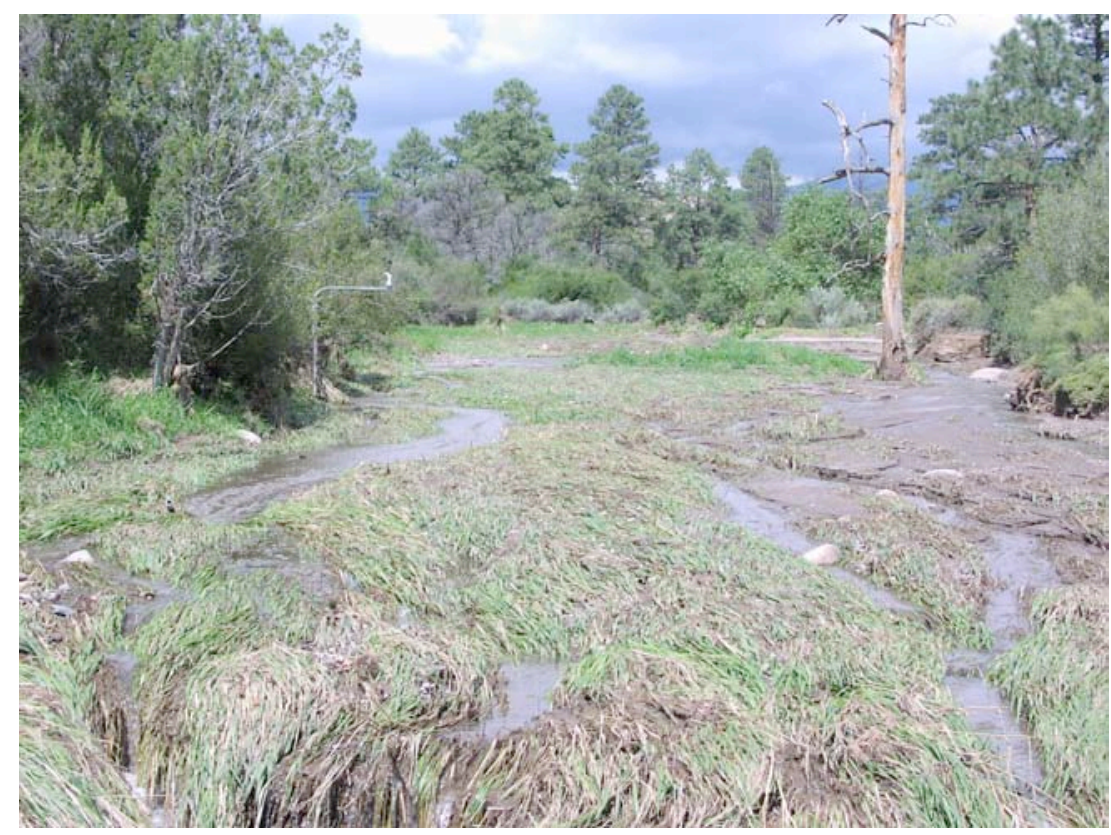




\section{E060 Pueblo Canyon above SR 502}

\section{Station Analysis \\ 2009 Water Year}

Equipment. Station is equipped with Sutron 8210 data logger (5-min. interval) with a Sutron Accubar bubble sensor housed in a NEMA shelter on right bank. The station is also equipped with a pair of ISCO samplers for water quality sample collection. ISCO is housed in a separate shelter, a $3^{\prime} \times 4^{\prime}$ metal box. Sampler is triggered by stage through the data logger. An outside staff is available for reference gage. No provision for discharge measurements above wading stage.

An auxiliary 6" Parshall flume is located downstream from E060 used to verify the low-flow record.

Field Work. This station was visited 28 times to conduct discharge measurements and service the instrumentation. Field inspections for the gage are listed under site history files on the Hydstra database. Discharge measurements for the gage are listed under site gauging files on the Hydstra database.

Datum Correction. None. Levels of May 7, 2007, found gage to be correct.

Gage-Height Record. The data logger referenced to the outside staff gave a complete and satisfactory record, except for several periods throughout the winter and spring when gage height was affected by ice or silting.

Rating. Channel consists of sand gravel with hard pan bed. Sand degrades easily and will change with flow events. Channel is straight at high flow but incised in sand and meandering at low flow. Channel bottom elevation or PZF may change many times throughout the year and is critical in determining shift values. Grasses become 4-5' tall and cause considerable backwater at most stages. These grasses are usually flattened at high flow.

Three discharge measurements (Nos. 126-128) and eight inspections of no flow were made this year.

Rating No. 8 was developed based on measurements from previous years. The upper end of the rating is based on slope area measurement from the previous year.

Measuring conditions at this site are poor. Generally, low flows are shallow and characterized by high velocities and uneven measuring sections. Peak flows are flashy and change quickly; mean gage heights for measurements are difficult to determine.

Discharge. Discharge was computed by applying gage height to Rating No. 8 using V diagram.

Remarks. Records are fair except for estimated daily discharges, which are poor. 


\section{E060 Pueblo ab ove SR-502}

Daily Mean Discharge in Cubic Feet per Second

Water Year October 2008 to September 2009

\begin{tabular}{|c|c|c|c|c|c|c|c|c|c|c|c|c|}
\hline DAY & OCT & NOV & DEC & JAN & FEB & MAR & APR & MAY & JUN & JUL & AUG & SEP \\
\hline 1 & 0 & 0 & 0 & $0^{*}$ & .07 & .49 & $.11^{*}$ & $.01^{\star}$ & 0 & 0 & 0 & 0 \\
\hline 2 & 0 & 0 & 0 & $0^{*}$ & 0 & $.45^{*}$ & $.05^{*}$ & $.01^{*}$ & 0 & 0 & 0 & 0 \\
\hline 3 & 0 & 0 & 0 & $0^{*}$ & $.05^{\star}$ & .42 & $.02^{*}$ & $.01^{*}$ & $.01^{*}$ & 0 & 0 & 0 \\
\hline 4 & 0 & 0 & 0 & $0^{*}$ & 0 & .30 & 0 & 0 & $.03^{\star}$ & 0 & 0 & 0 \\
\hline 5 & 0 & 0 & 0 & $0^{*}$ & $.05^{\star}$ & 0 & $.04^{*}$ & 0 & $.06^{*}$ & 0 & 0 & 0 \\
\hline 6 & 0 & 0 & 0 & .29 & $.05^{\star}$ & 0 & .08 & 0 & $.01^{*}$ & .52 & 0 & 0 \\
\hline 7 & 0 & .01 & .03 & .24 & .04 & .04 & $.08^{*}$ & 0 & $.02^{*}$ & .63 & 0 & 0 \\
\hline 8 & 0 & .07 & .12 & .35 & $.08^{*}$ & $.10^{*}$ & $.01^{*}$ & 0 & $.02^{\star}$ & .51 & 0 & 0 \\
\hline 9 & 0 & .08 & .02 & .35 & $.08^{*}$ & $.20^{*}$ & 0 & 0 & 0 & .05 & 0 & 0 \\
\hline 10 & 0 & $.08^{*}$ & 0 & .26 & .10 & $.10^{*}$ & $.02^{*}$ & 0 & 0 & 0 & 0 & 0 \\
\hline 11 & .01 & $.08^{*}$ & 0 & $.10^{*}$ & .08 & $.05^{*}$ & $.21^{*}$ & 0 & $0^{*}$ & 0 & 0 & 0 \\
\hline 12 & 0 & $0^{*}$ & .02 & $.08^{*}$ & $.05^{\star}$ & $.01^{*}$ & $.09^{*}$ & 0 & $.01^{*}$ & 0 & 0 & 0 \\
\hline 13 & 0 & 0 & .17 & .12 & $.05^{\star}$ & .39 & $.09^{*}$ & 0 & $.01^{*}$ & 0 & 0 & 0 \\
\hline 14 & 0 & 0 & .13 & $.12^{*}$ & .01 & $.25^{*}$ & $.12^{*}$ & 0 & 0 & 0 & 0 & 0 \\
\hline 15 & 0 & 0 & .12 & .12 & 0 & $.25^{*}$ & $.08^{*}$ & 0 & 0 & 0 & 0 & 0 \\
\hline 16 & 0 & 0 & .02 & .10 & .05 & $.20^{*}$ & $.07^{*}$ & 0 & $.03^{*}$ & 0 & 0 & 0 \\
\hline 17 & 0 & 0 & .07 & $.08^{*}$ & $.10^{*}$ & .14 & $.16^{*}$ & 0 & $.01^{*}$ & 0 & 0 & 0 \\
\hline 18 & 0 & 0 & .02 & $.08^{*}$ & $.05^{*}$ & .02 & $.15^{*}$ & 0 & 0 & 0 & 0 & 0 \\
\hline 19 & 0 & 0 & 0 & .08 & $.05^{*}$ & 0 & $.09^{*}$ & 0 & 0 & 0 & 0 & 0 \\
\hline 20 & 0 & 0 & .02 & .15 & $.01^{*}$ & $.03^{*}$ & $.11^{*}$ & 0 & 0 & 0 & 0 & 0 \\
\hline 21 & 0 & $0^{*}$ & 0 & $.05^{\star}$ & $.05^{\star}$ & 0 & $.05^{*}$ & 0 & 0 & 0 & 0 & 0 \\
\hline 22 & 0 & .08 & .08 & $.08^{*}$ & $.08^{*}$ & 0 & $.02^{*}$ & 0 & 0 & 0 & 0 & 0 \\
\hline 23 & 0 & .13 & .20 & $.08^{*}$ & $.05^{\star}$ & $.03^{*}$ & $.01^{*}$ & 0 & 0 & 0 & 0 & 0 \\
\hline 24 & 0 & $.05^{*}$ & .07 & $.15^{\star}$ & .52 & $.11^{*}$ & $.01^{*}$ & 0 & 0 & 0 & 0 & 0 \\
\hline 25 & 0 & $.05^{*}$ & .07 & $.15^{\star}$ & .64 & $.15^{*}$ & $.01^{*}$ & 0 & 0 & 0 & 0 & 0 \\
\hline 26 & 0 & .05 & .04 & $0^{*}$ & .62 & $.19^{*}$ & $.01^{*}$ & 0 & 0 & 0 & 0 & 0 \\
\hline 27 & 0 & $.05^{*}$ & .08 & $0^{*}$ & .60 & $.25^{\star}$ & $.01^{*}$ & 0 & 0 & 0 & 0 & 0 \\
\hline 28 & 0 & 0 & $.59^{*}$ & $0^{*}$ & .53 & $.19^{*}$ & $.01^{*}$ & $.01^{*}$ & 0 & 0 & 0 & 0 \\
\hline 29 & 0 & 0 & $.05^{*}$ & 0 & --- & $.18^{*}$ & $.01^{*}$ & $.02^{*}$ & 0 & 0 & 0 & 0 \\
\hline 30 & 0 & 0 & $.05^{*}$ & .10 & --- & $.05^{*}$ & $.01^{*}$ & $.01^{*}$ & 0 & 0 & 0 & 0 \\
\hline 31 & 0 & --- & $.05^{\star}$ & .08 & $-\cdots$ & $.13^{*}$ & ----- & $.01^{*}$ & --- & 0 & 0 & ----- \\
\hline Total & 0.01 & 0.73 & 2.02 & 3.21 & 4.06 & 4.72 & 1.73 & 0.08 & 0.21 & 1.71 & 0 & 0 \\
\hline Mean & 0 & .024 & .065 & .10 & .15 & .15 & .058 & .003 & .007 & .055 & 0 & 0 \\
\hline Max & .01 & .13 & .59 & .35 & .64 & .49 & .21 & .02 & .06 & .63 & 0 & 0 \\
\hline M in & 0 & 0 & 0 & 0 & 0 & 0 & 0 & 0 & 0 & 0 & 0 & 0 \\
\hline cre-F t & .02 & 1.4 & 4.0 & 6.4 & 8.1 & 9.4 & 3.4 & .16 & .42 & 3.4 & 0 & 0 \\
\hline Wtr Year & 2009 & Total & 18.48 & Mean & & 051 & Max & .64 & Min & 0 & Acre- $\mathrm{Ft}$ & 37 \\
\hline Cal Year & 2008 & Total & 75.92 & Mean & & .21 & $\operatorname{Max}$ & .92 & Min & 0 & Acre- $\mathrm{Ft}$ & 151 \\
\hline
\end{tabular}

${ }^{\star}$ Estimate 


\section{E121 Sandia Canyon Right Fork at Power Plant}

Location. Lat $35^{\circ} 52^{\prime} 31^{\prime \prime}$, long $106^{\circ} 19^{\prime} 7^{\prime \prime}$, SW 1/4, Sec. 16, T. 19 N., R. 6 E., Los Alamos County.

Drainage Area. $0.08 \mathrm{mi}^{2}$.

Period of Record. October 1, 2006, to September 30, 2009.

Revised Record. Period of Record (2008).

Gage. Data logger. Elevation of gage is 7,283, $\mathrm{ft}$ above NGVD from GPS survey.

Remarks. Records are good. Records for this site existed before period of record but are not reliable.

Extremes for Period of Record. Maximum discharge, $191 \mathrm{ft}^{3} / \mathrm{s}$, June 21, 2002, from peak flow computation, gage height $8.13 \mathrm{ft}$. Minimum daily discharge $0.05 \mathrm{ft}^{3} / \mathrm{s}$, August 12, 2008.

Extremes for Current Year. Peak discharges above $35 \mathrm{ft}^{3} / \mathrm{s}$ and maximum (*):

\begin{tabular}{|c|c|c|c|}
\hline Date & Time & Discharge $\left(\mathbf{f t}^{\mathbf{3}} / \mathbf{s}\right)$ & Gage Height (ft) \\
\hline July 5 & 1220 & $42^{*}$ & $6.62^{*}$ \\
\hline July 6 & 1225 & 39 & 6.57 \\
\hline
\end{tabular}

Minimum daily discharge, $0.18 \mathrm{ft}^{3} / \mathrm{s}$ August 25 .

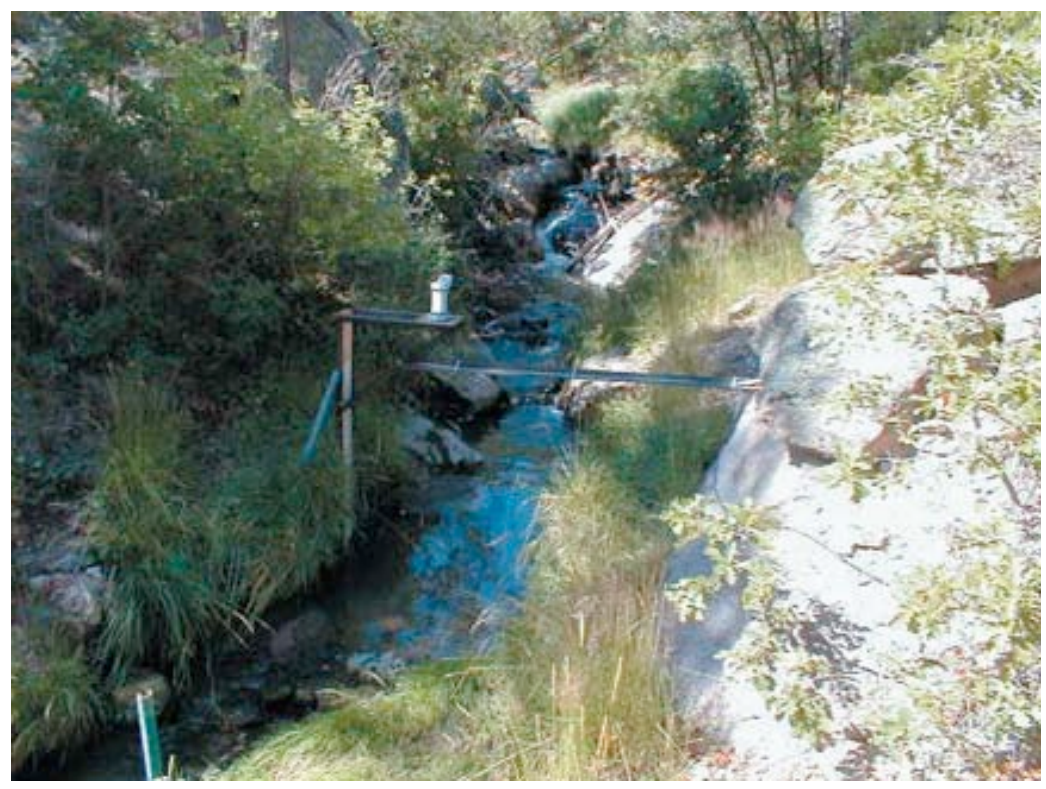




\title{
E121 Sandia Canyon Right Fork at Power Plant
}

\author{
Station Analysis
}

\section{Water Year}

Equipment. Station is equipped with Sutron 8210 data logger (5-min. interval) with a Sutron Accubar bubble sensor. System is powered by a solar panel battery system housed in a NEMA shelter. Station is equipped with an ISCO pump sampler for water quality sample collection. ISCO is housed in a separate shelter, a $3^{\prime} \times 4^{\prime}$ metal box. Sampler is triggered by stage through the data logger. An outside staff is available for reference. No provision for direct measurements above wading stage.

Field Work. The station was visited 21 times to conduct discharge measurements and service the instrumentation. Field inspections for the gage are listed under site history files on the Hydstra database. Discharge measurements for the gage are listed under site gauging files on the Hydstra database.

Datum Correction. None.

Gage-Height. The data logger reference to the outside staff gave a complete and satisfactory record for the year, except for the period from December 2 and 3 when gage height was affected by ice.

Rating. The channel is straight for about $30^{\prime}$ with a step upstream slope and straight for $50^{\prime}$ downstream with a sharp slope downstream. The streambed through this reach consists of primarily sand, gravel, and cobbles, more so below the gage. The low-water control is a bedrock riffle below gage.

Four discharge measurements (Nos. 82-85) were made during the year. Discharge measurements were used to define a V diagram. Range in stage is fairly limited because most flow is effluent.

Rating No. 4 was developed based on previous measurements verified with current-year measurements.

Discharge. Discharge was computed by applying Rating No. 4 with variable shifts defined by measurements and applied by V diagram. No shifts were applied to high flows.

Remarks. Records are good. 
E121 Sand ia Canyon Right Fork at Power Plant

Daily Mean Discharge in Cubic Feet per Second

Water Year October 2008 to September 2009

\begin{tabular}{|c|c|c|c|c|c|c|c|c|c|c|c|c|}
\hline DAY & OCT & NOV & DEC & JAN & FE B & MAR & APR & MAY & JUN & JUL & AUG & SEP \\
\hline 1 & .53 & .56 & .48 & .43 & .66 & .67 & .57 & .49 & .53 & .51 & .49 & .44 \\
\hline 2 & .47 & .61 & $.37^{*}$ & .46 & .75 & .79 & .53 & .44 & .59 & .58 & .43 & .59 \\
\hline 3 & .57 & .52 & $.45^{\star}$ & .49 & .60 & .61 & .49 & .46 & 1.3 & .61 & .48 & .52 \\
\hline 4 & .56 & .56 & .45 & .44 & .62 & .61 & .59 & .47 & .66 & .61 & .49 & .52 \\
\hline 5 & .59 & .54 & .47 & .58 & .64 & .66 & .61 & .44 & .66 & 1.1 & .47 & .48 \\
\hline 6 & .48 & .50 & .48 & .43 & .61 & .66 & .53 & .42 & .71 & 1.1 & .47 & .57 \\
\hline 7 & .50 & .50 & .42 & .42 & .66 & .76 & .61 & .51 & .68 & .52 & .45 & .64 \\
\hline 8 & .53 & .53 & .44 & .46 & .65 & .81 & .46 & .50 & .66 & .49 & .53 & .58 \\
\hline 9 & .34 & .63 & .43 & .44 & .68 & .81 & .53 & .59 & .65 & .49 & .46 & .58 \\
\hline 10 & .45 & .58 & .46 & .46 & .70 & .84 & .53 & .44 & 1.0 & .48 & .48 & .59 \\
\hline 11 & 1.5 & .48 & .45 & .56 & .62 & .84 & .65 & .51 & .64 & .53 & .47 & .56 \\
\hline 12 & .56 & .48 & .46 & .46 & .52 & .73 & .77 & .54 & .69 & .52 & .68 & .53 \\
\hline 13 & .56 & .41 & .50 & .43 & .56 & .79 & .56 & .45 & .65 & .49 & .53 & .51 \\
\hline 14 & .65 & .39 & .55 & .52 & .65 & .84 & .49 & .41 & .81 & .50 & .69 & .53 \\
\hline 15 & .62 & .49 & .49 & .47 & .55 & .97 & .52 & .43 & .60 & .45 & .45 & .46 \\
\hline 16 & .51 & .46 & .39 & .47 & .56 & .78 & .46 & .43 & .62 & .56 & .43 & .66 \\
\hline 17 & .52 & .47 & .48 & .45 & .67 & .90 & .60 & .42 & .57 & .52 & .47 & .65 \\
\hline 18 & .47 & .40 & .47 & .48 & .57 & .65 & .60 & .45 & .53 & .55 & .44 & .50 \\
\hline 19 & .60 & .45 & .39 & .56 & .57 & .85 & .57 & .46 & .62 & .52 & .44 & .66 \\
\hline 20 & .63 & .49 & .47 & .63 & .65 & .90 & .70 & .49 & .91 & .72 & .48 & .49 \\
\hline 21 & .50 & .51 & .47 & .59 & .72 & .87 & .42 & .67 & .59 & .93 & .52 & .44 \\
\hline 22 & .59 & .47 & .44 & .55 & .92 & .89 & .45 & .56 & .67 & .61 & .50 & .50 \\
\hline 23 & .54 & .47 & .35 & .52 & .64 & .66 & .44 & .97 & .55 & .61 & .52 & .62 \\
\hline 24 & .59 & .50 & .46 & .54 & .63 & .63 & .47 & .68 & .60 & .65 & .53 & .52 \\
\hline 25 & .55 & .37 & .53 & .62 & .55 & .61 & .52 & .61 & .60 & .62 & .18 & .50 \\
\hline 26 & .61 & .36 & .47 & .57 & .64 & .71 & .46 & .58 & .56 & .77 & .31 & .48 \\
\hline 27 & .53 & .70 & .48 & .64 & .61 & .72 & .48 & .78 & .59 & .66 & .35 & .55 \\
\hline 28 & .44 & .47 & .52 & .62 & .69 & .70 & .52 & .58 & .57 & .88 & .33 & .49 \\
\hline 29 & .46 & .43 & .54 & .59 & ----- & .72 & .48 & .50 & .65 & .83 & .43 & .48 \\
\hline 30 & .48 & .51 & .46 & .60 & ----- & .65 & .44 & .59 & .48 & .80 & .89 & .45 \\
\hline 31 & .50 & ------ & .48 & .70 & ----- & .61 & ------ & .51 & ------ & .54 & .56 & ----- \\
\hline T otal & 17.43 & 14.84 & 14.30 & 16.18 & 17.89 & 23.24 & 16.05 & 16.38 & 19.94 & 19.75 & 14.95 & 16.09 \\
\hline Mean & .56 & .49 & .46 & .52 & .64 & .75 & .54 & .53 & .66 & .64 & .48 & .54 \\
\hline $\operatorname{Max}$ & 1.5 & .70 & .55 & .70 & .92 & .97 & .77 & .97 & 1.3 & 1.1 & .89 & .66 \\
\hline Min & .34 & .36 & .35 & .42 & .52 & .61 & .42 & .41 & .48 & .45 & .18 & .44 \\
\hline Acre-F t & 35 & 29 & 28 & 32 & 35 & 46 & 32 & 32 & 40 & 39 & 30 & 32 \\
\hline Wtr Year & 2009 & Total & 207.04 & & & .57 & Max & 1.5 & Min & .18 & Acre-Ft & 411 \\
\hline Cal Year & 2008 & Total & 186.79 & & & .51 & Max & 1.7 & Min & .05 & Acre-Ft & 370 \\
\hline
\end{tabular}

${ }^{\star}$ Estimate 


\section{E1219 Sandia Canyon East of Power Plant}

Location. Lat $35^{\circ}$ 52' 30", long $106^{\circ}$ 19' 10", SW 1/4, Sec. 16, T 19 N., R 6 E., Los Alamos County.

Drainage Area. $0.002 \mathrm{mi}^{2}$.

Period of Record. March 3, 2006, to September 30, 2009.

Gage. Data logger, 9" Parshall flume, rain gage with cellular telemetry. Elevation of gage is 7,337 ft above NGVD from land survey.

Remarks. Records are good.

Extremes for Period of Record. Maximum discharge, $5.2 \mathrm{ft}^{3} / \mathrm{s}$, August 10, 2008, gage height $1.41 \mathrm{ft}$. No flow most of the time.

Extremes for Current Year. Peak discharges above base of $2.0 \mathrm{ft}^{3} / \mathrm{s}$ and maximum (*):

\begin{tabular}{|c|c|c|c|}
\hline Date & Time & Discharge $\left(\mathbf{f t}^{\mathbf{3}} / \mathbf{s}\right)$ & Gage Height $(\mathbf{f t})$ \\
\hline June 3 & 1200 & $2.52^{*}$ & $0.88^{*}$ \\
\hline July 6 & 1220 & 2.30 & 0.83 \\
\hline
\end{tabular}

No flow most of the time.

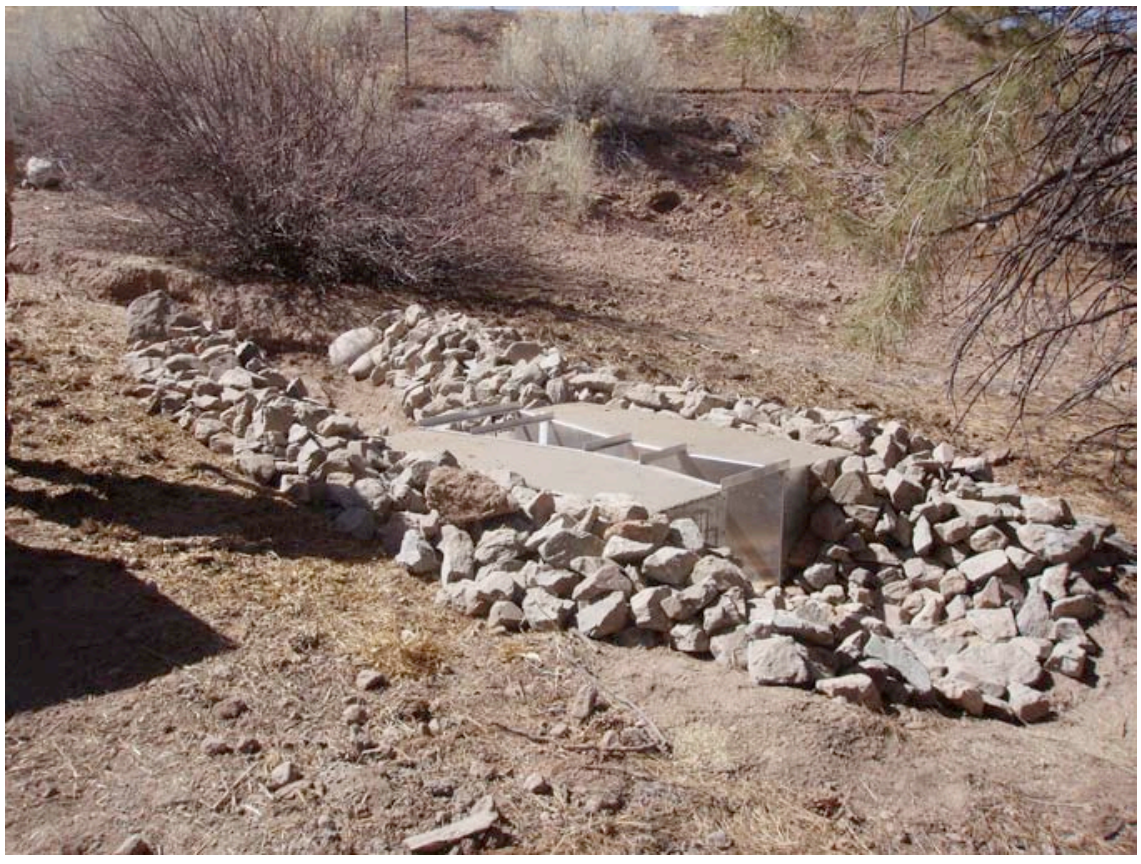




\title{
E1219 Sandia Canyon East of Power Plant
}

\author{
Station Analysis
}

\section{Water Year}

Equipment. Station is equipped with Sutron 8210 data logger (5-min. interval) and Milltronics sonic probe mounted on a 9" Parshall flume and cellular telemetry with speech modem. System is powered by a solar panel battery system housed in a NEMA shelter. Station is equipped with an ISCO pump sampler for water quality sample collection. ISCO is housed in a separate shelter, a $3^{\prime} \times 4^{\prime}$ metal box. Sampler is triggered by stage through the data logger. The staff in the 9" Parshall flume is the reference gage. No provision for discharge measurements above wading stage.

Station is also equipped with a tipping bucket rain gage, Rain Collection II. All equipment is powered with a solar panel battery charging system.

Field Work. The station was visited 25 times to conduct discharge measurements and service the instrumentation. Field inspections for the gage are listed under site history files on the Hydstra database. Discharge measurements for the gage are listed under site gauging files on the Hydstra database.

Datum Correction. None.

Gage-Height Record. The data logger referenced to the outside staff gave a complete and satisfactory record for the water year, except for the periods of October 11-14 due to data logger malfunction and December thru March when gage height was affected by ice.

Rating. The channel is straight above and below gage and is confined to the main channel by cut banks on both sides. The bottom is a $4^{\prime}$ wide channel prone to some shifting with vegetation on each bank. Low-water control is the 9" Parshall flume.

Twenty-four inspections of no flow were made during the year.

Rating No. 1 was developed based on the computation of 9" Parshall flume. Point of zero flow is 0.00 gage height.

Discharge. Discharge was computed by applying Rating No. 1 directly.

Remarks. Records are good. 
E1219 Sandia $C$ an yon East of Power Plant

Daily Mean Discharge in Cubic Feet per Second

Water Year Octo ber 2008 to September 2009

\begin{tabular}{|c|c|c|c|c|c|c|c|c|c|c|c|c|}
\hline DAY & OCT & NOV & DEC & JAN & FEB & MAR & APR & MAY & JUN & JUL & AUG & SEP \\
\hline 1 & 0 & 0 & 0 & $0^{*}$ & 0 & 0 & 0 & 0 & 0 & 0 & 0 & 0 \\
\hline 2 & 0 & 0 & 0 & $0^{*}$ & 0 & 0 & 0 & 0 & 0 & 0 & 0 & 0 \\
\hline 3 & 0 & 0 & 0 & $0^{*}$ & 0 & 0 & 0 & 0 & .05 & 0 & 0 & 0 \\
\hline 4 & .01 & 0 & 0 & $0^{*}$ & 0 & 0 & 0 & 0 & 0 & 0 & 0 & 0 \\
\hline 5 & 0 & 0 & 0 & $0^{*}$ & 0 & 0 & 0 & 0 & 0 & .04 & 0 & 0 \\
\hline 6 & 0 & 0 & 0 & $0^{*}$ & 0 & 0 & 0 & 0 & 0 & .03 & 0 & 0 \\
\hline 7 & 0 & 0 & 0 & $0^{*}$ & 0 & 0 & 0 & 0 & 0 & 0 & 0 & 0 \\
\hline 8 & 0 & 0 & 0 & $0^{*}$ & 0 & 0 & 0 & 0 & 0 & 0 & 0 & 0 \\
\hline 9 & 0 & 0 & .01 & $0^{*}$ & 0 & 0 & 0 & 0 & 0 & 0 & 0 & 0 \\
\hline 10 & 0 & 0 & 0 & $0^{*}$ & 0 & 0 & 0 & 0 & .04 & 0 & 0 & .01 \\
\hline 11 & $.01^{*}$ & 0 & 0 & $0^{*}$ & 0 & 0 & .03 & 0 & 0 & 0 & 0 & 0 \\
\hline 12 & $0^{*}$ & 0 & 0 & $0^{*}$ & 0 & 0 & .01 & 0 & 0 & 0 & .02 & 0 \\
\hline 13 & $0^{*}$ & 0 & $0^{*}$ & $0^{*}$ & 0 & $0^{*}$ & 0 & 0 & 0 & 0 & 0 & 0 \\
\hline 14 & $.01^{*}$ & 0 & $0^{*}$ & $0^{*}$ & 0 & 0 & 0 & 0 & .02 & 0 & .03 & 0 \\
\hline 15 & 0 & 0 & $0^{*}$ & $0^{*}$ & 0 & 0 & 0 & 0 & 0 & 0 & 0 & 0 \\
\hline 16 & 0 & 0 & $0^{*}$ & $0^{*}$ & 0 & 0 & 0 & 0 & 0 & 0 & 0 & .02 \\
\hline 17 & 0 & 0 & $0^{*}$ & $0^{*}$ & $0^{*}$ & 0 & .01 & 0 & 0 & 0 & 0 & .01 \\
\hline 18 & 0 & 0 & $0^{*}$ & $0^{*}$ & 0 & 0 & 0 & 0 & 0 & 0 & 0 & 0 \\
\hline 19 & 0 & 0 & 0 & $0^{*}$ & 0 & 0 & 0 & 0 & 0 & 0 & 0 & 0 \\
\hline 20 & 0 & 0 & 0 & $0^{*}$ & 0 & 0 & 0 & 0 & .04 & .01 & 0 & 0 \\
\hline 21 & 0 & 0 & 0 & $0^{*}$ & 0 & 0 & 0 & .01 & 0 & .02 & 0 & 0 \\
\hline 22 & 0 & 0 & $0^{*}$ & $0^{*}$ & $0^{*}$ & 0 & 0 & .01 & 0 & 0 & 0 & 0 \\
\hline 23 & 0 & 0 & $0^{*}$ & $0^{*}$ & $0^{*}$ & 0 & 0 & .04 & 0 & 0 & .01 & .01 \\
\hline 24 & 0 & 0 & $0^{*}$ & $0^{*}$ & $0^{*}$ & 0 & 0 & .01 & 0 & 0 & .01 & .01 \\
\hline 25 & 0 & 0 & $0^{*}$ & 0 & $0^{*}$ & 0 & 0 & 0 & .01 & 0 & 0 & 0 \\
\hline 26 & 0 & 0 & $0^{*}$ & 0 & 0 & $0^{*}$ & 0 & 0 & 0 & .01 & 0 & 0 \\
\hline 27 & 0 & .02 & $0^{*}$ & 0 & 0 & $0^{*}$ & 0 & .02 & 0 & 0 & 0 & 0 \\
\hline 28 & 0 & 0 & $0^{*}$ & 0 & 0 & 0 & 0 & 0 & 0 & .01 & 0 & 0 \\
\hline 29 & 0 & 0 & $0^{*}$ & 0 & - & 0 & 0 & 0 & 0 & .01 & 0 & 0 \\
\hline 30 & 0 & 0 & $0^{*}$ & 0 & --- & 0 & 0 & 0 & 0 & .01 & .02 & 0 \\
\hline 31 & 0 & 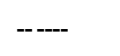 & $0^{*}$ & 0 & ---- & 0 & ----- & 0 & ---- & 0 & 0 & ----- \\
\hline Total & 0.03 & 0.02 & 0.01 & 0 & 0 & 0 & 0.05 & 0.09 & 0.16 & 0.14 & 0.09 & 0.06 \\
\hline Mean & .001 & .001 & 0 & 0 & 0 & 0 & .002 & .003 & .005 & .005 & .003 & .002 \\
\hline $\operatorname{Max}$ & .01 & .02 & .01 & 0 & 0 & 0 & .03 & .04 & .05 & .04 & .03 & .02 \\
\hline M in & 0 & 0 & 0 & 0 & 0 & 0 & 0 & 0 & 0 & 0 & 0 & 0 \\
\hline Acre-Ft & .06 & .04 & .02 & 0 & 0 & 0 & .10 & .18 & .32 & .28 & .18 & .12 \\
\hline Wtr Year & 2009 & Total & 0.65 & Mean & & 02 & Max & .05 & Min & 0 & Acre-Ft & 1.3 \\
\hline Cal Year & 2008 & Total & 0.63 & Mean & & 02 & Max & .13 & Min & 0 & Acre- $\mathrm{Ft}$ & 1.2 \\
\hline
\end{tabular}

*Estimated 
Location. Lat $35^{\circ}$ 52' 31", long $106^{\circ}$ 9' 6", SW 1/4, Sec. 16, T. 19 N., R. 6 E., Los Alamos County.

Drainage Area. $0.08 \mathrm{mi}^{2}$.

Period of Record. October 1, 2006, to September 30, 2009.

Gage. Data logger. Elevation of gage is 7,290 ft above NGVD.

Remarks. Records are good. Records for this site existed before period of record but are not reliable.

Extremes for Period of Record. Maximum discharge, $88 \mathrm{ft}^{3} / \mathrm{s}$ August 23, 2003, gage height $4.23 \mathrm{ft}$. Minimum daily discharge $0.00 \mathrm{ft}^{3} / \mathrm{s}$, March 17, 2009.

Extremes for Current Year. Peak discharges above base of $15 \mathrm{ft}^{3} / \mathrm{s}$ and maximum (*):

\begin{tabular}{|c|c|c|c|}
\hline Date & Time & Discharge $\left(\mathbf{f t}^{\mathbf{3}} / \mathbf{s}\right)$ & Gage Height (ft) \\
\hline July 5 & 1215 & $15^{*}$ & $2.78^{*}$ \\
\hline
\end{tabular}

Minimum daily discharge, $0.0 \mathrm{ft}^{3} / \mathrm{s}$ March 17.

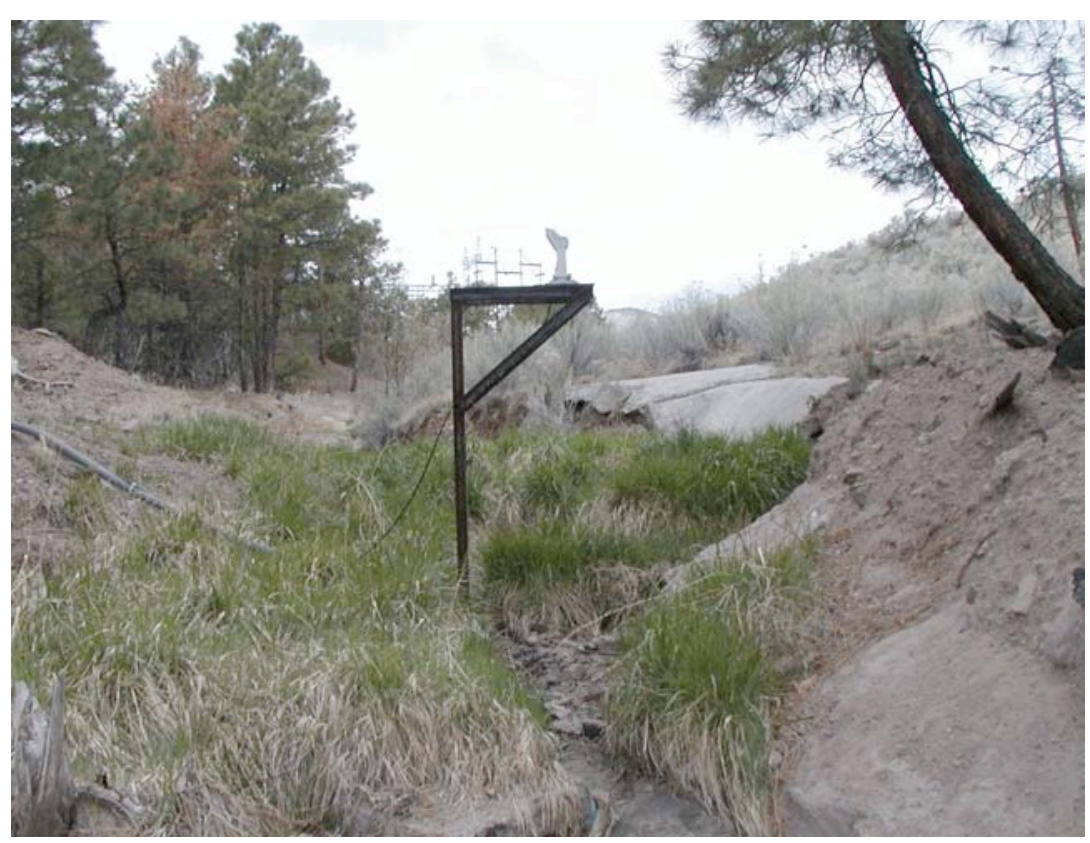




\title{
E122 Sandia near Roads and Grounds at TA-3
}

\author{
Station Analysis
}

\section{Water Year}

Equipment. Station is equipped with Sutron 8210 data logger (5-min. interval) and a Milltronics sonic probe. The system is powered by a solar panel battery system housed in a NEMA shelter. Station is also equipped with ISCO pump sampler for water quality sample collection. ISCO is housed in a separate shelter, a $3^{\prime} \times 4^{\prime}$ metal box. Sampler is triggered by stage through the data logger. An outside staff is available for reference. No provision for discharge measurements above wading stage.

Field Work. The station was visited 22 times to conduct discharge measurements and service the instrumentation. Field inspections for the gage are listed under site history files on the Hydstra database. Discharge measurements for the gage are listed under site gauging files on the Hydstra database.

Datum Correction. None, levels of July 25, 2005, found gage to be within limits.

Gage-Height Record. The data logger referenced to the outside staff gave a complete and satisfactory record for the year.

Rating. The channel is straight for about $20^{\prime}$ above with a step downstream slope and straight for $15^{\prime}$ downstream with a sharp slope $5^{\prime}$ downstream. The streambed through this reach is primarily bed rock with some cobbles below gage. The low-water control is bedrock riffle below gage.

Three discharge measurements (Nos. 48-50) and 22 inspections were made this year.

Rating No. 2 was developed based on the measurements made the previous year and verified with measurements made this year. Shifts are small and mostly negative, caused by small amounts of deposition near gage or some bank slough during high flows. They have been distributed using variable diagrams with no shifts applied on the peak flows.

Discharge. Discharge computed from Rating No. 2 with shifts applied by V diagrams.

Remarks. Records are good. 
E122 Sandia Canyon near Roads and Grounds at TA-3

Daily Mean Discharge in Cubic Feet per Second

Water Year October 2008 to September 2009

\begin{tabular}{|c|c|c|c|c|c|c|c|c|c|c|c|c|}
\hline DAY & OCT & NOV & DEC & JAN & FEB & MAR & APR & MAY & JUN & JUL & AUG & SEP \\
\hline 1 & .05 & .02 & .01 & .03 & .01 & .01 & .02 & .03 & .04 & .02 & .10 & .13 \\
\hline 2 & .05 & .02 & .02 & .04 & .01 & .02 & .02 & .03 & .04 & .04 & .12 & .09 \\
\hline 3 & .07 & .02 & .02 & .04 & .01 & .02 & .02 & .03 & .58 & .10 & .12 & .09 \\
\hline 4 & .19 & .02 & .02 & .03 & .02 & .02 & .02 & .03 & .07 & .06 & .13 & .08 \\
\hline 5 & .11 & .02 & .02 & .03 & .02 & .03 & .02 & .03 & .06 & .59 & .13 & .08 \\
\hline 6 & .05 & .02 & .01 & .02 & .02 & .02 & .02 & .03 & .07 & .68 & .14 & .17 \\
\hline 7 & .05 & .02 & .01 & .02 & .02 & .02 & .02 & .04 & .05 & .24 & .11 & .11 \\
\hline 8 & .05 & .02 & .02 & .02 & .02 & .02 & .02 & .03 & .06 & .22 & .10 & .12 \\
\hline 9 & .05 & .02 & .03 & .03 & .02 & .07 & .02 & .03 & .09 & .21 & .09 & .09 \\
\hline 10 & .05 & .02 & .03 & .02 & .02 & .02 & .02 & .03 & .51 & .22 & .09 & .15 \\
\hline 11 & .73 & .02 & .03 & .02 & .02 & .04 & .34 & .03 & .03 & .18 & .09 & .05 \\
\hline 12 & 0 & .02 & .02 & .02 & .03 & .03 & .32 & .03 & .02 & .17 & .32 & .06 \\
\hline 13 & 0 & .02 & .09 & .02 & .02 & .13 & .11 & .02 & .02 & .22 & .14 & .05 \\
\hline 14 & .09 & .02 & .02 & .02 & .02 & .05 & .05 & .02 & .17 & .22 & .39 & .07 \\
\hline 15 & .01 & .01 & .02 & .02 & .02 & .01 & .05 & .02 & .03 & .21 & .12 & .11 \\
\hline 16 & .01 & .02 & .02 & .02 & .01 & 0 & .04 & .03 & .02 & .20 & .10 & .30 \\
\hline 17 & .01 & .02 & .08 & .02 & .02 & 0 & .15 & .02 & .02 & .21 & .06 & .25 \\
\hline 18 & .01 & .01 & .12 & .02 & .02 & .02 & .14 & .03 & .02 & .13 & .04 & .06 \\
\hline 19 & 0 & .01 & .05 & .02 & .02 & .01 & .05 & .02 & .02 & .12 & .03 & .05 \\
\hline 20 & .01 & .01 & .03 & .03 & .02 & .03 & .05 & .03 & .46 & .26 & .03 & .04 \\
\hline 21 & .01 & .02 & .03 & .02 & .02 & .03 & .05 & .20 & .01 & .34 & .06 & .04 \\
\hline 22 & 0 & .03 & .03 & .03 & .01 & .02 & .05 & .12 & .01 & .23 & .06 & .03 \\
\hline 23 & .01 & .02 & .04 & .06 & .03 & .02 & .05 & .66 & .01 & .26 & .18 & .14 \\
\hline 24 & .01 & .02 & .02 & .09 & .03 & .02 & .05 & .34 & .02 & .26 & .14 & .16 \\
\hline 25 & .01 & .02 & .02 & .03 & .03 & .02 & .05 & .05 & .04 & .25 & .09 & .05 \\
\hline 26 & .02 & .02 & .03 & .03 & .02 & .06 & .03 & .08 & .04 & .42 & .08 & .04 \\
\hline 27 & .01 & .26 & .01 & .02 & .02 & .10 & .02 & .25 & .02 & .24 & .08 & .03 \\
\hline 28 & .01 & .09 & .02 & .01 & .02 & .06 & .03 & .04 & .04 & .40 & .07 & .04 \\
\hline 29 & .03 & .02 & .04 & .01 & ---- & .07 & .02 & .03 & .02 & .42 & .08 & .05 \\
\hline 30 & .03 & .02 & .04 & .01 & --- & .02 & .02 & .04 & .03 & .38 & .39 & .06 \\
\hline 31 & .03 & ---- & .02 & .01 & ----- & .02 & ----- & .04 & ---- & .12 & .18 & ---- \\
\hline Total & 1.76 & 0.88 & 0.97 & 0.81 & 0.55 & 1.01 & 1.87 & 2.41 & 262 & 7.62 & 3.86 & 2.79 \\
\hline Mean & .057 & .029 & .031 & .026 & .020 & .033 & .062 & .078 & .087 & .25 & .12 & .093 \\
\hline Max & .73 & .26 & .12 & .09 & .03 & .13 & .34 & .66 & .58 & .68 & .39 & .30 \\
\hline Min & 0 & .01 & .01 & .01 & .01 & 0 & .02 & .02 & .01 & .02 & .03 & .03 \\
\hline Acre-F t & 3.5 & 1.7 & 1.9 & 1.6 & 1.1 & 2.0 & 3.7 & 4.8 & 5.2 & 15 & 7.7 & 5.5 \\
\hline Wtr Year & 2009 & Total & 27.15 & Mean & & 074 & $\operatorname{Max}$ & .73 & Min & 0 & Acre- $\mathrm{Ft}$ & 54 \\
\hline Cal Year & 2008 & Total & 27.89 & Mean & & 076 & $\operatorname{Max}$ & .73 & Min & 0 & Acre-Ft & 55 \\
\hline
\end{tabular}




\section{E1222 Sandia Canyon Tributary from Roads and Grounds}

Location. Lat $35^{\circ}$ 52' 33", long $106^{\circ}$ 19' 5", Sec. 16, T. 19 N., R. 6 E., Los Alamos County.

Drainage Area. $0.01 \mathrm{mi}^{2}$.

Period of Record. October 1, 2006, to September 30, 2009.

Gage. Data logger and 9" Parshall flume. Elevation of gage is 7,326 ft above NGVD.

Remarks. Records are fair. Records for this site existed before period of record but are not reliable.

Extremes for Period of Record. Maximum discharge, $4.4 \mathrm{ft}^{3} / \mathrm{s}$ September 2, 2007, gage height $1.26 \mathrm{ft}$. No flow most of the time.

Extremes for Current Year. Maximum discharge is $1.19 \mathrm{ft}^{3} / \mathrm{s}$ at $1230 \mathrm{~h}$, July 6, gage height $0.55 \mathrm{ft}$. No peak discharges above base of $2.0 \mathrm{ft}^{3} / \mathrm{s}$. No flow most of the time.

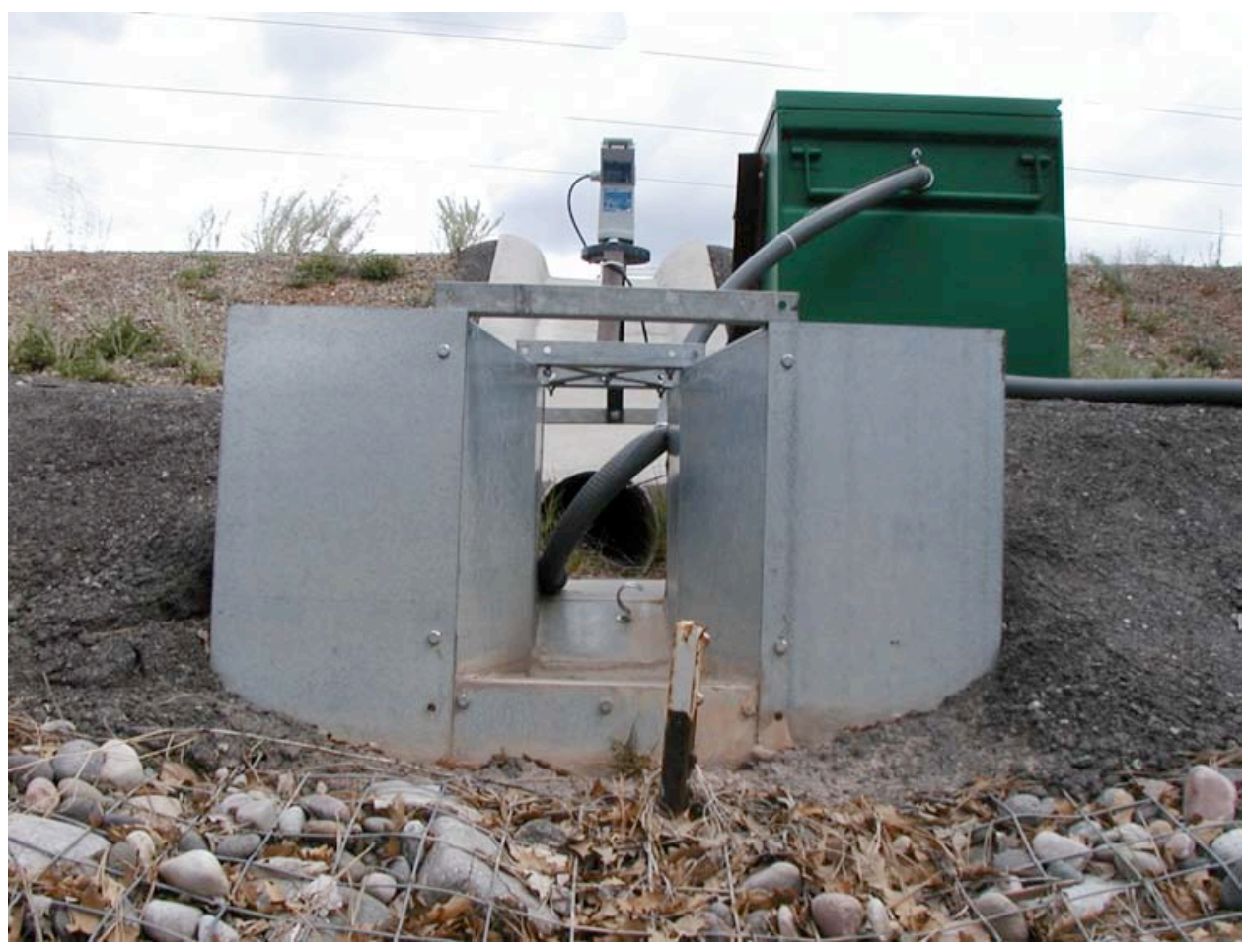




\title{
E1222 Sandia Canyon Tributary from Roads and Grounds
}

\author{
Station Analysis
}

\section{Water Year}

Equipment. Station is equipped with Sutron 8210 data logger (5-min. interval) and Milltronics sonic probe mounted on a 9" Parshall flume. The system is powered by a solar panel battery system housed in a NEMA shelter. Station is equipped with an ISCO pump sampler for water quality sample collection. ISCO is housed in a separate shelter, a $3^{\prime} \times 4^{\prime}$ metal box. Sampler is triggered by stage through the data logger. The staff in the 9" Parshall flume is the reference gage. No provision for discharge measurements above wading stage. All high measurements will be by slope area or peak flow computation methods.

Field Work. This station was visited 15 times to conduct discharge measurements and service the instrumentation. Field inspections for the gage are listed under site history files on the Hydstra database. Discharge measurements for the gage are listed under site gauging files on the Hydstra database.

Datum Correction. None.

Gage-Height Record. The data logger referenced to the outside staff gave a complete and satisfactory record, except during the periods December 15 to January 21 and March 26, 27 when gage height was affected by ice in flume and June 4 to July 1 and July 15 to August 3 when data logger malfunctioned.

Rating. Channel is straight above and below gage. Channel bottom is vegetation, bedrock, and gravel.

Fifteen inspections of no flow were made this water year.

Rating No. 1 was developed based on the computation of 9" Parshall flume. Point of zero flow is 0.00 gage height.

Discharge. Discharge was computed by applying Rating No. 1 directly. Those days estimated at zero flow were based on precipitation and nearby gage stations.

Remarks. Records are fair. 


\section{E1222 Sandia Canyon Tributary from Roads and Grounds}

Daily Mean Discharge in Cubic Feet per Second

Water Year October 2008 to September 2009

\begin{tabular}{|c|c|c|c|c|c|c|c|c|c|c|c|c|}
\hline DAY & ОСт & NOV & DEC & JAN & FEB & MAR & APR & MAY & JUN & JUL & AUG & SEP \\
\hline 1 & 0 & 0 & 0 & $0^{*}$ & 0 & 0 & 0 & 0 & 0 & $0^{*}$ & $0^{*}$ & 0 \\
\hline 2 & 0 & 0 & 0 & $0^{*}$ & 0 & 0 & 0 & 0 & 0 & 0 & $0^{*}$ & 0 \\
\hline 3 & 0 & 0 & 0 & $0^{*}$ & 0 & 0 & 0 & 0 & 0 & 0 & $0^{*}$ & 0 \\
\hline 4 & 0 & 0 & 0 & $0^{*}$ & 0 & 0 & 0 & 0 & $0^{*}$ & 0 & 0 & 0 \\
\hline 5 & 0 & 0 & 0 & $0^{*}$ & 0 & 0 & 0 & 0 & $0^{*}$ & .05 & 0 & 0 \\
\hline 6 & 0 & 0 & 0 & $0^{*}$ & 0 & 0 & 0 & 0 & $0^{*}$ & .05 & 0 & 0 \\
\hline 7 & 0 & 0 & 0 & $0^{*}$ & 0 & 0 & 0 & 0 & $0^{*}$ & 0 & 0 & 0 \\
\hline 8 & 0 & 0 & 0 & $0^{*}$ & 0 & 0 & 0 & 0 & $0^{*}$ & 0 & 0 & 0 \\
\hline 9 & 0 & 0 & 0 & $0^{*}$ & 0 & 0 & 0 & 0 & $0^{*}$ & 0 & 0 & 0 \\
\hline 10 & 0 & 0 & 0 & $0^{*}$ & 0 & 0 & 0 & 0 & $.03^{\star}$ & 0 & 0 & 0 \\
\hline 11 & .09 & 0 & 0 & $0^{*}$ & 0 & 0 & .01 & 0 & $0^{*}$ & 0 & 0 & 0 \\
\hline 12 & 0 & 0 & 0 & $0^{*}$ & 0 & 0 & 0 & 0 & $0^{*}$ & 0 & 0 & 0 \\
\hline 13 & 0 & 0 & 0 & $0^{*}$ & 0 & 0 & 0 & 0 & $0^{*}$ & 0 & 0 & 0 \\
\hline 14 & 0 & 0 & 0 & $0^{*}$ & 0 & 0 & 0 & 0 & $.01^{*}$ & 0 & .01 & 0 \\
\hline 15 & 0 & 0 & $0^{*}$ & $0^{*}$ & 0 & 0 & 0 & 0 & $0^{*}$ & $0^{*}$ & 0 & 0 \\
\hline 16 & 0 & 0 & $0^{*}$ & $0^{*}$ & 0 & 0 & 0 & 0 & $0^{*}$ & $0^{*}$ & 0 & .01 \\
\hline 17 & 0 & 0 & $0^{*}$ & $0^{*}$ & 0 & 0 & 0 & 0 & $0^{*}$ & $0^{*}$ & 0 & 0 \\
\hline 18 & 0 & 0 & $0^{*}$ & $0^{*}$ & 0 & 0 & 0 & 0 & $0^{*}$ & $0^{*}$ & 0 & 0 \\
\hline 19 & 0 & 0 & $0^{*}$ & $0^{*}$ & 0 & 0 & 0 & 0 & $0^{*}$ & $0^{*}$ & 0 & 0 \\
\hline 20 & 0 & 0 & $0^{*}$ & $0^{*}$ & 0 & 0 & 0 & 0 & $.03^{\star}$ & $.01^{*}$ & 0 & 0 \\
\hline 21 & 0 & 0 & $0^{*}$ & $0^{*}$ & 0 & 0 & 0 & 0 & $0^{*}$ & $.02^{*}$ & 0 & 0 \\
\hline 22 & 0 & 0 & $0^{*}$ & 0 & 0 & 0 & 0 & 0 & $0^{*}$ & $0^{*}$ & 0 & 0 \\
\hline 23 & 0 & 0 & $0^{*}$ & 0 & 0 & 0 & 0 & .03 & $0^{*}$ & $0^{*}$ & 0 & 0 \\
\hline 24 & 0 & 0 & $0^{*}$ & 0 & 0 & 0 & 0 & .01 & $0^{*}$ & $0^{*}$ & 0 & .01 \\
\hline 25 & 0 & 0 & $0^{*}$ & 0 & 0 & 0 & 0 & 0 & $.01^{*}$ & $0^{*}$ & 0 & 0 \\
\hline 26 & 0 & 0 & $0^{*}$ & 0 & 0 & $0^{*}$ & 0 & 0 & $0^{*}$ & $.01^{*}$ & 0 & 0 \\
\hline 27 & 0 & 0 & $0^{*}$ & 0 & 0 & $0^{*}$ & 0 & .01 & $0^{*}$ & $0^{*}$ & 0 & 0 \\
\hline 28 & 0 & 0 & $0^{*}$ & 0 & 0 & 0 & 0 & 0 & $0^{*}$ & $.01^{*}$ & 0 & 0 \\
\hline 29 & 0 & 0 & $0^{*}$ & 0 & ------ & 0 & 0 & 0 & $0^{*}$ & $.01^{*}$ & 0 & 0 \\
\hline 30 & 0 & 0 & $0^{*}$ & 0 & ----- & 0 & 0 & 0 & $0^{*}$ & $.01^{*}$ & .03 & 0 \\
\hline 31 & 0 & ----- & $0^{*}$ & 0 & ----- & 0 & ----- & 0 & ---- & $0^{*}$ & 0 & ----- \\
\hline Total & 0.09 & 0 & 0 & 0 & 0 & 0 & 0.01 & 0.05 & 0.08 & 0.17 & 0.04 & 0.02 \\
\hline Mean & .003 & 0 & 0 & 0 & 0 & 0 & 0 & .002 & .003 & .006 & .001 & .001 \\
\hline Max & .09 & 0 & 0 & 0 & 0 & 0 & .01 & .03 & .03 & .05 & .03 & .01 \\
\hline Min & 0 & 0 & 0 & 0 & 0 & 0 & 0 & 0 & 0 & 0 & 0 & 0 \\
\hline Acre-Ft & .18 & 0 & 0 & 0 & 0 & 0 & .02 & .10 & .16 & .34 & .08 & .04 \\
\hline Wtr Year & 2009 & Total & 0.46 & Mean & & 001 & Max & .09 & Min & 0 & Acre-Ft & 0.91 \\
\hline Cal Year & 2008 & Total & 0.29 & Mean & & 001 & Max & .09 & Min & 0 & Acre- $\mathrm{Ft}$ & 0.58 \\
\hline
\end{tabular}




\section{E1223 Sandia Canyon Tributary from Sigma Building}

Location. Lat $35^{\circ} 52^{\prime} 22^{\prime \prime}$, long $106^{\circ}$ 19' 3", SW 1/4, Sec. 16, T. 19 N., R. 6 E., Los

Alamos County.

Drainage Area. $0.003 \mathrm{mi}^{2}$.

Period of Record. October 1, 2006, to September 30, 2009.

Gage. Data logger and 9" Parshall flume. Elevation of gage is 7,368 ft above NGVD.

Remarks. Records are good. Records for this site existed before period of record but are not reliable.

Extremes for Period of Record. Maximum discharge, $1.89 \mathrm{ft}^{3} / \mathrm{s}$, August 16, 2009, gage height $0.73 \mathrm{ft}$. No flow most of the time.

Extremes for Current Year. Peak discharges above base of $1.0 \mathrm{ft}^{3} / \mathrm{s}$ and maximum (*):

\begin{tabular}{|c|c|c|c|}
\hline Date & Time & Discharge $\left(\mathbf{f t}^{\mathbf{3}} / \mathbf{s}\right)$ & Gage Height (ft) \\
\hline August 16 & 1305 & $1.9^{*}$ & $0.73^{*}$ \\
\hline
\end{tabular}

No flow most of the time.

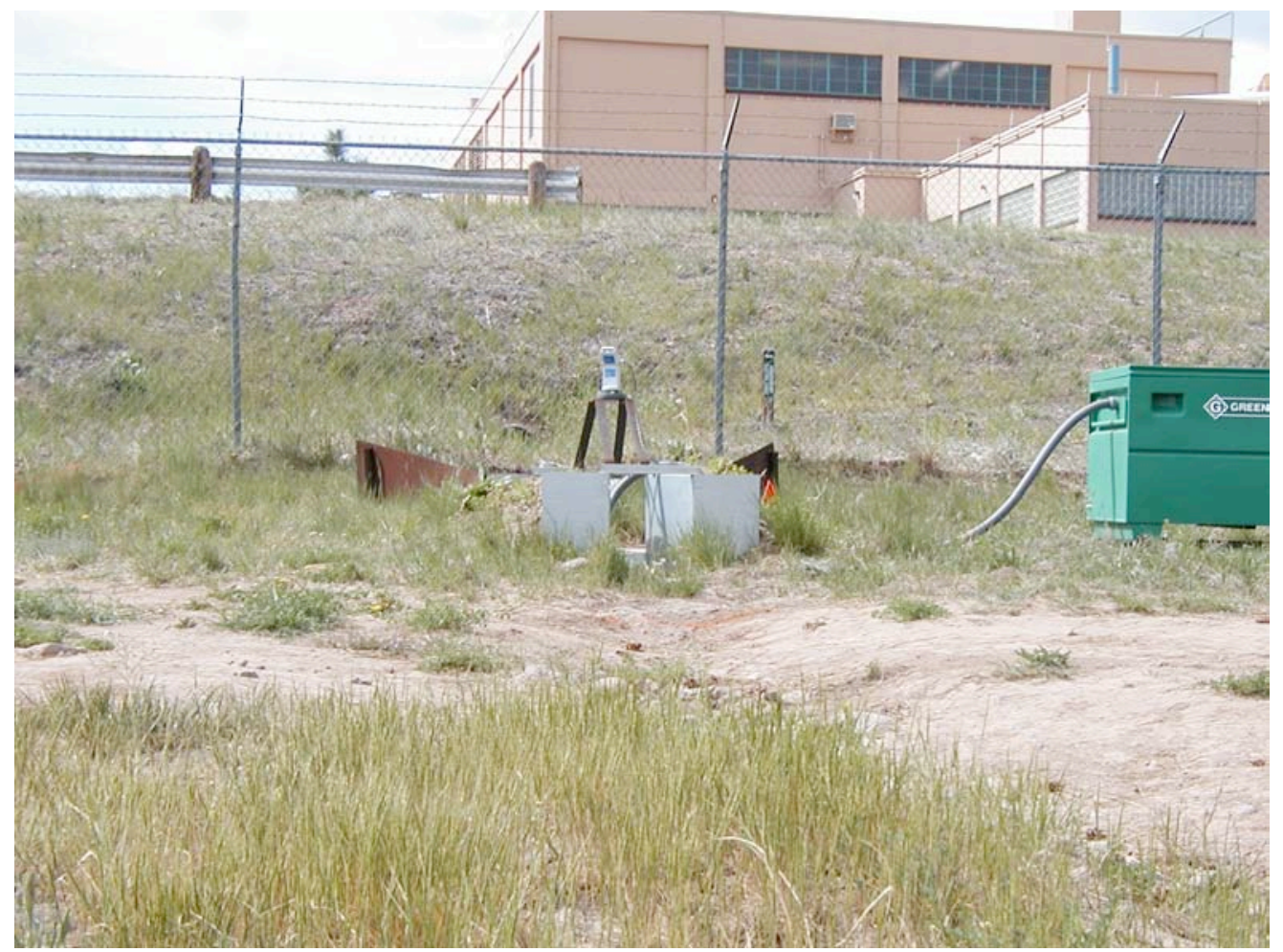




\section{E1223 Sandia Canyon Tributary from Sigma Building \\ Station Analysis}

2009 Water Year

Equipment. Station is equipped with Sutron 8210 data logger (5-min. interval) and Milltronics sonic probe mounted on a 9" Parshall flume. The system is powered by a solar panel battery system housed in a NEMA shelter. Station is equipped with an ISCO pump sampler for water quality sample collection. ISCO is housed in a separate shelter, a $3^{\prime} \times 4^{\prime}$ metal box. Sampler is triggered by stage through the data logger. The staff in the 9" Parshall flume is the reference gage. No provision for discharge measurements above wading stage.

Field Work. This station was visited 28 times to conduct discharge measurements and service the instrumentation. Field inspections for the gage are listed under site history files on the Hydstra database. Discharge measurements for the gage are listed under site gauging files on the Hydstra database.

Datum Correction. None.

Gage-Height Record. The data logger referenced to the outside staff gave a complete and satisfactory record, except during the periods from December 9, December 15-17, and December 22 to January 8 when gage height was affected by snow and ice.

Rating. Above 9" Parshall flume is asphalt lot. Flume is located southwest of roadway on the shoulder of the road. Below flume is asphalt roadway.

Twenty-eight inspections of no flow were made this year.

Rating No. 1 was developed based on the computation of 9" Parshall flume. Point of zero flow is 0.00 gage height.

Discharge. Discharge was computed by applying Rating No. 1 directly. Those days estimated at zero flow were based on precipitation and nearby gage stations.

Remarks. Records are good. 


\section{E1223 Sandia Canyon Tributary from Sigma Building}

Daily Mean Discharge in Cubic Feet per Second

Water Year October 2008 to September 2009

\begin{tabular}{|c|c|c|c|c|c|c|c|c|c|c|c|c|}
\hline DAY & OCT & NOV & DEC & JAN & FEB & MAR & APR & MAY & JUN & JUL & AUG & SEP \\
\hline 1 & 0 & 0 & 0 & $0^{*}$ & 0 & 0 & 0 & 0 & 0 & 0 & 0 & 0 \\
\hline 2 & 0 & 0 & 0 & $0^{*}$ & 0 & 0 & 0 & 0 & 0 & 0 & 0 & 0 \\
\hline 3 & 0 & 0 & 0 & $0^{*}$ & 0 & 0 & 0 & 0 & 0 & 0 & 0 & 0 \\
\hline 4 & 0 & 0 & 0 & $0^{*}$ & 0 & 0 & 0 & 0 & 0 & 0 & 0 & 0 \\
\hline 5 & 0 & 0 & 0 & $0^{*}$ & 0 & 0 & 0 & 0 & 0 & .01 & 0 & 0 \\
\hline 6 & 0 & 0 & 0 & $0^{*}$ & 0 & 0 & 0 & 0 & 0 & .01 & 0 & 0 \\
\hline 7 & 0 & 0 & 0 & $0^{*}$ & 0 & 0 & 0 & 0 & 0 & 0 & 0 & 0 \\
\hline 8 & 0 & 0 & 0 & $0^{*}$ & 0 & 0 & 0 & 0 & 0 & 0 & 0 & 0 \\
\hline 9 & 0 & 0 & $0^{*}$ & 0 & 0 & 0 & 0 & 0 & 0 & 0 & 0 & 0 \\
\hline 10 & 0 & 0 & 0 & 0 & 0 & 0 & 0 & 0 & .01 & 0 & 0 & 0 \\
\hline 11 & .01 & 0 & 0 & 0 & 0 & 0 & 0 & 0 & 0 & 0 & 0 & 0 \\
\hline 12 & 0 & 0 & 0 & 0 & 0 & 0 & 0 & 0 & 0 & 0 & 0 & 0 \\
\hline 13 & 0 & 0 & 0 & 0 & 0 & 0 & 0 & 0 & 0 & 0 & 0 & 0 \\
\hline 14 & 0 & 0 & 0 & 0 & 0 & 0 & 0 & 0 & 0 & 0 & 0 & 0 \\
\hline 15 & 0 & 0 & $0^{*}$ & 0 & 0 & 0 & 0 & 0 & 0 & 0 & 0 & 0 \\
\hline 16 & 0 & 0 & $0^{*}$ & 0 & 0 & 0 & 0 & 0 & 0 & 0 & .01 & 0 \\
\hline 17 & 0 & 0 & $0^{*}$ & 0 & 0 & 0 & 0 & 0 & 0 & 0 & 0 & 0 \\
\hline 18 & 0 & 0 & 0 & 0 & 0 & 0 & 0 & 0 & 0 & 0 & 0 & 0 \\
\hline 19 & 0 & 0 & 0 & 0 & 0 & 0 & 0 & 0 & 0 & 0 & 0 & 0 \\
\hline 20 & 0 & 0 & 0 & 0 & 0 & 0 & 0 & 0 & 0 & 0 & 0 & 0 \\
\hline 21 & 0 & 0 & 0 & 0 & 0 & 0 & 0 & 0 & 0 & 0 & 0 & 0 \\
\hline 22 & 0 & 0 & $0^{*}$ & 0 & 0 & 0 & 0 & 0 & 0 & 0 & 0 & 0 \\
\hline 23 & 0 & 0 & $0^{*}$ & 0 & 0 & 0 & 0 & 0 & 0 & 0 & 0 & 0 \\
\hline 24 & 0 & 0 & $0^{*}$ & 0 & 0 & 0 & 0 & 0 & 0 & 0 & 0 & 0 \\
\hline 25 & 0 & 0 & $0^{*}$ & 0 & 0 & 0 & 0 & 0 & 0 & 0 & 0 & 0 \\
\hline 26 & 0 & 0 & $0^{*}$ & 0 & 0 & $0^{*}$ & 0 & 0 & 0 & 0 & 0 & 0 \\
\hline 27 & 0 & 0 & $0^{*}$ & 0 & 0 & $0^{*}$ & 0 & 0 & 0 & 0 & 0 & 0 \\
\hline 28 & 0 & 0 & $0^{*}$ & 0 & 0 & 0 & 0 & 0 & 0 & 0 & 0 & 0 \\
\hline 29 & 0 & 0 & $0^{*}$ & 0 & ---- & 0 & 0 & 0 & 0 & 0 & 0 & 0 \\
\hline 30 & 0 & 0 & $0^{*}$ & 0 & ---- & 0 & 0 & 0 & 0 & 0 & 0 & 0 \\
\hline 31 & 0 & ----- & $0^{*}$ & 0 & --.-- & 0 & ---- & 0 & --- & 0 & 0 & ---- \\
\hline Total & 0.01 & 0 & 0 & 0 & 0 & 0 & 0 & 0 & 0.01 & 0.02 & 0.01 & 0 \\
\hline Mean & 0 & 0 & 0 & 0 & 0 & 0 & 0 & 0 & 0 & .001 & 0 & 0 \\
\hline Max & .01 & 0 & 0 & 0 & 0 & 0 & 0 & 0 & .01 & .01 & .01 & 0 \\
\hline Min & 0 & 0 & 0 & 0 & 0 & 0 & 0 & 0 & 0 & 0 & 0 & 0 \\
\hline Acre-Ft & .02 & 0 & 0 & 0 & 0 & 0 & 0 & 0 & .02 & .04 & .02 & 0 \\
\hline Wtr Year & 2009 & Total & 0.05 & Mean & & 0 & $\operatorname{Max}$ & .01 & Min & 0 & Acre- $\mathrm{Ft}$ & 0.10 \\
\hline Cal Year & 2008 & Total & 0.05 & Mean & & 0 & $\operatorname{Max}$ & .01 & Min & 0 & Acre- $\mathrm{Ft}$ & 0.10 \\
\hline
\end{tabular}




\section{E12235 Sandia Canyon Tributary from MRF}

Location. Lat $35^{\circ}$ 52' 26", long $106^{\circ} 18^{\prime}$ 47", SW 1/4, Sec. 16, T. 19 N., R. 6 E., Los Alamos County.

Drainage Area. $0.001 \mathrm{mi}^{2}$.

Period of Record. October 1, 2006, to September 30, 2009.

Gage. Data logger and 9" Parshall flume. Elevation of gage is 7,285 ft above NGVD.

Remarks. Records are good. Records for this site existed before period of record but are not reliable.

Extremes for Period of Record. Maximum discharge, $2.50 \mathrm{ft}^{3} / \mathrm{s}$ August 26, 2007, gage height $1.13 \mathrm{ft}$. No flow most of the time.

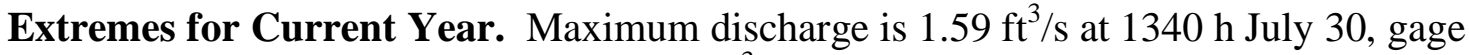
height $0.65 \mathrm{ft}$. No peak above base of $2.0 \mathrm{ft}^{3} / \mathrm{s}$. No flow most of the time.

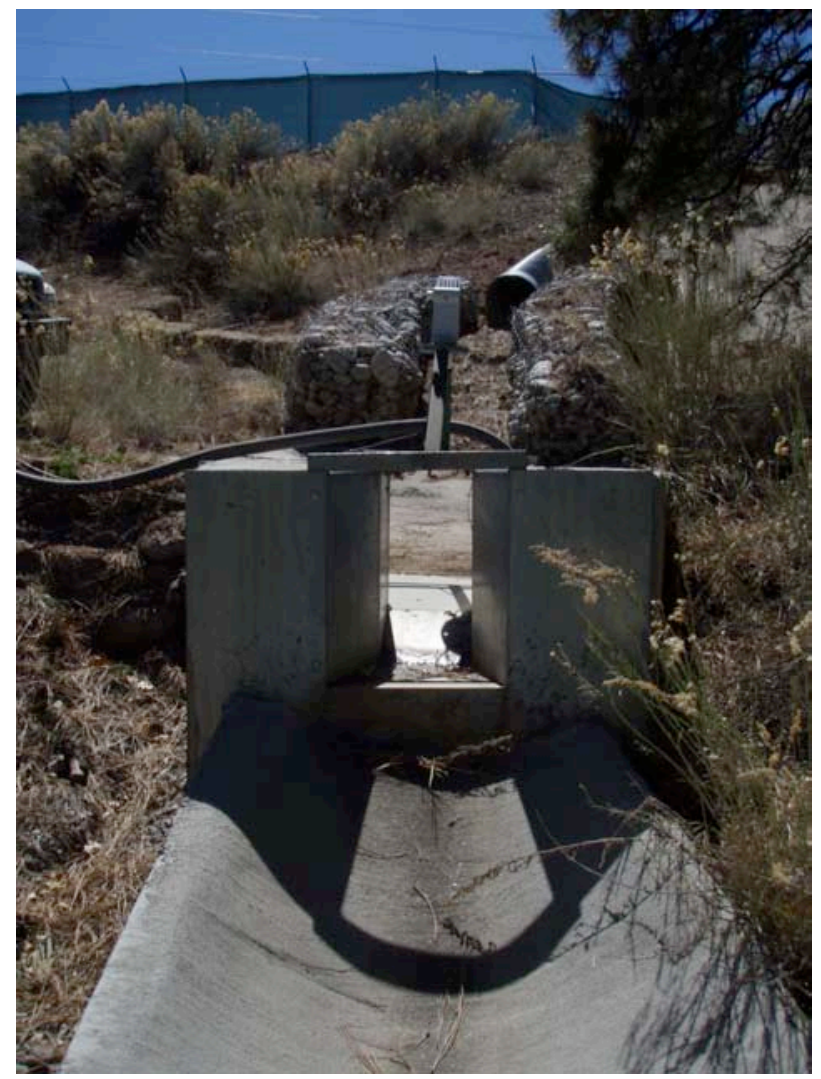




\section{E12235 Sandia Canyon Tributary from MRF

\author{
Station Analysis
}

2009 Water Year

Equipment. Station is equipped with Sutron 8210 data logger (5-min. interval) and Milltronics sonic probe mounted on a 9" Parshall flume. The system is powered by a solar panel battery system housed in a NEMA shelter. Station is equipped with an ISCO pump sampler for water quality sample collection. ISCO is housed in a separate shelter, a $3^{\prime} \times 4^{\prime}$ metal box. Sampler is triggered by stage through the data logger. The staff in the 9" Parshall flume is the reference gage. No provision for discharge measurements above wading stage.

Field Work. This station was visited 27 times to conduct discharge measurements and service the instrumentation. Field inspections for the gage are listed under site history files on the Hydstra database. Discharge measurements for the gage are listed under site gauging files on the Hydstra database.

Datum Correction. None.

Gage-Height Record. The data logger referenced to the outside staff gave a complete and satisfactory record, except during the periods from December 15 to January 8 when gage height was affected by ice and September $2-10$ when data logger malfunctioned.

Rating. Channel is straight above and below 9" Parshall flume with large cobble.

Twenty-six inspections of no flow were made this year.

Rating No. 1 was developed based on the computation of 9" Parshall flume. Point of zero flow is 0.00 gage height.

Discharge. Discharge was computed by applying Rating No. 1 directly. Those days estimated at zero flow were based on precipitation and nearby gage stations.

Remarks. Records are good. 
E12235 Sandia Canyon Tributary from MRF

Daily Mean Discharge in Cubic Feet per Second

Water Year October 2008 to September 2009

\begin{tabular}{|c|c|c|c|c|c|c|c|c|c|c|c|c|}
\hline DAY & OCT & NOV & DEC & JAN & FEB & MAR & APR & MAY & JUN & JUL & AUG & SEP \\
\hline 1 & 0 & 0 & 0 & $0^{*}$ & 0 & 0 & 0 & 0 & 0 & 0 & 0 & 0 \\
\hline 2 & 0 & 0 & 0 & $0^{*}$ & 0 & 0 & 0 & 0 & 0 & 0 & 0 & $0^{*}$ \\
\hline 3 & 0 & 0 & 0 & $0^{*}$ & 0 & 0 & 0 & 0 & .01 & 0 & 0 & $0^{*}$ \\
\hline 4 & 0 & 0 & 0 & $0^{*}$ & 0 & 0 & 0 & 0 & 0 & 0 & 0 & $0^{*}$ \\
\hline 5 & 0 & 0 & 0 & $0^{*}$ & 0 & 0 & 0 & 0 & 0 & .01 & 0 & $0^{*}$ \\
\hline 6 & 0 & .03 & 0 & $0^{*}$ & 0 & 0 & 0 & 0 & 0 & .01 & 0 & $0^{*}$ \\
\hline 7 & 0 & 0 & 0 & $0^{*}$ & 0 & 0 & 0 & 0 & 0 & 0 & 0 & $0^{*}$ \\
\hline 8 & 0 & 0 & 0 & $0^{*}$ & 0 & 0 & 0 & 0 & 0 & 0 & 0 & $0^{*}$ \\
\hline 9 & 0 & 0 & 0 & 0 & 0 & 0 & 0 & 0 & 0 & 0 & 0 & $0^{*}$ \\
\hline 10 & 0 & 0 & 0 & 0 & 0 & 0 & 0 & 0 & 0 & 0 & 0 & $0^{*}$ \\
\hline 11 & .01 & 0 & 0 & 0 & 0 & 0 & 0 & 0 & 0 & 0 & 0 & 0 \\
\hline 12 & 0 & 0 & 0 & 0 & 0 & 0 & 0 & 0 & 0 & 0 & 0 & 0 \\
\hline 13 & 0 & 0 & 0 & 0 & 0 & 0 & 0 & 0 & 0 & 0 & 0 & 0 \\
\hline 14 & 0 & 0 & 0 & 0 & 0 & 0 & 0 & 0 & 0 & 0 & 0 & 0 \\
\hline 15 & 0 & 0 & $0^{*}$ & 0 & 0 & 0 & 0 & 0 & 0 & 0 & 0 & 0 \\
\hline 16 & 0 & 0 & $0^{*}$ & 0 & 0 & 0 & 0 & 0 & 0 & 0 & 0 & 0 \\
\hline 17 & 0 & 0 & $0^{*}$ & 0 & 0 & 0 & 0 & 0 & 0 & 0 & 0 & 0 \\
\hline 18 & 0 & 0 & $0^{*}$ & 0 & 0 & 0 & 0 & 0 & 0 & 0 & 0 & 0 \\
\hline 19 & 0 & 0 & $0^{*}$ & 0 & 0 & 0 & 0 & 0 & 0 & 0 & 0 & 0 \\
\hline 20 & 0 & 0 & $0^{*}$ & 0 & 0 & 0 & 0 & 0 & 0 & 0 & 0 & 0 \\
\hline 21 & 0 & 0 & $0^{*}$ & 0 & 0 & 0 & 0 & 0 & 0 & 0 & 0 & 0 \\
\hline 22 & 0 & 0 & $0^{*}$ & 0 & 0 & 0 & 0 & 0 & 0 & 0 & 0 & 0 \\
\hline 23 & 0 & 0 & $0^{*}$ & 0 & 0 & 0 & 0 & .01 & 0 & 0 & 0 & 0 \\
\hline 24 & 0 & 0 & $0^{*}$ & 0 & 0 & 0 & 0 & 0 & 0 & 0 & 0 & 0 \\
\hline 25 & 0 & 0 & $0^{*}$ & 0 & 0 & 0 & 0 & 0 & 0 & 0 & 0 & 0 \\
\hline 26 & 0 & 0 & $0^{*}$ & 0 & 0 & 0 & 0 & 0 & 0 & 0 & 0 & 0 \\
\hline 27 & 0 & 0 & $0^{*}$ & 0 & 0 & .02 & 0 & 0 & 0 & 0 & 0 & 0 \\
\hline 28 & 0 & 0 & $0^{*}$ & 0 & 0 & 0 & 0 & 0 & 0 & 0 & 0 & 0 \\
\hline 29 & 0 & 0 & $0^{*}$ & 0 & ----- & 0 & 0 & 0 & 0 & 0 & 0 & 0 \\
\hline 30 & 0 & 0 & $0^{*}$ & 0 & ----- & 0 & 0 & 0 & 0 & .01 & 0 & 0 \\
\hline 31 & 0 & ---- & $0^{*}$ & 0 & --.-- & 0 & ----- & 0 & --- & 0 & 0 & ---- \\
\hline Total & 0.01 & 0.03 & 0 & 0 & 0 & 0.02 & 0 & 0.01 & 0.01 & 0.03 & 0 & 0 \\
\hline Mean & 0 & .001 & 0 & 0 & 0 & .001 & 0 & 0 & 0 & .001 & 0 & 0 \\
\hline Max & .01 & .03 & 0 & 0 & 0 & .02 & 0 & .01 & .01 & .01 & 0 & 0 \\
\hline Min & 0 & 0 & 0 & 0 & 0 & 0 & 0 & 0 & 0 & 0 & 0 & 0 \\
\hline Acre-Ft & .02 & .06 & 0 & 0 & 0 & .04 & 0 & .02 & .02 & .06 & 0 & 0 \\
\hline Wtr Year & 2009 & Total & 0.11 & Mean & & 0 & $\operatorname{Max}$ & .03 & Min & 0 & Acre- $\mathrm{Ft}$ & 0.22 \\
\hline Cal Year & 2008 & Total & 0.11 & Mean & & 0 & Max & .03 & Min & 0 & Acre- $\mathrm{Ft}$ & 0.22 \\
\hline
\end{tabular}




\section{E1225 Sandia Canyon Tributary at Heavy Equipment}

Location. Lat $35^{\circ}$ 52' 22", long $106^{\circ} 18^{\prime} 46^{\prime \prime}$, SW 1/4, Sec. 16, T.19 N., R 6 E., Los Alamos County.

Drainage Area. $0.008 \mathrm{mi}^{2}$.

Period of Record. October 1, 2002, to September 30, 2009.

Gage. Data logger, 12" Parshall flume, rain gage with cellular telemetry. Elevation of gage is 7,322 ft above NGVD from land survey.

Remarks. Records are good.

Average Discharge. $7 \mathrm{yr}, 0.003 \mathrm{ft}^{3} / \mathrm{s}, 2.17$ acre- $\mathrm{ft} / \mathrm{yr}$.

Extremes for Period of Record. Maximum discharge, $8.90 \mathrm{ft}^{3} / \mathrm{s}$ August 10, 2008, gage height $1.69 \mathrm{ft}$. No flow most of the time.

Extremes for Current Year. Peak discharges above base of $5.0 \mathrm{ft}^{3} / \mathrm{s}$ and maximum (*):

\begin{tabular}{|c|c|c|c|}
\hline Date & Time & Discharge $\left(\mathbf{f t}^{\mathbf{3}} / \mathbf{s}\right)$ & Gage Height $(\mathbf{f t})$ \\
\hline April 12 & 0235 & 5.7 & 1.26 \\
\hline July 5 & 1215 & $6.0^{*}$ & $1.30^{*}$ \\
\hline July 30 & 1345 & 5.1 & 1.17 \\
\hline
\end{tabular}

No flow most of the time.

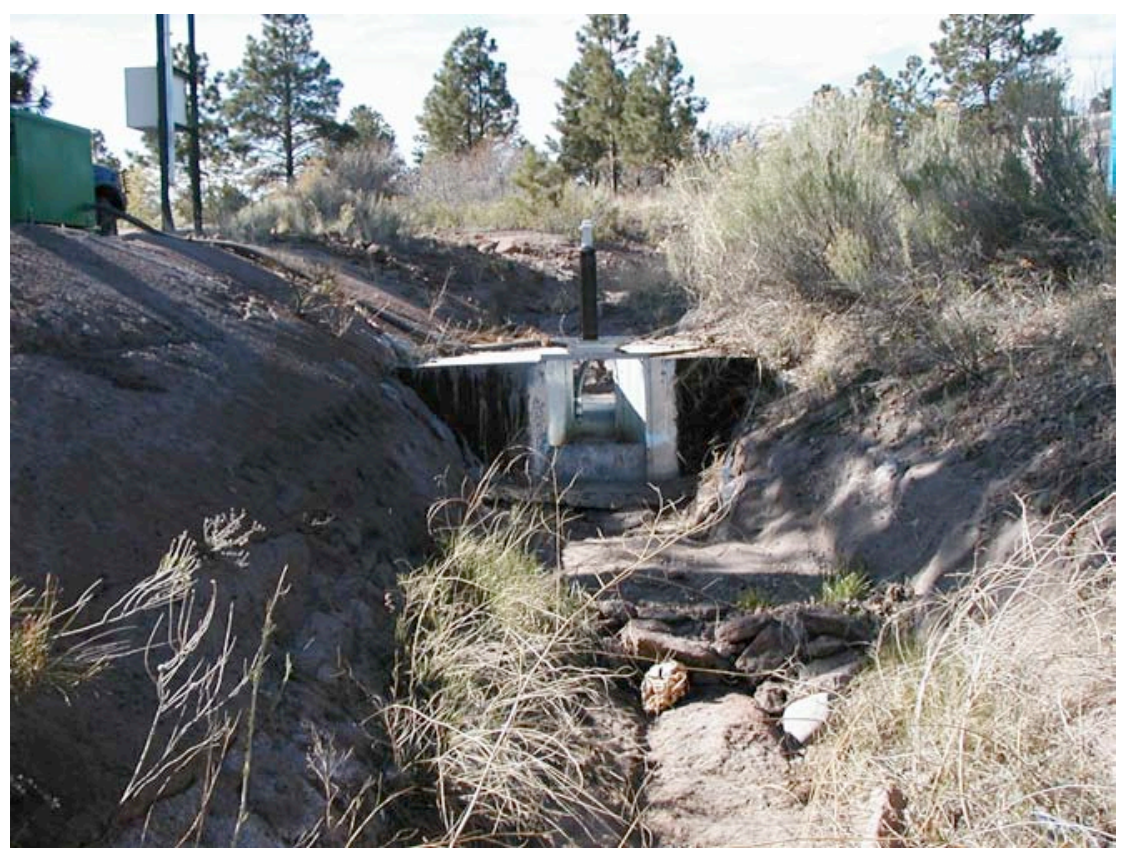




\title{
E1225 Sandia Canyon Tributary at Heavy Equipment
}

\author{
Station Analysis
}

\section{Water Year}

Equipment. Station is equipped with Sutron 8210 data logger (5-min. interval) with Milltronics sonic probe mounted on a 12" Parshall flume and cellular telemetry with speech modem. System is powered by a solar panel battery system housed in a NEMA shelter. The gage station is also equipped with an ISCO pump sampler for water quality data collection. ISCO is housed in a separate shelter, a $3^{\prime} \times 4^{\prime}$ metal box. Sampler is triggered by stage through the data logger. The staff in the 12" Parshall flume is the reference gage. There is no provision for direct discharge measurements above wading stage.

Station is also equipped with a tipping bucket rain gage, Rain Collection II. All equipment is powered with a solar panel battery charging system.

Field Work. The station was visited 31 times to conduct discharge measurements and service the instrumentation. Field inspections for the gage are listed under site history files on the Hydstra database. Discharge measurements for the gage are listed under site gauging files on the Hydstra database.

Datum Correction. None.

Gage-Height Record. The data logger referenced to the outside staff gave a complete and satisfactory record for the year, except for the periods from December 4 to January 20 and March 25 to April 6 when gage height was affected by ice in the flume.

Rating. The channel is straight above and below gage. It is confined to the main channel by cut banks on both sides. The bottom is a $10^{\prime}$ wide channel prone to no shifting. Low-water control is the $12^{\prime \prime}$ Parshall flume.

Thirty-one inspections of no flow were made this year.

Rating No. 1 was developed based on the computation of 12" Parshall flume. Point of zero flow is 0.00 gage height.

Discharge. Discharge was computed by applying Rating No. 1 directly. Those days estimated at zero flow were based on precipitation and nearby gage stations.

Records. Records are good. 
E1225 Sandia Canyon Tributary at Heavy Equipment

Daily Mean Discharge in Cubic Feet per Second

Water Year October 2008 to September 2009

\begin{tabular}{|c|c|c|c|c|c|c|c|c|c|c|c|c|}
\hline DAY & OCT & NOV & DEC & JAN & FEB & MAR & APR & MAY & JUN & JUL & AUG & SEP \\
\hline 1 & 0 & 0 & 0 & $0^{*}$ & 0 & 0 & $0^{*}$ & 0 & 0 & 0 & 0 & 0 \\
\hline 2 & 0 & 0 & 0 & $0^{*}$ & 0 & 0 & $0^{*}$ & 0 & 0 & 0 & 0 & 0 \\
\hline 3 & 0 & 0 & 0 & $0^{*}$ & 0 & 0 & $0^{*}$ & 0 & .08 & 0 & 0 & 0 \\
\hline 4 & .01 & 0 & $0^{*}$ & $0^{*}$ & 0 & 0 & $0^{*}$ & 0 & 0 & 0 & 0 & 0 \\
\hline 5 & 0 & 0 & $0^{*}$ & $0^{*}$ & 0 & 0 & $0^{*}$ & 0 & 0 & .11 & 0 & 0 \\
\hline 6 & 0 & .03 & $0^{*}$ & $0^{*}$ & 0 & 0 & $0^{*}$ & 0 & 0 & 0 & 0 & .01 \\
\hline 7 & 0 & .01 & $0^{*}$ & $0^{*}$ & 0 & 0 & 0 & 0 & 0 & 0 & 0 & 0 \\
\hline 8 & 0 & .01 & $0^{*}$ & $0^{*}$ & 0 & 0 & 0 & 0 & 0 & 0 & 0 & 0 \\
\hline 9 & 0 & 0 & $0^{*}$ & $0^{*}$ & 0 & 0 & 0 & 0 & 0 & 0 & 0 & 0 \\
\hline 10 & 0 & 0 & $0^{*}$ & $0^{*}$ & 0 & 0 & 0 & 0 & .08 & 0 & 0 & .01 \\
\hline 11 & .10 & 0 & $0^{*}$ & $0^{*}$ & 0 & 0 & .04 & 0 & 0 & 0 & 0 & 0 \\
\hline 12 & 0 & 0 & $0^{*}$ & $0^{*}$ & 0 & 0 & .09 & 0 & 0 & 0 & .02 & 0 \\
\hline 13 & 0 & 0 & $0^{*}$ & $0^{*}$ & 0 & 0 & 0 & 0 & 0 & 0 & .01 & 0 \\
\hline 14 & 0 & 0 & $0^{*}$ & $0^{*}$ & 0 & 0 & 0 & 0 & 0 & 0 & .07 & 0 \\
\hline 15 & 0 & 0 & $0^{*}$ & $0^{*}$ & 0 & 0 & 0 & 0 & 0 & 0 & 0 & 0 \\
\hline 16 & 0 & 0 & $0^{*}$ & $0^{*}$ & 0 & 0 & 0 & 0 & 0 & 0 & 0 & .04 \\
\hline 17 & 0 & 0 & $0^{*}$ & $0^{*}$ & 0 & 0 & .01 & 0 & 0 & 0 & 0 & .07 \\
\hline 18 & 0 & 0 & $0^{*}$ & $0^{*}$ & 0 & 0 & 0 & 0 & 0 & 0 & 0 & 0 \\
\hline 19 & 0 & 0 & $0^{*}$ & $0^{*}$ & 0 & 0 & 0 & 0 & 0 & 0 & 0 & 0 \\
\hline 20 & 0 & 0 & $0^{*}$ & $0^{*}$ & 0 & 0 & 0 & 0 & 0 & .02 & 0 & 0 \\
\hline 21 & 0 & 0 & $0^{*}$ & 0 & 0 & 0 & 0 & .02 & 0 & .05 & 0 & 0 \\
\hline 22 & 0 & 0 & $0^{*}$ & 0 & 0 & 0 & 0 & .01 & 0 & 0 & 0 & 0 \\
\hline 23 & 0 & 0 & $0^{*}$ & 0 & 0 & 0 & 0 & .10 & 0 & .02 & .01 & .04 \\
\hline 24 & 0 & 0 & $0^{*}$ & 0 & 0 & 0 & 0 & .02 & 0 & 0 & .02 & .03 \\
\hline 25 & 0 & 0 & $0^{*}$ & 0 & 0 & $0^{*}$ & 0 & 0 & 0 & 0 & 0 & 0 \\
\hline 26 & 0 & 0 & $0^{*}$ & 0 & 0 & $0^{*}$ & 0 & 0 & 0 & .02 & 0 & 0 \\
\hline 27 & 0 & .03 & $0^{*}$ & 0 & 0 & $0^{*}$ & 0 & .04 & 0 & 0 & 0 & 0 \\
\hline 28 & 0 & 0 & $0^{*}$ & 0 & 0 & $0^{*}$ & 0 & 0 & 0 & .04 & 0 & 0 \\
\hline 29 & 0 & 0 & $0^{*}$ & 0 & $-\ldots$ & $0^{*}$ & 0 & 0 & 0 & .03 & .01 & 0 \\
\hline 30 & 0 & 0 & $0^{*}$ & 0 & $-\ldots$ & $0^{*}$ & 0 & 0 & 0 & .05 & .05 & 0 \\
\hline 31 & 0 & ---- & $0^{*}$ & 0 & $-\cdots$ & $0^{*}$ & ----- & 0 & $-\cdots-$ & 0 & 0 & ---- \\
\hline Total & 0.11 & 0.08 & 0 & 0 & 0 & 0 & 0.14 & 0.19 & 0.16 & 0.34 & 0.19 & 0.20 \\
\hline Mean & .004 & .003 & 0 & 0 & 0 & 0 & .005 & .006 & .005 & .011 & .006 & .007 \\
\hline Max & .10 & .03 & 0 & 0 & 0 & 0 & .09 & .10 & .08 & .11 & .07 & .07 \\
\hline Min & 0 & 0 & 0 & 0 & 0 & 0 & 0 & 0 & 0 & 0 & 0 & 0 \\
\hline Acre-Ft & .22 & .16 & 0 & 0 & 0 & 0 & .28 & .38 & .32 & .67 & .38 & .40 \\
\hline Wtr Year & 2009 & Total & 1.41 & Mean & & 04 & $\operatorname{lax}$ & .11 & Min & 0 & Acre-Ft & 2.8 \\
\hline Cal Year & 2008 & Total & 1.14 & Mean & & 03 & $\operatorname{lax}$ & .13 & Min & 0 & Acre-Ft & 2.3 \\
\hline
\end{tabular}

${ }^{*}$ Estimate 


\section{E123 Sandia Canyon below Wetlands}

Location. Lat $35^{\circ}$ 52' 23", long $106^{\circ} 18^{\prime} 35^{\prime \prime}$, SE 1/4, Sec. 16, T. 19 N., R. 6 E., Los Alamos County.

Drainage Area. $0.29 \mathrm{mi}^{2}$.

Period of Record. August 1, 1999, to September 30, 2009.

Revised Record. Drainage Area (2006); Section (2007).

Gage. Data logger with cellular telemetry. Elevation of gage is 7,204 ft above NGVD from GPS survey.

Remarks. Records are fair to good.

Average Discharge. $9 \mathrm{yr}, 0.61 \mathrm{ft}^{3} / \mathrm{s}, 439$ acre- $\mathrm{ft} /$ year.

Extremes for Period of Record. Maximum discharge, $88 \mathrm{ft}^{3} / \mathrm{s}$, August 23, 2003, gage height $4.23 \mathrm{ft}$. Minimum daily discharge, $0.08 \mathrm{ft}^{3} / \mathrm{s}$ June 22, 2003.

Extremes for Current Year. Peak discharges above base of $40 \mathrm{ft}^{3} / \mathrm{s}$ and maximum (*):

\begin{tabular}{|c|c|c|c|}
\hline Date & Time & Discharge $\left(\mathbf{f t}^{\mathbf{3}} / \mathbf{s}\right)$ & Gage Height (ft) \\
\hline July 5 & 1305 & 54 & 3.47 \\
\hline July 6 & 1320 & 54 & 3.47 \\
\hline July 28 & 1335 & 43 & 3.27 \\
\hline July 30 & 1445 & 48 & 3.36 \\
\hline August 30 & 1755 & $54 *$ & $3.48^{*}$ \\
\hline
\end{tabular}

Minimum daily discharge, $0.12 \mathrm{ft}^{3} / \mathrm{s}$ July 10 .

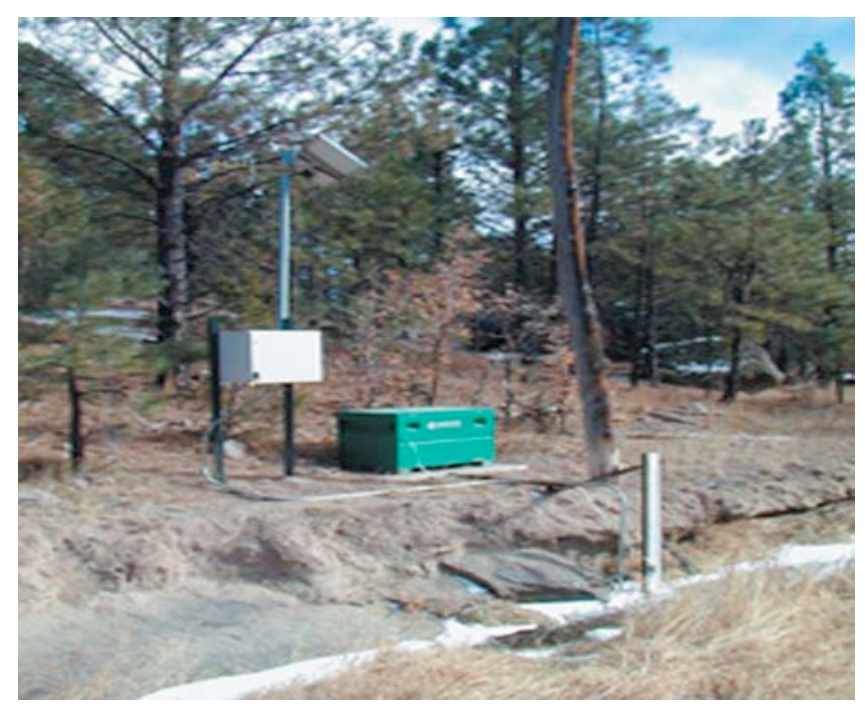




\title{
E123 Sandia Canyon below Wetlands
}

\author{
Station Analysis
}

\section{Water Year}

Equipment. Station is equipped with Sutron 8210 data logger (5-min. interval) with a Sutron Accubar bubble sensor. Data logger is equipped with cellular speech modem telemetry. The system is powered by a solar panel battery system housed in a NEMA shelter. Station is also equipped with ISCO pump sampler for water quality sample collection. ISCO is housed in a separate shelter, a $3^{\prime} \times 4^{\prime}$ metal box. Sampler is triggered by stage through the data logger. An outside staff is available for reference. No provision for discharge measurements above wading stage.

An auxiliary 6" Parshall flume is located downstream from E123 used to verify the lowflow record.

Field Work. The station was visited 26 times to conduct discharge measurements and service the instrumentation. Field inspections for the gage are listed under site history files on the Hydstra database. Discharge measurements for the gage are listed under site gauging files on the Hydstra database.

Datum Correction. None, levels run June 27, 2008, found within limits.

Gage-Height Record. The data logger referenced to the inside gage height gave a complete and satisfactory record for the year, except during the periods from November 3-10, November 27 to December 11, and December 29 to January 20 when the data logger malfunctioned.

Rating. Channel is trapezoidal with rock outcrop and small depositional bars within pools. Banks have some grass, not very tall or thick. Channel is straight for about 100' above and below gage.

Twenty-three discharge measurements (Nos. 110-132) were made this year.

Rating No. 4 was developed based on measurements made previous years. Shifts are small and mostly negative caused by small amounts of deposition near gage or some bank slough during high flows. They have been distributed using variable diagrams with no shifts applied on the peak flows.

Discharge. Discharge computed from Rating No. 4 with shifts applied by V diagrams.

Remarks. Records are good except for estimated days, which are fair. 


\section{E123 Sandia Canyon below W etlands}

Daily Mean Discharge in Cubic Feet per Second

Water Year October 2008 to September 2009

\begin{tabular}{|c|c|c|c|c|c|c|c|c|c|c|c|c|}
\hline DAY & OCT & NOV & DEC & JAN & FE B & MAR & APR & MAY & JUN & JUL & AUG & SEP \\
\hline 1 & .45 & .45 & $.97^{*}$ & $.35^{\star}$ & .40 & .42 & .46 & .38 & .30 & .37 & .43 & .39 \\
\hline 2 & .41 & .49 & $.97^{\star}$ & $.46^{*}$ & .59 & .57 & .39 & .32 & .35 & .42 & .36 & .54 \\
\hline 3 & .55 & .44 & $.97^{*}$ & $.51^{*}$ & .39 & .34 & .36 & .35 & 1.0 & .65 & .42 & .42 \\
\hline 4 & .71 & $.26^{*}$ & $.97^{\star}$ & $.35^{\star}$ & .44 & .36 & .49 & .43 & .27 & .58 & .43 & .43 \\
\hline 5 & .70 & $.27^{\star}$ & $.97^{*}$ & $.81^{*}$ & .46 & .41 & .51 & .50 & .25 & 1.4 & .42 & .39 \\
\hline 6 & .37 & $.27^{*}$ & $.97^{\star}$ & $.39^{*}$ & .37 & .40 & .44 & .33 & .23 & .93 & .39 & .55 \\
\hline 7 & .39 & $.27^{*}$ & $.97^{\star}$ & $.42^{*}$ & .45 & .43 & .52 & .58 & .24 & .17 & .36 & .66 \\
\hline 8 & .49 & $.27^{*}$ & $.97^{*}$ & $.47^{*}$ & .43 & .43 & .34 & .35 & .22 & .12 & .43 & .52 \\
\hline 9 & .19 & $.27^{*}$ & $.97^{\star}$ & $.34^{*}$ & .46 & .46 & .38 & .55 & .20 & .14 & .37 & .52 \\
\hline 10 & .35 & $.40^{*}$ & $.97^{*}$ & $.31^{*}$ & .53 & .43 & .47 & .31 & .96 & .12 & .37 & .46 \\
\hline 11 & 1.2 & .42 & $.70^{\star}$ & $.59^{*}$ & .45 & .49 & 1.1 & .49 & .15 & .19 & .40 & .51 \\
\hline 12 & .38 & .47 & .45 & $.38^{*}$ & .36 & .44 & 1.3 & .56 & .13 & .19 & .78 & .41 \\
\hline 13 & .37 & .36 & .59 & $.33^{*}$ & .38 & .73 & .73 & .42 & .16 & .40 & .53 & .43 \\
\hline 14 & .69 & .33 & .58 & $.62^{*}$ & .48 & .55 & .42 & .26 & .38 & .47 & 1.3 & .46 \\
\hline 15 & .51 & .47 & .48 & $.42^{*}$ & .38 & .57 & .43 & .34 & .70 & .38 & .46 & .33 \\
\hline 16 & .34 & .46 & .40 & $.39^{*}$ & .39 & .31 & .34 & .32 & .33 & .42 & .40 & .89 \\
\hline 17 & .37 & .50 & .57 & $.34^{*}$ & .49 & .40 & .72 & .34 & .35 & .53 & .43 & 1.1 \\
\hline 18 & .29 & .36 & .58 & $.40^{*}$ & .35 & .23 & .72 & .42 & .31 & .51 & .40 & .55 \\
\hline 19 & .42 & .40 & .38 & $.50^{\star}$ & .28 & .40 & .54 & .36 & .44 & .48 & .36 & .66 \\
\hline 20 & .41 & .46 & .47 & $.62^{*}$ & .41 & .46 & .67 & .41 & 1.4 & .75 & .45 & .48 \\
\hline 21 & .31 & .52 & .51 & .46 & .47 & .46 & .36 & .70 & .38 & 1.0 & .47 & .39 \\
\hline 22 & .42 & .43 & .46 & .55 & .74 & .46 & .37 & .57 & .42 & .56 & .43 & .43 \\
\hline 23 & .35 & .43 & .33 & .62 & .47 & .34 & .36 & 1.6 & .41 & .53 & .63 & .60 \\
\hline 24 & .45 & .53 & .47 & .66 & .42 & .40 & .37 & .77 & .59 & .57 & .63 & .95 \\
\hline 25 & .39 & .34 & .49 & .69 & .36 & .38 & .42 & .47 & .60 & .44 & .16 & .47 \\
\hline 26 & .48 & .27 & .41 & .55 & .39 & .55 & .33 & .44 & .52 & .75 & .22 & .42 \\
\hline 27 & .47 & $.59^{*}$ & .44 & .52 & .41 & .69 & .36 & 1.2 & .50 & .53 & .33 & .50 \\
\hline 28 & .34 & $.97^{*}$ & $.38^{*}$ & .48 & .47 & .70 & .39 & 1.3 & .56 & .83 & .25 & .42 \\
\hline 29 & .43 & $.97^{*}$ & $.36^{*}$ & .41 & ----- & .75 & .36 & .28 & .59 & .72 & .36 & .46 \\
\hline 30 & .43 & $.97^{*}$ & $.38^{*}$ & .57 & ----- & .56 & .32 & .35 & .37 & 1.0 & $.95^{*}$ & .39 \\
\hline 31 & .38 & ------ & $.38^{*}$ & .54 & ----- & .48 & ----- & .30 & ----- & .50 & .57 & ---- \\
\hline Total & 14.04 & 13.64 & 19.51 & 15.05 & 12.22 & 14.60 & 14.97 & 16.00 & 13.31 & 16.65 & 14.49 & 15.73 \\
\hline Mean & .45 & .45 & .63 & .49 & .44 & .47 & .50 & .52 & .44 & .54 & .47 & .52 \\
\hline $\operatorname{Max}$ & 1.2 & .97 & .97 & .81 & .74 & .75 & 1.3 & 1.6 & 1.4 & 1.4 & 1.3 & 1.1 \\
\hline Min & .19 & .26 & .33 & .31 & .28 & .23 & .32 & .26 & .13 & .12 & .16 & .33 \\
\hline Acre-F t & 28 & 27 & 39 & 30 & 24 & 29 & 30 & 32 & 26 & 33 & 29 & 31 \\
\hline Wtr Year & 2009 & Total & 180.21 & & & .49 & Max & 1.6 & Min & .12 & Acre-Ft & 357 \\
\hline Cal Year & 2008 & Total & 217.20 & & & .59 & Max & 6.7 & Min & .15 & Acre-Ft & 431 \\
\hline
\end{tabular}




\section{E1234 Sandia Canyon Roads and Grounds at Sigma}

Location. Lat $35^{\circ}$ 52' 14", long $106^{\circ} 18^{\prime}$ 24", Sec. 21, T. 19 N., R. 6 E., Los Alamos County.

Drainage Area. $0.001 \mathrm{mi}^{2}$.

Period of Record. August 2, 2007, to September 30, 2009.

Gage. Data logger and 24" Parshall flume. Elevation 7,311 ft above NGVD.

Remarks. Records are good.

Extremes for Period of Record. Maximum discharge is $5.77 \mathrm{ft}^{3} / \mathrm{s}$, August 10, 2008, gage height $0.81 \mathrm{ft}$. No flow most of the time.

Extremes for Current Year. Peak discharges above base of $2.0 \mathrm{ft}^{3} / \mathrm{s}$ and maximum (*):

\begin{tabular}{|c|c|c|c|}
\hline Date & Time & Discharge $\left(\mathbf{f t}^{\mathbf{3}} / \mathbf{s}\right)$ & Gage Height $(\mathbf{f t})$ \\
\hline July 5 & 1210 & 2.0 & 0.40 \\
\hline July 6 & 1220 & 2.0 & 0.40 \\
\hline July 23 & 1220 & 2.2 & 0.44 \\
\hline July 30 & 1340 & $2.2^{*}$ & $0.44^{*}$ \\
\hline
\end{tabular}

No flow most of the time.

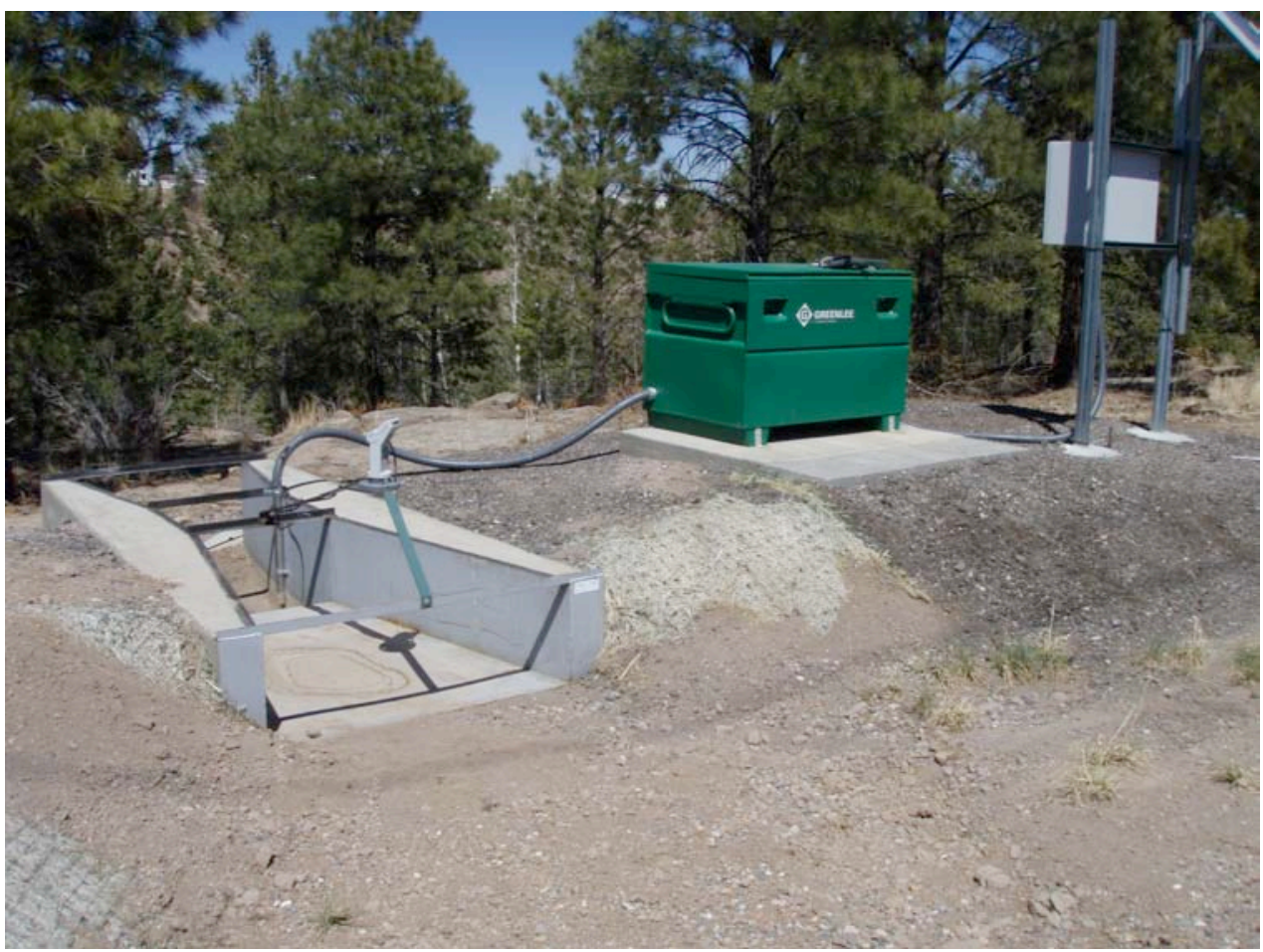




\title{
E1234 Sandia Canyon Roads and Grounds at Sigma
}

\author{
Station Analysis
}

\section{Water Year}

Equipment. Station is equipped with Sutron 8210 data logger (5-min. interval) and Milltronics sonic probe mounted on a 24" Parshall flume. The system is powered by a solar panel battery system housed in a NEMA shelter. Station is equipped with an ISCO pump sampler for water quality sample collection. ISCO is housed in a separate shelter, a $3^{\prime} \times 4^{\prime}$ metal box. Sampler is triggered by stage through the data logger. The staff in the 24 " Parshall flume is the reference gage. No provision for discharge measurements above wading stage.

Field Work. This station was visited 22 times to conduct discharge measurements and service the instrumentation. Field inspections for the gage are listed under site history files on the Hydstra database. Discharge measurements for the gage are listed under site gauging files on the Hydstra database.

Datum Correction. None.

Gage-Height Record. The data logger referenced to the outside staff gave a complete and satisfactory record for the year, except for the periods from November 28 to December 30 and several days in February, March, and April when gage height was affected by ice.

Rating. The control for this station is the 24 " Parshall flume.

Twenty-two inspections of no flow and one day of snow melt were made this year.

Rating No. 1 was developed based on the computation of 24" Parshall flume. Point of zero flow is 0.00 gage height.

Discharge. Discharge was computed by applying Rating No. 1 directly. Those days estimated at zero flow were based on precipitation and nearby gage stations.

Remarks. Records are good. 
E1234 Sandia Canyon Roads and Grounds at Sigma

Daily Mean Discharge in Cubic Feet per Second

Water Year October 2008 to September 2009

\begin{tabular}{|c|c|c|c|c|c|c|c|c|c|c|c|c|}
\hline DAY & OCT & NOV & DEC & JAN & FEB & MAR & APR & MAY & JUN & JUL & AUG & SEP \\
\hline 1 & 0 & 0 & $0^{*}$ & $0^{*}$ & 0 & 0 & 0 & 0 & 0 & 0 & 0 & 0 \\
\hline 2 & 0 & 0 & 0 & $0^{*}$ & 0 & 0 & $0^{*}$ & 0 & 0 & 0 & .02 & 0 \\
\hline 3 & 0 & 0 & 0 & $0^{*}$ & 0 & 0 & 0 & 0 & .06 & 0 & .03 & 0 \\
\hline 4 & .03 & 0 & 0 & $0^{*}$ & 0 & 0 & 0 & 0 & 0 & 0 & 0 & 0 \\
\hline 5 & .04 & 0 & 0 & $0^{*}$ & 0 & 0 & 0 & 0 & 0 & .09 & 0 & 0 \\
\hline 6 & 0 & 0 & 0 & $0^{*}$ & 0 & 0 & $0^{*}$ & 0 & 0 & .06 & 0 & .01 \\
\hline 7 & 0 & 0 & $0^{*}$ & 0 & 0 & 0 & $0^{*}$ & 0 & 0 & 0 & 0 & 0 \\
\hline 8 & 0 & 0 & 0 & $0^{*}$ & 0 & $0^{*}$ & 0 & 0 & 0 & 0 & 0 & 0 \\
\hline 9 & 0 & 0 & $0^{*}$ & $0^{*}$ & 0 & $0^{*}$ & 0 & 0 & 0 & 0 & 0 & 0 \\
\hline 10 & 0 & 0 & $0^{*}$ & $0^{*}$ & $0^{*}$ & $0^{*}$ & 0 & 0 & .09 & .16 & 0 & 0 \\
\hline 11 & .07 & 0 & $0^{*}$ & $0^{*}$ & $0^{*}$ & $0^{*}$ & $0^{*}$ & 0 & 0 & 0 & 0 & 0 \\
\hline 12 & 0 & 0 & $0^{*}$ & $0^{*}$ & 0 & $0^{*}$ & $0^{*}$ & 0 & 0 & 0 & .03 & 0 \\
\hline 13 & 0 & 0 & $0^{*}$ & $0^{*}$ & 0 & $0^{*}$ & $0^{*}$ & 0 & 0 & 0 & .04 & 0 \\
\hline 14 & 0 & 0 & $0^{*}$ & $0^{*}$ & 0 & $0^{*}$ & $0^{*}$ & 0 & .05 & 0 & .09 & .03 \\
\hline 15 & 0 & 0 & $0^{*}$ & $0^{*}$ & $0^{*}$ & $0^{*}$ & 0 & 0 & 0 & 0 & 0 & .02 \\
\hline 16 & 0 & 0 & $0^{*}$ & $0^{*}$ & 0 & $0^{*}$ & 0 & 0 & 0 & 0 & 0 & .05 \\
\hline 17 & 0 & 0 & $0^{*}$ & $0^{*}$ & 0 & 0 & .08 & 0 & 0 & 0 & 0 & .14 \\
\hline 18 & 0 & 0 & $0^{*}$ & $0^{*}$ & 0 & 0 & $0^{*}$ & 0 & 0 & 0 & 0 & 0 \\
\hline 19 & 0 & 0 & $0^{*}$ & $0^{*}$ & 0 & $0^{*}$ & $0^{*}$ & 0 & 0 & 0 & 0 & 0 \\
\hline 20 & 0 & 0 & $0^{*}$ & $0^{*}$ & $0^{*}$ & 0 & $0^{*}$ & 0 & .10 & .02 & 0 & 0 \\
\hline 21 & 0 & 0 & 0 & $0^{*}$ & 0 & 0 & $0^{*}$ & .02 & 0 & .03 & 0 & 0 \\
\hline 22 & 0 & 0 & $0^{*}$ & $0^{*}$ & 0 & 0 & $0^{*}$ & .07 & 0 & 0 & 0 & 0 \\
\hline 23 & 0 & 0 & $0^{*}$ & $0^{*}$ & 0 & 0 & $0^{*}$ & .12 & 0 & .04 & .02 & .02 \\
\hline 24 & 0 & 0 & $0^{*}$ & $0^{*}$ & 0 & 0 & 0 & .04 & 0 & 0 & .03 & .03 \\
\hline 25 & 0 & 0 & $0^{*}$ & $0^{*}$ & 0 & 0 * & 0 & 0 & .03 & 0 & 0 & 0 \\
\hline 26 & 0 & 0 & $0^{*}$ & $0^{*}$ & 0 & $0^{*}$ & 0 & 0 & 0 & .02 & 0 & 0 \\
\hline 27 & 0 & .09 & $0^{*}$ & $0^{*}$ & 0 & $0^{*}$ & $0^{*}$ & .05 & 0 & 0 & 0 & 0 \\
\hline 28 & 0 & $0^{*}$ & $0^{*}$ & $0^{*}$ & 0 & $0^{*}$ & 0 & 0 & 0 & .03 & 0 & 0 \\
\hline 29 & 0 & $0^{*}$ & $0^{*}$ & $0^{*}$ & ----- & $0^{*}$ & 0 & 0 & 0 & .02 & 0 & 0 \\
\hline 30 & 0 & $0^{*}$ & $0^{*}$ & $0^{*}$ & ----- & $0^{*}$ & $0^{*}$ & 0 & .01 & .05 & .02 & 0 \\
\hline 31 & 0 & ----- & $0^{*}$ & 0 & ----- & 0 & ----- & 0 & ---- & 0 & 0 & ---- \\
\hline Total & 0.14 & 0.09 & 0 & 0 & 0 & 0 & 0.08 & 0.30 & 0.34 & 0.52 & 0.28 & 0.30 \\
\hline Mean & .005 & .003 & 0 & 0 & 0 & 0 & .003 & .010 & .011 & .017 & .009 & .010 \\
\hline Max & .07 & .09 & 0 & 0 & 0 & 0 & .08 & .12 & .10 & .16 & .09 & .14 \\
\hline Min & 0 & 0 & 0 & 0 & 0 & 0 & 0 & 0 & 0 & 0 & 0 & 0 \\
\hline Acre-Ft & .28 & .18 & 0 & 0 & 0 & 0 & .16 & .60 & .67 & 1.0 & .56 & .60 \\
\hline Wtr Year & 2009 & Total & 2.05 & Mean & & 06 & Max & .16 & Min & 0 & Acre- $\mathrm{Ft}$ & 4.1 \\
\hline Cal Year & 2008 & Total & 1.45 & Mean & & 004 & Max & .25 & Min & 0 & Acre-Ft & 2.9 \\
\hline
\end{tabular}

${ }^{\star}$ Estimate 


\section{E125 Sandia Canyon above SR 4}

Location. Lat $35^{\circ}$ 51' 32", long $106^{\circ}$ 13' 34", SW 1/4, Sec. 20, T. 19 N., R.7 E., Santa Fe County.

Drainage Area. $2.05 \mathrm{mi}^{2}$.

Period of Record. October 1, 1994, to September 30, 2009.

Revised Record. Drainage Area (2006).

Gage. Data logger and concrete control. Elevation of gage is 6,495 ft above NGVD from GPS survey.

Remarks. Records are good.

Average Discharge. $15 \mathrm{yr}, 0.003 \mathrm{ft}^{3} / \mathrm{s}, 2.17 \mathrm{acre}-\mathrm{ft} / \mathrm{yr}$.

Extremes for Period of Record. Maximum discharge, $59 \mathrm{ft}^{3} / \mathrm{s}$, August 25, 2006, gage height $3.60 \mathrm{ft}$ (from slope-area measurement). No flow most of the time.

Extremes for Current Year. No flow for the year.

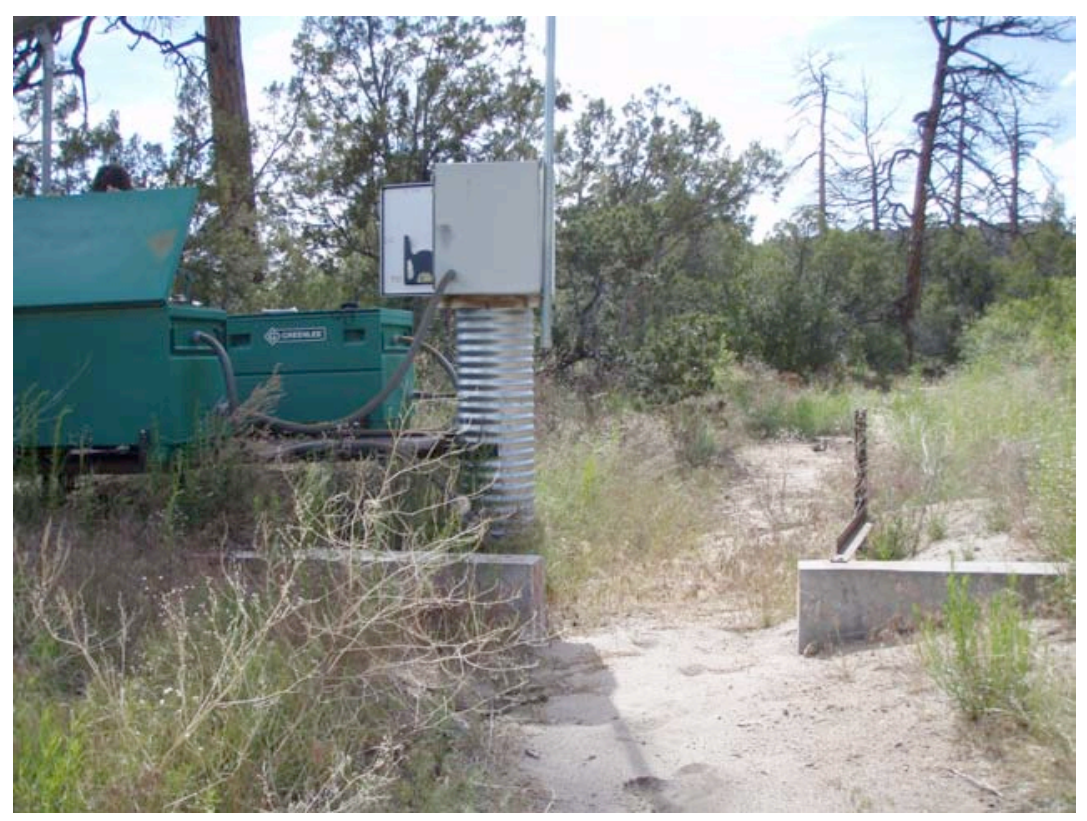




\title{
E125 Sandia Canyon above SR 4
}

\author{
Station Analysis
}

\section{Water Year}

Equipment. Station is equipped with Sutron 8210 data logger (5-min. interval) and a shaft encoder float system. The system is powered by a solar panel battery system. All equipment is housed in NEMA shelter on 18" CMP well. Station is equipped with an ISCO pump sampler for water quality sample collection. ISCO is housed in a separate shelter, a $3^{\prime} \times 4^{\prime}$ metal box. Sampler is triggered by stage through the data logger.

Control is a concrete broad-crested weir. No provision for measurements above wading stage.

Field Work. The station was visited 14 times to conduct discharge measurements and service the instrumentation. Field inspections for the gage are listed under site history files on the Hydstra database. Discharge measurements for the gage are listed under site gauging files on the Hydstra database.

Datum Correction. None.

Gage-Height Record. The data logger referenced to the outside staff gave a complete and satisfactory record for the year.

Rating. Channel is straight for $150^{\prime}$ above and $100^{\prime}$ below gage. Bed material is sand with vegetation on banks, bottom is well supported.

Fourteen inspections of no flow were made this year.

Rating No. 1 is from theoretical points computed from broad-crested weir formula from USGS-TWRI. Worksheet in record folder shows computations including estimated velocity head used in computation because "p" in equation was functionally zero. Rating No. 1 is considered fair.

Discharge. Discharge computed directly from Rating No.1 without shift correction.

Remarks. Records are good. 


\section{E125 Sandia Canyon above SR 4}

Daily Mean Discharge in Cubic Feet per Second

Water Year October 2008 to September 2009

\begin{tabular}{|c|c|c|c|c|c|c|c|c|c|c|c|c|}
\hline DAY & ОСТ & NOV & DEC & JAN & FEB & MAR & APR & MAY & JUN & JUL & AUG & SEP \\
\hline 1 & 0 & 0 & 0 & 0 & 0 & 0 & 0 & 0 & 0 & 0 & 0 & 0 \\
\hline 2 & 0 & 0 & 0 & 0 & 0 & 0 & 0 & 0 & 0 & 0 & 0 & 0 \\
\hline 3 & 0 & 0 & 0 & 0 & 0 & 0 & 0 & 0 & 0 & 0 & 0 & 0 \\
\hline 4 & 0 & 0 & 0 & 0 & 0 & 0 & 0 & 0 & 0 & 0 & 0 & 0 \\
\hline 5 & 0 & 0 & 0 & 0 & 0 & 0 & 0 & 0 & 0 & 0 & 0 & 0 \\
\hline 6 & 0 & 0 & 0 & 0 & 0 & 0 & 0 & 0 & 0 & 0 & 0 & 0 \\
\hline 7 & 0 & 0 & 0 & 0 & 0 & 0 & 0 & 0 & 0 & 0 & 0 & 0 \\
\hline 8 & 0 & 0 & 0 & 0 & 0 & 0 & 0 & 0 & 0 & 0 & 0 & 0 \\
\hline 9 & 0 & 0 & 0 & 0 & 0 & 0 & 0 & 0 & 0 & 0 & 0 & 0 \\
\hline 10 & 0 & 0 & 0 & 0 & 0 & 0 & 0 & 0 & 0 & 0 & 0 & 0 \\
\hline 11 & 0 & 0 & 0 & 0 & 0 & 0 & 0 & 0 & 0 & 0 & 0 & 0 \\
\hline 12 & 0 & 0 & 0 & 0 & 0 & 0 & 0 & 0 & 0 & 0 & 0 & 0 \\
\hline 13 & 0 & 0 & 0 & 0 & 0 & 0 & 0 & 0 & 0 & 0 & 0 & 0 \\
\hline 14 & 0 & 0 & 0 & 0 & 0 & 0 & 0 & 0 & 0 & 0 & 0 & 0 \\
\hline 15 & 0 & 0 & 0 & 0 & 0 & 0 & 0 & 0 & 0 & 0 & 0 & 0 \\
\hline 16 & 0 & 0 & 0 & 0 & 0 & 0 & 0 & 0 & 0 & 0 & 0 & 0 \\
\hline 17 & 0 & 0 & 0 & 0 & 0 & 0 & 0 & 0 & 0 & 0 & 0 & 0 \\
\hline 18 & 0 & 0 & 0 & 0 & 0 & 0 & 0 & 0 & 0 & 0 & 0 & 0 \\
\hline 19 & 0 & 0 & 0 & 0 & 0 & 0 & 0 & 0 & 0 & 0 & 0 & 0 \\
\hline 20 & 0 & 0 & 0 & 0 & 0 & 0 & 0 & 0 & 0 & 0 & 0 & 0 \\
\hline 21 & 0 & 0 & 0 & 0 & 0 & 0 & 0 & 0 & 0 & 0 & 0 & 0 \\
\hline 22 & 0 & 0 & 0 & 0 & 0 & 0 & 0 & 0 & 0 & 0 & 0 & 0 \\
\hline 23 & 0 & 0 & 0 & 0 & 0 & 0 & 0 & 0 & 0 & 0 & 0 & 0 \\
\hline 24 & 0 & 0 & 0 & 0 & 0 & 0 & 0 & 0 & 0 & 0 & 0 & 0 \\
\hline 25 & 0 & 0 & 0 & 0 & 0 & 0 & 0 & 0 & 0 & 0 & 0 & 0 \\
\hline 26 & 0 & 0 & 0 & 0 & 0 & 0 & 0 & 0 & 0 & 0 & 0 & 0 \\
\hline 27 & 0 & 0 & 0 & 0 & 0 & 0 & 0 & 0 & 0 & 0 & 0 & 0 \\
\hline 28 & 0 & 0 & 0 & 0 & 0 & 0 & 0 & 0 & 0 & 0 & 0 & 0 \\
\hline 29 & 0 & 0 & 0 & 0 & ---- & 0 & 0 & 0 & 0 & 0 & 0 & 0 \\
\hline 30 & 0 & 0 & 0 & 0 & -.--- & 0 & 0 & 0 & 0 & 0 & 0 & 0 \\
\hline 31 & 0 & --- & 0 & 0 & ----- & 0 & ----- & 0 & ---- & 0 & 0 & ---- \\
\hline Total & 0 & 0 & 0 & 0 & 0 & 0 & 0 & 0 & 0 & 0 & 0 & 0 \\
\hline Mean & 0 & 0 & 0 & 0 & 0 & 0 & 0 & 0 & 0 & 0 & 0 & 0 \\
\hline Max & 0 & 0 & 0 & 0 & 0 & 0 & 0 & 0 & 0 & 0 & 0 & 0 \\
\hline Min & 0 & 0 & 0 & 0 & 0 & 0 & 0 & 0 & 0 & 0 & 0 & 0 \\
\hline Acre-Ft & 0 & 0 & 0 & 0 & 0 & 0 & 0 & 0 & 0 & 0 & 0 & 0 \\
\hline Wtr Year & 2009 & Total & 0 & Mean & & 0 & Max & 0 & Min & 0 & Acre- Ft & 0 \\
\hline Cal Year & 2008 & Total & 7.6 & Mean & & 21 & Max & 7.6 & Min & 0 & Acre- $\mathrm{Ft}$ & 15 \\
\hline
\end{tabular}




\section{E196 TA-55 above Effluent Canyon}

Location. Lat $35^{\circ} 51^{\prime}$ 52", long $106^{\circ} 18^{\prime} 13^{\prime \prime}$, NE 1/4, Sec. 21, T. 19 N., R. 6 E., Los Alamos County.

Drainage Area. $0.008 \mathrm{mi}^{2}$.

Period of Record. October 1, 2006, to September 30, 2009.

Gage. Data logger and 12" Parshall flume, as well as rain gage with cellular telemetry. Elevation of gage is 7,270 ft above NGVD.

Remarks. Records are good. Records for this site existed before period of record but are not reliable.

Extremes for Period of Record. Maximum discharge, $0.95 \mathrm{ft}^{3} / \mathrm{s}$, September 2, 2007, gage height $0.42 \mathrm{ft}$. No flow most of the time.

Extremes for Current Year. Maximum discharge, $0.77 \mathrm{ft}^{3} / \mathrm{s}$ at $1225 \mathrm{~h}$, July 23, gage height $0.37 \mathrm{ft}$. No peak above base of $1.0 \mathrm{ft}^{3} / \mathrm{s}$. No flow most of the time.

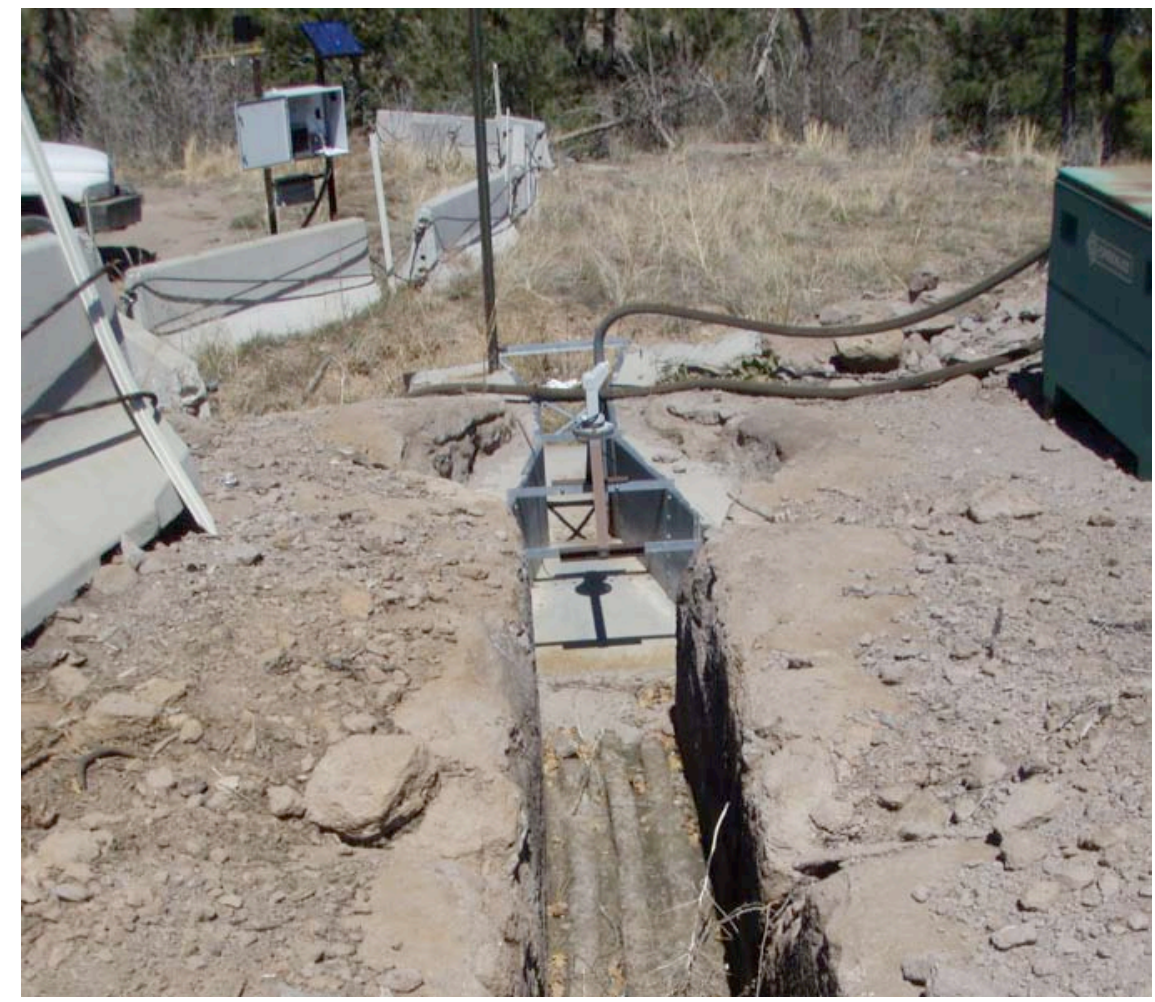




\title{
E196 TA-55 above Effluent Canyon
}

\author{
Station Analysis
}

\section{Water Year}

Equipment. Station is equipped with Sutron 8210 data logger (5-min. interval) and Milltronics sonic probe mounted on a 12" Parshall flume and cellular telemetry with speech modem. The system is powered by a solar panel battery system housed in a NEMA shelter. Station is equipped with an ISCO pump sampler for water quality sample collection. ISCO is housed in a separate shelter, a $3^{\prime} \times 4^{\prime}$ metal box. Sampler is triggered by stage through the data logger. The staff in the 12" Parshall flume is the reference gage. No provision for discharge measurements above wading stage.

Station is also equipped with a tipping bucket rain gage, Rain Collection II. All equipment is powered with a solar panel battery charging system.

Field Work. This station was visited 28 times for the purpose of making a discharge measurement and or servicing the instrumentation. Field inspections for the gage are listed under site history files on the Hydstra database. Discharge measurements for the gage are listed under site gauging files on the Hydstra database.

Datum Correction. None.

Gage-Height Record. The data logger referenced to the outside staff gave a complete and satisfactory record, except during the periods from December to March when gage height was affected by ice and March 4-20 and April 20-22 when data logger malfunctioned.

Rating. The control for the station is a 12" Parshall flume.

Twenty-eight inspections of no flow were made this year.

Rating No. 1 was developed based on the computation of 12" Parshall flume. Point of zero flow is 0.00 gage height.

Discharge. Discharge was computed by applying Rating No. 1 directly. Those days estimated at zero flow were based on precipitation and nearby gage stations.

Remarks. Records are good. 


\section{E196 TA-55 above Effluent Can yo $n$}

Daily Mean Discharge in Cubic Feet per Second

Water Year October 2008 to September 2009

\begin{tabular}{|c|c|c|c|c|c|c|c|c|c|c|c|c|}
\hline DAY & OCT & NOV & DEC & JAN & FEB & MAR & APR & MAY & JUN & JUL & AUG & SEP \\
\hline 1 & 0 & 0 & 0 & $0^{*}$ & 0 & 0 & 0 & 0 & 0 & 0 & 0 & 0 \\
\hline 2 & 0 & 0 & 0 & $0^{*}$ & 0 & 0 & 0 & 0 & 0 & 0 & 0 & 0 \\
\hline 3 & 0 & 0 & 0 & $0^{*}$ & 0 & 0 & 0 & 0 & 0 & 0 & 0 & 0 \\
\hline 4 & 0 & 0 & 0 & $0^{*}$ & 0 & $0^{*}$ & 0 & 0 & 0 & 0 & 0 & 0 \\
\hline 5 & 0 & 0 & 0 & $0^{*}$ & 0 & $0^{*}$ & 0 & 0 & 0 & .01 & 0 & 0 \\
\hline 6 & 0 & 0 & 0 & $0^{*}$ & $0^{*}$ & $0^{*}$ & 0 & 0 & 0 & $.04^{*}$ & 0 & 0 \\
\hline 7 & 0 & 0 & 0 & $0^{*}$ & $0^{*}$ & $0^{*}$ & 0 & 0 & 0 & $0^{*}$ & 0 & 0 \\
\hline 8 & 0 & 0 & 0 & $0^{*}$ & 0 & $0^{*}$ & 0 & 0 & 0 & 0 & 0 & 0 \\
\hline 9 & 0 & 0 & $0^{*}$ & $0^{*}$ & $0^{*}$ & $0^{*}$ & 0 & 0 & 0 & 0 & 0 & 0 \\
\hline 10 & 0 & 0 & 0 & $0^{*}$ & 0 & $0^{*}$ & 0 & 0 & .01 & 0 & 0 & 0 \\
\hline 11 & .02 & 0 & $0^{*}$ & $0^{*}$ & 0 & $0^{*}$ & 0 & 0 & 0 & 0 & 0 & 0 \\
\hline 12 & 0 & 0 & 0 & $0^{*}$ & 0 & $0^{*}$ & 0 & 0 & 0 & 0 & 0 & 0 \\
\hline 13 & 0 & 0 & 0 & 0 & 0 & $0^{*}$ & 0 & 0 & 0 & 0 & 0 & 0 \\
\hline 14 & 0 & 0 & $0^{*}$ & $0^{*}$ & 0 & $0^{*}$ & 0 & 0 & 0 & 0 & 0 & 0 \\
\hline 15 & 0 & 0 & $0^{*}$ & 0 & 0 & $0^{*}$ & 0 & 0 & 0 & 0 & 0 & 0 \\
\hline 16 & 0 & 0 & $0^{*}$ & 0 & 0 & $0^{*}$ & 0 & 0 & 0 & 0 & 0 & 0 \\
\hline 17 & 0 & 0 & $0^{*}$ & $0^{*}$ & 0 & $0^{*}$ & 0 & 0 & 0 & 0 & 0 & 0 \\
\hline 18 & 0 & 0 & 0 & $0^{*}$ & 0 & $0^{*}$ & 0 & 0 & 0 & 0 & 0 & 0 \\
\hline 19 & 0 & 0 & 0 & $0^{*}$ & 0 & $0^{*}$ & 0 & 0 & 0 & 0 & 0 & 0 \\
\hline 20 & 0 & 0 & 0 & $0^{*}$ & 0 & $0^{*}$ & $0^{*}$ & 0 & 0 & 0 & 0 & 0 \\
\hline 21 & 0 & 0 & $0^{*}$ & $0^{*}$ & 0 & 0 & $0^{*}$ & 0 & 0 & 0 & 0 & 0 \\
\hline 22 & 0 & 0 & $0^{*}$ & $0^{*}$ & 0 & 0 & $0^{*}$ & 0 & 0 & 0 & 0 & 0 \\
\hline 23 & 0 & 0 & $0^{*}$ & 0 & 0 & 0 & 0 & .01 & 0 & .02 & 0 & 0 \\
\hline 24 & 0 & 0 & $0^{*}$ & 0 & 0 & 0 & 0 & 0 & 0 & 0 & 0 & 0 \\
\hline 25 & 0 & 0 & $0^{*}$ & 0 & 0 & 0 & 0 & 0 & 0 & 0 & 0 & 0 \\
\hline 26 & 0 & 0 & $0^{*}$ & $0^{*}$ & 0 & $0^{*}$ & 0 & 0 & 0 & 0 & 0 & 0 \\
\hline 27 & 0 & 0 & $0^{*}$ & $0^{*}$ & 0 & $0^{*}$ & 0 & 0 & 0 & 0 & 0 & 0 \\
\hline 28 & 0 & 0 & $0^{*}$ & 0 & 0 & $0^{*}$ & 0 & 0 & 0 & .01 & 0 & 0 \\
\hline 29 & 0 & 0 & $0^{*}$ & 0 & ---- & 0 & 0 & 0 & 0 & 0 & 0 & 0 \\
\hline 30 & 0 & 0 & $0^{*}$ & 0 & --.-- & $0^{*}$ & 0 & 0 & 0 & 0 & 0 & 0 \\
\hline 31 & 0 & - & $0^{*}$ & 0 & --.-- & 0 & ---- & 0 & - & 0 & 0 & ----- \\
\hline Total & 0.02 & 0 & 0 & 0 & 0 & 0 & 0 & 0.01 & 0.01 & 0.08 & 0 & 0 \\
\hline Mean & .001 & 0 & 0 & 0 & 0 & 0 & 0 & 0 & 0 & .003 & 0 & 0 \\
\hline Max & .02 & 0 & 0 & 0 & 0 & 0 & 0 & .01 & .01 & .04 & 0 & 0 \\
\hline Min & 0 & 0 & 0 & 0 & 0 & 0 & 0 & 0 & 0 & 0 & 0 & 0 \\
\hline Acre-Ft & .04 & 0 & 0 & 0 & 0 & 0 & 0 & .02 & .02 & .16 & 0 & 0 \\
\hline Wtr Year & 2009 & Total & 0.12 & Mean & & 0 & Max & .04 & Min & 0 & Acre-Ft & .24 \\
\hline Cal Year & 2008 & Total & 0.51 & Mean & & 01 & $\operatorname{Max}$ & .13 & Min & 0 & Acre- $\mathrm{Ft}$ & 1.0 \\
\hline
\end{tabular}

*Estimate 


\section{E200 Mortandad Canyon below Effluent Canyon}

Location. Lat $35^{\circ}$ 51' 55", long $106^{\circ}$ 17' 46", NW 1/4, Sec. 22, T. 19 N., R. 6 E., Los Alamos County.

Drainage Area. $0.49 \mathrm{mi}^{2}$.

Period of Record. May 10, 1995, to September 30, 2009.

Gage. Data logger with cellular telemetry and steel "fabricated" nonstandard flume as low-water control. Elevation of gage is 7,062.50 ft above NGVD from survey.

Remarks. Records are good, except estimated daily discharges, which are fair. Flow is mostly effluent from LANL TA-50, liquid radiological waste plant.

Average Discharge. $15 \mathrm{yr}, 0.053 \mathrm{ft}^{3} / \mathrm{s}, 38$ acre- $\mathrm{ft} / \mathrm{yr}$.

Extremes Outside Period of Record. Maximum discharge, $34 \mathrm{ft}^{3}$ /s, August 19, 1970, gage height $3.07 \mathrm{ft}$, from old data files of USGS.

Extremes for Period of Record. Maximum discharge, $448 \mathrm{ft}^{3} / \mathrm{s}$, August 24, 2006, gage height $5.38 \mathrm{ft}$ (from critical depth computation of flood marks). No flow at times.

Extremes for Current Year. Maximum discharge $14 \mathrm{ft}^{3} / \mathrm{s}$ at $1245 \mathrm{~h}$, July 23, gage height $2.25 \mathrm{ft}$. No peak above base of $15 \mathrm{ft}^{3} / \mathrm{s}$. No flow at times.

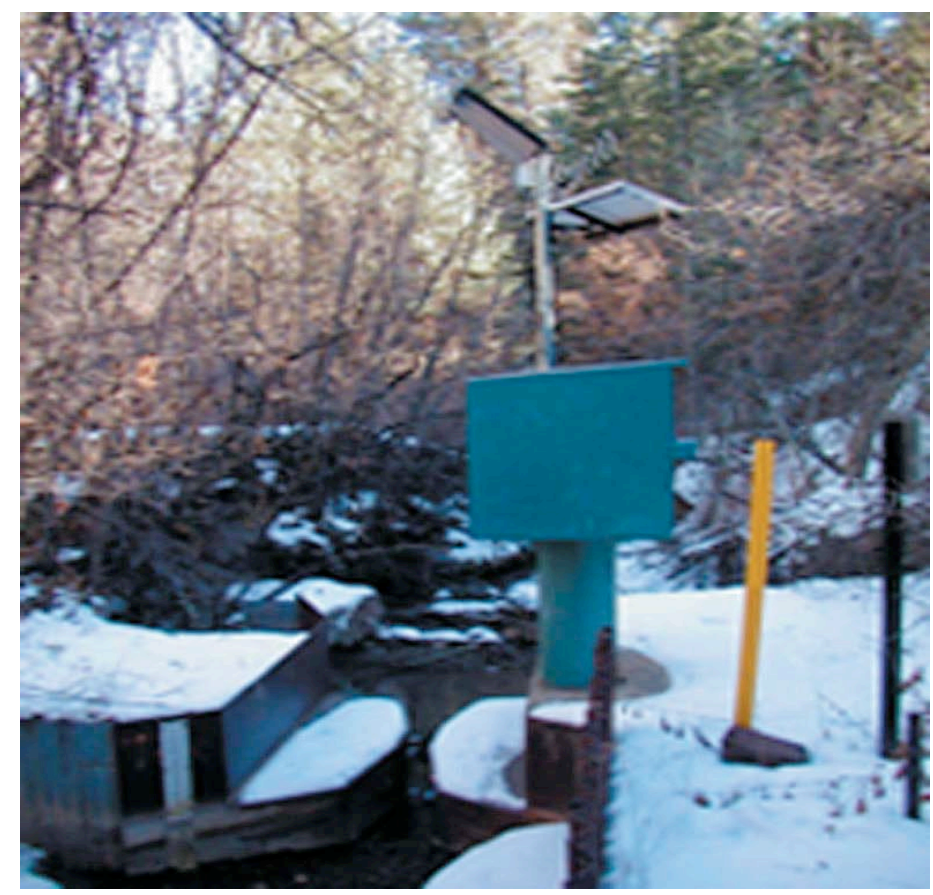




\title{
E200 Mortandad Canyon below Effluent Canyon
}

\author{
Station Analysis
}

2009 Water Year

Equipment. Station is equipped with Sutron 8210 data logger (5-min. interval) and Sutron Accubar bubble sensor with cellular telemetry and speech modem. The system is powered by a solar panel battery system. All equipment is housed in a NEMA shelter mounted on a 2' CMP well. Station is equipped with an ISCO pump sampler for water quality sample collection. ISCO is housed in a separate shelter, a $3^{\prime} \times 4^{\prime}$ metal box. Sampler is triggered by stage through the data logger. The staff in the 9" flume is the reference gage. A larger staff is also available for high flow. No provision for measurements above wading stage.

Field Work. The station was visited 15 times to conduct discharge measurements and service the instrumentation. Field inspections for the gage are listed under site history files on the Hydstra database. Discharge measurements for the gage are listed under site gauging files on the Hydstra database.

Datum Correction. None.

Gage-Height Record. The data logger referenced to the outside staff gave a complete and satisfactory record for the water year except during the periods from November 20, January 20-23, 25-27, February 4-10, 25, 26, March 28-30, April 11-13, 15, and May 4-7 when gage height was affected by ice.

Rating. The channel at the gage is about $33^{\prime}$ wide and straight for about $50^{\prime}$ upstream and about $75^{\prime}$ below gage. The streambed is sand and gravel and subject to fill behind flume from flow events and gage silting problem from effluent release. Flow is mostly effluent from TA-50 water treatment plant. The control is a fabricated steel flume about $5^{\prime \prime}$ at the throat.

Fifteen inspections were made, 11 of which observed no flow during the year.

Rating No. 1, which was developed based on measurements made during previous years, is effective and was used with a variable shift diagram from last measurement made at gage station.

Discharge. Discharge was computed by applying gage height to Rating No. 1 through shift adjustment based on variable shift diagram. Estimated days were computed based on TA-50 release and precipitation records.

Remarks. Records are good, except for estimated daily discharges, which are fair. 


\section{E200 M ortan dad Canyon below Effluent Can yo $\mathrm{n}$}

Daily Mean Discharge in Cubic Feet per Second

Water Year October 2008 to September 2009

\begin{tabular}{|c|c|c|c|c|c|c|c|c|c|c|c|c|}
\hline DAY & OCT & NOV & DEC & JAN & FEB & M AR & APR & MAY & JUN & JUL & AUG & SEP \\
\hline 1 & 0 & 0 & 0 & 0 & 0 & 0 & 0 & 0 & 0 & .02 & .08 & .02 \\
\hline 2 & .04 & 0 & 0 & 0 & 0 & 0 & 0 & 0 & 0 & 0 & .04 & 0 \\
\hline 3 & 0 & 0 & 0 & 0 & 0 & .02 & 0 & 0 & .12 & 0 & .03 & 0 \\
\hline 4 & .02 & 0 & 0 & 0 & $.01^{*}$ & .02 & 0 & .01 & .08 & 0 & .01 & 0 \\
\hline 5 & .04 & 0 & 0 & 0 & $0^{\star}$ & 0 & 0 & 0 & 0 & .76 & 0 & 0 \\
\hline 6 & .04 & .01 & 0 & 0 & $0^{*}$ & 0 & .02 & .01 & 0 & .96 & .04 & .06 \\
\hline 7 & .04 & .01 & 0 & 0 & $0^{*}$ & 0 & 0 & 0 & 0 & .08 & .01 & .02 \\
\hline 8 & .02 & 0 & 0 & 0 & $0^{*}$ & 0 & 0 & 0 & 0 & .01 & 0 & 0 \\
\hline 9 & 0 & 0 & 0 & 0 & $0^{*}$ & 0 & .01 & 0 & 0 & .03 & 0 & .03 \\
\hline 10 & 0 & .01 & .07 & 0 & $.01^{*}$ & .02 & 0 & 0 & .44 & 0 & 0 & .01 \\
\hline 11 & .49 & 0 & 0 & 0 & 0 & 0 & $.01^{*}$ & .01 & .03 & 0 & .01 & .01 \\
\hline 12 & .01 & .01 & 5.2 & 0 & 0 & .04 & $.01^{*}$ & 0 & .01 & 0 & 0 & 0 \\
\hline 13 & 0 & 0 & 5.2 & 0 & 0 & .03 & $.01^{*}$ & 0 & .01 & 0 & .03 & 0 \\
\hline 14 & .03 & 0 & .01 & 0 & 0 & .01 & .01 & 0 & .07 & 0 & .13 & .03 \\
\hline 15 & .02 & 0 & .22 & 0 & 0 & .02 & 0 & 0 & .03 & .01 & .02 & .01 \\
\hline 16 & 0 & 0 & 0 & 0 & 0 & 0 & $.02^{*}$ & 0 & .02 & 0 & 0 & .16 \\
\hline 17 & 0 & .01 & .01 & 0 & 0 & 0 & .03 & 0 & .03 & .01 & 0 & .18 \\
\hline 18 & 0 & 0 & .01 & 0 & 0 & 0 & .02 & $.01^{*}$ & 0 & 0 & .02 & .06 \\
\hline 19 & 0 & .02 & .02 & 0 & 0 & .02 & .01 & 0 & 0 & 0 & 0 & .01 \\
\hline 20 & .01 & $.01^{*}$ & 0 & $.01^{*}$ & 0 & 0 & 0 & 0 & .16 & .03 & .02 & 0 \\
\hline 21 & 0 & .01 & 0 & $.01^{*}$ & 0 & 0 & 0 & 0 & .01 & .07 & 0 & 0 \\
\hline 22 & 0 & .02 & .28 & $.01^{*}$ & 0 & 0 & 0 & 0 & 0 & .08 & 0 & .02 \\
\hline 23 & 0 & .01 & 0 & .01 & 0 & 0 & .02 & .30 & .02 & .86 & 0 & .08 \\
\hline 24 & 0 & 0 & 0 & 0 & 0 & .01 & 0 & .09 & 0 & .05 & 0 & .18 \\
\hline 25 & 0 & .02 & 0 & $0^{*}$ & $.01^{*}$ & 0 & 0 & .16 & .02 & .02 & .01 & .01 \\
\hline 26 & 0 & 0 & 0 & $0^{*}$ & $0^{*}$ & 0 & 0 & .07 & .03 & .03 & 0 & .01 \\
\hline 27 & 0 & .15 & 0 & $.01^{*}$ & .04 & .04 & 0 & .18 & 0 & .01 & .02 & 0 \\
\hline 28 & 0 & .04 & 0 & .01 & 0 & $.02^{*}$ & 0 & .15 & 0 & .34 & 0 & .02 \\
\hline 29 & 0 & 0 & 0 & 0 & --.-- & $0^{*}$ & 0 & 0 & 0 & .17 & 0 & 0 \\
\hline 30 & 0 & 0 & 0 & 0 & --.-- & $.01^{*}$ & .01 & 0 & 0 & .86 & .09 & 0 \\
\hline 31 & 0 & 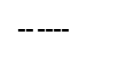 & 0 & 0 & --.-- & 0 & ----- & .03 & --.-- & .16 & .01 & --.-- \\
\hline Total & 0.76 & 0.33 & 11.02 & 0.06 & 0.07 & 0.26 & 0.18 & 1.02 & 1.08 & 4.56 & 0.57 & 0.92 \\
\hline Mean & .025 & .011 & .36 & .002 & .003 & .008 & .006 & .033 & .036 & .15 & .018 & .031 \\
\hline Max & .49 & .15 & 5.2 & .01 & .04 & .04 & .03 & .30 & .44 & .96 & .13 & .18 \\
\hline$M$ in & 0 & 0 & 0 & 0 & 0 & 0 & 0 & 0 & 0 & 0 & 0 & 0 \\
\hline Acre-Ft & 1.5 & .65 & 22 & .12 & .14 & .52 & .36 & 2.0 & 2.1 & 9.0 & 1.1 & 1.8 \\
\hline Wtr Year & 2009 & Total & 20.83 & Mean & & 57 & Max & 5.2 & Min & 0 & Acre- $\mathrm{Ft}$ & 41 \\
\hline Cal Year & 2008 & Total & 18.66 & Mean & & 51 & Max & 5.2 & Min & 0 & Acre- $\mathrm{Ft}$ & 37 \\
\hline
\end{tabular}

${ }^{\star}$ Estimate 


\section{E2005 Mortandad Canyon Tributary Batch Plant at Sigma}

Location. Lat $35^{\circ} 51^{\prime}$ 57", long $106^{\circ} 17^{\prime} 24 "$, NE 1/4, Sec. 22, T.19 N., R. 6 E., Los Alamos County.

Drainage Area. $7.69 \mathrm{mi}^{2}$.

Period of Record. July 24, 2007, to September 30, 2009.

Gage. Data logger and 24" Parshall flume. Elevation of gage is 7,215 ft above NGVD.

Remarks. Records are good.

Extremes for Period of Record. Maximum discharge, $3.17 \mathrm{ft}^{3} / \mathrm{s}$, July 26, 2008, gage height $0.55 \mathrm{ft}$. No flow most of the time.

Extremes for Current Year. Maximum discharge $1.1 \mathrm{ft}^{3} / \mathrm{s}$ at $1240 \mathrm{~h}$ July 6, gage height $0.28 \mathrm{ft}$. No peak discharge above base of $5.0 \mathrm{ft}^{3} / \mathrm{s}$. No flow most of the time.

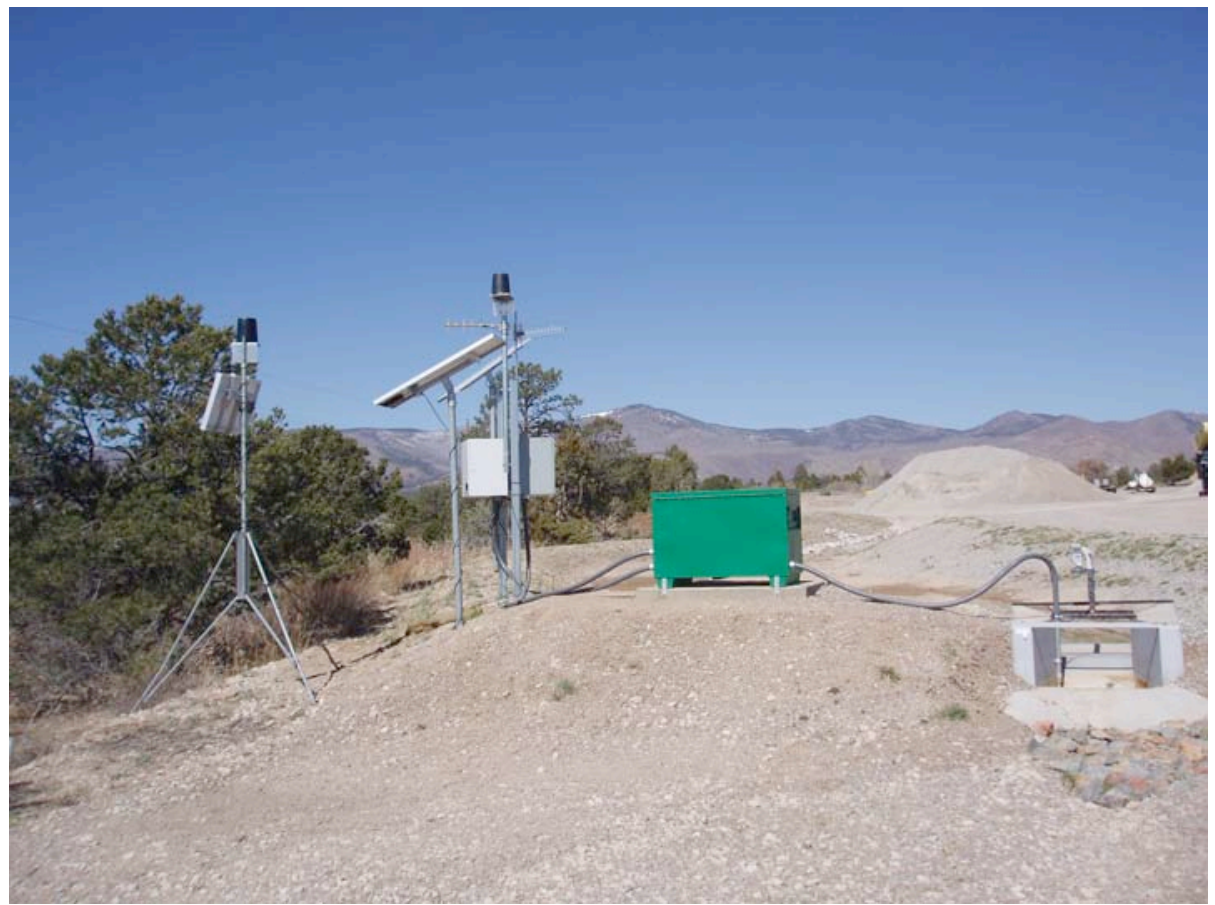




\title{
E2005 Mortandad Canyon Tributary Batch Plant at Sigma
}

\author{
Station Analysis
}

\section{Water Year}

Equipment. Station is equipped with Sutron 8210 data logger (5-min. interval) and Milltronics sonic probe mounted on a 24" Parshall flume. The system is powered by a solar panel battery system housed in a NEMA shelter. Station is equipped with an ISCO pump sampler for water quality sample collection. ISCO is housed in a separate shelter, a $3^{\prime} \times 4^{\prime}$ metal box. Sampler is triggered by stage through the data logger. The staff in the 24" Parshall flume is the reference gage. No provision for discharge measurements above wading stage.

Rain gage and cellular telemetry removed April 15.

Field Work. This station was visited 34 times to conduct discharge measurements and service the instrumentation. Field inspections for the gage are listed under site history files on the Hydstra database. Discharge measurements for the gage are listed under site gauging files on the Hydstra database.

Datum Correction. None.

Gage-Height Record. The data logger referenced to the outside staff gave a complete and satisfactory record, except for the periods from December 9 to January 6 and March 26-28 when gage height was affected by ice.

Rating. The site has an upstream catchment pond. The channel is straight for $25^{\prime}$ below gage.

Thirty-four inspections of no flow were made this year.

Rating No. 1 was developed based on the computation of 24" Parshall flume. Point of zero flow is 0.00 gage height.

Discharge. Discharge was computed by applying Rating No 1 directly. Those days estimated at zero flow were based on precipitation and nearby gage stations.

Remarks. Records are good. 
E2005 Mortandad Canyon Tributary Batch Plant at Sigma

Daily Mean Discharge in Cubic Feet per Second

Water Year October 2008 to September 2009

\begin{tabular}{|c|c|c|c|c|c|c|c|c|c|c|c|c|}
\hline DAY & OCT & NOV & DEC & JAN & FEB & MAR & APR & MAY & JUN & JUL & AUG & SEP \\
\hline 1 & 0 & 0 & 0 & $0^{*}$ & 0 & 0 & 0 & 0 & 0 & 0 & 0 & 0 \\
\hline 2 & 0 & 0 & 0 & $0^{*}$ & 0 & 0 & 0 & 0 & 0 & 0 & 0 & 0 \\
\hline 3 & 0 & 0 & 0 & $0^{*}$ & 0 & 0 & 0 & 0 & 0 & 0 & 0 & 0 \\
\hline 4 & 0 & 0 & 0 & $0^{*}$ & 0 & 0 & 0 & 0 & 0 & 0 & 0 & 0 \\
\hline 5 & 0 & 0 & 0 & $0^{*}$ & 0 & 0 & 0 & 0 & 0 & 0 & 0 & 0 \\
\hline 6 & 0 & 0 & 0 & $0^{*}$ & 0 & 0 & 0 & 0 & 0 & .08 & 0 & 0 \\
\hline 7 & 0 & 0 & 0 & 0 & 0 & 0 & 0 & 0 & 0 & 0 & 0 & 0 \\
\hline 8 & 0 & 0 & 0 & 0 & 0 & 0 & 0 & 0 & 0 & 0 & 0 & 0 \\
\hline 9 & 0 & 0 & $0^{*}$ & 0 & 0 & 0 & 0 & 0 & 0 & 0 & 0 & 0 \\
\hline 10 & 0 & 0 & $0^{*}$ & 0 & 0 & 0 & 0 & 0 & 0 & 0 & 0 & 0 \\
\hline 11 & 0 & 0 & $0^{*}$ & 0 & 0 & 0 & .02 & 0 & 0 & 0 & 0 & 0 \\
\hline 12 & 0 & 0 & $0^{*}$ & 0 & 0 & 0 & 0 & 0 & 0 & 0 & 0 & 0 \\
\hline 13 & 0 & 0 & $0^{*}$ & 0 & 0 & 0 & 0 & 0 & 0 & 0 & 0 & 0 \\
\hline 14 & 0 & 0 & $0^{*}$ & 0 & 0 & 0 & 0 & 0 & 0 & 0 & 0 & 0 \\
\hline 15 & 0 & 0 & $0^{*}$ & 0 & 0 & 0 & 0 & 0 & 0 & 0 & 0 & 0 \\
\hline 16 & 0 & 0 & $0^{*}$ & 0 & 0 & 0 & 0 & 0 & 0 & 0 & 0 & 0 \\
\hline 17 & 0 & 0 & $0^{*}$ & 0 & 0 & 0 & 0 & 0 & 0 & 0 & 0 & 0 \\
\hline 18 & 0 & 0 & $0^{*}$ & 0 & 0 & 0 & 0 & 0 & 0 & 0 & 0 & 0 \\
\hline 19 & 0 & 0 & $0^{*}$ & 0 & 0 & 0 & 0 & 0 & 0 & 0 & 0 & 0 \\
\hline 20 & 0 & 0 & $0^{*}$ & 0 & 0 & 0 & 0 & 0 & 0 & 0 & 0 & 0 \\
\hline 21 & 0 & 0 & $0^{*}$ & 0 & 0 & 0 & 0 & 0 & 0 & 0 & 0 & 0 \\
\hline 22 & 0 & 0 & $0^{*}$ & 0 & 0 & 0 & 0 & 0 & 0 & 0 & 0 & 0 \\
\hline 23 & 0 & 0 & $0^{*}$ & 0 & 0 & 0 & 0 & 0 & 0 & 0 & 0 & 0 \\
\hline 24 & 0 & 0 & $0^{*}$ & 0 & 0 & 0 & 0 & 0 & 0 & 0 & 0 & 0 \\
\hline 25 & 0 & 0 & $0^{*}$ & 0 & 0 & 0 & 0 & 0 & 0 & 0 & 0 & 0 \\
\hline 26 & 0 & 0 & $0^{*}$ & 0 & 0 & $0^{*}$ & 0 & 0 & 0 & 0 & 0 & 0 \\
\hline 27 & 0 & 0 & $0^{*}$ & 0 & 0 & $0^{*}$ & 0 & 0 & 0 & 0 & 0 & 0 \\
\hline 28 & 0 & 0 & $0^{*}$ & 0 & 0 & $0^{*}$ & 0 & 0 & 0 & 0 & 0 & 0 \\
\hline 29 & 0 & 0 & $0^{*}$ & 0 & 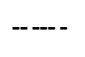 & 0 & 0 & 0 & 0 & 0 & 0 & 0 \\
\hline 30 & 0 & 0 & $0^{*}$ & 0 & ---- & 0 & 0 & 0 & 0 & .02 & 0 & 0 \\
\hline 31 & 0 & ---- & $0^{*}$ & 0 & --- & 0 & ----- & 0 & 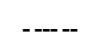 & 0 & 0 & ----- \\
\hline Total & 0 & 0 & 0 & 0 & 0 & 0 & 0.02 & 0 & 0 & 0.10 & 0 & 0 \\
\hline Mean & 0 & 0 & 0 & 0 & 0 & 0 & .001 & 0 & 0 & .003 & 0 & 0 \\
\hline Max & 0 & 0 & 0 & 0 & 0 & 0 & .02 & 0 & 0 & .08 & 0 & 0 \\
\hline Min & 0 & 0 & 0 & 0 & 0 & 0 & 0 & 0 & 0 & 0 & 0 & 0 \\
\hline Acre-Ft & 0 & 0 & 0 & 0 & 0 & 0 & .04 & 0 & 0 & .20 & 0 & 0 \\
\hline Wtr Year & 2009 & Total & 0.12 & Mean & & 0 & $\operatorname{Max}$ & .08 & Min & 0 & Acre-Ft & .24 \\
\hline Cal Year & 2008 & Total & 0.80 & Mean & & 02 & Max & .12 & Min & 0 & Acre- $\mathrm{Ft}$ & 1.6 \\
\hline
\end{tabular}

${ }^{*}$ Estimate 


\section{E201 Mortandad Canyon above Ten Site Canyon}

Location. Lat $35^{\circ} 51^{\prime} 46^{\prime \prime}$, long $106^{\circ} 16^{\prime}$ 29", SW 1/4, Sec. 22, T. 19 N., R. 6 E., Los Alamos County.

Drainage Area. $0.25 \mathrm{mi}^{2}$.

Period of Record. October 1, 2006, to September 30, 2009.

Revised Record. Period of Record (2008).

Gage. Data logger with steel "fabricated" nonstandard flume. Elevation of gage is 6,864 $\mathrm{ft}$ above NGVD.

Remarks. Records are good. Records for this site existed before period of record but are not reliable.

Extremes for Period of Record. Maximum discharge, $78 \mathrm{ft}^{3} / \mathrm{s}$, August 10, 2008, gage height $2.43 \mathrm{ft}$. No flow most of the time.

Extremes for Current Year. No flow for the year.

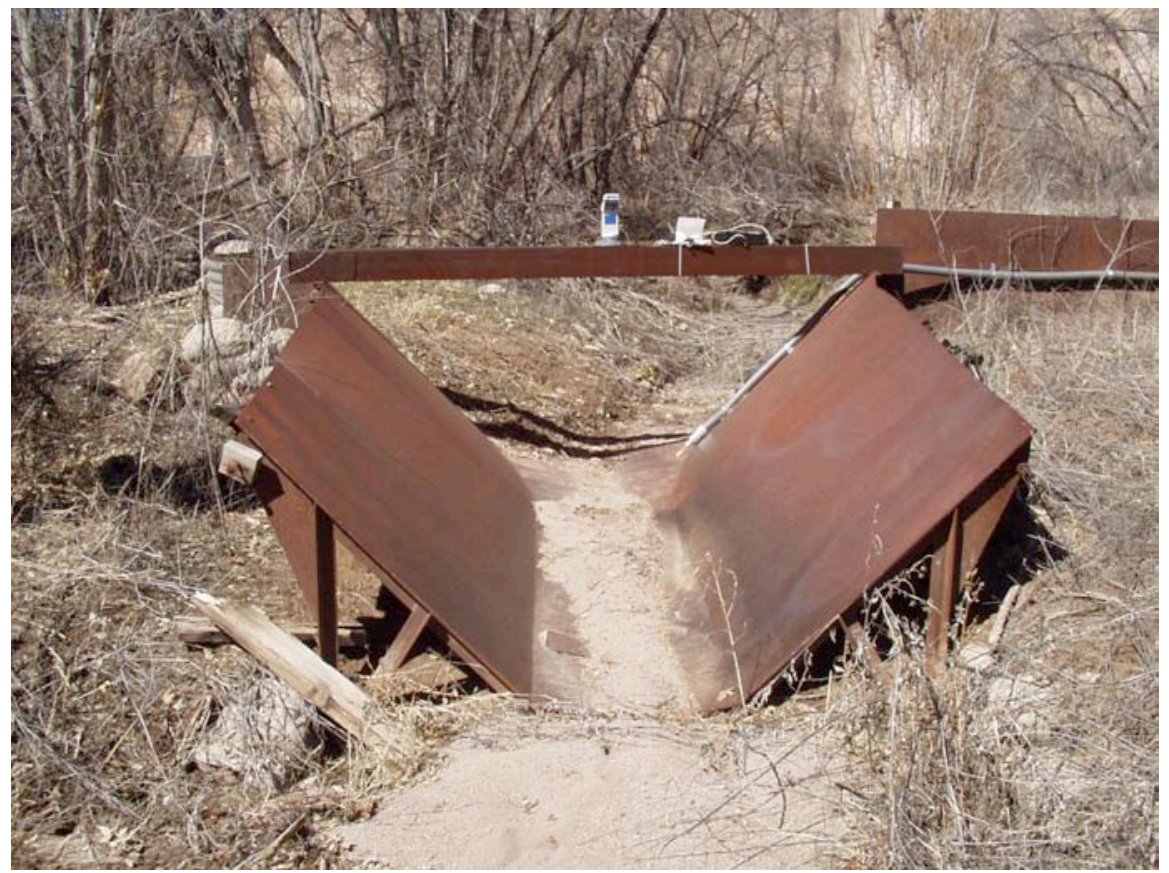




\section{E201 Mortandad Canyon above Ten Site Canyon \\ Station Analysis}

2009 Water Year

Equipment. Station is equipped with Sutron 8210 data logger (5-min. interval) and Milltronics sonic probe mounted on a $10^{\prime}$ flume. The system is powered by a solar panel battery system housed in a NEMA shelter. Station is equipped with an ISCO pump sampler for water quality sample collection. ISCO is housed in a separate shelter, a $3^{\prime} \times$ 4 ' metal box. Sampler is trigger by stage through the data logger. An outside staff is available for reference. No provision for measurements above wading stage.

Field Work. The station was visited 12 times to conduct discharge measurements and service the instrumentation. Field inspections for the gage are listed under site history files on the Hydstra database. Discharge measurements for the gage are listed under site gauging files on the Hydstra database.

Datum Correction. None.

Gage-Height Record. The data logger referenced to the outside staff gave a complete and satisfactory record except during the periods from December 15 to January 7 and March 27 when ice affected gage height.

Rating. Channel is straight above and below modified flume. Flow is confined to cut banks. Channel bottom is $3^{\prime} \mathrm{ft}$ wide with some vegetation above and below flume.

The streambed is sand and gravel and subject to fill flume from low-flow events. The control is a fabricated steel flume $10^{\prime}$ at the throat.

Twelve inspections of no flow were made this year.

Rating No. 1 was developed based on slope area computations and discharge measurements

Discharge. Discharge was computed by applying Rating No. 1 directly.

Remarks. Records are good. 
E201 Mortandad Canyon above Ten Site Can yon

Daily Mean Discharge in Cubic Feet per Second

Water Year October 2008 to September 2009

\begin{tabular}{|c|c|c|c|c|c|c|c|c|c|c|c|c|}
\hline DAY & OCT & NOV & DEC & JAN & FEB & MAR & APR & MAY & JUN & JUL & AUG & SEP \\
\hline 1 & 0 & 0 & 0 & $0^{*}$ & 0 & 0 & 0 & 0 & 0 & 0 & 0 & 0 \\
\hline 2 & 0 & 0 & 0 & $0^{*}$ & 0 & 0 & 0 & 0 & 0 & 0 & 0 & 0 \\
\hline 3 & 0 & 0 & 0 & $0^{*}$ & 0 & 0 & 0 & 0 & 0 & 0 & 0 & 0 \\
\hline 4 & 0 & 0 & 0 & $0^{*}$ & 0 & 0 & 0 & 0 & 0 & 0 & 0 & 0 \\
\hline 5 & 0 & 0 & 0 & $0^{*}$ & 0 & 0 & 0 & 0 & 0 & 0 & 0 & 0 \\
\hline 6 & 0 & 0 & 0 & $0^{*}$ & 0 & 0 & 0 & 0 & 0 & 0 & 0 & 0 \\
\hline 7 & 0 & 0 & 0 & $0^{*}$ & 0 & 0 & 0 & 0 & 0 & 0 & 0 & 0 \\
\hline 8 & 0 & 0 & 0 & 0 & 0 & 0 & 0 & 0 & 0 & 0 & 0 & 0 \\
\hline 9 & 0 & 0 & 0 & 0 & 0 & 0 & 0 & 0 & 0 & 0 & 0 & 0 \\
\hline 10 & 0 & 0 & 0 & 0 & 0 & 0 & 0 & 0 & 0 & 0 & 0 & 0 \\
\hline 11 & 0 & 0 & 0 & 0 & 0 & 0 & 0 & 0 & 0 & 0 & 0 & 0 \\
\hline 12 & 0 & 0 & 0 & 0 & 0 & 0 & 0 & 0 & 0 & 0 & 0 & 0 \\
\hline 13 & 0 & 0 & 0 & 0 & 0 & 0 & 0 & 0 & 0 & 0 & 0 & 0 \\
\hline 14 & 0 & 0 & 0 & 0 & 0 & 0 & 0 & 0 & 0 & 0 & 0 & 0 \\
\hline 15 & 0 & 0 & $0^{*}$ & 0 & 0 & 0 & 0 & 0 & 0 & 0 & 0 & 0 \\
\hline 16 & 0 & 0 & $0^{*}$ & 0 & 0 & 0 & 0 & 0 & 0 & 0 & 0 & 0 \\
\hline 17 & 0 & 0 & $0^{*}$ & 0 & 0 & 0 & 0 & 0 & 0 & 0 & 0 & 0 \\
\hline 18 & 0 & 0 & $0^{*}$ & 0 & 0 & 0 & 0 & 0 & 0 & 0 & 0 & 0 \\
\hline 19 & 0 & 0 & $0^{*}$ & 0 & 0 & 0 & 0 & 0 & 0 & 0 & 0 & 0 \\
\hline 20 & 0 & 0 & $0^{*}$ & 0 & 0 & 0 & 0 & 0 & 0 & 0 & 0 & 0 \\
\hline 21 & 0 & 0 & $0^{*}$ & 0 & 0 & 0 & 0 & 0 & 0 & 0 & 0 & 0 \\
\hline 22 & 0 & 0 & $0^{*}$ & 0 & 0 & 0 & 0 & 0 & 0 & 0 & 0 & 0 \\
\hline 23 & 0 & 0 & $0^{*}$ & 0 & 0 & 0 & 0 & 0 & 0 & 0 & 0 & 0 \\
\hline 24 & 0 & 0 & $0^{*}$ & 0 & 0 & 0 & 0 & 0 & 0 & 0 & 0 & 0 \\
\hline 25 & 0 & 0 & $0^{*}$ & 0 & 0 & 0 & 0 & 0 & 0 & 0 & 0 & 0 \\
\hline 26 & 0 & 0 & $0^{*}$ & 0 & 0 & 0 & 0 & 0 & 0 & 0 & 0 & 0 \\
\hline 27 & 0 & 0 & $0^{*}$ & 0 & 0 & $0^{*}$ & 0 & 0 & 0 & 0 & 0 & 0 \\
\hline 28 & 0 & 0 & $0^{*}$ & 0 & 0 & 0 & 0 & 0 & 0 & 0 & 0 & 0 \\
\hline 29 & 0 & 0 & $0^{*}$ & 0 & ----- & 0 & 0 & 0 & 0 & 0 & 0 & 0 \\
\hline 30 & 0 & 0 & $0^{*}$ & 0 & ----- & 0 & 0 & 0 & 0 & 0 & 0 & 0 \\
\hline 31 & 0 & ----- & $0^{*}$ & 0 & ---- & 0 & ---- & 0 & $-\cdots$ & 0 & 0 & --.- \\
\hline Total & 0 & 0 & 0 & 0 & 0 & 0 & 0 & 0 & 0 & 0 & 0 & 0 \\
\hline Mean & 0 & 0 & 0 & 0 & 0 & 0 & 0 & 0 & 0 & 0 & 0 & 0 \\
\hline Max & 0 & 0 & 0 & 0 & 0 & 0 & 0 & 0 & 0 & 0 & 0 & 0 \\
\hline Min & 0 & 0 & 0 & 0 & 0 & 0 & 0 & 0 & 0 & 0 & 0 & 0 \\
\hline Acre-Ft & 0 & 0 & 0 & 0 & 0 & 0 & 0 & 0 & 0 & 0 & 0 & 0 \\
\hline Wtr Year & 2009 & Total & 0 & Mean & & 0 & $\operatorname{lax}$ & 0 & Min & 0 & Acre-Ft & 0 \\
\hline Cal Year & 2008 & Total & 2.75 & Mean & & 08 & $\operatorname{lax}$ & 2.4 & Min & 0 & Acre-Ft & 5.5 \\
\hline
\end{tabular}

*Estimate 


\section{E2011 TA-50 Area 006 (C)}

Location. Lat $35^{\circ} 51^{\prime} 41^{\prime \prime}$, long $106^{\circ} 17^{\prime}$ 50", SW 1/4, Sec. 22, T. 19 N., R. 6 E., Los Alamos County.

Drainage Area. $0.019 \mathrm{mi}^{2}$.

Period of Record. October 1, 2006, to September 30, 2009.

Gage. Data logger and 24" Parshall flume. Elevation of gage is 7,220 ft above NGVD.

Remarks. Records are good. Records for this site existed before period of record but are not reliable.

Extremes for Period of Record. Maximum discharge, $6.0 \mathrm{ft}^{3} / \mathrm{s}$, August 10, 2008, gage height $0.83 \mathrm{ft}$. No flow most of the time.

Extremes for Current Year. Peak discharges above base of $3.0 \mathrm{ft}^{3} / \mathrm{s}$ and maximum (*):

\begin{tabular}{|c|c|c|c|}
\hline Date & Time & Discharge $\left(\mathbf{f t}^{\mathbf{3}} / \mathbf{s}\right)$ & Gage Height (ft) \\
\hline July 5 & 1220 & 4.7 & 0.71 \\
\hline July 23 & 1220 & $5.0^{*}$ & $0.74^{*}$ \\
\hline July 28 & 1235 & 3.1 & 0.54 \\
\hline July 30 & 1350 & 4.0 & 0.64 \\
\hline
\end{tabular}

No flow most of the time.

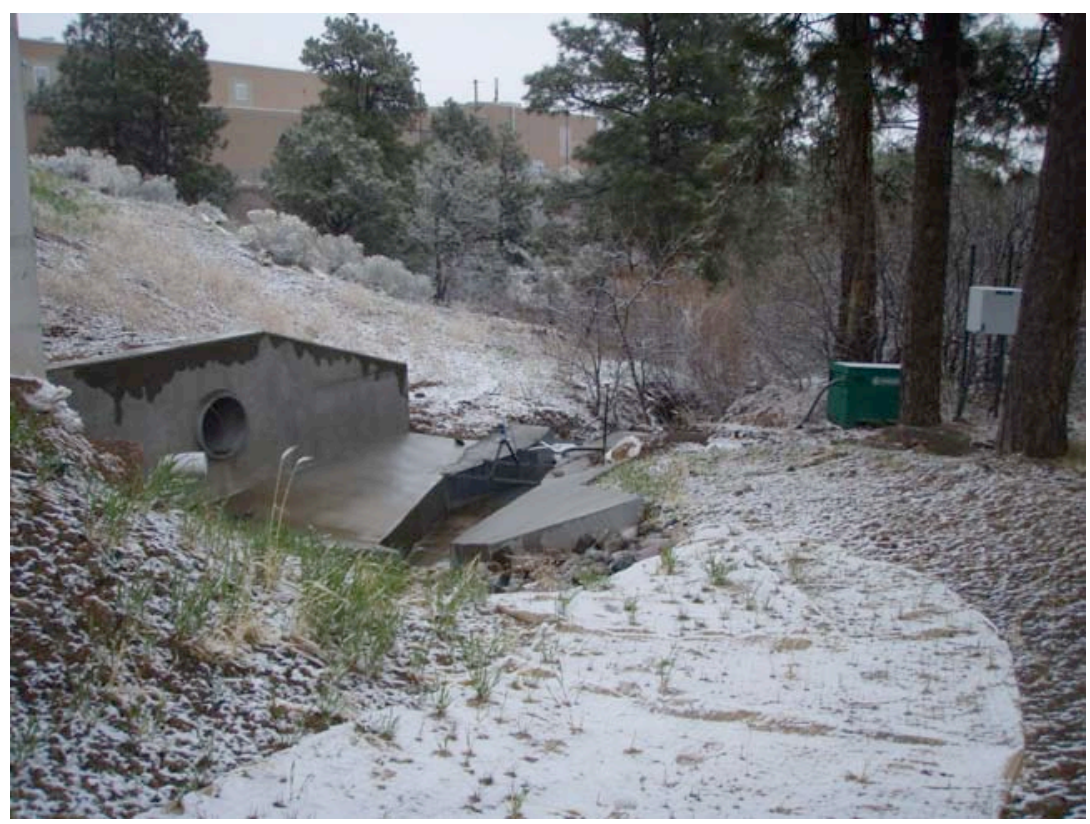




\section{E2011 TA-50 Area 006 (C)}

\section{Station Analysis}

\section{Water Year}

Equipment. Station is equipped with Sutron 8210 data logger (5-min. interval) and Milltronics sonic probe mounted on a 24" Parshall flume. The system is powered by a solar panel battery system housed in a NEMA shelter. Station is equipped with an ISCO pump sampler for water quality sample collection. ISCO is housed in a separate shelter, a $3^{\prime} \times 4^{\prime}$ metal box. Sampler is triggered by stage through the data logger. The staff in the 24" Parshall flume is the reference gage. No provision for discharge measurements above wading stage.

Field Work. This station was visited 15 times to conduct discharge measurements and service the instrumentation. Field inspections for the gage are listed under site history files on the Hydstra database. Discharge measurements for the gage are listed under site gauging files on the Hydstra database.

Datum Correction. None

Gage-Height Record. The data logger referenced to the outside staff gave a complete and satisfactory record except for the periods from November 28 to March 6 and March $9,10,13-15$, and March 26 to April 4 when gage height was affected by ice.

Rating. Upstream and downstream sections are formed cement as a result of recent construction to building adjacent to the site.

Fifteen inspections of no flow were made this year

Rating No. 1 was developed based on the computation of 24" Parshall flume. Point of zero flow is 0.00 gage height.

Discharge. Discharge was computed by applying Rating No. 1 directly.

Remarks. Records are good. 
E2011 TA-50 Area 006 (C)

Daily Mean Discharge in Cubic Feet per Second

Water Year October 2008 to September 2009

\begin{tabular}{|c|c|c|c|c|c|c|c|c|c|c|c|c|}
\hline DAY & OCT & NOV & DEC & JAN & FEB & MAR & APR & MAY & JUN & JUL & AUG & SEP \\
\hline 1 & 0 & 0 & $0^{*}$ & $0^{*}$ & $0^{*}$ & $0^{*}$ & $0^{*}$ & 0 & 0 & 0 & 0 & 0 \\
\hline 2 & 0 & 0 & $0^{*}$ & $0^{*}$ & $0^{*}$ & $0^{*}$ & $0^{*}$ & 0 & 0 & 0 & 0 & 0 \\
\hline 3 & 0 & 0 & $0^{*}$ & $0^{*}$ & $0^{*}$ & $0^{*}$ & $0^{*}$ & 0 & .03 & .01 & 0 & 0 \\
\hline 4 & .01 & 0 & $0^{*}$ & $0^{*}$ & $0^{*}$ & $0^{*}$ & $0^{*}$ & 0 & 0 & 0 & 0 & 0 \\
\hline 5 & .01 & 0 & $0^{*}$ & $0^{*}$ & $0^{*}$ & $0^{*}$ & 0 & 0 & 0 & .07 & 0 & 0 \\
\hline 6 & 0 & 0 & $0^{*}$ & $0^{*}$ & $0^{*}$ & $0^{*}$ & 0 & 0 & 0 & .04 & 0 & .03 \\
\hline 7 & 0 & 0 & $0^{*}$ & $0^{*}$ & $0^{*}$ & 0 & 0 & 0 & 0 & 0 & .01 & .01 \\
\hline 8 & 0 & 0 & $0^{*}$ & $0^{*}$ & $0^{*}$ & 0 & 0 & 0 & 0 & 0 & 0 & 0 \\
\hline 9 & 0 & 0 & $0^{*}$ & $0^{*}$ & $0^{*}$ & $0^{*}$ & 0 & 0 & 0 & 0 & 0 & 0 \\
\hline 10 & 0 & 0 & $0^{*}$ & $0^{*}$ & $0^{*}$ & $0^{*}$ & 0 & 0 & .06 & 0 & 0 & 0 \\
\hline 11 & .09 & 0 & $0^{*}$ & $0^{*}$ & $0^{*}$ & 0 & .06 & 0 & 0 & 0 & 0 & 0 \\
\hline 12 & 0 & 0 & $0^{*}$ & $0^{*}$ & $0^{*}$ & 0 & .08 & 0 & 0 & 0 & 0 & 0 \\
\hline 13 & 0 & 0 & $0^{*}$ & $0^{*}$ & $0^{*}$ & $0^{*}$ & 0 & 0 & 0 & 0 & 0 & 0 \\
\hline 14 & .02 & 0 & $0^{*}$ & $0^{*}$ & $0^{*}$ & $0^{*}$ & 0 & 0 & .01 & 0 & .03 & .01 \\
\hline 15 & 0 & 0 & $0^{*}$ & $0^{*}$ & $0^{*}$ & $0^{*}$ & 0 & 0 & .01 & 0 & 0 & .01 \\
\hline 16 & 0 & 0 & $0^{*}$ & $0^{*}$ & $0^{*}$ & 0 & 0 & 0 & 0 & 0 & 0 & .03 \\
\hline 17 & 0 & 0 & $0^{*}$ & $0^{*}$ & $0^{*}$ & 0 & .01 & 0 & 0 & 0 & 0 & .05 \\
\hline 18 & 0 & 0 & $0^{*}$ & $0^{*}$ & $0^{*}$ & 0 & 0 & 0 & 0 & 0 & 0 & 0 \\
\hline 19 & 0 & 0 & $0^{*}$ & $0^{*}$ & $0^{*}$ & 0 & 0 & 0 & 0 & 0 & 0 & 0 \\
\hline 20 & 0 & 0 & $0^{*}$ & $0^{*}$ & $0^{*}$ & 0 & 0 & 0 & .04 & .01 & 0 & 0 \\
\hline 21 & 0 & 0 & $0^{*}$ & $0^{*}$ & $0^{*}$ & 0 & 0 & .01 & .01 & .02 & 0 & 0 \\
\hline 22 & 0 & 0 & $0^{*}$ & $0^{*}$ & $0^{*}$ & 0 & 0 & .02 & 0 & 0 & 0 & 0 \\
\hline 23 & 0 & 0 & $0^{*}$ & $0^{*}$ & $0^{*}$ & 0 & 0 & .05 & 0 & .13 & 0 & .02 \\
\hline 24 & 0 & 0 & $0^{*}$ & $0^{*}$ & $0^{*}$ & 0 & 0 & .03 & 0 & 0 & 0 & .01 \\
\hline 25 & 0 & 0 & $0^{*}$ & $0^{*}$ & $0^{*}$ & 0 & 0 & .01 & .01 & 0 & 0 & 0 \\
\hline 26 & 0 & 0 & $0^{*}$ & $0^{*}$ & $0^{*}$ & $0^{*}$ & 0 & 0 & .01 & .01 & 0 & 0 \\
\hline 27 & 0 & .01 & $0^{*}$ & $0^{*}$ & $0^{*}$ & $0^{*}$ & 0 & .03 & 0 & 0 & 0 & 0 \\
\hline 28 & 0 & $0^{*}$ & $0^{*}$ & $0^{*}$ & $0^{*}$ & $0^{*}$ & 0 & .01 & .01 & .04 & 0 & 0 \\
\hline 29 & 0 & $0^{*}$ & $0^{*}$ & $0^{*}$ & ---- & $0^{*}$ & 0 & 0 & 0 & .01 & 0 & 0 \\
\hline 30 & 0 & $0^{*}$ & $0^{*}$ & $0^{*}$ & -..-- & $0^{*}$ & 0 & 0 & 0 & .11 & .03 & 0 \\
\hline 31 & 0 & --.-- & $0^{*}$ & $0^{*}$ & ----- & $0^{*}$ & ----- & 0 & --- & 0 & 0 & ----- \\
\hline Total & 0.13 & 0.01 & 0 & 0 & 0 & 0 & 0.15 & 0.16 & 0.19 & 0.45 & 0.07 & 0.17 \\
\hline Mean & .004 & 0 & 0 & 0 & 0 & 0 & .005 & .005 & .006 & .015 & .002 & .006 \\
\hline Max & .09 & .01 & 0 & 0 & 0 & 0 & .08 & .05 & .06 & .13 & .03 & .05 \\
\hline Min & 0 & 0 & 0 & 0 & 0 & 0 & 0 & 0 & 0 & 0 & 0 & 0 \\
\hline Acre-Ft & .26 & .02 & 0 & 0 & 0 & 0 & .30 & .32 & .38 & .89 & .14 & .34 \\
\hline Wtr Year & 2009 & Total & 1.33 & Mean & & 04 & Max & .13 & Min & 0 & Acre-Ft & 2.6 \\
\hline Cal Year & 2008 & Total & 0.77 & Mean & & 02 & Max & .14 & Min & 0 & Acre-Ft & 1.5 \\
\hline
\end{tabular}

${ }^{\star}$ Estimate 


\section{E2013 TA-50 Area C}

Location. Lat $35^{\circ} 51^{\prime} 41^{\prime \prime}$, long $106^{\circ} 17^{\prime}$ 49", SW 1/4, Sec. 22, T. 19 N., R. 6 E., Los Alamos County.

Drainage Area. $0.002 \mathrm{mi}^{2}$.

Period of Record. October 1, 2006, to September 30, 2009.

Gage. Data logger and 12" Parshall flume. Elevation of gage is 7,213 ft above NGVD.

Remarks. Records are good except for estimated daily discharges, which are fair. Records for this site existed before period of record but are not reliable.

Extremes for Period of Record. Maximum discharge, $7.56 \mathrm{ft}^{3} / \mathrm{s}$, July 23, 2009, gage height $1.52 \mathrm{ft}$. No flow most of the time.

Extremes for Current Year. Peak discharges above base of $2.0 \mathrm{ft}^{3} / \mathrm{s}$ and maximum (*):

\begin{tabular}{|c|c|c|c|}
\hline Date & Time & Discharge $\left(\mathbf{f t}^{\mathbf{3}} / \mathbf{s}\right)$ & Gage Height (ft) \\
\hline July 23 & 1220 & $7.56^{*}$ & $1.52^{*}$ \\
\hline September 20 & 0420 & 4.12 & 1.02 \\
\hline
\end{tabular}

No flow most of the time.

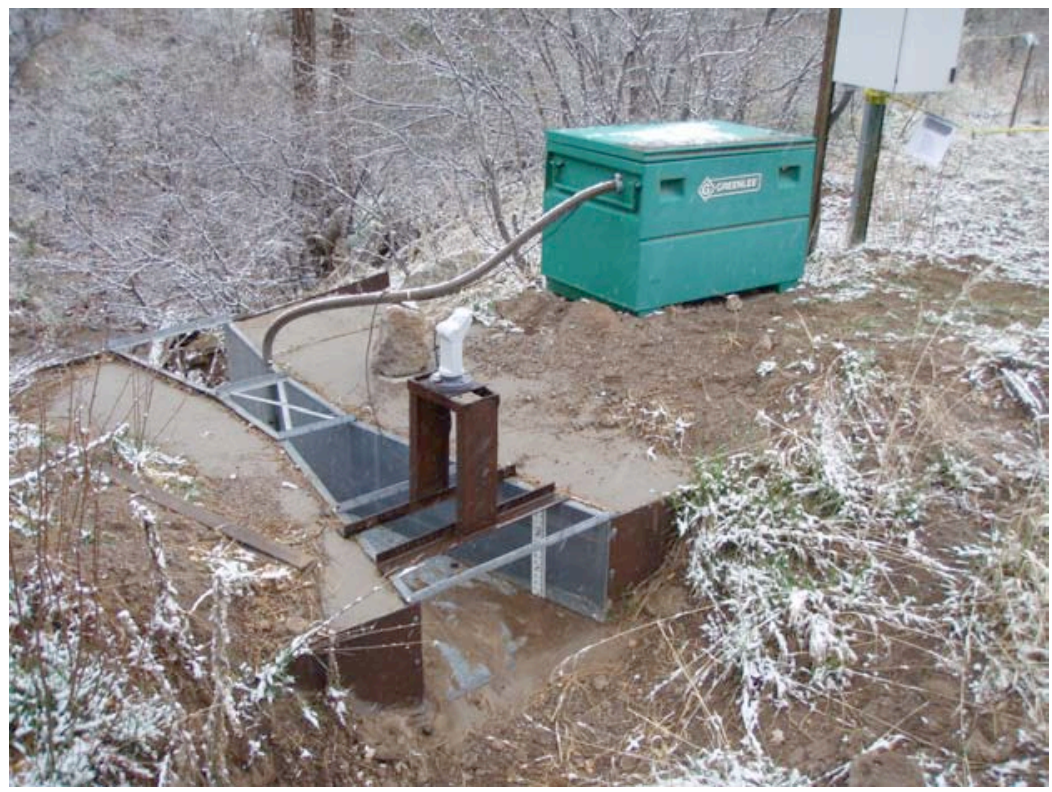




\section{E2013 TA-50 Area C}

\section{Station Analysis}

\section{Water Year}

Equipment. Station is equipped with Sutron 8210 data logger (5-min. interval) and Milltronics sonic probe mounted on a 12" Parshall flume. The system is powered by a solar panel battery system housed in a NEMA shelter. Station is equipped with an ISCO pump sampler for water quality sample collection. ISCO is housed in a separate shelter, a $3^{\prime} \times 4^{\prime}$ metal box. Sampler is triggered by stage through the data logger. The staff in the 12" Parshall flume is the reference gage. No provision for discharge measurements above wading stage.

Field Work. This station was visited 29 times to conduct discharge measurements and service the instrumentation. Field inspections for the gage are listed under site history files on the Hydstra database. Discharge measurements for the gage are listed under site gauging files on the Hydstra database.

Datum Correction. None

Gage-Height Record. The data logger referenced to the outside staff gave a complete and satisfactory record except during the periods of December 6, 9 to January 18, March 13, 26-29, and April 18 when gage height was affected by ice and May 26 to July 10 and August 4 to September 14 when data logger malfunctioned.

Rating. Rating No. 1 was developed based on the computation of 12" Parshall flume. Point of zero flow is 0.00 gage height.

Twenty-nine inspections of no flow were made.

Discharge. Discharge was computed by applying Rating No. 1 directly. Those days estimated at zero flow were based on precipitation and nearby gage stations.

Remarks. Records are good except for estimated daily discharges, which are fair. 
E2013 T A-50 Area C

Daily Mean Discharge in Cubic Feet per Second

Water Year October 2008 to September 2009

\begin{tabular}{|c|c|c|c|c|c|c|c|c|c|c|c|c|}
\hline DAY & OCT & NOV & DEC & J AN & FEB & MAR & APR & MAY & JUN & JUL & AUG & SEP \\
\hline 1 & 0 & 0 & 0 & $0^{*}$ & 0 & 0 & 0 & 0 & $0^{*}$ & $0^{*}$ & 0 & $0^{*}$ \\
\hline 2 & 0 & 0 & 0 & $0^{*}$ & 0 & 0 & 0 & 0 & $0^{*}$ & $0^{*}$ & 0 & $0^{*}$ \\
\hline 3 & 0 & 0 & 0 & $0^{*}$ & 0 & 0 & 0 & 0 & $.03^{*}$ & $.01^{*}$ & 0 & $0^{*}$ \\
\hline 4 & 0 & 0 & 0 & $0^{*}$ & 0 & 0 & 0 & 0 & $0^{*}$ & $0^{*}$ & $0^{*}$ & $0^{*}$ \\
\hline 5 & 0 & 0 & 0 & $0^{*}$ & 0 & 0 & 0 & 0 & $0^{*}$ & $.07^{\star}$ & $0^{*}$ & $0^{*}$ \\
\hline 6 & 0 & 0 & $0^{*}$ & $0^{*}$ & 0 & 0 & 0 & 0 & $0^{*}$ & $.04^{\star}$ & $0^{*}$ & $.03^{*}$ \\
\hline 7 & 0 & 0 & 0 & $0^{*}$ & 0 & 0 & 0 & 0 & $0^{*}$ & $0^{*}$ & $.01^{*}$ & $.01^{*}$ \\
\hline 8 & 0 & 0 & 0 & $0^{*}$ & 0 & 0 & 0 & 0 & $0^{*}$ & $0^{*}$ & $0^{*}$ & $0^{*}$ \\
\hline 9 & 0 & 0 & $0^{*}$ & $0^{*}$ & 0 & 0 & 0 & 0 & $0^{*}$ & $0^{*}$ & $0^{*}$ & $0^{*}$ \\
\hline 10 & 0 & 0 & $0^{*}$ & $0^{*}$ & 0 & 0 & 0 & 0 & $.06^{*}$ & $0^{*}$ & $0^{*}$ & $0^{*}$ \\
\hline 11 & .06 & 0 & $0^{*}$ & $0^{*}$ & 0 & 0 & .01 & 0 & $0^{*}$ & 0 & $0^{*}$ & $.01^{*}$ \\
\hline 12 & 0 & 0 & $0^{*}$ & $0^{*}$ & 0 & 0 & .01 & 0 & $0^{*}$ & 0 & $0^{*}$ & $0^{*}$ \\
\hline 13 & 0 & 0 & $0^{*}$ & $0^{*}$ & 0 & $0^{*}$ & 0 & 0 & $0^{*}$ & 0 & $0^{*}$ & $0^{*}$ \\
\hline 14 & 0 & 0 & $0^{*}$ & $0^{*}$ & 0 & 0 & 0 & 0 & $.01^{*}$ & 0 & $.03^{*}$ & $0^{*}$ \\
\hline 15 & 0 & 0 & $0^{*}$ & $0^{*}$ & 0 & 0 & 0 & 0 & $.01^{\star}$ & 0 & $0^{*}$ & 0 \\
\hline 16 & 0 & 0 & $0^{*}$ & $0^{*}$ & 0 & 0 & 0 & 0 & $0^{*}$ & 0 & $0^{*}$ & .01 \\
\hline 17 & 0 & 0 & $0^{*}$ & $0^{*}$ & 0 & 0 & .03 & 0 & $0^{*}$ & 0 & $0^{*}$ & .01 \\
\hline 18 & 0 & 0 & $0^{*}$ & $0^{*}$ & 0 & 0 & $0^{*}$ & 0 & $0^{*}$ & 0 & $0^{*}$ & 0 \\
\hline 19 & 0 & 0 & $0^{*}$ & 0 & 0 & 0 & 0 & 0 & $0^{*}$ & 0 & $0^{*}$ & 0 \\
\hline 20 & 0 & 0 & $0^{*}$ & 0 & 0 & 0 & 0 & 0 & $.04^{*}$ & 0 & $0^{*}$ & .02 \\
\hline 21 & 0 & 0 & $0^{*}$ & 0 & 0 & 0 & 0 & 0 & $.01^{*}$ & .01 & $0^{*}$ & 0 \\
\hline 22 & 0 & 0 & $0^{*}$ & 0 & 0 & 0 & 0 & 0 & $0^{*}$ & 0 & $0^{*}$ & 0 \\
\hline 23 & 0 & 0 & $0^{*}$ & 0 & 0 & 0 & 0 & .02 & $0^{*}$ & .07 & $0^{*}$ & .01 \\
\hline 24 & 0 & 0 & $0^{*}$ & 0 & 0 & 0 & 0 & .01 & $0^{*}$ & 0 & $0^{*}$ & .01 \\
\hline 25 & 0 & 0 & $0^{*}$ & 0 & 0 & 0 & 0 & 0 & $.01^{*}$ & 0 & $0^{*}$ & 0 \\
\hline 26 & 0 & 0 & $0^{*}$ & 0 & 0 & $0^{*}$ & 0 & $0^{*}$ & $.01^{*}$ & .01 & $0^{*}$ & 0 \\
\hline 27 & 0 & .01 & $0^{*}$ & 0 & 0 & $0^{*}$ & 0 & $.03^{*}$ & $0^{*}$ & 0 & $0^{*}$ & 0 \\
\hline 28 & 0 & 0 & $0^{*}$ & 0 & 0 & $0^{*}$ & 0 & $.01^{*}$ & $.01^{*}$ & .02 & $0^{*}$ & 0 \\
\hline 29 & 0 & $0^{*}$ & $0^{*}$ & 0 & ----- & $0^{*}$ & 0 & $0^{*}$ & $0^{*}$ & 0 & $0^{*}$ & 0 \\
\hline 30 & 0 & 0 & $0^{*}$ & 0 & ---- & 0 & 0 & $0^{*}$ & $0^{*}$ & .02 & $.03^{*}$ & 0 \\
\hline 31 & 0 & --- & $0^{*}$ & 0 & ---- & 0 & ----- & $0^{*}$ & --- & 0 & $0^{*}$ & ---- \\
\hline Total & 0.06 & 0.01 & 0 & 0 & 0 & 0 & 0.05 & 0.07 & 0.19 & 0.25 & 0.07 & 0.11 \\
\hline Mean & .002 & 0 & 0 & 0 & 0 & 0 & .002 & .002 & .006 & .008 & .002 & .004 \\
\hline Max & .06 & .01 & 0 & 0 & 0 & 0 & .03 & .03 & .06 & .07 & .03 & .03 \\
\hline Min & 0 & 0 & 0 & 0 & 0 & 0 & 0 & 0 & 0 & 0 & 0 & 0 \\
\hline Acre-F t & .12 & .02 & 0 & 0 & 0 & 0 & .10 & .14 & .38 & .50 & .14 & .22 \\
\hline Wtr Year & 2009 & Total & 0.81 & Mean & & & $a x$ & .07 & Min & 0 & Acre- $\mathrm{Ft}$ & 1.6 \\
\hline Cal Year & 2008 & Total & 0.91 & Mean & & 3 & $a x$ & .25 & Min & 0 & Acre-Ft & 1.8 \\
\hline
\end{tabular}

${ }^{*}$ Estimate 


\section{E2015 Ten Site Canyon above Mortandad Canyon}

Location. Lat $35^{\circ}$ 51' 38", long $106^{\circ} 16^{\prime}$ 30", SE 1/4, Sec. 23, T. 19 N., R. 6 E., Los Alamos County.

Drainage Area. $0.32 \mathrm{mi}^{2}$.

Period of Record. October 2000 to September 30, 2009.

Revised record. Drainage Area (2006).

Gage. Data logger with $90^{\circ}$ sharp-crested weir. Elevation of gage is $6,858 \mathrm{ft}$ above NGVD from GPS survey.

Remarks. Records are good.

Average Discharge. $9 \mathrm{yr}, 0.005 \mathrm{ft}^{3} / \mathrm{s}, 3.62$ acre- $\mathrm{ft} / \mathrm{yr}$.

Extremes for Period of Record. Maximum discharge, $303 \mathrm{ft}^{3} / \mathrm{s}$, August 25, 2006, gage height $4.60 \mathrm{ft}$ (from slope-area measurement of peak flow). No flow most of the time.

Extremes for Current Year. Maximum discharge $2.45 \mathrm{ft}^{3} / \mathrm{s}$ at $1405 \mathrm{~h}$, July 30, gage height 2.25. No peak discharge above base of $10.0 \mathrm{ft}^{3} / \mathrm{s}$. No flow most of the time.

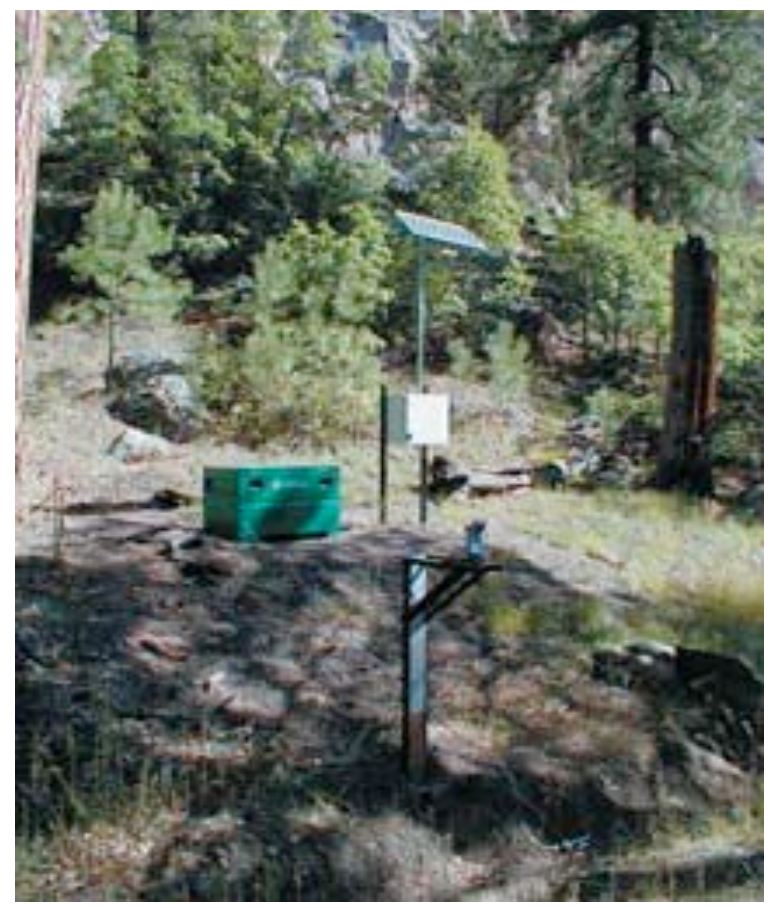




\title{
E2015 Ten Site Canyon above Mortandad Canyon
}

\author{
Station Analysis
}

\section{Water Year}

Equipment. Station is equipped with Sutron 8210 data logger (5-min. interval) and Sutron Accubar bubble sensor. The system is powered by a solar panel battery system housed in a NEMA shelter. Station is also equipped with an ISCO pump sampler for water quality collection. ISCO is housed in a separate shelter, a $3^{\prime} \times 4^{\prime}$ metal box. Sampler is triggered by stage through the data logger. An outside staff is available for reference. No provisions are made for measurement above wading stage.

Field Work. The station was visited 12 times to conduct discharge measurements and service the instrumentation. Field inspections for the gage are listed under site history files on the Hydstra database. Discharge measurements for the gage are listed under site gauging files on the Hydstra database.

Datum Correction. May 24, 2007, gage set to correct datum. Gage destroyed by flood on August 25, 2006. Bubbler outlet reset to gage datum of $1.33 \mathrm{ft}$.

Gage-Height Record. The data logger reference to the outside staff gave a complete and satisfactory record for the year.

Rating. The channel is about $8^{\prime}$ wide and straight for about $60^{\prime}$ upstream and about $30^{\prime}$ downstream. The streambed through this reach is primarily sand with gravel.

Twelve inspections of no flow were made this year.

Rating No. 2 is based on a theoretical computation for $90^{\circ}$ sharp-crested weir and one critical depth computation.

Discharge. Discharge was computed by applying Rating No. 2 directly.

Remarks. Records are good. 
E2015 Ten Site $C$ anyon above Mortan dad Canyon

Daily Mean Discharge in Cubic Feet per Second

Water Year October 2008 to September 2009

\begin{tabular}{|c|c|c|c|c|c|c|c|c|c|c|c|c|}
\hline DAY & OCT & NOV & DEC & JAN & FEB & MAR & APR & MAY & JUN & JUL & AUG & SEP \\
\hline 1 & 0 & 0 & 0 & 0 & 0 & 0 & 0 & 0 & 0 & 0 & 0 & 0 \\
\hline 2 & 0 & 0 & 0 & 0 & 0 & 0 & 0 & 0 & 0 & 0 & 0 & 0 \\
\hline 3 & 0 & 0 & 0 & 0 & 0 & 0 & 0 & 0 & 0 & 0 & 0 & 0 \\
\hline 4 & 0 & 0 & 0 & 0 & 0 & 0 & 0 & 0 & 0 & 0 & 0 & 0 \\
\hline 5 & 0 & 0 & 0 & 0 & 0 & 0 & 0 & 0 & 0 & 0 & 0 & 0 \\
\hline 6 & 0 & 0 & 0 & 0 & 0 & 0 & 0 & 0 & 0 & 0 & 0 & 0 \\
\hline 7 & 0 & 0 & 0 & 0 & 0 & 0 & 0 & 0 & 0 & 0 & 0 & 0 \\
\hline 8 & 0 & 0 & 0 & 0 & 0 & 0 & 0 & 0 & 0 & 0 & 0 & 0 \\
\hline 9 & 0 & 0 & 0 & 0 & 0 & 0 & 0 & 0 & 0 & 0 & 0 & 0 \\
\hline 10 & 0 & 0 & 0 & 0 & 0 & 0 & 0 & 0 & 0 & 0 & 0 & 0 \\
\hline 11 & .03 & 0 & 0 & 0 & 0 & 0 & 0 & 0 & 0 & 0 & 0 & 0 \\
\hline 12 & 0 & 0 & 0 & 0 & 0 & 0 & 0 & 0 & 0 & 0 & 0 & 0 \\
\hline 13 & 0 & 0 & 0 & 0 & 0 & 0 & 0 & 0 & 0 & 0 & 0 & 0 \\
\hline 14 & 0 & 0 & 0 & 0 & 0 & 0 & 0 & 0 & 0 & 0 & 0 & 0 \\
\hline 15 & 0 & 0 & 0 & 0 & 0 & 0 & 0 & 0 & 0 & 0 & 0 & 0 \\
\hline 16 & 0 & 0 & 0 & 0 & 0 & 0 & 0 & 0 & 0 & 0 & 0 & 0 \\
\hline 17 & 0 & 0 & 0 & 0 & 0 & 0 & 0 & 0 & 0 & 0 & 0 & 0 \\
\hline 18 & 0 & 0 & 0 & 0 & 0 & 0 & 0 & 0 & 0 & 0 & 0 & 0 \\
\hline 19 & 0 & 0 & 0 & 0 & 0 & 0 & 0 & 0 & 0 & 0 & 0 & 0 \\
\hline 20 & 0 & 0 & 0 & 0 & 0 & 0 & 0 & 0 & 0 & 0 & 0 & 0 \\
\hline 21 & 0 & 0 & 0 & 0 & 0 & 0 & 0 & 0 & 0 & 0 & 0 & 0 \\
\hline 22 & 0 & 0 & 0 & 0 & 0 & 0 & 0 & 0 & 0 & 0 & 0 & 0 \\
\hline 23 & 0 & 0 & 0 & 0 & 0 & 0 & 0 & 0 & 0 & 0 & 0 & 0 \\
\hline 24 & 0 & 0 & 0 & 0 & 0 & 0 & 0 & 0 & 0 & 0 & 0 & 0 \\
\hline 25 & 0 & 0 & 0 & 0 & 0 & 0 & 0 & 0 & 0 & 0 & 0 & 0 \\
\hline 26 & 0 & 0 & 0 & 0 & 0 & 0 & 0 & 0 & 0 & 0 & 0 & 0 \\
\hline 27 & 0 & 0 & 0 & 0 & 0 & 0 & 0 & 0 & 0 & 0 & 0 & 0 \\
\hline 28 & 0 & 0 & 0 & 0 & 0 & 0 & 0 & 0 & 0 & 0 & 0 & 0 \\
\hline 29 & 0 & 0 & 0 & 0 & --.-- & 0 & 0 & 0 & 0 & 0 & 0 & 0 \\
\hline 30 & 0 & 0 & 0 & 0 & ----- & 0 & 0 & 0 & 0 & .04 & 0 & 0 \\
\hline 31 & 0 & ---- & 0 & 0 & ----- & 0 & ----- & 0 & ---- & 0 & 0 & ---- \\
\hline Total & 0.03 & 0 & 0 & 0 & 0 & 0 & 0 & 0 & 0 & 0.04 & 0 & 0 \\
\hline Mean & .001 & 0 & 0 & 0 & 0 & 0 & 0 & 0 & 0 & .001 & 0 & 0 \\
\hline Max & .03 & 0 & 0 & 0 & 0 & 0 & 0 & 0 & 0 & .04 & 0 & 0 \\
\hline Min & 0 & 0 & 0 & 0 & 0 & 0 & 0 & 0 & 0 & 0 & 0 & 0 \\
\hline Acre-Ft & .06 & 0 & 0 & 0 & 0 & 0 & 0 & 0 & 0 & .08 & 0 & 0 \\
\hline Wtr Year & 2009 & Total & 0.07 & Mean & & 0 & Max & .04 & Min & 0 & Acre-Ft & .14 \\
\hline Cal Year & 2008 & Total & 8.04 & Mean & & 22 & Max & 7.2 & Min & 0 & Acre- $\mathrm{Ft}$ & 16 \\
\hline
\end{tabular}




\section{E202 Mortandad Canyon above Sediment Traps}

Location. Lat $35^{\circ}$ 51' 39", long $106^{\circ} 16^{\prime} 15^{\prime \prime}$, SE 1/4, Sec. 23, T. 19 N., R. 6 E., Los Alamos County.

Drainage Area. $1.14 \mathrm{mi}^{2}$.

Period of Record. October 1, 1997, to September 30, 2009.

Revised Record. Average discharge 2007 (2008)

Gage. Data logger with 30" Parshall flume. Elevation of gage is 6,833 ft above NGVD from land survey.

Remarks. Records are good.

Average Discharge. $12 \mathrm{yr}, 0.003 \mathrm{ft}^{3} / \mathrm{s}, 2.17 \mathrm{acre}-\mathrm{ft} / \mathrm{yr}$.

Extremes for Period of Record. Maximum discharge, $292 \mathrm{ft}^{3} / \mathrm{s}$, gage height unknown, August 25, 2006 (from critical depth computation of peak flow). No flow most of the time.

Extremes for Current Year. No flow for the year.

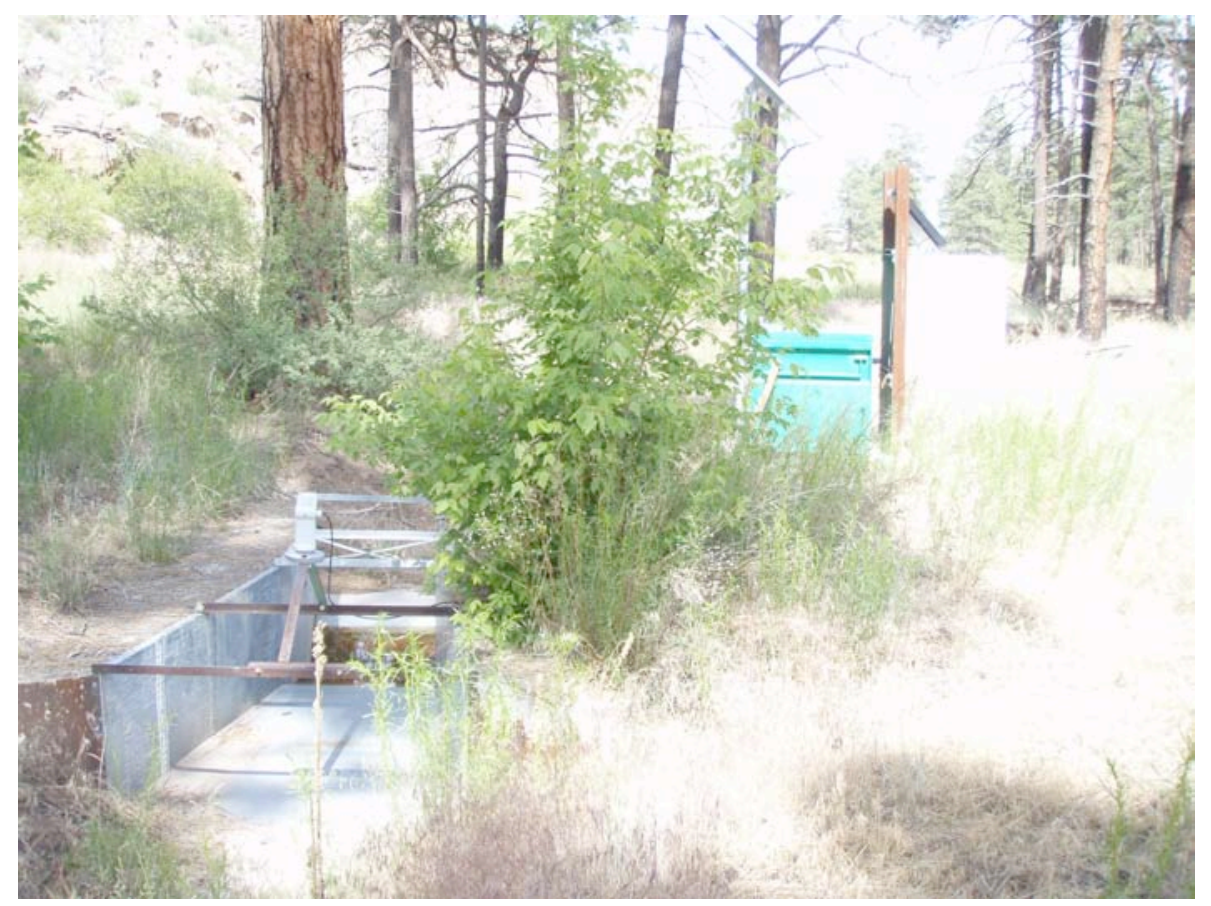




\title{
E202 Mortandad Canyon above Sediment Traps
}

\author{
Station Analysis
}

\section{Water Year}

Equipment. Station is equipped with Sutron 8210 data logger (5-min. interval) and Milltronics sonic probe mounted on a 30" Parshall flume. The system is powered by a solar panel battery system housed in a NEMA shelter. Station is equipped with an ISCO pump sampler for water quality sample collection. ISCO is housed in a separate shelter, a $3^{\prime} \times 4^{\prime}$ metal box. Sampler is triggered by stage through the data logger. The staff in the 30" Parshall Flume is the reference gage. No provision for discharge measurements above wading stage.

Field Work. The station was visited 13 times to conduct discharge measurements and service the instrumentation. Field inspections for the gage are listed under site history files on the Hydstra database. Discharge measurements for the gage are listed under site gauging files on the Hydstra database.

Datum Correction. None

Gage-Height Record. The data logger referenced to the outside staff gave a complete and satisfactory record, except during the periods from November 21-24, 26, December 9, 10, 15 to January 7, March 26-28, and April 7 when gage height was affected by ice and from August 10 to September 8 when the data logger malfunctioned.

Rating. Approach and escape sections are spread out because of overgrowth and debris in channel.

Thirteen inspections of no flow were made this year.

Rating No.1 was developed based on the computation of 30" Parshall flume. Point of zero flow is 0.00 gage height.

Discharge. Discharge was computed by applying Rating No. 1 directly.

Remarks. Records are good. 


\section{E202 Mortandad Canyon above Sediment Traps}

Daily Mean Discharge in Cubic Feet per Second

Water Year October 2008 to September 2009

\begin{tabular}{|c|c|c|c|c|c|c|c|c|c|c|c|c|}
\hline DAY & ОСт & NOV & DEC & JAN & FEB & MAR & APR & MAY & JUN & JUL & AUG & SEP \\
\hline 1 & 0 & 0 & 0 & $0^{*}$ & 0 & 0 & 0 & 0 & 0 & 0 & 0 & $0^{*}$ \\
\hline 2 & 0 & 0 & 0 & $0^{*}$ & 0 & 0 & 0 & 0 & 0 & 0 & 0 & $0^{*}$ \\
\hline 3 & 0 & 0 & 0 & $0^{*}$ & 0 & 0 & 0 & 0 & 0 & 0 & 0 & $0^{*}$ \\
\hline 4 & 0 & 0 & 0 & $0^{*}$ & 0 & 0 & 0 & 0 & 0 & 0 & 0 & $0^{*}$ \\
\hline 5 & 0 & 0 & 0 & $0^{*}$ & 0 & 0 & 0 & 0 & 0 & 0 & 0 & $0^{*}$ \\
\hline 6 & 0 & 0 & 0 & $0^{*}$ & 0 & 0 & 0 & 0 & 0 & 0 & 0 & $0^{*}$ \\
\hline 7 & 0 & 0 & 0 & $0^{*}$ & 0 & 0 & $0^{*}$ & 0 & 0 & 0 & 0 & $0^{*}$ \\
\hline 8 & 0 & 0 & 0 & 0 & 0 & 0 & 0 & 0 & 0 & 0 & 0 & $0^{*}$ \\
\hline 9 & 0 & 0 & $0^{*}$ & 0 & 0 & 0 & 0 & 0 & 0 & 0 & 0 & 0 \\
\hline 10 & 0 & 0 & $0^{*}$ & 0 & 0 & 0 & 0 & 0 & 0 & 0 & $0^{*}$ & 0 \\
\hline 11 & 0 & 0 & 0 & 0 & 0 & 0 & 0 & 0 & 0 & 0 & $0^{*}$ & 0 \\
\hline 12 & 0 & 0 & 0 & 0 & 0 & 0 & 0 & 0 & 0 & 0 & $0^{*}$ & 0 \\
\hline 13 & 0 & 0 & 0 & 0 & 0 & 0 & 0 & 0 & 0 & 0 & $0^{*}$ & 0 \\
\hline 14 & 0 & 0 & 0 & 0 & 0 & 0 & 0 & 0 & 0 & 0 & $0^{*}$ & 0 \\
\hline 15 & 0 & 0 & $0^{*}$ & 0 & 0 & 0 & 0 & 0 & 0 & 0 & $0^{*}$ & 0 \\
\hline 16 & 0 & 0 & $0^{*}$ & 0 & 0 & 0 & 0 & 0 & 0 & 0 & $0^{*}$ & 0 \\
\hline 17 & 0 & 0 & $0^{*}$ & 0 & 0 & 0 & 0 & 0 & 0 & 0 & $0^{*}$ & 0 \\
\hline 18 & 0 & 0 & $0^{*}$ & 0 & 0 & 0 & 0 & 0 & 0 & 0 & $0^{*}$ & 0 \\
\hline 19 & 0 & 0 & $0^{*}$ & 0 & 0 & 0 & 0 & 0 & 0 & 0 & $0^{*}$ & 0 \\
\hline 20 & 0 & 0 & $0^{*}$ & 0 & 0 & 0 & 0 & 0 & 0 & 0 & $0^{*}$ & 0 \\
\hline 21 & 0 & $0^{*}$ & $0^{*}$ & 0 & 0 & 0 & 0 & 0 & 0 & 0 & $0^{*}$ & 0 \\
\hline 22 & 0 & $0^{*}$ & $0^{*}$ & 0 & 0 & 0 & 0 & 0 & 0 & 0 & $0^{*}$ & 0 \\
\hline 23 & 0 & $0^{*}$ & $0^{*}$ & 0 & 0 & 0 & 0 & 0 & 0 & 0 & $0^{*}$ & 0 \\
\hline 24 & 0 & $0^{*}$ & $0^{*}$ & 0 & 0 & 0 & 0 & 0 & 0 & 0 & $0^{*}$ & 0 \\
\hline 25 & 0 & 0 & $0^{*}$ & 0 & 0 & 0 & 0 & 0 & 0 & 0 & $0^{*}$ & 0 \\
\hline 26 & 0 & $0^{*}$ & $0^{*}$ & 0 & 0 & $0^{*}$ & 0 & 0 & 0 & 0 & $0^{*}$ & 0 \\
\hline 27 & 0 & 0 & $0^{*}$ & 0 & 0 & $0^{*}$ & 0 & 0 & 0 & 0 & $0^{*}$ & 0 \\
\hline 28 & 0 & 0 & $0^{*}$ & 0 & 0 & $0^{*}$ & 0 & 0 & 0 & 0 & $0^{*}$ & 0 \\
\hline 29 & 0 & 0 & $0^{*}$ & 0 & --.-- & 0 & 0 & 0 & 0 & 0 & $0^{*}$ & 0 \\
\hline 30 & 0 & 0 & $0^{*}$ & 0 & -.-- & 0 & 0 & 0 & 0 & 0 & $0^{*}$ & 0 \\
\hline 31 & 0 & - & $0^{*}$ & 0 & --.-- & 0 & 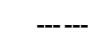 & 0 & --- & 0 & $0^{*}$ & ----- \\
\hline Total & 0 & 0 & 0 & 0 & 0 & 0 & 0 & 0 & 0 & 0 & 0 & 0 \\
\hline Mean & 0 & 0 & 0 & 0 & 0 & 0 & 0 & 0 & 0 & 0 & 0 & 0 \\
\hline Max & 0 & 0 & 0 & 0 & 0 & 0 & 0 & 0 & 0 & 0 & 0 & 0 \\
\hline Min & 0 & 0 & 0 & 0 & 0 & 0 & 0 & 0 & 0 & 0 & 0 & 0 \\
\hline Acre-Ft & 0 & 0 & 0 & 0 & 0 & 0 & 0 & 0 & 0 & 0 & 0 & 0 \\
\hline Wtr Year & 2009 & Total & 0 & Mean & & 0 & Max & 0 & Min & 0 & Acre-Ft & 0 \\
\hline Cal Year & 2008 & Total & 1.03 & Mean & & 03 & Max & .73 & Min & 0 & Acre-Ft & 2.0 \\
\hline
\end{tabular}

*Estimate 


\section{E203 Mortandad Canyon below Sediment Traps}

Location. Lat 35 51' 39", long 106 16' 6", SE 1/4, Sec. 23, T. 19 N., R. 6 E., Los Alamos County.

Drainage Area. $1.17 \mathrm{mi}^{2}$.

Period of Record. October 1, 1996, to August 25, 2006 (destroyed by flood), September 2006 to September 30, 2008.

Revised Record. Drainage Area (2006).

Gage. Data logger and 6" Parshall flume, rain gage with cellular telemetry. Elevation of gage is $6,817 \mathrm{ft}$ above NGVD from land survey.

Remarks. Records are good.

Average Discharge. $13 \mathrm{yr}, 0.025 \mathrm{ft}^{3} / \mathrm{s}, 1.45 \mathrm{acre} \mathrm{ft} / \mathrm{yr}$.

Extremes for Period of Record. Maximum discharge, $220 \mathrm{ft}^{3} / \mathrm{s}$, August 25, 2006 (from critical depth computation), gage height unknown. No flow most of the time.

Extremes for Current Year. No flow for the year.

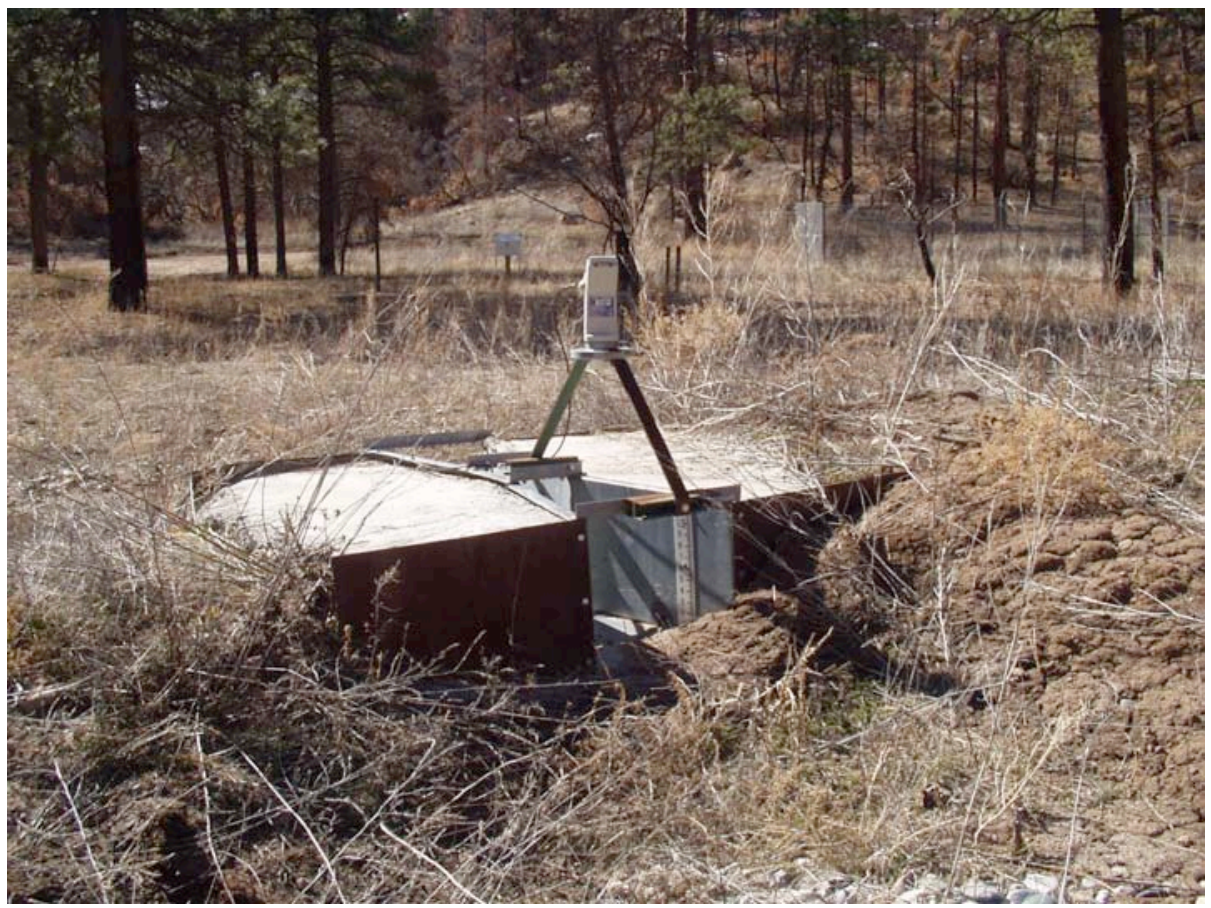




\title{
E203 Mortandad Canyon below Sediment Traps
}

\author{
Station Analysis
}

\section{Water Year}

Equipment. Station is equipped with Sutron 8210 data logger (5-min. interval) and Milltronics sonic probe mounted on a 6" Parshall flume and cellular telemetry with speech modem. The system is powered by a solar panel battery system housed in a NEMA shelter. Station is equipped with an ISCO pump sampler for water quality sample collection. ISCO is housed in a separate shelter, a $3^{\prime} \times 4^{\prime}$ metal box. Sampler is triggered by stage through the data logger. The staff in the 6" Parshall flume is the reference gage. No provision for discharge measurements above wading stage.

Station is also equipped with a rain gage, Rain Collection II. All equipment is powered with a solar panel battery charging system.

Field Work. This station was visited 14 times to conduct discharge measurements and service the instrumentation. Field inspections for the gage are listed under site history files on the Hydstra database. Discharge measurements for the gage are listed under site gauging files on the Hydstra database.

Datum Correction. None.

Gage-Height Record. The data logger referenced to the outside staff gave a complete and satisfactory record, except for the periods from November 23, 26, 27; December 2, 3, 7, 9 to January 7; March 26-29, and April 17, 18 when gage height was affected by ice.

Rating. Approach and escape sections are spread out because channel is somewhat undefined.

Fourteen inspections of no flow were made this year.

Rating No. 1 was developed based on the computation of 6" Parshall flume. Point of zero flow is 0.00 gage height.

Discharge. Discharge was computed by applying Rating No. 1 directly.

Remarks. Records are good. No discharge for the year. 


\section{E203 Mortandad Canyon below Sediment Traps}

Daily Mean Discharge in Cubic Feet per Second

Water Year October 2008 to September 2009

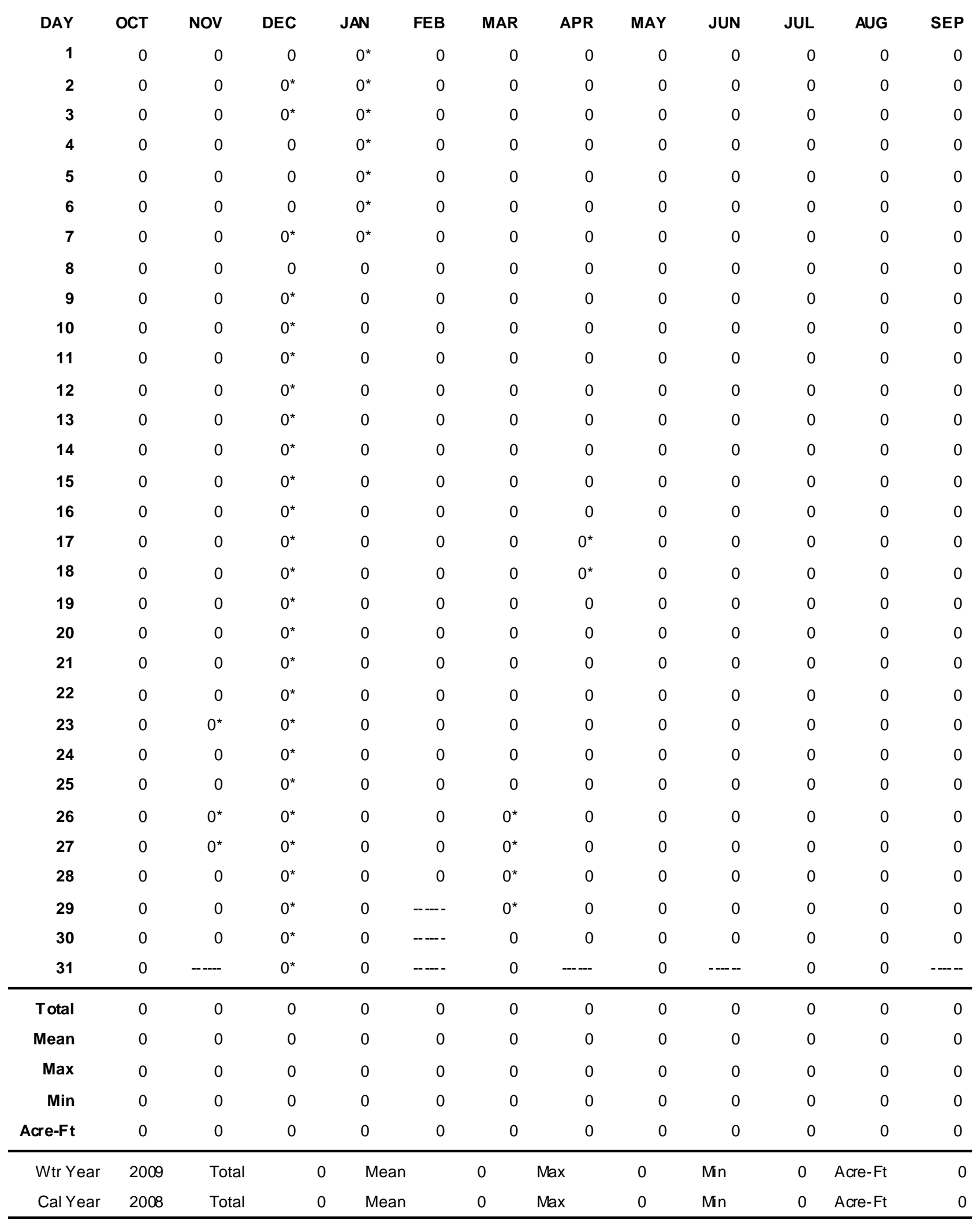

${ }^{\star}$ Estimate 


\section{E204 Mortandad Canyon at LANL Boundary}

Location. Lat $35^{\circ}$ 51' 21", long $106^{\circ}$ 14' 43", NW 1/4, Sec. 30, T. 19 N., R. 7 E., Santa Fe County.

Drainage Area. $1.61 \mathrm{mi}^{2}$.

Period of Record. October 1, 1993, to September 30, 2009.

Revised Record. Drainage Area (2006).

Gage. Data logger with cellular telemetry and concrete control. Elevation of gage is $6,651 \mathrm{ft}$ above NGVD from survey.

Remarks. Records are good.

Average Discharge. $15 \mathrm{yr}$, zero.

Extremes for Period of Record. No flow for period.

Extremes for Current Year. No flow for year.

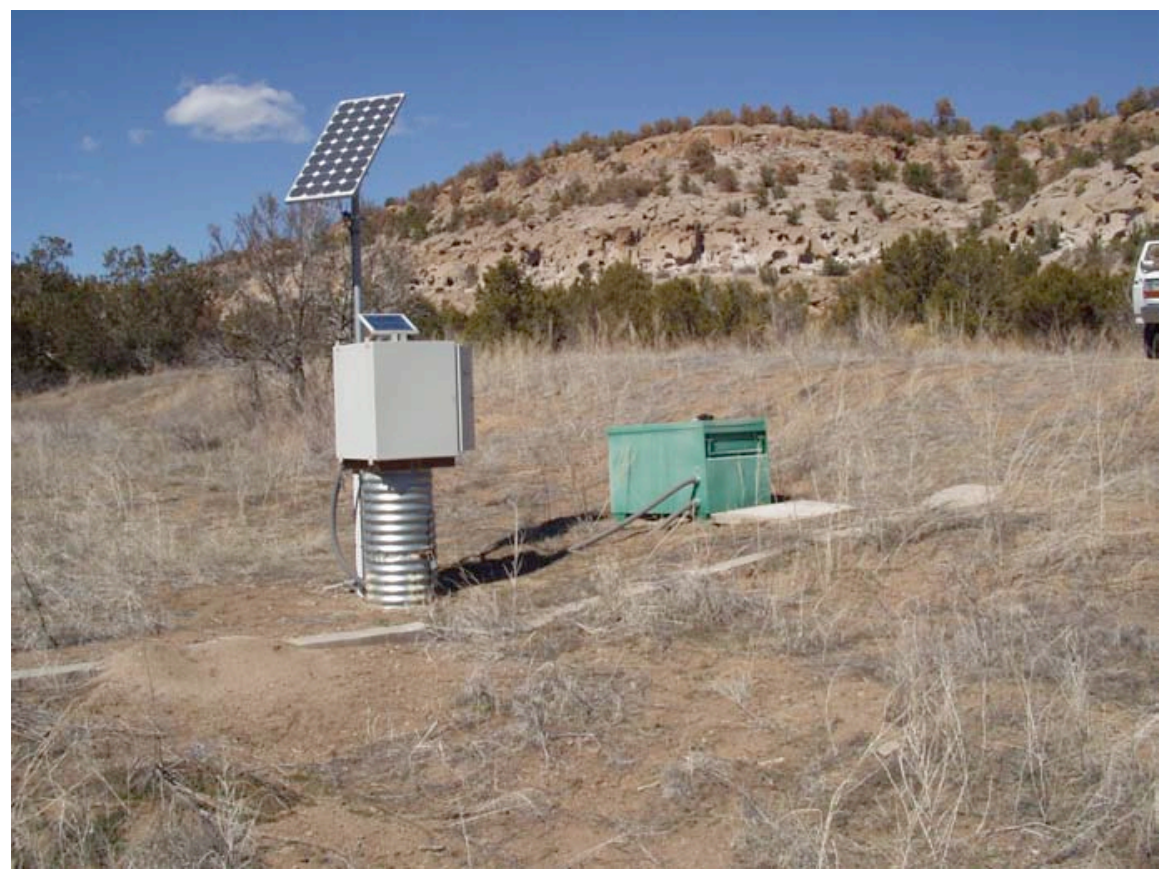




\section{E204 Mortandad Canyon at LANL Boundary}

\section{Station Analysis}

\section{Water Year}

Equipment. Station is equipped with Sutron 8210 (5-min. interval) and shaft encoder float system with cellular phone and speech modem. The system is powered by a solar panel battery system housed in a NEMA shelter on top of a 24" CMP well. Station is equipped with an ISCO pump sampler for water quality sample collection. ISCO is housed in a separate shelter, a $3^{\prime} \times 4^{\prime}$ metal box. Samplers are triggered by stage through the data logger. An outside staff is available for reference. No provision for measurement above wading stage. All high-flow measurement will be by slope area or critical depth computation methods.

Field Work. This station was visited 13 times for the purpose of making a discharge measurement and or servicing the instrumentation. Field inspections for the gage are listed under site history files on the Hydstra data base. Discharge measurements for the gage are listed under site gauging files on the Hydstra database.

Datum Correction. Levels run May 24, 2007, showed the gage to be reading within allowable limits.

Gage-Height Record. The data logger referenced to the outside staff gage gave a complete and satisfactory record.

Rating. Channel is straight above and below gage for $100 \mathrm{ft}$. Channel is not well defined and resembles a low grass-covered swale. Flow is infrequent. The control is broad-crested weir with $\mathrm{V}$ notch 5' downstream from gage.

Thirteen inspections of no flow were made.

No rating has been developed; PZF is well defined for concrete broad-crested weir.

Discharge. All recorded values were below PZF. No flow most of the time. Days with rain did not produce enough flow to pass over control.

Remarks. Records are good. 
E204 M ortand ad C an yon at LAN L Boundary

Daily Mean Discharge in Cubic Feet per Second

Water Year October 2008 to September 2009

\begin{tabular}{|c|c|c|c|c|c|c|c|c|c|c|c|c|}
\hline DAY & OCT & NOV & DEC & JAN & FEB & MAR & APR & MAY & JUN & JUL & $A U G$ & SEP \\
\hline 1 & 0 & 0 & 0 & 0 & 0 & 0 & 0 & 0 & 0 & 0 & 0 & 0 \\
\hline 2 & 0 & 0 & 0 & 0 & 0 & 0 & 0 & 0 & 0 & 0 & 0 & 0 \\
\hline 3 & 0 & 0 & 0 & 0 & 0 & 0 & 0 & 0 & 0 & 0 & 0 & 0 \\
\hline 4 & 0 & 0 & 0 & 0 & 0 & 0 & 0 & 0 & 0 & 0 & 0 & 0 \\
\hline 5 & 0 & 0 & 0 & 0 & 0 & 0 & 0 & 0 & 0 & 0 & 0 & 0 \\
\hline 6 & 0 & 0 & 0 & 0 & 0 & 0 & 0 & 0 & 0 & 0 & 0 & 0 \\
\hline 7 & 0 & 0 & 0 & 0 & 0 & 0 & 0 & 0 & 0 & 0 & 0 & 0 \\
\hline 8 & 0 & 0 & 0 & 0 & 0 & 0 & 0 & 0 & 0 & 0 & 0 & 0 \\
\hline 9 & 0 & 0 & 0 & 0 & 0 & 0 & 0 & 0 & 0 & 0 & 0 & 0 \\
\hline 10 & 0 & 0 & 0 & 0 & 0 & 0 & 0 & 0 & 0 & 0 & 0 & 0 \\
\hline 11 & 0 & 0 & 0 & 0 & 0 & 0 & 0 & 0 & 0 & 0 & 0 & 0 \\
\hline 12 & 0 & 0 & 0 & 0 & 0 & 0 & 0 & 0 & 0 & 0 & 0 & 0 \\
\hline 13 & 0 & 0 & 0 & 0 & 0 & 0 & 0 & 0 & 0 & 0 & 0 & 0 \\
\hline 14 & 0 & 0 & 0 & 0 & 0 & 0 & 0 & 0 & 0 & 0 & 0 & 0 \\
\hline 15 & 0 & 0 & 0 & 0 & 0 & 0 & 0 & 0 & 0 & 0 & 0 & 0 \\
\hline 16 & 0 & 0 & 0 & 0 & 0 & 0 & 0 & 0 & 0 & 0 & 0 & 0 \\
\hline 17 & 0 & 0 & 0 & 0 & 0 & 0 & 0 & 0 & 0 & 0 & 0 & 0 \\
\hline 18 & 0 & 0 & 0 & 0 & 0 & 0 & 0 & 0 & 0 & 0 & 0 & 0 \\
\hline 19 & 0 & 0 & 0 & 0 & 0 & 0 & 0 & 0 & 0 & 0 & 0 & 0 \\
\hline 20 & 0 & 0 & 0 & 0 & 0 & 0 & 0 & 0 & 0 & 0 & 0 & 0 \\
\hline 21 & 0 & 0 & 0 & 0 & 0 & 0 & 0 & 0 & 0 & 0 & 0 & 0 \\
\hline 22 & 0 & 0 & 0 & 0 & 0 & 0 & 0 & 0 & 0 & 0 & 0 & 0 \\
\hline 23 & 0 & 0 & 0 & 0 & 0 & 0 & 0 & 0 & 0 & 0 & 0 & 0 \\
\hline 24 & 0 & 0 & 0 & 0 & 0 & 0 & 0 & 0 & 0 & 0 & 0 & 0 \\
\hline 25 & 0 & 0 & 0 & 0 & 0 & 0 & 0 & 0 & 0 & 0 & 0 & 0 \\
\hline 26 & 0 & 0 & 0 & 0 & 0 & 0 & 0 & 0 & 0 & 0 & 0 & 0 \\
\hline 27 & 0 & 0 & 0 & 0 & 0 & 0 & 0 & 0 & 0 & 0 & 0 & 0 \\
\hline 28 & 0 & 0 & 0 & 0 & 0 & 0 & 0 & 0 & 0 & 0 & 0 & 0 \\
\hline 29 & 0 & 0 & 0 & 0 & ---- & 0 & 0 & 0 & 0 & 0 & 0 & 0 \\
\hline 30 & 0 & 0 & 0 & 0 & ----- & 0 & 0 & 0 & 0 & 0 & 0 & 0 \\
\hline 31 & 0 & - & 0 & 0 & ---- & 0 & --- & 0 & --- & 0 & 0 & --- \\
\hline Total & 0 & 0 & 0 & 0 & 0 & 0 & 0 & 0 & 0 & 0 & 0 & 0 \\
\hline Mean & 0 & 0 & 0 & 0 & 0 & 0 & 0 & 0 & 0 & 0 & 0 & 0 \\
\hline $\operatorname{Max}$ & 0 & 0 & 0 & 0 & 0 & 0 & 0 & 0 & 0 & 0 & 0 & 0 \\
\hline Min & 0 & 0 & 0 & 0 & 0 & 0 & 0 & 0 & 0 & 0 & 0 & 0 \\
\hline Acre $-\mathrm{Ft}$ & 0 & 0 & 0 & 0 & 0 & 0 & 0 & 0 & 0 & 0 & 0 & 0 \\
\hline Wtr Year & 2009 & Total & & & & 0 & Max & 0 & Min & 0 & Acre-Ft & 0 \\
\hline Cal Year & 2008 & Total & & & & 0 & Max & 0 & Min & 0 & Acre-Ft & 0 \\
\hline
\end{tabular}




\section{E218 Cañada del Buey near TA-46}

Location. Lat $35^{\circ}$ 51' 31", long $106^{\circ} 17^{\prime} 17^{\prime \prime}$ SW 1/4, Sec. 26, T. 19 N., R. 6 E., Los Alamos County.

Drainage Area. $0.30 \mathrm{mi}^{2}$.

Period of Record. June 1, 2000, to September 30, 2009.

Revised Record. Drainage Area (2006).

Gage. Data logger and 24" Parshall flume. Elevation of gage is 6,937 ft above NGVD from GPS survey.

Remarks. Records are good.

Average Discharge. $9 \mathrm{yr}, 0.01 \mathrm{ft}^{3} / \mathrm{s}, 10$ acre- $\mathrm{ft} /$ year.

Extremes for Period of Record. Maximum discharge, $228 \mathrm{ft}^{3} / \mathrm{s}$, August 25, 2005, gage height $3.40 \mathrm{ft}$, from critical depth computation of peak flow. No flow most of the time.

Extremes for Current Year. No flow for the year.

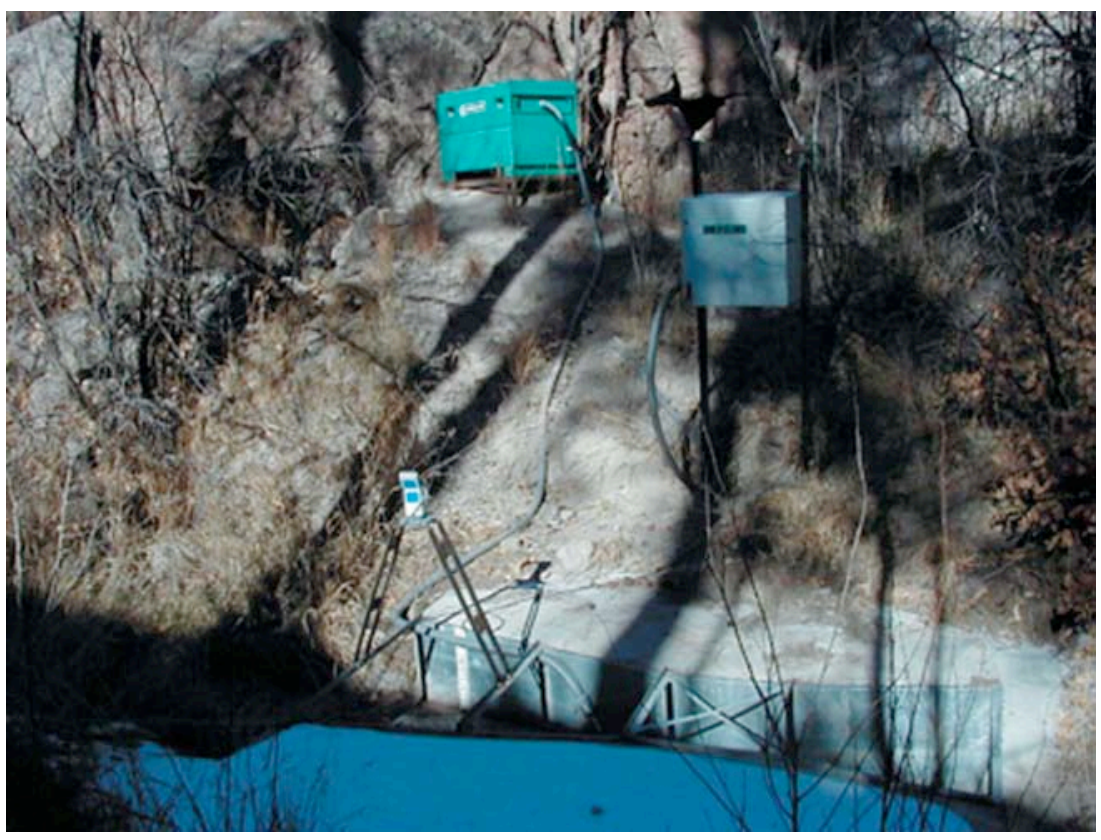




\title{
E218 Cañada del Buey near TA-46
}

\author{
Station Analysis
}

\section{Water Year}

Equipment. Station is equipped with Sutron 8210 data logger (5-min. interval) with Milltronics sonic probe mounted on a 24" Parshall flume. The system is powered by a solar panel battery system housed in a NEMA shelter. Station is equipped with ISCO pump sampler for water quality sample collection. ISCO is housed in a separate shelter, a $3^{\prime} \times 4^{\prime}$ metal box. Samplers are triggered by stage through the data logger. An outside staff is available for reference. No provision for discharge measurements above wading stage. All high-flow measurement will be by slope area or peak flow computation methods.

Field Work. The station was visited 11 times to conduct discharge measurements and service the instrumentation. Field inspections for the gage are listed under site history files on the Hydstra database. Discharge measurements for the gage are listed under site gauging files on the Hydstra database.

Datum Correction. None.

Gage-Height Record. The data logger referenced to the outside staff gave a complete and satisfactory record, except for the period from December 9 to January 13 when gage height was affected by ice.

Rating. The channel is $15^{\prime}$ wide and straight upstream and downstream for about $100^{\prime}$. The streambed through this reach is boulders with sand and gravel. The low-flow control is the 24" Parshall flume; at very high flow the channel becomes control.

Eleven inspections of no flow were made this year.

Rating No. 1 was developed based on the computation of 24" Parshall flume and two peak flow computations.

Discharge. Discharge was computed by applying gage height to Rating No. 1 directly with shift adjustment based on PZF.

Remarks. Records are good. 
E218 C añ ada del Buey near TA-46

Daily Mean Discharge in Cubic Feet per Second

Water Year October 2008 to September 2009

\begin{tabular}{|c|c|c|c|c|c|c|c|c|c|c|c|c|}
\hline DAY & OCT & NOV & DEC & JAN & FE B & MAR & APR & MAY & JUN & JUL & AUG & SEP \\
\hline 1 & 0 & 0 & 0 & $0^{*}$ & 0 & 0 & 0 & 0 & 0 & 0 & 0 & 0 \\
\hline 2 & 0 & 0 & 0 & $0^{*}$ & 0 & 0 & 0 & 0 & 0 & 0 & 0 & 0 \\
\hline 3 & 0 & 0 & 0 & $0^{*}$ & 0 & 0 & 0 & 0 & 0 & 0 & 0 & 0 \\
\hline 4 & 0 & 0 & 0 & $0^{*}$ & 0 & 0 & 0 & 0 & 0 & 0 & 0 & 0 \\
\hline 5 & 0 & 0 & 0 & $0^{*}$ & 0 & 0 & 0 & 0 & 0 & 0 & 0 & 0 \\
\hline 6 & 0 & 0 & 0 & $0^{*}$ & 0 & 0 & 0 & 0 & 0 & 0 & 0 & 0 \\
\hline 7 & 0 & 0 & 0 & $0^{*}$ & 0 & 0 & 0 & 0 & 0 & 0 & 0 & 0 \\
\hline 8 & 0 & 0 & 0 & $0^{*}$ & 0 & 0 & 0 & 0 & 0 & 0 & 0 & 0 \\
\hline 9 & 0 & 0 & $0^{*}$ & $0^{*}$ & 0 & 0 & 0 & 0 & 0 & 0 & 0 & 0 \\
\hline 10 & 0 & 0 & $0^{*}$ & $0^{*}$ & 0 & 0 & 0 & 0 & 0 & 0 & 0 & 0 \\
\hline 11 & 0 & 0 & $0^{*}$ & $0^{*}$ & 0 & 0 & 0 & 0 & 0 & 0 & 0 & 0 \\
\hline 12 & 0 & 0 & $0^{*}$ & $0^{*}$ & 0 & 0 & 0 & 0 & 0 & 0 & 0 & 0 \\
\hline 13 & 0 & 0 & $0^{*}$ & $0^{*}$ & 0 & 0 & 0 & 0 & 0 & 0 & 0 & 0 \\
\hline 14 & 0 & 0 & $0^{*}$ & 0 & 0 & 0 & 0 & 0 & 0 & 0 & 0 & 0 \\
\hline 15 & 0 & 0 & $0^{*}$ & 0 & 0 & 0 & 0 & 0 & 0 & 0 & 0 & 0 \\
\hline 16 & 0 & 0 & $0^{*}$ & 0 & 0 & 0 & 0 & 0 & 0 & 0 & 0 & 0 \\
\hline 17 & 0 & 0 & $0^{*}$ & 0 & 0 & 0 & 0 & 0 & 0 & 0 & 0 & 0 \\
\hline 18 & 0 & 0 & $0^{*}$ & 0 & 0 & 0 & 0 & 0 & 0 & 0 & 0 & 0 \\
\hline 19 & 0 & 0 & $0^{*}$ & 0 & 0 & 0 & 0 & 0 & 0 & 0 & 0 & 0 \\
\hline 20 & 0 & 0 & $0^{*}$ & 0 & 0 & 0 & 0 & 0 & 0 & 0 & 0 & 0 \\
\hline 21 & 0 & 0 & $0^{*}$ & 0 & 0 & 0 & 0 & 0 & 0 & 0 & 0 & 0 \\
\hline 22 & 0 & 0 & $0^{*}$ & 0 & 0 & 0 & 0 & 0 & 0 & 0 & 0 & 0 \\
\hline 23 & 0 & 0 & $0^{*}$ & 0 & 0 & 0 & 0 & 0 & 0 & 0 & 0 & 0 \\
\hline 24 & 0 & 0 & $0^{*}$ & 0 & 0 & 0 & 0 & 0 & 0 & 0 & 0 & 0 \\
\hline 25 & 0 & 0 & $0^{*}$ & 0 & 0 & 0 & 0 & 0 & 0 & 0 & 0 & 0 \\
\hline 26 & 0 & 0 & $0^{*}$ & 0 & 0 & $0^{*}$ & 0 & 0 & 0 & 0 & 0 & 0 \\
\hline 27 & 0 & 0 & $0^{*}$ & 0 & 0 & $0^{*}$ & 0 & 0 & 0 & 0 & 0 & 0 \\
\hline 28 & 0 & 0 & $0^{*}$ & 0 & 0 & $0^{*}$ & 0 & 0 & 0 & 0 & 0 & 0 \\
\hline 29 & 0 & 0 & $0^{*}$ & 0 & ----- & 0 & 0 & 0 & 0 & 0 & 0 & 0 \\
\hline 30 & 0 & 0 & $0^{*}$ & 0 & -..-- & 0 & 0 & 0 & 0 & 0 & 0 & 0 \\
\hline 31 & 0 & --- & $0^{*}$ & 0 & ----- & 0 & ----- & 0 & $-\cdots-$ & 0 & 0 & ---- \\
\hline Total & 0 & 0 & 0 & 0 & 0 & 0 & 0 & 0 & 0 & 0 & 0 & 0 \\
\hline Mean & 0 & 0 & 0 & 0 & 0 & 0 & 0 & 0 & 0 & 0 & 0 & 0 \\
\hline Max & 0 & 0 & 0 & 0 & 0 & 0 & 0 & 0 & 0 & 0 & 0 & 0 \\
\hline M in & 0 & 0 & 0 & 0 & 0 & 0 & 0 & 0 & 0 & 0 & 0 & 0 \\
\hline Acre-Ft & 0 & 0 & 0 & 0 & 0 & 0 & 0 & 0 & 0 & 0 & 0 & 0 \\
\hline Wtr Year & 2009 & Total & 0 & Mean & & 0 & Max & 0 & Min & 0 & Acre-Ft & 0 \\
\hline Cal Year & 2008 & Total & 0.71 & Mean & & 02 & $\operatorname{Max}$ & .42 & Min & 0 & Acre-Ft & 1.4 \\
\hline
\end{tabular}

${ }^{*}$ Estimate 
Location. Lat $35^{\circ} 50^{\prime} 41^{\prime \prime}$, long $106^{\circ}$ 15' 52", Sec. 25, T. 19 N., R. 6 E., Ramon Vigil Grant, Los Alamos County.

Drainage Area. $0.0004 \mathrm{mi}^{2}$.

Period of Record. October 1, 2006, to September 30, 2009.

Gage. Data logger and 9" Parshall flume. Elevation of gage is 6,877 ft above NGVD.

Remarks. Records are good. Records for this site existed before period of record but are not reliable. Legal location based on projected values.

Extremes for Period of Record. Maximum discharge, $2.09 \mathrm{ft}^{3} / \mathrm{s}$, July 30, 2007, gage height $0.78 \mathrm{ft}$. No flow most of the time.

Extremes for Current Year. Peak discharge above base of $1.0 \mathrm{ft}^{3} / \mathrm{s}$ and maximum (*):

\begin{tabular}{|c|c|c|c|}
\hline Date & Time & Discharge $\left(\mathbf{f t}^{\mathbf{3}} / \mathbf{s}\right)$ & Gage Height $(\mathbf{f t})$ \\
\hline June 3 & 1510 & $1.67^{*}$ & $0.67^{*}$ \\
\hline July 30 & 1355 & 1.37 & 0.59 \\
\hline
\end{tabular}

No flow most of the time.

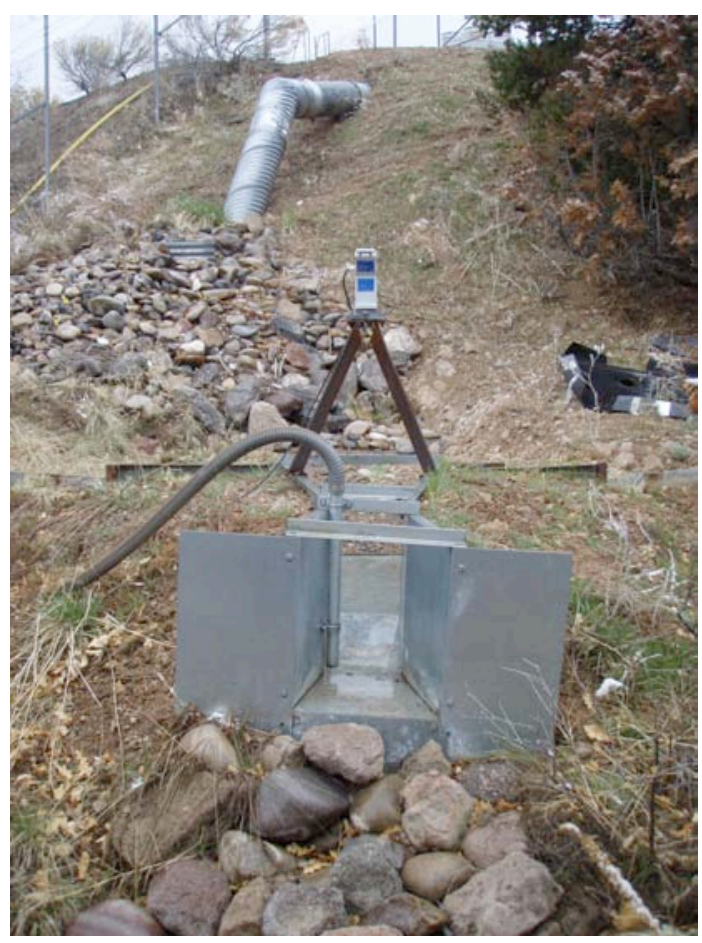




\section{E220 TA-54 RANT}

\section{Station Analysis}

\section{Water Year}

Equipment. Station is equipped with Sutron 8210 data logger (5-min. interval) and Milltronics sonic probe mounted on a 9" Parshall flume. The system is powered by a solar panel battery system housed in a NEMA shelter. Station is equipped with an ISCO pump sampler for water quality sample collection. ISCO is housed in a separate shelter, a $3^{\prime} \times 4^{\prime}$ metal box. Sampler is triggered by stage through the data logger. The staff in the 9" Parshall flume is the reference gage. No provision for discharge measurements above wading stage.

Field Work. This station was visited 16 times to conduct discharge measurements and service the instrumentation. Field inspections for the gage are listed under site history files on the Hydstra database. Discharge measurements for the gage are listed under site gauging files on the Hydstra database.

Datum Correction. None.

Gage-Height Record. The data logger referenced to the outside staff gave a complete and satisfactory record, except for the periods from November 13 to December 9 when data malfunctioned and December 10 to January 12 and January 18-22 when gage height was affected by ice.

Rating. Channel is straight above and below gage for $10^{\prime}$. The streambed is gravel and large cobble.

Sixteen inspections of no flow were made this year.

Rating No. 1 was developed based on the computation of 9" Parshall flume. Point of zero flow is 0.00 gage height.

Discharge. Discharge was computed by applying gage height to Rating No. 1 directly.

Remarks. Records are good. 
E220 TA-54 R ANT

Daily Mean Discharge in Cubic Feet per Second

Water Year October 2008 to September 2009

\begin{tabular}{|c|c|c|c|c|c|c|c|c|c|c|c|c|}
\hline DAY & OCT & NOV & DEC & JAN & FE B & MAR & APR & MAY & JUN & JUL & AUG & SEP \\
\hline 1 & 0 & 0 & $0^{*}$ & $0^{*}$ & 0 & 0 & 0 & 0 & 0 & 0 & 0 & 0 \\
\hline 2 & 0 & 0 & $0^{*}$ & $0^{*}$ & 0 & 0 & 0 & 0 & 0 & 0 & 0 & 0 \\
\hline 3 & 0 & 0 & $0^{*}$ & $0^{*}$ & 0 & 0 & 0 & 0 & .01 & 0 & 0 & 0 \\
\hline 4 & 0 & 0 & $0^{*}$ & $0^{*}$ & 0 & 0 & 0 & 0 & 0 & 0 & 0 & 0 \\
\hline 5 & 0 & 0 & $0^{*}$ & $0^{*}$ & 0 & 0 & 0 & 0 & 0 & .01 & 0 & 0 \\
\hline 6 & 0 & 0 & $0^{*}$ & $0^{*}$ & 0 & 0 & 0 & 0 & 0 & .01 & 0 & 0 \\
\hline 7 & 0 & 0 & $0^{*}$ & $0^{*}$ & 0 & 0 & 0 & 0 & 0 & 0 & 0 & 0 \\
\hline 8 & 0 & 0 & $0^{*}$ & $0^{*}$ & 0 & 0 & 0 & 0 & 0 & 0 & 0 & 0 \\
\hline 9 & 0 & 0 & $0^{*}$ & $0^{*}$ & 0 & 0 & 0 & 0 & 0 & 0 & 0 & 0 \\
\hline 10 & 0 & 0 & $0^{*}$ & $0^{*}$ & 0 & 0 & 0 & 0 & .01 & 0 & 0 & 0 \\
\hline 11 & .02 & 0 & $0^{*}$ & $0^{*}$ & 0 & 0 & 0 & 0 & 0 & 0 & 0 & 0 \\
\hline 12 & 0 & 0 & 0 & $0^{*}$ & 0 & 0 & 0 & 0 & 0 & 0 & 0 & 0 \\
\hline 13 & 0 & $0^{*}$ & $0^{*}$ & 0 & 0 & 0 & 0 & 0 & .01 & 0 & 0 & 0 \\
\hline 14 & 0 & $0^{*}$ & 0 & 0 & 0 & 0 & 0 & 0 & .01 & 0 & .01 & 0 \\
\hline 15 & 0 & $0^{*}$ & $0^{*}$ & 0 & 0 & 0 & 0 & 0 & 0 & 0 & 0 & 0 \\
\hline 16 & 0 & $0^{*}$ & $0^{*}$ & 0 & 0 & 0 & 0 & 0 & 0 & 0 & 0 & 0 \\
\hline 17 & 0 & $0^{*}$ & $0^{*}$ & 0 & 0 & 0 & 0 & 0 & 0 & 0 & 0 & 0 \\
\hline 18 & 0 & $0^{*}$ & $0^{*}$ & $0^{*}$ & 0 & 0 & 0 & 0 & 0 & 0 & 0 & 0 \\
\hline 19 & 0 & $0^{*}$ & $0^{*}$ & $0^{*}$ & 0 & 0 & 0 & 0 & 0 & 0 & 0 & 0 \\
\hline 20 & 0 & $0^{*}$ & $0^{*}$ & $0^{*}$ & 0 & 0 & 0 & 0 & 0 & 0 & 0 & 0 \\
\hline 21 & 0 & $0^{*}$ & $0^{*}$ & $0^{*}$ & 0 & 0 & 0 & 0 & 0 & 0 & 0 & 0 \\
\hline 22 & 0 & $0^{*}$ & $0^{*}$ & $0^{*}$ & 0 & 0 & 0 & 0 & 0 & 0 & 0 & 0 \\
\hline 23 & 0 & $0^{*}$ & $0^{*}$ & 0 & 0 & 0 & 0 & 0 & 0 & 0 & 0 & 0 \\
\hline 24 & 0 & $0^{*}$ & $0^{*}$ & 0 & 0 & 0 & 0 & 0 & 0 & 0 & 0 & 0 \\
\hline 25 & 0 & $0^{*}$ & $0^{*}$ & 0 & 0 & 0 & 0 & 0 & 0 & 0 & 0 & 0 \\
\hline 26 & 0 & $0^{*}$ & $0^{*}$ & 0 & 0 & 0 & 0 & 0 & 0 & 0 & 0 & 0 \\
\hline 27 & 0 & $0^{*}$ & $0^{*}$ & 0 & 0 & 0 & 0 & 0 & 0 & 0 & 0 & 0 \\
\hline 28 & 0 & $0^{*}$ & $0^{*}$ & 0 & 0 & 0 & 0 & 0 & 0 & 0 & 0 & 0 \\
\hline 29 & 0 & $0^{*}$ & $0^{*}$ & 0 & -..-- & 0 & 0 & 0 & 0 & 0 & 0 & 0 \\
\hline 30 & 0 & $0^{*}$ & $0^{*}$ & 0 & -.--- & 0 & 0 & 0 & 0 & .01 & 0 & 0 \\
\hline 31 & 0 & -.--- & $0^{*}$ & 0 & -.--- & 0 & ----- & 0 & ----- & 0 & 0 & --.-- \\
\hline Total & 0.02 & 0 & 0 & 0 & 0 & 0 & 0 & 0 & 0.04 & 0.03 & 0.01 & 0 \\
\hline Mean & .001 & 0 & 0 & 0 & 0 & 0 & 0 & 0 & .001 & .001 & 0 & 0 \\
\hline Max & .02 & 0 & 0 & 0 & 0 & 0 & 0 & 0 & .01 & .01 & .01 & 0 \\
\hline Min & 0 & 0 & 0 & 0 & 0 & 0 & 0 & 0 & 0 & 0 & 0 & 0 \\
\hline Acre-Ft & .04 & 0 & 0 & 0 & 0 & 0 & 0 & 0 & .08 & .06 & .02 & 0 \\
\hline Wtr Year & 2009 & Total & 0.10 & Mean & & 0 & Max & .02 & Min & 0 & Acre- $\mathrm{Ft}$ & .20 \\
\hline Cal Year & 2008 & Total & 0.06 & Mean & & 0 & Max & .02 & Min & 0 & Acre-Ft & .12 \\
\hline
\end{tabular}

${ }^{*}$ Estimate 


\section{E223 MDA AREA L}

Location. Lat $35^{\circ}$ 50' 8", long $106^{\circ}$ 15' 2", Sec. 36, T. 19 N., R. 6 E., Ramon Vigil Grant, Los Alamos County.

Drainage Area. $0.003 \mathrm{mi}^{2}$.

Period of Record. October 1, 2006, to September 30, 2009.

Gage. Data logger and 9" Parshall flume. Elevation of gage is 6,776 ft above NGVD.

Remarks. Records are good. Records for this site existed before period of record but are not reliable. Legal location based on projected values.

Extremes for Period of Record. Maximum discharge, $1.80 \mathrm{ft}^{3} / \mathrm{s}$, September 23,2007 , gage height $0.92 \mathrm{ft}$. No flow most of the time.

Extremes for Current Year. Peak discharge above base of $1.0 \mathrm{ft}^{3} / \mathrm{s}$ and maximum (*):

\begin{tabular}{|c|c|c|c|}
\hline Date & Time & Discharge $\left(\mathbf{f t}^{\mathbf{3}} / \mathbf{s}\right)$ & Gage Height (ft) \\
\hline July 30 & 1355 & $1.28^{*}$ & $0.74^{*}$ \\
\hline July 31 & 1200 & 1.09 & 0.67 \\
\hline
\end{tabular}

No flow most of the time.

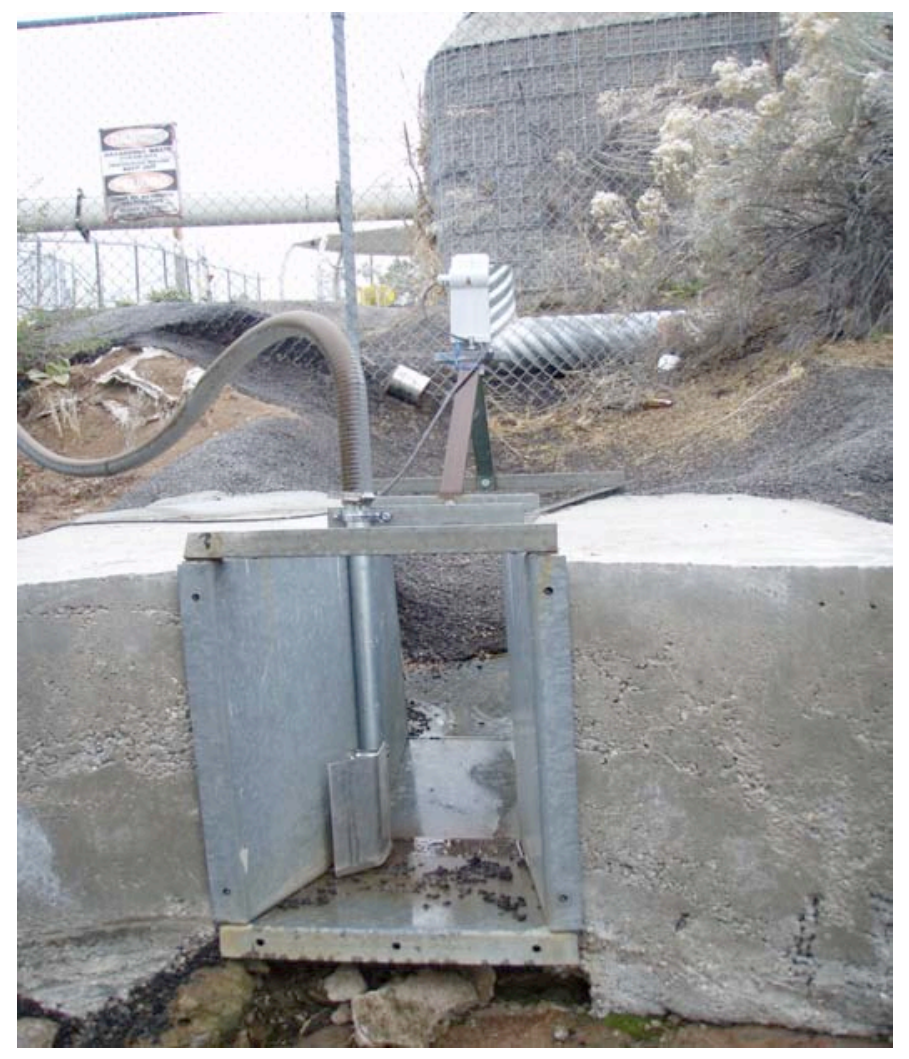




\section{E223 MDA Area L}

\section{Station Analysis}

\section{Water Year}

Equipment. Station is equipped with Sutron 8210 data logger (5-min. interval) and Milltronics sonic probe mounted on a 9" Parshall flume. The system is powered by a solar panel battery system housed in a NEMA shelter. Station is equipped with an ISCO pump sampler for water quality sample collection. ISCO is housed in a separate shelter, a $3^{\prime} \times 4^{\prime}$ metal box. Sampler is triggered by stage through the data logger. The staff in the 9" Parshall flume is the reference gage. No provision for discharge measurements above wading stage.

Field Work. This station was visited 25 times to conduct discharge measurements and service the instrumentation. Field inspections for the gage are listed under site history files on the Hydstra database. Discharge measurements for the gage are listed under site gauging files on the Hydstra database.

Datum Correction. None.

Gage-Height Record. The data logger referenced to the outside staff gave a complete and satisfactory record, except for the periods from November 13 to December 8 and February 5 to March 16 when the data logger malfunctioned and from December 9, 10, 15 to January 13, January 15 to January 23, and March 27 when gage height was affected by ice.

Rating. Upstream of 9" Parshall flume is asphalt-paved lot; below gage the channel drops steeply.

Twenty-five inspections of no flow were made.

Rating No. 1 was developed based on the computation of 9" Parshall flume. Point of zero flow is 0.00 gage height.

Discharge. Discharge was computed by applying gage height to Rating No. 1 directly.

Remarks. Records are good. 
E223 MDA Area L

Daily Mean Discharge in Cubic Feet per Second

Water Year October 2008 to September 2009

\begin{tabular}{|c|c|c|c|c|c|c|c|c|c|c|c|c|}
\hline DAY & ОСТ & NOV & DEC & JAN & FEB & MAR & APR & MAY & JUN & JUL & AUG & SEP \\
\hline 1 & 0 & 0 & $0^{*}$ & $0^{*}$ & 0 & $0^{*}$ & 0 & 0 & 0 & 0 & 0 & 0 \\
\hline 2 & 0 & 0 & $0^{*}$ & $0^{*}$ & 0 & $0^{*}$ & 0 & 0 & 0 & 0 & 0 & 0 \\
\hline 3 & 0 & 0 & $0^{*}$ & $0^{*}$ & 0 & $0^{*}$ & 0 & 0 & 0 & 0 & 0 & 0 \\
\hline 4 & 0 & 0 & $0^{*}$ & $0^{*}$ & 0 & $0^{*}$ & 0 & 0 & 0 & 0 & 0 & 0 \\
\hline 5 & 0 & 0 & $0^{*}$ & $0^{*}$ & $0^{*}$ & $0^{*}$ & 0 & 0 & 0 & 0 & 0 & 0 \\
\hline 6 & 0 & 0 & $0^{*}$ & $0^{*}$ & $0^{*}$ & $0^{*}$ & 0 & 0 & 0 & 0 & 0 & 0 \\
\hline 7 & 0 & 0 & $0^{*}$ & $0^{*}$ & $0^{*}$ & $0^{*}$ & 0 & 0 & 0 & 0 & 0 & 0 \\
\hline 8 & 0 & 0 & $0^{*}$ & $0^{*}$ & $0^{*}$ & $0^{*}$ & 0 & 0 & 0 & 0 & 0 & 0 \\
\hline 9 & 0 & 0 & $0^{*}$ & $0^{*}$ & $0^{*}$ & $0^{*}$ & 0 & 0 & 0 & 0 & 0 & 0 \\
\hline 10 & 0 & 0 & $0^{*}$ & $0^{*}$ & $0^{*}$ & $0^{*}$ & 0 & 0 & 0 & 0 & 0 & 0 \\
\hline 11 & .01 & 0 & 0 & $0^{*}$ & $0^{*}$ & $0^{*}$ & 0 & 0 & 0 & 0 & 0 & 0 \\
\hline 12 & 0 & 0 & 0 & $0^{*}$ & $0^{*}$ & $0^{*}$ & 0 & 0 & 0 & 0 & 0 & 0 \\
\hline 13 & 0 & $0^{*}$ & 0 & $0^{*}$ & $0^{*}$ & $0^{*}$ & 0 & 0 & 0 & 0 & 0 & 0 \\
\hline 14 & 0 & $0^{*}$ & 0 & 0 & $0^{*}$ & $0^{*}$ & 0 & 0 & 0 & 0 & 0 & 0 \\
\hline 15 & 0 & $0^{*}$ & $0^{*}$ & $0^{*}$ & $0^{*}$ & $0^{*}$ & 0 & 0 & 0 & 0 & 0 & 0 \\
\hline 16 & 0 & $0^{*}$ & $0^{*}$ & $0^{*}$ & $0^{*}$ & $0^{*}$ & 0 & 0 & 0 & 0 & 0 & 0 \\
\hline 17 & 0 & $0^{*}$ & $0^{*}$ & $0^{*}$ & $0^{*}$ & 0 & 0 & 0 & 0 & 0 & 0 & 0 \\
\hline 18 & 0 & $0^{*}$ & $0^{*}$ & $0^{*}$ & $0^{*}$ & 0 & 0 & 0 & 0 & 0 & 0 & 0 \\
\hline 19 & 0 & $0^{*}$ & $0^{*}$ & $0^{*}$ & $0^{*}$ & 0 & 0 & 0 & 0 & 0 & 0 & 0 \\
\hline 20 & 0 & $0^{*}$ & $0^{*}$ & $0^{*}$ & $0^{*}$ & 0 & 0 & 0 & 0 & 0 & 0 & 0 \\
\hline 21 & 0 & $0^{*}$ & $0^{*}$ & $0^{*}$ & $0^{*}$ & 0 & 0 & 0 & 0 & 0 & 0 & 0 \\
\hline 22 & 0 & $0^{*}$ & $0^{*}$ & $0^{*}$ & $0^{*}$ & 0 & 0 & 0 & 0 & 0 & 0 & 0 \\
\hline 23 & 0 & $0^{*}$ & $0^{*}$ & $0^{*}$ & $0^{*}$ & 0 & 0 & 0 & 0 & 0 & 0 & 0 \\
\hline 24 & 0 & $0^{*}$ & $0^{*}$ & 0 & $0^{*}$ & 0 & 0 & 0 & 0 & 0 & 0 & 0 \\
\hline 25 & 0 & $0^{*}$ & $0^{*}$ & 0 & $0^{*}$ & 0 & 0 & 0 & 0 & 0 & 0 & 0 \\
\hline 26 & 0 & $0^{*}$ & $0^{*}$ & 0 & $0^{*}$ & 0 & 0 & 0 & 0 & 0 & 0 & 0 \\
\hline 27 & 0 & $0^{*}$ & $0^{*}$ & 0 & $0^{*}$ & $0^{*}$ & 0 & 0 & 0 & 0 & 0 & 0 \\
\hline 28 & 0 & $0^{*}$ & $0^{*}$ & 0 & $0^{*}$ & 0 & 0 & 0 & 0 & 0 & 0 & 0 \\
\hline 29 & 0 & $0^{*}$ & $0^{*}$ & 0 & --.-- & 0 & 0 & 0 & 0 & 0 & 0 & 0 \\
\hline 30 & 0 & $0^{*}$ & $0^{*}$ & 0 & ----. & 0 & 0 & 0 & 0 & .01 & 0 & 0 \\
\hline 31 & 0 & -- & $0^{*}$ & 0 & $-\cdots$ & 0 & ---- & 0 & 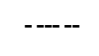 & .01 & 0 & ---- \\
\hline Total & 0.01 & 0 & 0 & 0 & 0 & 0 & 0 & 0 & 0 & 0.02 & 0 & 0 \\
\hline Mean & 0 & 0 & 0 & 0 & 0 & 0 & 0 & 0 & 0 & .001 & 0 & 0 \\
\hline Max & .01 & 0 & 0 & 0 & 0 & 0 & 0 & 0 & 0 & .01 & 0 & 0 \\
\hline Min & 0 & 0 & 0 & 0 & 0 & 0 & 0 & 0 & 0 & 0 & 0 & 0 \\
\hline Acre-Ft & .02 & 0 & 0 & 0 & 0 & 0 & 0 & 0 & 0 & .04 & 0 & 0 \\
\hline Wtr Year & 2009 & Total & 0.03 & Mean & & 0 & Max & .01 & Min & 0 & Acre- $\mathrm{Ft}$ & .06 \\
\hline Cal Year & 2008 & Total & 0.05 & Mean & & 0 & Max & .02 & Min & 0 & Acre-Ft & .10 \\
\hline
\end{tabular}

*Estimate 


\section{E225 Cañada del Buey near MDA G}

Location. Lat $35^{\circ}$ 50' 1", long $106^{\circ}$ 14' 22", Sec. 31, T. 19 N., R. 7 E., Ramon Vigil Grant, Los Alamos County.

Drainage Area. $1.48 \mathrm{mi}^{2}$.

Period of Record. October 1, 1993, to September 30, 2009.

Revised Record. Drainage Area (2006).

Gage. Data logger and concrete control. Elevation of gage is 6,599 ft above NGVD from GPS survey.

Remarks. Records are good. Legal location based on projected values.

Average Discharge. $15 \mathrm{yr}$, zero.

Extremes for Period of Record. Maximum discharge, $17 \mathrm{ft}^{3} / \mathrm{s}$, September 8, 1995, gage height $2.71 \mathrm{ft}$. No flow most of the time.

Extremes for Current Year. No flow for the year.

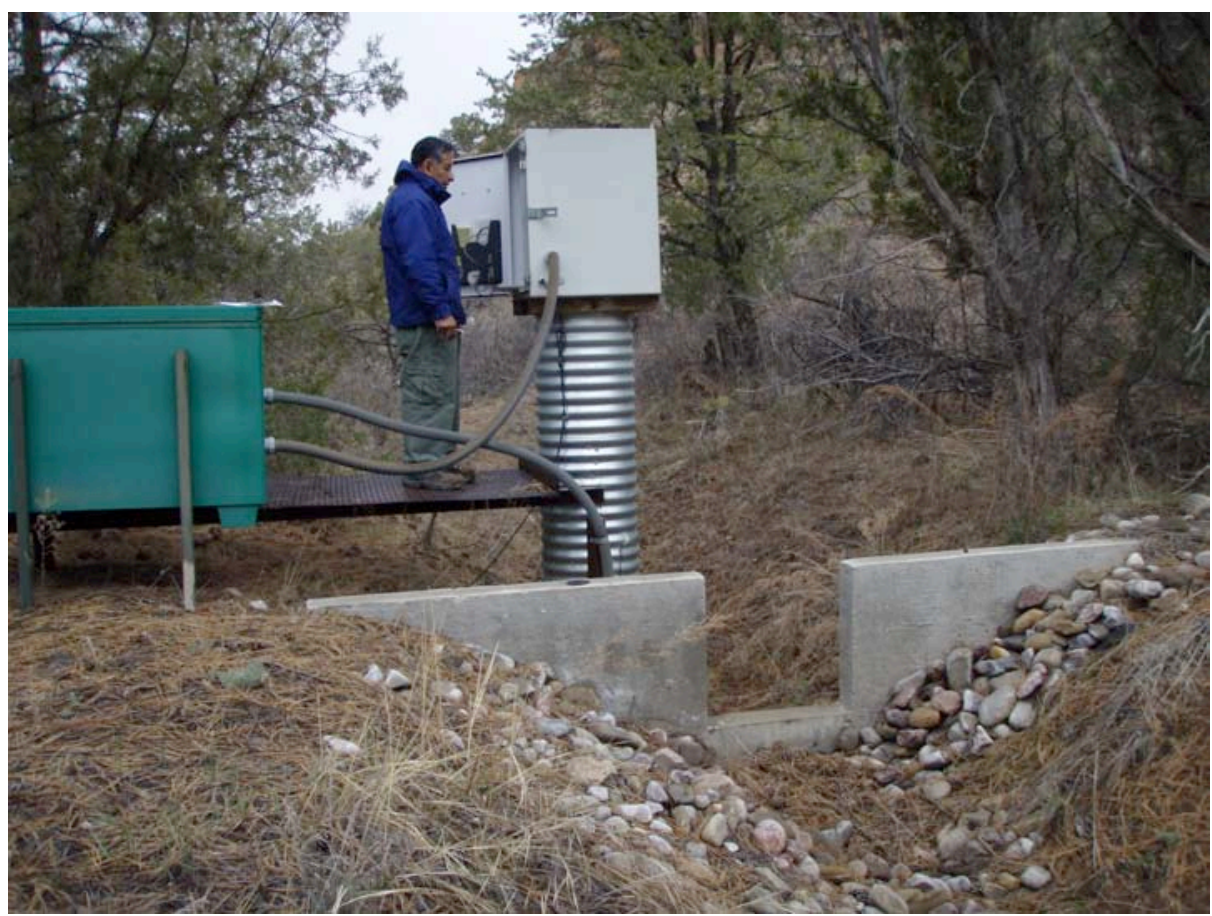




\section{E225 Cañada del Buey near MDA G}

\section{Station Analysis}

\section{Water Year}

Equipment. Station is equipped with Sutron 8210 data logger (5-min. interval) and a shaft encoder float system. The system is powered by a solar panel battery system. All equipment is housed in a NEMA shelter on 18" CMP well. Station is equipped with an ISCO pump sampler for water quality sample collection. ISCO is housed in a separate shelter, a $3^{\prime} \times 4^{\prime}$ metal box. Sampler is triggered by stage through the data logger. An outside staff is available for reference. No provision for discharge measurements above wading stage.

Field Work. The station was visited 13 times to conduct discharge measurements and service the instrumentation. Field inspections for the gage are listed under site history files on the Hydstra database. Discharge measurements for the gage are listed under site gauging files on the Hydstra database.

\section{Datum Correction. None.}

Gage-Height Record. The data logger referenced to the outside staff gave a complete and satisfactory record.

Rating. Channel is straight for at least $100^{\prime}$ above and below gage. Bed material is sand with thin covering of grass. The control is a concrete broad-crested weir 10' downstream of gage.

Thirteen inspections of no flow were made during the year.

Rating No. 1 was developed by broad-crested weir computation.

Discharge. Discharge was computed by applying gage height to Rating No. 1 directly.

Remarks. Records are good. 


\section{E225 Cañada del Buey near MDA G}

\section{Daily Mean Discharge in Cubic Feet per Second}

Water Year October 2008 to September 2009

\begin{tabular}{|c|c|c|c|c|c|c|c|c|c|c|c|c|}
\hline DAY & OCT & NOV & DEC & JAN & FEB & M AR & APR & MAY & JUN & JUL & $A \cup G$ & SEP \\
\hline 1 & 0 & 0 & 0 & 0 & 0 & 0 & 0 & 0 & 0 & 0 & 0 & 0 \\
\hline 2 & 0 & 0 & 0 & 0 & 0 & 0 & 0 & 0 & 0 & 0 & 0 & 0 \\
\hline 3 & 0 & 0 & 0 & 0 & 0 & 0 & 0 & 0 & 0 & 0 & 0 & 0 \\
\hline 4 & 0 & 0 & 0 & 0 & 0 & 0 & 0 & 0 & 0 & 0 & 0 & 0 \\
\hline 5 & 0 & 0 & 0 & 0 & 0 & 0 & 0 & 0 & 0 & 0 & 0 & 0 \\
\hline 6 & 0 & 0 & 0 & 0 & 0 & 0 & 0 & 0 & 0 & 0 & 0 & 0 \\
\hline 7 & 0 & 0 & 0 & 0 & 0 & 0 & 0 & 0 & 0 & 0 & 0 & 0 \\
\hline 8 & 0 & 0 & 0 & 0 & 0 & 0 & 0 & 0 & 0 & 0 & 0 & 0 \\
\hline 9 & 0 & 0 & 0 & 0 & 0 & 0 & 0 & 0 & 0 & 0 & 0 & 0 \\
\hline 10 & 0 & 0 & 0 & 0 & 0 & 0 & 0 & 0 & 0 & 0 & 0 & 0 \\
\hline 11 & 0 & 0 & 0 & 0 & 0 & 0 & 0 & 0 & 0 & 0 & 0 & 0 \\
\hline 12 & 0 & 0 & 0 & 0 & 0 & 0 & 0 & 0 & 0 & 0 & 0 & 0 \\
\hline 13 & 0 & 0 & 0 & 0 & 0 & 0 & 0 & 0 & 0 & 0 & 0 & 0 \\
\hline 14 & 0 & 0 & 0 & 0 & 0 & 0 & 0 & 0 & 0 & 0 & 0 & 0 \\
\hline 15 & 0 & 0 & 0 & 0 & 0 & 0 & 0 & 0 & 0 & 0 & 0 & 0 \\
\hline 16 & 0 & 0 & 0 & 0 & 0 & 0 & 0 & 0 & 0 & 0 & 0 & 0 \\
\hline 17 & 0 & 0 & 0 & 0 & 0 & 0 & 0 & 0 & 0 & 0 & 0 & 0 \\
\hline 18 & 0 & 0 & 0 & 0 & 0 & 0 & 0 & 0 & 0 & 0 & 0 & 0 \\
\hline 19 & 0 & 0 & 0 & 0 & 0 & 0 & 0 & 0 & 0 & 0 & 0 & 0 \\
\hline 20 & 0 & 0 & 0 & 0 & 0 & 0 & 0 & 0 & 0 & 0 & 0 & 0 \\
\hline 21 & 0 & 0 & 0 & 0 & 0 & 0 & 0 & 0 & 0 & 0 & 0 & 0 \\
\hline 22 & 0 & 0 & 0 & 0 & 0 & 0 & 0 & 0 & 0 & 0 & 0 & 0 \\
\hline 23 & 0 & 0 & 0 & 0 & 0 & 0 & 0 & 0 & 0 & 0 & 0 & 0 \\
\hline 24 & 0 & 0 & 0 & 0 & 0 & 0 & 0 & 0 & 0 & 0 & 0 & 0 \\
\hline 25 & 0 & 0 & 0 & 0 & 0 & 0 & 0 & 0 & 0 & 0 & 0 & 0 \\
\hline 26 & 0 & 0 & 0 & 0 & 0 & 0 & 0 & 0 & 0 & 0 & 0 & 0 \\
\hline 27 & 0 & 0 & 0 & 0 & 0 & 0 & 0 & 0 & 0 & 0 & 0 & 0 \\
\hline 28 & 0 & 0 & 0 & 0 & 0 & 0 & 0 & 0 & 0 & 0 & 0 & 0 \\
\hline 29 & 0 & 0 & 0 & 0 & --- & 0 & 0 & 0 & 0 & 0 & 0 & 0 \\
\hline 30 & 0 & 0 & 0 & 0 & $-\cdots$ & 0 & 0 & 0 & 0 & 0 & 0 & 0 \\
\hline 31 & 0 & --- & 0 & 0 & --- & 0 & --- & 0 & ---- & 0 & 0 & ---- \\
\hline Total & 0 & 0 & 0 & 0 & 0 & 0 & 0 & 0 & 0 & 0 & 0 & 0 \\
\hline Mean & 0 & 0 & 0 & 0 & 0 & 0 & 0 & 0 & 0 & 0 & 0 & 0 \\
\hline $\operatorname{Max}$ & 0 & 0 & 0 & 0 & 0 & 0 & 0 & 0 & 0 & 0 & 0 & 0 \\
\hline Min & 0 & 0 & 0 & 0 & 0 & 0 & 0 & 0 & 0 & 0 & 0 & 0 \\
\hline Acre-F t & 0 & 0 & 0 & 0 & 0 & 0 & 0 & 0 & 0 & 0 & 0 & 0 \\
\hline Wtr Year & 2009 & Total & 0 & Mean & & 0 & $\operatorname{Max}$ & 0 & Min & 0 & Acre-Ft & 0 \\
\hline Cal Year & 2008 & Total & 0.02 & Mean & & 0 & $\operatorname{Max}$ & .02 & Min & 0 & Acre-Ft & .04 \\
\hline
\end{tabular}




\section{E227 MDA G-13}

Location. Lat $35^{\circ}$ 49' 58", long $106^{\circ}$ 14' 21", Sec. 31, T. 19 N., R. 7 E., Ramon Vigil Grant, Los Alamos County.

Drainage Area. $0.012 \mathrm{mi}^{2}$.

Period of Record. October 1, 2006, to September 30, 2009.

Gage. Data logger and 9" Parshall flume. Elevation of gage is 6,614 ft above NGVD.

Remarks. Records are good. Records for this site existed before period of record but are not reliable. Legal location based on projected values.

Extremes for Period of Record. Maximum discharge, $1.7 \mathrm{ft}^{3} / \mathrm{s}$, July 26, 2007, gage height $0.67 \mathrm{ft}$. No flow most of the time.

Extremes for Current Year. No flow for the year.

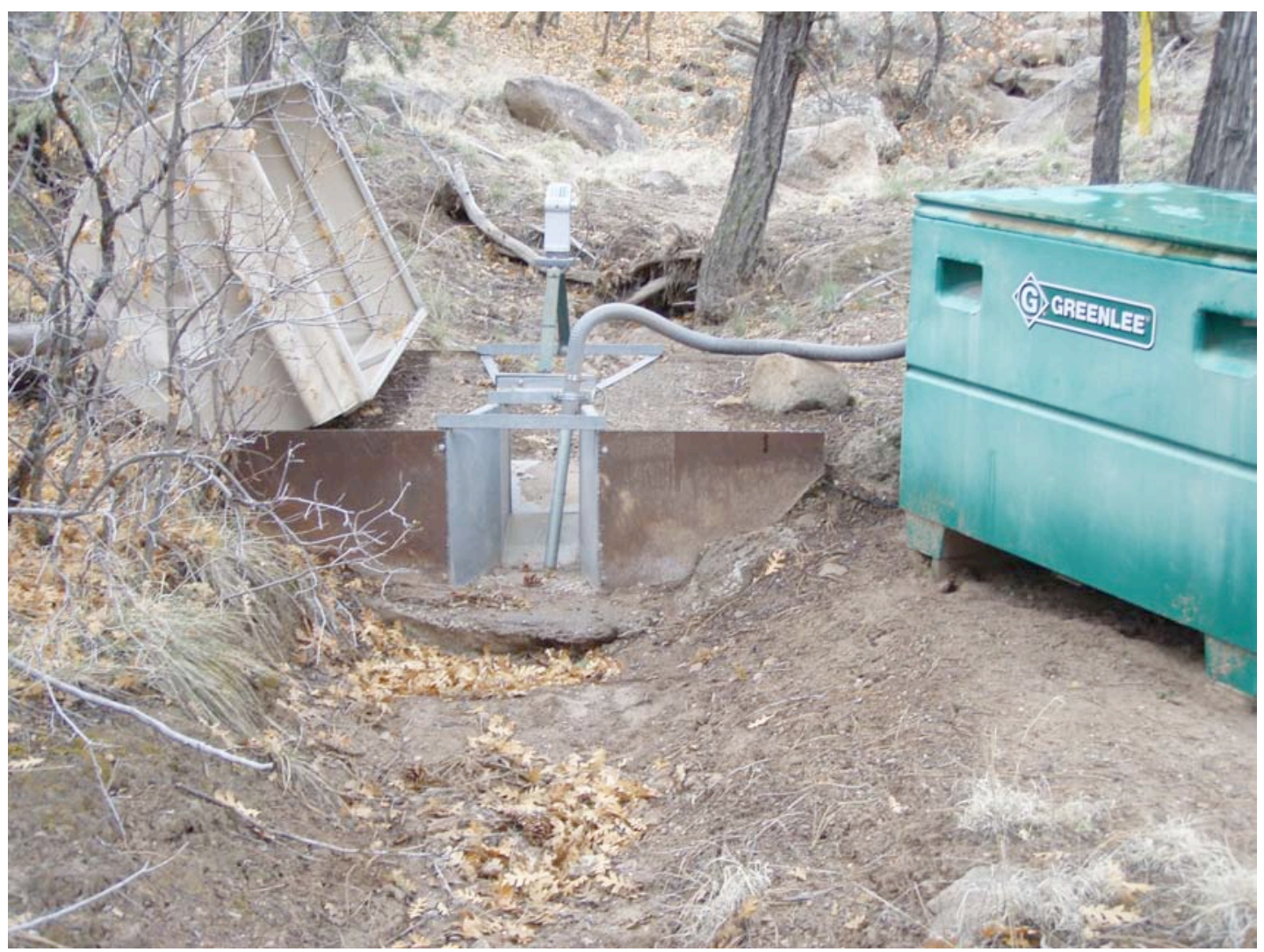




\section{E227 MDA G-13}

\section{Station Analysis}

\section{Water Year}

Equipment. Station is equipped with Sutron 8210 data logger (5-min. interval) and Milltronics sonic probe mounted on a 9" Parshall flume. The system is powered by a solar panel battery system housed in a NEMA shelter. Station is equipped with an ISCO pump sampler for water quality sample collection. ISCO is housed in a separate shelter, a $3^{\prime} \times 4^{\prime}$ metal box. Sampler is triggered by stage through the data logger. The staff in the 9" Parshall flume is the reference gage. No provision for discharge measurements above wading stage.

Field Work. This station was visited 22 times to conduct discharge measurements and service the instrumentation. Field inspections for the gage are listed under site history files on the Hydstra database. Discharge measurements for the gage are listed under site gauging files on the Hydstra database.

Datum Correction. None.

Gage-Height Record. The data logger referenced to the outside staff gave a complete and satisfactory record.

Rating. Channel is straight above and below flume. Channel is shallow and streambed is mostly sand and gravel.

Twenty-two inspections of no flow were made this year.

Rating No. 1 was developed based on the computation of 9" Parshall flume. Point of zero flow is 0.00 gage height.

Discharge. Discharge was computed by applying gage height to Rating No 1 directly. No flow most of the time.

Remarks. Records are good. 


\section{E227 M DA G-13}

Daily Mean Discharge in Cubic Feet per Second

Water Year October 2008 to September 2009

\begin{tabular}{|c|c|c|c|c|c|c|c|c|c|c|c|c|}
\hline DAY & OCT & NOV & DEC & JAN & FEB & MAR & APR & MAY & JUN & JUL & AUG & SEP \\
\hline 1 & 0 & 0 & 0 & 0 & 0 & 0 & 0 & 0 & 0 & 0 & 0 & 0 \\
\hline 2 & 0 & 0 & 0 & 0 & 0 & 0 & 0 & 0 & 0 & 0 & 0 & 0 \\
\hline 3 & 0 & 0 & 0 & 0 & 0 & 0 & 0 & 0 & 0 & 0 & 0 & 0 \\
\hline 4 & 0 & 0 & 0 & 0 & 0 & 0 & 0 & 0 & 0 & 0 & 0 & 0 \\
\hline 5 & 0 & 0 & 0 & 0 & 0 & 0 & 0 & 0 & 0 & 0 & 0 & 0 \\
\hline 6 & 0 & 0 & 0 & 0 & 0 & 0 & 0 & 0 & 0 & 0 & 0 & 0 \\
\hline 7 & 0 & 0 & 0 & 0 & 0 & 0 & 0 & 0 & 0 & 0 & 0 & 0 \\
\hline 8 & 0 & 0 & 0 & 0 & 0 & 0 & 0 & 0 & 0 & 0 & 0 & 0 \\
\hline 9 & 0 & 0 & 0 & 0 & 0 & 0 & 0 & 0 & 0 & 0 & 0 & 0 \\
\hline 10 & 0 & 0 & 0 & 0 & 0 & 0 & 0 & 0 & 0 & 0 & 0 & 0 \\
\hline 11 & 0 & 0 & 0 & 0 & 0 & 0 & 0 & 0 & 0 & 0 & 0 & 0 \\
\hline 12 & 0 & 0 & 0 & 0 & 0 & 0 & 0 & 0 & 0 & 0 & 0 & 0 \\
\hline 13 & 0 & 0 & 0 & 0 & 0 & 0 & 0 & 0 & 0 & 0 & 0 & 0 \\
\hline 14 & 0 & 0 & 0 & 0 & 0 & 0 & 0 & 0 & 0 & 0 & 0 & 0 \\
\hline 15 & 0 & 0 & 0 & 0 & 0 & 0 & 0 & 0 & 0 & 0 & 0 & 0 \\
\hline 16 & 0 & 0 & 0 & 0 & 0 & 0 & 0 & 0 & 0 & 0 & 0 & 0 \\
\hline 17 & 0 & 0 & 0 & 0 & 0 & 0 & 0 & 0 & 0 & 0 & 0 & 0 \\
\hline 18 & 0 & 0 & 0 & 0 & 0 & 0 & 0 & 0 & 0 & 0 & 0 & 0 \\
\hline 19 & 0 & 0 & 0 & 0 & 0 & 0 & 0 & 0 & 0 & 0 & 0 & 0 \\
\hline 20 & 0 & 0 & 0 & 0 & 0 & 0 & 0 & 0 & 0 & 0 & 0 & 0 \\
\hline 21 & 0 & 0 & 0 & 0 & 0 & 0 & 0 & 0 & 0 & 0 & 0 & 0 \\
\hline 22 & 0 & 0 & 0 & 0 & 0 & 0 & 0 & 0 & 0 & 0 & 0 & 0 \\
\hline 23 & 0 & 0 & 0 & 0 & 0 & 0 & 0 & 0 & 0 & 0 & 0 & 0 \\
\hline 24 & 0 & 0 & 0 & 0 & 0 & 0 & 0 & 0 & 0 & 0 & 0 & 0 \\
\hline 25 & 0 & 0 & 0 & 0 & 0 & 0 & 0 & 0 & 0 & 0 & 0 & 0 \\
\hline 26 & 0 & 0 & 0 & 0 & 0 & 0 & 0 & 0 & 0 & 0 & 0 & 0 \\
\hline 27 & 0 & 0 & 0 & 0 & 0 & 0 & 0 & 0 & 0 & 0 & 0 & 0 \\
\hline 28 & 0 & 0 & 0 & 0 & 0 & 0 & 0 & 0 & 0 & 0 & 0 & 0 \\
\hline 29 & 0 & 0 & 0 & 0 & $-\cdots--$ & 0 & 0 & 0 & 0 & 0 & 0 & 0 \\
\hline 30 & 0 & 0 & 0 & 0 & ----- & 0 & 0 & 0 & 0 & 0 & 0 & 0 \\
\hline 31 & 0 & --- & 0 & 0 & $-\cdots--$ & 0 & --- & 0 & $-\cdots$ & 0 & 0 & ---- \\
\hline Total & 0 & 0 & 0 & 0 & 0 & 0 & 0 & 0 & 0 & 0 & 0 & 0 \\
\hline Mean & 0 & 0 & 0 & 0 & 0 & 0 & 0 & 0 & 0 & 0 & 0 & 0 \\
\hline Max & 0 & 0 & 0 & 0 & 0 & 0 & 0 & 0 & 0 & 0 & 0 & 0 \\
\hline Min & 0 & 0 & 0 & 0 & 0 & 0 & 0 & 0 & 0 & 0 & 0 & 0 \\
\hline cre $-\mathrm{Ft}$ & 0 & 0 & 0 & 0 & 0 & 0 & 0 & 0 & 0 & 0 & 0 & 0 \\
\hline Wtr Year & 2009 & Total & 0 & Mean & & 0 & $\operatorname{Max}$ & 0 & Min & 0 & Acre-Ft & 0 \\
\hline Cal Year & 2008 & Total & 0.01 & Mean & & 0 & Max & .01 & Min & 0 & Acre-Ft & .02 \\
\hline
\end{tabular}




\section{E230 Cañada del Buey above SR 4}

Location. Lat $35^{\circ}$ 49' 38", long $106^{\circ} 12^{\prime}$ 43", Sec. 33, T. 19 N., R. 7 E., Ramon Vigil Grant, Los Alamos County.

Drainage Area. $2.15 \mathrm{mi}^{2}$.

Period of Record. October 1991 to September 30, 2009.

Revised Record. Drainage Area (2006).

Gage. Data logger with cellular telemetry and concrete control. Elevation of gage is $6,395 \mathrm{ft}$ above NGVD from GPS survey.

Remarks. Records are good. Legal location based on projected values.

Average Discharge. $15 \mathrm{yr}, 0.008 \mathrm{ft}^{3} / \mathrm{s}, 5.80 \mathrm{acre}-\mathrm{ft} / \mathrm{yr}$.

Extremes for Period of Record. Maximum discharge $210 \mathrm{ft}^{3} / \mathrm{s}$ June 17, 1999, gage height $3.30 \mathrm{ft}$. No flow most of the time.

Extremes for Current Year. Maximum discharge, $12 \mathrm{ft}^{3} / \mathrm{s}$ at $1425 \mathrm{~h}$, July 30, gage height $0.95 \mathrm{ft}$. No peak discharges above base of $20 \mathrm{ft}^{3} / \mathrm{s}$. No flow most of the year.

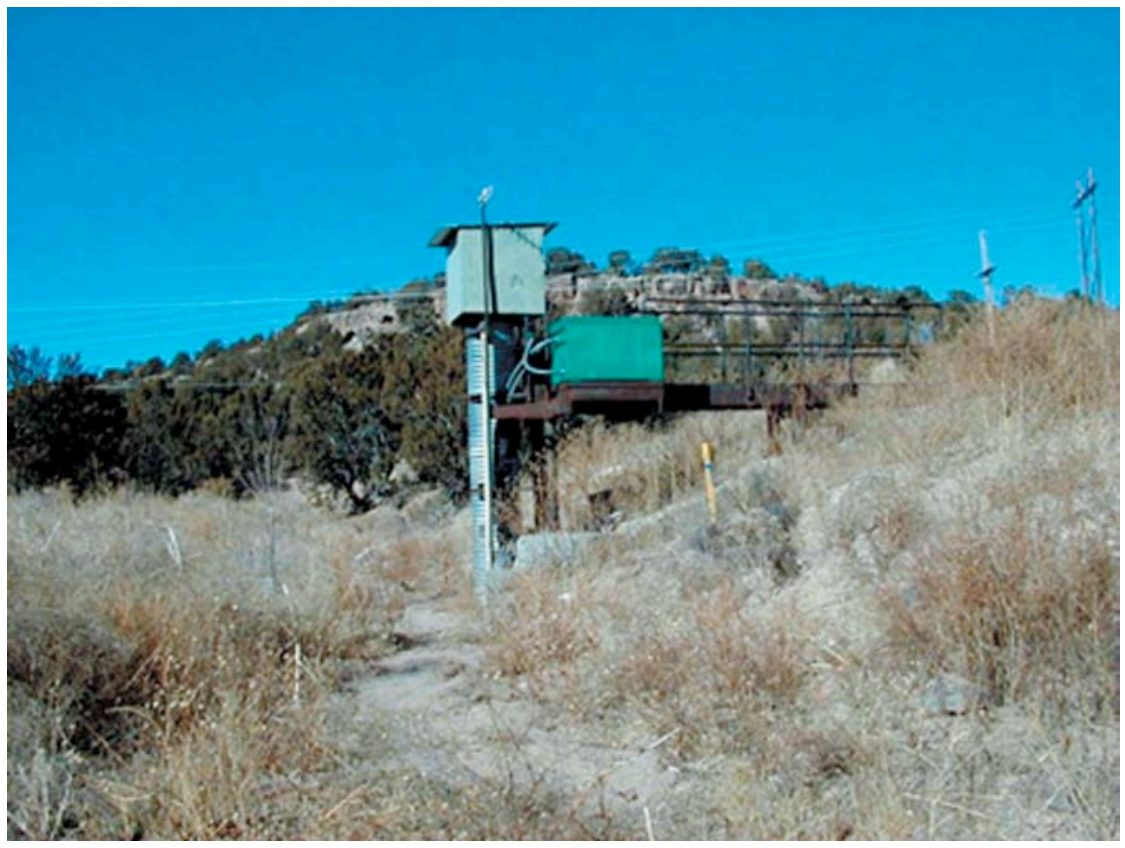




\section{E230 Cañada del Buey above SR 4}

\section{Station Analysis}

\section{Water Year}

Equipment. Station is equipped with Sutron 8210 data logger (5 min. interval) and shaft encoder float system with cellular phone and speech modem. The system is powered by a solar panel battery system housed in a NEMA shelter on top of a 24" CMP well. Station is equipped with an ISCO pump sampler for water quality sample collection. ISCO is housed in a separate shelter, a $3^{\prime} \times 4^{\prime}$ metal box. Sampler is triggered by stage through the data logger. A second auxiliary shelter will accommodate two additional ISCO samplers. No provision for discharge measurements above wading stage.

Field Work. This station was visited 24 times to conduct discharge measurements and service the instrumentation. Field inspections for the gage are listed under site history files on the Hydstra database. Discharge measurements for the gage are listed under site gauging files on the Hydstra database.

Datum Correction. None.

Gage-Height Record. The data logger reference to the outside staff gave a complete and satisfactory record.

Rating. Channel has fairly sharp right bend $50^{\prime}$ above gage where two channels converge. Channel is straight for $100^{\prime}$ below gage where it enters a rectangular double box culvert under SR 4. Control is a tapered (low-end on left) broad-crested weir.

Twenty-four inspections of no flow were made during the year.

Rating No. 1 is based on discharge measurements Nos. $1-8$ that were made in previous years.

Discharge. Discharge was computed by applying gage height to Rating No. 1 directly.

Remarks. Records are good. 
E230 C añ ada del Buey above SR 4

Daily Mean Discharge in Cubic Feet per Second

Water Year October 2008 to September 2009

\begin{tabular}{|c|c|c|c|c|c|c|c|c|c|c|c|c|}
\hline DAY & OCT & NOV & DEC & JAN & FE B & MAR & APR & MAY & JUN & JUL & AUG & SEP \\
\hline 1 & 0 & 0 & 0 & 0 & 0 & 0 & 0 & 0 & 0 & 0 & 0 & 0 \\
\hline 2 & 0 & 0 & 0 & 0 & 0 & 0 & 0 & 0 & 0 & 0 & 0 & 0 \\
\hline 3 & 0 & 0 & 0 & 0 & 0 & 0 & 0 & 0 & 0 & 0 & 0 & 0 \\
\hline 4 & 0 & 0 & 0 & 0 & 0 & 0 & 0 & 0 & 0 & 0 & 0 & 0 \\
\hline 5 & 0 & 0 & 0 & 0 & 0 & 0 & 0 & 0 & 0 & 0 & 0 & 0 \\
\hline 6 & 0 & 0 & 0 & 0 & 0 & 0 & 0 & 0 & 0 & 0 & 0 & 0 \\
\hline 7 & 0 & 0 & 0 & 0 & 0 & 0 & 0 & 0 & 0 & 0 & 0 & 0 \\
\hline 8 & 0 & 0 & 0 & 0 & 0 & 0 & 0 & 0 & 0 & 0 & 0 & 0 \\
\hline 9 & 0 & 0 & 0 & 0 & 0 & 0 & 0 & 0 & 0 & 0 & 0 & 0 \\
\hline 10 & 0 & 0 & 0 & 0 & 0 & 0 & 0 & 0 & 0 & 0 & 0 & 0 \\
\hline 11 & .27 & 0 & 0 & 0 & 0 & 0 & 0 & 0 & 0 & 0 & 0 & 0 \\
\hline 12 & 0 & 0 & 0 & 0 & 0 & 0 & 0 & 0 & 0 & 0 & 0 & 0 \\
\hline 13 & 0 & 0 & 0 & 0 & 0 & 0 & 0 & 0 & 0 & 0 & 0 & 0 \\
\hline 14 & 0 & 0 & 0 & 0 & 0 & 0 & 0 & 0 & 0 & 0 & 0 & 0 \\
\hline 15 & 0 & 0 & 0 & 0 & 0 & 0 & 0 & 0 & 0 & 0 & 0 & 0 \\
\hline 16 & 0 & 0 & 0 & 0 & 0 & 0 & 0 & 0 & 0 & 0 & 0 & .12 \\
\hline 17 & 0 & 0 & 0 & 0 & 0 & 0 & 0 & 0 & 0 & 0 & 0 & 0 \\
\hline 18 & 0 & 0 & 0 & 0 & 0 & 0 & 0 & 0 & 0 & 0 & 0 & 0 \\
\hline 19 & 0 & 0 & 0 & 0 & 0 & 0 & 0 & 0 & 0 & 0 & 0 & 0 \\
\hline 20 & 0 & 0 & 0 & 0 & 0 & 0 & 0 & 0 & 0 & 0 & 0 & 0 \\
\hline 21 & 0 & 0 & 0 & 0 & 0 & 0 & 0 & 0 & 0 & 0 & 0 & 0 \\
\hline 22 & 0 & 0 & 0 & 0 & 0 & 0 & 0 & 0 & 0 & 0 & 0 & 0 \\
\hline 23 & 0 & 0 & 0 & 0 & 0 & 0 & 0 & 0 & 0 & 0 & 0 & 0 \\
\hline 24 & 0 & 0 & 0 & 0 & 0 & 0 & 0 & 0 & 0 & 0 & 0 & 0 \\
\hline 25 & 0 & 0 & 0 & 0 & 0 & 0 & 0 & 0 & 0 & 0 & 0 & 0 \\
\hline 26 & 0 & 0 & 0 & 0 & 0 & 0 & 0 & 0 & 0 & 0 & 0 & 0 \\
\hline 27 & 0 & 0 & 0 & 0 & 0 & 0 & 0 & 0 & 0 & 0 & 0 & 0 \\
\hline 28 & 0 & 0 & 0 & 0 & 0 & 0 & 0 & 0 & 0 & 0 & 0 & 0 \\
\hline 29 & 0 & 0 & 0 & 0 & $-\cdots$ & 0 & 0 & 0 & 0 & 0 & 0 & 0 \\
\hline 30 & 0 & 0 & 0 & 0 & --.-- & 0 & 0 & 0 & 0 & .28 & 0 & 0 \\
\hline 31 & 0 & ---- & 0 & 0 & ----- & 0 & ---- & 0 & $-\cdots--$ & .13 & 0 & ---- \\
\hline Total & 0.27 & 0 & 0 & 0 & 0 & 0 & 0 & 0 & 0 & 0.41 & 0 & 0.12 \\
\hline Mean & .009 & 0 & 0 & 0 & 0 & 0 & 0 & 0 & 0 & .013 & 0 & .004 \\
\hline $\operatorname{Max}$ & .27 & 0 & 0 & 0 & 0 & 0 & 0 & 0 & 0 & .28 & 0 & .12 \\
\hline Min & 0 & 0 & 0 & 0 & 0 & 0 & 0 & 0 & 0 & 0 & 0 & 0 \\
\hline Acre-F t & .54 & 0 & 0 & 0 & 0 & 0 & 0 & 0 & 0 & .81 & 0 & .24 \\
\hline Wtr Year & 2009 & Total & 0.80 & Mean & & 02 & $\operatorname{Max}$ & .28 & Min & 0 & Acre-Ft & 1.6 \\
\hline Cal Year & 2008 & Total & 3.74 & Mean & & 10 & $\operatorname{Max}$ & 2.9 & Min & 0 & Acre-Ft & 7.4 \\
\hline
\end{tabular}




\section{E240 Pajarito Canyon below SR 501}

Location. Lat $35^{\circ} 52^{\prime}$ 02", long $106^{\circ} 21^{\prime}$ 05", NW 1/4, Sec. 19, T. 19 N., R. 6 E., Los Alamos County.

Drainage Area. $1.90 \mathrm{mi}^{2}$.

Period of Record. October 1993 to June 28, 2000 (destroyed by flood); April 2001 to September 30, 2009.

Revised Records. WDR 1997: Gage height "Extremes for Period of Record." Drainage Area (2006). Levels date published as 2004, correction December 2001 (2008).

Gage. Data logger with cellular telemetry. Elevation of gage is 7,719 ft above NGVD from GPS survey. Formerly published as "Pajarito Canyon above Highway 501 near Los Alamos, NM" at different datum.

Remarks. Records are good.

Average Discharge. $15 \mathrm{yr}, 0.09 \mathrm{ft}^{3} / \mathrm{s}, 65$ acre- $\mathrm{ft} / \mathrm{yr}$.

Extremes for Period of Record. Maximum discharge, 1,020 ft $\mathrm{ft}^{3} / \mathrm{s}$, June 28, 2000, from peak flow computation, gage height not determined. No flow at times

Extremes for Current Year. Peak discharge above base of $5.0 \mathrm{ft}^{3} / \mathrm{s}$ and maximum (*):

\begin{tabular}{|c|c|c|c|}
\hline Date & Time & Discharge $\left(\mathbf{f t}^{\mathbf{3}} / \mathbf{s}\right)$ & Gage Height (ft) \\
\hline August 30 & 1705 & $8.6^{*}$ & $1.32^{*}$ \\
\hline
\end{tabular}

No flow most of the time.

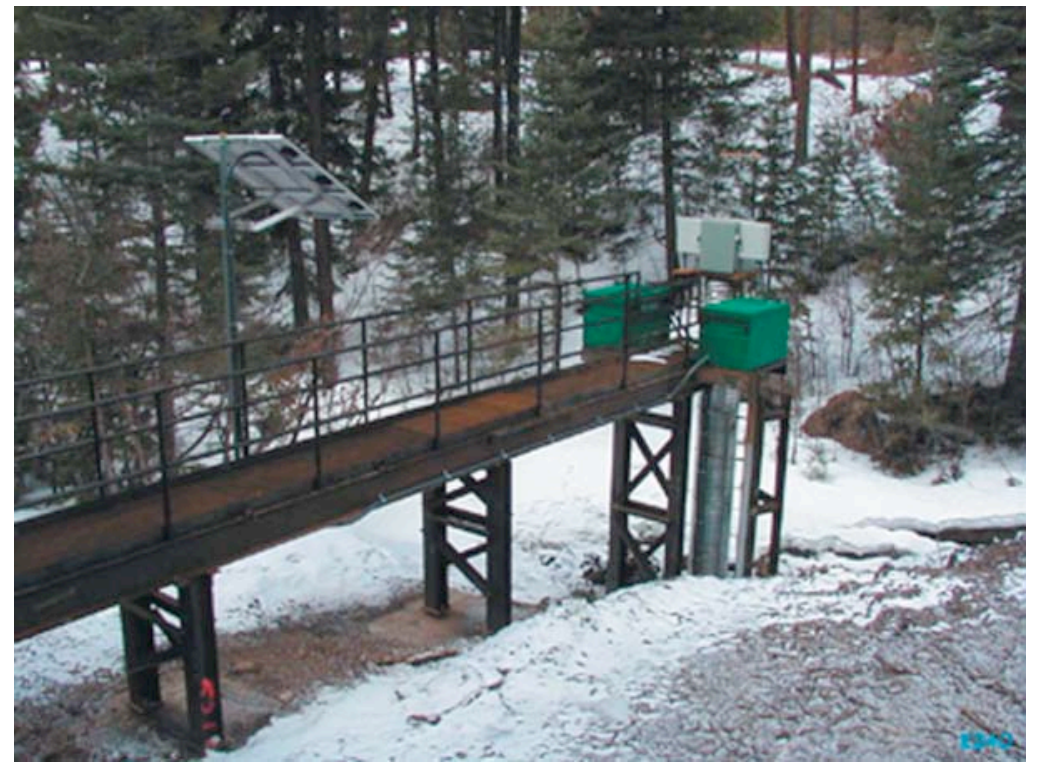




\title{
E240 Pajarito Canyon below SR 501
}

\author{
Station Analysis
}

\section{Water Year}

Equipment. Station is equipped with Sutron 8210 data logger (5-min. interval) and shaft encoder float system with cellular phone and speech modem. The system is powered by a solar panel battery system housed in a NEMA shelter on top of a 24" CMP well. Station is equipped with an ISCO pump sampler for water quality sample collection. ISCO is housed in a separate shelter, a $3^{\prime} \times 4^{\prime}$ metal box. Sampler is triggered by stage through the data logger. An outside staff is available for reference. No provision for discharge measurements above wading stage.

Station is also equipped with a rain gage, Rain Collection II. All equipment is powered with a solar panel battery charging system.

Field Work. This station was visited 23 times to conduct discharge measurements and service the instrumentation. Field inspections for the gage are listed under site history files on the Hydstra database. Discharge measurements for the gage are listed under site gauging files on the Hydstra database.

Datum Correction. Levels run December 11, 2001, show gage to be within limits.

Gage-Height Record. The data logger referenced to the outside staff gave a complete and satisfactory record except for the period December 8, 9 when data logger malfunctioned.

Rating. Gage is about 300' below outlet of two round culverts through Highway 501 roadbed. Channel bed is sand and gravel and subject to movement. Grass and brush are fairly thick in over banks areas. Banks are not high (about $1^{\prime}$ to $2^{\prime}$ most places). Two gabions were installed in the fall of 2001, which act as low-water controls. One is 2' below gage across entire width of channel with a 6" V notch for low water. Another gabion is $50^{\prime}$ above gage.

Twenty-three inspections of no flow were made this year.

Rating No. 3 was developed based on the six measurements and slope area from previous years.

Discharge. Discharge was computed by applying gage height to Rating No. 3 using variable shift diagrams.

Remarks. Records are good. 
E240 Pajarito below SR 501

Daily Mean Discharge in Cubic Feet per Second

Water Year October 2008 to September 2009

\begin{tabular}{|c|c|c|c|c|c|c|c|c|c|c|c|c|}
\hline DAY & OCT & NOV & DEC & JAN & FEB & MAR & APR & MAY & JUN & JUL & $A U G$ & SEP \\
\hline 1 & 0 & 0 & 0 & 0 & 0 & 0 & 0 & 0 & 0 & 0 & 0 & 0 \\
\hline 2 & 0 & 0 & 0 & 0 & 0 & 0 & 0 & 0 & 0 & 0 & 0 & 0 \\
\hline 3 & 0 & 0 & 0 & 0 & 0 & 0 & 0 & 0 & 0 & 0 & 0 & 0 \\
\hline 4 & 0 & 0 & 0 & 0 & 0 & 0 & 0 & 0 & 0 & 0 & 0 & 0 \\
\hline 5 & 0 & 0 & 0 & 0 & 0 & 0 & 0 & 0 & 0 & 0 & 0 & 0 \\
\hline 6 & 0 & 0 & 0 & 0 & 0 & 0 & 0 & 0 & 0 & 0 & 0 & 0 \\
\hline 7 & 0 & 0 & 0 & 0 & 0 & 0 & 0 & 0 & 0 & 0 & 0 & 0 \\
\hline 8 & 0 & 0 & $0^{*}$ & 0 & 0 & 0 & 0 & 0 & 0 & 0 & 0 & 0 \\
\hline 9 & 0 & 0 & $0^{*}$ & 0 & 0 & 0 & 0 & 0 & 0 & 0 & 0 & 0 \\
\hline 10 & 0 & 0 & 0 & 0 & 0 & 0 & 0 & 0 & 0 & 0 & 0 & 0 \\
\hline 11 & 0 & 0 & 0 & 0 & 0 & 0 & 0 & 0 & 0 & 0 & 0 & 0 \\
\hline 12 & 0 & 0 & 0 & 0 & 0 & 0 & 0 & 0 & 0 & 0 & 0 & 0 \\
\hline 13 & 0 & 0 & 0 & 0 & 0 & 0 & 0 & 0 & 0 & 0 & 0 & 0 \\
\hline 14 & 0 & 0 & 0 & 0 & 0 & 0 & 0 & 0 & 0 & 0 & 0 & 0 \\
\hline 15 & 0 & 0 & 0 & 0 & 0 & 0 & 0 & 0 & 0 & 0 & 0 & 0 \\
\hline 16 & 0 & 0 & 0 & 0 & 0 & 0 & 0 & 0 & 0 & 0 & 0 & 0 \\
\hline 17 & 0 & 0 & 0 & 0 & 0 & 0 & 0 & 0 & 0 & 0 & 0 & 0 \\
\hline 18 & 0 & 0 & 0 & 0 & 0 & 0 & 0 & 0 & 0 & 0 & 0 & 0 \\
\hline 19 & 0 & 0 & 0 & 0 & 0 & 0 & 0 & 0 & 0 & 0 & 0 & 0 \\
\hline 20 & 0 & 0 & 0 & 0 & 0 & 0 & 0 & 0 & 0 & 0 & 0 & 0 \\
\hline 21 & 0 & 0 & 0 & 0 & 0 & 0 & 0 & 0 & 0 & 0 & 0 & 0 \\
\hline 22 & 0 & 0 & 0 & 0 & 0 & 0 & 0 & 0 & 0 & 0 & 0 & 0 \\
\hline 23 & 0 & 0 & 0 & 0 & 0 & 0 & 0 & 0 & 0 & 0 & 0 & 0 \\
\hline 24 & 0 & 0 & 0 & 0 & 0 & 0 & 0 & 0 & 0 & 0 & 0 & 0 \\
\hline 25 & 0 & 0 & 0 & 0 & 0 & 0 & 0 & 0 & 0 & 0 & 0 & 0 \\
\hline 26 & 0 & 0 & 0 & 0 & 0 & 0 & 0 & 0 & 0 & 0 & 0 & 0 \\
\hline 27 & 0 & 0 & 0 & 0 & 0 & 0 & 0 & 0 & 0 & 0 & 0 & 0 \\
\hline 28 & 0 & 0 & 0 & 0 & 0 & 0 & 0 & 0 & 0 & 0 & 0 & 0 \\
\hline 29 & 0 & 0 & 0 & 0 & ---- & 0 & 0 & 0 & 0 & 0 & 0 & 0 \\
\hline 30 & 0 & 0 & 0 & 0 & --- & 0 & 0 & 0 & 0 & 0 & .05 & 0 \\
\hline 31 & 0 & - & 0 & 0 & -.-- & 0 & ---- & 0 & ---- & 0 & 0 & ---- \\
\hline Total & 0 & 0 & 0 & 0 & 0 & 0 & 0 & 0 & 0 & 0 & 0.05 & 0 \\
\hline Mean & 0 & 0 & 0 & 0 & 0 & 0 & 0 & 0 & 0 & 0 & .002 & 0 \\
\hline Max & 0 & 0 & 0 & 0 & 0 & 0 & 0 & 0 & 0 & 0 & .05 & 0 \\
\hline Min & 0 & 0 & 0 & 0 & 0 & 0 & 0 & 0 & 0 & 0 & 0 & 0 \\
\hline Acre-Ft & 0 & 0 & 0 & 0 & 0 & 0 & 0 & 0 & 0 & 0 & .10 & 0 \\
\hline Wtr Year & 2009 & Total & 0.05 & Mean & & 0 & $\operatorname{Max}$ & .05 & Min & 0 & Acre-Ft & .10 \\
\hline Cal Year & 2008 & Total & 0.54 & Mean & & 002 & Max & .06 & Min & 0 & Acre-Ft & 1.1 \\
\hline
\end{tabular}




\section{E241 Pajarito Canyon above Starmer's Gulch}

Location. Lat $35^{\circ} 51^{\prime} 33.6^{\prime \prime}$, long 106²0'12.6", SW 1/4, Sec. 20, T. 19 N., R. 6 E., Los Alamos County.

Drainage Area. $3.97 \mathrm{mi}^{2}$.

Period of Record. March 1999 to June 28, 2000 (destroyed by flood); July 2001 to September 30, 2009.

Revised Record. Drainage Area (2006).

Gage. Data logger and $90^{\circ}$ sharp-crested weir. Elevation of gage is 7,382 ft above NGVD from GPS survey.

Remarks. Records are good.

Average Discharge. $9 \mathrm{yr}, 0.06 \mathrm{ft}^{3} / \mathrm{s}, 42$ acre- $\mathrm{ft} / \mathrm{yr}$.

Extremes for Period of Record. Maximum discharge, $300 \mathrm{ft}^{3} / \mathrm{s}$, June 28, 2000, from peak flow computation, gage height $5.0 \mathrm{ft}$. No flow at times.

Extremes for Current Year. Maximum discharge, $2.20 \mathrm{ft}^{3} / \mathrm{s}$ at $1440 \mathrm{~h}$, July 30, gage height $1.31 \mathrm{ft}$. No peak discharge above base of $10 \mathrm{ft}^{3} / \mathrm{s}$. No flow at times.

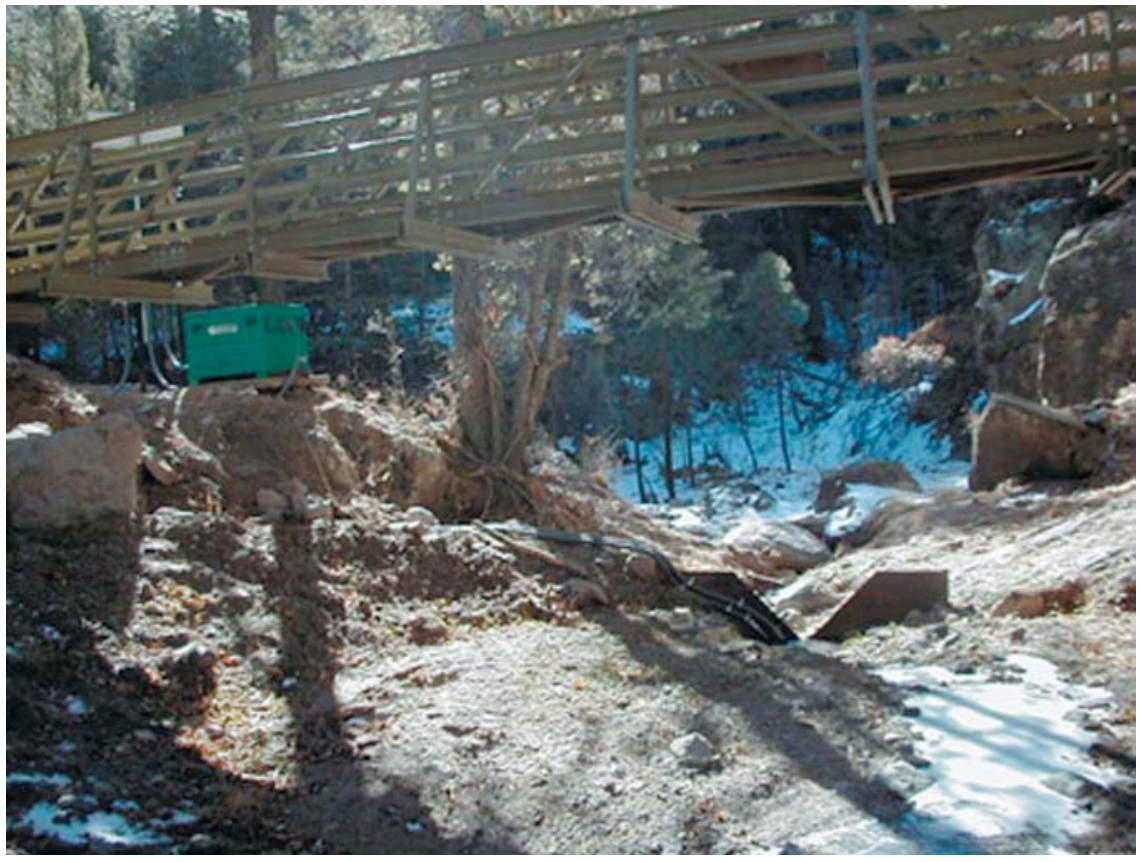




\title{
E241 Pajarito Canyon above Starmer's Gulch
}

\author{
Station Analysis
}

\section{Water Year}

Equipment. Station is equipped with Sutron 8210 data logger (5-min. interval) with Sutron Accubar bubble sensor. The system is powered by a solar panel battery system housed in a NEMA shelter. Station is equipped with an ISCO pump sampler for water quality sample collection. ISCO is housed in a separate shelter, a $3^{\prime} \times 4^{\prime}$ metal box. An outside staff is available for reference. Gage was rebuilt after destruction by June 28, 2000 , flood. Footbridge was installed as part of reconstruction and may be used for highflow measurements and sampling. Bridge also provides access to gage E242 during highflow periods.

Field Work. The station was visited 18 times to conduct discharge measurements and service the instrumentation. Field inspections for the gage are listed under site history files on the Hydstra database. Discharge measurements for the gage are listed under site gauging files on the Hydstra database.

Datum Correction. Levels run September 22, 2005, found the wire weight gage and PZF within limits.

Gage-Height Record. The data logger referenced to the outside staff gave a complete and satisfactory record except for the periods of December 28-30, January 11-16, 17-29, and February 1-4, 15-21 when gage height was affected by ice.

Rating. The channel is straight for $100^{\prime}$ above and below weir. Banks have significant vegetation and streambed is sand and gravel, somewhat armored and firm.

Thirteen discharge measurements (Nos. 55-67) were made the year. Observed flow is usually very little falling over the $\mathrm{V}$ notch.

Rating No. 3 is based on standard $90^{\circ}$ sharp-crested weir formula verified with current measurements. Point of zero flow is $0.70 \mathrm{ft}$ from levels. Shifts defined by measurements were used for V diagrams. Shifts were computed and record worked to inside gage readings. Although wire weight is reference gage, natural fall occurs between the wire weight and the orifice from filling after flow events. Effectively, the wire weight becomes a general check at this station.

Weir should be very effective with virtually no approach velocity to interfere.

Discharge. Discharge was computed by applying gage height to Rating No. 3 directly.

Remarks. Records are good. 


\section{E241 Pajarito Canyon above Starmer's Gulch}

Daily Mean Discharge in Cubic Feet per Second

Water Year October 2008 to September 2009

\begin{tabular}{|c|c|c|c|c|c|c|c|c|c|c|c|c|}
\hline DAY & OCT & NOV & DEC & JAN & FEB & MAR & APR & MAY & JUN & JUL & AUG & SEP \\
\hline 1 & .01 & .01 & .01 & .03 & $.01^{*}$ & .01 & .02 & .01 & .01 & .01 & .01 & .01 \\
\hline 2 & .01 & .01 & .01 & .03 & $.01^{*}$ & .01 & .02 & .02 & .01 & .01 & .01 & .01 \\
\hline 3 & .01 & .01 & .01 & .01 & $.01^{*}$ & .01 & .02 & .02 & .03 & .01 & .01 & .01 \\
\hline 4 & .01 & .01 & .01 & .01 & $.01^{*}$ & .01 & .02 & .01 & .01 & .01 & .01 & .01 \\
\hline 5 & .01 & .01 & .01 & .01 & .01 & .01 & .02 & .01 & .01 & .05 & .01 & .01 \\
\hline 6 & .01 & .01 & .01 & .01 & .01 & .01 & .02 & .01 & .01 & .02 & .01 & .01 \\
\hline 7 & .01 & .01 & .01 & .01 & .01 & .01 & .02 & .01 & .01 & .01 & .01 & .01 \\
\hline 8 & .01 & .01 & .01 & .01 & .01 & .01 & .01 & .01 & .01 & .01 & .01 & .01 \\
\hline 9 & .01 & .01 & .01 & .01 & .01 & .01 & .01 & .01 & .01 & .01 & 0 & .01 \\
\hline 10 & .01 & .01 & .02 & .01 & .01 & .01 & .01 & .01 & .02 & .01 & 0 & .01 \\
\hline 11 & .04 & .01 & .01 & $.02^{\star}$ & .01 & .01 & .01 & .01 & .01 & .01 & 0 & .01 \\
\hline 12 & .01 & .01 & .01 & $.02^{*}$ & .01 & .01 & .01 & .01 & .01 & .01 & .01 & .01 \\
\hline 13 & .01 & .01 & .01 & $.02^{*}$ & .01 & .01 & .01 & .01 & .01 & .01 & .01 & .01 \\
\hline 14 & .01 & .01 & .01 & $.02^{\star}$ & .01 & .01 & .01 & .01 & .01 & .01 & .01 & .01 \\
\hline 15 & .01 & .01 & .01 & $.02^{\star}$ & $.01^{*}$ & .01 & .01 & .01 & .01 & .01 & .01 & .01 \\
\hline 16 & .01 & .01 & .01 & $.02^{\star}$ & $.01^{*}$ & .01 & .01 & .01 & .01 & .01 & .01 & .01 \\
\hline 17 & .01 & .01 & .01 & .03 & $.01^{*}$ & .01 & .01 & .01 & .01 & .01 & .01 & .02 \\
\hline 18 & .01 & .01 & .01 & .02 & $.01^{*}$ & .01 & .02 & .01 & .01 & .01 & .01 & .02 \\
\hline 19 & .01 & .01 & .01 & .02 & $.01^{*}$ & .01 & .02 & .01 & .01 & .01 & .01 & .01 \\
\hline 20 & .01 & .01 & .01 & .01 & $.01^{*}$ & .01 & .02 & .01 & .01 & .01 & .01 & .01 \\
\hline 21 & .01 & .01 & .02 & .01 & $.01^{*}$ & .01 & .02 & .01 & .01 & .01 & .01 & .01 \\
\hline 22 & .01 & .01 & .02 & .01 & .01 & .01 & .02 & .01 & .01 & .01 & .01 & .01 \\
\hline 23 & .01 & .01 & .01 & .01 & .01 & .02 & .02 & .02 & .01 & .01 & .01 & .01 \\
\hline 24 & .01 & .01 & .01 & .01 & .01 & .02 & .02 & .02 & .01 & .01 & .01 & .02 \\
\hline 25 & .01 & .01 & .01 & .01 & .01 & .03 & .02 & .01 & .01 & .01 & .01 & .02 \\
\hline 26 & .01 & .01 & .01 & .01 & .01 & .02 & .02 & .01 & .01 & .01 & .01 & .02 \\
\hline 27 & .01 & .01 & .03 & .01 & .01 & .04 & .02 & .03 & .01 & .01 & .01 & .01 \\
\hline 28 & .01 & .01 & $.02^{*}$ & $.01^{*}$ & .01 & .03 & .02 & .02 & .01 & .08 & .01 & .01 \\
\hline 29 & .01 & .01 & $.02^{*}$ & $.01^{*}$ & --.- & .03 & .02 & .01 & .01 & .06 & .01 & .01 \\
\hline 30 & .01 & .01 & $.02^{*}$ & $.01^{*}$ & ---- & .03 & .02 & .01 & .01 & .13 & .01 & .01 \\
\hline 31 & .01 & - & .01 & .01 & -.-- & .02 & ---- & .01 & ---- & .01 & .01 & - \\
\hline Total & 0.34 & 0.30 & 0.39 & 0.45 & 0.28 & 0.46 & 0.50 & 0.38 & 0.33 & 0.60 & 0.28 & 0.35 \\
\hline Mean & .011 & .010 & .013 & .015 & .010 & .015 & .017 & .012 & .011 & .019 & .009 & .012 \\
\hline Max & .04 & .01 & .03 & .03 & .01 & .04 & .02 & .03 & .03 & .13 & .01 & .02 \\
\hline Min & .01 & .01 & .01 & .01 & .01 & .01 & .01 & .01 & .01 & .01 & 0 & .01 \\
\hline Acre-Ft & .67 & .60 & .77 & .89 & .56 & .91 & .99 & .75 & .65 & 1.2 & .56 & .69 \\
\hline Wtr Year & 2009 & Total & 4.66 & Mean & & 13 & $\operatorname{Max}$ & .13 & Min & 0 & Acre-Ft & 9.2 \\
\hline Cal Year & 2008 & Total & 7.45 & Mean & & 20 & $\operatorname{Max}$ & 1.4 & Min & 0 & Acre- $\mathrm{Ft}$ & 15 \\
\hline
\end{tabular}

${ }^{\star}$ Estimate 


\section{E242 Starmer's Gulch above Pajarito Canyon}

Location. Lat $35^{\circ}$ 51' 33", long $106^{\circ} 20^{\prime}$ 13", SW 1/4, Sec. 20, T. 19 N., R. 6 E., Los Alamos County.

Drainage Area. $1.03 \mathrm{mi}^{2}$.

Period of Record. March 1999 to September 30, 2009.

Revised Record. Drainage Area (2006).

Gage. Data logger. Elevation of gage is $7,377 \mathrm{ft}$ above NGVD from GPS survey.

Remarks. Records are good, except estimated daily discharges, which are fair.

Average Discharge. $9 \mathrm{yr}, 0.23 \mathrm{ft}^{3} / \mathrm{s}, 166$ acre- $\mathrm{ft} / \mathrm{yr}$.

Extremes for Period of Record. Maximum discharge, $628 \mathrm{ft}^{3} / \mathrm{s}$, August 29, 2007, gage height $3.98 \mathrm{ft}$. No flow at times.

Extremes for Current Year. Peak discharges above base of $10 \mathrm{ft}^{3} / \mathrm{s}$ and maximum (*):

\begin{tabular}{|c|c|c|c|}
\hline Date & Time & Discharge $\left(\mathbf{f t}^{\mathbf{3}} / \mathbf{s}\right)$ & Gage Height (ft) \\
\hline August 30 & 1750 & $10^{*}$ & $1.95^{*}$ \\
\hline
\end{tabular}

Minimum daily $0.01 \mathrm{ft}^{3} / \mathrm{s}$, April 12 .

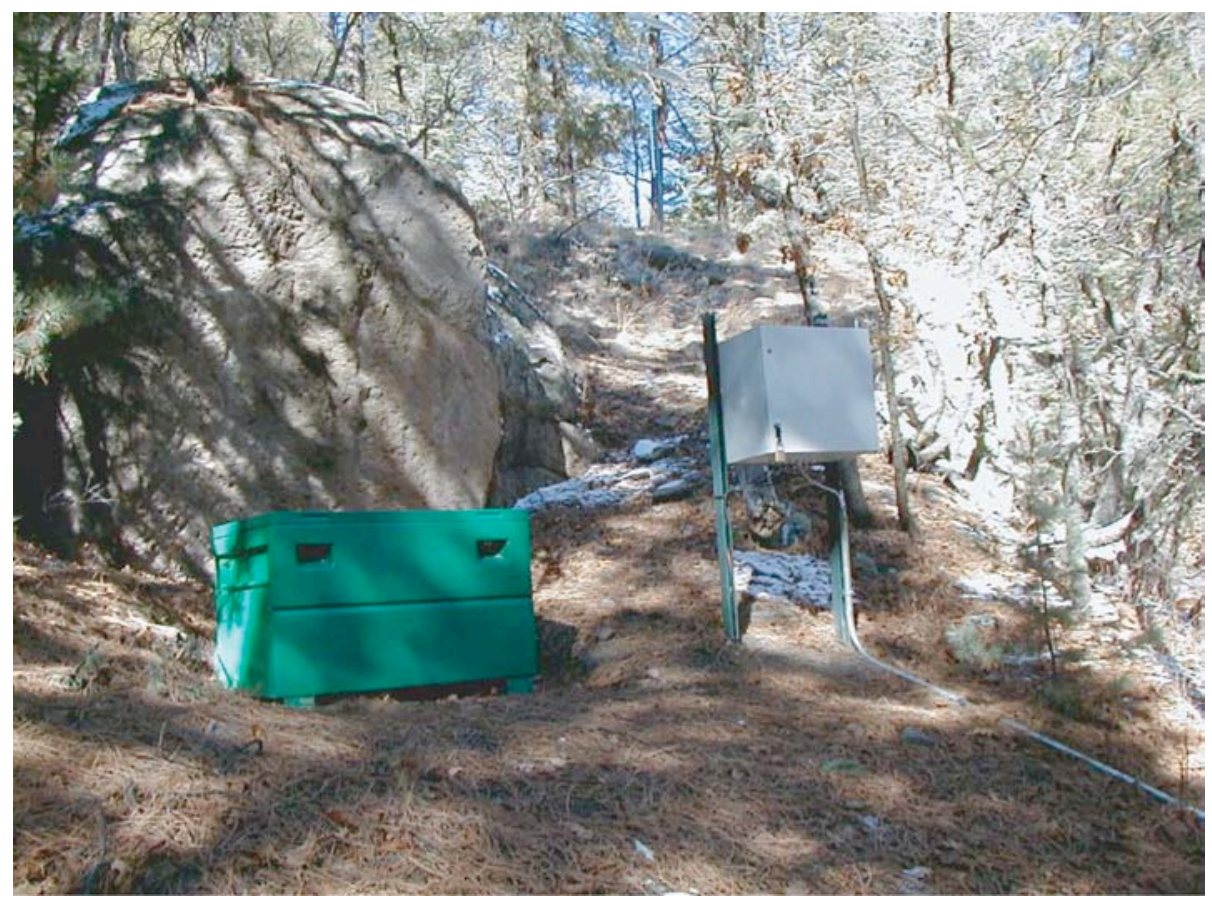




\title{
E242 Starmer's Gulch above Pajarito Canyon
}

\author{
Station Analysis
}

\section{Water Year}

Equipment. Station is equipped with Sutron 8210 data logger (5-min. interval) with Sutron Accubar bubble sensor and Milltronics probe sensor. The system is powered by a solar panel battery system housed in a NEMA shelter. Station is equipped with an ISCO pump sampler for water quality sample collection. ISCO is housed in a separate shelter, a $3^{\prime} \times 4^{\prime}$ metal box. An outside staff is available for reference. No provision for discharge measurement above wading stage.

Field Work. The station was visited 19 times to conduct discharge measurements and service the instrumentation. Field inspections for the gage are listed under site history files on the Hydstra database. Discharge measurements for the gage are listed under site gauging files on the Hydstra database.

Datum Correction. Levels run September 22, 2009, found gage within limits.

Gage-Height Record. The data logger reference to the outside staff gave a complete and satisfactory record, except for the periods from March 18-22, 29, 30, and April 7-10 when gage height was affected by ice.

Rating. The channel is about $13^{\prime}$ wide and straight for about $100^{\prime}$ upstream and straight for about 50' downstream then bends to the left. The streambed through this reach is rock with cobbles. The right and left bank are covered with scrub oak and some conifers.

Twelve discharge measurements (Nos. 61-72) were made this water year.

Rating No. 4 was used all year. Stage application of shifts is illustrated by V diagrams. Rating 4 is considered good.

Discharge. Discharge was computed by applying gage height directly to Rating No. 4 with V diagrams. Discharge estimates due to ice effect were based on bubbler.

Remarks. Records are good except for estimated daily discharges, which are fair. 


\section{E242 Starmer's Gulch above Pajarito Canyon}

Daily Mean Discharge in Cubic Feet per Second

Water Year October 2008 to September 2009

\begin{tabular}{|c|c|c|c|c|c|c|c|c|c|c|c|c|}
\hline DAY & OCT & NOV & DEC & JAN & FEB & MAR & APR & MAY & JUN & JUL & AUG & SEP \\
\hline 1 & .01 & .01 & .01 & .01 & .01 & .01 & .01 & 1.6 & .24 & .08 & .13 & .12 \\
\hline 2 & .01 & .01 & .01 & .01 & .01 & .01 & .01 & 1.4 & .21 & .07 & .08 & .11 \\
\hline 3 & .01 & .01 & .01 & .01 & .01 & .01 & .01 & 1.1 & .27 & .06 & .06 & .08 \\
\hline 4 & .01 & .01 & .01 & .01 & .01 & .01 & .01 & .91 & .32 & .05 & .05 & .07 \\
\hline 5 & .01 & .01 & .01 & .01 & .01 & .01 & .01 & .78 & .27 & .10 & .04 & .07 \\
\hline 6 & .01 & .01 & .01 & .01 & .01 & .01 & .01 & .62 & .24 & .14 & .03 & .06 \\
\hline 7 & .01 & .01 & .01 & .01 & .01 & .01 & $.01^{*}$ & .52 & .20 & .16 & .03 & .06 \\
\hline 8 & .01 & .01 & .01 & .01 & .01 & .01 & $.01^{*}$ & .38 & .16 & .12 & .03 & .07 \\
\hline 9 & .01 & .01 & .01 & .01 & .01 & .01 & $.01^{*}$ & .31 & .15 & .08 & .03 & .08 \\
\hline 10 & .01 & .01 & .01 & .01 & .01 & .01 & $.01^{*}$ & .27 & .41 & .05 & .03 & .08 \\
\hline 11 & .18 & .01 & .01 & .01 & .01 & .01 & .01 & .26 & .27 & .03 & .02 & .06 \\
\hline 12 & .01 & .01 & .01 & .01 & .01 & .01 & .01 & .22 & .29 & .03 & .03 & .04 \\
\hline 13 & .01 & .01 & .01 & .01 & .01 & .01 & .08 & .19 & .25 & .03 & .03 & .04 \\
\hline 14 & .01 & .01 & .01 & .01 & .01 & .01 & .05 & .14 & .21 & .02 & .09 & .04 \\
\hline 15 & .01 & .01 & .01 & .01 & .01 & .01 & .10 & .12 & .17 & .02 & .09 & .03 \\
\hline 16 & .01 & .01 & .01 & .01 & .01 & .01 & .30 & .13 & .16 & .03 & .08 & .07 \\
\hline 17 & .01 & .01 & .01 & .01 & .01 & .02 & .62 & .14 & .14 & .03 & .06 & .09 \\
\hline 18 & .01 & .01 & .01 & .01 & .01 & $.01^{*}$ & 1.2 & .10 & .12 & .03 & .05 & .19 \\
\hline 19 & .01 & .01 & .01 & .01 & .01 & $.01^{*}$ & 1.6 & .08 & .11 & .03 & .05 & .11 \\
\hline 20 & .01 & .01 & .01 & .01 & .01 & $.01^{*}$ & 1.7 & .08 & .20 & .03 & .04 & .08 \\
\hline 21 & .01 & .01 & .01 & .01 & .01 & $.01^{*}$ & 1.9 & .08 & .23 & .04 & .03 & .05 \\
\hline 22 & .01 & .01 & .01 & .01 & .01 & $.01^{*}$ & 2.2 & .09 & .28 & .05 & .03 & .04 \\
\hline 23 & .01 & .01 & .01 & .01 & .01 & .01 & 2.3 & .18 & .25 & .05 & .03 & .04 \\
\hline 24 & .01 & .01 & .01 & .01 & .01 & .01 & 2.3 & .25 & .17 & .04 & .03 & .12 \\
\hline 25 & .01 & .01 & .01 & .01 & .01 & .01 & 2.3 & .44 & .15 & .03 & .04 & .08 \\
\hline 26 & .01 & .01 & .01 & .01 & .01 & .01 & 2.2 & .47 & .12 & .03 & .04 & .08 \\
\hline 27 & .01 & .01 & .01 & .01 & .01 & .01 & 2.1 & .56 & .11 & .04 & .04 & .05 \\
\hline 28 & .01 & .01 & .01 & .01 & .01 & .01 & 2.0 & .72 & .11 & .19 & .04 & .04 \\
\hline 29 & .01 & .01 & .01 & .01 & -..-- & $.01^{*}$ & 1.8 & .47 & .09 & .11 & .03 & .03 \\
\hline 30 & .01 & .01 & .01 & .01 & ----- & $.01^{*}$ & 1.7 & .38 & .09 & .18 & .42 & .03 \\
\hline 31 & .01 & --.-- & .01 & .01 & --.-- & .01 & ------ & .29 & ----- & .16 & .21 & ----- \\
\hline Total & 0.48 & 0.30 & 0.31 & 0.31 & 0.28 & 0.32 & 26.57 & 13.28 & 5.99 & 2.11 & 1.99 & 2.11 \\
\hline Mean & .015 & .010 & .010 & .010 & .010 & .010 & .89 & .43 & .20 & .068 & .064 & .070 \\
\hline Max & .18 & .01 & .01 & .01 & .01 & .02 & 2.3 & 1.6 & .41 & .19 & .42 & .19 \\
\hline Min & .01 & .01 & .01 & .01 & .01 & .01 & .01 & .08 & .09 & .02 & .02 & .03 \\
\hline Acre-Ft & .95 & .60 & .61 & .61 & .56 & .63 & 53 & 26 & 12 & 4.2 & 3.9 & 4.2 \\
\hline Wtr Year & 2009 & Total & 54.05 & Mean & & .15 & Max & 2.3 & Min & .01 & Acre-Ft & 107 \\
\hline Cal Year & 2008 & Total & 165.45 & Mean & & .45 & $\operatorname{Max}$ & 5.8 & Min & 0 & Acre-Ft & 328 \\
\hline
\end{tabular}

*Estimate 


\section{E2425 Arroyo de la Delfe above Pajarito Canyon}

Location. Lat $35^{\circ}$ 51' 25", long $106^{\circ} 19^{\prime}$ 56", NW 1/4, Sec. 29, T. 19 N., R. 6 E., Ramon Vigil Grant, Los Alamos County.

Drainage Area. $0.15 \mathrm{mi}^{2}$.

Period of Record. June 1, 2000, to September 30, 2009.

Revised Record. Drainage Area (2006).

Gage. Data logger and $90^{\circ}$ sharp-crested weir. Elevation of gage is $7,311 \mathrm{ft}$ above NGVD from GPS survey.

Remarks. Records are good.

Average Discharge. $9 \mathrm{yr}, 0.04 \mathrm{ft}^{3} / \mathrm{s}, 28$ acre-ft/yr.

Extremes for Period of Record. Maximum discharge, $30 \mathrm{ft}^{3} / \mathrm{s}$, August 24, 2005, gage height $2.64 \mathrm{ft}$. No flow at times.

Extremes for Current Year. Maximum discharge, $0.10 \mathrm{ft}^{3} / \mathrm{s}$ at $1350 \mathrm{~h}$, July 6, gage height $0.84 \mathrm{ft}$. No peak discharge above base of $5.0 \mathrm{ft}^{3} / \mathrm{s}$.

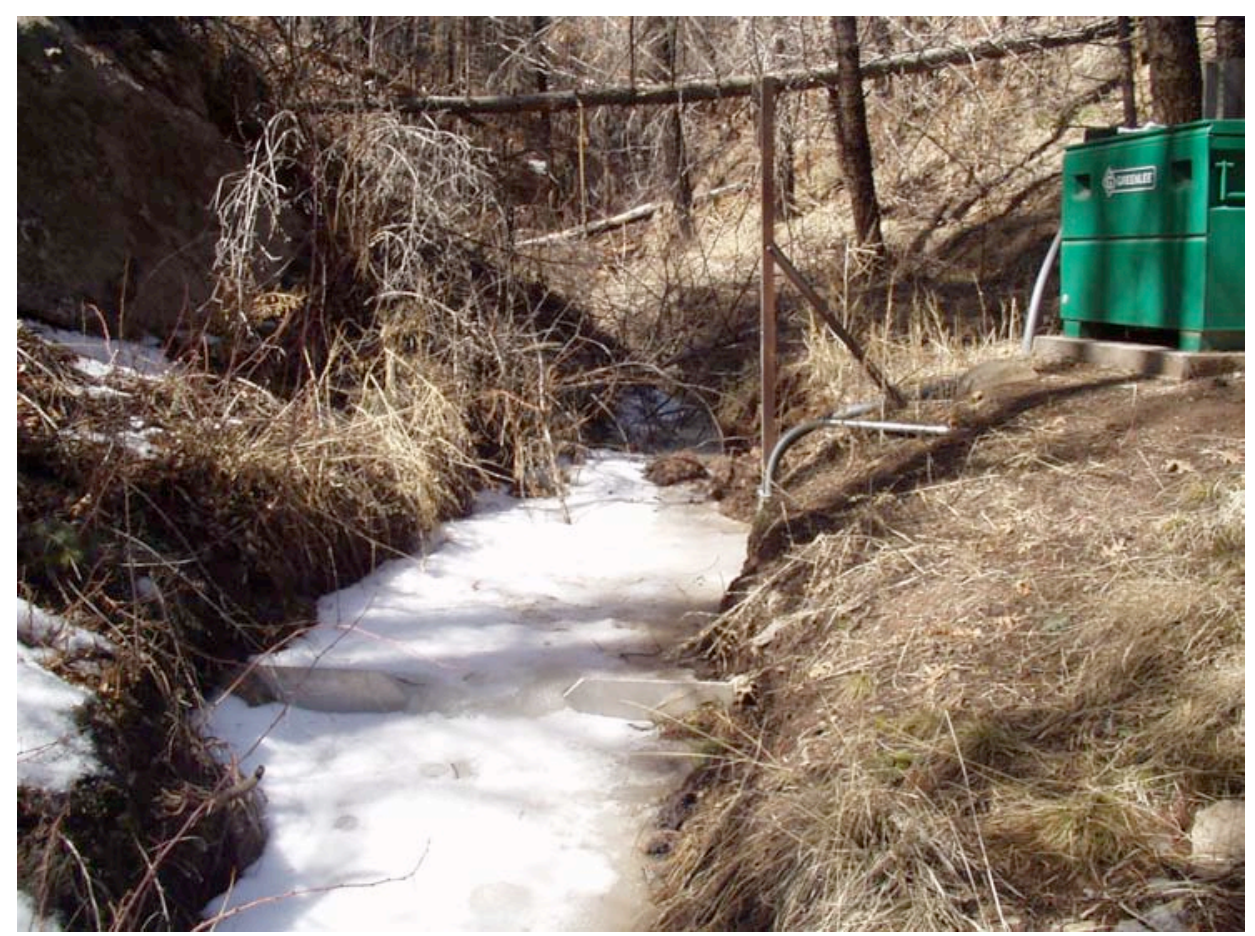




\title{
E2425 Arroyo de la Delfe above Pajarito Canyon
}

\author{
Station Analysis
}

\section{Water Year}

Equipment. Station is equipped with Sutron 8210 data logger (5-min. interval) with Sutron Accubar bubble sensor. The system is powered by a solar panel battery system housed in a NEMA shelter. Station is equipped with an ISCO pump sampler for water quality sample collection. ISCO is housed in a separate shelter, a $3^{\prime} \times 4^{\prime}$ metal box. Sampler is triggered by stage through the data logger. An outside staff is available for reference. No provision for measurements above wading stage.

Field Work. The station was visited 16 times to conduct discharge measurements and service the instrumentation. Field inspections for the gage are listed under site history files on the Hydstra database. Discharge measurements for the gage are listed under site gauging files on the Hydstra database.

Datum Correction. None.

Gage-Height Record. The data logger referenced to the outside staff gave a complete and satisfactory record except for the periods from January 14-22, January 28 to February 5, February 14-22, and March 27 when gage height was affected by ice.

Rating. Channel is straight and narrow above and below gage. Bed material is sand and coarse gravel. Control is $90^{\circ}$ sharp-crested weir plate.

Fourteen discharge measurements (Nos. 31-44) were made this year.

Rating No. 1 was continued in use. V diagrams were used to apply shift when necessary.

Discharge. Discharge was computed by applying gage height to Rating No.1.

Remarks. Records are good, except estimated daily discharge, which are fair. 
E2425 Arro yo de la Delfe above Pajarito $C$ an yon

Daily Mean Discharge in Cubic Feet per Second

Water Year October 2008 to September 2009

\begin{tabular}{|c|c|c|c|c|c|c|c|c|c|c|c|c|}
\hline DAY & OCT & NOV & DEC & JAN & FEB & MAR & APR & MAY & JUN & JUL & AUG & SEP \\
\hline 1 & .01 & .01 & .01 & .01 & $.01^{*}$ & .01 & .02 & .05 & .04 & .02 & .03 & .02 \\
\hline 2 & .01 & .01 & .01 & .01 & $.01^{*}$ & .01 & .02 & .05 & .04 & .02 & .03 & .02 \\
\hline 3 & .01 & .01 & .01 & .01 & $.01^{*}$ & .02 & .02 & .05 & .04 & .02 & .03 & .02 \\
\hline 4 & .01 & .01 & .01 & .01 & $.01^{*}$ & .02 & .02 & .05 & .03 & .02 & .03 & .02 \\
\hline 5 & .01 & .01 & .01 & .01 & $.01^{*}$ & .02 & .02 & .05 & .03 & .03 & .02 & .02 \\
\hline 6 & .01 & .01 & .01 & .01 & .01 & .02 & .02 & .04 & .03 & .04 & .01 & .02 \\
\hline 7 & .01 & .01 & .01 & .01 & .01 & .02 & .02 & .03 & .03 & .04 & .01 & .02 \\
\hline 8 & .01 & .01 & .01 & .01 & .01 & .02 & .02 & .03 & .03 & .03 & .01 & .02 \\
\hline 9 & .01 & .01 & .01 & .01 & .01 & .02 & .02 & .03 & .03 & .03 & .01 & .02 \\
\hline 10 & .01 & .01 & .03 & .01 & .01 & .02 & .02 & .03 & .04 & .03 & .01 & .02 \\
\hline 11 & .02 & .01 & .02 & .01 & .01 & .02 & .02 & .03 & .04 & .03 & .01 & .02 \\
\hline 12 & .01 & .01 & .01 & .01 & .02 & .02 & .02 & .03 & .03 & .03 & .01 & .01 \\
\hline 13 & .01 & .01 & .01 & .01 & .02 & .02 & .03 & .03 & .03 & .03 & .01 & .01 \\
\hline 14 & .01 & .01 & .01 & $.01^{*}$ & $.02^{\star}$ & .02 & .03 & .03 & .03 & .03 & .02 & .01 \\
\hline 15 & .01 & .01 & .01 & $.01^{*}$ & $.02^{*}$ & .02 & .03 & .03 & .03 & .03 & .02 & .01 \\
\hline 16 & .01 & .01 & .01 & $.01^{*}$ & $.02^{\star}$ & .02 & .03 & .03 & .03 & .03 & .01 & .02 \\
\hline 17 & .01 & .01 & .01 & $.01^{*}$ & $.02^{\star}$ & .02 & .03 & .03 & .03 & .03 & .01 & .02 \\
\hline 18 & .01 & .01 & .01 & $.01^{*}$ & $.02^{\star}$ & .02 & .03 & .03 & .03 & .03 & .02 & .02 \\
\hline 19 & .01 & .01 & .01 & $.01^{*}$ & $.02^{\star}$ & .02 & .04 & .03 & .03 & .03 & .02 & .02 \\
\hline 20 & .01 & .01 & .01 & $.01^{*}$ & $.02^{\star}$ & .01 & .04 & .03 & .03 & .03 & .02 & .02 \\
\hline 21 & .01 & .01 & .01 & $.01^{*}$ & $.02^{\star}$ & .01 & .04 & .03 & .03 & .04 & .02 & .02 \\
\hline 22 & .01 & .01 & .01 & $.01^{*}$ & $.02^{\star}$ & .01 & .05 & .03 & .03 & .03 & .02 & .02 \\
\hline 23 & .01 & .01 & .01 & .01 & .02 & .02 & .05 & .04 & .03 & .03 & .02 & .02 \\
\hline 24 & .01 & .01 & .01 & .01 & .01 & .02 & .05 & .04 & .03 & .03 & .02 & .02 \\
\hline 25 & .01 & .01 & .01 & .01 & .01 & .02 & .06 & .03 & .03 & .03 & .02 & .02 \\
\hline 26 & .01 & .01 & .01 & .01 & .02 & .02 & .06 & .03 & .03 & .03 & .02 & .02 \\
\hline 27 & .01 & .01 & .01 & .01 & .02 & $.02^{*}$ & .06 & .04 & .03 & .03 & .02 & .02 \\
\hline 28 & .01 & .01 & .01 & $.01^{*}$ & .01 & .02 & .05 & .05 & .03 & .02 & .02 & .02 \\
\hline 29 & .01 & .01 & .01 & $.01^{*}$ & ---- & .02 & .05 & .04 & .02 & .02 & .01 & .02 \\
\hline 30 & .01 & .01 & .01 & $.01^{*}$ & ----- & .02 & .05 & .04 & .02 & .03 & .02 & .02 \\
\hline 31 & .01 & --- & .01 & $.01^{*}$ & --.- & .02 & ---- & .04 & --- & .04 & .02 & ---- \\
\hline Total & 0.32 & 0.30 & 0.34 & 0.31 & 0.42 & 0.57 & 1.02 & 1.12 & 0.93 & 0.91 & 0.55 & 0.56 \\
\hline Mean & .010 & .010 & .011 & .010 & .015 & .018 & .034 & .036 & .031 & .029 & .018 & .019 \\
\hline $\operatorname{Max}$ & .02 & .01 & .03 & .01 & .02 & .02 & .06 & .05 & .04 & .04 & .03 & .02 \\
\hline Min & .01 & .01 & .01 & .01 & .01 & .01 & .02 & .03 & .02 & .02 & .01 & .01 \\
\hline Acre-F t & .63 & .60 & .67 & .61 & .83 & 1.1 & 2.0 & 2.2 & 1.8 & 1.8 & 1.1 & 1.1 \\
\hline Wtr Year & 2009 & Total & 7.35 & Mean & & 020 & $\operatorname{Max}$ & .06 & Min & .01 & Acre- $\mathrm{Ft}$ & 15 \\
\hline Cal Year & 2008 & Total & 9.19 & Mean & & 025 & $\operatorname{Max}$ & .21 & Min & 0 & Acre-Ft & 18 \\
\hline
\end{tabular}

${ }^{*}$ Estimate 


\section{E243 Pajarito Canyon above Two Mile Canyon}

Location. Lat $35^{\circ}$ 51' 14", long $106^{\circ}$ 17' 48", Sec. 27, T. 19N., R. 6 E., Ramon Vigil Grant, Los Alamos County.

Drainage Area. $4.24 \mathrm{mi}^{2}$.

Period of Record. February 2002 to September 30, 2009.

Revisions. Drainage Area (2006).

Gage. Data logger with cellular telemetry. Elevation of gage 6,941 ft above NGVD from GPS survey.

Remarks. Records are good. Legal location based on projected values.

Average Discharge. $7 \mathrm{yr}, 0.23 \mathrm{ft}^{3} / \mathrm{s}, 165$ acre-ft/yr.

Extremes for Period of Record. Maximum discharge, $272 \mathrm{ft}^{3} / \mathrm{s}$ August 24, 2005, gage height $4.38 \mathrm{ft}$. No flow most of the time.

Extremes for Current Year. Maximum discharge, $0.62 \mathrm{ft}^{3} / \mathrm{s}$ at $0130 \mathrm{~h}$, April 26, gage height $1.23 \mathrm{ft}$. No peak discharges above base of $5.0 \mathrm{ft}^{3} / \mathrm{s}$ and maximum. No flow part of the time.

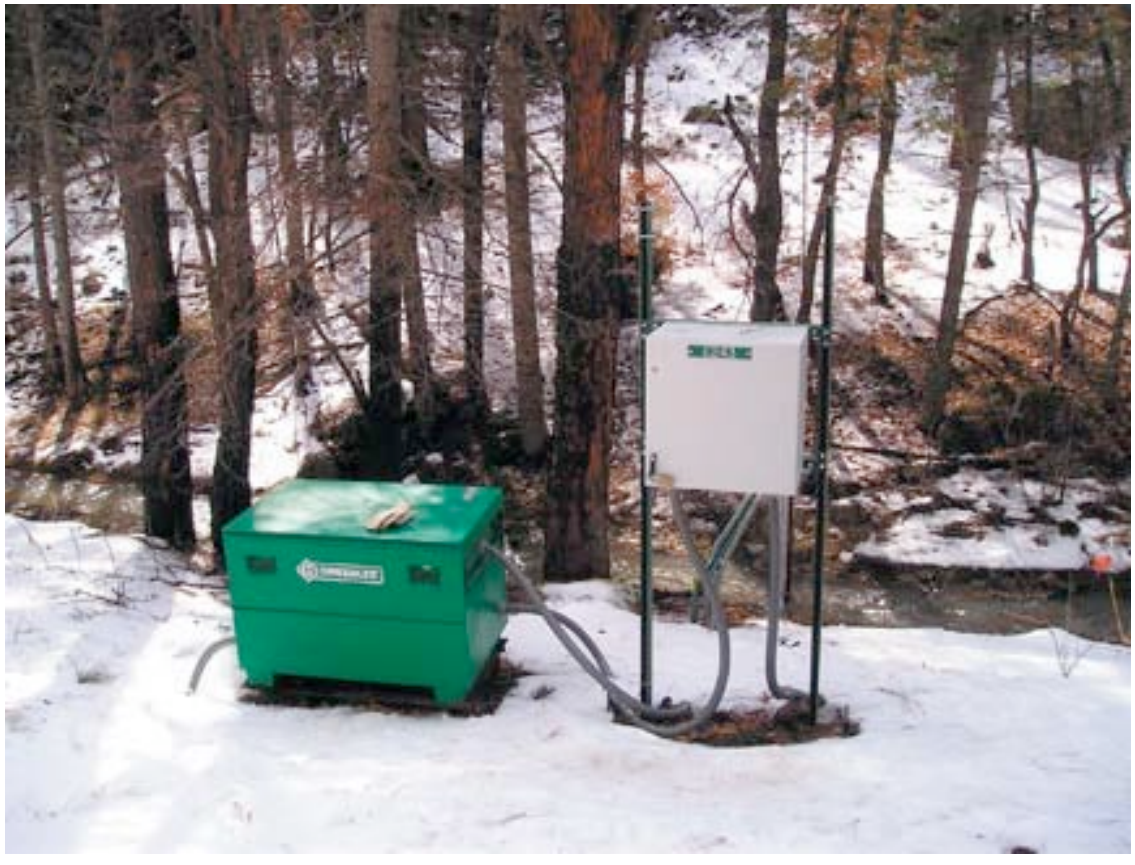




\title{
E243 Pajarito Canyon above Two Mile Canyon
}

\author{
Station Analysis
}

\section{Water Year}

Equipment. Station is equipped with Sutron 8210 data logger (5-min. interval) with Sutron Accubar bubble sensor with cellular telemetry and speech modem. The system is powered by a solar panel battery system housed in a NEMA shelter. Station is equipped with an ISCO pump sampler for water quality sample collection. ISCO is housed in a separate shelter, a $3^{\prime} \times 4^{\prime}$ metal box. Sampler is triggered by stage through the data logger. No provision for direct measurement above wading stage.

Field Work. The station was visited 22 times to conduct discharge measurements and service the instrumentation. Field inspections for the gage are listed under site history files on the Hydstra database. Discharge measurements for the gage are listed under site gauging files on the Hydstra database.

Datum Correction. None. Levels run April 7, 2006, found gage within limits, no corrections necessary.

Gage-Height Record. The data logger referenced to the outside staff gave a complete and satisfactory record, except during the periods from January 27, 28, February 3, 15, 20, 27, 28, and March 1, 2, 8, 11, 12, 27 when gage height was affected by ice.

Rating. The channel is straight for $150^{\prime}$ above and below gage. It is trapezoidal with the bed fairly well armored with large gravel and some cobbles. Banks are fairly well vegetated with grasses and should remain stable at all flows.

Eight discharge measurements (Nos. 30-37) were made this year.

Rating No. 4 was continued in use and considered fair.

Discharge. Discharge was computed by applying gage height to Rating No. 4 with shifts at low flow applied by $\mathrm{V}$ diagrams. PZF shows some estimated zero flow in winter from icing over orifice, during this time stream was frozen dry.

Remarks. This station was originally at a site downstream about $0.5 \mathrm{mi}$. With the building of the Pajarito Flood Control Structure, it had to be moved. That site was never rated and although gage height record is available in Hydstra, the record for 1998-2002 will not be published. Records are good. 


\section{E243 Pajarito Canyon above Two Mile Canyon}

\section{Daily Mean Discharge in Cubic Feet per Second}

Water Year October 2008 to September 2009

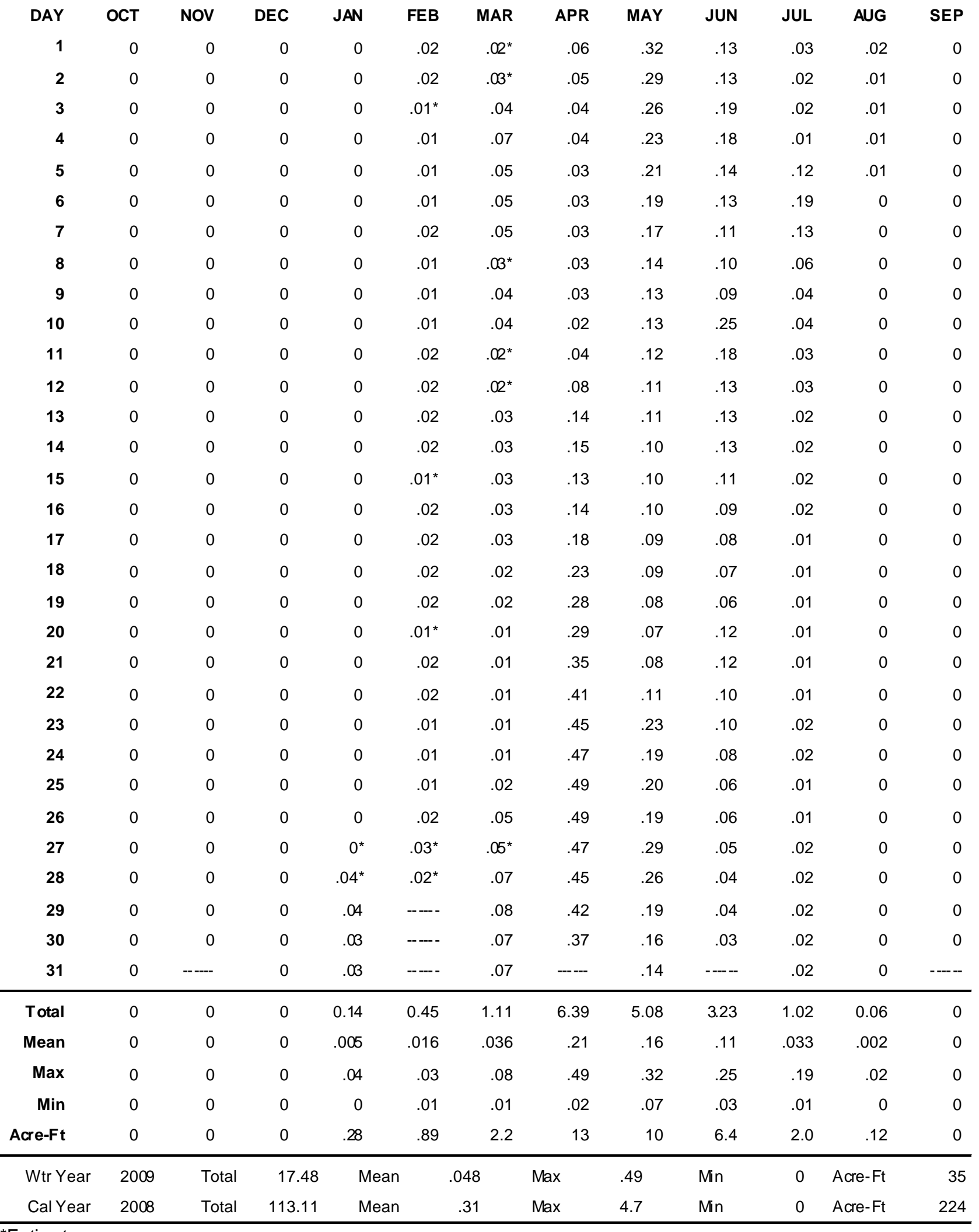




\section{E2435 Two Mile Canyon Tributary at TA-3}

Location. Lat $35^{\circ} 52^{\prime} 08^{\prime \prime}$, long $106^{\circ} 19^{\prime} 21 "$ ", NE 1/4, Sec. 20, T. 19 N., R. 6 E., Ramon Vigil Grant, Los Alamos County.

Drainage Area. $0.02 \mathrm{mi}^{2}$.

Period of Record. October 1, 2005, to September 30, 2009.

Revisions. Drainage Area (2006).

Gage. Data logger and 12" Parshall flume. Elevation of gage is 7,402 ft above NGVD from land survey.

Remarks. Records are good. Records for this site existed before period of record but are not reliable.

Extremes for Period of Record. Maximum discharge, $60 \mathrm{ft}^{3} / \mathrm{s}$ July 14, 2007, gage height $2.40 \mathrm{ft}$. No flow most time.

Extremes for Current Year. Peak discharges above base of $6.0 \mathrm{ft}^{3} / \mathrm{s}$ and maximum (*):

\begin{tabular}{|c|c|c|c|}
\hline Date & Time & Discharge $\left(\mathbf{f t}^{\mathbf{3}} / \mathbf{s}\right)$ & Gage Height $(\mathbf{f t})$ \\
\hline October 11 & 1140 & $7.7^{*}$ & $1.54^{*}$ \\
\hline May 23 & 1215 & 6.9 & 1.44 \\
\hline
\end{tabular}

No flow most of the time.

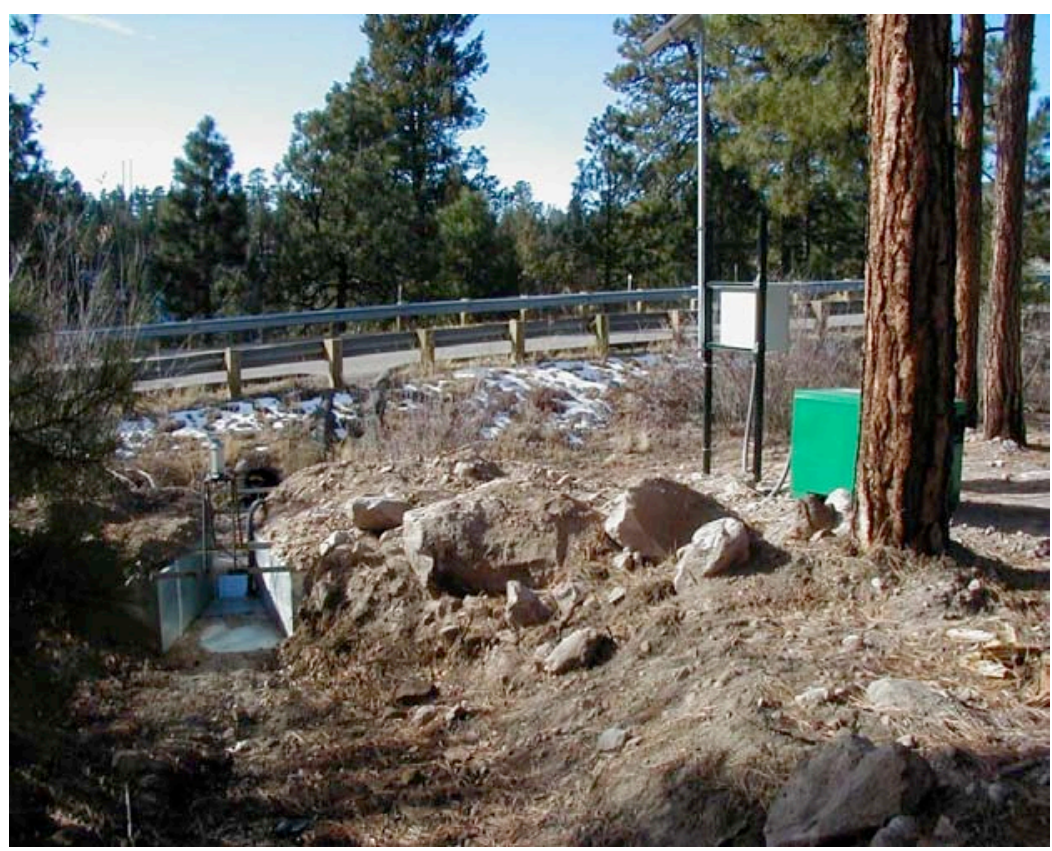




\title{
E2435 Two Mile Canyon Tributary at TA-3
}

\author{
Station Analysis
}

\section{Water Year}

Equipment. Station is equipped with Sutron 8210 data logger (5-min. interval) and Milltronics sonic probe mounted on a 12" Parshall flume. The system is powered by a solar panel battery system housed in a NEMA shelter. Station is equipped with an ISCO pump sampler for water quality sample collection. ISCO is housed in a separate shelter, a $3^{\prime} \times 4^{\prime}$ metal box. Sampler is triggered by stage through the data logger. The staff in the 12" Parshall flume is the reference gage. No provision for discharge measurements above wading stage.

Field Work. The station was visited 37 times to conduct discharge measurements and service the instrumentation. Field inspections for the gage are listed under site history files on the Hydstra database. Discharge measurements for the gage are listed under site gauging files on the Hydstra database.

Datum Correction. None.

Gage-Height Record. The data logger referenced to the outside staff gave a complete and satisfactory record except for the periods from December 13, 15-17, December 2229, January 4, 5, and March 14 when gage height was affected by ice and June 1 to July 9 when the data logger malfunctioned.

Rating. The channel is straight above and below gage. It is confined to the main channel by cut banks on both sides. The bottom is a $10^{\prime}$ wide channel prone to some shifting with vegetation on each bank. Low-water control is the 12" Parshall flume.

Thirty-five inspections of no flow and two inspections of observed flow were made this year.

Rating No. 1 was developed based on the computation of 12" Parshall flume. Point of zero flow is 0.00 gage height.

Discharge. Discharge was computed by applying gage height to Rating No. 1 directly.

Remarks. Records are good, except daily discharges, which are fair. 


\section{E2435 Two Mile $C$ an yon Tributary at T A-3}

Daily Mean Discharge in Cubic Feet per Second

Water Year October 2008 to September 2009

\begin{tabular}{|c|c|c|c|c|c|c|c|c|c|c|c|c|}
\hline DAY & OCT & NOV & DEC & J AN & FEB & MAR & APR & MAY & JUN & JUL & AUG & SEP \\
\hline 1 & $0^{*}$ & 0 & 0 & 0 & 0 & 0 & 0 & 0 & $0^{*}$ & $0^{*}$ & 0 & 0 \\
\hline 2 & 0 & 0 & 0 & 0 & 0 & 0 & 0 & 0 & $0^{*}$ & $0^{*}$ & 0 & 0 \\
\hline 3 & 0 & 0 & 0 & 0 & 0 & 0 & 0 & 0 & $.10^{*}$ & $0^{*}$ & 0 & 0 \\
\hline 4 & .03 & 0 & 0 & $0^{*}$ & 0 & 0 & 0 & 0 & $0^{*}$ & $0^{*}$ & 0 & 0 \\
\hline 5 & 0 & 0 & 0 & $0^{*}$ & 0 & 0 & 0 & 0 & $0^{*}$ & $.10^{*}$ & 0 & 0 \\
\hline 6 & 0 & 0 & 0 & 0 & 0 & 0 & 0 & 0 & $0^{*}$ & $.05^{\star}$ & 0 & .03 \\
\hline 7 & 0 & 0 & 0 & 0 & 0 & 0 & 0 & 0 & $0^{*}$ & $0^{*}$ & 0 & 0 \\
\hline 8 & 0 & 0 & 0 & 0 & 0 & 0 & 0 & 0 & $0^{*}$ & $0^{*}$ & 0 & .01 \\
\hline 9 & 0 & 0 & 0 & 0 & 0 & 0 & 0 & 0 & $0^{*}$ & $0^{*}$ & 0 & 0 \\
\hline 10 & 0 & 0 & 0 & 0 & 0 & 0 & 0 & 0 & $.10^{*}$ & 0 & 0 & .03 \\
\hline 11 & .22 & 0 & 0 & 0 & 0 & 0 & .02 & 0 & $0^{*}$ & 0 & 0 & 0 \\
\hline 12 & 0 & 0 & 0 & 0 & 0 & 0 & .04 & 0 & $0^{*}$ & 0 & .06 & 0 \\
\hline 13 & 0 & 0 & $0^{*}$ & 0 & 0 & 0 & 0 & 0 & $0^{*}$ & 0 & 0 & 0 \\
\hline 14 & .01 & 0 & 0 & 0 & 0 & $0^{*}$ & 0 & 0 & $.05^{*}$ & 0 & .06 & 0 \\
\hline 15 & 0 & 0 & $0^{*}$ & 0 & 0 & 0 & 0 & 0 & $0^{*}$ & 0 & 0 & .02 \\
\hline 16 & 0 & 0 & $0^{*}$ & 0 & 0 & 0 & 0 & 0 & $0^{*}$ & 0 & 0 & .05 \\
\hline 17 & 0 & 0 & $0^{*}$ & 0 & 0 & 0 & 0 & 0 & $0^{*}$ & 0 & 0 & .03 \\
\hline 18 & 0 & 0 & 0 & 0 & 0 & 0 & .02 & 0 & $0^{*}$ & 0 & 0 & 0 \\
\hline 19 & 0 & 0 & 0 & 0 & 0 & 0 & 0 & 0 & $0^{*}$ & 0 & 0 & 0 \\
\hline 20 & 0 & 0 & 0 & 0 & 0 & 0 & 0 & 0 & $.10^{*}$ & .06 & 0 & 0 \\
\hline 21 & 0 & 0 & 0 & 0 & 0 & 0 & 0 & .03 & $0^{*}$ & .08 & 0 & 0 \\
\hline 22 & 0 & 0 & $0^{*}$ & 0 & 0 & 0 & 0 & .01 & $0^{*}$ & 0 & 0 & 0 \\
\hline 23 & 0 & 0 & $0^{*}$ & 0 & 0 & 0 & 0 & .15 & $0^{*}$ & 0 & .01 & .04 \\
\hline 24 & 0 & 0 & $0^{*}$ & 0 & 0 & 0 & 0 & .03 & $0^{*}$ & 0 & .01 & .01 \\
\hline 25 & 0 & 0 & $0^{*}$ & 0 & 0 & 0 & 0 & 0 & $.03^{*}$ & 0 & 0 & 0 \\
\hline 26 & 0 & 0 & $0^{*}$ & 0 & 0 & 0 & 0 & 0 & $0^{*}$ & .03 & 0 & 0 \\
\hline 27 & 0 & .04 & $0^{*}$ & 0 & 0 & 0 & 0 & .04 & $0^{*}$ & 0 & 0 & 0 \\
\hline 28 & 0 & 0 & $0^{*}$ & 0 & 0 & 0 & 0 & 0 & $0^{*}$ & .07 & 0 & 0 \\
\hline 29 & 0 & 0 & $0^{*}$ & 0 & ----- & 0 & 0 & 0 & $0^{*}$ & .05 & 0 & 0 \\
\hline 30 & 0 & 0 & 0 & 0 & ---- & 0 & 0 & 0 & $0^{*}$ & .05 & .09 & 0 \\
\hline 31 & 0 & --- & 0 & 0 & ---- & 0 & ----- & 0 & --- & 0 & 0 & ---- \\
\hline Total & 0.26 & 0.04 & 0 & 0 & 0 & 0 & 0.08 & 0.26 & 0.38 & 0.49 & 0.23 & 0.22 \\
\hline Mean & .008 & .001 & 0 & 0 & 0 & 0 & .003 & .008 & .013 & .016 & .007 & .007 \\
\hline Max & .22 & .04 & 0 & 0 & 0 & 0 & .04 & .15 & .10 & .10 & .09 & .05 \\
\hline Min & 0 & 0 & 0 & 0 & 0 & 0 & 0 & 0 & 0 & 0 & 0 & 0 \\
\hline Acre-F t & .52 & .08 & 0 & 0 & 0 & 0 & .16 & .52 & .75 & .97 & .46 & .44 \\
\hline Wtr Year & 2009 & Total & 1.96 & Mean & & & $a x$ & .22 & Min & 0 & Acre- $\mathrm{Ft}$ & 3.9 \\
\hline Cal Year & 2008 & Total & 1.45 & Mean & & 4 & $a x$ & .22 & Min & 0 & Acre-Ft & 2.9 \\
\hline
\end{tabular}

${ }^{*}$ Estimate 


\section{E244 Two Mile Canyon above Pajarito Canyon}

Location. Lat $35^{\circ}$ 51' 15", long $106^{\circ} 17^{\prime}$ '46", Sec. 27, T. 19 N., R. 6 E., Ramon Vigil Grant, Los Alamos County.

Drainage Area. $3.15 \mathrm{mi}^{2}$.

Period of Record. October 1, 2002, to September 30, 2009.

Revised Record. Drainage Area (2006). Period of Record (2008).

Gage. Data logger with cellular telemetry. Elevation of gage is $6,940 \mathrm{ft}$ above NGVD from GPS survey.

Remarks. Records are good. Legal location based on projected values.

Average Discharge. $7 \mathrm{yr}, 0.10 \mathrm{ft}^{3} / \mathrm{s}, 72$ acre-ft/yr.

Extremes for Period of Record. Maximum discharge, $628 \mathrm{ft}^{3} / \mathrm{s}$ August 25, 2006, gage height $6.01 \mathrm{ft}$ (from flood marks). No flow most of the time.

Extremes for Current Year. Maximum discharge, $4.0 \mathrm{ft}^{3} / \mathrm{s}$ at $1310 \mathrm{~h}$, July 23, gage height $1.05 \mathrm{ft}$. No peak discharges above base of $30 \mathrm{ft}^{3} / \mathrm{s}$. No flow most of the time.

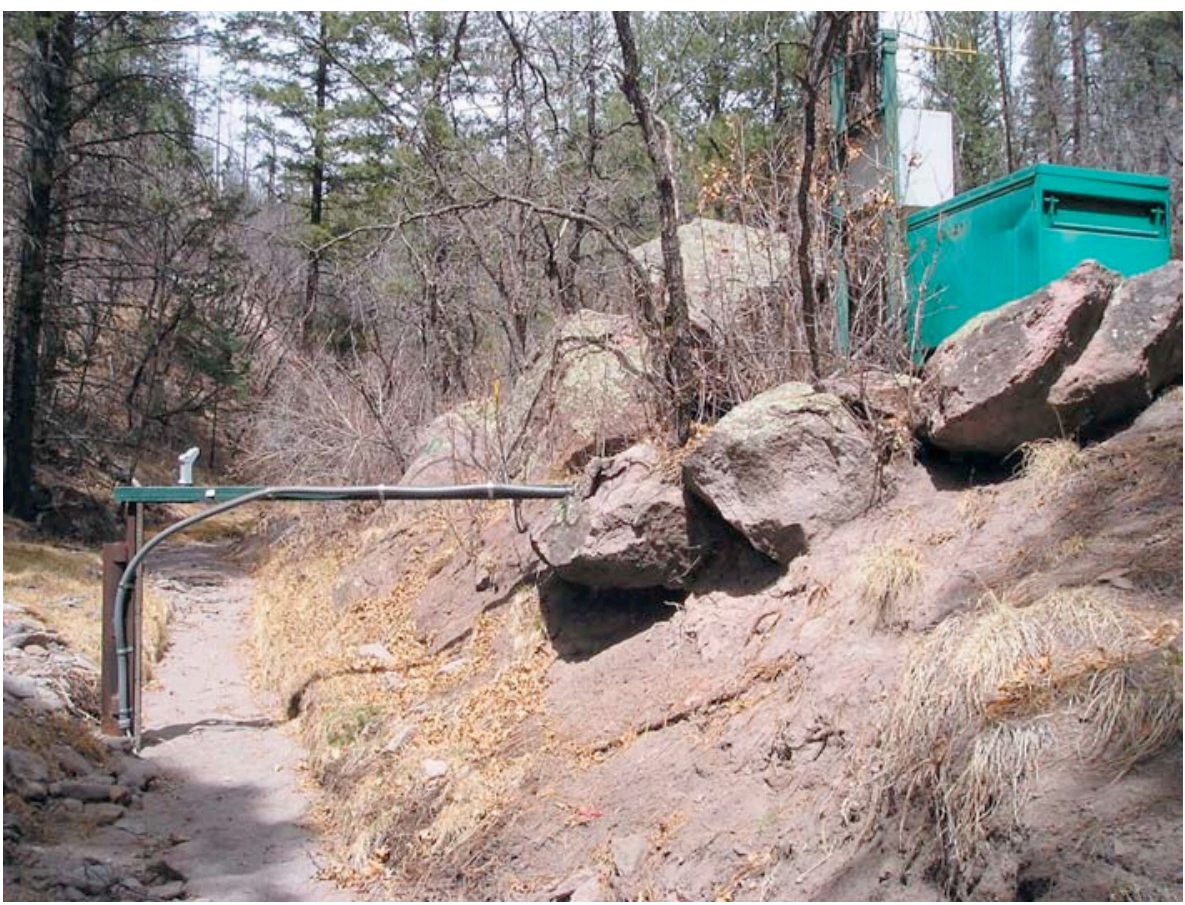




\title{
E244 Two Mile Canyon above Pajarito Canyon
}

\author{
Station Analysis
}

\section{Water Year}

Equipment. Station is equipped with Sutron 8210 data logger (5-min. interval) and Milltronics sonic probe with cellular phone and speech modem. The system is powered by a solar panel battery system housed in a NEMA shelter. Station is equipped with an ISCO pump sampler for water quality sample collection. ISCO is housed in a separate shelter, a $3^{\prime} \times 4^{\prime}$ metal box. Sampler is triggered by stage through the data logger. An outside staff gage is available for reference. Wading measurements can be in the vicinity of the gage. No provision for measurement above wading stages.

Field Work. The station was visited 15 times to conduct discharge measurements and service the instrumentation. Field inspections for the gage are listed under site history files on the Hydstra database. Discharge measurements for the gage are listed under site gauging files on the Hydstra database.

Datum Correction. None.

Gage-Height Record. The data logger referenced to the outside staff gage gave a complete and satisfactory record, except for the periods from December 8 to January 8 , February 10, March 13, 26-30, and April 11, 17, 18 when gage height was affected by ice.

Rating. The channel at the gage is straight for about $150^{\prime}$ above gage and $50^{\prime}$ feet below gage. Channel expands quite a bit below gage. Bed material is coarse sand and gravel. Banks are grassy with some small trees and outcrops affecting roughness at higher flows.

Four discharge measurements (Nos. 21-24) and 10 inspections of no flow were made this year.

Rating No. 2 was developed from previous measurements and one slope area measurement.

Discharge. Discharge was computed by applying gage height to Rating No. 2 directly. Some periods have large shifts on lower end because of dry condition varying the PZF.

Remarks. Records are good. This station was operated at a site $200^{\prime}$ downstream but never rated. It had to be moved because that site is in backwater from the Pajarito Flood Control structure, which was built in 2000 just after the Cerro Grande fire. 
E244 Two Mile Canyon above Pajarito Canyon

Daily Mean Discharge in Cubic Feet per Second

Water Year October 2008 to September 2009

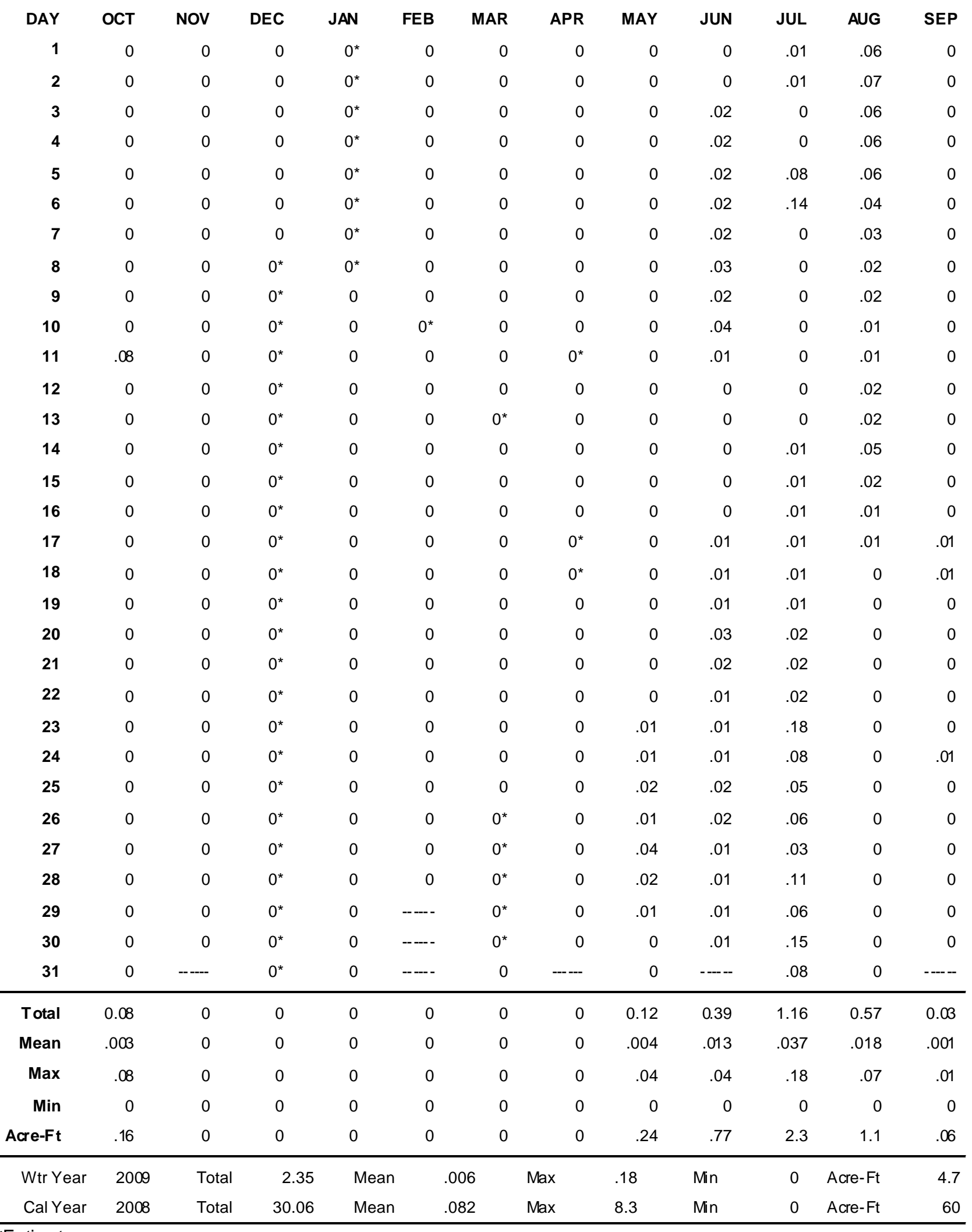

${ }^{*}$ Estimate 


\section{E245 Pajarito Canyon above TA-18}

Location. Lat $35^{\circ}$ 51' 4", long $106^{\circ}$ 17' 11", Sec. 27, T. 19 N., R. 6 E., Ramon Vigil Grant, Los Alamos County.

Drainage Area. $7.56 \mathrm{mi}^{2}$.

Period of Record. November 1993 to September 30, 2009.

Revisions. Drainage Area (2006).

Gage. Data logger and concrete control. Elevation of gage is $6,880 \mathrm{ft}$ above NGVD from GPS survey.

Remarks. Records are good. Legal location based on projected values.

Average Discharge. $15 \mathrm{yr}, 0.20 \mathrm{ft}^{3} / \mathrm{s}, 141$ acre-ft/yr.

Extremes for Period of Record. Maximum discharge, $517 \mathrm{ft}^{3} / \mathrm{s} \mathrm{June} \mathrm{28,} \mathrm{2000,} \mathrm{gage}$ height $5.03 \mathrm{ft}$ (from flood mark). No flow most of the time.

Extremes for Current Year. Maximum discharge $2.1 \mathrm{ft}^{3} / \mathrm{s}$ at $1530 \mathrm{~h}$, July 6, gage height $1.04 \mathrm{ft}$. No peak discharge above base of $25 \mathrm{ft}^{3} / \mathrm{s}$. No flow most of the time.

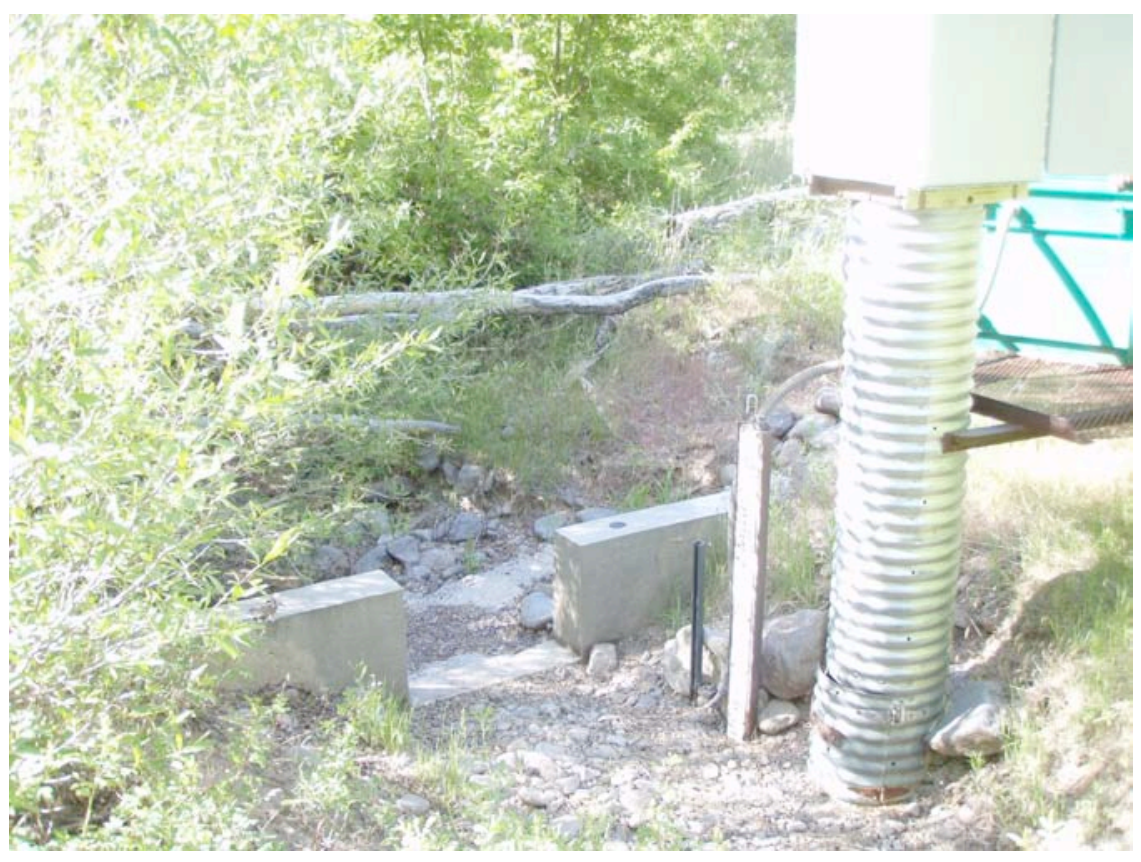




\title{
E245 Pajarito Canyon above TA-18
}

\author{
Station Analysis
}

\section{Water Year}

Equipment. Station is equipped with Sutron 8210 data logger (5-min. interval) and shaft encoder float system. The system is powered by a solar panel battery system housed in NEMA shelter on 18" CMP well on the right bank. Station is equipped with an ISCO pump sampler for water quality sample collection. ISCO is housed in a separate shelter, a $3^{\prime} \times 4^{\prime}$ metal box. Sampler is triggered by stage through the data logger. An outside staff is available for reference. No provision for direct discharge measurements above wading stages.

Field Work. The station was visited 26 times to conduct discharge measurements and service the instrumentation. Field inspections for the gage are listed under site history files on the Hydstra database. Discharge measurements for the gage are listed under site gauging files on the Hydstra database.

Datum Correction. None. Levels run May 12, 2008, show gage to be reading within allowable limits.

Gage-Height Record. The data logger referenced to the outside staff gage gave a complete and satisfactory record, except for the periods from October 1-14, May 4 to June 15, June 19-23, and August 17 to September 10 when the data logger malfunctioned.

Rating. The channel is straight for $100^{\prime}$ above and below gage. Bed material is gravel with fine sand movement during flow events. Control is a concrete broad-crested weir.

Twenty-six inspections of no flow were made this year.

Rating No. 2 was used all year.

Discharge. Discharge was computed by applying Rating No. 2 using V shift diagrams. Long periods of lost record were estimated at zero flow based on precipitation and nearby gage stations.

Remarks. Records are good. 


\section{E245 Pajarito $C$ an yon above TA-18}

Daily Mean Discharge in Cubic Feet per Second

Water Year October 2008 to September 2009

\begin{tabular}{|c|c|c|c|c|c|c|c|c|c|c|c|c|}
\hline DAY & ОСТ & NOV & DEC & JAN & FEB & MAR & APR & MAY & JUN & JUL & $A U G$ & SEP \\
\hline 1 & $0^{*}$ & 0 & 0 & 0 & 0 & 0 & 0 & .05 & $0^{*}$ & 0 & 0 & $0^{*}$ \\
\hline 2 & $0^{*}$ & 0 & 0 & 0 & 0 & 0 & 0 & .04 & $0^{*}$ & 0 & 0 & $0^{*}$ \\
\hline 3 & $0^{*}$ & 0 & 0 & 0 & 0 & 0 & 0 & 0 & $0^{*}$ & 0 & 0 & $0^{*}$ \\
\hline 4 & $0^{*}$ & 0 & 0 & 0 & 0 & 0 & 0 & $0^{*}$ & $0^{*}$ & 0 & 0 & $0^{*}$ \\
\hline 5 & $0^{*}$ & 0 & 0 & 0 & 0 & 0 & 0 & $0^{*}$ & $0^{*}$ & 0 & 0 & $0^{*}$ \\
\hline 6 & $0^{*}$ & 0 & 0 & 0 & 0 & 0 & 0 & $0^{*}$ & $0^{*}$ & .37 & 0 & $0^{*}$ \\
\hline 7 & $0^{*}$ & 0 & 0 & 0 & 0 & 0 & 0 & $0^{*}$ & $0^{*}$ & 0 & 0 & $0^{*}$ \\
\hline 8 & $0^{*}$ & 0 & 0 & 0 & 0 & 0 & 0 & $0^{*}$ & $0^{*}$ & 0 & 0 & $0^{*}$ \\
\hline 9 & $0^{*}$ & 0 & 0 & 0 & 0 & 0 & 0 & $0^{*}$ & $0^{*}$ & 0 & 0 & $0^{*}$ \\
\hline 10 & $0^{*}$ & 0 & 0 & 0 & 0 & 0 & 0 & $0^{*}$ & $0^{*}$ & 0 & 0 & $0^{*}$ \\
\hline 11 & $0^{*}$ & 0 & 0 & 0 & 0 & 0 & 0 & $0^{*}$ & $0^{*}$ & 0 & 0 & 0 \\
\hline 12 & $0^{*}$ & 0 & 0 & 0 & 0 & 0 & 0 & $0^{*}$ & $0^{*}$ & 0 & 0 & 0 \\
\hline 13 & $0^{*}$ & 0 & 0 & 0 & 0 & 0 & 0 & $0^{*}$ & $0^{*}$ & 0 & 0 & 0 \\
\hline 14 & $0^{*}$ & 0 & 0 & 0 & 0 & 0 & 0 & $0^{*}$ & $0^{*}$ & 0 & 0 & 0 \\
\hline 15 & 0 & 0 & 0 & 0 & 0 & 0 & 0 & $0^{*}$ & $0^{*}$ & 0 & 0 & 0 \\
\hline 16 & 0 & 0 & 0 & 0 & 0 & 0 & 0 & $0^{*}$ & 0 & 0 & 0 & 0 \\
\hline 17 & 0 & 0 & 0 & 0 & 0 & 0 & 0 & $0^{*}$ & 0 & 0 & $0^{*}$ & 0 \\
\hline 18 & 0 & 0 & 0 & 0 & 0 & 0 & 0 & $0^{*}$ & 0 & 0 & $0^{*}$ & 0 \\
\hline 19 & 0 & 0 & 0 & 0 & 0 & 0 & 0 & $0^{*}$ & $0^{*}$ & 0 & $0^{*}$ & 0 \\
\hline 20 & 0 & 0 & 0 & 0 & 0 & 0 & 0 & $0^{*}$ & $0^{*}$ & 0 & $0^{*}$ & 0 \\
\hline 21 & 0 & 0 & 0 & 0 & 0 & 0 & 0 & $0^{*}$ & $0^{*}$ & 0 & $0^{*}$ & 0 \\
\hline 22 & 0 & 0 & 0 & 0 & 0 & 0 & 0 & $0^{*}$ & $0^{*}$ & 0 & $0^{*}$ & 0 \\
\hline 23 & 0 & 0 & 0 & 0 & 0 & 0 & 0 & $0^{*}$ & $0^{*}$ & 0 & $0^{*}$ & 0 \\
\hline 24 & 0 & 0 & 0 & 0 & 0 & 0 & 0 & $0^{*}$ & 0 & 0 & $0^{*}$ & 0 \\
\hline 25 & 0 & 0 & 0 & 0 & 0 & 0 & 0 & $0^{*}$ & 0 & 0 & $0^{*}$ & 0 \\
\hline 26 & 0 & 0 & 0 & 0 & 0 & 0 & 0 & $0^{*}$ & 0 & 0 & $0^{*}$ & 0 \\
\hline 27 & 0 & 0 & 0 & 0 & 0 & 0 & 0 & $0^{*}$ & 0 & 0 & $0^{*}$ & 0 \\
\hline 28 & 0 & 0 & 0 & 0 & 0 & 0 & 0 & $0^{*}$ & 0 & 0 & $0^{*}$ & 0 \\
\hline 29 & 0 & 0 & 0 & 0 & ---- & 0 & .06 & $0^{*}$ & 0 & 0 & $0^{*}$ & 0 \\
\hline 30 & 0 & 0 & 0 & 0 & --- & 0 & .07 & $0^{*}$ & 0 & .07 & $0^{*}$ & 0 \\
\hline 31 & 0 & --- & 0 & 0 & --- & 0 & --- & $0^{*}$ & ---- & 0 & $0^{*}$ & ---- \\
\hline Total & 0 & 0 & 0 & 0 & 0 & 0 & 0.13 & 0.09 & 0 & 0.44 & 0 & 0 \\
\hline Mean & 0 & 0 & 0 & 0 & 0 & 0 & .004 & .003 & 0 & .014 & 0 & 0 \\
\hline $\operatorname{Max}$ & 0 & 0 & 0 & 0 & 0 & 0 & .07 & .05 & 0 & .37 & 0 & 0 \\
\hline Min & 0 & 0 & 0 & 0 & 0 & 0 & 0 & 0 & 0 & 0 & 0 & 0 \\
\hline Acre-F t & 0 & 0 & 0 & 0 & 0 & 0 & .26 & .18 & 0 & .87 & 0 & 0 \\
\hline Wtr Year & 2009 & Total & 0.66 & Mean & & 02 & Max & .37 & Min & 0 & Acre-Ft & 1.3 \\
\hline Cal Year & 2008 & Total & 93.65 & Mean & & 26 & Max & 4.6 & Min & 0 & Acre- $\mathrm{Ft}$ & 186 \\
\hline
\end{tabular}

${ }^{*}$ Estimate 


\section{E2455 Pajarito Canyon above Three Mile Canyon}

Location. Lat $35^{\circ}$ 50' 45.3", long $106^{\circ} 16^{\prime}$ 29", Sec. 16, T. 19N., R. 6 E., Ramon Vigil Grant, Los Alamos County.

Drainage Area. $7.81 \mathrm{mi}^{2}$.

Period of Record. October 1, 2002, to September 30, 2009.

Revisions. Drainage Area (2008).

Gage. Data logger and cellular telemetry and rain gage. Elevation of gage is $6,796 \mathrm{ft}$ from LIDAR DEM.

Remarks. Records are good.

Average Discharge. $7 \mathrm{yr}, 0.20 \mathrm{ft}^{3} / \mathrm{s}, 146$ acre- $\mathrm{ft} / \mathrm{yr}$.

Extremes for Period of Record. Maximum discharge, $228 \mathrm{ft}^{3} / \mathrm{s}$, August 24, 2005, gage height $2.86 \mathrm{ft}$.

Extremes for Current Year. No flow for the year.

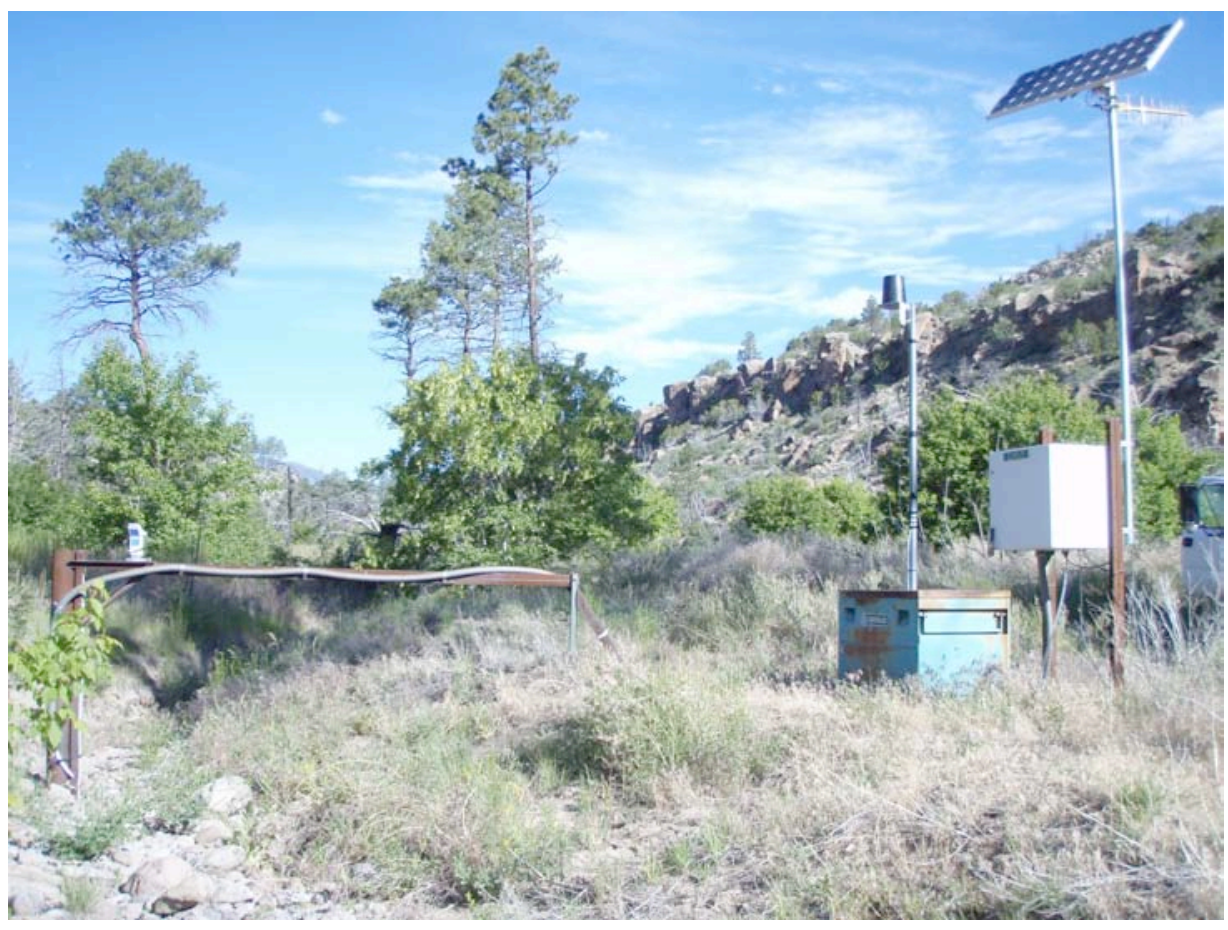




\title{
E2455 Pajarito Canyon above Three Mile Canyon
}

\author{
Station Analysis
}

\section{Water Year}

Equipment. Station is equipped with Sutron 8210 data logger (5-min. interval) and Milltronics sonic probe and cellular telemetry with speech modem. The system is powered by a solar panel battery system housed in NEMA shelter. Station is equipped with an ISCO pump sampler for water quality sample collection. ISCO is housed in a separate shelter, a $3^{\prime} \times 4^{\prime}$ metal box. Sampler is triggered by stage through the data logger. An outside staff is available for reference. No provision for direct discharge measurements above wading stages.

Station is also equipped with a tipping bucket rain gage, Rain Collection II. All equipment is powered with a solar panel battery charging system.

Field Work. The station was visited 21 times to conduct discharge measurements and service the instrumentation. Field inspections for the gage are listed under site history files on the Hydstra database. Discharge measurements for the gage are listed under site gauging files on the Hydstra database.

Datum Correction. Levels run May 12, 2008, show gage within limits.

Gage-Height Record. The data logger referenced to the outside staff gage gave a complete and satisfactory record for the year.

Rating. The channel is straight for $80^{\prime}$ above and below gage. Banks have some vegetation, and streambed is sand and gravel.

Twenty-one inspections of no flow were made this year.

Rating No. 4 was developed from previous measurements and one critical depth computation.

Discharge. Discharge was computed by applying Rating No. 4 directly.

Remarks. Records are good. The records for 2007 are available but are not reliable. 
E2455 Pajarito Canyon above Three Mile Canyon

Daily Mean Discharge in Cubic Feet per Second

Water Year October 2008 to September 2009

\begin{tabular}{|c|c|c|c|c|c|c|c|c|c|c|c|c|}
\hline DAY & OCT & NOV & DEC & JAN & FEB & MAR & APR & MAY & JUN & JUL & AUG & SEP \\
\hline 1 & 0 & 0 & 0 & 0 & 0 & 0 & 0 & 0 & 0 & 0 & 0 & 0 \\
\hline 2 & 0 & 0 & 0 & 0 & 0 & 0 & 0 & 0 & 0 & 0 & 0 & 0 \\
\hline 3 & 0 & 0 & 0 & 0 & 0 & 0 & 0 & 0 & 0 & 0 & 0 & 0 \\
\hline 4 & 0 & 0 & 0 & $0^{*}$ & 0 & 0 & 0 & 0 & 0 & 0 & 0 & 0 \\
\hline 5 & 0 & 0 & 0 & $0^{*}$ & 0 & 0 & 0 & 0 & 0 & 0 & 0 & 0 \\
\hline 6 & 0 & 0 & 0 & $0^{*}$ & 0 & 0 & 0 & 0 & 0 & 0 & 0 & 0 \\
\hline 7 & 0 & 0 & 0 & $0^{*}$ & 0 & 0 & 0 & 0 & 0 & 0 & 0 & 0 \\
\hline 8 & 0 & 0 & 0 & $0^{*}$ & 0 & 0 & 0 & 0 & 0 & 0 & 0 & 0 \\
\hline 9 & 0 & 0 & $0^{*}$ & $0^{*}$ & 0 & 0 & 0 & 0 & 0 & 0 & 0 & 0 \\
\hline 10 & 0 & 0 & $0^{*}$ & $0^{*}$ & 0 & 0 & 0 & 0 & 0 & 0 & 0 & 0 \\
\hline 11 & 0 & 0 & $0^{*}$ & $0^{*}$ & 0 & 0 & 0 & 0 & 0 & 0 & 0 & 0 \\
\hline 12 & 0 & 0 & $0^{*}$ & $0^{*}$ & 0 & 0 & 0 & 0 & 0 & 0 & 0 & 0 \\
\hline 13 & 0 & 0 & $0^{*}$ & $0^{*}$ & 0 & 0 & 0 & 0 & 0 & 0 & 0 & 0 \\
\hline 14 & 0 & 0 & $0^{*}$ & 0 & 0 & 0 & 0 & 0 & 0 & 0 & 0 & 0 \\
\hline 15 & 0 & 0 & $0^{*}$ & 0 & 0 & 0 & 0 & 0 & 0 & 0 & 0 & 0 \\
\hline 16 & 0 & 0 & $0^{*}$ & 0 & 0 & 0 & 0 & 0 & 0 & 0 & 0 & $0^{*}$ \\
\hline 17 & 0 & 0 & $0^{*}$ & 0 & 0 & 0 & $0^{*}$ & 0 & 0 & 0 & 0 & $0^{*}$ \\
\hline 18 & 0 & 0 & $0^{*}$ & 0 & 0 & 0 & 0 & 0 & 0 & 0 & 0 & $0^{*}$ \\
\hline 19 & 0 & 0 & $0^{*}$ & 0 & 0 & 0 & 0 & 0 & 0 & 0 & 0 & $0^{*}$ \\
\hline 20 & 0 & 0 & $0^{*}$ & 0 & 0 & 0 & 0 & 0 & 0 & 0 & 0 & $0^{*}$ \\
\hline 21 & 0 & 0 & $0^{*}$ & 0 & 0 & 0 & 0 & 0 & 0 & 0 & 0 & $0^{*}$ \\
\hline 22 & 0 & 0 & $0^{*}$ & 0 & 0 & 0 & 0 & 0 & 0 & 0 & 0 & 0 \\
\hline 23 & 0 & 0 & $0^{*}$ & 0 & 0 & 0 & 0 & 0 & 0 & 0 & 0 & 0 \\
\hline 24 & 0 & 0 & $0^{*}$ & 0 & 0 & 0 & 0 & 0 & 0 & 0 & 0 & 0 \\
\hline 25 & 0 & 0 & $0^{*}$ & 0 & 0 & 0 & 0 & 0 & 0 & 0 & 0 & 0 \\
\hline 26 & 0 & 0 & $0^{*}$ & 0 & 0 & $0^{*}$ & 0 & 0 & 0 & 0 & 0 & 0 \\
\hline 27 & 0 & 0 & $0^{*}$ & 0 & 0 & 0 & 0 & 0 & 0 & 0 & 0 & 0 \\
\hline 28 & 0 & 0 & 0 & 0 & 0 & 0 & 0 & 0 & 0 & 0 & 0 & 0 \\
\hline 29 & 0 & 0 & 0 & 0 & ----- & 0 & 0 & 0 & 0 & 0 & 0 & 0 \\
\hline 30 & 0 & 0 & 0 & 0 & --.-- & 0 & 0 & 0 & 0 & 0 & 0 & 0 \\
\hline 31 & 0 & ----- & 0 & 0 & ----- & 0 & ----- & 0 & ---- & 0 & 0 & ---- \\
\hline Total & 0 & 0 & 0 & 0 & 0 & 0 & 0 & 0 & 0 & 0 & 0 & 0 \\
\hline Mean & 0 & 0 & 0 & 0 & 0 & 0 & 0 & 0 & 0 & 0 & 0 & 0 \\
\hline Max & 0 & 0 & 0 & 0 & 0 & 0 & 0 & 0 & 0 & 0 & 0 & 0 \\
\hline Min & 0 & 0 & 0 & 0 & 0 & 0 & 0 & 0 & 0 & 0 & 0 & 0 \\
\hline Acre-F t & 0 & 0 & 0 & 0 & 0 & 0 & 0 & 0 & 0 & 0 & 0 & 0 \\
\hline Wtr Year & 2009 & Total & 0 & Mean & & 0 & Max & 0 & Min & 0 & Acre-Ft & 0 \\
\hline Cal Year & 2008 & Total & 91.85 & Mean & & .25 & Max & 14 & Min & 0 & Acre- $\mathrm{Ft}$ & 182 \\
\hline
\end{tabular}

${ }^{*}$ Estimate 


\section{E246 Three Mile Canyon above Pajarito Canyon}

Location. Lat $35^{\circ}$ 50' 20", long $106^{\circ}$ 16' 17", Sec. 35, T. 19 N., R. 6 E., Ramon Vigil Grant, Los Alamos County.

Drainage Area. $1.62 \mathrm{mi}^{2}$.

Period of Record. October 1998 to September 30, 2009.

Revised Record. Drainage Area (2006).

Gage. Data logger and 9" Parshall flume with cellular telemetry. Elevation of gage is 6,755 ft above NGVD.

Remarks. Records are good.

Average Discharge. $11 \mathrm{yr}, 0.02 \mathrm{ft}^{3} / \mathrm{s}, 12$ acre-ft/yr.

Extremes for Period of Record. Maximum discharge, $536 \mathrm{ft}^{3} / \mathrm{s}$ August 25, 2006, gage height $3.50 \mathrm{ft}$ from critical dept computation of peak flow. No flow most of the time.

Extremes for Current Year. Maximum discharge, $0.04 \mathrm{ft}^{3} / \mathrm{s}$ at $0745 \mathrm{~h}$, August 10, gage height of $0.40 \mathrm{ft}$. No peak discharge above base of $1.0 \mathrm{ft}^{3} / \mathrm{s}$. Minimal flow during the year. No flow most of the time.

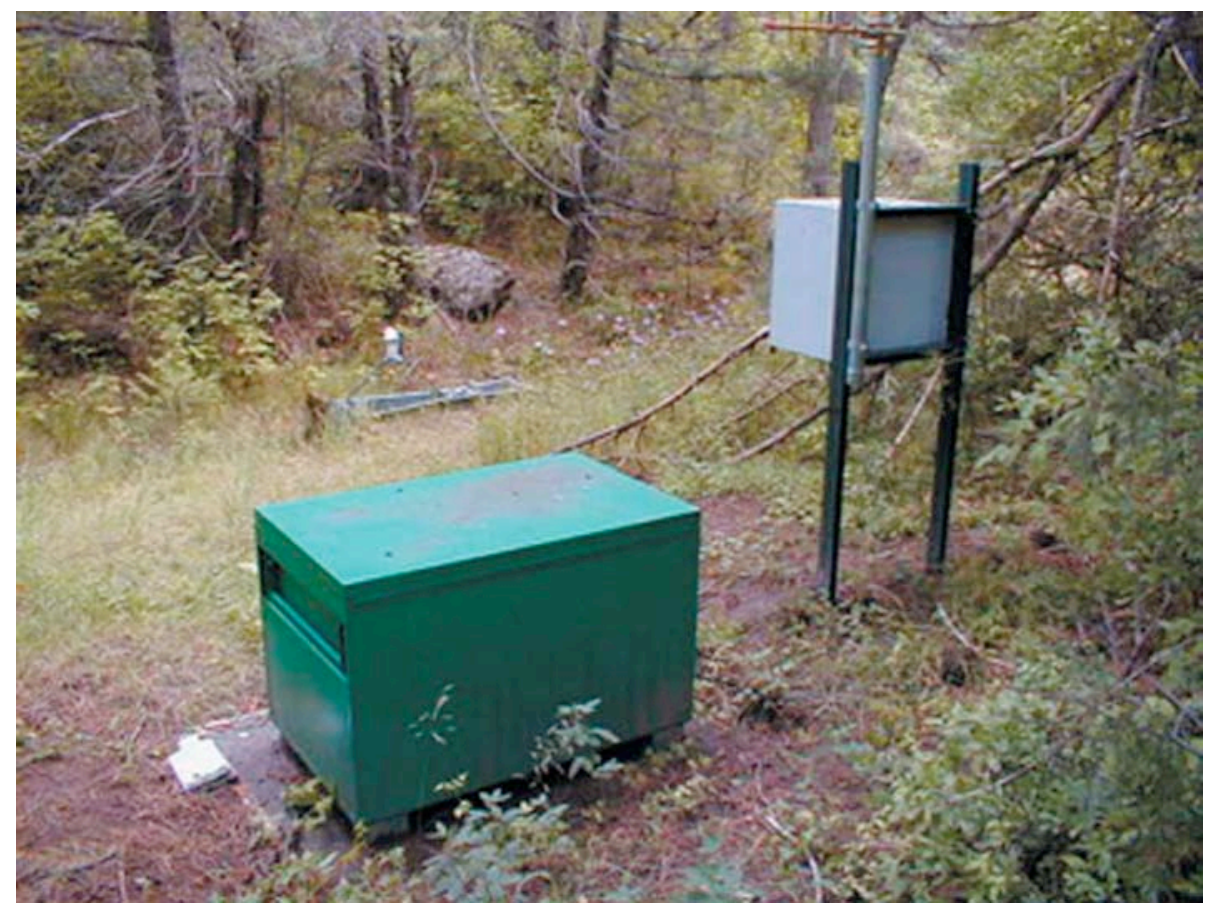




\title{
E246 Three Mile Canyon above Pajarito Canyon
}

\author{
Station Analysis
}

\section{Water Year}

Equipment. Station is equipped with Sutron 8210 data logger (5-min. interval) and Milltronics sonic probe mounted on 9" Parshall flume and cellular telemetry with speech modem. The system is powered by a solar panel battery system housed in a NEMA shelter on right bank. Station is equipped with an ISCO pump sampler for water quality sample collection. ISCO is housed in a separate shelter, a $3^{\prime} \times 4^{\prime}$ metal box. Sampler is triggered by stage through the data logger. The staff in the 9" Parshall flume is the reference gage. There is no provision for direct discharge measurements above wading stage.

Field Work. The station was visited 18 times to conduct discharge measurements and service the instrumentation. Field inspections for the gage are listed under site history files on the Hydstra database. Discharge measurements for the gage are listed under site gauging files on the Hydstra database.

Datum Correction. None.

Gage-Height Record. The data logger referenced to the outside staff gave a complete and satisfactory record except for the periods from December 9, January 13, March 2628, and April 11, 17 when gage height was affected by ice.

Rating. The channel is straight above and below gage. It is confined to the main channel by cut banks on both sides. The bottom is $10^{\prime}$ wide, channel prone to some shifting with vegetation on each bank. Low-water control is the 9" Parshall flume.

Eighteen inspections of now flow were made this year.

Rating No. 1 was developed based on the computation of 9" Parshall flume and was extended on the basis of two critical depth computations. Point of zero flow is 0.00 gage height.

Discharge. Discharge was computed by applying gage height to Rating No. 1 directly.

Remarks. Records are good. 


\section{E246 Three M ile Canyon above $P$ ajarito $C$ an yon}

Daily Mean Discharge in Cubic Feet per Second

Water Year October 2008 to September 2009

\begin{tabular}{|c|c|c|c|c|c|c|c|c|c|c|c|c|}
\hline DAY & OCT & NOV & DEC & JAN & FEB & MAR & APR & MAY & JUN & JUL & AUG & SEP \\
\hline 1 & 0 & 0 & 0 & $0^{*}$ & 0 & 0 & 0 & 0 & 0 & 0 & 0 & 0 \\
\hline 2 & 0 & 0 & 0 & $0^{*}$ & 0 & 0 & 0 & 0 & 0 & 0 & 0 & 0 \\
\hline 3 & 0 & 0 & 0 & $0^{*}$ & 0 & 0 & 0 & 0 & 0 & 0 & 0 & 0 \\
\hline 4 & 0 & 0 & 0 & $0^{*}$ & 0 & 0 & 0 & 0 & 0 & 0 & 0 & 0 \\
\hline 5 & 0 & 0 & 0 & $0^{*}$ & 0 & 0 & 0 & 0 & 0 & 0 & 0 & 0 \\
\hline 6 & 0 & 0 & 0 & $0^{*}$ & 0 & 0 & 0 & 0 & 0 & 0 & 0 & 0 \\
\hline 7 & 0 & 0 & 0 & $0^{*}$ & 0 & 0 & 0 & 0 & 0 & 0 & 0 & 0 \\
\hline 8 & 0 & 0 & 0 & $0^{*}$ & 0 & 0 & 0 & 0 & 0 & 0 & 0 & 0 \\
\hline 9 & 0 & 0 & $0^{*}$ & $0^{*}$ & 0 & 0 & 0 & 0 & 0 & 0 & 0 & 0 \\
\hline 10 & 0 & 0 & $0^{*}$ & $0^{*}$ & 0 & 0 & 0 & 0 & 0 & 0 & 0 & 0 \\
\hline 11 & 0 & 0 & $0^{*}$ & $0^{*}$ & 0 & 0 & $0^{*}$ & 0 & 0 & 0 & 0 & 0 \\
\hline 12 & 0 & 0 & $0^{*}$ & $0^{*}$ & 0 & 0 & 0 & 0 & 0 & 0 & 0 & 0 \\
\hline 13 & 0 & 0 & $0^{*}$ & $0^{*}$ & 0 & 0 & 0 & 0 & 0 & 0 & 0 & 0 \\
\hline 14 & 0 & 0 & $0^{*}$ & 0 & 0 & 0 & 0 & 0 & 0 & 0 & 0 & 0 \\
\hline 15 & 0 & 0 & $0^{*}$ & 0 & 0 & 0 & 0 & 0 & 0 & 0 & 0 & 0 \\
\hline 16 & 0 & 0 & $0^{*}$ & 0 & 0 & 0 & 0 & 0 & 0 & 0 & 0 & 0 \\
\hline 17 & 0 & 0 & $0^{*}$ & 0 & 0 & 0 & $0^{*}$ & 0 & 0 & 0 & 0 & 0 \\
\hline 18 & 0 & 0 & $0^{*}$ & 0 & 0 & 0 & 0 & 0 & 0 & 0 & 0 & 0 \\
\hline 19 & 0 & 0 & $0^{*}$ & 0 & 0 & 0 & 0 & 0 & 0 & 0 & 0 & 0 \\
\hline 20 & 0 & 0 & $0^{*}$ & 0 & 0 & 0 & 0 & 0 & 0 & 0 & 0 & 0 \\
\hline 21 & 0 & 0 & $0^{*}$ & 0 & 0 & 0 & 0 & 0 & 0 & 0 & 0 & 0 \\
\hline 22 & 0 & 0 & $0^{*}$ & 0 & 0 & 0 & 0 & .01 & 0 & 0 & 0 & 0 \\
\hline 23 & 0 & 0 & $0^{*}$ & 0 & 0 & 0 & 0 & .01 & 0 & 0 & 0 & 0 \\
\hline 24 & 0 & 0 & $0^{*}$ & 0 & 0 & 0 & 0 & 0 & 0 & 0 & 0 & 0 \\
\hline 25 & 0 & 0 & $0^{*}$ & 0 & 0 & 0 & 0 & 0 & 0 & 0 & 0 & 0 \\
\hline 26 & 0 & 0 & $0^{*}$ & 0 & 0 & $0^{*}$ & 0 & 0 & 0 & 0 & 0 & 0 \\
\hline 27 & 0 & 0 & $0^{*}$ & 0 & 0 & $0^{*}$ & 0 & 0 & 0 & 0 & 0 & 0 \\
\hline 28 & 0 & 0 & $0^{*}$ & 0 & 0 & $0^{*}$ & 0 & 0 & 0 & 0 & 0 & 0 \\
\hline 29 & 0 & 0 & $0^{*}$ & 0 & -.--- & 0 & 0 & 0 & 0 & 0 & 0 & 0 \\
\hline 30 & 0 & 0 & $0^{*}$ & 0 & ---- & 0 & 0 & 0 & 0 & 0 & 0 & 0 \\
\hline 31 & 0 & ---- & $0^{*}$ & 0 & ---- & 0 & ----- & 0 & ---- & 0 & 0 & ----- \\
\hline Total & 0 & 0 & 0 & 0 & 0 & 0 & 0 & 0.02 & 0 & 0 & 0 & 0 \\
\hline Mean & 0 & 0 & 0 & 0 & 0 & 0 & 0 & .001 & 0 & 0 & 0 & 0 \\
\hline Max & 0 & 0 & 0 & 0 & 0 & 0 & 0 & .01 & 0 & 0 & 0 & 0 \\
\hline Min & 0 & 0 & 0 & 0 & 0 & 0 & 0 & 0 & 0 & 0 & 0 & 0 \\
\hline Acre-Ft & 0 & 0 & 0 & 0 & 0 & 0 & 0 & .04 & 0 & 0 & 0 & 0 \\
\hline Wtr Year & 2009 & Total & 0.02 & Mean & & 0 & Max & .01 & Min & 0 & Acre-Ft & .04 \\
\hline Cal Year & 2008 & Total & 12.84 & Mean & & 035 & $\operatorname{Max}$ & 1.8 & Min & 0 & Acre- $\mathrm{Ft}$ & 25 \\
\hline
\end{tabular}

${ }^{\star}$ Estimate 


\section{E247 MDA G-1}

Location. Lat $35^{\circ}$ 49' 51", long $106^{\circ}$ 14' 41", Sec. 31, T. 19 N., R. 7 E., Ramon Vigil Grant, Los Alamos County.

Drainage Area. $0.002 \mathrm{mi}^{2}$.

Period of Record. October 1, 2004, to September 30, 2009.

Gage. Data logger and 9" Parshall flume. Elevation of gage is 6,626 ft above NGVD.

Remarks. Records are good. Records for this site existed before period of record but are not reliable. Legal location based on projected values.

Extremes for Period of Record. Maximum discharge, $0.94 \mathrm{ft}^{3} / \mathrm{s}$, September 23, 2007 , gage height $0.46 \mathrm{ft}$. No flow most of the time.

Extremes for Current Year. Maximum discharge, $0.51 \mathrm{ft}^{3} / \mathrm{s}$ at $1525 \mathrm{~h}$, October 11 , gage height $0.31 \mathrm{ft}$. No peak discharge above base of $1.0 \mathrm{ft}^{3} / \mathrm{s}$. No flow most of the time.

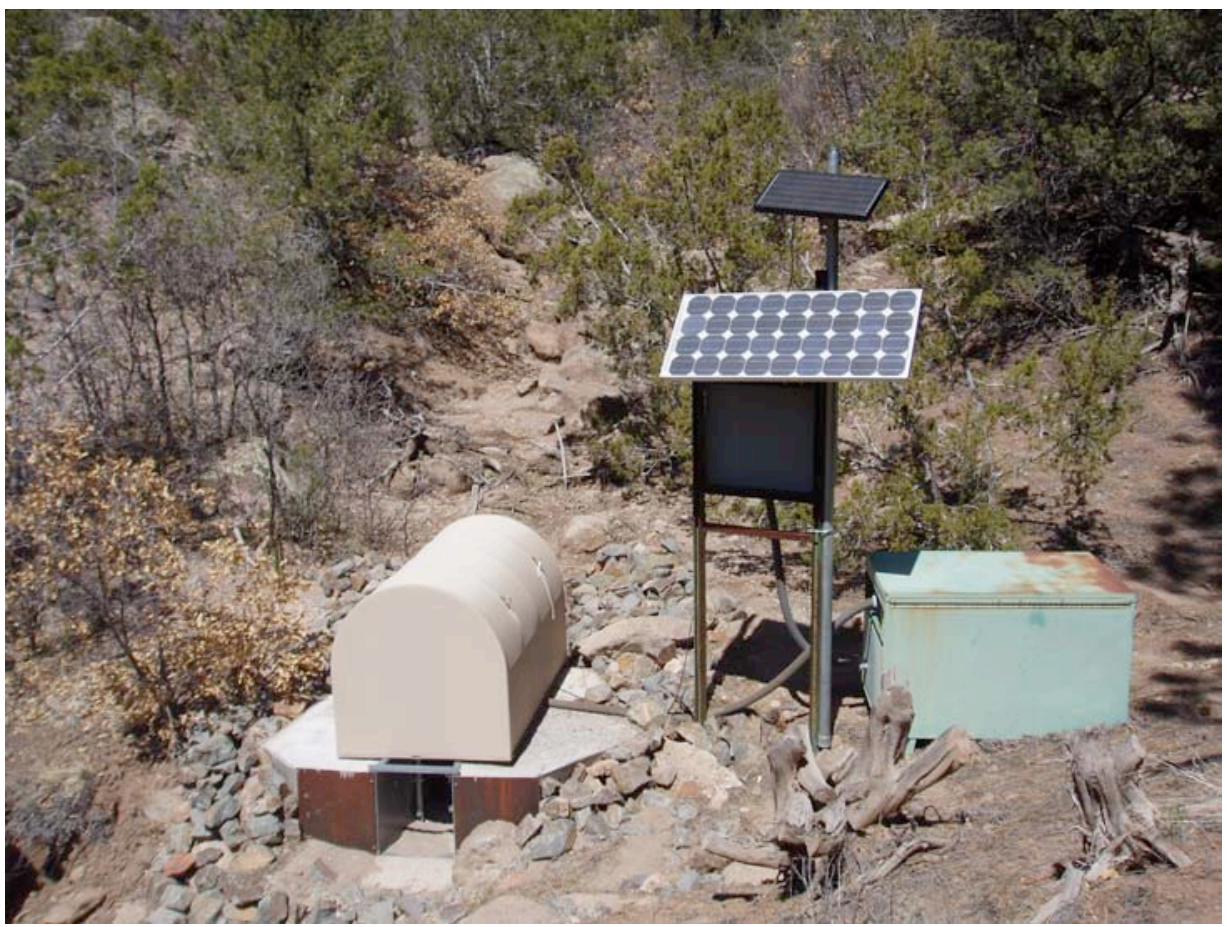




\section{E247 MDA G-1}

\section{Station Analysis}

\section{Water Year}

Equipment. Station is equipped with Sutron 8210 data logger (5-min. interval) and Milltronics sonic probe mounted on a 9" Parshall flume. The system is powered by a solar panel battery system housed in a NEMA shelter. Station is equipped with an ISCO pump sampler for water quality sample collection. ISCO is housed in a separate shelter, a $3^{\prime} \times 4^{\prime}$ metal box. Sampler is triggered by stage through the data logger. The staff in the 9" Parshall flume is the reference gage. No provision for discharge measurements above wading stage. All high measurements will be by slope area or peak flow computation methods.

Field Work. This station was visited 12 times to conduct discharge measurements and service the instrumentation. Field inspections for the gage are listed under site history files on the Hydstra database. Discharge measurements for the gage are listed under site gauging files on the Hydstra database.

Datum Correction. None.

Gage-Height Record. The data logger referenced to the outside staff gave a complete and satisfactory record.

Rating. The channel is straight $30^{\prime}$ upstream with sand and gravel. The channel downstream from the flume is $40^{\prime}$ long with vegetation on both banks. Streambed is sand and gravel. The control for this station is the 9" Parshall flume.

Twelve inspections of no flow were made this year.

Rating No. 1 was developed based on the computation of 9" Parshall flume. Point of zero flow is 0.00 gage height.

Discharge. Discharge was computed by applying gage height to Rating No. 1 directly.

Remarks. Records are good. 


\section{E247 MD A G-1}

Daily Mean Discharge in Cubic Feet per Second

Water Year October 2008 to September 2009

\begin{tabular}{|c|c|c|c|c|c|c|c|c|c|c|c|c|}
\hline DAY & OCT & NOV & DEC & JAN & FEB & MAR & APR & MAY & JUN & JUL & AUG & SEP \\
\hline 1 & 0 & 0 & 0 & 0 & 0 & 0 & 0 & 0 & 0 & 0 & 0 & 0 \\
\hline 2 & 0 & 0 & 0 & 0 & 0 & 0 & 0 & 0 & 0 & 0 & 0 & 0 \\
\hline 3 & 0 & 0 & 0 & 0 & 0 & 0 & 0 & 0 & 0 & 0 & 0 & 0 \\
\hline 4 & 0 & 0 & 0 & 0 & 0 & 0 & 0 & 0 & 0 & 0 & 0 & 0 \\
\hline 5 & 0 & 0 & 0 & 0 & 0 & 0 & 0 & 0 & 0 & 0 & 0 & 0 \\
\hline 6 & 0 & 0 & 0 & 0 & 0 & 0 & 0 & 0 & 0 & 0 & 0 & 0 \\
\hline 7 & 0 & 0 & 0 & 0 & 0 & 0 & 0 & 0 & 0 & 0 & 0 & 0 \\
\hline 8 & 0 & 0 & 0 & 0 & 0 & 0 & 0 & 0 & 0 & 0 & 0 & 0 \\
\hline 9 & 0 & 0 & 0 & 0 & 0 & 0 & 0 & 0 & 0 & 0 & 0 & 0 \\
\hline 10 & 0 & 0 & 0 & 0 & 0 & 0 & 0 & 0 & 0 & 0 & 0 & 0 \\
\hline 11 & .01 & 0 & 0 & 0 & 0 & 0 & 0 & 0 & 0 & 0 & 0 & 0 \\
\hline 12 & 0 & 0 & 0 & 0 & 0 & 0 & 0 & 0 & 0 & 0 & 0 & 0 \\
\hline 13 & 0 & 0 & 0 & 0 & 0 & 0 & 0 & 0 & 0 & 0 & 0 & 0 \\
\hline 14 & 0 & 0 & 0 & 0 & 0 & 0 & 0 & 0 & 0 & 0 & 0 & 0 \\
\hline 15 & 0 & 0 & 0 & 0 & 0 & 0 & 0 & 0 & 0 & 0 & 0 & 0 \\
\hline 16 & 0 & 0 & 0 & 0 & 0 & 0 & 0 & 0 & 0 & 0 & 0 & 0 \\
\hline 17 & 0 & 0 & 0 & 0 & 0 & 0 & 0 & 0 & 0 & 0 & 0 & 0 \\
\hline 18 & 0 & 0 & 0 & 0 & 0 & 0 & 0 & 0 & 0 & 0 & 0 & 0 \\
\hline 19 & 0 & 0 & 0 & 0 & 0 & 0 & 0 & 0 & 0 & 0 & 0 & 0 \\
\hline 20 & 0 & 0 & 0 & 0 & 0 & 0 & 0 & 0 & 0 & 0 & 0 & 0 \\
\hline 21 & 0 & 0 & 0 & 0 & 0 & 0 & 0 & 0 & 0 & 0 & 0 & 0 \\
\hline 22 & 0 & 0 & 0 & 0 & 0 & 0 & 0 & 0 & 0 & 0 & 0 & 0 \\
\hline 23 & 0 & 0 & 0 & 0 & 0 & 0 & 0 & 0 & 0 & 0 & 0 & 0 \\
\hline 24 & 0 & 0 & 0 & 0 & 0 & 0 & 0 & 0 & 0 & 0 & 0 & 0 \\
\hline 25 & 0 & 0 & 0 & 0 & 0 & 0 & 0 & 0 & 0 & 0 & 0 & 0 \\
\hline 26 & 0 & 0 & 0 & 0 & 0 & 0 & 0 & 0 & 0 & 0 & 0 & 0 \\
\hline 27 & 0 & 0 & 0 & 0 & 0 & 0 & 0 & 0 & 0 & 0 & 0 & 0 \\
\hline 28 & 0 & 0 & 0 & 0 & 0 & 0 & 0 & 0 & 0 & 0 & 0 & 0 \\
\hline 29 & 0 & 0 & 0 & 0 & --- & 0 & 0 & 0 & 0 & 0 & 0 & 0 \\
\hline 30 & 0 & 0 & 0 & 0 & -..-- & 0 & 0 & 0 & 0 & 0 & 0 & 0 \\
\hline 31 & 0 & --.- & 0 & 0 & ---- & 0 & ----- & 0 & ---- & 0 & 0 & ---- \\
\hline Total & 0.01 & 0 & 0 & 0 & 0 & 0 & 0 & 0 & 0 & 0 & 0 & 0 \\
\hline Mean & 0 & 0 & 0 & 0 & 0 & 0 & 0 & 0 & 0 & 0 & 0 & 0 \\
\hline Max & .01 & 0 & 0 & 0 & 0 & 0 & 0 & 0 & 0 & 0 & 0 & 0 \\
\hline Min & 0 & 0 & 0 & 0 & 0 & 0 & 0 & 0 & 0 & 0 & 0 & 0 \\
\hline Acre-Ft & .02 & 0 & 0 & 0 & 0 & 0 & 0 & 0 & 0 & 0 & 0 & 0 \\
\hline Wtr Year & 2009 & Total & 0.01 & Mean & & 0 & Max & .01 & Min & 0 & Acre-Ft & .02 \\
\hline Cal Year & 2008 & Total & 0.06 & Mean & & 0 & Max & .05 & Min & 0 & Acre- $\mathrm{Ft}$ & .12 \\
\hline
\end{tabular}




\section{E248 MDA G-2}

Location. Lat $35^{\circ}$ 49' 48", long $106^{\circ}$ 14' 33", Sec. 31. T. 19 N., R. 7 E., Ramon Vigil Grant, Los Alamos County.

Drainage Area. $0.016 \mathrm{mi}^{2}$.

Period of Record. October 1, 2006, to September 30, 2009.

Gage. Data logger and 9" Parshall Flume. Elevation of gage is 6,621 ft above NGVD.

Remarks. Records are good. Records for this site existed before period of record but are not reliable. Legal location based on projected values.

Extremes for Period of Record. Maximum discharge, $4.9 \mathrm{ft}^{3} / \mathrm{s}$, January 28, 2008, gage height $1.72 \mathrm{ft}$. No flow most of the time.

Extremes for Current Year. Peak discharges above base of $1.0 \mathrm{ft}^{3} / \mathrm{s}$ and maximum (*):

\begin{tabular}{|c|c|c|c|}
\hline Date & Time & Discharge $\left(\mathbf{f t}^{\mathbf{3}} / \mathbf{s}\right)$ & Gage Height (ft) \\
\hline October 11 & 1535 & $1.40^{*}$ & $0.60^{*}$ \\
\hline
\end{tabular}

No flow most of the time.

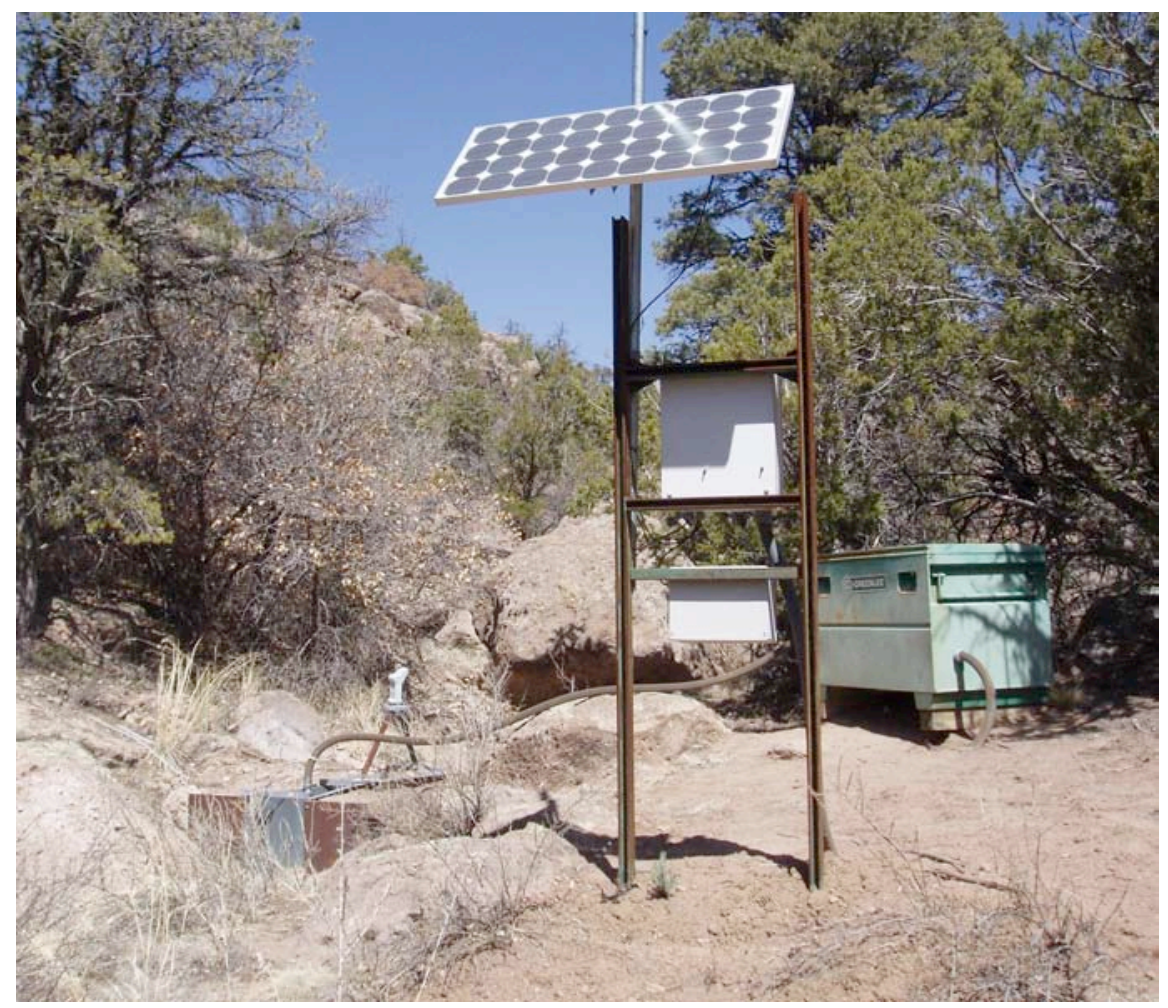




\section{E248 MDA G-2}

\section{Station Analysis}

\section{Water Year}

Equipment. Station is equipped with Sutron 8210 data logger (5-min. interval) and Milltronics sonic probe mounted on a 9" Parshall flume. The system is powered by a solar panel battery system housed in a NEMA shelter. Station is equipped with an ISCO pump sampler for water quality sample collection. ISCO is housed in a separate shelter, a $3^{\prime} \times 4^{\prime}$ metal box. Sampler is triggered by stage through the data logger. The staff in the 9" Parshall flume is the reference gage. No provision for discharge measurements above wading stage. All high measurements will be by slope area or peak flow computation methods.

Field Work. This station was visited 29 times to conduct discharge measurements and service the instrumentation. Field inspections for the gage are listed under site history files on the Hydstra database. Discharge measurements for the gage are listed under site gauging files on the Hydstra data base.

Datum Correction. None.

Gage-Height Record. The data logger referenced to the outside staff gave a complete and satisfactory record, except for the period from December 15 to January 14 when gage height was affected by ice.

Rating. The control for this station is the 9" Parshall flume. The channel is straight $30^{\prime}$ upstream with sand, gravel, and vegetation. The channel downstream from the flume is $40^{\prime}$ long with large boulders on both banks.

Twenty-nine inspections of no flow were made this year.

Rating No. 1 was developed based on the computation of 9" Parshall flume. PZF is 0.00 gage height.

Discharge. Discharge was computed by applying gage height to Rating No. 1 directly.

Remarks. Records are good. 


\section{E248 MD A G-2}

Daily Mean Discharge in Cubic Feet per Second

Water Year October 2008 to September 2009

\begin{tabular}{|c|c|c|c|c|c|c|c|c|c|c|c|c|}
\hline DAY & ОСТ & NOV & DEC & JAN & FEB & M AR & APR & MAY & JUN & JUL & AUG & SEP \\
\hline 1 & 0 & 0 & 0 & $0^{*}$ & 0 & 0 & 0 & 0 & 0 & 0 & 0 & 0 \\
\hline 2 & 0 & 0 & 0 & $0^{*}$ & 0 & 0 & 0 & 0 & 0 & 0 & 0 & 0 \\
\hline 3 & 0 & 0 & 0 & $0^{*}$ & 0 & 0 & 0 & 0 & 0 & 0 & 0 & 0 \\
\hline 4 & 0 & 0 & 0 & $0^{*}$ & 0 & 0 & 0 & 0 & 0 & 0 & 0 & 0 \\
\hline 5 & 0 & 0 & 0 & $0^{*}$ & 0 & 0 & 0 & 0 & 0 & 0 & 0 & 0 \\
\hline 6 & 0 & 0 & 0 & $0^{*}$ & 0 & 0 & 0 & 0 & 0 & 0 & 0 & 0 \\
\hline 7 & 0 & 0 & 0 & $0^{*}$ & 0 & 0 & 0 & 0 & 0 & 0 & 0 & 0 \\
\hline 8 & 0 & 0 & 0 & $0^{*}$ & 0 & 0 & 0 & 0 & 0 & 0 & 0 & 0 \\
\hline 9 & 0 & 0 & 0 & $0^{*}$ & 0 & 0 & 0 & 0 & 0 & 0 & 0 & 0 \\
\hline 10 & 0 & 0 & 0 & $0^{*}$ & 0 & 0 & 0 & 0 & 0 & 0 & 0 & 0 \\
\hline 11 & .01 & 0 & 0 & $0^{*}$ & 0 & 0 & 0 & 0 & 0 & 0 & 0 & 0 \\
\hline 12 & 0 & 0 & 0 & $0^{*}$ & 0 & 0 & 0 & 0 & 0 & 0 & 0 & 0 \\
\hline 13 & 0 & 0 & 0 & $0^{*}$ & 0 & 0 & 0 & 0 & 0 & 0 & 0 & 0 \\
\hline 14 & 0 & 0 & 0 & $0^{*}$ & 0 & 0 & 0 & 0 & 0 & 0 & 0 & 0 \\
\hline 15 & 0 & 0 & $0^{*}$ & 0 & 0 & 0 & 0 & 0 & 0 & 0 & 0 & 0 \\
\hline 16 & 0 & 0 & $0^{*}$ & 0 & 0 & 0 & 0 & 0 & 0 & 0 & 0 & 0 \\
\hline 17 & 0 & 0 & $0^{*}$ & 0 & 0 & 0 & 0 & 0 & 0 & 0 & 0 & 0 \\
\hline 18 & 0 & 0 & $0^{*}$ & 0 & 0 & 0 & 0 & 0 & 0 & 0 & 0 & 0 \\
\hline 19 & 0 & 0 & $0^{*}$ & 0 & 0 & 0 & 0 & 0 & 0 & 0 & 0 & 0 \\
\hline 20 & 0 & 0 & $0^{*}$ & 0 & 0 & 0 & 0 & 0 & 0 & 0 & 0 & 0 \\
\hline 21 & 0 & 0 & $0^{*}$ & 0 & 0 & 0 & 0 & 0 & 0 & 0 & 0 & 0 \\
\hline 22 & 0 & 0 & $0^{*}$ & 0 & 0 & 0 & 0 & 0 & 0 & 0 & 0 & 0 \\
\hline 23 & 0 & 0 & $0^{*}$ & 0 & 0 & 0 & 0 & 0 & 0 & 0 & 0 & 0 \\
\hline 24 & 0 & 0 & $0^{*}$ & 0 & 0 & 0 & 0 & 0 & 0 & 0 & 0 & 0 \\
\hline 25 & 0 & 0 & $0^{*}$ & 0 & 0 & 0 & 0 & 0 & 0 & 0 & 0 & 0 \\
\hline 26 & 0 & 0 & $0^{*}$ & 0 & 0 & 0 & 0 & 0 & 0 & 0 & 0 & 0 \\
\hline 27 & 0 & 0 & $0^{*}$ & 0 & 0 & 0 & 0 & 0 & 0 & 0 & 0 & 0 \\
\hline 28 & 0 & 0 & $0^{*}$ & 0 & 0 & 0 & 0 & 0 & 0 & 0 & 0 & 0 \\
\hline 29 & 0 & 0 & $0^{*}$ & 0 & --.-- & 0 & 0 & 0 & 0 & 0 & 0 & 0 \\
\hline 30 & 0 & 0 & $0^{*}$ & 0 & --.-- & 0 & 0 & 0 & 0 & 0 & 0 & 0 \\
\hline 31 & 0 & --.- & $0^{*}$ & 0 & --.-- & 0 & 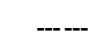 & 0 & 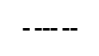 & 0 & 0 & ----- \\
\hline Total & 0.01 & 0 & 0 & 0 & 0 & 0 & 0 & 0 & 0 & 0 & 0 & 0 \\
\hline Mean & 0 & 0 & 0 & 0 & 0 & 0 & 0 & 0 & 0 & 0 & 0 & 0 \\
\hline $\operatorname{Max}$ & .01 & 0 & 0 & 0 & 0 & 0 & 0 & 0 & 0 & 0 & 0 & 0 \\
\hline Min & 0 & 0 & 0 & 0 & 0 & 0 & 0 & 0 & 0 & 0 & 0 & 0 \\
\hline Acre-F t & .02 & 0 & 0 & 0 & 0 & 0 & 0 & 0 & 0 & 0 & 0 & 0 \\
\hline Wtr Year & 2009 & Total & 0.01 & Mean & & 0 & $\operatorname{Max}$ & .01 & Min & 0 & Acre- $\mathrm{Ft}$ & .02 \\
\hline Cal Year & 2008 & Total & 0.03 & Mean & & 0 & Max & .02 & Min & 0 & Acre- $\mathrm{Ft}$ & .06 \\
\hline
\end{tabular}




\section{E2485 MDA G-6U}

Location. Lat $35^{\circ}$ 49' 45", long $106^{\circ}$ 14' 12", Sec. 31, T. 19 N., R. 7 E., Ramon Vigil Grant, Los Alamos County.

Drainage Area. $0.03 \mathrm{mi}^{2}$.

Period of Record. October 1, 2006, to September 30, 2009.

Gage. Data logger and 9" Parshall flume. Elevation of gage is 6,602 ft above NGVD.

Remarks. Records are good. Records for this site existed before period of record but are not reliable. Legal location based on projected values.

Extremes for Period of Record. Maximum discharge, $3.8 \mathrm{ft}^{3} / \mathrm{s}$, September 17, 2007, gage height $1.15 \mathrm{ft}$. No flow most of the time.

Extremes for Current Year. Peak discharges above base of $1.0 \mathrm{ft}^{3} / \mathrm{s}$ and maximum (*):

\begin{tabular}{|c|c|c|c|}
\hline Date & Time & Discharge $\left(\mathbf{f t}^{\mathbf{3}} / \mathbf{s}\right)$ & Gage Height (ft) \\
\hline October 11 & 1400 & $1.40^{*}$ & $0.60^{*}$ \\
\hline
\end{tabular}

No flow most of the time.

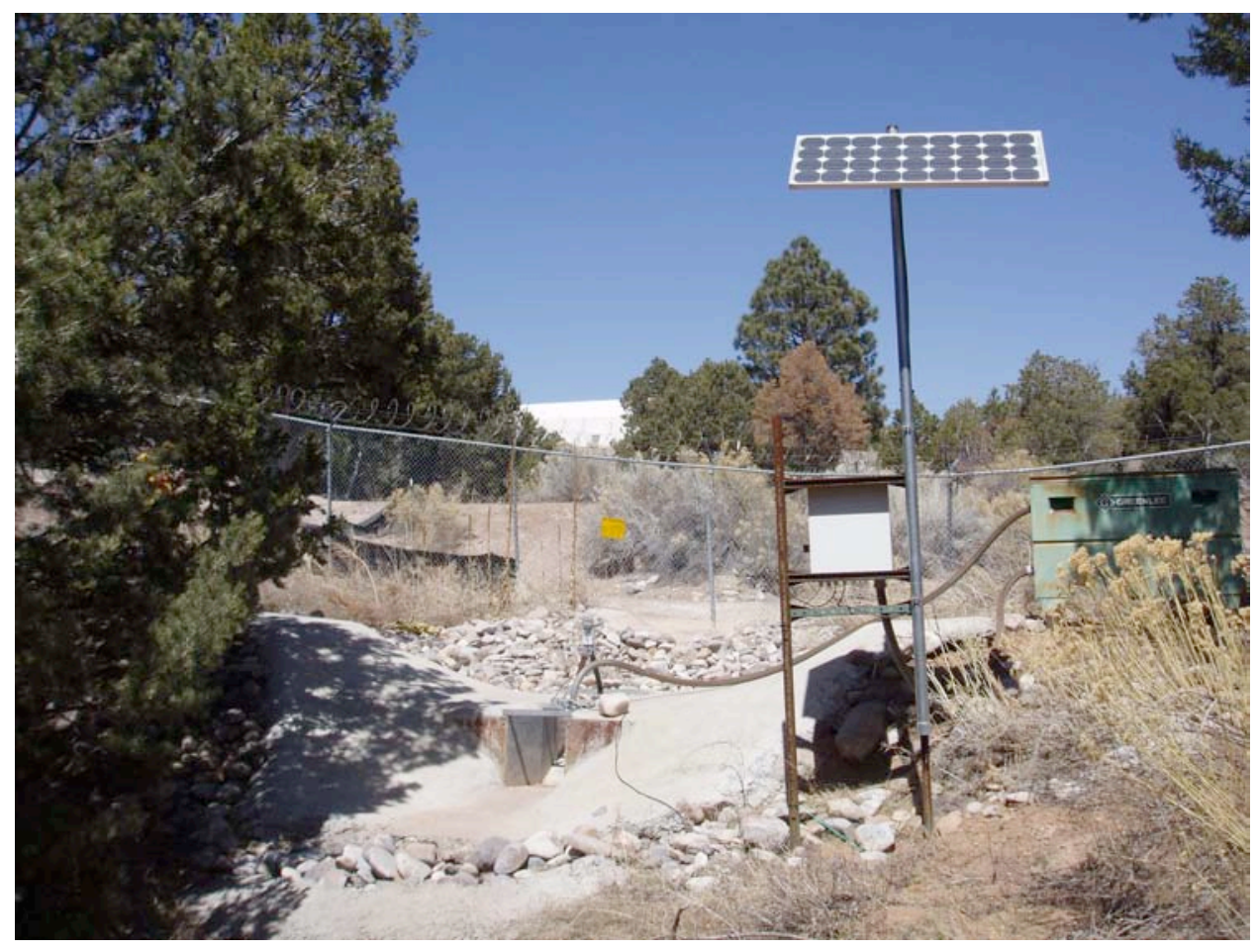




\section{E2485 MDA G-6U}

\section{Station Analysis}

\section{Water Year}

Equipment. Station is equipped with Sutron 8210 data logger (5-min. interval) and Milltronics sonic probe mounted on a 9" Parshall flume. The system is powered by a solar panel battery system housed in a NEMA shelter. Station is equipped with an ISCO pump sampler for water quality sample collection. ISCO is housed in a separate shelter, a $3^{\prime} \times 4^{\prime}$ metal box. Sampler is triggered by stage through the data logger. The staff in the 9" Parshall flume is the reference gage. No provision for discharge measurements above wading stage. All measurements above wading stage will be by slope area or peak flow computation methods.

Field Work. This station was visited 28 times to conduct discharge measurements and service the instrumentation. Field inspections for the gage are listed under site history files on the Hydstra database. Discharge measurements for the gage are listed under site gauging files on the Hydstra data base.

Datum Correction. None.

Gage-Height Record. The data logger referenced to the outside staff gave a complete and satisfactory record, except for the period from December 9 to January 14, 17, February 22, and March 26-28 when gage height was affected by ice.

Rating. The control for this station is the 9" Parshall flume. The channel is straight 40' upstream with sand, gravel, and vegetation. The channel downstream from the flume is $70^{\prime}$ long with vegetation and sand on both banks.

Twenty-eight inspections of no flow were made this year.

Rating No. 1 was developed based on the computation of 9" Parshall flume. PZF is 0.00 gage height.

Discharge. Discharge was computed by applying gage height to Rating No. 1 directly.

Remarks. Records are good. 
E2485 M DA G-6U

Daily Mean Discharge in Cubic Feet per Second

Water Year October 2008 to September 2009

\begin{tabular}{|c|c|c|c|c|c|c|c|c|c|c|c|c|}
\hline DAY & OCT & NOV & DEC & JAN & FEB & MAR & APR & MAY & JUN & JUL & AUG & SEP \\
\hline 1 & 0 & 0 & 0 & $0^{*}$ & 0 & 0 & 0 & 0 & 0 & 0 & 0 & 0 \\
\hline 2 & 0 & 0 & 0 & $0^{*}$ & 0 & 0 & 0 & 0 & 0 & 0 & 0 & 0 \\
\hline 3 & 0 & 0 & 0 & $0^{*}$ & 0 & 0 & 0 & 0 & 0 & 0 & 0 & 0 \\
\hline 4 & 0 & 0 & 0 & $0^{*}$ & 0 & 0 & 0 & 0 & 0 & 0 & 0 & 0 \\
\hline 5 & 0 & 0 & 0 & $0^{*}$ & 0 & 0 & 0 & 0 & 0 & 0 & 0 & 0 \\
\hline 6 & 0 & 0 & 0 & $0^{*}$ & 0 & 0 & 0 & 0 & 0 & 0 & 0 & 0 \\
\hline 7 & 0 & 0 & 0 & $0^{*}$ & 0 & 0 & 0 & 0 & 0 & 0 & 0 & 0 \\
\hline 8 & 0 & 0 & 0 & $0^{*}$ & 0 & 0 & 0 & 0 & 0 & 0 & 0 & 0 \\
\hline 9 & 0 & 0 & $0^{*}$ & $0^{*}$ & 0 & 0 & 0 & 0 & 0 & 0 & 0 & 0 \\
\hline 10 & 0 & 0 & $0^{*}$ & $0^{*}$ & 0 & 0 & 0 & 0 & .01 & 0 & 0 & 0 \\
\hline 11 & .07 & 0 & $0^{*}$ & $0^{*}$ & 0 & 0 & 0 & 0 & 0 & 0 & 0 & 0 \\
\hline 12 & 0 & 0 & $0^{*}$ & $0^{*}$ & 0 & 0 & 0 & 0 & 0 & 0 & 0 & 0 \\
\hline 13 & 0 & 0 & $0^{*}$ & $0^{*}$ & 0 & 0 & 0 & 0 & 0 & 0 & 0 & 0 \\
\hline 14 & 0 & 0 & $0^{*}$ & $0^{*}$ & 0 & 0 & 0 & 0 & 0 & 0 & 0 & 0 \\
\hline 15 & 0 & 0 & $0^{*}$ & 0 & 0 & 0 & 0 & 0 & 0 & 0 & 0 & 0 \\
\hline 16 & 0 & 0 & $0^{*}$ & 0 & 0 & 0 & 0 & 0 & 0 & 0 & 0 & 0 \\
\hline 17 & 0 & 0 & $0^{*}$ & $0^{*}$ & 0 & 0 & 0 & 0 & 0 & 0 & 0 & 0 \\
\hline 18 & 0 & 0 & $0^{*}$ & 0 & 0 & 0 & 0 & 0 & 0 & 0 & 0 & 0 \\
\hline 19 & 0 & 0 & $0^{*}$ & 0 & 0 & 0 & 0 & 0 & 0 & 0 & 0 & 0 \\
\hline 20 & 0 & 0 & $0^{*}$ & 0 & 0 & 0 & 0 & 0 & 0 & 0 & 0 & 0 \\
\hline 21 & 0 & 0 & $0^{*}$ & 0 & 0 & 0 & 0 & .01 & 0 & 0 & 0 & 0 \\
\hline 22 & 0 & 0 & $0^{*}$ & 0 & $0^{*}$ & 0 & 0 & 0 & 0 & 0 & 0 & 0 \\
\hline 23 & 0 & 0 & $0^{*}$ & 0 & 0 & 0 & 0 & 0 & 0 & 0 & 0 & 0 \\
\hline 24 & 0 & 0 & $0^{*}$ & 0 & 0 & 0 & 0 & 0 & 0 & 0 & 0 & 0 \\
\hline 25 & 0 & 0 & $0^{*}$ & 0 & 0 & 0 & 0 & 0 & 0 & 0 & 0 & 0 \\
\hline 26 & 0 & 0 & $0^{*}$ & 0 & 0 & $0^{*}$ & 0 & 0 & 0 & 0 & 0 & 0 \\
\hline 27 & 0 & 0 & $0^{*}$ & 0 & 0 & $0^{*}$ & 0 & 0 & 0 & 0 & 0 & 0 \\
\hline 28 & 0 & 0 & $0^{*}$ & 0 & 0 & $0^{*}$ & 0 & 0 & 0 & 0 & 0 & 0 \\
\hline 29 & 0 & 0 & $0^{*}$ & 0 & ----- & 0 & 0 & 0 & 0 & 0 & 0 & 0 \\
\hline 30 & 0 & 0 & $0^{*}$ & 0 & ----- & 0 & 0 & 0 & 0 & .02 & 0 & 0 \\
\hline 31 & 0 & ----- & $0^{*}$ & 0 & ----- & 0 & ---- & 0 & ---- & 0 & 0 & $-\cdots$ \\
\hline Total & 0.07 & 0 & 0 & 0 & 0 & 0 & 0 & 0.01 & 0.01 & 0.02 & 0 & 0 \\
\hline Mean & .002 & 0 & 0 & 0 & 0 & 0 & 0 & 0 & 0 & .001 & 0 & 0 \\
\hline Max & .07 & 0 & 0 & 0 & 0 & 0 & 0 & .01 & .01 & .02 & 0 & 0 \\
\hline Min & 0 & 0 & 0 & 0 & 0 & 0 & 0 & 0 & 0 & 0 & 0 & 0 \\
\hline Acre-F t & .14 & 0 & 0 & 0 & 0 & 0 & 0 & .02 & .02 & .04 & 0 & 0 \\
\hline Wtr Year & 2009 & Total & 0.11 & Mean & & 0 & $\operatorname{lax}$ & .07 & Min & 0 & Acre- $\mathrm{Ft}$ & .22 \\
\hline Cal Year & 2008 & Total & 0.31 & Mean & & 001 & $\operatorname{lax}$ & .16 & Min & 0 & Acre- $\mathrm{Ft}$ & .61 \\
\hline
\end{tabular}




\section{E249 MDA G-4}

Location. Lat $35^{\circ} 49^{\prime} 42^{\prime \prime}$, long $106^{\circ}$ 14' 17", Sec. 31, T. 19 N., R. 7 E., Ramon Vigil Grant, Los Alamos County.

Drainage Area. $0.007 \mathrm{mi}^{2}$.

Period of Record. October 1, 2006, to September 30, 2009.

Gage. Data logger 9" Parshall flume. Elevation of gage is 6,602 ft above NGVD.

Remarks. Records are good. Records for this site existed before period of record but are not reliable. Legal location based on projected values.

Extremes for Period of Record. Maximum discharge, $1.20 \mathrm{ft}^{3} / \mathrm{s}$, July 17, 2008, gage height $0.54 \mathrm{ft}$. No flow most of the time

Extremes for Current Year. No peak discharge above $1.0 \mathrm{ft}^{3} / \mathrm{s}$. No flow for the year.

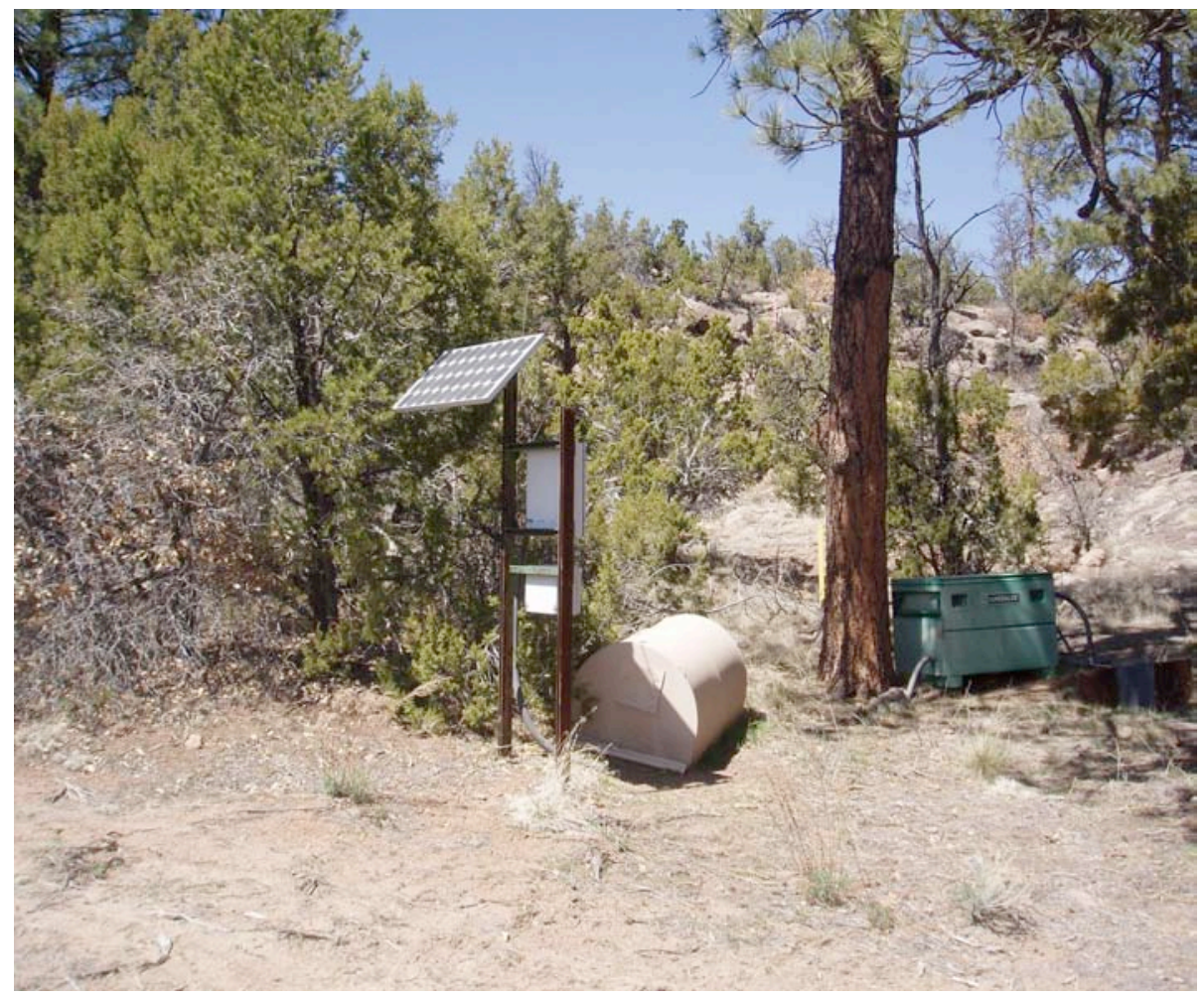




\section{E249 MDA G-4}

\section{Station Analysis}

\section{Water Year}

Equipment. Station is equipped with Sutron 8210 data logger (5-min. interval) and Milltronics sonic probe mounted on a 9" Parshall flume. The system is powered by a solar panel battery system housed in a NEMA shelter. Station is equipped with an ISCO pump sampler for water quality sample collection. ISCO is housed in a separate shelter, a $3^{\prime} \times 4^{\prime}$ metal box. Sampler is triggered by stage through the data logger. The staff in the 9" Parshall flume is the reference gage. No provision for discharge measurements above wading stage.

Field Work. The station was visited 15 times to conduct discharge measurements and service the instrumentation. Field inspections for the gage are listed under site history files on the Hydstra database. Discharge measurements for the gage are listed under site gauging files on the Hydstra database.

Datum Correction. None.

Gage-Height Record. The data logger referenced to the outside staff gave a complete and satisfactory record, except for the periods from December 11 to January 24 and March 26-29 when gage height was affected by ice.

Rating. The control for this station is the 9" Parshall flume. The channel is straight $20^{\prime}$ above and below gage. The streambed is sand and boulders.

Fifteen inspections of no flow were made this year.

Rating No. 1 was developed based on the computation of a 9" Parshall flume. PZF is 0.00 gage height.

Discharge. Discharge was computed by applying gage height to Rating No. 1 directly. Those days estimated at zero flow were based on precipitation and nearby gage stations.

Remarks. Records are good. 


\section{E249 MD A G-4}

Daily Mean Discharge in Cubic Feet per Second

Water Year October 2008 to September 2009

\begin{tabular}{|c|c|c|c|c|c|c|c|c|c|c|c|c|}
\hline DAY & OCT & NOV & DEC & JAN & FEB & MAR & APR & MAY & JUN & JUL & AUG & SEP \\
\hline 1 & 0 & 0 & 0 & $0^{*}$ & 0 & 0 & 0 & 0 & 0 & 0 & 0 & 0 \\
\hline 2 & 0 & 0 & 0 & $0^{*}$ & 0 & 0 & 0 & 0 & 0 & 0 & 0 & 0 \\
\hline 3 & 0 & 0 & 0 & $0^{*}$ & 0 & 0 & 0 & 0 & 0 & 0 & 0 & 0 \\
\hline 4 & 0 & 0 & 0 & $0^{*}$ & 0 & 0 & 0 & 0 & 0 & 0 & 0 & 0 \\
\hline 5 & 0 & 0 & 0 & $0^{*}$ & 0 & 0 & 0 & 0 & 0 & 0 & 0 & 0 \\
\hline 6 & 0 & 0 & 0 & $0^{*}$ & 0 & 0 & 0 & 0 & 0 & 0 & 0 & 0 \\
\hline 7 & 0 & 0 & 0 & $0^{*}$ & 0 & 0 & 0 & 0 & 0 & 0 & 0 & 0 \\
\hline 8 & 0 & 0 & 0 & $0^{*}$ & 0 & 0 & 0 & 0 & 0 & 0 & 0 & 0 \\
\hline 9 & 0 & 0 & 0 & $0^{*}$ & 0 & 0 & 0 & 0 & 0 & 0 & 0 & 0 \\
\hline 10 & 0 & 0 & 0 & $0^{*}$ & 0 & 0 & 0 & 0 & 0 & 0 & 0 & 0 \\
\hline 11 & 0 & 0 & $0^{*}$ & $0^{*}$ & 0 & 0 & 0 & 0 & 0 & 0 & 0 & 0 \\
\hline 12 & 0 & 0 & $0^{*}$ & $0^{*}$ & 0 & 0 & 0 & 0 & 0 & 0 & 0 & 0 \\
\hline 13 & 0 & 0 & $0^{*}$ & $0^{*}$ & 0 & 0 & 0 & 0 & 0 & 0 & 0 & 0 \\
\hline 14 & 0 & 0 & $0^{*}$ & $0^{*}$ & 0 & 0 & 0 & 0 & 0 & 0 & 0 & 0 \\
\hline 15 & 0 & 0 & $0^{*}$ & $0^{*}$ & 0 & 0 & 0 & 0 & 0 & 0 & 0 & 0 \\
\hline 16 & 0 & 0 & $0^{*}$ & $0^{*}$ & 0 & 0 & 0 & 0 & 0 & 0 & 0 & 0 \\
\hline 17 & 0 & 0 & $0^{*}$ & $0^{*}$ & 0 & 0 & 0 & 0 & 0 & 0 & 0 & 0 \\
\hline 18 & 0 & 0 & $0^{*}$ & $0^{*}$ & 0 & 0 & 0 & 0 & 0 & 0 & 0 & 0 \\
\hline 19 & 0 & 0 & $0^{*}$ & $0^{*}$ & 0 & 0 & 0 & 0 & 0 & 0 & 0 & 0 \\
\hline 20 & 0 & 0 & $0^{*}$ & $0^{*}$ & 0 & 0 & 0 & 0 & 0 & 0 & 0 & 0 \\
\hline 21 & 0 & 0 & $0^{*}$ & $0^{*}$ & 0 & 0 & 0 & 0 & 0 & 0 & 0 & 0 \\
\hline 22 & 0 & 0 & $0^{*}$ & $0^{*}$ & 0 & 0 & 0 & 0 & 0 & 0 & 0 & 0 \\
\hline 23 & 0 & 0 & $0^{*}$ & $0^{*}$ & 0 & 0 & 0 & 0 & 0 & 0 & 0 & 0 \\
\hline 24 & 0 & 0 & $0^{*}$ & $0^{*}$ & 0 & 0 & 0 & 0 & 0 & 0 & 0 & 0 \\
\hline 25 & 0 & 0 & $0^{*}$ & 0 & 0 & 0 & 0 & 0 & 0 & 0 & 0 & 0 \\
\hline 26 & 0 & 0 & $0^{*}$ & 0 & 0 & $0^{*}$ & 0 & 0 & 0 & 0 & 0 & 0 \\
\hline 27 & 0 & 0 & $0^{*}$ & 0 & 0 & $0^{*}$ & 0 & 0 & 0 & 0 & 0 & 0 \\
\hline 28 & 0 & 0 & $0^{*}$ & 0 & 0 & $0^{*}$ & 0 & 0 & 0 & 0 & 0 & 0 \\
\hline 29 & 0 & 0 & $0^{*}$ & 0 & --.-- & $0^{*}$ & 0 & 0 & 0 & 0 & 0 & 0 \\
\hline 30 & 0 & 0 & $0^{*}$ & 0 & --.-- & 0 & 0 & 0 & 0 & 0 & 0 & 0 \\
\hline 31 & 0 & --.-- & $0^{*}$ & 0 & ----- & 0 & ---- & 0 & ----- & 0 & 0 & ---- \\
\hline Total & 0 & 0 & 0 & 0 & 0 & 0 & 0 & 0 & 0 & 0 & 0 & 0 \\
\hline Mean & 0 & 0 & 0 & 0 & 0 & 0 & 0 & 0 & 0 & 0 & 0 & 0 \\
\hline Max & 0 & 0 & 0 & 0 & 0 & 0 & 0 & 0 & 0 & 0 & 0 & 0 \\
\hline Min & 0 & 0 & 0 & 0 & 0 & 0 & 0 & 0 & 0 & 0 & 0 & 0 \\
\hline Acre-F t & 0 & 0 & 0 & 0 & 0 & 0 & 0 & 0 & 0 & 0 & 0 & 0 \\
\hline Wtr Year & 2009 & Total & 0 & Mean & & 0 & $\operatorname{Max}$ & 0 & Min & 0 & Acre- $\mathrm{Ft}$ & 0 \\
\hline Cal Year & 2008 & Total & 0.07 & Mean & & 0 & $\operatorname{Max}$ & .04 & Min & 0 & Acre-Ft & .14 \\
\hline
\end{tabular}


Location. Lat $35^{\circ}$ 49' 47", long $106^{\circ}$ 14' 05", Sec. 31, T. 19 N., R. 7 E., Ramon Vigil Grant, Los Alamos County on left bank.

Drainage Area. $0.01 \mathrm{mi}^{2}$.

Period of Record. October 1, 2005, to September 30, 2009.

Gage. Data logger and 9" Parshall flume, rain gage with cellular telemetry. Elevation of gage is $6,633 \mathrm{ft}$ above NGVD.

Remarks. Records are good. Records for this site existed before period of record but are not reliable. Legal location based on projected values.

Extremes for Period of Record. Maximum discharge, $5.7 \mathrm{ft}^{3} / \mathrm{s}$, August 7, 2006, gage height $1.50 \mathrm{ft}$. No flow most of the time.

Extremes for Current Year. Peak discharges above $1.0 \mathrm{ft}^{3} / \mathrm{s}$ and maximum (*):

\begin{tabular}{|c|c|c|c|}
\hline Date & Time & Discharge $\left(\mathbf{f t}^{\mathbf{3}} / \mathbf{s}\right)$ & Gage Height (ft) \\
\hline October 11 & 1345 & $1.82^{*}$ & $0.71^{*}$ \\
\hline May 23 & 1215 & 1.03 & 0.41 \\
\hline June 10 & 0610 & 1.51 & 0.63 \\
\hline September 6 & 2210 & 1.16 & 0.53 \\
\hline September 16 & 0210 & 1.33 & 0.58 \\
\hline
\end{tabular}

No flow most of the time.

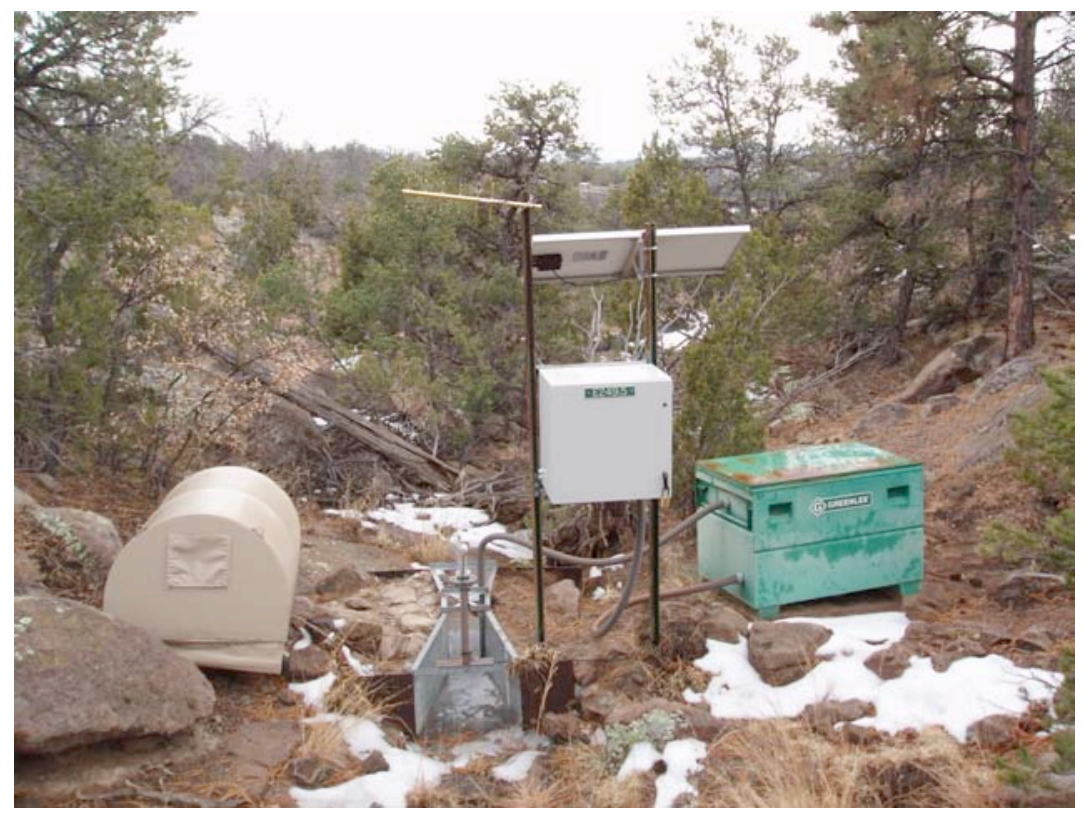




\section{E2495 MDA G-7}

\section{Station Analysis}

\section{Water Year}

Equipment. Station is equipped with Sutron 8210 data logger (5-min. interval) and Milltronics sonic probe mounted on a 9" Parshall flume with cellular phone and speech modem. The system is powered by a solar panel battery system housed in a NEMA shelter. Station is equipped with an ISCO pump sampler for water quality sample collection. ISCO is housed in a separate shelter, a $3^{\prime} \times 4^{\prime}$ metal box. Sampler is triggered by stage through the data logger. The staff in the $9^{\prime \prime}$ Parshall flume is the reference gage. No provision for discharge measurements above wading stage.

Station is also equipped with a rain gage, Rain Collection II. All equipment is powered with a solar panel battery charging system.

Field Work. The station was visited 28 times to conduct discharge measurements and service the instrumentation. Field inspections for the gage are listed under site history files on the Hydstra database. Discharge measurements for the gage are listed under site gauging files on the Hydstra database.

Datum Correction. None.

Gage-Height Record. The data logger referenced to the outside staff gave a complete and satisfactory record, except for the periods from December 17 to January 3, 7, 8, March 26-28 when gage height was affected by ice and March 11-19 and July 24-27 when the data logger malfunctioned.

Rating. The channel is straight above and below gage. It is confined to the main channel by cut banks on both sides. The bottom is $4^{\prime}$ wide channel; both banks should be very stable. Low-water control is the 9" Parshall flume.

Twenty-seven visits of no flow and one inspection of observed flow were made this year.

Rating No. 1 was developed based on the computation of 9" Parshall flume. Point of zero flow is 0.00 gage height.

Discharge. Discharge was computed by applying gage height to Rating No. 1 directly.

Remarks. Records are good. 
E2495 MDA G-7

Daily Mean Discharge in Cubic Feet per Second

Water Year October 2008 to September 2009

\begin{tabular}{|c|c|c|c|c|c|c|c|c|c|c|c|c|}
\hline DAY & OCT & NOV & DEC & JAN & FEB & MAR & APR & MAY & JUN & JUL & AUG & SEP \\
\hline 1 & 0 & 0 & 0 & $0^{*}$ & 0 & 0 & 0 & 0 & 0 & 0 & 0 & 0 \\
\hline 2 & 0 & 0 & 0 & $0^{*}$ & 0 & 0 & 0 & 0 & 0 & 0 & 0 & 0 \\
\hline 3 & 0 & 0 & 0 & $0^{*}$ & 0 & 0 & 0 & 0 & 0 & 0 & 0 & 0 \\
\hline 4 & .04 & 0 & 0 & 0 & 0 & 0 & 0 & 0 & 0 & 0 & 0 & 0 \\
\hline 5 & .02 & 0 & 0 & 0 & 0 & 0 & 0 & 0 & 0 & .01 & 0 & 0 \\
\hline 6 & 0 & 0 & 0 & 0 & 0 & 0 & 0 & 0 & 0 & 0 & 0 & .05 \\
\hline 7 & 0 & 0 & 0 & $0^{*}$ & 0 & 0 & 0 & 0 & 0 & 0 & 0 & 0 \\
\hline 8 & 0 & 0 & 0 & $0^{*}$ & 0 & 0 & 0 & 0 & 0 & 0 & 0 & 0 \\
\hline 9 & 0 & 0 & 0 & 0 & 0 & 0 & 0 & 0 & 0 & 0 & 0 & 0 \\
\hline 10 & 0 & 0 & 0 & 0 & 0 & 0 & 0 & 0 & .08 & 0 & 0 & 0 \\
\hline 11 & .18 & 0 & 0 & 0 & 0 & $0^{*}$ & .06 & 0 & 0 & 0 & 0 & 0 \\
\hline 12 & 0 & 0 & 0 & 0 & 0 & $0^{*}$ & .01 & 0 & 0 & 0 & 0 & 0 \\
\hline 13 & 0 & 0 & 0 & 0 & 0 & $0^{*}$ & .01 & 0 & 0 & 0 & 0 & 0 \\
\hline 14 & .05 & 0 & 0 & 0 & 0 & $0^{*}$ & 0 & 0 & 0 & 0 & 0 & 0 \\
\hline 15 & 0 & 0 & 0 & 0 & 0 & $0^{*}$ & 0 & 0 & 0 & 0 & 0 & 0 \\
\hline 16 & 0 & 0 & 0 & 0 & 0 & $0^{*}$ & 0 & 0 & 0 & 0 & 0 & .10 \\
\hline 17 & 0 & 0 & $0^{*}$ & 0 & 0 & $0^{*}$ & .02 & 0 & 0 & 0 & 0 & .03 \\
\hline 18 & 0 & 0 & $0^{*}$ & 0 & 0 & $0^{*}$ & 0 & 0 & 0 & 0 & 0 & 0 \\
\hline 19 & 0 & 0 & $0^{*}$ & 0 & 0 & $0^{*}$ & 0 & 0 & 0 & 0 & 0 & 0 \\
\hline 20 & 0 & 0 & $0^{*}$ & 0 & 0 & 0 & 0 & 0 & .01 & 0 & 0 & 0 \\
\hline 21 & 0 & 0 & $0^{*}$ & 0 & 0 & 0 & 0 & 0 & 0 & 0 & 0 & 0 \\
\hline 22 & 0 & 0 & $0^{*}$ & 0 & 0 & 0 & 0 & 0 & 0 & 0 & 0 & 0 \\
\hline 23 & 0 & 0 & $0^{*}$ & 0 & 0 & 0 & 0 & .03 & 0 & 0 & 0 & .01 \\
\hline 24 & 0 & 0 & $0^{*}$ & 0 & 0 & 0 & 0 & .02 & 0 & $0^{*}$ & 0 & .02 \\
\hline 25 & 0 & 0 & $0^{*}$ & 0 & 0 & 0 & 0 & 0 & 0 & $0^{*}$ & 0 & 0 \\
\hline 26 & 0 & 0 & $0^{*}$ & 0 & 0 & $0^{*}$ & 0 & 0 & 0 & $.10^{*}$ & 0 & 0 \\
\hline 27 & 0 & .04 & $0^{*}$ & 0 & 0 & $0^{*}$ & 0 & .01 & 0 & $0^{*}$ & 0 & 0 \\
\hline 28 & 0 & 0 & $0^{*}$ & 0 & 0 & $0^{*}$ & 0 & 0 & 0 & .01 & 0 & 0 \\
\hline 29 & 0 & 0 & $0^{*}$ & 0 & ----- & 0 & 0 & 0 & 0 & 0 & 0 & 0 \\
\hline 30 & 0 & 0 & $0^{*}$ & 0 & ----- & 0 & 0 & 0 & 0 & .03 & .01 & 0 \\
\hline 31 & 0 & --.-- & $0^{*}$ & 0 & -.--- & 0 & ----- & 0 & $-\cdot--$ & 0 & 0 & --.-- \\
\hline Total & 0.29 & 0.04 & 0 & 0 & 0 & 0 & 0.10 & 0.06 & 0.09 & 0.15 & 0.01 & 0.21 \\
\hline Mean & .009 & .001 & 0 & 0 & 0 & 0 & .003 & .002 & .003 & .005 & 0 & .007 \\
\hline Max & .18 & .04 & 0 & 0 & 0 & 0 & .06 & .03 & .08 & .10 & .01 & .10 \\
\hline$M$ in & 0 & 0 & 0 & 0 & 0 & 0 & 0 & 0 & 0 & 0 & 0 & 0 \\
\hline Acre-F t & .58 & .08 & 0 & 0 & 0 & 0 & .20 & .12 & .18 & .30 & .02 & .42 \\
\hline Wtr Year & 2009 & Total & 0.95 & Mean & & & Max & .18 & Min & 0 & Acre- $\mathrm{Ft}$ & 1.9 \\
\hline CalYear & 2008 & Total & 0.96 & Mean & & 3 & Max & .18 & Min & 0 & Acre- $\mathrm{Ft}$ & 1.9 \\
\hline
\end{tabular}

*Estimate 


\section{E250 Pajarito Canyon above SR 4}

Location. Lat 35 49' 26", long $106^{\circ}$ 13' 40", Sec. 5, T. 18 N., R. 7 E., Ramon Vigil Grant, Los Alamos County.

Drainage Area. $10.6 \mathrm{mi}^{2}$.

Period of Record. November 1993 to August 25, 2006 (destroyed by flood); September 2006 to September 30, 2009.

Revised Record. Drainage Area (2006).

Gage. Data logger with cellular telemetry and concrete control. Elevation of gage is 6,528 ft above NGVD from GPS survey.

Remarks. Records are good. Legal location based on projected values.

Average Discharge. $15 \mathrm{yr}, 0.05 \mathrm{ft}^{3} / \mathrm{s}, 37$ acre-ft/yr.

Extremes for Period of Record. Maximum discharge, $206 \mathrm{ft}^{3} / \mathrm{s}$, August 25, 2006, gage height $4.62 \mathrm{ft}$ (from peak flow computations). No flow most of the time.

Extremes for Current Water Year. No peak discharge above base of $5.0 \mathrm{ft}^{3} / \mathrm{s}$. No flow for the year.

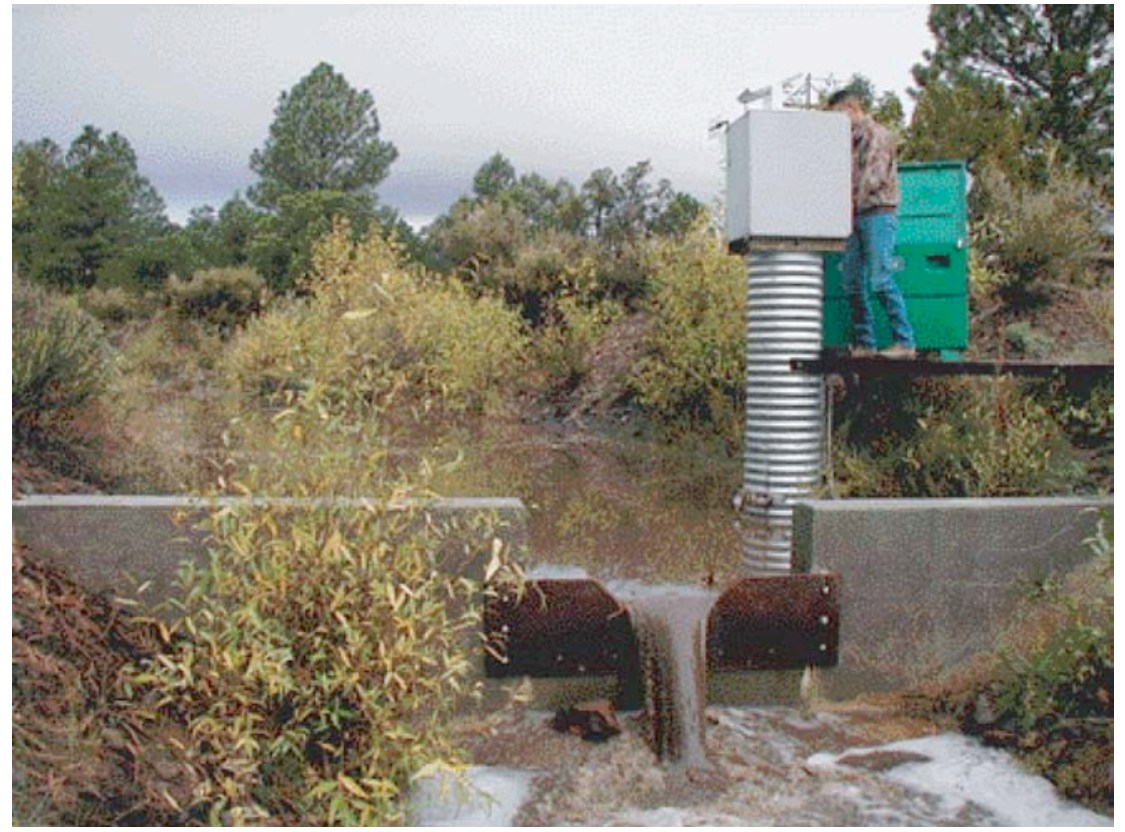




\title{
E250 Pajarito Canyon above SR 4
}

\author{
Station Analysis
}

\section{Water Year}

Equipment. Station is equipped with Sutron 8210 data logger (5-min. interval) with shaft encoder float system (5-min. interval) and cellular phone with speech modem. The system is powered by a solar panel battery system housed in NEMA shelter on 18" CMP well. Station is equipped with an ISCO pump sampler for water quality sample collection. ISCO is housed in a separate shelter, a $3^{\prime} \times 4^{\prime}$ metal box. Sampler is triggered by stage through the data logger. An outside staff is available for reference. No provision for direct discharge measurements above wading stages.

Field Work. The station was visited 24 times to conduct discharge measurements and service the instrumentation. Field inspections for the gage are listed under site history files on the Hydstra database. Discharge measurements for the gage are listed under site gauging files on the Hydstra database.

Datum Correction. None. Most recent levels run November 17, 2004, found gage within acceptable limits.

Gage-Height Record. The data logger referenced to the outside staff gave a complete and satisfactory record, except for the period from July 8-28 when data logger malfunctioned.

Rating. The channel is straight for $50^{\prime}$ above and $100^{\prime}$ below gage. Streambed material is gravel. The control is concrete with a $90^{\circ}$ weir plate.

Twenty-four inspections of no flow were made this year.

Rating No. 1 was developed from $90^{\circ}$ weir plate formula and broad-crested weir computation above notch. Rating No. 1 was continued in use and is considered good.

Discharge. Discharge was computed by applying gage height to Rating No. 1 directly.

Remarks. Records are good. Access to this station is controlled by DX access control. 
E250 Pajarito Canyon above SR 4

Daily Mean Discharge in Cubic Feet per Second

Water Year October 2008 to September 2009

\begin{tabular}{|c|c|c|c|c|c|c|c|c|c|c|c|c|}
\hline DAY & OCT & NOV & DEC & JAN & FEB & MAR & APR & MAY & JUN & JUL & $A U G$ & SEP \\
\hline 1 & 0 & 0 & 0 & 0 & 0 & 0 & 0 & 0 & 0 & 0 & 0 & 0 \\
\hline 2 & 0 & 0 & 0 & 0 & 0 & 0 & 0 & 0 & 0 & 0 & 0 & 0 \\
\hline 3 & 0 & 0 & 0 & 0 & 0 & 0 & 0 & 0 & 0 & 0 & 0 & 0 \\
\hline 4 & 0 & 0 & 0 & 0 & 0 & 0 & 0 & 0 & 0 & 0 & 0 & 0 \\
\hline 5 & 0 & 0 & 0 & 0 & 0 & 0 & 0 & 0 & 0 & 0 & 0 & 0 \\
\hline 6 & 0 & 0 & 0 & 0 & 0 & 0 & 0 & 0 & 0 & 0 & 0 & 0 \\
\hline 7 & 0 & 0 & 0 & 0 & 0 & 0 & 0 & 0 & 0 & 0 & 0 & 0 \\
\hline 8 & 0 & 0 & 0 & 0 & 0 & 0 & 0 & 0 & 0 & $0^{*}$ & 0 & 0 \\
\hline 9 & 0 & 0 & 0 & 0 & 0 & 0 & 0 & 0 & 0 & $0^{*}$ & 0 & 0 \\
\hline 10 & 0 & 0 & 0 & 0 & 0 & 0 & 0 & 0 & 0 & $0^{*}$ & 0 & 0 \\
\hline 11 & 0 & 0 & 0 & 0 & 0 & 0 & 0 & 0 & 0 & $0^{*}$ & 0 & 0 \\
\hline 12 & 0 & 0 & 0 & 0 & 0 & 0 & 0 & 0 & 0 & $0^{*}$ & 0 & 0 \\
\hline 13 & 0 & 0 & 0 & 0 & 0 & 0 & 0 & 0 & 0 & $0^{*}$ & 0 & 0 \\
\hline 14 & 0 & 0 & 0 & 0 & 0 & 0 & 0 & 0 & 0 & $0^{*}$ & 0 & 0 \\
\hline 15 & 0 & 0 & 0 & 0 & 0 & 0 & 0 & 0 & 0 & $0^{*}$ & 0 & 0 \\
\hline 16 & 0 & 0 & 0 & 0 & 0 & 0 & 0 & 0 & 0 & $0^{*}$ & 0 & 0 \\
\hline 17 & 0 & 0 & 0 & 0 & 0 & 0 & 0 & 0 & 0 & $0^{\star}$ & 0 & 0 \\
\hline 18 & 0 & 0 & 0 & 0 & 0 & 0 & 0 & 0 & 0 & $0^{*}$ & 0 & 0 \\
\hline 19 & 0 & 0 & 0 & 0 & 0 & 0 & 0 & 0 & 0 & $0^{*}$ & 0 & 0 \\
\hline 20 & 0 & 0 & 0 & 0 & 0 & 0 & 0 & 0 & 0 & $0^{*}$ & 0 & 0 \\
\hline 21 & 0 & 0 & 0 & 0 & 0 & 0 & 0 & 0 & 0 & $0^{*}$ & 0 & 0 \\
\hline 22 & 0 & 0 & 0 & 0 & 0 & 0 & 0 & 0 & 0 & $0^{*}$ & 0 & 0 \\
\hline 23 & 0 & 0 & 0 & 0 & 0 & 0 & 0 & 0 & 0 & $0^{*}$ & 0 & 0 \\
\hline 24 & 0 & 0 & 0 & 0 & 0 & 0 & 0 & 0 & 0 & $0^{*}$ & 0 & 0 \\
\hline 25 & 0 & 0 & 0 & 0 & 0 & 0 & 0 & 0 & 0 & $0^{*}$ & 0 & 0 \\
\hline 26 & 0 & 0 & 0 & 0 & 0 & 0 & 0 & 0 & 0 & $0^{*}$ & 0 & 0 \\
\hline 27 & 0 & 0 & 0 & 0 & 0 & 0 & 0 & 0 & 0 & $0^{*}$ & 0 & 0 \\
\hline 28 & 0 & 0 & 0 & 0 & 0 & 0 & 0 & 0 & 0 & $0^{*}$ & 0 & 0 \\
\hline 29 & 0 & 0 & 0 & 0 & --.-- & 0 & 0 & 0 & 0 & 0 & 0 & 0 \\
\hline 30 & 0 & 0 & 0 & 0 & ----- & 0 & 0 & 0 & 0 & 0 & 0 & 0 \\
\hline 31 & 0 & --- & 0 & 0 & ----- & 0 & ----- & 0 & ---- & 0 & 0 & ---- \\
\hline Total & 0 & 0 & 0 & 0 & 0 & 0 & 0 & 0 & 0 & 0 & 0 & 0 \\
\hline Mean & 0 & 0 & 0 & 0 & 0 & 0 & 0 & 0 & 0 & 0 & 0 & 0 \\
\hline $\operatorname{Max}$ & 0 & 0 & 0 & 0 & 0 & 0 & 0 & 0 & 0 & 0 & 0 & 0 \\
\hline Min & 0 & 0 & 0 & 0 & 0 & 0 & 0 & 0 & 0 & 0 & 0 & 0 \\
\hline Acre-F t & 0 & 0 & 0 & 0 & 0 & 0 & 0 & 0 & 0 & 0 & 0 & 0 \\
\hline Wtr Year & 2009 & Total & 0 & Mean & & 0 & Max & 0 & Min & 0 & Acre- $\mathrm{Ft}$ & 0 \\
\hline Cal Year & 2008 & Total & 26.14 & Mean & & 771 & Max & 3.2 & Min & 0 & Acre- $\mathrm{Ft}$ & 52 \\
\hline
\end{tabular}

${ }^{\star}$ Estimate 


\section{E252 Water Canyon above SR 501}

Location. Lat $35^{\circ}$ 50' 18", long $106^{\circ} 21^{\prime}$ 42", Sec. 36, T. 19 N., R. 5 E., Los Alamos County in Santa Fe National Forest.

Drainage Area. $3.25 \mathrm{mi}^{2}$.

Period of Record. October 1994 to June 2000 (destroyed by flood); April 2001 to September 2009.

Revised Record. Drainage Area (2006).

Gage. Data logger with cellular telemetry. Elevation of gage is 7,553 ft above NGVD from GPS survey.

Remarks. Records are good. Legal location based on projected values.

Average Discharge. $15 \mathrm{yr}, 0.11 \mathrm{ft}^{3} / \mathrm{s}, 83$ acre-ft/yr.

Extremes for Period of Record. Maximum discharge, $840 \mathrm{ft}^{3} / \mathrm{s}$ on June 28, 2000, from peak flow computation, gage height $7.91 \mathrm{ft}$. No flow at times.

Extremes for Current Year. Maximum discharge $0.21 \mathrm{ft}^{3} / \mathrm{s}$ at $0610 \mathrm{~h}$, May 2, gage height $2.53 \mathrm{ft}$. No peak discharges above base of $2.0 \mathrm{ft}^{3} / \mathrm{s}$. Minimal flow most of the time.

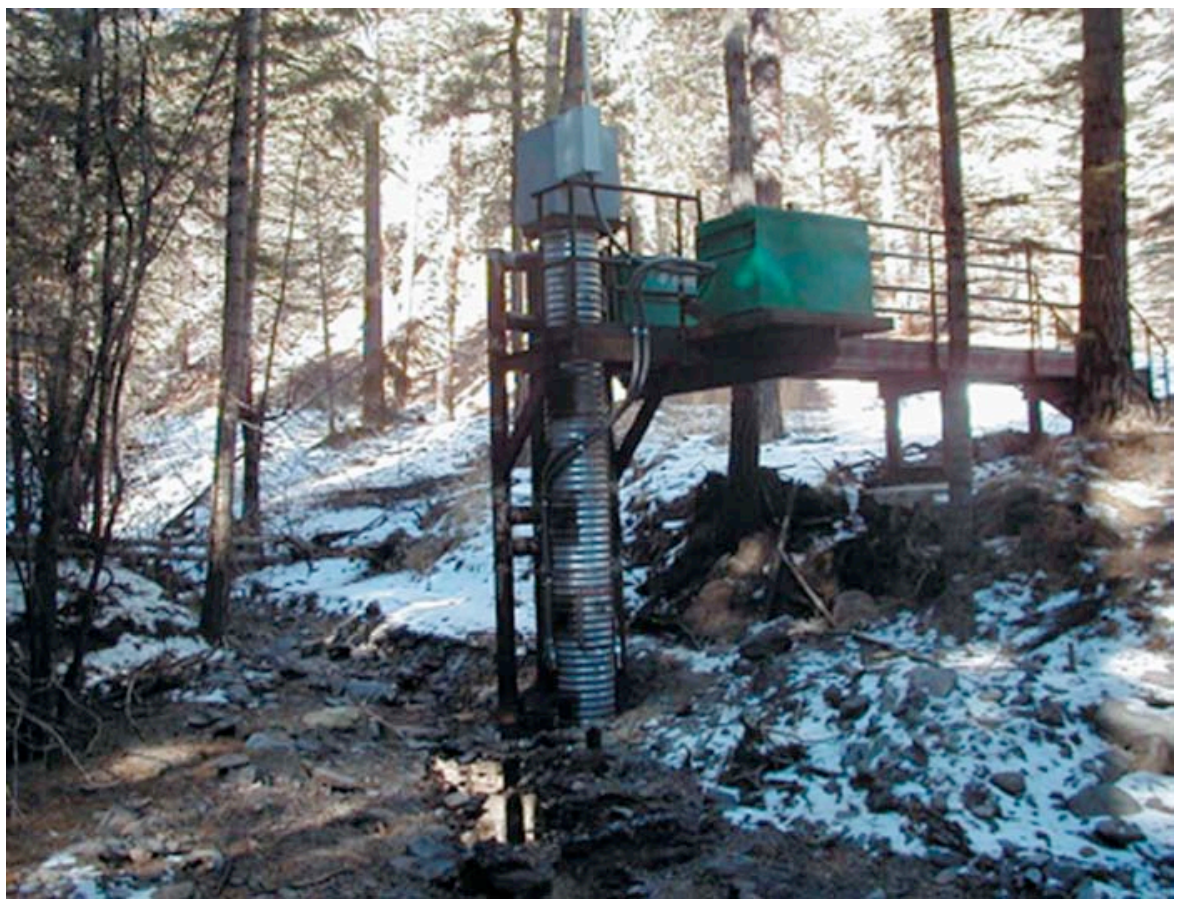




\title{
E252 Water Canyon above SR 501
}

\author{
Station Analysis
}

\section{Water Year}

Equipment. Station is equipped with Sutron 8210 data logger (5-min. interval), with shaft encoder float system (5-min. interval) and cellular phone with speech modem. The system is powered by a solar panel battery system housed in NEMA shelter on 24" CMP well. Station is equipped with an ISCO pump sampler for water quality sample collection. ISCO is housed in a separate shelter, a $3^{\prime} \times 4^{\prime}$ metal box. Sampler is triggered by stage through the data logger. An outside staff is available for reference. There is no low-water control. No provision for direct discharge measurements above wading stages.

Field Work. The station was visited 22 times to conduct discharge measurement and service the instrumentation. Field inspections for the gage are listed under site history files on the Hydstra database. Discharge measurements for the gage are listed under site gauging files on the Hydstra database.

Datum Correction. None. Levels run when gage was established April 16, 2001. New gage is at same datum as old and is about $20^{\prime}$ upstream.

Gage-Height Record. The data logger referenced to the inside staff and reference point gave a complete and satisfactory record for the year.

Rating. The channel at the gage is $30^{\prime}$ wide and straight for about 40' upstream then bends to the left; downstream the gage is straight for 100'. The streambed through this reach is primary sand, gravel, and cobbles. Low-flow control is rock riffle 5' below gage. The channel has been scoured and filled significantly by high flows resulting from the Cerro Grande fire.

Two discharge measurements (Nos. 57-58) were made this year. Small shifts were applied based on PZF.

Rating No. 3 should be considered good except for the extreme lower end (less than 0.5 $\mathrm{ft}^{3} / \mathrm{s}$ ), which will continue to change back and forth in response to high flows. Steep slopes in the gage reach and throughout the region cause considerable movement of material either scours or fills. Low-water records at this site will continue to be a problem until increased runoff from the burned areas returns to something close to prefire conditions.

Discharge. Discharge was computed by applying inside gage height to Rating No. 3 directly.

Remarks. Records are good. 
E252 W ater Can yon above SR 501

Daily Mean Discharge in Cubic Feet per Second

Water Year October 2008 to September 2009

\begin{tabular}{|c|c|c|c|c|c|c|c|c|c|c|c|c|}
\hline DAY & OCT & NOV & DEC & JAN & FEB & MAR & APR & MAY & JUN & JUL & AUG & SEP \\
\hline 1 & .01 & .06 & .06 & .07 & .07 & .07 & .11 & .17 & .06 & .06 & .06 & .03 \\
\hline 2 & .01 & .06 & .06 & .07 & .07 & .07 & .11 & .17 & .06 & .06 & .06 & .03 \\
\hline 3 & .01 & .06 & .06 & .07 & .07 & .07 & .11 & .17 & .06 & .06 & .06 & .03 \\
\hline 4 & .01 & .06 & .06 & .07 & .07 & .07 & .11 & .17 & .06 & .06 & .06 & .03 \\
\hline 5 & .01 & .06 & .06 & .07 & .07 & .07 & .11 & .17 & .06 & .06 & .05 & .03 \\
\hline 6 & .01 & .06 & .06 & .07 & .07 & .07 & .11 & .17 & .06 & .06 & .06 & .03 \\
\hline 7 & 0 & .06 & .06 & .07 & .07 & .07 & .11 & .17 & .06 & .06 & .06 & .03 \\
\hline 8 & 0 & .06 & .06 & .07 & .07 & .07 & .11 & .17 & .06 & .06 & .05 & .03 \\
\hline 9 & 0 & .06 & .06 & .07 & .07 & .07 & .11 & .17 & .06 & .06 & .04 & .03 \\
\hline 10 & .01 & .07 & .06 & .07 & .07 & .08 & .11 & .17 & .06 & .06 & .04 & .03 \\
\hline 11 & .01 & .07 & .06 & .07 & .07 & .08 & .11 & .17 & .06 & .05 & .04 & .03 \\
\hline 12 & .01 & .07 & .06 & .07 & .07 & .09 & .11 & .17 & .06 & .06 & .03 & .03 \\
\hline 13 & .01 & .07 & .07 & .07 & .07 & .09 & .11 & .17 & .06 & .06 & .03 & .03 \\
\hline 14 & .01 & .07 & .07 & .07 & .07 & .09 & .11 & .17 & .06 & .06 & .03 & .03 \\
\hline 15 & .01 & .07 & .07 & .07 & .07 & .09 & .11 & .17 & .06 & .06 & .03 & .03 \\
\hline 16 & .01 & .07 & .07 & .07 & .07 & .10 & .11 & .17 & .06 & .06 & .03 & .03 \\
\hline 17 & .01 & .06 & .07 & .07 & .07 & .10 & .11 & .17 & .05 & .06 & .03 & .04 \\
\hline 18 & .01 & .06 & .07 & .07 & .07 & .11 & .11 & .17 & .04 & .06 & .03 & .04 \\
\hline 19 & .01 & .06 & .07 & .07 & .07 & .11 & .11 & .15 & .04 & .06 & .03 & .04 \\
\hline 20 & .01 & .06 & .07 & .07 & .07 & .11 & .11 & .14 & .04 & .05 & .03 & .04 \\
\hline 21 & .01 & .06 & .07 & .07 & .07 & .11 & .11 & .14 & .05 & .05 & .03 & .04 \\
\hline 22 & .01 & .06 & .07 & .07 & .07 & .11 & .13 & .14 & .06 & .06 & .03 & .04 \\
\hline 23 & .01 & .06 & .07 & .07 & .07 & .11 & .14 & .14 & .06 & .06 & .03 & .04 \\
\hline 24 & .01 & .06 & .07 & .07 & .07 & .11 & .14 & .08 & .06 & .05 & .03 & .04 \\
\hline 25 & .01 & .06 & .07 & .07 & .07 & .11 & .17 & .06 & .06 & .05 & .03 & .04 \\
\hline 26 & .01 & .06 & .07 & .07 & .07 & .11 & .17 & .06 & .06 & .06 & .03 & .04 \\
\hline 27 & .01 & .06 & .07 & .07 & .07 & .11 & .17 & .06 & .06 & .06 & .03 & .04 \\
\hline 28 & .01 & .06 & .07 & .07 & .07 & .11 & .17 & .06 & .05 & .06 & .03 & .04 \\
\hline 29 & .01 & .06 & .07 & .07 & ---- & .11 & .17 & .06 & .06 & .06 & .03 & .04 \\
\hline 30 & .05 & .06 & .07 & .07 & ---- & .11 & .17 & .06 & .06 & .06 & .03 & .04 \\
\hline 31 & .06 & --- & .07 & .07 & ---- & .11 & ----- & .06 & ---- & .06 & .03 & --- \\
\hline Total & 0.37 & 1.87 & 2.05 & 2.17 & 1.96 & 2.89 & 3.74 & 4.27 & 1.71 & 1.81 & 1.18 & 1.04 \\
\hline Mean & .012 & .062 & .066 & .070 & .070 & .093 & .12 & .14 & .057 & .058 & .038 & .035 \\
\hline Max & .06 & .07 & .07 & .07 & .07 & .11 & .17 & .17 & .06 & .06 & .06 & .04 \\
\hline Min & 0 & .06 & .06 & .07 & .07 & .07 & .11 & .06 & .04 & .05 & .03 & .03 \\
\hline Acre-Ft & .73 & 3.7 & 4.1 & 4.3 & 3.9 & 5.7 & 7.4 & 8.5 & 3.4 & 3.6 & 2.3 & 21 \\
\hline Wtr Year & 2009 & Total & 25.06 & Mean & & 69 & Max & .17 & Min & 0 & Acre-Ft & 50 \\
\hline Cal Year & 2008 & Total & 80.28 & Mean & & 22 & Max & 1.6 & Min & 0 & Acre-Ft & 159 \\
\hline
\end{tabular}




\section{E2525 Water Canyon above S Site Canyon}

Location. Lat $35^{\circ}$ 49' 50", long $106^{\circ}$ 18' 26", Sec. 33, T. 19 N., R. 6 E., Ramon Vigil Grant, Los Alamos County.

Drainage Area. $5.64 \mathrm{mi}^{2}$.

Period of Record. October 1, 2008, to September 30, 2009.

Gage. Data logger and $90^{\circ}$ sharp-crested weir. Elevation of gage is $6,980 \mathrm{ft}$ above NGVD from GPS survey.

Remarks. Records are good. Records for this site existed before published record but are not reliable. Legal location based on projected values.

Extremes for Period of Record. Maximum discharge $0.27 \mathrm{ft}^{3} / \mathrm{s}$, June 10, 2009, gage height $1.13 \mathrm{ft}$.

Extremes for Current Year. Maximum discharge of $0.27 \mathrm{ft}^{3} / \mathrm{s}$ at $0940 \mathrm{~h}$, June 10, gage height of $1.13 \mathrm{ft}$. No peak discharge above base of $1.00 \mathrm{ft}^{3} / \mathrm{s}$.

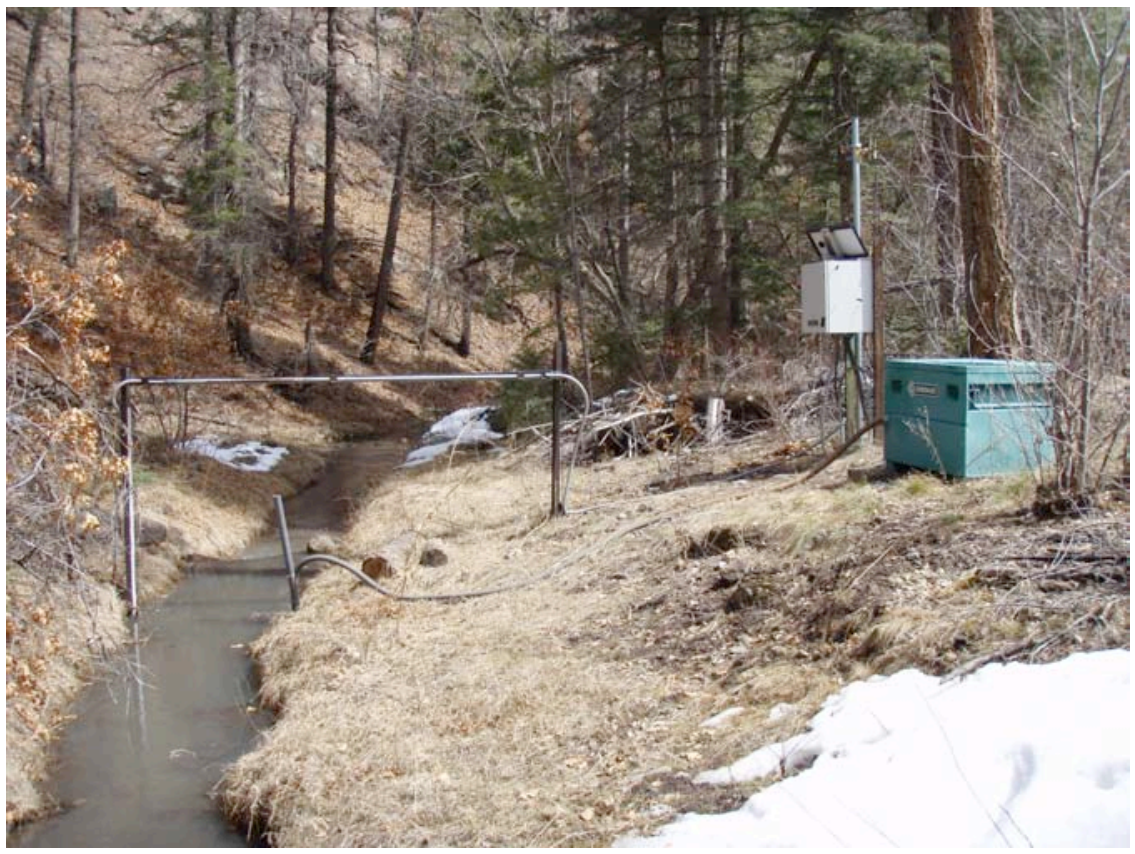




\title{
E2525 Water Canyon above S Site Canyon
}

\author{
Station Analysis
}

2009 Water Year

Equipment. Station is equipped with Sutron 8210 data logger (5-min. interval) with Sutron Accubar bubble sensor. The system is powered by a solar panel battery system housed in a NEMA shelter. Station is equipped with an ISCO pump sampler for water quality sample collection. ISCO is housed in a separate shelter, a $3^{\prime} \times 4^{\prime}$ metal box. Sampler is triggered by stage through the data logger. An outside staff is available for reference. No provision for discharge measurements above wading stage.

Field Work. The station was visited 16 times to conduct discharge measurements and service the instrumentation. Field inspections for the gage are listed under site history files on the Hydstra database. Discharge measurements for the gage are listed under site gauging files on the Hydstra database.

Datum Correction. None. Level run February 27, 2006, show gage to be within allowable limits.

Gage-Height Record. The data logger referenced to the outside staff gave a complete and satisfactory record, except for the period from November 16 to February 26 when gage height was affected by ice.

Rating. The channel is straight $50^{\prime}$ above and below the gage $30^{\prime}$ then forks to the right. The streambed consists of rock and cobble. The banks are stable with vegetation.

Eight discharge measurements (Nos. 33-40) and five inspections of no flow were made this year.

Rating No. 2 was developed using the current-year measurements and one critical depth computation.

Discharge. Discharge was computed by applying gage height to Rating No. 2 directly.

Remarks. Records are good. 
E2525 Water Canyon above S Site Canyon

Daily Mean Discharge in Cubic Feet per Second

Water Year October 2008 to September 2009

\begin{tabular}{|c|c|c|c|c|c|c|c|c|c|c|c|c|}
\hline DAY & OCT & NOV & DEC & JAN & FE B & MAR & APR & MAY & JUN & JUL & AUG & SEP \\
\hline 1 & 0 & $.03^{*}$ & $.03^{*}$ & $.09^{*}$ & .08 & .11 & .14 & .18 & .10 & 0 & 0 & 0 \\
\hline 2 & 0 & $.03^{*}$ & $.03^{*}$ & $.09^{*}$ & $.08^{*}$ & .12 & .14 & .19 & .11 & 0 & 0 & 0 \\
\hline 3 & 0 & $.03^{*}$ & $.03^{*}$ & .16 & .07 & .15 & .14 & .19 & .12 & 0 & 0 & 0 \\
\hline 4 & 0 & $.03^{*}$ & $.03^{*}$ & .12 & $.08^{*}$ & .18 & .14 & .18 & .11 & 0 & 0 & 0 \\
\hline 5 & 0 & $.03^{*}$ & $.03^{*}$ & .11 & .08 & .15 & .14 & .18 & .09 & 0 & 0 & 0 \\
\hline 6 & 0 & $.03^{*}$ & $.03^{*}$ & .09 & $.08^{*}$ & .14 & .14 & .18 & .06 & 0 & 0 & 0 \\
\hline 7 & 0 & $.03^{*}$ & $.03^{*}$ & .07 & $.08^{*}$ & .11 & .13 & .17 & .03 & 0 & 0 & 0 \\
\hline 8 & 0 & $.03^{*}$ & $.03^{*}$ & .07 & .08 & .10 & .14 & .17 & 0 & 0 & 0 & 0 \\
\hline 9 & 0 & $.03^{*}$ & $.03^{*}$ & .08 & .07 & .10 & .14 & .17 & 0 & 0 & 0 & 0 \\
\hline 10 & 0 & $.03^{*}$ & $.03^{*}$ & .07 & $.07^{*}$ & .10 & .14 & .17 & .14 & 0 & 0 & 0 \\
\hline 11 & 0 & $.03^{*}$ & .02 & .07 & $.07^{*}$ & .09 & .19 & .17 & .10 & 0 & 0 & 0 \\
\hline 12 & 0 & $.03^{*}$ & .04 & .07 & $.07^{*}$ & .09 & .18 & .16 & .06 & 0 & 0 & 0 \\
\hline 13 & $.03^{*}$ & $.03^{*}$ & .08 & .07 & $.07^{*}$ & .11 & .19 & .16 & .02 & 0 & 0 & 0 \\
\hline 14 & $.03^{*}$ & $.03^{*}$ & $.07^{*}$ & .08 & $.07^{\star}$ & .10 & .19 & .16 & .02 & 0 & 0 & 0 \\
\hline 15 & $.03^{*}$ & $.03^{*}$ & $.07^{*}$ & .08 & $.07^{*}$ & .10 & .17 & .15 & .02 & 0 & 0 & 0 \\
\hline 16 & $.03^{*}$ & $.03^{*}$ & $.07^{\star}$ & .07 & $.07^{*}$ & .10 & .15 & .15 & 0 & 0 & 0 & 0 \\
\hline 17 & $.03^{*}$ & $.03^{*}$ & $.07^{*}$ & .07 & .07 & .10 & .16 & .15 & 0 & 0 & 0 & 0 \\
\hline 18 & $.03^{*}$ & $.03^{*}$ & $.07^{*}$ & .07 & .06 & .10 & .18 & .14 & 0 & 0 & 0 & 0 \\
\hline 19 & $.03^{*}$ & $.03^{*}$ & $.07^{*}$ & .07 & .05 & .10 & .18 & .14 & 0 & 0 & 0 & 0 \\
\hline 20 & $.03^{*}$ & $.03^{*}$ & .06 & $.07^{*}$ & .06 & .10 & .17 & .13 & .04 & 0 & 0 & 0 \\
\hline 21 & $.03^{*}$ & $.03^{*}$ & .05 & $.07^{*}$ & $.08^{*}$ & .10 & .16 & .14 & .03 & 0 & 0 & 0 \\
\hline 22 & $.03^{*}$ & $.03^{*}$ & .07 & .08 & $.08^{*}$ & .10 & .16 & .16 & 0 & 0 & 0 & 0 \\
\hline 23 & $.03^{*}$ & $.03^{*}$ & .10 & .09 & .09 & .09 & .16 & .20 & 0 & 0 & 0 & 0 \\
\hline 24 & $.03^{*}$ & $.03^{*}$ & .07 & $.05^{\star}$ & .10 & .09 & .16 & .17 & 0 & 0 & 0 & .01 \\
\hline 25 & $.03^{*}$ & $.03^{*}$ & .09 & $.05^{*}$ & $.10^{*}$ & .10 & .16 & .15 & 0 & 0 & 0 & 0 \\
\hline 26 & $.03^{*}$ & $.03^{*}$ & $.09^{*}$ & $.05^{*}$ & $.10^{*}$ & .11 & .17 & .13 & 0 & .03 & 0 & 0 \\
\hline 27 & $.03^{*}$ & $.03^{*}$ & $.09^{*}$ & $.05^{*}$ & .13 & .13 & .18 & .15 & 0 & 0 & 0 & 0 \\
\hline 28 & $.03^{*}$ & $.03^{*}$ & $.09^{*}$ & .06 & .12 & .14 & .18 & .13 & 0 & 0 & 0 & 0 \\
\hline 29 & $.03^{*}$ & $.03^{*}$ & $.09^{*}$ & .07 & ----- & .14 & .18 & .11 & 0 & 0 & 0 & 0 \\
\hline 30 & $.03^{*}$ & $.03^{*}$ & $.09^{*}$ & .06 & ------ & .14 & .18 & .11 & 0 & .01 & 0 & 0 \\
\hline 31 & $.03^{*}$ & ------ & $.09^{*}$ & .08 & ----- & .14 & ------ & .11 & ----- & .02 & 0 & ------ \\
\hline Total & 0.57 & 0.90 & 1.84 & 2.38 & 2.23 & 3.53 & 4.84 & 4.85 & 1.05 & 0.06 & 0 & 0.01 \\
\hline Mean & .018 & .030 & .059 & .077 & .080 & .11 & .16 & .16 & .035 & .002 & 0 & 0 \\
\hline $\operatorname{Max}$ & .03 & .03 & .10 & .16 & .13 & .18 & .19 & .20 & .14 & .03 & 0 & .01 \\
\hline M in & 0 & .03 & .02 & .05 & .05 & .09 & .13 & .11 & 0 & 0 & 0 & 0 \\
\hline cre $-\mathrm{Ft}$ & 1.1 & 1.8 & 3.6 & 4.7 & 4.4 & 7.0 & 9.6 & 9.6 & 2.1 & .12 & 0 & .02 \\
\hline Wtr Year & 2009 & Total & 22.26 & Mean & & 061 & Max & .20 & Min & 0 & Acre-Ft & 44 \\
\hline Cal Year & 2008 & Total & 36.14 & Mean & & 099 & Max & 3.8 & Min & 0 & Acre-Ft & 72 \\
\hline
\end{tabular}

${ }^{\star}$ Estimate 


\section{E2528 S Site Canyon above Water Canyon}

Location. Lat $35^{\circ}$ 49' 51", long $106^{\circ}$ 18' 27", Sec. 33, T. 19 N., R. 6 E., Ramon Vigil Grant, Los Alamos County.

Drainage Area. $0.76 \mathrm{mi}^{2}$.

Period of Record. April 1999 to September 30, 2009.

Revised Record. Drainage Area (2006)

Gage. Data logger and $90^{\circ}$ sharp-crested weir. Elevation of gage is $6,840 \mathrm{ft}$ above NGVD from GPS survey.

Remarks. Records are good. Legal location based on projected values.

Average Discharge. $10 \mathrm{yr}, 0.006 \mathrm{ft}^{3} / \mathrm{s}, 4.3 \mathrm{acre}-\mathrm{ft} / \mathrm{yr}$.

Extremes for Period of Record. Maximum discharge, of $162 \mathrm{ft}^{3} / \mathrm{s}$, August 20, 2004, gage height $4.03 \mathrm{ft}$. No flow most of the time.

Extremes for Current Year. No peak discharge above base of $10 \mathrm{ft}^{3} / \mathrm{s}$. No flow for the year.

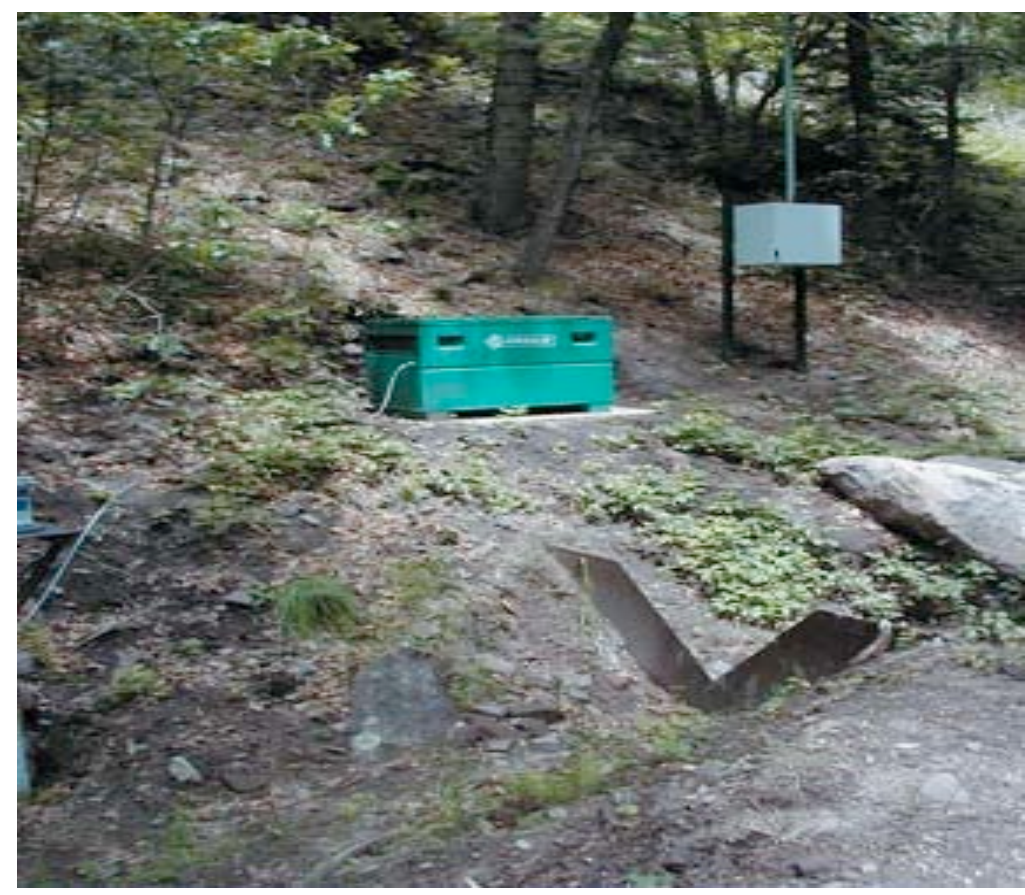




\title{
E2528 S Site Canyon above Water Canyon
}

\author{
Station Analysis
}

2009 Water Year

Equipment. Station is equipped with Sutron 8210 data logger (5-min. interval) with Milltronics sonic probe. The system is powered by a solar panel battery system housed in a NEMA shelter on left bank. Station is equipped with an ISCO pump sampler for water quality sample collection. ISCO is housed in a separate shelter, a $3^{\prime} \times 4^{\prime}$ metal box. Sampler is triggered by stage through the data logger. An outside staff is available for reference. No provision for discharge measurements above wading stage.

Field Work. The station was visited 14 times to conduct discharge measurements and service the instrumentation. Field inspections for the gage are listed under site history files on the Hydstra database. Discharge measurements for the gage are listed under site gauging files on the Hydstra database.

Datum Correction. None.

Gage-Height Record. The data logger referenced to the outside staff gave a complete and satisfactory record, except for the periods from December 3 to January 15, 17, 21, 30, February 4, 9, 10, 17, March 4, 7, 8, 15, 26, 27, and April 12, 17 when gage height was affected by ice.

Rating. Control is $90^{\circ}$ weir with $2^{\prime}$ deep notch. Canyon is very steep directly above station, but does flatten out enough to allow weir to be effective.

Fourteen inspections of no flow were made this year.

Rating No. 1 was developed using weir formula and one critical depth computation. Rating No. 1 is considered fair. Large shifts were applied to the low end (PZF) because of filling in the pool. These are most likely to change over time when fill conditions occur.

Discharge. Discharge was computed by applying gage height to Rating No. 1 with V diagrams adjusting the PZF. Those periods estimated at zero flow were based on precipitation and adjoining stations E2525 and E262.

Remarks. Records are good. 


\section{E2528 S Site Canyon above Water Canyon}

Daily Mean Discharge in Cubic Feet per Second

Water Year October 2008 to September 2009

\begin{tabular}{|c|c|c|c|c|c|c|c|c|c|c|c|c|}
\hline DAY & ОСТ & NOV & DEC & JAN & FEB & MAR & APR & MAY & JUN & JUL & $A U G$ & SEP \\
\hline 1 & 0 & 0 & 0 & $0^{*}$ & 0 & 0 & 0 & 0 & 0 & 0 & 0 & 0 \\
\hline 2 & 0 & 0 & 0 & $0^{*}$ & 0 & 0 & 0 & 0 & 0 & 0 & 0 & 0 \\
\hline 3 & 0 & 0 & $0^{*}$ & $0^{*}$ & 0 & 0 & 0 & 0 & 0 & 0 & 0 & 0 \\
\hline 4 & 0 & 0 & $0^{*}$ & $0^{*}$ & $0^{*}$ & $0^{*}$ & 0 & 0 & 0 & 0 & 0 & 0 \\
\hline 5 & 0 & 0 & $0^{*}$ & $0^{*}$ & 0 & 0 & 0 & 0 & 0 & 0 & 0 & 0 \\
\hline 6 & 0 & 0 & $0^{*}$ & $0^{*}$ & 0 & 0 & 0 & 0 & 0 & 0 & 0 & 0 \\
\hline 7 & 0 & 0 & $0^{*}$ & $0^{*}$ & 0 & $0^{*}$ & 0 & 0 & 0 & 0 & 0 & 0 \\
\hline 8 & 0 & 0 & $0^{*}$ & $0^{*}$ & 0 & $0^{*}$ & 0 & 0 & 0 & 0 & 0 & 0 \\
\hline 9 & 0 & 0 & $0^{*}$ & $0^{*}$ & $0^{*}$ & 0 & 0 & 0 & 0 & 0 & 0 & 0 \\
\hline 10 & 0 & 0 & $0^{*}$ & $0^{*}$ & $0^{*}$ & 0 & 0 & 0 & 0 & 0 & 0 & 0 \\
\hline 11 & 0 & 0 & $0^{*}$ & $0^{*}$ & 0 & 0 & 0 & 0 & 0 & 0 & 0 & 0 \\
\hline 12 & 0 & 0 & $0^{*}$ & $0^{*}$ & 0 & 0 & $0^{*}$ & 0 & 0 & 0 & 0 & 0 \\
\hline 13 & 0 & 0 & $0^{*}$ & $0^{*}$ & 0 & 0 & 0 & 0 & 0 & 0 & 0 & 0 \\
\hline 14 & 0 & 0 & $0^{*}$ & $0^{*}$ & 0 & 0 & 0 & 0 & 0 & 0 & 0 & 0 \\
\hline 15 & 0 & 0 & $0^{*}$ & $0^{*}$ & 0 & $0^{*}$ & 0 & 0 & 0 & 0 & 0 & 0 \\
\hline 16 & 0 & 0 & $0^{*}$ & 0 & 0 & 0 & 0 & 0 & 0 & 0 & 0 & 0 \\
\hline 17 & 0 & 0 & $0^{*}$ & $0^{*}$ & $0^{*}$ & 0 & $0^{*}$ & 0 & 0 & 0 & 0 & 0 \\
\hline 18 & 0 & 0 & $0^{*}$ & 0 & 0 & 0 & 0 & 0 & 0 & 0 & 0 & 0 \\
\hline 19 & 0 & 0 & $0^{*}$ & 0 & 0 & 0 & 0 & 0 & 0 & 0 & 0 & 0 \\
\hline 20 & 0 & 0 & $0^{*}$ & 0 & 0 & 0 & 0 & 0 & 0 & 0 & 0 & 0 \\
\hline 21 & 0 & 0 & $0^{*}$ & $0^{*}$ & 0 & 0 & 0 & 0 & 0 & 0 & 0 & 0 \\
\hline 22 & 0 & 0 & $0^{*}$ & 0 & 0 & 0 & 0 & 0 & 0 & 0 & 0 & 0 \\
\hline 23 & 0 & 0 & $0^{*}$ & 0 & 0 & 0 & 0 & 0 & 0 & 0 & 0 & 0 \\
\hline 24 & 0 & 0 & $0^{*}$ & 0 & 0 & 0 & 0 & 0 & 0 & 0 & 0 & 0 \\
\hline 25 & 0 & 0 & $0^{*}$ & 0 & 0 & 0 & 0 & 0 & 0 & 0 & 0 & 0 \\
\hline 26 & 0 & 0 & $0^{*}$ & 0 & 0 & $0^{*}$ & 0 & 0 & 0 & 0 & 0 & 0 \\
\hline 27 & 0 & 0 & $0^{*}$ & 0 & 0 & $0^{*}$ & 0 & 0 & 0 & 0 & 0 & 0 \\
\hline 28 & 0 & 0 & $0^{*}$ & 0 & 0 & 0 & 0 & 0 & 0 & 0 & 0 & 0 \\
\hline 29 & 0 & 0 & $0^{*}$ & 0 & ----- & 0 & 0 & 0 & 0 & 0 & 0 & 0 \\
\hline 30 & 0 & 0 & $0^{*}$ & $0^{*}$ & --- & 0 & 0 & 0 & 0 & 0 & 0 & 0 \\
\hline 31 & 0 & --- & $0^{*}$ & 0 & ---- & 0 & ---- & 0 & ---- & 0 & 0 & ---- \\
\hline Total & 0 & 0 & 0 & 0 & 0 & 0 & 0 & 0 & 0 & 0 & 0 & 0 \\
\hline Mean & 0 & 0 & 0 & 0 & 0 & 0 & 0 & 0 & 0 & 0 & 0 & 0 \\
\hline Max & 0 & 0 & 0 & 0 & 0 & 0 & 0 & 0 & 0 & 0 & 0 & 0 \\
\hline Min & 0 & 0 & 0 & 0 & 0 & 0 & 0 & 0 & 0 & 0 & 0 & 0 \\
\hline Acre-F t & 0 & 0 & 0 & 0 & 0 & 0 & 0 & 0 & 0 & 0 & 0 & 0 \\
\hline Wtr Year & 2009 & Total & 0 & Mean & & 0 & Max & 0 & Min & 0 & Acre- $\mathrm{Ft}$ & 0 \\
\hline Cal Year & 2008 & Total & 6.80 & Mean & & 019 & Max & 3.5 & Min & 0 & Acre- $\mathrm{Ft}$ & 13 \\
\hline
\end{tabular}




\section{E253 Cañon de Valle above SR 501}

Location. Lat $35^{\circ} 51^{\prime}$ 6", long $106^{\circ} 21^{\prime} 17^{\prime \prime}$, NE 1/4, Sec. 25, T. 19 N., R. 5 E., Los Alamos County in Santa Fe National Forest.

Drainage Area. $2.27 \mathrm{mi}^{2}$.

Period of Record. October 1994 to June 2000 (gage destroyed by flood); January 31, 2001, to September 30, 2009.

Gage. Data logger and $120^{\circ}$ weir plate, rain gage with cellular telemetry. Elevation of gage is 7,701 ft above NGVD from GPS survey.

Remarks. Records are good.

Average Discharge. $15 \mathrm{yr}, 0.02 \mathrm{ft}^{3} / \mathrm{s}, 16$ acre-ft/yr.

Extremes for Period of Record. Maximum discharge, $740 \mathrm{ft}^{3} / \mathrm{s}$, June 28, 2000, from peak flow computation, gage height $8.42 \mathrm{ft}$. No flow most of the time.

Extremes for Current Year. No peak discharge above base of $5.0 \mathrm{ft}^{3} / \mathrm{s}$. No flow for the year.

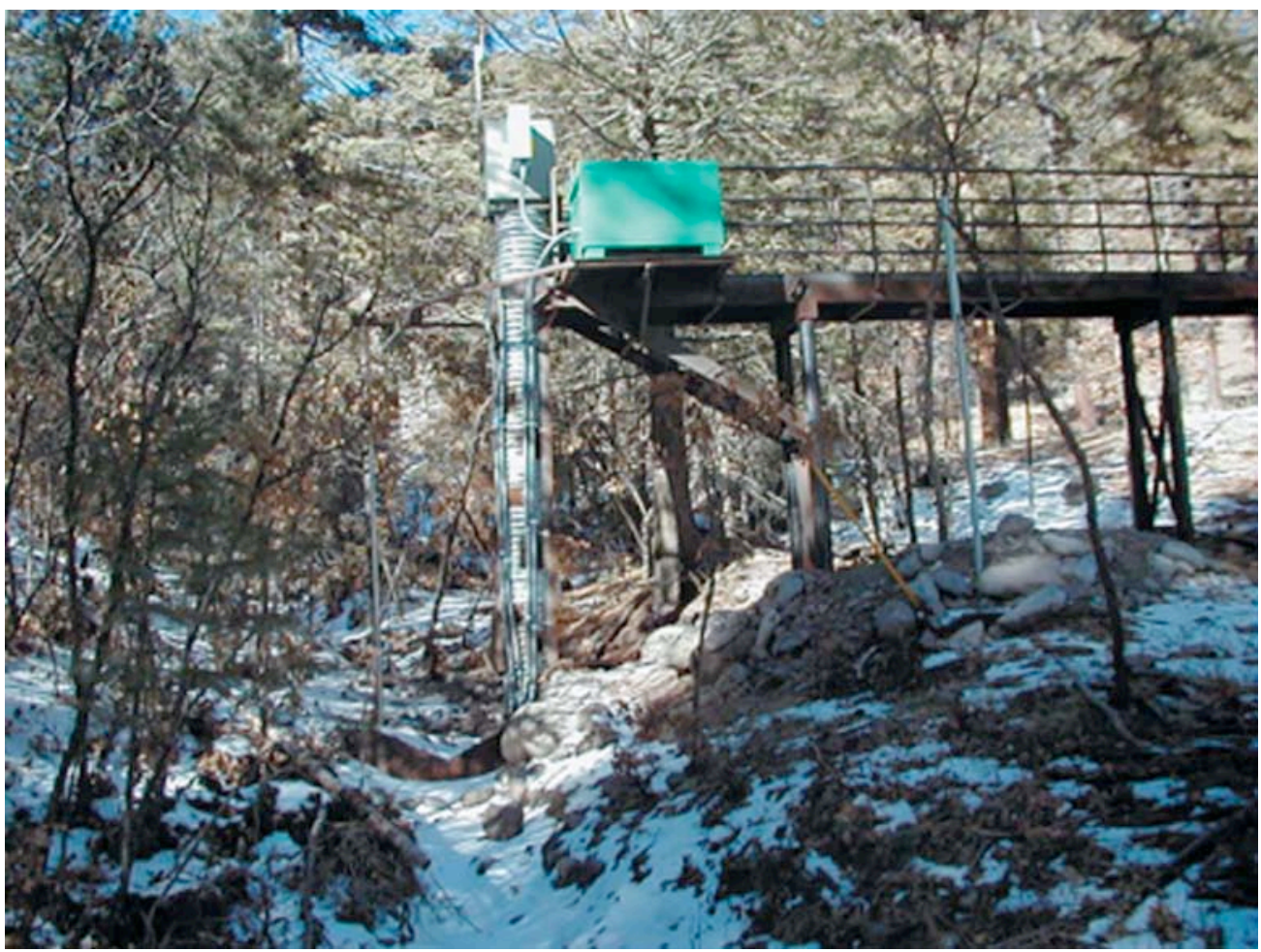




\title{
E253 Cañon del Valle above SR 501
}

\author{
Station Analysis
}

\section{Water Year}

Equipment. Station is equipped with Sutron 8210 data logger (5-min. interval) with shaft encoder float system (5-min. interval) and cellular phone with speech modem. The system is powered by a solar panel battery system housed in NEMA shelter on 24" CMP well, 16' long attached to a 60' metal walkway. Station is equipped with an ISCO pump sampler for water quality sample collection. ISCO is housed in a separate shelter, a $3^{\prime} \times$ $4^{\prime}$ metal box. Sampler is triggered by stage through the data logger. An outside staff is available for reference. No provision for direct discharge measurements above wading stages.

Station is also equipped with a rain gage, Rain Collection II. All equipment is powered with a solar panel battery charging system.

Field Work. The station was visited 43 times to conduct discharge measurements and service the instrumentation. Field inspections for the gage are listed under site history files on the Hydstra database. Discharge measurements for the gage are listed under site gauging files on the Hydstra database.

Datum Correction. None. Levels were run in April 16, 2001, when gage was reestablished.

Gage-Height Record. The data logger referenced to the outside staff gave a complete and satisfactory record for the year, except for the periods from March 4-20 and May 1119 when data logger malfunctioned.

Rating. The channel at the gage is about $8^{\prime}$ wide and straight for about $50^{\prime}$ upstream then bends to the left and straight for 100' downstream and bends to the right. The streambed through this reach is primarily gravel with cobbles. The low-flow control is a $120^{\circ}$ sharp-crested weir. The channel becomes the control at high flow.

Forty-three inspections of no flow were made this year.

Rating No. 2 is based on four discharge measurements, one critical depth computation, and theoretical computation for $120^{\circ}$ sharp-crested weir to a gage height of 2.30 feet. Broad-crested weir computation is used above that stage.

Discharge. Discharge was computed by applying gage height to Rating No. 2 directly with one variable shift applied. Those days estimated at zero flow were based on precipitation and nearby stations.

Remarks. Records are good. 
E253 Cañ on del Valle above SR 501

Daily Mean Discharge in Cubic Feet per Second

Water Year October 2008 to September 2009

\begin{tabular}{|c|c|c|c|c|c|c|c|c|c|c|c|c|}
\hline DAY & ОСТ & NOV & DEC & JAN & FEB & MAR & APR & MAY & JUN & JUL & AUG & SEP \\
\hline 1 & 0 & 0 & 0 & 0 & 0 & 0 & 0 & 0 & 0 & 0 & 0 & 0 \\
\hline 2 & 0 & 0 & 0 & 0 & 0 & 0 & 0 & 0 & 0 & 0 & 0 & 0 \\
\hline 3 & 0 & 0 & 0 & 0 & 0 & 0 & 0 & 0 & 0 & 0 & 0 & 0 \\
\hline 4 & 0 & 0 & 0 & 0 & 0 & $0^{*}$ & 0 & 0 & 0 & 0 & 0 & 0 \\
\hline 5 & 0 & 0 & 0 & 0 & 0 & $0^{*}$ & 0 & 0 & 0 & 0 & 0 & 0 \\
\hline 6 & 0 & 0 & 0 & 0 & 0 & $0^{*}$ & 0 & 0 & 0 & 0 & 0 & 0 \\
\hline 7 & 0 & 0 & 0 & 0 & 0 & $0^{*}$ & 0 & 0 & 0 & 0 & 0 & 0 \\
\hline 8 & 0 & 0 & 0 & 0 & 0 & $0^{*}$ & 0 & 0 & 0 & 0 & 0 & 0 \\
\hline 9 & 0 & 0 & 0 & 0 & 0 & $0^{*}$ & 0 & 0 & 0 & 0 & 0 & 0 \\
\hline 10 & 0 & 0 & 0 & 0 & 0 & $0^{*}$ & 0 & 0 & 0 & 0 & 0 & 0 \\
\hline 11 & 0 & 0 & 0 & 0 & 0 & $0^{*}$ & 0 & $0^{*}$ & 0 & 0 & 0 & 0 \\
\hline 12 & 0 & 0 & 0 & 0 & 0 & $0^{*}$ & 0 & $0^{*}$ & 0 & 0 & 0 & 0 \\
\hline 13 & 0 & 0 & 0 & 0 & 0 & $0^{*}$ & 0 & $0^{*}$ & 0 & 0 & 0 & 0 \\
\hline 14 & 0 & 0 & 0 & 0 & 0 & $0^{*}$ & 0 & $0^{*}$ & 0 & 0 & 0 & 0 \\
\hline 15 & 0 & 0 & 0 & 0 & 0 & $0^{*}$ & 0 & $0^{*}$ & 0 & 0 & 0 & 0 \\
\hline 16 & 0 & 0 & 0 & 0 & 0 & $0^{*}$ & 0 & $0^{*}$ & 0 & 0 & 0 & 0 \\
\hline 17 & 0 & 0 & 0 & 0 & 0 & $0^{*}$ & 0 & $0^{*}$ & 0 & 0 & 0 & 0 \\
\hline 18 & 0 & 0 & 0 & 0 & 0 & $0^{*}$ & 0 & $0^{*}$ & 0 & 0 & 0 & 0 \\
\hline 19 & 0 & 0 & 0 & 0 & 0 & $0^{*}$ & 0 & $0^{*}$ & 0 & 0 & 0 & 0 \\
\hline 20 & 0 & 0 & 0 & 0 & 0 & $0^{*}$ & 0 & 0 & 0 & 0 & 0 & 0 \\
\hline 21 & 0 & 0 & 0 & 0 & 0 & 0 & 0 & 0 & 0 & 0 & 0 & 0 \\
\hline 22 & 0 & 0 & 0 & 0 & 0 & 0 & 0 & 0 & 0 & 0 & 0 & 0 \\
\hline 23 & 0 & 0 & 0 & 0 & 0 & 0 & 0 & 0 & 0 & 0 & 0 & 0 \\
\hline 24 & 0 & 0 & 0 & 0 & 0 & 0 & 0 & 0 & 0 & 0 & 0 & 0 \\
\hline 25 & 0 & 0 & 0 & 0 & 0 & 0 & 0 & 0 & 0 & 0 & 0 & 0 \\
\hline 26 & 0 & 0 & 0 & 0 & 0 & 0 & 0 & 0 & 0 & 0 & 0 & 0 \\
\hline 27 & 0 & 0 & 0 & 0 & 0 & 0 & 0 & 0 & 0 & 0 & 0 & 0 \\
\hline 28 & 0 & 0 & 0 & 0 & 0 & 0 & 0 & 0 & 0 & 0 & 0 & 0 \\
\hline 29 & 0 & 0 & 0 & 0 & ---- & 0 & 0 & 0 & 0 & 0 & 0 & 0 \\
\hline 30 & 0 & 0 & 0 & 0 & ----- & 0 & 0 & 0 & 0 & 0 & 0 & 0 \\
\hline 31 & 0 & -- & 0 & 0 & ---- & 0 & --- & 0 & $-\cdots$ & 0 & 0 & --- \\
\hline Total & 0 & 0 & 0 & 0 & 0 & 0 & 0 & 0 & 0 & 0 & 0 & 0 \\
\hline Mean & 0 & 0 & 0 & 0 & 0 & 0 & 0 & 0 & 0 & 0 & 0 & 0 \\
\hline Max & 0 & 0 & 0 & 0 & 0 & 0 & 0 & 0 & 0 & 0 & 0 & 0 \\
\hline Min & 0 & 0 & 0 & 0 & 0 & 0 & 0 & 0 & 0 & 0 & 0 & 0 \\
\hline Acre-Ft & 0 & 0 & 0 & 0 & 0 & 0 & 0 & 0 & 0 & 0 & 0 & 0 \\
\hline Wtr Year & 2009 & Total & & Mean & & 0 & Max & 0 & Min & 0 & Acre- $\mathrm{Ft}$ & 0 \\
\hline CalYear & 2008 & Total & & Mean & & 0 & Max & 0 & Min & 0 & Acre-Ft & 0 \\
\hline
\end{tabular}

${ }^{*}$ Estimate 


\section{E256 Cañon de Valle below MDA P}

Location. Lat $35^{\circ}$ 51' 01", long $106^{\circ}$ 19' 57", Sec. 29, T.19 N., R. 6 E., Ramon Vigil Grant, Los Alamos County.

Drainage Area. $3.13 \mathrm{mi}^{2}$.

Period of Record. January 24, 2002, to September 30, 2009.

Revised Record. Drainage Area (2006).

Gage. Data logger and 24" Parshall flume. Elevation of gage is 7,329 ft above NGVD from GPS survey.

Remarks. Records are good. Legal location based on projected values.

Average Discharge. $7 \mathrm{yr}, 0.03 \mathrm{ft}^{3} / \mathrm{s}, 41$ acre-ft/yr.

Extremes for Period of Record. Maximum discharge, $19 \mathrm{ft}^{3} / \mathrm{s}$, August 24, 2005, gage height $1.74 \mathrm{ft}$. No flow most of the time.

Extremes for Current Year. Maximum discharge of $0.19 \mathrm{ft}^{3} / \mathrm{s}$ at $1125 \mathrm{~h}$, October 11 , gage height of $0.18 \mathrm{ft}$. No peak discharge above base of $10 \mathrm{ft}^{3} / \mathrm{s}$.

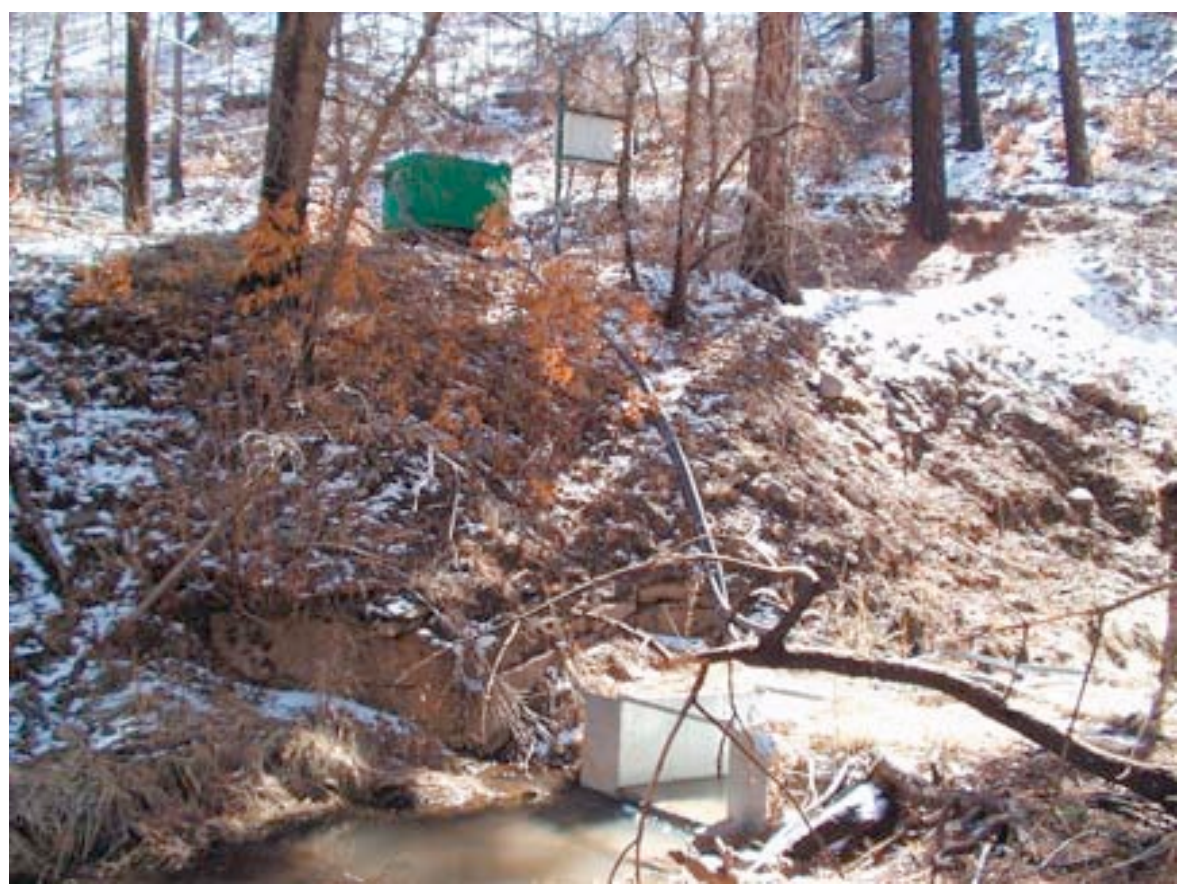




\section{E256 Cañon del Valle below MDA P}

\section{Station Analysis}

\section{Water Year}

Equipment. Station is equipped with Sutron 8210 data logger (5-min. interval) with Sutron Accubar bubble sensor within 24" Parshall flume. The system is powered by a solar panel battery system housed in a NEMA shelter on left bank. Station is equipped with an ISCO pump sampler for water quality sample collection. ISCO is housed in a separate shelter, a $3^{\prime} \times 4^{\prime}$ metal box. An outside staff is available for reference. There is no provision for discharge measurement above wading stage.

Field Work. The station was visited 15 times to conduct discharge measurements and service the instrumentation. Field inspections for the gage are listed under site history files on the Hydstra database. Discharge measurements for the gage are listed under site gauging files on the Hydstra database.

Datum Corrections. None.

Gage-Height Record. The data logger referenced to the inside staff gave a complete and satisfactory record, except for the periods from December 15 to January 3 and January 11 to February 28 when gage height was affected by ice.

Rating. The channel is straight for 50' upstream and $20^{\prime}$ downstream from gage. The streambed consists of sand with gravel subject to fill behind flume from flow events and gage silting problems. The banks are covered with vegetation.

Fifteen observations of flow were made this year.

Rating No. 1 is based on 24" Parshall flume.

Discharge. Discharge computed by applying gage height to Rating No. 1 using variable shift diagrams.

Remarks. Records are good. 


\section{E256 Cañon del Valle below MDA P}

Daily Mean Discharge in Cubic Feet per Second

Water Year October 2008 to September 2009

\begin{tabular}{|c|c|c|c|c|c|c|c|c|c|c|c|c|}
\hline DAY & OCT & NOV & DEC & JAN & FE B & MAR & APR & MAY & JUN & JUL & AUG & SEP \\
\hline 1 & .04 & .06 & .06 & $.03^{*}$ & $.03^{*}$ & .02 & .04 & .02 & .02 & .01 & .01 & 0 \\
\hline 2 & .04 & .06 & .06 & $.03^{*}$ & $.03^{*}$ & .02 & .03 & .02 & .02 & .01 & .01 & 0 \\
\hline 3 & .04 & .06 & .06 & $.03^{*}$ & $.03^{*}$ & .03 & .04 & .02 & .03 & .02 & .01 & 0 \\
\hline 4 & .05 & .06 & .07 & .04 & $.03^{*}$ & .03 & .04 & .02 & .03 & .02 & .01 & 0 \\
\hline 5 & .05 & .06 & $.05^{\star}$ & .03 & $.03^{*}$ & .03 & .05 & .02 & .02 & .03 & .01 & 0 \\
\hline 6 & .05 & .06 & $.05^{\star}$ & .03 & $.02^{*}$ & .03 & .06 & .02 & .02 & .02 & .01 & .01 \\
\hline 7 & .05 & .06 & $.05^{*}$ & .04 & $.02^{*}$ & .03 & .07 & .02 & .02 & .02 & .01 & .01 \\
\hline 8 & .06 & .06 & $.05^{*}$ & .03 & $.02^{*}$ & .03 & .07 & .02 & .02 & .02 & 0 & .01 \\
\hline 9 & .05 & .06 & $.05^{\star}$ & .03 & $.02^{*}$ & .03 & .06 & .02 & .02 & .02 & 0 & .01 \\
\hline 10 & .05 & .06 & $.05^{*}$ & .04 & $.02^{*}$ & .02 & .06 & .02 & .03 & .02 & 0 & .01 \\
\hline 11 & .07 & .06 & $.02^{*}$ & $.03^{*}$ & $.02^{*}$ & .02 & .06 & .02 & .03 & .01 & 0 & .01 \\
\hline 12 & .06 & .06 & $.02^{*}$ & $.03^{*}$ & $.02^{*}$ & .02 & .04 & .02 & .02 & .01 & .01 & .02 \\
\hline 13 & .05 & .06 & $.02^{*}$ & $.03^{*}$ & $.02^{*}$ & .02 & .05 & .02 & .02 & .01 & 0 & .02 \\
\hline 14 & .06 & .06 & $.02^{*}$ & $.03^{*}$ & $.02^{*}$ & .02 & .04 & .02 & .02 & .01 & .02 & .02 \\
\hline 15 & .05 & .06 & $.02^{*}$ & $.03^{*}$ & $.02^{*}$ & .02 & .04 & .02 & .02 & .01 & .01 & .02 \\
\hline 16 & .05 & .06 &. $\mathscr{B}^{*}$ & $.03^{*}$ & $.02^{*}$ & .02 & .03 & .02 & .02 & .01 & 0 & .02 \\
\hline 17 & .05 & .06 & $.03^{*}$ & $.03^{*}$ & $.02^{*}$ & .02 & .02 & .02 & .02 & .01 & 0 & .03 \\
\hline 18 & .05 & .06 & $.03^{*}$ & $.03^{*}$ & $.02^{*}$ & .02 & .03 & .02 & .02 & 0 & 0 & .03 \\
\hline 19 & .06 & .06 & $.03^{*}$ & $.03^{*}$ & $.02^{*}$ & .02 & .03 & .02 & .02 & 0 & 0 & .02 \\
\hline 20 & .06 & .06 & $.03^{*}$ & $.03^{*}$ & $.02^{*}$ & .02 & .03 & .02 & .03 & .01 & 0 & .03 \\
\hline 21 & .06 & .06 & $.0 B^{\star}$ & $.03^{*}$ & $.02^{*}$ & .02 & .03 & .02 & .02 & .01 & 0 & .03 \\
\hline 22 & .06 & .06 & $.03^{*}$ & $.03^{*}$ & $.02^{*}$ & .02 & .03 & .02 & .02 & .01 & 0 & .03 \\
\hline 23 & .06 & .06 & $.03^{*}$ & $.03^{*}$ & $.02^{*}$ & .02 & .03 & .03 & .02 & .01 & 0 & .03 \\
\hline 24 & .06 & .06 & $.03^{\star}$ & $.03^{*}$ & $.02^{*}$ & .02 & .02 & .03 & .02 & .01 & .01 & .04 \\
\hline 25 & .06 & .06 & $.03^{*}$ & $.03^{*}$ & $.02^{*}$ & .01 & .02 & .02 & .02 & .01 & 0 & .04 \\
\hline 26 & .06 & .06 & $.03^{*}$ & $.03^{*}$ & $.02^{*}$ & .02 & .02 & .02 & .02 & .02 & 0 & .04 \\
\hline 27 & .06 & .07 & $.03^{*}$ & $.03^{*}$ & $.02^{*}$ & .07 & .02 & .04 & .02 & .01 & 0 & .04 \\
\hline 28 & .06 & .06 & $.03^{*}$ & $.03^{*}$ & $.02^{*}$ & .07 & .02 & .03 & .02 & .02 & 0 & .05 \\
\hline 29 & .06 & .06 & $.03^{*}$ & $.03^{*}$ & ----- & .06 & .02 & .03 & .01 & .02 & 0 & .05 \\
\hline 30 & .06 & .06 & $.03^{*}$ & $.03^{*}$ & ----- & .06 & .02 & .03 & .02 & .02 & .01 & .05 \\
\hline 31 & .06 & ----- & $.03^{*}$ & $.03^{*}$ & ----- & .04 & ------ & .03 & ----- & .02 & .01 & ----- \\
\hline Total & 1.70 & 1.81 & 1.13 & 0.96 & 0.61 & 0.88 & 1.12 & 0.70 & 0.64 & 0.43 & 0.14 & 0.67 \\
\hline Mean & .055 & .060 & .036 & .031 & .022 & .028 & .037 & .023 & .021 & .014 & .005 & .022 \\
\hline Max & .07 & .07 & .07 & .04 & .03 & .07 & .07 & .04 & .03 & .03 & .02 & .05 \\
\hline Min & .04 & .06 & .02 & .03 & .02 & .01 & .02 & .02 & .01 & 0 & 0 & 0 \\
\hline Acre-F t & 3.4 & 3.6 & 2.2 & 1.9 & 1.2 & 1.7 & 2.2 & 1.4 & 1.3 & .85 & .28 & 1.3 \\
\hline Wtr Year & 2009 & Total & 10.79 & Mean & & 030 & Max & .07 & Min & 0 & Acre-Ft & 21 \\
\hline Cal Year & 2008 & Total & 19.82 & Mean & & 054 & Max & 2.6 & Min & 0 & Acre-Ft & 39 \\
\hline
\end{tabular}

${ }^{\star}$ Estimate 


\section{E2565 Cañon del Valle at Q Site}

Location. Lat $35^{\circ}$ 50' 52", long $106^{\circ} 19^{\prime}$ 0.9", Sec. 28, T.19 N., R. 6 E., Ramon Vigil Grant, Los Alamos County.

Drainage Area. $0.00 \mathrm{mi}^{2} ; 0.11$ acre.

Period of Record. October 1, 2007, to September 30, 2009.

Gage. Data logger and 24" Parshall flume. Elevation of gage is 7,346 ft above NGVD from GPS survey.

Remarks. Records are good. Records for this site existed before period of record but are not reliable. Legal location based on projected values.

Extremes for Period of Record. Maximum discharge $1.0 \mathrm{ft}^{3} / \mathrm{s}$, August 8, 2008, gage height $0.26 \mathrm{ft}$. No flow most of the time.

Extremes for Current Year. Maximum discharge of $0.87 \mathrm{ft}^{3} / \mathrm{s}$ at $1230 \mathrm{~h}$, April 17, gage height of $0.26 \mathrm{ft}$. No peak discharge above base of $1.0 \mathrm{ft}^{3} / \mathrm{s}$.

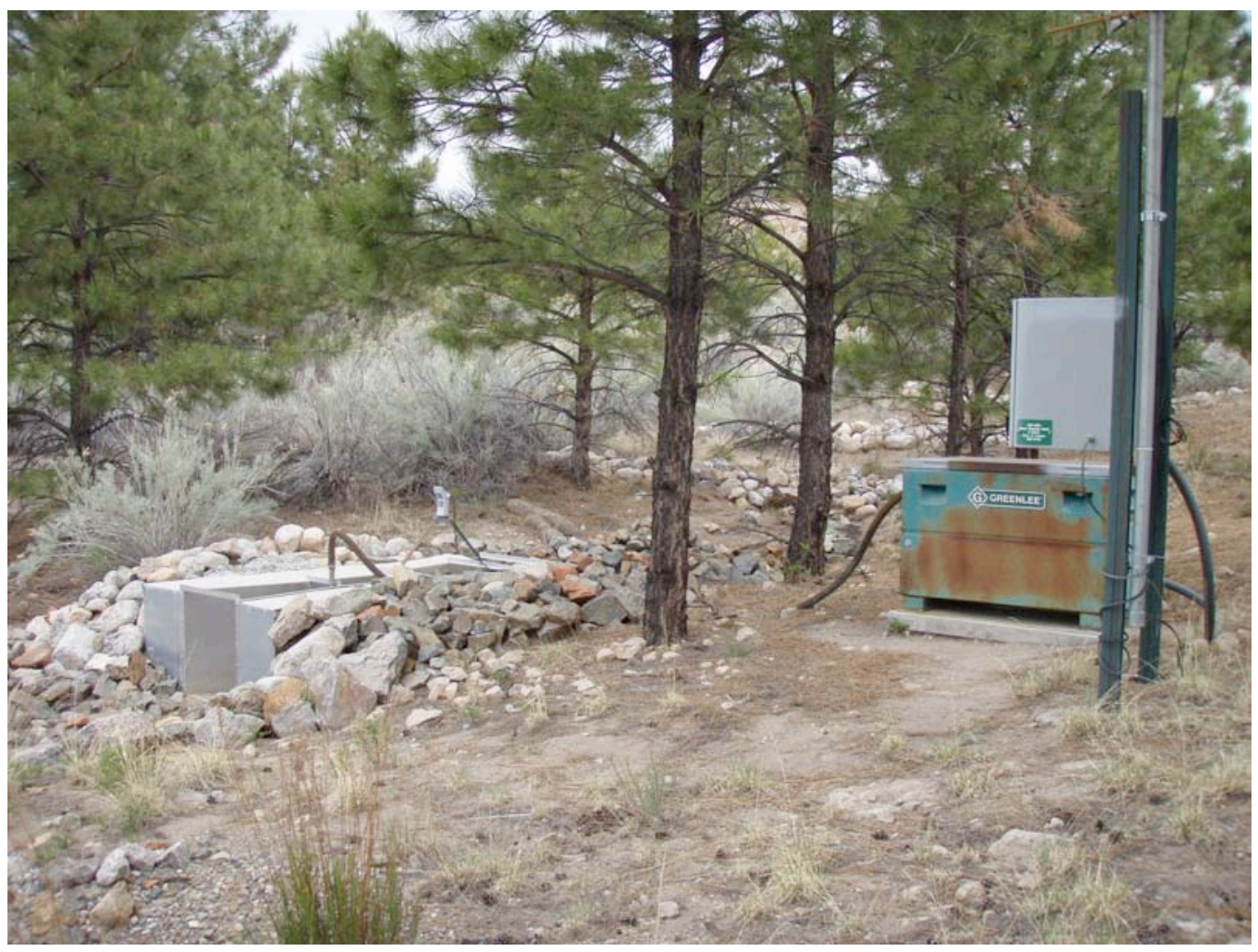




\title{
E2565 Cañon del Valle at Q Site
}

\author{
Station Analysis
}

\section{Water Year}

Equipment. Station is equipped with Sutron 8210 data logger (5-min. interval) with Milltronics sonic probe mounted on a 24" Parshall flume. The system is powered by a solar panel battery system housed in a NEMA shelter. Station is equipped with an ISCO pump sampler for water quality sample collection. ISCO is housed in a separate shelter, a $3^{\prime} \times 4^{\prime}$ metal box. Sampler is triggered by stage through the data logger. An outside staff is available for reference. No provision for discharge measurements above wading stage.

Field Work. The station was visited 23 times to conduct discharge measurements and service the instrumentation. Field inspections for the gage are listed under site history files on the Hydstra database. Discharge measurements for the gage are listed under site gauging files on the Hydstra database.

Datum Corrections. None.

Gage-Height Record. The data logger referenced to the outside staff gave a complete and satisfactory record, except for the periods from December 9 to January 15, 18, February 12, 13, 15-24, February 26, 27, and March 3, 5, 26-28 when gage height was affected by ice.

Rating. The channel is lined with angular rock and filter fabric. It is confined to the main channel. The bottom is a $4^{\prime}$ wide channel and prone to some shifting with vegetation on each bank. Low-water control is the 12" Parshall flume.

Twenty-three inspections of no flow were made this year.

Rating No. 1 was developed based on the computation of 12" Parshall flume. PZF is 0.00 gage height.

Discharge. Discharge computed by applying gage height to Rating No. 1 directly.

Remarks. Records are good. 


\section{E2565 C añ on del Valle at $Q$ Site}

\section{Daily Mean Discharge in Cubic Feet per Second}

Water Year October 2008 to September 2009

\begin{tabular}{|c|c|c|c|c|c|c|c|c|c|c|c|c|}
\hline DAY & OCT & NOV & DEC & JAN & FE B & M AR & APR & MAY & JUN & JUL & AUG & SEP \\
\hline 1 & 0 & 0 & 0 & $0^{*}$ & 0 & 0 & 0 & 0 & 0 & 0 & 0 & 0 \\
\hline 2 & 0 & 0 & 0 & $0^{*}$ & 0 & 0 & 0 & 0 & 0 & 0 & 0 & 0 \\
\hline 3 & 0 & 0 & 0 & $0^{*}$ & 0 & $0^{*}$ & 0 & 0 & .01 & 0 & 0 & 0 \\
\hline 4 & .01 & 0 & 0 & $0^{*}$ & 0 & 0 & 0 & 0 & 0 & 0 & 0 & 0 \\
\hline 5 & .01 & 0 & 0 & $0^{*}$ & 0 & $0^{*}$ & 0 & 0 & 0 & .01 & 0 & 0 \\
\hline 6 & 0 & 0 & 0 & $0^{*}$ & 0 & 0 & 0 & 0 & 0 & 0 & 0 & 0 \\
\hline 7 & 0 & 0 & 0 & $0^{*}$ & 0 & 0 & 0 & 0 & 0 & 0 & 0 & .02 \\
\hline 8 & 0 & 0 & 0 & $0^{*}$ & 0 & 0 & 0 & 0 & 0 & 0 & 0 & 0 \\
\hline 9 & 0 & 0 & $0^{*}$ & $0^{*}$ & 0 & 0 & 0 & 0 & 0 & 0 & 0 & .01 \\
\hline 10 & 0 & 0 & $0^{*}$ & $0^{*}$ & 0 & 0 & 0 & 0 & .01 & 0 & 0 & 0 \\
\hline 11 & .01 & 0 & $0^{*}$ & $0^{*}$ & 0 & 0 & .06 & 0 & 0 & 0 & 0 & .01 \\
\hline 12 & 0 & 0 & $0^{*}$ & $0^{*}$ & $0^{*}$ & 0 & 0 & 0 & 0 & 0 & .01 & 0 \\
\hline 13 & 0 & 0 & $0^{*}$ & $0^{*}$ & $0^{*}$ & 0 & 0 & 0 & 0 & 0 & .01 & 0 \\
\hline 14 & 0 & 0 & $0^{*}$ & $0^{*}$ & 0 & 0 & 0 & 0 & 0 & 0 & .01 & .01 \\
\hline 15 & 0 & 0 & $0^{*}$ & $0^{*}$ & $0^{*}$ & 0 & 0 & 0 & 0 & 0 & 0 & .01 \\
\hline 16 & 0 & 0 & $0^{*}$ & 0 & $0^{*}$ & 0 & 0 & 0 & 0 & 0 & 0 & .01 \\
\hline 17 & 0 & 0 & $0^{*}$ & 0 & $0^{*}$ & 0 & .03 & 0 & 0 & 0 & 0 & .01 \\
\hline 18 & 0 & 0 & $0^{*}$ & $0^{*}$ & $0^{*}$ & 0 & 0 & 0 & 0 & 0 & 0 & 0 \\
\hline 19 & 0 & 0 & $0^{*}$ & 0 & $0^{*}$ & 0 & 0 & 0 & 0 & 0 & 0 & 0 \\
\hline 20 & 0 & 0 & $0^{*}$ & 0 & $0^{*}$ & 0 & 0 & 0 & .01 & 0 & 0 & 0 \\
\hline 21 & 0 & 0 & $0^{*}$ & 0 & $0^{*}$ & 0 & 0 & .01 & 0 & 0 & 0 & 0 \\
\hline 22 & 0 & 0 & $0^{*}$ & 0 & $0^{*}$ & 0 & 0 & .01 & 0 & 0 & 0 & 0 \\
\hline 23 & 0 & 0 & $0^{*}$ & 0 & $0^{*}$ & 0 & 0 & .02 & 0 & 0 & 0 & 0 \\
\hline 24 & 0 & 0 & $0^{*}$ & 0 & $0^{*}$ & 0 & 0 & .01 & 0 & 0 & 0 & 0 \\
\hline 25 & 0 & 0 & $0^{*}$ & 0 & 0 & 0 & 0 & 0 & 0 & 0 & 0 & 0 \\
\hline 26 & 0 & 0 & $0^{*}$ & 0 & $0^{*}$ & $0^{*}$ & 0 & 0 & 0 & 0 & 0 & 0 \\
\hline 27 & 0 & 0 & $0^{*}$ & 0 & $0^{*}$ & $0^{*}$ & 0 & .01 & 0 & 0 & 0 & 0 \\
\hline 28 & 0 & 0 & $0^{*}$ & 0 & 0 & $0^{*}$ & 0 & 0 & 0 & 0 & 0 & 0 \\
\hline 29 & 0 & 0 & $0^{*}$ & 0 & ----- & 0 & 0 & 0 & 0 & 0 & 0 & 0 \\
\hline 30 & 0 & 0 & $0^{*}$ & 0 & ----- & 0 & 0 & 0 & 0 & .01 & 0 & 0 \\
\hline 31 & 0 & ------ & $0^{*}$ & 0 & ----- & 0 & ------ & 0 & ----- & 0 & 0 & ----- \\
\hline Total & 0.03 & 0 & 0 & 0 & 0 & 0 & 0.09 & 0.06 & 0.03 & 0.02 & 0.03 & 0.08 \\
\hline Mean & .001 & 0 & 0 & 0 & 0 & 0 & .003 & .002 & .001 & .001 & .001 & .003 \\
\hline $\operatorname{Max}$ & .01 & 0 & 0 & 0 & 0 & 0 & .06 & .02 & .01 & .01 & .01 & .02 \\
\hline Min & 0 & 0 & 0 & 0 & 0 & 0 & 0 & 0 & 0 & 0 & 0 & 0 \\
\hline Acre-F t & .06 & 0 & 0 & 0 & 0 & 0 & .18 & .12 & .06 & .04 & .06 & .16 \\
\hline Wtr Year & 2009 & Total & 0.34 & Mean & & 001 & $\operatorname{Max}$ & .06 & Min & 0 & Acre-Ft & .67 \\
\hline Cal Year & 2008 & Total & 0.99 & Mean & & 003 & Max & .08 & Min & 0 & Acre-Ft & 2.0 \\
\hline
\end{tabular}




\section{E257 Cañon del Valle Tributary at Burn Grounds}

Location. Lat $35^{\circ}$ 50' 47", long $106^{\circ}$ 19' 50", Sec. 29, T. 19 N., R. 6 E., Ramon Vigil Grant, Los Alamos County.

Drainage Area. $0.040 \mathrm{mi}^{2}$.

Period of Record. October 1, 2002, to September 30, 2009.

Gage. Data logger and 12" Parshall flume, rain gage with cellular telemetry. Elevation of gage is $7,359 \mathrm{ft}$ above NGVD.

Remarks. Records are good. Records for this site existed before period of record but are not reliable. Legal location based on projected values.

Average Discharge. $7 \mathrm{yr}, 0.01 \mathrm{ft}^{3} / \mathrm{s}, 9$ acre-ft/yr.

Extremes for Period of Record. Maximum discharge, $9.5 \mathrm{ft}^{3} / \mathrm{s}$, August 29, 2007, gage height $1.77 \mathrm{ft}$. No flow most of the time.

Extremes for Current Year. Maximum discharge of $0.71 \mathrm{ft}^{3} / \mathrm{s}$ at $1320 \mathrm{~h}$, April 17, gage height $0.32 \mathrm{ft}$. No peak discharges above base of $3.0 \mathrm{ft}^{3} / \mathrm{s}$.

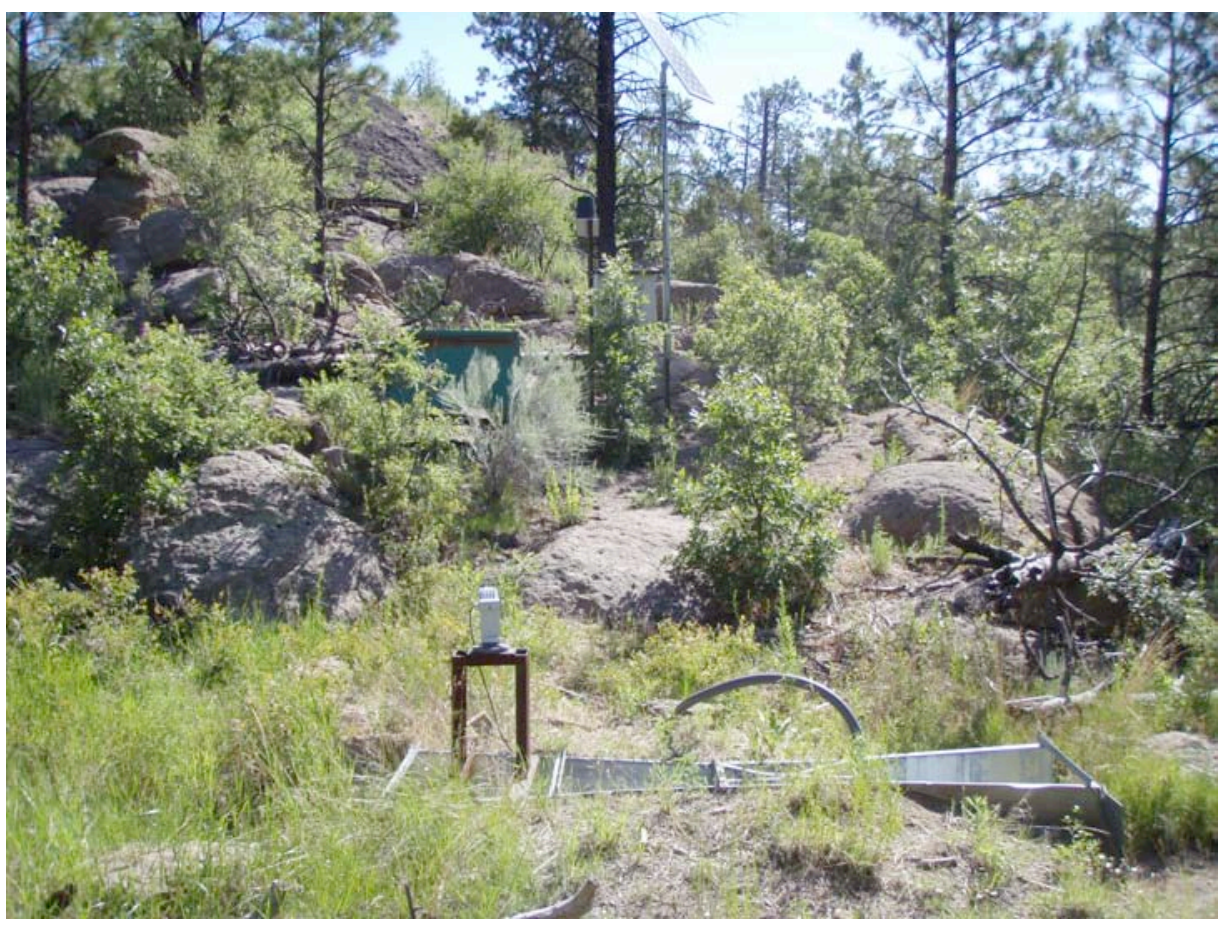




\title{
E257 Cañon del Valle Tributary at Burn Grounds
}

\author{
Station Analysis
}

\section{Water Year}

Equipment. Station is equipped with Sutron 8210 data logger (5-min. interval) and Milltronics sonic probe mounted on a 12" Parshall flume and cellular phone with speech modem. The system is powered by a solar panel battery system housed in a NEMA shelter. Station is equipped with an ISCO pump sampler for water quality sample collection. ISCO is housed in a separate shelter, a $3^{\prime} \times 4^{\prime}$ metal box. Sampler is triggered by stage through the data logger. The staff in the $12^{\prime \prime}$ Parshall flume is the reference gage. No provision for discharge measurements above wading stage.

Station is also equipped with a tipping bucket rain gage, Rain Collection II. All equipment is powered with a solar panel battery charging system.

Field Work. This station was visited 34 times to conduct discharge measurements and service the instrumentation. Field inspections for the gage are listed under site history files on the Hydstra database. Discharge measurements for the gage are listed under site gauging files on the Hydstra data base.

Datum Correction. None.

Gage-Height Record. The data logger referenced to the outside staff gave a complete and satisfactory record, except for the periods from December 9 to January 7, 24, 25, January 28 to February 3, 8, 9, 15, and March 24-29 when gage height was affected by ice.

Rating. The channel is straight above and below gage. It is confined to the main channel by cut banks on both sides. The bottom is $10^{\prime}$ wide; channel is prone to some shifting with vegetation on each bank. Low-water control is the $12^{\prime \prime}$ Parshall flume.

Thirty-four inspections of no flow were made this year.

Rating No. 1 was developed based on the computation of 12" Parshall flume. PZF is 0.00 gage height.

Discharge. Discharge was computed by applying gage height to Rating No. 1 directly.

Remarks. Records are good. 


\section{E257 Cañon del Valle Tributary at Burn Grounds}

Daily Mean Discharge in Cubic Feet per Second

Water Year October 2008 to September 2009

\begin{tabular}{|c|c|c|c|c|c|c|c|c|c|c|c|c|}
\hline DAY & ОСТ & NOV & DEC & JAN & FEB & MAR & APR & MAY & JUN & JUL & $A U G$ & SEP \\
\hline 1 & 0 & 0 & 0 & $0^{*}$ & $0^{*}$ & 0 & 0 & 0 & 0 & 0 & 0 & 0 \\
\hline 2 & 0 & 0 & 0 & $0^{*}$ & $0^{*}$ & 0 & 0 & 0 & 0 & 0 & 0 & 0 \\
\hline 3 & 0 & 0 & 0 & $0^{*}$ & $0^{*}$ & 0 & 0 & 0 & .01 & 0 & 0 & 0 \\
\hline 4 & 0 & 0 & 0 & $0^{*}$ & 0 & 0 & 0 & 0 & 0 & 0 & 0 & 0 \\
\hline 5 & 0 & 0 & 0 & $0^{*}$ & 0 & 0 & 0 & 0 & 0 & 0 & 0 & 0 \\
\hline 6 & 0 & 0 & 0 & $0^{*}$ & 0 & 0 & 0 & 0 & 0 & .01 & 0 & 0 \\
\hline 7 & 0 & 0 & 0 & $0^{*}$ & 0 & 0 & 0 & 0 & 0 & 0 & 0 & 0 \\
\hline 8 & 0 & 0 & 0 & 0 & $0^{*}$ & 0 & 0 & 0 & 0 & 0 & 0 & 0 \\
\hline 9 & 0 & 0 & $0^{*}$ & 0 & $0^{*}$ & 0 & 0 & 0 & 0 & 0 & 0 & 0 \\
\hline 10 & 0 & 0 & $0^{*}$ & 0 & 0 & 0 & 0 & 0 & .01 & 0 & 0 & 0 \\
\hline 11 & .01 & 0 & $0^{*}$ & 0 & 0 & 0 & .02 & 0 & 0 & 0 & 0 & 0 \\
\hline 12 & 0 & 0 & $0^{*}$ & 0 & 0 & 0 & 0 & 0 & 0 & 0 & 0 & 0 \\
\hline 13 & 0 & 0 & $0^{*}$ & 0 & 0 & 0 & 0 & 0 & 0 & 0 & 0 & 0 \\
\hline 14 & 0 & 0 & $0^{*}$ & 0 & 0 & 0 & 0 & 0 & 0 & 0 & 0 & 0 \\
\hline 15 & 0 & 0 & $0^{*}$ & 0 & $0^{*}$ & 0 & 0 & 0 & 0 & 0 & 0 & 0 \\
\hline 16 & 0 & 0 & $0^{*}$ & 0 & 0 & 0 & 0 & 0 & 0 & 0 & 0 & 0 \\
\hline 17 & 0 & 0 & $0^{*}$ & 0 & 0 & 0 & .05 & 0 & 0 & 0 & 0 & .01 \\
\hline 18 & 0 & 0 & $0^{*}$ & 0 & 0 & 0 & 0 & 0 & 0 & 0 & 0 & 0 \\
\hline 19 & 0 & 0 & $0^{*}$ & 0 & 0 & 0 & 0 & 0 & 0 & 0 & 0 & 0 \\
\hline 20 & 0 & 0 & $0^{*}$ & 0 & 0 & 0 & 0 & 0 & 0 & 0 & 0 & 0 \\
\hline 21 & 0 & 0 & $0^{*}$ & 0 & 0 & 0 & 0 & 0 & 0 & 0 & 0 & 0 \\
\hline 22 & 0 & 0 & $0^{*}$ & 0 & 0 & 0 & 0 & 0 & 0 & 0 & 0 & 0 \\
\hline 23 & 0 & 0 & $0^{*}$ & 0 & 0 & 0 & 0 & 0 & 0 & 0 & 0 & 0 \\
\hline 24 & 0 & 0 & $0^{*}$ & $0^{*}$ & 0 & $0^{*}$ & 0 & 0 & 0 & 0 & 0 & .01 \\
\hline 25 & 0 & 0 & $0^{*}$ & $0^{*}$ & 0 & $0^{*}$ & 0 & 0 & 0 & 0 & 0 & 0 \\
\hline 26 & 0 & 0 & $0^{*}$ & 0 & 0 & $0^{*}$ & 0 & 0 & 0 & 0 & 0 & 0 \\
\hline 27 & 0 & 0 & $0^{*}$ & 0 & 0 & $0^{*}$ & 0 & .01 & 0 & 0 & 0 & 0 \\
\hline 28 & 0 & 0 & $0^{*}$ & $0^{*}$ & 0 & $0^{*}$ & 0 & 0 & 0 & 0 & 0 & 0 \\
\hline 29 & 0 & 0 & $0^{*}$ & $0^{*}$ & ---- & $0^{*}$ & 0 & 0 & 0 & 0 & 0 & 0 \\
\hline 30 & 0 & 0 & $0^{*}$ & $0^{*}$ & -..-- & 0 & 0 & 0 & 0 & .01 & 0 & 0 \\
\hline 31 & 0 & --.-- & $0^{*}$ & $0^{*}$ & ---- & 0 & ---- & 0 & --.-- & 0 & 0 & ----- \\
\hline Total & 0.01 & 0 & 0 & 0 & 0 & 0 & 0.07 & 0.01 & 0.02 & 0.02 & 0 & 0.02 \\
\hline Mean & 0 & 0 & 0 & 0 & 0 & 0 & .002 & 0 & .001 & .001 & 0 & .001 \\
\hline Max & .01 & 0 & 0 & 0 & 0 & 0 & .05 & .01 & .01 & .01 & 0 & .01 \\
\hline Min & 0 & 0 & 0 & 0 & 0 & 0 & 0 & 0 & 0 & 0 & 0 & 0 \\
\hline Acre-F t & .02 & 0 & 0 & 0 & 0 & 0 & .14 & .02 & .04 & .04 & 0 & .04 \\
\hline Wtr Year & 2009 & Total & 0.15 & Mean & & 0 & Max & .05 & Min & 0 & Acre- $\mathrm{Ft}$ & .30 \\
\hline Cal Year & 2008 & Total & 1.01 & Mean & & 03 & $\operatorname{Max}$ & .40 & Min & 0 & Acre- $\mathrm{Ft}$ & 2.0 \\
\hline
\end{tabular}


E262 Cañon de Valle above Water Canyon

Location. Lat $35^{\circ} 49^{\prime} 51^{\prime \prime}$, long $106^{\circ} 18^{\prime}$ 14", Sec. 33, T. 19 N., R. 6 E., Ramon Vigil Grant, Los Alamos County.

Drainage Area. $4.32 \mathrm{mi}^{2}$.

Period of Record. October 1, 1998, to September 30, 2009.

Revised Record. Drainage Area (2006).

Gage. Data logger and $90^{\circ}$ weir plate. Elevation of gage is $6,840 \mathrm{ft}$ above NGVD.

Remarks. Records are good. Legal location based on projected values.

Average Discharge. $10 \mathrm{yr}, 0.012 \mathrm{ft}^{3} / \mathrm{s}, 8.7$ acre-ft/yr.

Extremes for Period of Record. Maximum discharge, $63 \mathrm{ft}^{3} / \mathrm{s}$, August 20, 2004, gage height $4.10 \mathrm{ft}$. No flow most of the time.

Extremes for Current Year. No peak discharge above base of $5.0 \mathrm{ft}^{3} / \mathrm{s}$. No flow for the year.

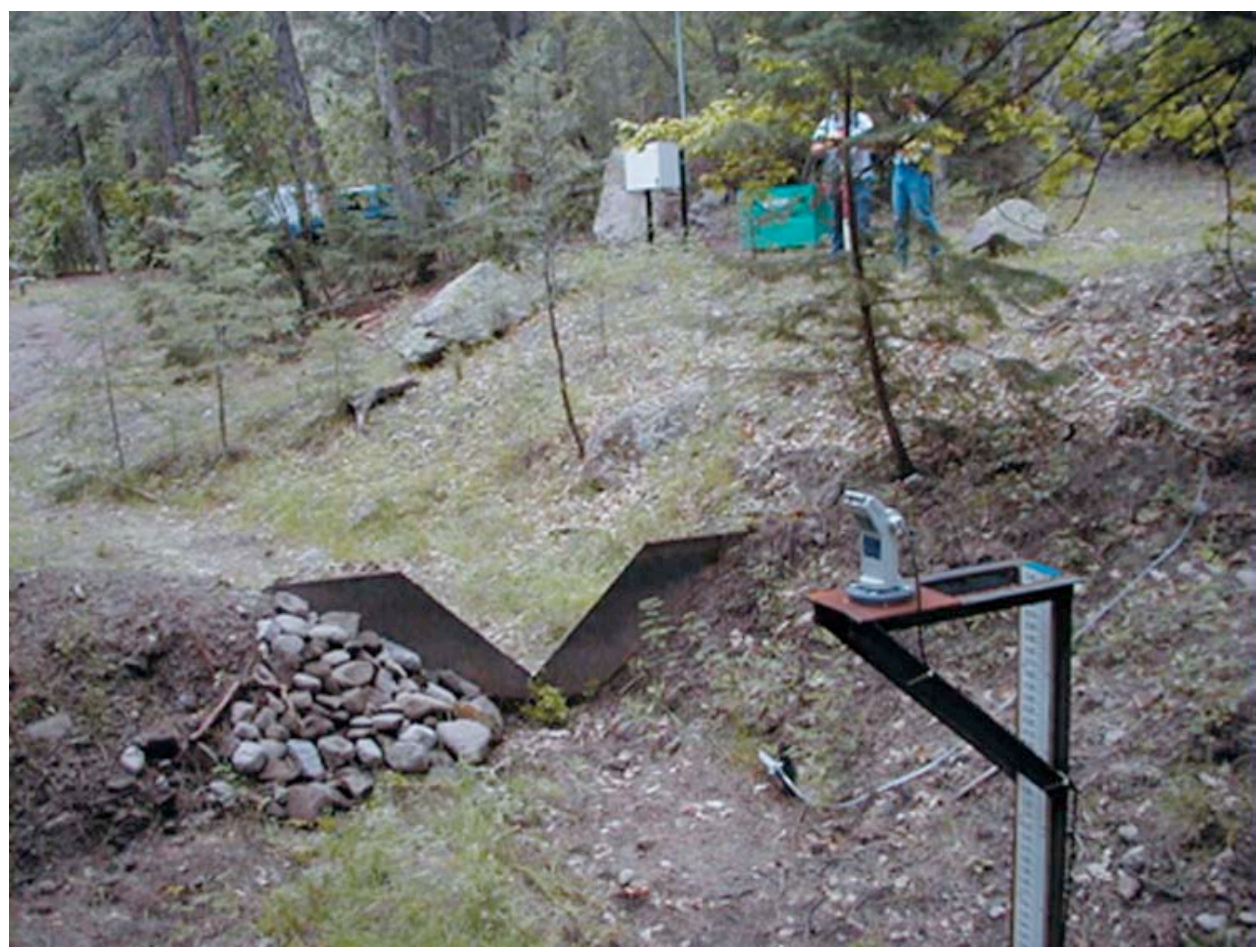




\title{
E262 Cañon del Valle above Water Canyon
}

\author{
Station Analysis
}

\section{Water Year}

Equipment. Station is equipped with Sutron 8210 data logger (5-min. interval) and Milltronics sonic probe mounted on a 6" channel cantilevered spanning into stream. The system is powered by a solar panel battery system housed in a NEMA shelter. Station is equipped with an ISCO pump sampler for water quality sample collection. ISCO is housed in a $3^{\prime} \times 4^{\prime}$ metal box. Sampler is triggered by stage through the data logger. An outside staff is available for reference. No provision for discharge measurements above wading stage.

Field Work. The station was visited 14 times to conduct discharge measurements and service the instrumentation. Field inspections for the gage are listed under site history files on the Hydstra database. Discharge measurements for the gage are listed under site gauging files on the Hydstra database.

Datum Correction. None.

Gage-Height Record. The data logger referenced to the outside staff gave a complete and satisfactory record, except for the periods from November 19, 20 when data logger malfunctioned and December 15 to January 15, 21, February 5, March 27, and April 3, 17 when gage height was affected by ice.

Rating. The channel is about $10^{\prime}$ wide and straight for about $50^{\prime}$ upstream and straight for about 30' downstream. The streambed through this reach is primarily rock with gravel, sand, and cobbles.

Fourteen inspections of no flow were made this year.

Rating No. 1 is based on a theoretical computation for $90^{\circ}$ sharp-crested weir up to a gage height of $2.95 \mathrm{ft}$. Broad-crested weir computation is used above that stage.

Discharge. Discharge was computed by applying gage height to Rating No. 1 directly.

Remarks. Records are good. 
E262 Cañon del Valle above Water Can yo $n$

Daily Mean Discharge in Cubic Feet per Second

Water Year October 2008 to September 2009

\begin{tabular}{|c|c|c|c|c|c|c|c|c|c|c|c|c|}
\hline DAY & OCT & NOV & DEC & JAN & FEB & MAR & APR & MAY & JUN & JUL & AUG & SEP \\
\hline 1 & 0 & 0 & 0 & $0^{*}$ & 0 & 0 & 0 & 0 & 0 & 0 & 0 & 0 \\
\hline 2 & 0 & 0 & 0 & $0^{*}$ & 0 & 0 & 0 & 0 & 0 & 0 & 0 & 0 \\
\hline 3 & 0 & 0 & 0 & $0^{*}$ & 0 & 0 & $0^{*}$ & 0 & 0 & 0 & 0 & 0 \\
\hline 4 & 0 & 0 & 0 & $0^{*}$ & 0 & 0 & 0 & 0 & 0 & 0 & 0 & 0 \\
\hline 5 & 0 & 0 & 0 & $0^{*}$ & $0^{*}$ & 0 & 0 & 0 & 0 & 0 & 0 & 0 \\
\hline 6 & 0 & 0 & 0 & $0^{*}$ & 0 & 0 & 0 & 0 & 0 & 0 & 0 & 0 \\
\hline 7 & 0 & 0 & 0 & $0^{*}$ & 0 & 0 & 0 & 0 & 0 & 0 & 0 & 0 \\
\hline 8 & 0 & 0 & 0 & $0^{*}$ & 0 & 0 & 0 & 0 & 0 & 0 & 0 & 0 \\
\hline 9 & 0 & 0 & 0 & $0^{*}$ & 0 & 0 & 0 & 0 & 0 & 0 & 0 & 0 \\
\hline 10 & 0 & 0 & 0 & $0^{*}$ & 0 & 0 & 0 & 0 & 0 & 0 & 0 & 0 \\
\hline 11 & 0 & 0 & 0 & $0^{*}$ & 0 & 0 & 0 & 0 & 0 & 0 & 0 & 0 \\
\hline 12 & 0 & 0 & 0 & $0^{*}$ & 0 & 0 & 0 & 0 & 0 & 0 & 0 & 0 \\
\hline 13 & 0 & 0 & 0 & $0^{*}$ & 0 & 0 & 0 & 0 & 0 & 0 & 0 & 0 \\
\hline 14 & 0 & 0 & 0 & $0^{*}$ & 0 & 0 & 0 & 0 & 0 & 0 & 0 & 0 \\
\hline 15 & 0 & 0 & $0^{*}$ & $0^{*}$ & 0 & 0 & 0 & 0 & 0 & 0 & 0 & 0 \\
\hline 16 & 0 & 0 & $0^{*}$ & 0 & 0 & 0 & 0 & 0 & 0 & 0 & 0 & 0 \\
\hline 17 & 0 & 0 & $0^{*}$ & 0 & 0 & 0 & $0^{*}$ & 0 & 0 & 0 & 0 & 0 \\
\hline 18 & 0 & 0 & $0^{*}$ & 0 & 0 & 0 & 0 & 0 & 0 & 0 & 0 & 0 \\
\hline 19 & 0 & $0^{*}$ & $0^{*}$ & 0 & 0 & 0 & 0 & 0 & 0 & 0 & 0 & 0 \\
\hline 20 & 0 & $0^{*}$ & $0^{*}$ & 0 & 0 & 0 & 0 & 0 & 0 & 0 & 0 & 0 \\
\hline 21 & 0 & 0 & $0^{*}$ & $0^{*}$ & 0 & 0 & 0 & 0 & 0 & 0 & 0 & 0 \\
\hline 22 & 0 & 0 & $0^{*}$ & 0 & 0 & 0 & 0 & 0 & 0 & 0 & 0 & 0 \\
\hline 23 & 0 & 0 & $0^{*}$ & 0 & 0 & 0 & 0 & 0 & 0 & 0 & 0 & 0 \\
\hline 24 & 0 & 0 & $0^{*}$ & 0 & 0 & 0 & 0 & 0 & 0 & 0 & 0 & 0 \\
\hline 25 & 0 & 0 & $0^{*}$ & 0 & 0 & 0 & 0 & 0 & 0 & 0 & 0 & 0 \\
\hline 26 & 0 & 0 & $0^{*}$ & 0 & 0 & 0 & 0 & 0 & 0 & 0 & 0 & 0 \\
\hline 27 & 0 & 0 & $0^{*}$ & 0 & 0 & $0^{*}$ & 0 & 0 & 0 & 0 & 0 & 0 \\
\hline 28 & 0 & 0 & $0^{*}$ & 0 & 0 & 0 & 0 & 0 & 0 & 0 & 0 & 0 \\
\hline 29 & 0 & 0 & $0^{*}$ & 0 & --.-- & 0 & 0 & 0 & 0 & 0 & 0 & 0 \\
\hline 30 & 0 & 0 & $0^{*}$ & 0 & --.-- & 0 & 0 & 0 & 0 & 0 & 0 & 0 \\
\hline 31 & 0 & ---- & $0^{*}$ & 0 & -..--. & 0 & ----- & 0 & ---- & 0 & 0 & ---- \\
\hline Total & 0 & 0 & 0 & 0 & 0 & 0 & 0 & 0 & 0 & 0 & 0 & 0 \\
\hline Mean & 0 & 0 & 0 & 0 & 0 & 0 & 0 & 0 & 0 & 0 & 0 & 0 \\
\hline $\operatorname{Max}$ & 0 & 0 & 0 & 0 & 0 & 0 & 0 & 0 & 0 & 0 & 0 & 0 \\
\hline Min & 0 & 0 & 0 & 0 & 0 & 0 & 0 & 0 & 0 & 0 & 0 & 0 \\
\hline Acre $-\mathrm{Ft}$ & 0 & 0 & 0 & 0 & 0 & 0 & 0 & 0 & 0 & 0 & 0 & 0 \\
\hline Wtr Year & 2009 & Total & 0 & Mean & & 0 & $\operatorname{Max}$ & 0 & Min & 0 & Acre-Ft & 0 \\
\hline Cal Year & 2008 & Total & 1.38 & Mean & & 04 & Max & .98 & Min & 0 & Acre- $\mathrm{Ft}$ & 2.7 \\
\hline
\end{tabular}




\section{E2624 Phermex}

Location. Lat $35^{\circ}$ 49' 57", long $106^{\circ} 17^{\prime}$ 47", Sec. 34, T. 19 N., R. 6 E., Ramon Vigil Grant, Los Alamos County.

Drainage Area. $0.008 \mathrm{mi}^{2}$.

Period of Record. October 1, 2008, to September 30, 2009.

Gage. Data logger and 24" Parshall flume, rain gage with cellular telemetry. Elevation of gage is $6,998 \mathrm{ft}$ above NGVD.

Remarks. Records are good. Legal location based on projected values.

Extremes for Period of Record. Maximum discharge, $0.71 \mathrm{ft}^{3} / \mathrm{s}$, July 28 , 2009, gage height $0.21 \mathrm{ft}$. No flow most of the time.

Extremes for Current Year. Maximum discharge of $0.71 \mathrm{ft}^{3} / \mathrm{s}$ at $1250 \mathrm{~h}$, July 28, gage height $0.21 \mathrm{ft}$. No peak discharges above base of $1.0 \mathrm{ft}^{3} / \mathrm{s}$.

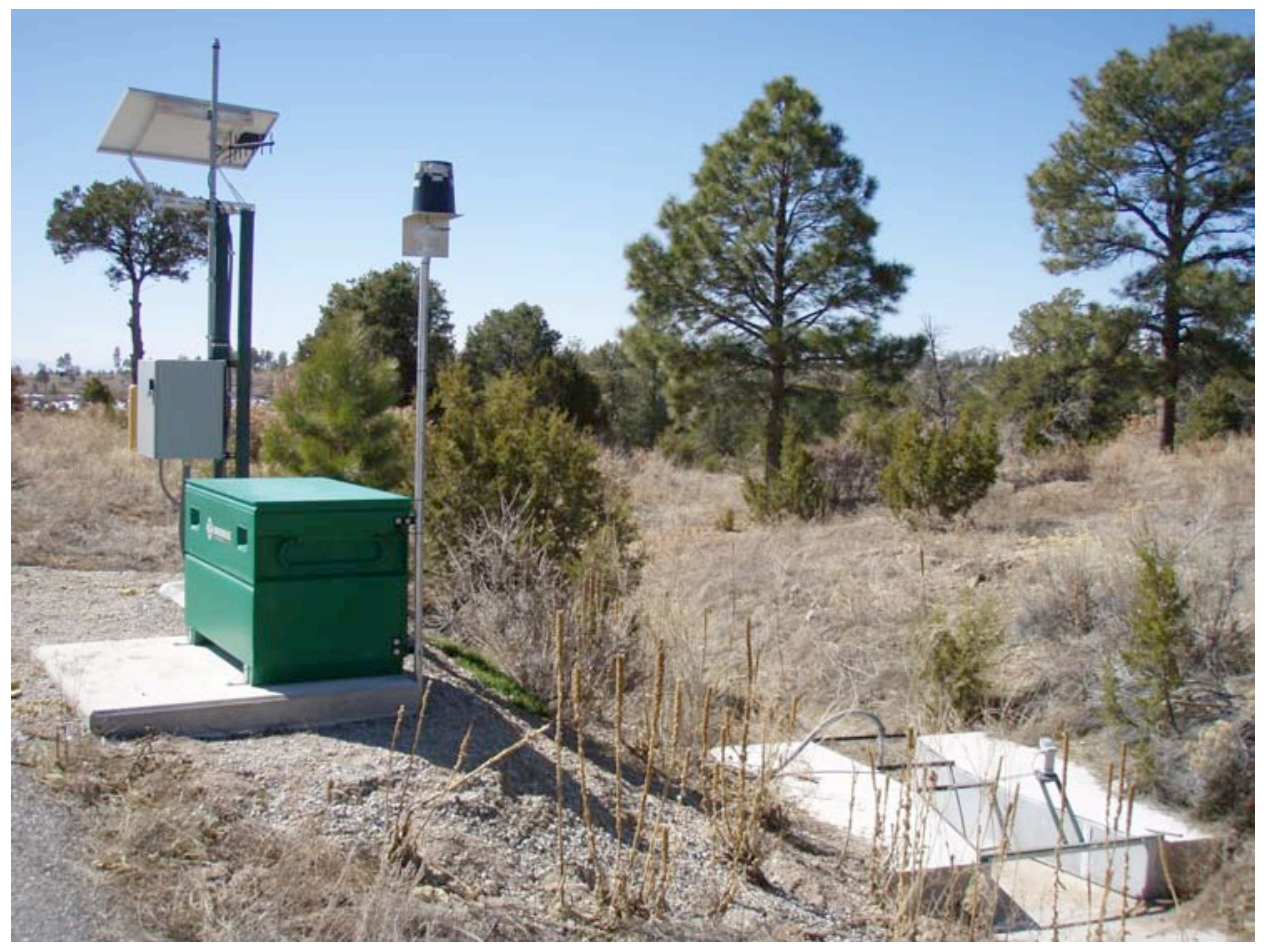




\section{E2624 Phermex}

\section{Station Analysis}

\section{Water Year}

Equipment. Station is equipped with Sutron 8210 data logger (5-min. interval) and Milltronics sonic probe mounted on a 24" Parshall flume. The system is powered by a solar panel battery system housed in a NEMA shelter. Station is equipped with an ISCO pump sampler for water quality sample collection. ISCO is housed in a separate shelter, a $3^{\prime} \times 4^{\prime}$ metal box. Sampler is triggered by stage through the data logger. The staff in the 24" Parshall flume is the reference gage. No provision for discharge measurements above wading stage.

Station is also equipped with a tipping bucket rain gage, Rain Collection II. All equipment is powered with a solar panel battery charging system.

Field Work. This station was visited 37 times to conduct discharge measurements and service the instrumentation. Field inspections for the gage are listed under site history files on the Hydstra database. Discharge measurements for the gage are listed under site gauging files on the Hydstra database.

Datum Correction. None.

Gage-Height Record. The data logger referenced to the outside staff gave a complete and satisfactory record, except for the periods of November 15 to December 2 when data logger malfunctioned and December 3 to January 31, February 11, and March 6, 9-19, $21,26-31$ when gage height was affected by ice.

Rating. Channel is straight above and below gage. The streambed consists of mostly sand. The flume is subject to silting after storm events.

Thirty-seven inspections of no flow were made this year.

Rating No. 1 was developed based on the computation of 24" Parshall flume. PZF is 0.00 gage height.

Discharge. Discharge was computed by applying gage height to Rating No. 1 directly.

Remarks. Records are good. 
E2624 Phermex

Daily Mean Discharge in Cubic Feet per Second

Water Year October 2008 to September 2009

\begin{tabular}{|c|c|c|c|c|c|c|c|c|c|c|c|c|}
\hline DAY & ОСТ & NOV & DEC & JAN & FEB & MAR & APR & MAY & JUN & JUL & AUG & SEP \\
\hline 1 & 0 & 0 & $0^{*}$ & $0^{*}$ & 0 & 0 & 0 & 0 & 0 & 0 & 0 & .01 \\
\hline 2 & 0 & 0 & $0^{*}$ & $0^{*}$ & 0 & 0 & 0 & 0 & .01 & 0 & 0 & 0 \\
\hline 3 & 0 & 0 & $0^{*}$ & $0^{*}$ & 0 & 0 & 0 & 0 & .02 & 0 & 0 & 0 \\
\hline 4 & .02 & 0 & $0^{*}$ & $0^{*}$ & 0 & 0 & 0 & 0 & 0 & 0 & 0 & 0 \\
\hline 5 & .04 & 0 & $0^{*}$ & $0^{*}$ & 0 & 0 & 0 & 0 & 0 & .03 & 0 & 0 \\
\hline 6 & 0 & 0 & $0^{*}$ & $0^{*}$ & 0 & $0^{*}$ & 0 & 0 & 0 & .01 & 0 & .01 \\
\hline 7 & 0 & 0 & $0^{*}$ & $0^{*}$ & 0 & 0 & 0 & 0 & 0 & 0 & 0 & 0 \\
\hline 8 & 0 & 0 & $0^{*}$ & $0^{*}$ & 0 & 0 & 0 & 0 & 0 & 0 & 0 & .01 \\
\hline 9 & 0 & 0 & $0^{*}$ & $0^{*}$ & 0 & $0^{*}$ & 0 & 0 & 0 & 0 & 0 & 0 \\
\hline 10 & 0 & 0 & $0^{*}$ & $0^{*}$ & 0 & $0^{*}$ & 0 & 0 & .05 & 0 & 0 & .01 \\
\hline 11 & .05 & 0 & $0^{*}$ & $0^{*}$ & $0^{*}$ & $0^{*}$ & $0^{\star}$ & 0 & 0 & 0 & 0 & 0 \\
\hline 12 & 0 & 0 & $0^{*}$ & $0^{*}$ & 0 & $0^{*}$ & $0^{*}$ & 0 & 0 & 0 & 0 & 0 \\
\hline 13 & 0 & 0 & $0^{*}$ & $0^{*}$ & 0 & $0^{*}$ & 0 & 0 & 0 & 0 & .03 & 0 \\
\hline 14 & .04 & 0 & $0^{*}$ & $0^{*}$ & 0 & $0^{*}$ & 0 & 0 & 0 & 0 & .06 & 0 \\
\hline 15 & 0 & $0^{*}$ & $0^{*}$ & $0^{*}$ & 0 & $0^{*}$ & 0 & 0 & 0 & 0 & 0 & 0 \\
\hline 16 & 0 & $0^{*}$ & $0^{*}$ & $0^{*}$ & 0 & $0^{*}$ & 0 & 0 & 0 & 0 & 0 & .02 \\
\hline 17 & 0 & $0^{*}$ & $0^{*}$ & $0^{*}$ & 0 & $0^{*}$ & $0^{*}$ & 0 & 0 & 0 & 0 & 0 \\
\hline 18 & 0 & $0^{*}$ & $0^{*}$ & $0^{*}$ & 0 & $0^{*}$ & 0 & 0 & 0 & 0 & 0 & 0 \\
\hline 19 & 0 & $0^{*}$ & $0^{*}$ & $0^{*}$ & 0 & $0^{*}$ & 0 & 0 & 0 & 0 & 0 & 0 \\
\hline 20 & 0 & $0^{*}$ & $0^{*}$ & $0^{*}$ & 0 & 0 & 0 & 0 & .04 & 0 & 0 & 0 \\
\hline 21 & 0 & $0^{*}$ & $0^{*}$ & $0^{*}$ & 0 & 0 & 0 & .03 & 0 & 0 & 0 & 0 \\
\hline 22 & 0 & $0^{*}$ & $0^{*}$ & $0^{*}$ & 0 & $0^{*}$ & 0 & .07 & 0 & 0 & 0 & 0 \\
\hline 23 & 0 & $0^{*}$ & $0^{*}$ & $0^{*}$ & 0 & 0 & 0 & .06 & 0 & .02 & .01 & .01 \\
\hline 24 & 0 & $0^{*}$ & $0^{*}$ & $0^{*}$ & 0 & 0 & 0 & 0 & 0 & 0 & .01 & .02 \\
\hline 25 & 0 & $0^{*}$ & $0^{*}$ & $0^{*}$ & 0 & 0 & 0 & 0 & 0 & 0 & 0 & 0 \\
\hline 26 & 0 & $0^{*}$ & $0^{*}$ & $0^{*}$ & 0 & $0^{*}$ & 0 & 0 & 0 & .02 & 0 & 0 \\
\hline 27 & 0 & $0^{*}$ & $0^{*}$ & $0^{*}$ & 0 & $0^{*}$ & 0 & .02 & 0 & 0 & 0 & 0 \\
\hline 28 & 0 & $0^{*}$ & $0^{*}$ & $0^{*}$ & 0 & $0^{*}$ & 0 & 0 & 0 & .03 & 0 & 0 \\
\hline 29 & 0 & $0^{*}$ & $0^{*}$ & $0^{*}$ & ---- & $0^{*}$ & 0 & 0 & 0 & .01 & 0 & 0 \\
\hline 30 & 0 & $0^{*}$ & $0^{*}$ & $0^{*}$ & -..-- & $0^{*}$ & 0 & 0 & 0 & .01 & .01 & 0 \\
\hline 31 & 0 & --.-- & $0^{*}$ & $0^{*}$ & ---- & $0^{*}$ & ---- & 0 & --.-- & .01 & .01 & ----- \\
\hline Total & 0.15 & 0 & 0 & 0 & 0 & 0 & 0 & 0.18 & 0.12 & 0.14 & 0.13 & 0.09 \\
\hline Mean & .005 & 0 & 0 & 0 & 0 & 0 & 0 & .006 & .004 & .005 & .004 & .003 \\
\hline Max & .05 & 0 & 0 & 0 & 0 & 0 & 0 & .07 & .05 & .03 & .06 & .02 \\
\hline Min & 0 & 0 & 0 & 0 & 0 & 0 & 0 & 0 & 0 & 0 & 0 & 0 \\
\hline Acre-Ft & .30 & 0 & 0 & 0 & 0 & 0 & 0 & .36 & .24 & .28 & .26 & .18 \\
\hline Wtr Year & 2009 & Total & 0.81 & Mean & & 02 & Max & .07 & Min & 0 & Acre- $\mathrm{Ft}$ & 1.6 \\
\hline Cal Year & 2008 & Total & 0.38 & Mean & & 03 & $\operatorname{Max}$ & .07 & Min & 0 & Acre- $\mathrm{Ft}$ & .75 \\
\hline
\end{tabular}




\section{E2625 Water Canyon below MDA AB}

Location. Lat $35^{\circ} 49^{\prime} 31^{\prime \prime}$, long $106^{\circ} 17^{\prime}$ 03", Sec. 3, T. 18 N., R. 6 E., Ramon Vigil Grant, Los Alamos County.

Drainage Area. $11.55 \mathrm{mi}^{2}$.

Period of Record. October 1, 2001, to September 30, 2009.

Revised Record. Drainage Area (2006).

Gage. Data logger and $90^{\circ}$ weir plate. Elevation of gage is 6,666 ft above NGVD.

Remarks. Records are fair. Legal location based on projected values. Record existed before period of record but are not reliable.

Average Discharge. $8 \mathrm{yr}, 0.13 \mathrm{ft}^{3} / \mathrm{s}, 97$ acre- $\mathrm{ft} / \mathrm{yr}$.

Extremes for Period of Record. Maximum discharge, $306 \mathrm{ft}^{3} / \mathrm{s}$, August 29, 2007, gage height $4.57 \mathrm{ft}$. No flow most of the time.

Extremes for Current Year. Maximum discharge of $2.7 \mathrm{ft}^{3} / \mathrm{s}$ at $0705 \mathrm{~h}$, June 25, gage height $1.93 \mathrm{ft}$. No peak discharges above base of $10 \mathrm{ft}^{3} / \mathrm{s}$.

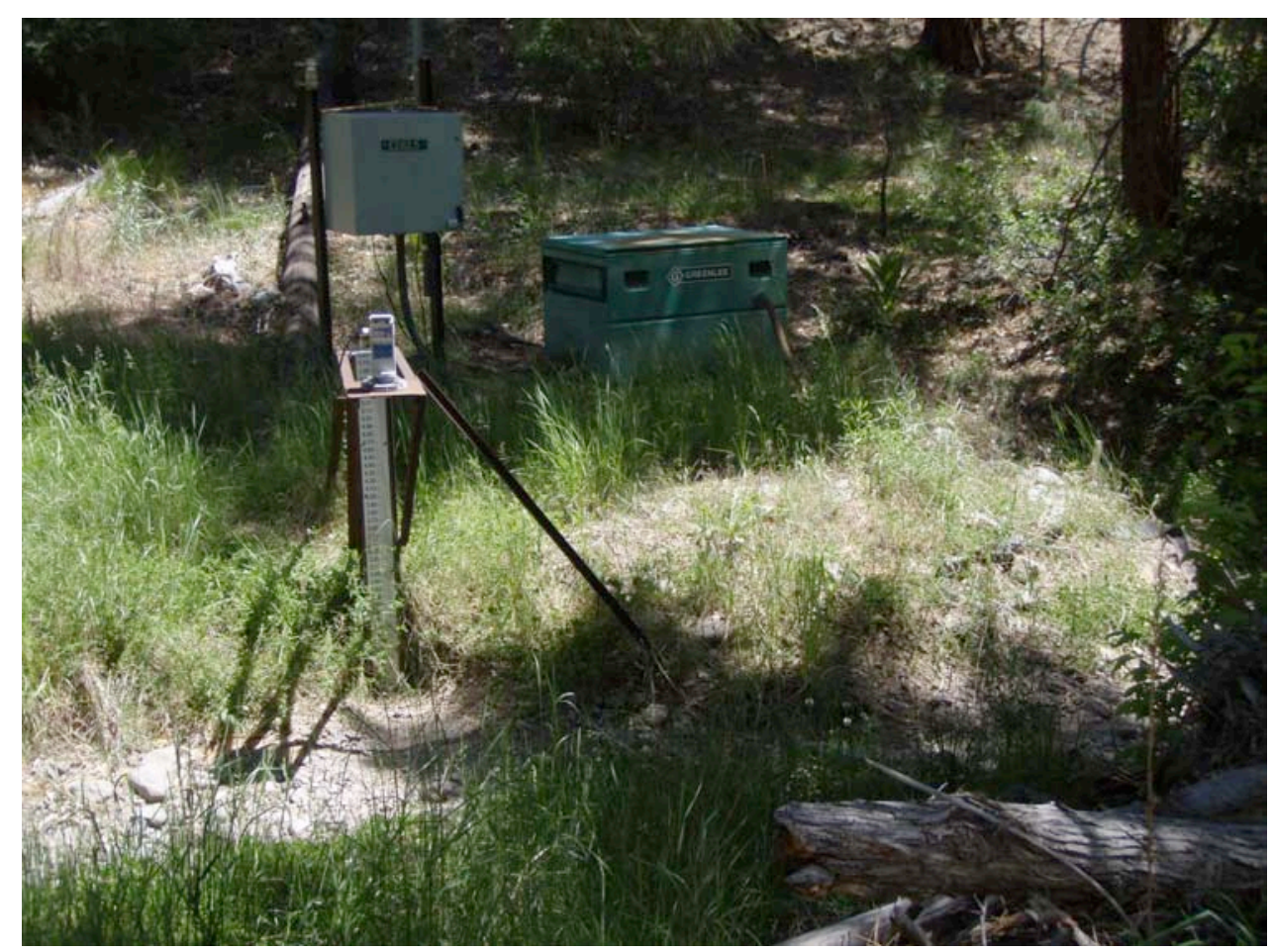




\title{
E2625 Water Canyon below MDA AB
}

\author{
Station Analysis
}

\section{Water Year}

Equipments. Station is equipped with Sutron 8210 data logger (5-min. interval) and Milltronics sonic probe mounted on a 6" channel cantilevered over the stream. The system is powered by a solar panel battery system housed in a NEMA shelter. Station is equipped with an ISCO pump sampler for water quality sample collection. ISCO is housed in a separate shelter, a $3^{\prime} \times 4^{\prime}$ metal box. Sampler is triggered by stage through the data logger. An outside staff is available for reference. No provisions are made for measurement above wading stage.

Field Work. The station was visited 13 times to conduct discharge measurements and service the instrumentation. Field inspections for the gage are listed under site history files on the Hydstra database. Discharge measurements for the gage are listed under site gauging files on the Hydstra database.

Datum Correction. None. Levels on May 29, 2009, found gage within allowable limits.

Gage-Height Record. The data logger referenced to the outside staff gave a complete and satisfactory record for the year, except for the periods from December 9 to January 15, March 26-28, and April 12, 13 when gage height was affected by ice.

Rating. The channel is about $20^{\prime}$ wide and straight for about $75^{\prime}$ upstream and about $100^{\prime}$ downstream. The streambed through this reach is primarily sand and cobbles. The lowwater control is a $90^{\circ}$ sharp-crested weir. During high flow, the channel becomes the control.

One discharge measurements (No. 19) and 12 inspections of no flow were made this year. All inspections of no flow were used to develop a $\mathrm{V}$ diagram shift needed to adjust for PZF.

Rating No. 2 is based on a theoretical computation for $90^{\circ}$ sharp-crested weir up to a gage height of $2.75 \mathrm{ft}$ and extended to $4.38 \mathrm{ft}$ gage height based on a slope area measurement.

Shifts were applied to low flow using V diagrams. Large negatives (about $0.76 \mathrm{ft}$ ) were also applied to zero flow observations.

Discharge. Discharge was computed by applying gage height to Rating No. 2 through shift adjustment based on V diagrams.

Remarks. Records are fair. 
E2625 Water Canyon below M DA AB

Daily Mean Discharge in Cubic Feet per Second

Water Year October 2008 to September 2009

\begin{tabular}{|c|c|c|c|c|c|c|c|c|c|c|c|c|}
\hline DAY & OCT & NOV & DEC & JAN & FEB & MAR & APR & MAY & JUN & JUL & AUG & SEP \\
\hline 1 & 0 & 0 & 0 & $0^{*}$ & 0 & 0 & 0 & 0 & 0 & 0 & 0 & 0 \\
\hline 2 & 0 & 0 & 0 & $0^{*}$ & 0 & 0 & 0 & 0 & 0 & 0 & 0 & 0 \\
\hline 3 & 0 & 0 & 0 & $0^{*}$ & 0 & 0 & 0 & 0 & 0 & 0 & 0 & 0 \\
\hline 4 & 0 & 0 & 0 & $0^{*}$ & 0 & 0 & 0 & 0 & 0 & 0 & 0 & 0 \\
\hline 5 & 0 & 0 & 0 & $0^{*}$ & 0 & 0 & 0 & 0 & 0 & 0 & 0 & 0 \\
\hline 6 & 0 & 0 & 0 & $0^{*}$ & 0 & 0 & 0 & 0 & 0 & 0 & 0 & 0 \\
\hline 7 & 0 & 0 & 0 & $0^{*}$ & 0 & 0 & 0 & 0 & 0 & 0 & 0 & 0 \\
\hline 8 & 0 & 0 & 0 & $0^{*}$ & 0 & 0 & 0 & 0 & 0 & 0 & 0 & 0 \\
\hline 9 & 0 & 0 & $0^{*}$ & $0^{*}$ & 0 & 0 & 0 & 0 & 0 & 0 & 0 & 0 \\
\hline 10 & 0 & 0 & 0 & $0^{*}$ & 0 & 0 & 0 & 0 & 0 & 0 & 0 & 0 \\
\hline 11 & 0 & 0 & 0 & $0^{*}$ & 0 & 0 & 0 & 0 & 0 & 0 & 0 & 0 \\
\hline 12 & 0 & 0 & 0 & $0^{*}$ & 0 & 0 & $0^{*}$ & 0 & 0 & 0 & 0 & 0 \\
\hline 13 & 0 & 0 & 0 & $0^{*}$ & 0 & 0 & $0^{*}$ & 0 & 0 & 0 & 0 & 0 \\
\hline 14 & 0 & 0 & 0 & $0^{*}$ & 0 & 0 & 0 & 0 & 0 & 0 & 0 & 0 \\
\hline 15 & 0 & 0 & $0^{*}$ & $0^{*}$ & 0 & 0 & 0 & 0 & 0 & 0 & 0 & 0 \\
\hline 16 & 0 & 0 & $0^{*}$ & 0 & 0 & 0 & 0 & 0 & 0 & 0 & 0 & 0 \\
\hline 17 & 0 & 0 & $0^{*}$ & 0 & 0 & 0 & 0 & 0 & 0 & 0 & 0 & 0 \\
\hline 18 & 0 & 0 & $0^{*}$ & 0 & 0 & 0 & 0 & 0 & 0 & 0 & 0 & 0 \\
\hline 19 & 0 & 0 & $0^{*}$ & 0 & 0 & 0 & 0 & 0 & 0 & 0 & 0 & 0 \\
\hline 20 & 0 & 0 & $0^{*}$ & 0 & 0 & 0 & 0 & 0 & 0 & 0 & 0 & 0 \\
\hline 21 & 0 & 0 & $0^{*}$ & 0 & 0 & 0 & 0 & 0 & 0 & 0 & 0 & 0 \\
\hline 22 & 0 & 0 & $0^{*}$ & 0 & 0 & 0 & 0 & 0 & 0 & 0 & 0 & 0 \\
\hline 23 & 0 & 0 & $0^{*}$ & 0 & 0 & 0 & 0 & 0 & 0 & 0 & 0 & 0 \\
\hline 24 & 0 & 0 & $0^{*}$ & 0 & 0 & 0 & 0 & 0 & 0 & 0 & 0 & 0 \\
\hline 25 & 0 & 0 & $0^{*}$ & 0 & 0 & 0 & 0 & 0 & .04 & 0 & 0 & 0 \\
\hline 26 & 0 & 0 & $0^{*}$ & 0 & 0 & $0^{*}$ & 0 & 0 & 0 & 0 & 0 & 0 \\
\hline 27 & 0 & 0 & $0^{*}$ & 0 & 0 & $0^{*}$ & 0 & 0 & 0 & 0 & 0 & 0 \\
\hline 28 & 0 & 0 & $0^{*}$ & 0 & 0 & $0^{*}$ & 0 & 0 & 0 & 0 & 0 & 0 \\
\hline 29 & 0 & 0 & $0^{*}$ & 0 & --- & 0 & 0 & 0 & 0 & 0 & 0 & 0 \\
\hline 30 & 0 & 0 & $0^{*}$ & 0 & -..-- & 0 & 0 & 0 & 0 & 0 & 0 & 0 \\
\hline 31 & 0 & --.- & $0^{*}$ & 0 & ---- & 0 & ----- & 0 & --- & 0 & 0 & ---- \\
\hline Total & 0 & 0 & 0 & 0 & 0 & 0 & 0 & 0 & 0.04 & 0 & 0 & 0 \\
\hline Mean & 0 & 0 & 0 & 0 & 0 & 0 & 0 & 0 & .001 & 0 & 0 & 0 \\
\hline $\operatorname{Max}$ & 0 & 0 & 0 & 0 & 0 & 0 & 0 & 0 & .04 & 0 & 0 & 0 \\
\hline Min & 0 & 0 & 0 & 0 & 0 & 0 & 0 & 0 & 0 & 0 & 0 & 0 \\
\hline Acre-F t & 0 & 0 & 0 & 0 & 0 & 0 & 0 & 0 & .08 & 0 & 0 & 0 \\
\hline Wtr Year & 2009 & Total & 0.04 & Mean & & 0 & Max & .04 & Min & 0 & Acre-Ft & .08 \\
\hline Cal Year & 2008 & Total & 81.17 & Mean & & .22 & Max & 11 & Min & 0 & Acre-Ft & 161 \\
\hline
\end{tabular}

${ }^{\star}$ Estimate 


\section{E263 Water Canyon at SR 4}

Location. Lat $35^{\circ} 48^{\prime} 20^{\prime \prime}$, long $106^{\circ} 14^{\prime}$ 52" Sec. 12, T. 18 N., R. 6 E., Ramon Vigil Grant, Los Alamos County.

Drainage Area. $12.43 \mathrm{mi}^{2}$.

Period of Record. April 1999 to September 30, 2009.

Revised Record. Drainage Area (2006).

Gage. Data logger and cellular telemetry. Elevation of gage is $6,365 \mathrm{ft}$ above NGVD from GPS survey.

Remarks. Records are good. Legal location based on projected values.

Average Discharge: $9 \mathrm{yr}, 0.07 \mathrm{ft}^{3} / \mathrm{s}, 51$ acre-ft/yr.

Extremes for Period of Record. Maximum discharge, $306 \mathrm{ft}^{3} / \mathrm{s}$, June 28, 2000, gage height $3.78 \mathrm{ft}$. No flow most of the time.

Extremes for Current Year. No peak discharge above base of $35 \mathrm{ft}^{3} / \mathrm{s}$. No flow for the year.

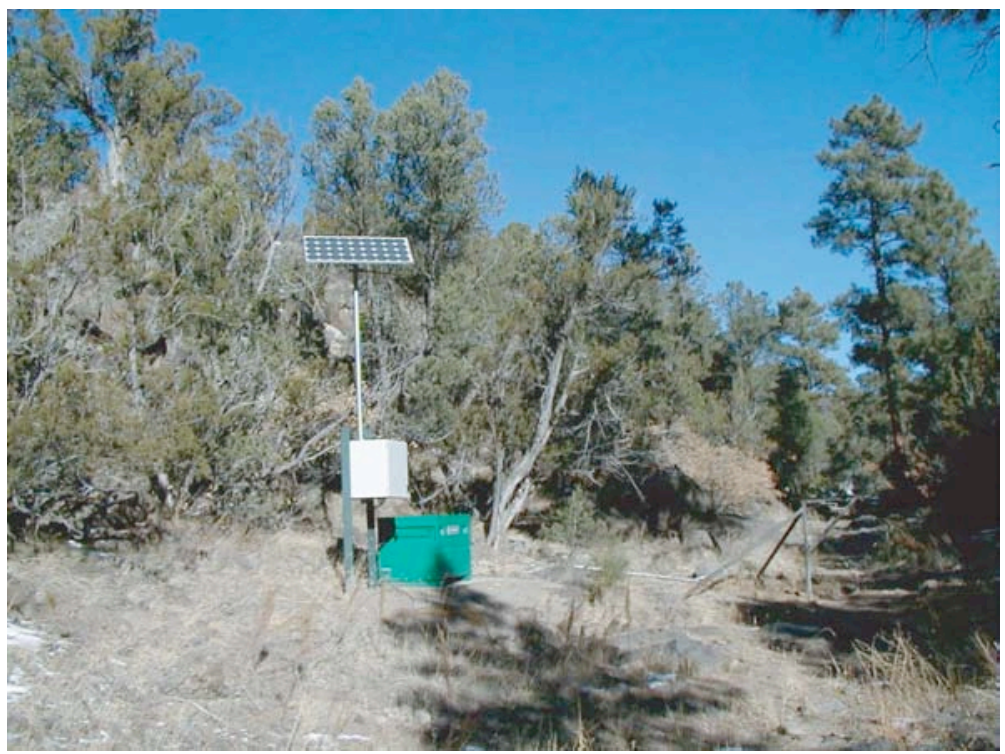




\section{E263 Water Canyon at SR 4}

\section{Station Analysis}

\section{Water Year}

Equipment. Station is equipped with Sutron 8210 data logger (5-min. interval) and Milltronics sonic probe and cellular telemetry. The system is powered by a solar panel battery system housed in a NEMA shelter. Station is equipped with an ISCO pump sampler for water quality sample collection. ISCO is housed in a separate shelter, a $3^{\prime} \times$ $4^{\prime}$ metal box. Sampler is triggered by stage through the data logger. An outside staff is available for reference. No provision for discharge measurements above wading stage.

Field Work. This station was visited 16 times to conduct discharge measurements and service the instrumentation. Field inspections for the gage are listed under site history files on the Hydstra database. Discharge measurements for the gage are listed under site gauging files on the Hydstra database.

Datum Correction. None.

Gage-Height Record. The data logger referenced to the outside staff gave a complete and satisfactory record, except for March 27 when gage height was affected by ice.

Rating. The channel is straight for $400^{\prime}$ upstream and $200^{\prime}$ downstream. Streambed is well armored with bedrock and boulders. Some pockets of sand exist from sediment deposition. Vegetation is sparse in the channel bottom and the banks. Scour should be minimal to nonexistent.

Rating No. 1 continued in use.

Discharge. Discharge was computed by applying gage height to Rating No. 1.

Remarks. Records are good. 


\section{E263 Water Canyon at SR 4}

Daily Mean Discharge in Cubic Feet per Second

Water Year October 2008 to September 2009

\begin{tabular}{|c|c|c|c|c|c|c|c|c|c|c|c|c|}
\hline DAY & OCT & NOV & DEC & JAN & FEB & MAR & APR & MAY & JUN & JUL & AUG & SEP \\
\hline 1 & 0 & 0 & 0 & 0 & 0 & 0 & 0 & 0 & 0 & 0 & 0 & 0 \\
\hline 2 & 0 & 0 & 0 & 0 & 0 & 0 & 0 & 0 & 0 & 0 & 0 & 0 \\
\hline 3 & 0 & 0 & 0 & 0 & 0 & 0 & 0 & 0 & 0 & 0 & 0 & 0 \\
\hline 4 & 0 & 0 & 0 & 0 & 0 & 0 & 0 & 0 & 0 & 0 & 0 & 0 \\
\hline 5 & 0 & 0 & 0 & 0 & 0 & 0 & 0 & 0 & 0 & 0 & 0 & 0 \\
\hline 6 & 0 & 0 & 0 & 0 & 0 & 0 & 0 & 0 & 0 & 0 & 0 & 0 \\
\hline 7 & 0 & 0 & 0 & 0 & 0 & 0 & 0 & 0 & 0 & 0 & 0 & 0 \\
\hline 8 & 0 & 0 & 0 & 0 & 0 & 0 & 0 & 0 & 0 & 0 & 0 & 0 \\
\hline 9 & 0 & 0 & 0 & 0 & 0 & 0 & 0 & 0 & 0 & 0 & 0 & 0 \\
\hline 10 & 0 & 0 & 0 & 0 & 0 & 0 & 0 & 0 & 0 & 0 & 0 & 0 \\
\hline 11 & 0 & 0 & 0 & 0 & 0 & 0 & 0 & 0 & 0 & 0 & 0 & 0 \\
\hline 12 & 0 & 0 & 0 & 0 & 0 & 0 & 0 & 0 & 0 & 0 & 0 & 0 \\
\hline 13 & 0 & 0 & 0 & 0 & 0 & 0 & 0 & 0 & 0 & 0 & 0 & 0 \\
\hline 14 & 0 & 0 & 0 & 0 & 0 & 0 & 0 & 0 & 0 & 0 & 0 & 0 \\
\hline 15 & 0 & 0 & 0 & 0 & 0 & 0 & 0 & 0 & 0 & 0 & 0 & 0 \\
\hline 16 & 0 & 0 & 0 & 0 & 0 & 0 & 0 & 0 & 0 & 0 & 0 & 0 \\
\hline 17 & 0 & 0 & 0 & 0 & 0 & 0 & 0 & 0 & 0 & 0 & 0 & 0 \\
\hline 18 & 0 & 0 & 0 & 0 & 0 & 0 & 0 & 0 & 0 & 0 & 0 & 0 \\
\hline 19 & 0 & 0 & 0 & 0 & 0 & 0 & 0 & 0 & 0 & 0 & 0 & 0 \\
\hline 20 & 0 & 0 & 0 & 0 & 0 & 0 & 0 & 0 & 0 & 0 & 0 & 0 \\
\hline 21 & 0 & 0 & 0 & 0 & 0 & 0 & 0 & 0 & 0 & 0 & 0 & 0 \\
\hline 22 & 0 & 0 & 0 & 0 & 0 & 0 & 0 & 0 & 0 & 0 & 0 & 0 \\
\hline 23 & 0 & 0 & 0 & 0 & 0 & 0 & 0 & 0 & 0 & 0 & 0 & 0 \\
\hline 24 & 0 & 0 & 0 & 0 & 0 & 0 & 0 & 0 & 0 & 0 & 0 & 0 \\
\hline 25 & 0 & 0 & 0 & 0 & 0 & 0 & 0 & 0 & 0 & 0 & 0 & 0 \\
\hline 26 & 0 & 0 & 0 & 0 & 0 & 0 & 0 & 0 & 0 & 0 & 0 & 0 \\
\hline 27 & 0 & 0 & 0 & 0 & 0 & $0^{*}$ & 0 & 0 & 0 & 0 & 0 & 0 \\
\hline 28 & 0 & 0 & 0 & 0 & 0 & 0 & 0 & 0 & 0 & 0 & 0 & 0 \\
\hline 29 & 0 & 0 & 0 & 0 & -..-- & 0 & 0 & 0 & 0 & 0 & 0 & 0 \\
\hline 30 & 0 & 0 & 0 & 0 & -..--. & 0 & 0 & 0 & 0 & 0 & 0 & 0 \\
\hline 31 & 0 & -.-- & 0 & 0 & ----- & 0 & --- & 0 & --- & 0 & 0 & 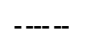 \\
\hline Total & 0 & 0 & 0 & 0 & 0 & 0 & 0 & 0 & 0 & 0 & 0 & 0 \\
\hline Mean & 0 & 0 & 0 & 0 & 0 & 0 & 0 & 0 & 0 & 0 & 0 & 0 \\
\hline Max & 0 & 0 & 0 & 0 & 0 & 0 & 0 & 0 & 0 & 0 & 0 & 0 \\
\hline Min & 0 & 0 & 0 & 0 & 0 & 0 & 0 & 0 & 0 & 0 & 0 & 0 \\
\hline Acre-Ft & 0 & 0 & 0 & 0 & 0 & 0 & 0 & 0 & 0 & 0 & 0 & 0 \\
\hline Wtr Year & 2009 & Total & 0 & Mean & & 0 & $\operatorname{Max}$ & 0 & Min & 0 & Acre-Ft & 0 \\
\hline Cal Year & 2008 & Total & 13 & Mean & & 36 & $\operatorname{Max}$ & 13 & Min & 0 & Acre-Ft & 26 \\
\hline
\end{tabular}

${ }^{*}$ Estimate 


\section{E264 Indio Canyon at SR 4}

Location. Lat $35^{\circ} 48^{\prime}$ 18", long $106^{\circ}$ 14' 51", Sec. 12, T. 18 N., R. 6 E., Ramon Vigil Grant, Los Alamos County.

Drainage Area. $0.49 \mathrm{mi}^{2}$.

Period of Record. October 1, 2006, to September 30, 2009.

Gage. Data logger and $120^{\circ}$ sharp-crested weir. Elevation of gage is $6,366 \mathrm{ft}$ above NGVD.

Remarks. Records are good. Records for this site existed before period of record but are not reliable.

Extremes for Period of Record. Maximum discharge, of $0.03 \mathrm{ft}^{3} / \mathrm{s}$, March 2, 2007, gage height $0.76 \mathrm{ft}$. No flow most of the time.

Extremes for Current Year. Maximum discharge of $0.01 \mathrm{ft}^{3} / \mathrm{s}$ at $0105 \mathrm{~h}$, September 16, gage height $0.74 \mathrm{ft}$. No peak discharge above $1.0 \mathrm{ft}^{3} / \mathrm{s}$. No flow most of the time.

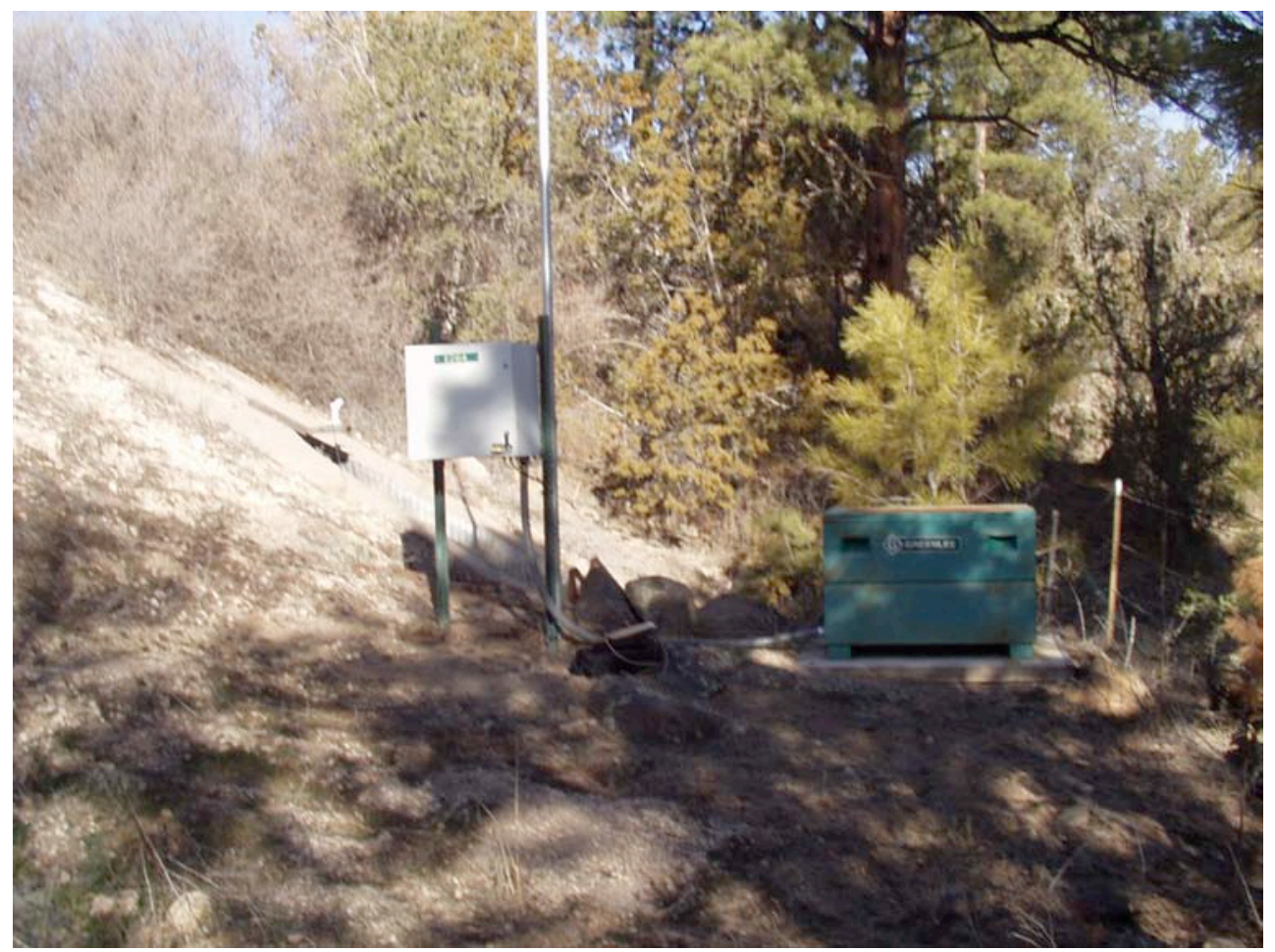




\title{
E264 Indio Canyon at SR 4
}

\author{
Station Analysis
}

\section{Water Year}

Equipment. Station is equipped with Sutron 8210 data logger (5-min. interval) with Sutron Accubar bubble sensor. The system is powered by a solar panel battery system housed in a NEMA shelter. Station is equipped with an ISCO pump sampler for water quality sample collection. ISCO is housed in a separate shelter, a $3^{\prime} \times 4^{\prime}$ metal box. An outside staff is available for reference. No provision for discharge measurement above wading stage.

Field Work. The station was visited 18 times to conduct discharge measurements and service the instrumentation. Inspections for the gage are listed under site history files on the Hydstra database. Discharge measurements for the gage are listed under site gauging files on the Hydstra database.

Datum Correction. None. Levels run May 13, 2005, found gage correct to datum.

Gage-Height Record. The data logger referenced to the outside staff gave a complete and satisfactory record for the year, except for the periods of December 27, January 2, January 26 to February 28, and April 12,18 when gage height was affected by ice and March 4-16 when data logger malfunctioned.

Rating. The channel at the gage is about $8^{\prime}$ wide and straight for about $50^{\prime}$ upstream and $25^{\prime}$ downstream and bends to the right. The streambed through this reach is primarily sand. The low-flow control is a $120^{\circ}$ sharp-crested weir. The channel becomes the control at high flow.

Eighteen inspections of no flow were made this year.

Rating No. 1 is based on a theoretical computation for $120^{\circ}$ sharp-crested weir to a gage height of $2.60 \mathrm{ft}$. Broad-crested weir computation is used above that stage.

Discharge. Discharge was computed by applying gage height to Rating No. 1 directly.

Remarks. Records are good. 
E264 Indio Canyon at SR 4

Daily Mean Discharge in Cubic Feet per Second

Water Year October 2008 to September 2009

\begin{tabular}{|c|c|c|c|c|c|c|c|c|c|c|c|c|}
\hline DAY & OCT & NOV & DEC & JAN & FEB & MAR & APR & MAY & JUN & JUL & AUG & SEP \\
\hline 1 & 0 & 0 & 0 & 0 & $0^{*}$ & 0 & 0 & 0 & 0 & 0 & 0 & 0 \\
\hline 2 & 0 & 0 & 0 & $0^{*}$ & $0^{*}$ & 0 & 0 & 0 & 0 & 0 & 0 & 0 \\
\hline 3 & 0 & 0 & 0 & 0 & $0^{*}$ & 0 & 0 & 0 & 0 & 0 & 0 & 0 \\
\hline 4 & 0 & 0 & 0 & 0 & $0^{*}$ & $0^{*}$ & 0 & 0 & 0 & 0 & 0 & 0 \\
\hline 5 & 0 & 0 & 0 & 0 & $0^{*}$ & $0^{*}$ & 0 & 0 & 0 & 0 & 0 & 0 \\
\hline 6 & 0 & 0 & 0 & 0 & $0^{*}$ & $0^{*}$ & 0 & 0 & 0 & .01 & 0 & 0 \\
\hline 7 & 0 & 0 & 0 & 0 & $0^{*}$ & $0^{*}$ & 0 & 0 & 0 & 0 & 0 & 0 \\
\hline 8 & 0 & 0 & 0 & 0 & $0^{*}$ & $0^{*}$ & 0 & 0 & 0 & 0 & 0 & 0 \\
\hline 9 & 0 & 0 & 0 & 0 & $0^{*}$ & $0^{*}$ & 0 & 0 & 0 & 0 & 0 & 0 \\
\hline 10 & 0 & 0 & 0 & 0 & $0^{*}$ & $0^{*}$ & 0 & 0 & 0 & 0 & 0 & 0 \\
\hline 11 & 0 & 0 & 0 & 0 & $0^{*}$ & $0^{*}$ & 0 & 0 & 0 & 0 & 0 & 0 \\
\hline 12 & 0 & 0 & 0 & 0 & $0^{*}$ & $0^{*}$ & $0^{*}$ & 0 & 0 & 0 & 0 & 0 \\
\hline 13 & 0 & 0 & 0 & 0 & $0^{*}$ & $0^{*}$ & 0 & 0 & 0 & 0 & 0 & 0 \\
\hline 14 & .01 & 0 & 0 & 0 & $0^{*}$ & $0^{*}$ & 0 & 0 & 0 & 0 & 0 & 0 \\
\hline 15 & 0 & 0 & 0 & 0 & $0^{*}$ & $0^{*}$ & 0 & 0 & 0 & 0 & 0 & 0 \\
\hline 16 & 0 & 0 & 0 & 0 & $0^{*}$ & $0^{*}$ & 0 & 0 & 0 & 0 & 0 & .01 \\
\hline 17 & 0 & 0 & 0 & 0 & $0^{*}$ & 0 & 0 & 0 & 0 & 0 & 0 & .01 \\
\hline 18 & 0 & 0 & 0 & 0 & $0^{*}$ & 0 & $0^{*}$ & 0 & 0 & 0 & 0 & 0 \\
\hline 19 & 0 & 0 & 0 & 0 & $0^{*}$ & 0 & 0 & 0 & 0 & 0 & 0 & 0 \\
\hline 20 & 0 & 0 & 0 & 0 & $0^{*}$ & 0 & 0 & 0 & 0 & 0 & 0 & 0 \\
\hline 21 & 0 & 0 & 0 & 0 & $0^{*}$ & 0 & 0 & 0 & 0 & 0 & 0 & 0 \\
\hline 22 & 0 & 0 & 0 & 0 & $0^{*}$ & 0 & 0 & 0 & 0 & 0 & 0 & 0 \\
\hline 23 & 0 & 0 & 0 & 0 & $0^{*}$ & 0 & 0 & 0 & 0 & 0 & 0 & 0 \\
\hline 24 & 0 & 0 & 0 & 0 & $0^{*}$ & 0 & 0 & 0 & 0 & 0 & 0 & 0 \\
\hline 25 & 0 & 0 & 0 & 0 & $0^{*}$ & 0 & 0 & 0 & 0 & 0 & 0 & 0 \\
\hline 26 & 0 & 0 & 0 & $0^{*}$ & $0^{*}$ & 0 & 0 & 0 & 0 & 0 & 0 & 0 \\
\hline 27 & 0 & 0 & $0^{*}$ & $0^{*}$ & $0^{*}$ & 0 & 0 & 0 & 0 & 0 & 0 & 0 \\
\hline 28 & 0 & 0 & 0 & $0^{*}$ & $0^{*}$ & 0 & 0 & 0 & 0 & 0 & 0 & 0 \\
\hline 29 & 0 & 0 & 0 & $0^{*}$ & ----- & 0 & 0 & 0 & 0 & 0 & 0 & 0 \\
\hline 30 & 0 & 0 & 0 & $0^{*}$ & ----- & 0 & 0 & 0 & 0 & 0 & 0 & 0 \\
\hline 31 & 0 & -.--- & 0 & $0^{*}$ & ----- & 0 & ----- & 0 & ---- & 0 & 0 & --.-- \\
\hline Total & 0.01 & 0 & 0 & 0 & 0 & 0 & 0 & 0 & 0 & 0.01 & 0 & 0.02 \\
\hline Mean & 0 & 0 & 0 & 0 & 0 & 0 & 0 & 0 & 0 & 0 & 0 & .001 \\
\hline Max & .01 & 0 & 0 & 0 & 0 & 0 & 0 & 0 & 0 & .01 & 0 & .01 \\
\hline Min & 0 & 0 & 0 & 0 & 0 & 0 & 0 & 0 & 0 & 0 & 0 & 0 \\
\hline Acre-F t & .02 & 0 & 0 & 0 & 0 & 0 & 0 & 0 & 0 & .02 & 0 & .04 \\
\hline Wtr Year & 2009 & Total & 0.04 & Mean & & 0 & Max & .01 & Min & 0 & Acre-Ft & .08 \\
\hline Cal Year & 2008 & Total & 0.01 & Mean & & 0 & Max & .01 & Min & 0 & Acre- $\mathrm{Ft}$ & .02 \\
\hline
\end{tabular}

${ }^{*}$ Estimate 


\section{E265 Water Canyon below SR 4}

Location. Lat $35^{\circ} 48^{\prime} 18^{\prime \prime}$, long $106^{\circ} 14^{\prime} 31^{\prime \prime}$ Sec. 7, T. 18 N., R. 7 E., Ramon Vigil Grant, Los Alamos County.

Drainage Area. $13.11 \mathrm{mi}^{2}$.

Period of Record. October 1993 to September 30, 2009.

Revised Records. Drainage area (2006).

Gage. Data logger with cellular telemetry, rain gage and stabilized natural rock control. Elevation of gage is $6,309 \mathrm{ft}$ above NGVD from GPS survey.

Remarks. Records good. Legal location based on projected values.

Average Discharge. $15 \mathrm{yr}, 0.04 \mathrm{ft}^{3} / \mathrm{s}, 29 \mathrm{acre}-\mathrm{ft} / \mathrm{yr}$.

Extremes for Period of Record. Maximum discharge, $274 \mathrm{ft}^{3} / \mathrm{s}$, June 28, 2000, gage height $5.13 \mathrm{ft}$ (from flood mark). No flow most of the time.

Extremes for Current Year. Maximum discharge, $0.16 \mathrm{ft}^{3} / \mathrm{s} 1520$ h, October 11, gage height $0.42 \mathrm{ft}$. No peak discharge above base of $50 \mathrm{ft}^{3} / \mathrm{s}$.

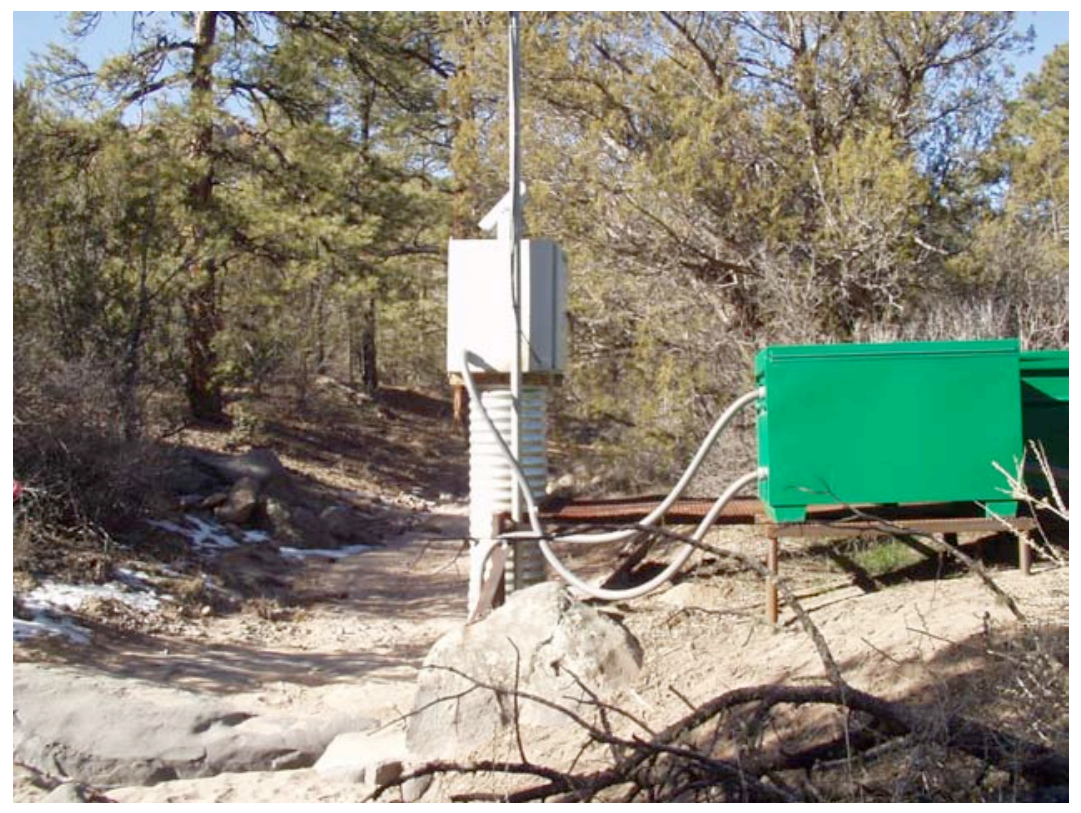




\title{
E265 Water Canyon below SR 4
}

\author{
Station Analysis
}

\section{Water Year}

Equipment. Station is equipped with Sutron 8210 data logger (5-min. interval) with shaft encoder float system (5-min. interval) and cellular phone with speech modem. The system is powered by a solar panel battery system housed in a NEMA shelter on 24" CMP well. Station is equipped with an ISCO pump sampler for water quality sample collection. ISCO is housed in a separate shelter, a $3^{\prime} \times 4^{\prime}$ metal box. Sampler is triggered by stage through the data logger. An outside staff is available for reference. No provision for measurements above wading stage.

Station is also equipped with a tipping bucket rain gage, Rain Collection II. All equipment is powered with a solar panel battery charging system.

Field Work. The station was visited 25 times to conduct discharge measurements and service the instrumentation. Field inspections for the gage are listed under site history files on the Hydstra database. Discharge measurements for the gage are listed under site gauging files on the Hydstra database.

Datum Correction. None.

Gage-Height Record. The data logger referenced to the outside staff gave complete and satisfactory record, except for the period from July 13-17 when data logger malfunctioned.

Rating. The channel is straight for $100^{\prime}$ above and below gage. Banks are low and have very little vegetation. Streambed is mostly rock with lenses of sand.

Twenty-five inspections of no flow were made this year.

Rating No. 4 was used for the entire water year.

Discharge. Discharge was computed by applying gage height to Rating No. 4 directly.

Remarks. Records are good. 


\section{E265 W ater Can yo $\mathrm{n}$ below SR 4}

Daily Mean Discharge in Cubic Feet per Second

Water Year October 2008 to September 2009

\begin{tabular}{|c|c|c|c|c|c|c|c|c|c|c|c|c|}
\hline DAY & OCT & NOV & DEC & JAN & FEB & MAR & APR & MAY & JUN & JUL & AUG & SEP \\
\hline 1 & 0 & 0 & 0 & 0 & 0 & 0 & 0 & 0 & 0 & 0 & 0 & 0 \\
\hline 2 & 0 & 0 & 0 & 0 & 0 & 0 & 0 & 0 & 0 & 0 & 0 & 0 \\
\hline 3 & 0 & 0 & 0 & 0 & 0 & 0 & 0 & 0 & 0 & 0 & 0 & 0 \\
\hline 4 & 0 & 0 & 0 & 0 & 0 & 0 & 0 & 0 & 0 & 0 & 0 & 0 \\
\hline 5 & 0 & 0 & 0 & 0 & 0 & 0 & 0 & 0 & 0 & 0 & 0 & 0 \\
\hline 6 & 0 & 0 & 0 & 0 & 0 & 0 & 0 & 0 & 0 & 0 & 0 & 0 \\
\hline 7 & 0 & 0 & 0 & 0 & 0 & 0 & 0 & 0 & 0 & 0 & 0 & 0 \\
\hline 8 & 0 & 0 & 0 & 0 & 0 & 0 & 0 & 0 & 0 & 0 & 0 & 0 \\
\hline 9 & 0 & 0 & 0 & 0 & 0 & 0 & 0 & 0 & 0 & 0 & 0 & 0 \\
\hline 10 & 0 & 0 & 0 & 0 & 0 & 0 & 0 & 0 & 0 & 0 & 0 & 0 \\
\hline 11 & 0 & 0 & 0 & 0 & 0 & 0 & 0 & 0 & 0 & 0 & 0 & 0 \\
\hline 12 & 0 & 0 & 0 & 0 & 0 & 0 & 0 & 0 & 0 & 0 & 0 & 0 \\
\hline 13 & 0 & 0 & 0 & 0 & 0 & 0 & 0 & 0 & 0 & $0^{*}$ & 0 & 0 \\
\hline 14 & 0 & 0 & 0 & 0 & 0 & 0 & 0 & 0 & 0 & $0^{*}$ & 0 & 0 \\
\hline 15 & 0 & 0 & 0 & 0 & 0 & 0 & 0 & 0 & 0 & $0^{*}$ & 0 & 0 \\
\hline 16 & 0 & 0 & 0 & 0 & 0 & 0 & 0 & 0 & 0 & $0^{*}$ & 0 & 0 \\
\hline 17 & 0 & 0 & 0 & 0 & 0 & 0 & 0 & 0 & 0 & $0^{*}$ & 0 & 0 \\
\hline 18 & 0 & 0 & 0 & 0 & 0 & 0 & 0 & 0 & 0 & 0 & 0 & 0 \\
\hline 19 & 0 & 0 & 0 & 0 & 0 & 0 & 0 & 0 & 0 & 0 & 0 & 0 \\
\hline 20 & 0 & 0 & 0 & 0 & 0 & 0 & 0 & 0 & 0 & 0 & 0 & 0 \\
\hline 21 & 0 & 0 & 0 & 0 & 0 & 0 & 0 & 0 & 0 & 0 & 0 & 0 \\
\hline 22 & 0 & 0 & 0 & 0 & 0 & 0 & 0 & 0 & 0 & 0 & 0 & 0 \\
\hline 23 & 0 & 0 & 0 & 0 & 0 & 0 & 0 & 0 & 0 & 0 & 0 & 0 \\
\hline 24 & 0 & 0 & 0 & 0 & 0 & 0 & 0 & 0 & 0 & 0 & 0 & 0 \\
\hline 25 & 0 & 0 & 0 & 0 & 0 & 0 & 0 & 0 & 0 & 0 & 0 & 0 \\
\hline 26 & 0 & 0 & 0 & 0 & 0 & 0 & 0 & 0 & 0 & 0 & 0 & 0 \\
\hline 27 & 0 & 0 & 0 & 0 & 0 & 0 & 0 & 0 & 0 & 0 & 0 & 0 \\
\hline 28 & 0 & 0 & 0 & 0 & 0 & 0 & 0 & 0 & 0 & 0 & 0 & 0 \\
\hline 29 & 0 & 0 & 0 & 0 & --.-- & 0 & 0 & 0 & 0 & 0 & 0 & 0 \\
\hline 30 & 0 & 0 & 0 & 0 & --.-- & 0 & 0 & 0 & 0 & 0 & 0 & 0 \\
\hline 31 & 0 & ---- & 0 & 0 & ----- & 0 & 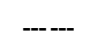 & 0 & ---- & 0 & 0 & ---- \\
\hline Total & 0 & 0 & 0 & 0 & 0 & 0 & 0 & 0 & 0 & 0 & 0 & 0 \\
\hline Mean & 0 & 0 & 0 & 0 & 0 & 0 & 0 & 0 & 0 & 0 & 0 & 0 \\
\hline Max & 0 & 0 & 0 & 0 & 0 & 0 & 0 & 0 & 0 & 0 & 0 & 0 \\
\hline Min & 0 & 0 & 0 & 0 & 0 & 0 & 0 & 0 & 0 & 0 & 0 & 0 \\
\hline Acre-F t & 0 & 0 & 0 & 0 & 0 & 0 & 0 & 0 & 0 & 0 & 0 & 0 \\
\hline Wtr Year & 2009 & Total & 0 & Mean & & 0 & lax & 0 & Min & 0 & Acre-Ft & 0 \\
\hline Cal Year & 2008 & Total & 8.61 & Mean & & 24 & $\operatorname{Max}$ & 8.6 & Min & 0 & Acre-Ft & 17 \\
\hline
\end{tabular}




\section{E267 Potrillo Canyon above SR 4}

Location. Lat $35^{\circ} 48^{\prime} 48^{\prime \prime}$, long $106^{\circ}$ 14' 00", Sec. 6, T. 18 N., R. 7 E., Ramon Vigil Grant, Los Alamos County.

Drainage Area. $2.26 \mathrm{mi}^{2}$.

Period of Record. October 1, 1995, to September 30, 2009.

Revised Record. LA-13551-PR (1998): Station number; Drainage Area (2006).

Gage. Data logger with cellular telemetry and concrete control. Elevation of gage is 6,454 ft above NGVD from GPS survey.

Remarks. Records are good. Legal location based on projected values.

Average Discharge. $15 \mathrm{yr}, 0.003 \mathrm{ft}^{3} / \mathrm{s}, 2.17 \mathrm{acre}-\mathrm{ft} / \mathrm{yr}$.

Extremes for Period of Record. Maximum discharge, $63 \mathrm{ft}^{3} / \mathrm{s}$, August 29, 1995, gage height $2.70 \mathrm{ft}$ (from slope-area determination). No flow most of the time.

Extremes for Current Year. Maximum discharge, $0.03 \mathrm{ft}^{3} / \mathrm{s} 1435$ h, July 30, gage height $0.58 \mathrm{ft}$. No peak discharge above base of $5.0 \mathrm{ft}^{3} / \mathrm{s}$. No flow most of the time.

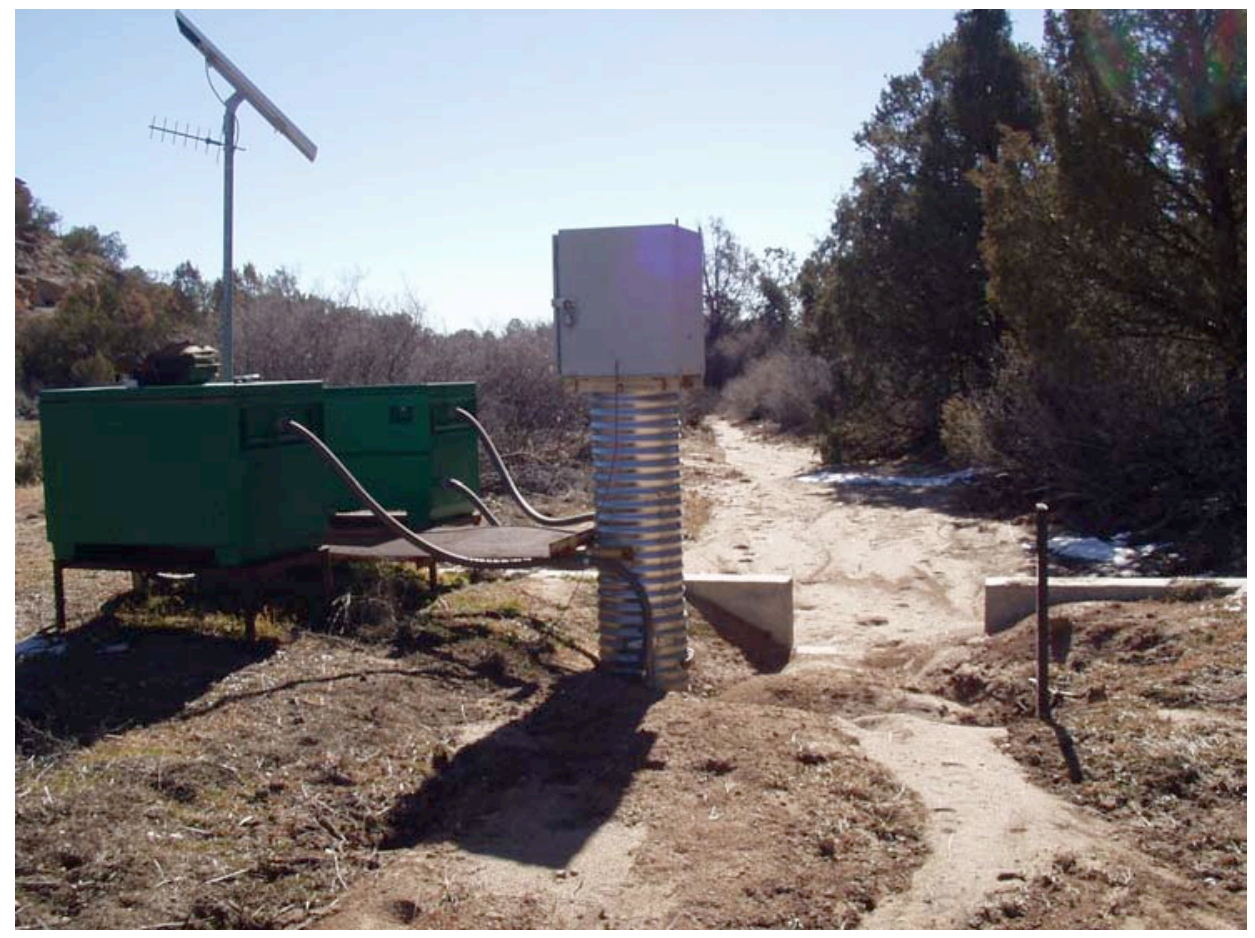




\section{E267 Potrillo Canyon above SR 4}

\section{Station Analysis}

\section{Water Year}

Equipment. Station is equipped with Sutron 8210 data logger (5-min. interval) with shaft encoder float system (5-min. interval) and cellular phone with speech modem. The system is powered by a solar panel battery system housed in NEMA shelter on 18" CMP well. Station is equipped with an ISCO pump sampler for water quality sample collection. ISCO is housed in a separate shelter, a $3^{\prime} \times 4^{\prime}$ metal box. Sampler is triggered by stage through the data logger. An outside staff is available for reference. No provision for direct discharge measurements above wading stages.

Field Work. The station was visited 20 times to conduct discharge measurements and service the instrumentation. Field inspections for the gage are listed under site history files on the Hydstra database. Discharge measurements for the gage are listed under site gauging files on the Hydstra database.

Datum Correction. None.

Gage-Height Record. The data logger referenced to the outside staff gave a complete and satisfactory record for the year.

Rating. The channel is fairly straight for $300^{\prime}$ above gage and $150^{\prime}$ below. Streambed is mostly sand. Brush is fairly thick along stream bank. The control is a concrete broadcrested weir.

Twenty inspections of no flow were made this year.

Rating No. 1 is considered good.

Original shape and definition of rating was by computation using weir geometry with slope area used to define peak discharge and slope of upper end.

Discharge. Discharge was computed by applying gage height to Rating No. 1 directly.

Remarks. Records are good. 


\section{E267 Potrillo Canyon above SR 4}

Daily Mean Discharge in Cubic Feet per Second

Water Year October 2008 to September 2009

\begin{tabular}{|c|c|c|c|c|c|c|c|c|c|c|c|c|}
\hline DAY & OCT & NOV & DEC & JAN & FEB & MAR & APR & MAY & JUN & JUL & AUG & SEP \\
\hline 1 & 0 & 0 & 0 & 0 & 0 & 0 & 0 & 0 & 0 & 0 & 0 & 0 \\
\hline 2 & 0 & 0 & 0 & 0 & 0 & 0 & 0 & 0 & 0 & 0 & 0 & 0 \\
\hline 3 & 0 & 0 & 0 & 0 & 0 & 0 & 0 & 0 & 0 & 0 & 0 & 0 \\
\hline 4 & 0 & 0 & 0 & 0 & 0 & 0 & 0 & 0 & 0 & 0 & 0 & 0 \\
\hline 5 & 0 & 0 & 0 & 0 & 0 & 0 & 0 & 0 & 0 & 0 & 0 & 0 \\
\hline 6 & 0 & 0 & 0 & 0 & 0 & 0 & 0 & 0 & 0 & 0 & 0 & 0 \\
\hline 7 & 0 & 0 & 0 & 0 & 0 & 0 & 0 & 0 & 0 & 0 & 0 & 0 \\
\hline 8 & 0 & 0 & 0 & 0 & 0 & 0 & 0 & 0 & 0 & 0 & 0 & 0 \\
\hline 9 & 0 & 0 & 0 & 0 & 0 & 0 & 0 & 0 & 0 & 0 & 0 & 0 \\
\hline 10 & 0 & 0 & 0 & 0 & 0 & 0 & 0 & 0 & 0 & 0 & 0 & 0 \\
\hline 11 & 0 & 0 & 0 & 0 & 0 & 0 & 0 & 0 & 0 & 0 & 0 & 0 \\
\hline 12 & 0 & 0 & 0 & 0 & 0 & 0 & 0 & 0 & 0 & 0 & 0 & 0 \\
\hline 13 & 0 & 0 & 0 & 0 & 0 & 0 & 0 & 0 & 0 & 0 & 0 & 0 \\
\hline 14 & 0 & 0 & 0 & 0 & 0 & 0 & 0 & 0 & 0 & 0 & 0 & 0 \\
\hline 15 & 0 & 0 & 0 & 0 & 0 & 0 & 0 & 0 & 0 & 0 & 0 & 0 \\
\hline 16 & 0 & 0 & 0 & 0 & 0 & 0 & 0 & 0 & 0 & 0 & 0 & 0 \\
\hline 17 & 0 & 0 & 0 & 0 & 0 & 0 & 0 & 0 & 0 & 0 & 0 & 0 \\
\hline 18 & 0 & 0 & 0 & 0 & 0 & 0 & 0 & 0 & 0 & 0 & 0 & 0 \\
\hline 19 & 0 & 0 & 0 & 0 & 0 & 0 & 0 & 0 & 0 & 0 & 0 & 0 \\
\hline 20 & 0 & 0 & 0 & 0 & 0 & 0 & 0 & 0 & 0 & 0 & 0 & 0 \\
\hline 21 & 0 & 0 & 0 & 0 & 0 & 0 & 0 & 0 & 0 & 0 & 0 & 0 \\
\hline 22 & 0 & 0 & 0 & 0 & 0 & 0 & 0 & 0 & 0 & 0 & 0 & 0 \\
\hline 23 & 0 & 0 & 0 & 0 & 0 & 0 & 0 & 0 & 0 & 0 & 0 & 0 \\
\hline 24 & 0 & 0 & 0 & 0 & 0 & 0 & 0 & 0 & 0 & 0 & 0 & 0 \\
\hline 25 & 0 & 0 & 0 & 0 & 0 & 0 & 0 & 0 & 0 & 0 & 0 & 0 \\
\hline 26 & 0 & 0 & 0 & 0 & 0 & 0 & 0 & 0 & 0 & 0 & 0 & 0 \\
\hline 27 & 0 & 0 & 0 & 0 & 0 & 0 & 0 & 0 & 0 & 0 & 0 & 0 \\
\hline 28 & 0 & 0 & 0 & 0 & 0 & 0 & 0 & 0 & 0 & 0 & 0 & 0 \\
\hline 29 & 0 & 0 & 0 & 0 & --.-- & 0 & 0 & 0 & 0 & 0 & 0 & 0 \\
\hline 30 & 0 & 0 & 0 & 0 & --.-- & 0 & 0 & 0 & 0 & 0 & 0 & 0 \\
\hline 31 & 0 & --- & 0 & 0 & $-\cdots$ & 0 & ---- & 0 & ---- & 0 & 0 & ---- \\
\hline Total & 0 & 0 & 0 & 0 & 0 & 0 & 0 & 0 & 0 & 0 & 0 & 0 \\
\hline Mean & 0 & 0 & 0 & 0 & 0 & 0 & 0 & 0 & 0 & 0 & 0 & 0 \\
\hline Max & 0 & 0 & 0 & 0 & 0 & 0 & 0 & 0 & 0 & 0 & 0 & 0 \\
\hline Min & 0 & 0 & 0 & 0 & 0 & 0 & 0 & 0 & 0 & 0 & 0 & 0 \\
\hline Acre-Ft & 0 & 0 & 0 & 0 & 0 & 0 & 0 & 0 & 0 & 0 & 0 & 0 \\
\hline Wtr Year & 2009 & Total & 0 & Mean & & 0 & Max & 0 & Min & 0 & Acre-Ft & 0 \\
\hline Cal Year & 2008 & Total & 0.07 & Mean & & 0 & $\operatorname{Max}$ & .04 & Min & 0 & Acre-Ft & .14 \\
\hline
\end{tabular}


Location. Lat $35^{\circ}$ 49' 38", long $106^{\circ} 16^{\prime} 36^{\prime \prime}$, Sec. 35, T. 19 N., R. 6 E., Ramon Vigil Grant, Santa Fe National Forest.

Drainage Area. $0.061 \mathrm{mi}^{2}$.

Period of Record. October 1, 2006, to September 30, 2009.

Gage. Data logger and 9" Parshall flume, rain gage with cellular telemetry. Elevation of gage is $6,858 \mathrm{ft}$ above NGVD.

Remarks. Records are good. Records for this site existed before published period but are not reliable. Legal location based on projected values.

Extremes for Period of Record. Maximum discharge, $0.99 \mathrm{ft}^{3} / \mathrm{s}$, January 28, 2008, gage height $0.45 \mathrm{ft}$. No flow most of the time.

Extremes for Current Year. Maximum discharge, $0.30 \mathrm{ft}^{3} / \mathrm{s}$, at $1520 \mathrm{~h}$, October 11, gage height $0.22 \mathrm{ft}$. No peak above base of $1.0 \mathrm{ft}^{3} / \mathrm{s}$. No flow most of the time.

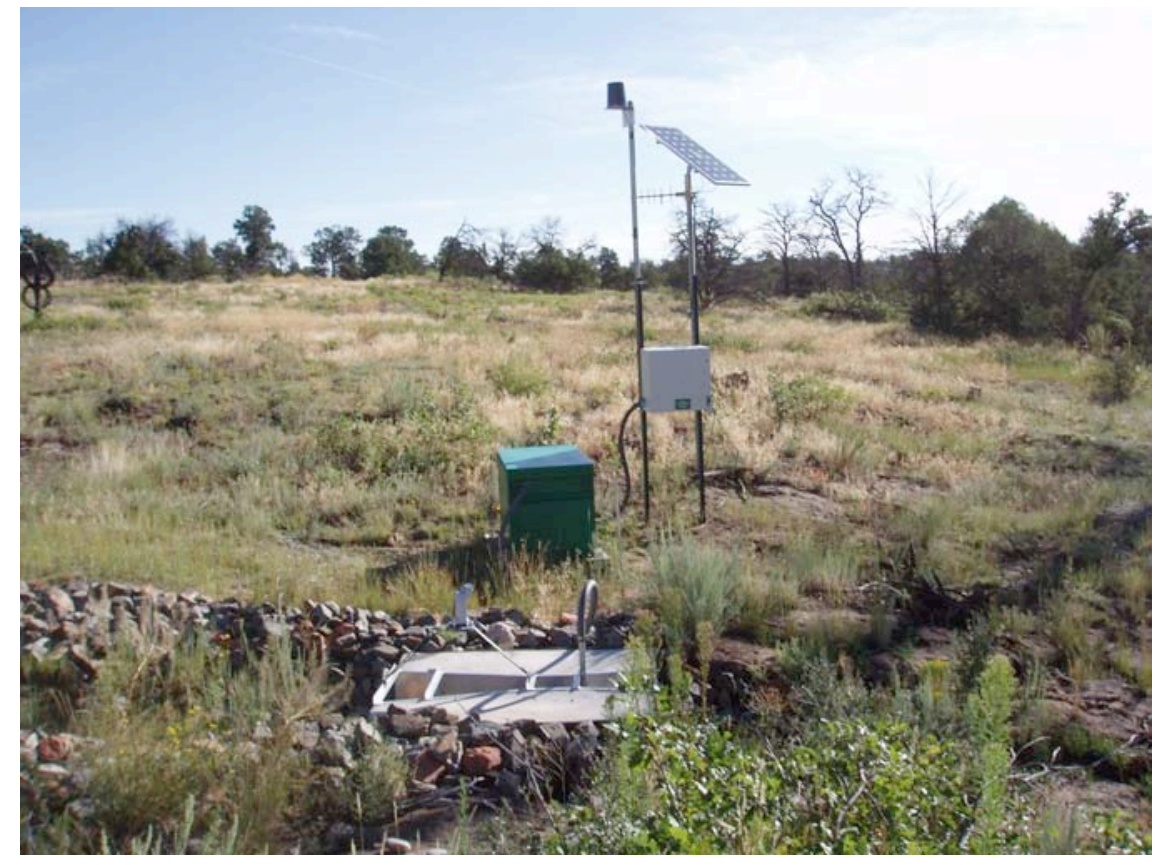




\section{E2674 TA-36 Minie Site}

\section{Station Analysis}

\section{Water Year}

Equipment. Station is equipped with Sutron 8210 data logger (5-min. interval) and Milltronics sonic probe mounted on a 9" Parshall flume and cellular phone with speech modem. The system is powered by a solar panel battery system housed in a NEMA shelter. Station is equipped with an ISCO pump sampler for water quality sample collection. ISCO is housed in a separate shelter, a $3^{\prime} \times 4^{\prime}$ metal box. Sampler is triggered by stage through the data logger. The staff in the 9" Parshall flume is the reference gage. No provision for discharge measurements above wading stage.

Station is also equipped with a tipping bucket rain gage, Rain Collection II. All equipment is powered with a solar panel battery charging system.

Field Work. This station was visited 33 times to conduct discharge measurements and service the instrumentation. Field inspections for the gage are listed under site history files on the Hydstra database. Discharge measurements for the gage are listed under site gauging files on the Hydstra database.

Datum Correction. None.

Gage-Height Record. The data logger referenced to the outside staff gave a complete and satisfactory record, except for the periods from December 9 to January 7 and March 26, 27 when gage height was affected by ice.

Rating. The channel is straight above and below the gage for 100'. The channel near the gage is lined with angular rock. The streambed is mostly sand.

Thirty-three inspections of no flow were made this year.

Rating No. 1 was developed based on the computation of 9" Parshall flume. PZF is 0.00 gage height.

Discharge. Discharge was computed by applying gage height to Rating No. 1 directly. Those days estimated at zero flow were based on precipitation and nearby gage stations for verification.

Remarks. Records are good. 


\section{E2674 TA-36 Min ie Site}

Daily Mean Discharge in Cubic Feet per Second

Water Year October 2008 to September 2009

\begin{tabular}{|c|c|c|c|c|c|c|c|c|c|c|c|c|}
\hline DAY & OCT & NOV & DEC & JAN & FEB & MAR & APR & MAY & JUN & JUL & AUG & SEP \\
\hline 1 & 0 & 0 & 0 & $0^{*}$ & 0 & 0 & 0 & 0 & 0 & 0 & 0 & 0 \\
\hline 2 & 0 & 0 & 0 & $0^{*}$ & 0 & 0 & 0 & 0 & 0 & 0 & 0 & 0 \\
\hline 3 & 0 & 0 & 0 & $0^{*}$ & 0 & 0 & 0 & 0 & 0 & 0 & 0 & 0 \\
\hline 4 & 0 & 0 & 0 & $0^{*}$ & 0 & 0 & 0 & 0 & 0 & 0 & 0 & 0 \\
\hline 5 & 0 & 0 & 0 & $0^{*}$ & 0 & 0 & 0 & 0 & 0 & 0 & 0 & 0 \\
\hline 6 & 0 & 0 & 0 & $0^{*}$ & 0 & 0 & 0 & 0 & 0 & 0 & 0 & 0 \\
\hline 7 & 0 & 0 & 0 & $0^{*}$ & 0 & 0 & 0 & 0 & 0 & 0 & 0 & 0 \\
\hline 8 & 0 & 0 & 0 & 0 & 0 & 0 & 0 & 0 & 0 & 0 & 0 & 0 \\
\hline 9 & 0 & 0 & $0^{*}$ & 0 & 0 & 0 & 0 & 0 & 0 & 0 & 0 & 0 \\
\hline 10 & 0 & 0 & $0^{*}$ & 0 & 0 & 0 & 0 & 0 & 0 & 0 & 0 & 0 \\
\hline 11 & .01 & 0 & $0^{*}$ & 0 & 0 & 0 & 0 & 0 & 0 & 0 & 0 & 0 \\
\hline 12 & 0 & 0 & $0^{*}$ & 0 & 0 & 0 & 0 & 0 & 0 & 0 & 0 & 0 \\
\hline 13 & 0 & 0 & $0^{*}$ & 0 & 0 & 0 & 0 & 0 & 0 & 0 & 0 & 0 \\
\hline 14 & 0 & 0 & $0^{*}$ & 0 & 0 & 0 & 0 & 0 & 0 & 0 & 0 & 0 \\
\hline 15 & 0 & 0 & $0^{*}$ & 0 & 0 & 0 & 0 & 0 & 0 & 0 & 0 & 0 \\
\hline 16 & 0 & 0 & $0^{*}$ & 0 & 0 & 0 & 0 & 0 & 0 & 0 & 0 & .01 \\
\hline 17 & 0 & 0 & $0^{*}$ & 0 & 0 & 0 & .01 & 0 & 0 & 0 & 0 & 0 \\
\hline 18 & 0 & 0 & $0^{*}$ & 0 & 0 & 0 & 0 & 0 & 0 & 0 & 0 & 0 \\
\hline 19 & 0 & 0 & $0^{*}$ & 0 & 0 & 0 & 0 & 0 & 0 & 0 & 0 & 0 \\
\hline 20 & 0 & 0 & $0^{*}$ & 0 & 0 & 0 & 0 & 0 & 0 & 0 & 0 & 0 \\
\hline 21 & 0 & 0 & $0^{*}$ & 0 & 0 & 0 & 0 & 0 & 0 & 0 & 0 & 0 \\
\hline 22 & 0 & 0 & $0^{*}$ & 0 & 0 & 0 & 0 & 0 & 0 & 0 & 0 & 0 \\
\hline 23 & 0 & 0 & $0^{*}$ & 0 & 0 & 0 & 0 & 0 & 0 & 0 & 0 & 0 \\
\hline 24 & 0 & 0 & $0^{*}$ & 0 & 0 & 0 & 0 & 0 & 0 & 0 & 0 & 0 \\
\hline 25 & 0 & 0 & $0^{*}$ & 0 & 0 & 0 & 0 & 0 & 0 & 0 & 0 & 0 \\
\hline 26 & 0 & 0 & $0^{*}$ & 0 & 0 & $0^{*}$ & 0 & 0 & 0 & 0 & 0 & 0 \\
\hline 27 & 0 & 0 & $0^{*}$ & 0 & 0 & $0^{*}$ & 0 & 0 & 0 & 0 & 0 & 0 \\
\hline 28 & 0 & 0 & $0^{*}$ & 0 & 0 & 0 & 0 & 0 & 0 & 0 & 0 & 0 \\
\hline 29 & 0 & 0 & $0^{*}$ & 0 & $-\ldots$ & 0 & 0 & 0 & 0 & 0 & 0 & 0 \\
\hline 30 & 0 & 0 & $0^{*}$ & 0 & $-\cdots$ & 0 & 0 & 0 & 0 & 0 & 0 & 0 \\
\hline 31 & 0 & ---- & $0^{*}$ & 0 & --.-- & 0 & ----- & 0 & --- & 0 & 0 & ---- \\
\hline Total & 0.01 & 0 & 0 & 0 & 0 & 0 & 0.01 & 0 & 0 & 0 & 0 & 0.01 \\
\hline Mean & 0 & 0 & 0 & 0 & 0 & 0 & 0 & 0 & 0 & 0 & 0 & 0 \\
\hline Max & .01 & 0 & 0 & 0 & 0 & 0 & .01 & 0 & 0 & 0 & 0 & .01 \\
\hline Min & 0 & 0 & 0 & 0 & 0 & 0 & 0 & 0 & 0 & 0 & 0 & 0 \\
\hline Acre-Ft & .02 & 0 & 0 & 0 & 0 & 0 & .02 & 0 & 0 & 0 & 0 & .02 \\
\hline Wtr Year & 2009 & Total & 0.03 & Mean & & 0 & $\operatorname{Max}$ & .01 & Min & 0 & Acre-Ft & .06 \\
\hline Cal Year & 2008 & Total & 0.08 & Mean & & 0 & Max & .05 & Min & 0 & Acre-Ft & .16 \\
\hline
\end{tabular}




\section{E274 North Fork Ancho Canyon below SR 4}

Location. Lat $35^{\circ} 47^{\prime}$ 12", long $106^{\circ} 15^{\prime}$ 4.7", Sec. 13, T. 18 N., R. 6 E., Ramon Vigil Grant, Los Alamos County.

Drainage Area. $1.53 \mathrm{mi}^{2}$.

Period of Record. October 1, 2007, to September 30, 2009.

Gage. Data logger. Elevation of gage is 6,398 $\mathrm{ft}$ above NGVD from GPS survey.

Remarks. Records are good. Records for this site existed before period of record but are not reliable.

Extremes for Period of Record. Maximum discharge, $89 \mathrm{ft}^{3} / \mathrm{s}$, gage height $2.79 \mathrm{ft}$, August 4, 2008. No flow most of the time.

Extremes for Current Year. Maximum discharge, $0.53 \mathrm{ft}^{3} / \mathrm{s}$ at $1435 \mathrm{~h}$, July 30, gage height $0.70 \mathrm{ft}$. No peak discharge above base of $5 \mathrm{ft}^{3} / \mathrm{s}$.

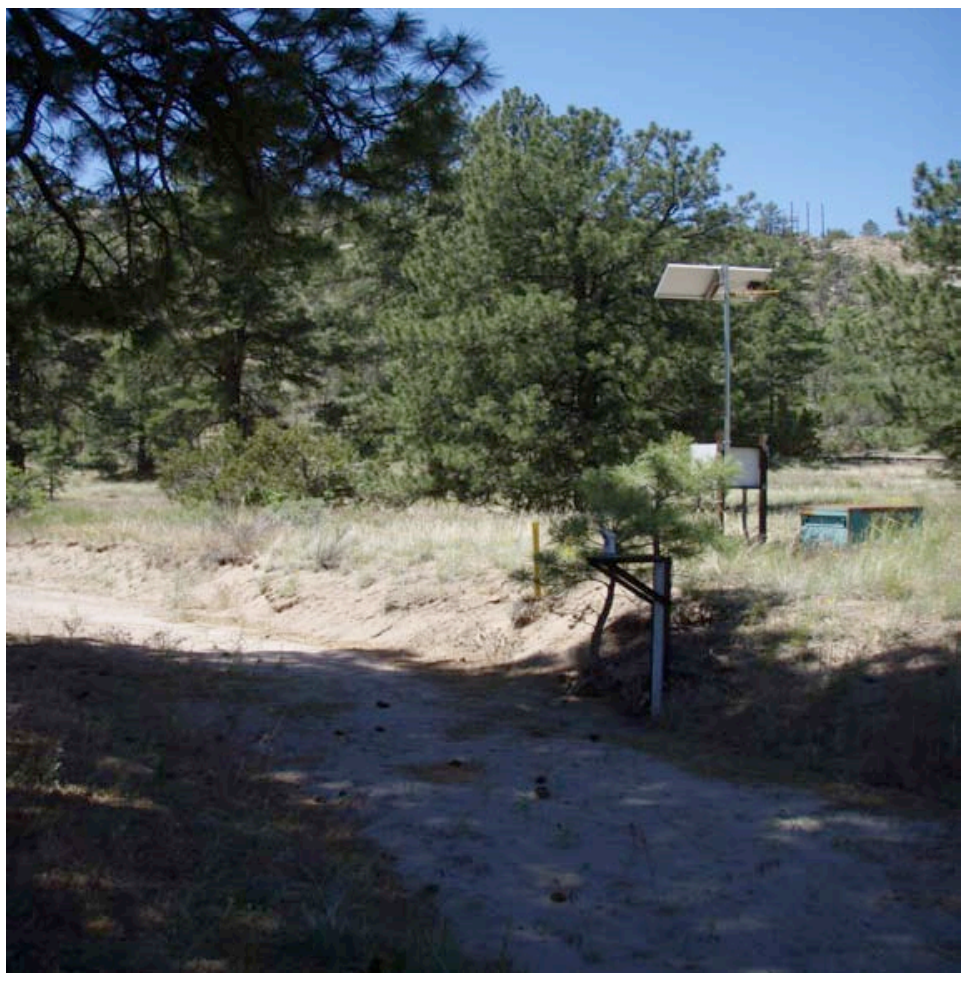




\title{
E274 North Fork Ancho Canyon below SR 4
}

\author{
Station Analysis
}

\section{Water Year}

Equipment. Station is equipped with Sutron 8210 data logger (5-min. interval) and Milltronics sonic probe. The system is powered by a solar panel battery system housed in a NEMA shelter. Station is equipped with an ISCO pump sampler for water quality sample collection. ISCO is housed in a separate shelter, a $3^{\prime} \times 4^{\prime}$ metal box. Sampler is triggered by stage through the data logger. Outside staff is available for reference. No provision for measurements above wading stage.

Field Work. The station was visited 16 times to conduct discharge measurements and service the instrumentation. Field inspections for the gage are listed under site history files on the Hydstra database. Discharge measurements for the gage are listed under site gauging files on the Hydstra database.

Datum Corrections. None.

Gage-Height Record. The data logger referenced to the outside gage gave a complete and satisfactory record for the year, except for the periods from November 29 when gage height became silted and January 9 to February 3 when gage height was affected by ice.

Rating. The channel is straight above and below the gage. Streambed is mostly sand.

Sixteen inspections of no flow were made this year.

Discharge. Discharge was computed by applying gage height to Rating No. 1 directly.

Remarks. Records are good. 
E274 N orth Fork Ancho Canyon below SR 4

Daily Mean Discharge in Cubic Feet per Second

Water Year October 2008 to September 2009

\begin{tabular}{|c|c|c|c|c|c|c|c|c|c|c|c|c|}
\hline DAY & OCT & NOV & DEC & JAN & FEB & MAR & APR & MAY & JUN & JUL & AUG & SEP \\
\hline 1 & 0 & 0 & 0 & $0^{*}$ & $0^{*}$ & 0 & 0 & 0 & 0 & 0 & 0 & 0 \\
\hline 2 & 0 & 0 & 0 & $0^{*}$ & $0^{*}$ & 0 & 0 & 0 & 0 & 0 & 0 & 0 \\
\hline 3 & 0 & 0 & 0 & $0^{*}$ & $0^{*}$ & 0 & 0 & 0 & 0 & 0 & 0 & 0 \\
\hline 4 & 0 & 0 & 0 & $0^{*}$ & 0 & 0 & 0 & 0 & 0 & 0 & 0 & 0 \\
\hline 5 & 0 & 0 & 0 & $0^{*}$ & 0 & 0 & 0 & 0 & 0 & 0 & 0 & 0 \\
\hline 6 & 0 & 0 & 0 & $0^{*}$ & 0 & 0 & 0 & 0 & 0 & 0 & 0 & 0 \\
\hline 7 & 0 & 0 & 0 & $0^{*}$ & 0 & 0 & 0 & 0 & 0 & 0 & 0 & 0 \\
\hline 8 & 0 & 0 & 0 & $0^{*}$ & 0 & 0 & 0 & 0 & 0 & 0 & 0 & 0 \\
\hline 9 & 0 & 0 & $0^{*}$ & $0^{*}$ & 0 & 0 & 0 & 0 & 0 & 0 & 0 & 0 \\
\hline 10 & 0 & 0 & $0^{*}$ & $0^{*}$ & 0 & 0 & 0 & 0 & 0 & 0 & 0 & 0 \\
\hline 11 & .01 & 0 & $0^{*}$ & $0^{*}$ & 0 & 0 & 0 & 0 & 0 & 0 & 0 & 0 \\
\hline 12 & 0 & 0 & $0^{*}$ & $0^{*}$ & 0 & 0 & 0 & 0 & 0 & 0 & 0 & 0 \\
\hline 13 & 0 & 0 & $0^{*}$ & $0^{*}$ & 0 & 0 & 0 & 0 & 0 & 0 & 0 & 0 \\
\hline 14 & 0 & 0 & $0^{*}$ & $0^{*}$ & 0 & 0 & 0 & 0 & 0 & 0 & 0 & 0 \\
\hline 15 & 0 & 0 & $0^{*}$ & $0^{*}$ & 0 & 0 & 0 & 0 & 0 & 0 & 0 & 0 \\
\hline 16 & 0 & 0 & $0^{*}$ & $0^{*}$ & 0 & 0 & 0 & 0 & 0 & 0 & 0 & 0 \\
\hline 17 & 0 & 0 & $0^{*}$ & $0^{*}$ & 0 & 0 & 0 & 0 & 0 & 0 & 0 & 0 \\
\hline 18 & 0 & 0 & $0^{*}$ & $0^{*}$ & 0 & 0 & 0 & 0 & 0 & 0 & 0 & 0 \\
\hline 19 & 0 & 0 & $0^{*}$ & $0^{*}$ & 0 & 0 & 0 & 0 & 0 & 0 & 0 & 0 \\
\hline 20 & 0 & 0 & $0^{*}$ & $0^{*}$ & 0 & 0 & 0 & 0 & 0 & 0 & 0 & 0 \\
\hline 21 & 0 & 0 & $0^{*}$ & $0^{*}$ & 0 & 0 & 0 & 0 & 0 & 0 & 0 & 0 \\
\hline 22 & 0 & 0 & $0^{*}$ & $0^{*}$ & 0 & 0 & 0 & 0 & 0 & 0 & 0 & 0 \\
\hline 23 & 0 & 0 & $0^{*}$ & $0^{*}$ & 0 & 0 & 0 & 0 & 0 & 0 & 0 & 0 \\
\hline 24 & 0 & 0 & $0^{*}$ & $0^{*}$ & 0 & 0 & 0 & 0 & 0 & 0 & 0 & 0 \\
\hline 25 & 0 & 0 & $0^{*}$ & $0^{*}$ & 0 & 0 & 0 & 0 & 0 & 0 & 0 & 0 \\
\hline 26 & 0 & 0 & $0^{*}$ & $0^{*}$ & 0 & 0 & 0 & 0 & 0 & 0 & 0 & 0 \\
\hline 27 & 0 & 0 & $0^{*}$ & $0^{*}$ & 0 & 0 & 0 & 0 & 0 & 0 & 0 & 0 \\
\hline 28 & 0 & .01 & $0^{*}$ & $0^{*}$ & 0 & 0 & 0 & 0 & 0 & 0 & 0 & 0 \\
\hline 29 & 0 & $0^{*}$ & $0^{*}$ & $0^{*}$ & --.-- & 0 & 0 & 0 & 0 & 0 & 0 & 0 \\
\hline 30 & 0 & 0 & $0^{*}$ & $0^{*}$ & --.-- & 0 & 0 & 0 & 0 & .01 & 0 & 0 \\
\hline 31 & 0 & ---- & $0^{*}$ & $0^{*}$ & ---- & 0 & ----- & 0 & $-\cdots$ & 0 & 0 & ---- \\
\hline Total & 0.01 & 0.01 & 0 & 0 & 0 & 0 & 0 & 0 & 0 & 0.01 & 0 & 0 \\
\hline Mean & 0 & 0 & 0 & 0 & 0 & 0 & 0 & 0 & 0 & 0 & 0 & 0 \\
\hline Max & .01 & .01 & 0 & 0 & 0 & 0 & 0 & 0 & 0 & .01 & 0 & 0 \\
\hline Min & 0 & 0 & 0 & 0 & 0 & 0 & 0 & 0 & 0 & 0 & 0 & 0 \\
\hline Acre-Ft & .02 & .02 & 0 & 0 & 0 & 0 & 0 & 0 & 0 & .02 & 0 & 0 \\
\hline Wtr Year & 2009 & Total & 0.03 & Mean & & 0 & Max & .01 & Min & 0 & Acre-Ft & .06 \\
\hline Cal Year & 2008 & Total & 1.36 & Mean & & 104 & $\operatorname{Max}$ & 1.3 & Min & 0 & Acre-Ft & 2.7 \\
\hline
\end{tabular}

*Estimate 


\section{E275 Ancho Canyon below SR 4}

Location. Lat $35^{\circ} 46^{\prime}$ 54", long $106^{\circ}$ 14' 42", Sec. 19, T. 18 N., R. 7 E., Ramon Vigil Grant, Los Alamos County.

Drainage Area. $4.75 \mathrm{mi}^{2}$.

Period of Record. December 1993 to September 30, 2009.

Revised Record. Drainage Area (2006)

Gage. Data logger with cellular telemetry and concrete stabilized natural control. Elevation of gage is 6,190 ft above NGVD from GPS survey.

Remarks. Records are good. Legal location based on projected values.

Average Discharge. $14 \mathrm{yr}, 0.015 \mathrm{ft}^{3} / \mathrm{s}, 10.87$ acre- $\mathrm{ft} / \mathrm{yr}$.

Extremes for Period of Record. Maximum discharge, $536 \mathrm{ft}^{3} / \mathrm{s}$, gage height $2.89 \mathrm{ft}$, August 4, 2008 (from flood marks). No flow most of the time.

Extremes for Current Year. Peak discharge above base of $15 \mathrm{ft}^{3} / \mathrm{s}$ and maximum (*):

\begin{tabular}{|c|c|c|c|}
\hline Date & Time & Discharge $\left(\mathbf{f t}^{\mathbf{3}} / \mathbf{s}\right)$ & Gage Height $(\mathbf{f t})$ \\
\hline October 11 & 1425 & 30 & 1.60 \\
\hline July 28 & 1335 & 144 & 1.92 \\
\hline July 30 & 1445 & $414^{*}$ & $2.48^{*}$ \\
\hline September 16 & 0125 & 16 & 1.51 \\
\hline
\end{tabular}

No flow most of the time.

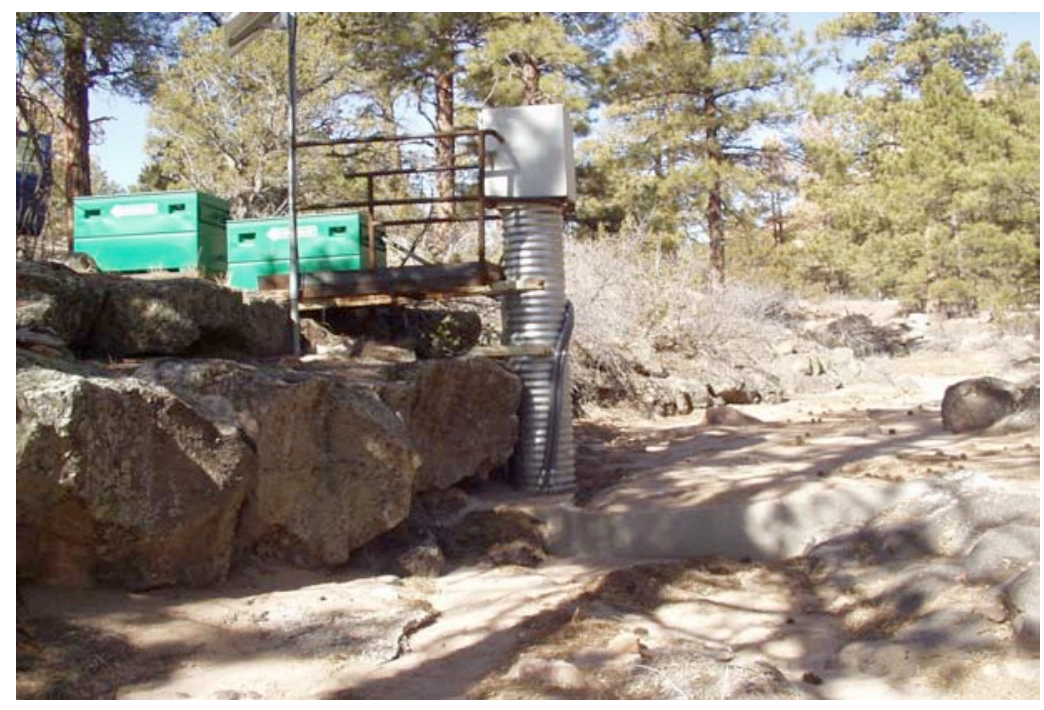




\title{
E275 Ancho Canyon below SR 4
}

\author{
Station Analysis
}

\section{Water Year}

Equipment. Station is equipped with Sutron 8210 data logger (5-min. interval) with shaft encoder float system (5-min. interval) and cellular telemetry with speech modem. The system is powered by a solar panel battery system housed in a NEMA shelter. Station is equipped with and ISCO pump sampler for water quality sample collection. ISCO is housed in a separate shelter, a $3^{\prime} \times 4^{\prime}$ metal box. Sampler is triggered by stage through the data logger. Outside staff is available for reference. No provision for measurements above wading stage.

Field Work. The station was visited 26 times to conduct discharge measurements and service the instrumentation. Field inspections for the gage are listed under site history files on the Hydstra database. Discharge measurements for the gage are listed under site gauging files on the Hydstra database.

Datum Corrections. None. Levels run August 27 show gage within acceptable limits.

Gage-Height Record. The data logger referenced to the outside gage gave a complete and satisfactory record for the year.

Rating. Streambed is a series of outcrops and sand pockets with moderate sand movement during flow events. High-water channel is straight for 200' upstream. Flow below gage goes into supercritical flow as fall increases radically below station. Onefourth mi upstream channel has very low banks and may spread out to large widths. It contracts markedly from there to the gage. The control is natural rock outcrop stabilized by concrete.

Twenty-five inspections of no flow and one observation of flow were made this year.

Rating No. 1 was developed from PZF and previous measurement and slope area. Rating No. 1 was extended from $1.85 \mathrm{ft}$ to $2.75 \mathrm{ft}$ from logarithmic plotting.

Discharge. Discharge computed by applying gage height to Rating No. 1 directly.

Remarks. Records are good. 
E275 Anch o Canyon below SR 4

Daily Mean Discharge in Cubic Feet per Second

Water Year October 2008 to September 2009

\begin{tabular}{|c|c|c|c|c|c|c|c|c|c|c|c|c|}
\hline DAY & OCT & NOV & DEC & JAN & FEB & MAR & APR & MAY & JUN & JUL & AUG & SEP \\
\hline 1 & 0 & 0 & 0 & 0 & 0 & 0 & 0 & 0 & 0 & 0 & 0 & 0 \\
\hline 2 & 0 & 0 & 0 & 0 & 0 & 0 & 0 & 0 & 0 & 0 & 0 & 0 \\
\hline 3 & 0 & 0 & 0 & 0 & 0 & 0 & 0 & 0 & 0 & 0 & 0 & 0 \\
\hline 4 & 0 & 0 & 0 & 0 & 0 & 0 & 0 & 0 & 0 & 0 & 0 & 0 \\
\hline 5 & 0 & 0 & 0 & 0 & 0 & 0 & 0 & 0 & 0 & 0 & 0 & 0 \\
\hline 6 & 0 & 0 & 0 & 0 & 0 & 0 & 0 & 0 & 0 & 0 & 0 & 0 \\
\hline 7 & 0 & 0 & 0 & 0 & 0 & 0 & 0 & 0 & 0 & 0 & 0 & 0 \\
\hline 8 & 0 & 0 & 0 & 0 & 0 & 0 & 0 & 0 & 0 & 0 & 0 & 0 \\
\hline 9 & 0 & 0 & 0 & 0 & 0 & 0 & 0 & 0 & 0 & 0 & 0 & 0 \\
\hline 10 & 0 & 0 & 0 & 0 & 0 & 0 & 0 & 0 & 0 & 0 & 0 & 0 \\
\hline 11 & 1.1 & 0 & 0 & 0 & 0 & 0 & 0 & 0 & 0 & 0 & 0 & 0 \\
\hline 12 & 0 & 0 & 0 & 0 & 0 & 0 & 0 & 0 & 0 & 0 & 0 & 0 \\
\hline 13 & 0 & 0 & 0 & 0 & 0 & 0 & 0 & 0 & 0 & 0 & 0 & 0 \\
\hline 14 & 0 & 0 & 0 & 0 & 0 & 0 & 0 & 0 & 0 & 0 & 0 & 0 \\
\hline 15 & 0 & 0 & 0 & 0 & 0 & 0 & 0 & 0 & 0 & 0 & 0 & 0 \\
\hline 16 & 0 & 0 & 0 & 0 & 0 & 0 & 0 & 0 & 0 & 0 & 0 & .22 \\
\hline 17 & 0 & 0 & 0 & 0 & 0 & 0 & 0 & 0 & 0 & 0 & 0 & 0 \\
\hline 18 & 0 & 0 & 0 & 0 & 0 & 0 & 0 & 0 & 0 & 0 & 0 & 0 \\
\hline 19 & 0 & 0 & 0 & 0 & 0 & 0 & 0 & 0 & 0 & 0 & 0 & 0 \\
\hline 20 & 0 & 0 & 0 & 0 & 0 & 0 & 0 & 0 & 0 & 0 & 0 & 0 \\
\hline 21 & 0 & 0 & 0 & 0 & 0 & 0 & 0 & 0 & 0 & 0 & 0 & 0 \\
\hline 22 & 0 & 0 & 0 & 0 & 0 & 0 & 0 & 0 & 0 & 0 & 0 & 0 \\
\hline 23 & 0 & 0 & 0 & 0 & 0 & 0 & 0 & 0 & 0 & 0 & 0 & 0 \\
\hline 24 & 0 & 0 & 0 & 0 & 0 & 0 & 0 & 0 & 0 & 0 & 0 & 0 \\
\hline 25 & 0 & 0 & 0 & 0 & 0 & 0 & 0 & 0 & 0 & 0 & 0 & 0 \\
\hline 26 & 0 & 0 & 0 & 0 & 0 & 0 & 0 & 0 & 0 & 0 & 0 & 0 \\
\hline 27 & 0 & 0 & 0 & 0 & 0 & 0 & 0 & 0 & 0 & 0 & 0 & 0 \\
\hline 28 & 0 & 0 & 0 & 0 & 0 & 0 & 0 & 0 & 0 & 1.8 & 0 & 0 \\
\hline 29 & 0 & 0 & 0 & 0 & ----- & 0 & 0 & 0 & 0 & .07 & 0 & 0 \\
\hline 30 & 0 & 0 & 0 & 0 & -..--. & 0 & 0 & 0 & 0 & 5.4 & 0 & 0 \\
\hline 31 & 0 & ---- & 0 & 0 & ---- & 0 & ----- & 0 & $-\cdots$ & 0 & 0 & ---- \\
\hline Total & 1.1 & 0 & 0 & 0 & 0 & 0 & 0 & 0 & 0 & 7.27 & 0 & 0.22 \\
\hline Mean & .035 & 0 & 0 & 0 & 0 & 0 & 0 & 0 & 0 & .23 & 0 & .007 \\
\hline Max & 1.1 & 0 & 0 & 0 & 0 & 0 & 0 & 0 & 0 & 5.4 & 0 & .22 \\
\hline Min & 0 & 0 & 0 & 0 & 0 & 0 & 0 & 0 & 0 & 0 & 0 & 0 \\
\hline Acre-Ft & 22 & 0 & 0 & 0 & 0 & 0 & 0 & 0 & 0 & 14 & 0 & .44 \\
\hline Wtr Year & 2009 & Total & 8.59 & Mean & & 24 & Max & 5.4 & Min & 0 & Acre-Ft & 17 \\
\hline Cal Year & 2008 & Total & 17.73 & Mean & & 48 & Max & 15 & Min & 0 & Acre-Ft & 35 \\
\hline
\end{tabular}




\section{E350 Rito de los Frijoles at Bandelier}

Location. Lat $35^{\circ}$ 46' 37", long 106 16' 09", Sec. 23, T. 18 N., R. 6 E., Ramon Vigil Grant, Sandoval County, in Bandelier National Monument.

Drainage Area. $18.35 \mathrm{mi}^{2}$.

Period of Record. July 1963 to September 1969; July 1977 to September 1982; May 1993 to September 1996; and October 1998 to September 30, 2009.

Revised Record. Drainage Area (2006)

Gage. Data logger and concrete control. Elevation of gage is 6,046 ft above NGVD from GPS survey.

Remarks. Records are good, except winter period, which are fair. Small diversion from left bank about $1.0 \mathrm{mi}$ upstream for irrigation of small orchard. The La Mesa fire, which occurred during mid June 1977 , burned about $40 \%$ of the forest covering this watershed. Legal location based on projected values.

Average Discharge. $11 \mathrm{yr}(1999-2009), 1.25 \mathrm{ft}^{3} / \mathrm{s}, 902 \mathrm{acre}-\mathrm{ft} / \mathrm{yr}$.

Extremes for Period of Record. Maximum discharge, 3,030 ft 3 /s, July 21, 1978, gage height $6.34 \mathrm{ft}$ site and datum then in use. Minimum daily discharge, $0 \mathrm{ft}^{3} / \mathrm{s}$, July $16-19$ and 26, 2003.

Extremes for Current Year. Maximum discharge $5.0 \mathrm{ft}^{3} / \mathrm{s}$ at $1430 \mathrm{~h}$, July 30 gage height of $2.04 \mathrm{ft}$. No peak discharge above base of $20 \mathrm{ft}^{3} / \mathrm{s}$. Minimum daily discharge, $0.24 \mathrm{ft}^{3} / \mathrm{s}$ August 11 .

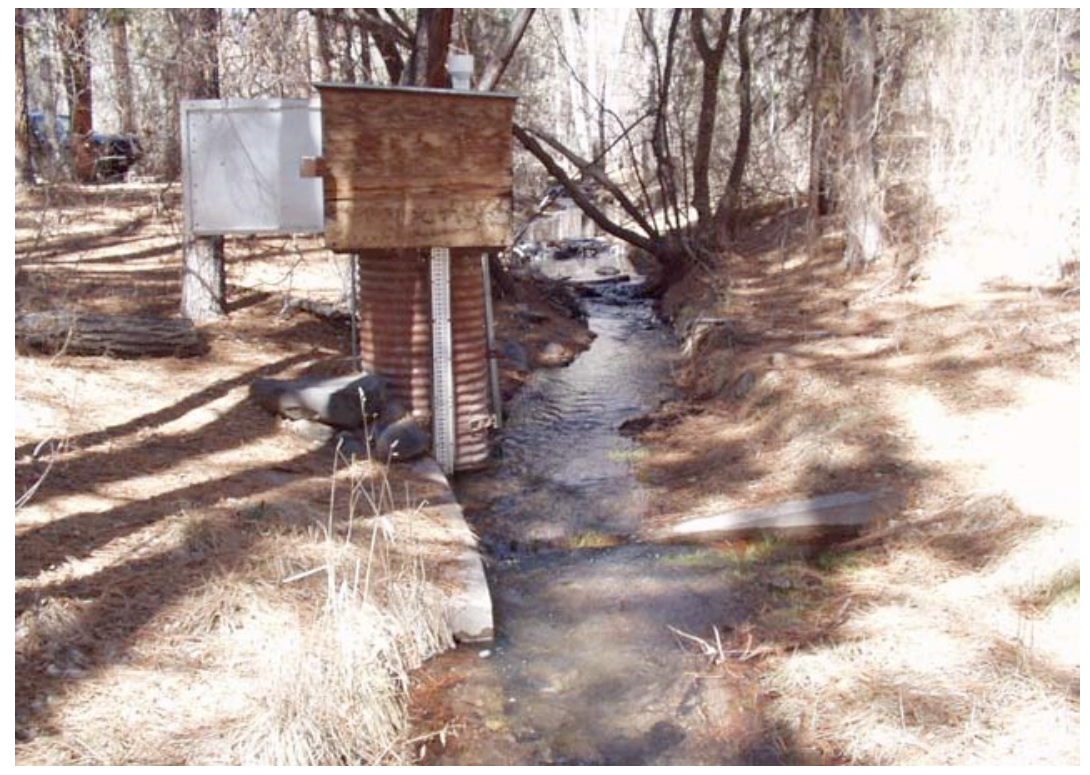




\title{
E350 Rito de los Frijoles at Bandelier
}

\author{
Station Analysis
}

2009 Water Year

Equipment. Station is equipped with Sutron 8210 data logger (5-min. interval) with shaft encoder float system (5-min. interval) housed in a $4^{\prime} \times 4^{\prime}$ metal shelter over a $24^{\prime \prime}$ CMP stilling well on right bank. An outside staff is available for reference. Wading measurement are made $30^{\prime}-40^{\prime}$ upstream from gage. High-flow measurement can be made up from bridge upstream from gage $200^{\prime}$ above gage.

Field Work. The station was visited 27 times to conduct discharge measurements and service the instrumentation. Field inspections for the gage are listed under site history files on the Hydstra database. Discharge measurements for the gage are listed under site gauging files on the Hydstra database.

Datum Correction. None from levels.

Gage-Height Record. The data logger referenced to the outside staff gave a complete and satisfactory record for the year.

Rating. The channel is about $10^{\prime}$ wide and straight for about $150^{\prime}$ upstream and downstream of gage. Low-water control is a concrete-tapered notch with low point on right bank. The channel bed through this reach is composed of gravel and cobbles and should be stable. Vegetation is grasses and fairly sparse.

Thirteen discharge measurements (Nos. 198-210) and 14 inspections of observed flow.

Rating No. 5 was developed based on the measurements and the slope conveyance measurement. The shifts were distributed based on time. Rating No. 5 is considered good.

Discharge. Discharge was computed by applying gage height to Rating No. 5 through a shift based on time.

Remarks. Records are good, except for estimated daily discharges, which are fair. 


\section{E350 R ito De los Frijoles at $B$ andelier}

Daily Mean Discharge in Cubic Feet per Second

Water Year October 2008 to September2009

\begin{tabular}{|c|c|c|c|c|c|c|c|c|c|c|c|c|}
\hline DAY & ОСТ & NOV & DEC & JAN & FEB & MAR & APR & MAY & JUN & JUL & AUG & SEP \\
\hline 1 & .76 & .98 & .65 & .91 & .99 & 1.0 & 1.2 & 1.3 & .62 & .37 & .49 & .43 \\
\hline 2 & .76 & 1.0 & .66 & .88 & .95 & 1.0 & 1.2 & 1.3 & .67 & .32 & .48 & .38 \\
\hline 3 & .76 & .98 & .63 & .87 & .96 & 1.1 & 1.2 & 1.3 & .78 & .45 & .53 & .41 \\
\hline 4 & .76 & .97 & .63 & .89 & .98 & 1.1 & 1.1 & 1.2 & .69 & .44 & .50 & .47 \\
\hline 5 & .76 & .92 & .62 & .90 & .96 & 1.2 & 1.1 & 1.1 & .61 & .83 & .42 & .42 \\
\hline 6 & .76 & .81 & .64 & 1.6 & .96 & 1.1 & 1.1 & 1.0 & .57 & .67 & .42 & .51 \\
\hline 7 & .76 & .81 & .66 & 1.7 & .96 & 1.1 & 1.1 & .99 & .53 & .55 & .40 & .53 \\
\hline 8 & .76 & .81 & .67 & 1.7 & 1.0 & 1.1 & 1.0 & .92 & .50 & .41 & .34 & .60 \\
\hline 9 & .77 & .81 & .69 & 1.6 & .99 & 1.2 & 1.0 & .90 & .48 & .36 & .32 & .51 \\
\hline 10 & .72 & .81 & .65 & 1.6 & .97 & 1.2 & .99 & .87 & 1.0 & .36 & .28 & .42 \\
\hline 11 & 1.3 & .81 & .66 & 1.6 & .85 & 1.1 & 1.4 & .84 & .71 & .34 & .24 & .41 \\
\hline 12 & 1.3 & .81 & .69 & 1.5 & .96 & 1.1 & 1.3 & .79 & .56 & .30 & .26 & .40 \\
\hline 13 & .97 & .75 & .75 & 1.4 & .91 & 1.3 & 1.3 & .75 & .51 & .27 & .32 & .51 \\
\hline 14 & 1.1 & .68 & .71 & 1.0 & .85 & 1.2 & 1.2 & .73 & .55 & .28 & .74 & .80 \\
\hline 15 & 1.1 & .70 & .43 & .99 & .76 & 1.2 & 1.2 & .70 & .54 & .28 & .57 & .73 \\
\hline 16 & .99 & .72 & .28 & .98 & 1.0 & 1.1 & 1.2 & .71 & .46 & .29 & .42 & .96 \\
\hline 17 & .97 & .72 & 1.1 & .98 & .86 & 1.1 & 1.3 & .72 & .45 & .28 & .35 & .73 \\
\hline 18 & .98 & .72 & .95 & .98 & .96 & 1.1 & 1.4 & .68 & .43 & .26 & 31 & .60 \\
\hline 19 & .98 & .71 & .82 & .80 & .54 & 1.1 & 1.4 & .64 & .40 & .27 & .28 & .50 \\
\hline 20 & .95 & .71 & .68 & .77 & .79 & 1.1 & 1.3 & .61 & .73 & .34 & .27 & .49 \\
\hline 21 & .94 & .69 & .74 & .83 & .80 & 1.1 & 1.4 & .70 & .63 & .33 & .27 & .40 \\
\hline 22 & .89 & .64 & .75 & .89 & .82 & 1.1 & 1.4 & .84 & .47 & .46 & .25 & .38 \\
\hline 23 & .92 & .69 & .86 & .95 & .86 & 1.2 & 1.5 & 1.2 & .41 & .41 & .25 & .39 \\
\hline 24 & .99 & .62 & .57 & .94 & .88 & 1.3 & 1.5 & 1.0 & .40 & .54 & .50 & .51 \\
\hline 25 & .95 & .63 & 1.0 & .96 & .98 & 1.3 & 1.5 & .91 & .40 & .40 & .56 & .44 \\
\hline 26 & .92 & .63 & .98 & .92 & 1.1 & 1.3 & 1.5 & .86 & .48 & .58 & .48 & .38 \\
\hline 27 & .89 & .80 & .37 & .85 & 1.0 & 1.4 & 1.4 & .93 & .42 & .53 & .40 & .36 \\
\hline 28 & .91 & .79 & .36 & .54 & 1.0 & 1.3 & 1.4 & .85 & .49 & .45 & .36 & .33 \\
\hline 29 & .91 & .71 & .58 & .73 & $-\cdots$ & 1.3 & 1.3 & .74 & .48 & .46 & .33 & .33 \\
\hline 30 & .91 & .67 & .87 & .79 & $-\cdots$ & 1.2 & 1.3 & .67 & .39 & .84 & .39 & .32 \\
\hline 31 & .95 & 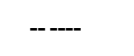 & 1.0 & 1.0 & --.-- & 1.2 & --- & .66 & ---- & .60 & .52 & --- \\
\hline Total & 28.39 & 23.10 & 21.65 & 33.05 & 25.64 & 36.2 & 38.19 & 27.41 & 16.36 & 13.27 & 12.25 & 14.65 \\
\hline Mean & .92 & .77 & .70 & 1.07 & .92 & 1.17 & 1.27 & .88 & .55 & .43 & .40 & .49 \\
\hline Max & 1.3 & 1.0 & 1.1 & 1.7 & 1.1 & 1.4 & 1.5 & 1.3 & 1.0 & .84 & .74 & .96 \\
\hline M in & .72 & .62 & .28 & .54 & .54 & 1.0 & .99 & .61 & .39 & .26 & .24 & .32 \\
\hline Acre-Ft & 56 & 46 & 43 & 66 & 51 & 72 & 76 & 54 & 32 & 26 & 24 & 29 \\
\hline Wtr Year & 2009 & Total & 290.16 & Mear & & .79 & $\operatorname{Max}$ & 1.7 & Min & .24 & Acre-Ft & 576 \\
\hline Cal Year & 2008 & Total & 968.96 & Mear & & 65 & $\operatorname{Max}$ & 57 & Min & .28 & Acre-Ft & 1920 \\
\hline
\end{tabular}




\section{S001 SWSC Line Spring at TA-16}

Location. Lat $35^{\circ} 51^{\prime} 1^{\prime \prime}$, long $106^{\circ} 20^{\prime} 23^{\prime \prime}, 30 \mathrm{ft}$ upstream from the SWSC line crossing of Cañon de Valle in LANL TA-16.

Gage. Data logger with $90^{\circ}$ weir. Elevation of gage is $7,437 \mathrm{ft}$ above NGVD from survey.

Period of Record. October 1, 1996, to September 30, 2009.

Remarks. Water discharge records are good. This spring is in the Cañon de Valle drainage.

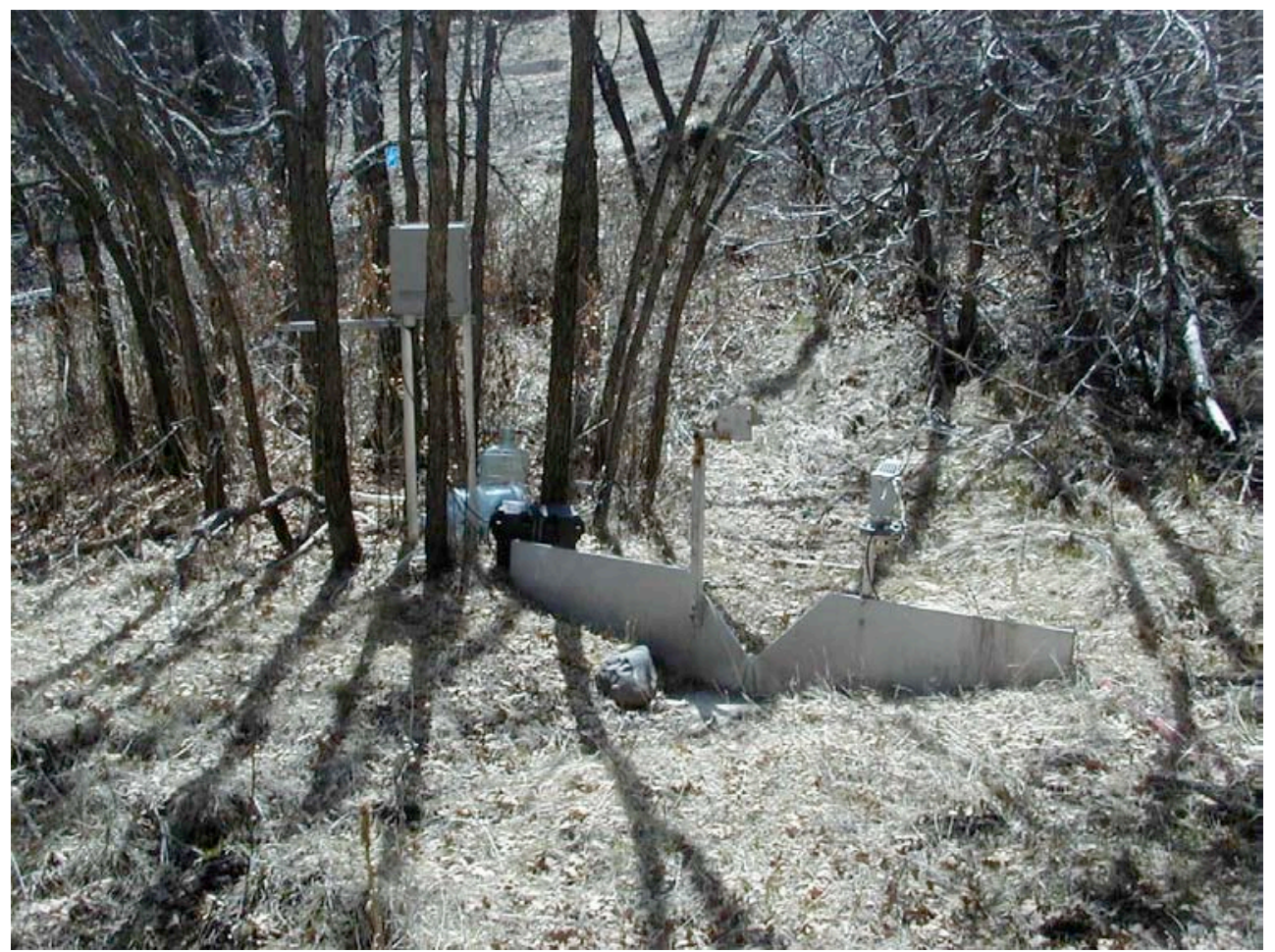


S001 SW SC Line Spring at TA-16

Daily Mean Discharge in Cubic Feet per Second

Water Year October 2008 to September 2009

\begin{tabular}{|c|c|c|c|c|c|c|c|c|c|c|c|c|}
\hline DAY & OCT & NOV & DEC & JAN & FE B & MAR & APR & MAY & JUN & JUL & AUG & SEP \\
\hline 1 & .001 & .001 & .008 & $.001^{*}$ & .003 & .002 & .003 & .003 & .004 & .003 & .003 & .002 \\
\hline 2 & .001 & .001 & .008 & $.001^{*}$ & .003 & .002 & .003 & .003 & .004 & .003 & .003 & .002 \\
\hline 3 & .001 & .001 & .006 & $.001^{*}$ & .003 & .002 & .003 & .004 & .004 & .003 & .003 & .002 \\
\hline 4 & .001 & .001 & .007 & $.001^{*}$ & .003 & .002 & .003 & .004 & .004 & .003 & .003 & .002 \\
\hline 5 & .001 & .001 & .009 & $.001^{*}$ & .003 & .002 & .003 & .004 & .004 & .020 & .003 & .002 \\
\hline 6 & .001 & .002 & .010 & $.001^{*}$ & .003 & .002 & .003 & .004 & .003 & .003 & .003 & .002 \\
\hline 7 & .001 & .006 & .010 & $.001^{*}$ & .002 & .002 & .003 & .004 & .003 & .003 & .003 & .002 \\
\hline 8 & .001 & .004 & .006 & .001 & .002 & .002 & .003 & .004 & .003 & .003 & .003 & .002 \\
\hline 9 & .002 & .001 & 0 & .001 & .002 & .002 & .003 & .004 & .003 & .003 & .003 & .002 \\
\hline 10 & .001 & .001 & $0^{*}$ & .001 & .002 & .002 & .003 & .004 & .004 & .003 & .002 & .002 \\
\hline 11 & .002 & .001 & $0^{*}$ & .001 & .002 & .002 & .004 & .004 & .004 & .003 & .003 & .002 \\
\hline 12 & .002 & .001 & $0^{*}$ & .002 & .002 & .002 & .004 & .004 & .003 & .003 & .003 & .002 \\
\hline 13 & .002 & .001 & $0^{*}$ & .003 & .002 & .002 & .003 & .004 & .004 & .003 & .002 & .002 \\
\hline 14 & .002 & .001 & $0^{*}$ & .007 & .002 & .002 & .003 & .004 & .004 & .003 & .002 & .002 \\
\hline 15 & .002 & .001 & $0^{*}$ & .010 & .002 & .002 & .003 & .004 & .003 & .003 & .002 & .002 \\
\hline 16 & .002 & .001 & $0^{*}$ & .011 & .002 & .002 & .003 & .004 & .003 & .003 & .002 & .002 \\
\hline 17 & .002 & .001 & $0^{*}$ & .012 & .001 & .002 & .004 & .004 & .003 & .003 & .002 & .002 \\
\hline 18 & .002 & .001 & $0^{*}$ & .012 & .001 & .002 & .004 & .004 & .003 & .003 & .002 & .003 \\
\hline 19 & .002 & .001 & $0^{*}$ & .012 & .001 & .002 & .004 & .004 & .003 & .003 & .002 & .003 \\
\hline 20 & .002 & .001 & $0^{*}$ & .012 & .002 & .003 & .004 & .005 & .004 & .003 & .002 & .003 \\
\hline 21 & .002 & .002 & $0^{*}$ & .011 & .002 & .003 & .006 & .005 & .003 & .003 & .002 & .003 \\
\hline 22 & .002 & .005 & $0^{*}$ & .010 & .002 & .003 & .004 & .005 & .003 & .003 & .002 & .003 \\
\hline 23 & .002 & .006 & $0^{*}$ & .008 & .001 & .002 & .004 & .005 & .003 & .003 & .002 & .003 \\
\hline 24 & .002 & .006 & $0^{*}$ & .009 & .001 & .002 & .003 & .005 & .003 & .002 & .002 & .004 \\
\hline 25 & .002 & .006 & $0^{*}$ & .009 & .001 & .002 & .003 & .004 & .003 & .003 & .002 & .003 \\
\hline 26 & .002 & .006 & $0^{*}$ & .006 & .002 & .003 & .003 & .004 & .003 & .003 & .002 & .003 \\
\hline 27 & .002 & .005 & $0^{*}$ & .003 & .002 & .002 & .004 & .005 & .003 & .002 & .002 & .003 \\
\hline 28 & .002 & .004 & $0^{*}$ & .003 & .002 & .002 & .004 & .005 & .003 & .003 & .001 & .003 \\
\hline 29 & .002 & .005 & $0^{*}$ & .003 & ----- & .003 & .004 & .005 & .003 & .003 & .001 & .003 \\
\hline 30 & .001 & .007 & $0^{*}$ & .003 & ----- & .003 & .004 & .005 & .003 & .003 & .001 & .003 \\
\hline 31 & .001 & ----- & $0^{*}$ & .003 & ----- & .003 & ----- & .005 & ----- & .003 & .002 & ----- \\
\hline Total & 0.051 & 0.081 & 0.064 & 0.160 & 0.056 & 0.069 & 0.105 & 0.132 & 0.100 & 0.108 & 0.070 & 0.074 \\
\hline Mean & .002 & .003 & .002 & .005 & .002 & .002 & .004 & .004 & .003 & .003 & .002 & .002 \\
\hline Max & .002 & .007 & .010 & .012 & .003 & .003 & .006 & .005 & .004 & .020 & .003 & .004 \\
\hline Min & .001 & .001 & 0 & .001 & .001 & .002 & .003 & .003 & .003 & .002 & .001 & .002 \\
\hline Acre-Ft & .101 & .161 & .127 & .317 & .111 & .137 & .208 & .262 & .198 & .214 & .139 & .147 \\
\hline Wtr Year & 2009 & Total & 1.070 & $\mathrm{Me}$ & & .003 & $\operatorname{Max}$ & .020 & Min & 0 & Acre-Ft & 2.12 \\
\hline Cal Year & 2008 & Total & 1.789 & & & .005 & $\operatorname{Max}$ & .276 & Min & 0 & Acre-Ft & 3.55 \\
\hline
\end{tabular}




\section{S002 Burn Ground Spring at TA-16}

Location. Lat $35^{\circ} 50^{\prime} 58^{\prime \prime}$, long $106^{\circ} 20^{\prime} 17^{\prime \prime}, 450 \mathrm{ft}$ downstream from the SWSC line crossing of Cañon de Valle in LANL TA-16.

Gage. Data logger with $90^{\circ}$ weir. Elevation of gage is $7,420 \mathrm{ft}$ above NGVD from survey.

Period of Record. October 1, 1996, to September 30, 2009.

Remarks. Water discharge records fair. This spring is in the Cañon de Valle drainage.

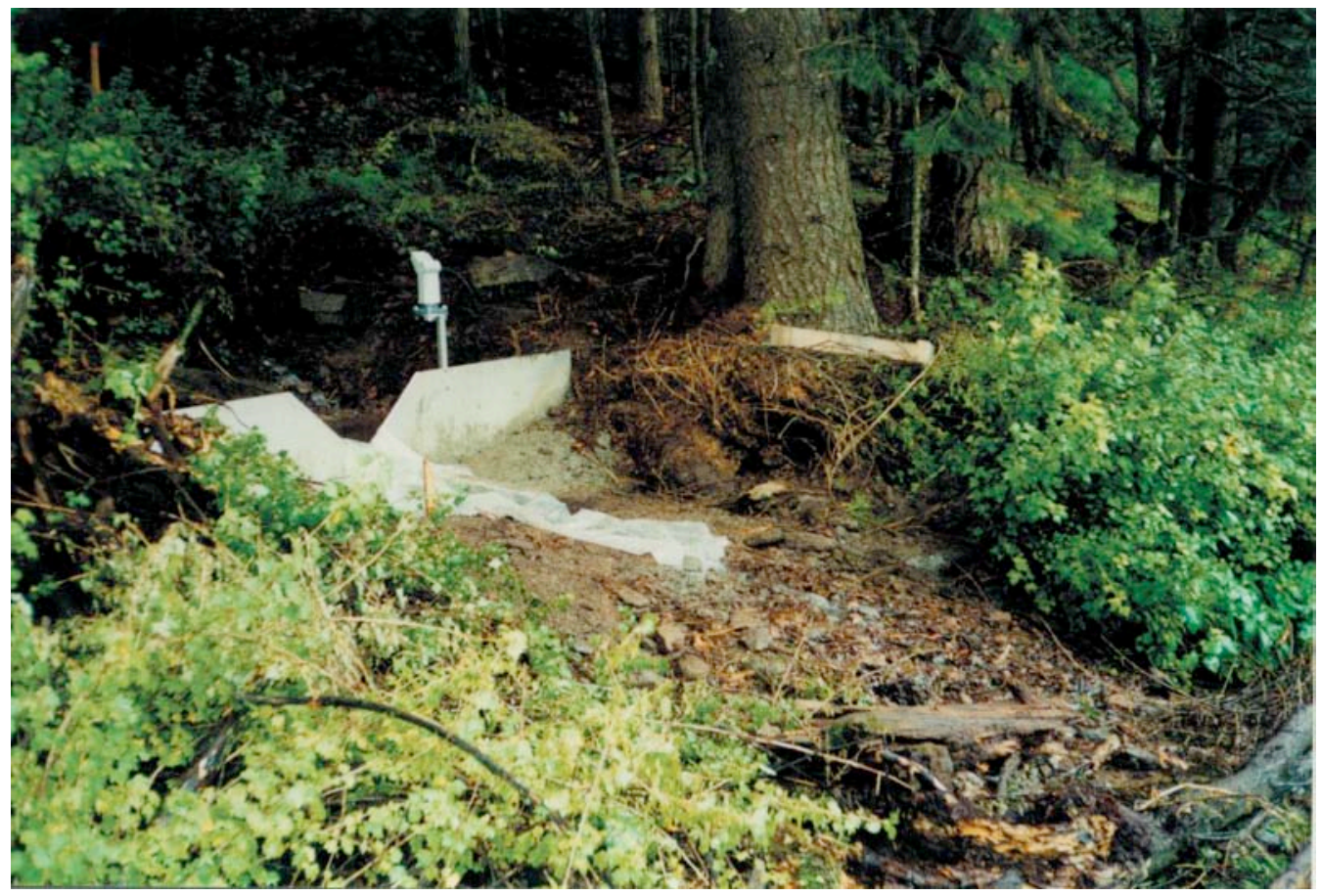




\section{S002 Burn Ground Spring at TA-16}

Daily Mean Discharge in Cubic Feet per Second

Water Year October 2008 to September 2009

\begin{tabular}{|c|c|c|c|c|c|c|c|c|c|c|c|c|}
\hline DAY & OCT & NOV & DEC & JAN & FEB & MAR & APR & MAY & JUN & JUL & AUG & SEP \\
\hline 1 & .004 & .007 & .006 & $.002^{*}$ & .005 & .005 & .013 & .006 & $.005^{\star}$ & $.005^{*}$ & .005 & $.005^{*}$ \\
\hline 2 & .004 & .007 & .006 & $.002^{*}$ & .005 & .004 & .009 & .006 & $.005^{*}$ & $.005^{\star}$ & .005 & $.005^{*}$ \\
\hline 3 & .005 & .006 & .006 & $.002^{\star}$ & .005 & .004 & .007 & .006 & $.005^{*}$ & $.005^{\star}$ & .005 & $.005^{*}$ \\
\hline 4 & .006 & .006 & .006 & $.002^{*}$ & .005 & .005 & .010 & .005 & $.005^{*}$ & $.005^{\star}$ & .005 & $.005^{*}$ \\
\hline 5 & .011 & .006 & .006 & $.002^{\star}$ & .005 & .005 & .009 & .006 & $.005^{*}$ & $.005^{\star}$ & .005 & .004 \\
\hline 6 & .010 & .005 & .006 & $.002^{*}$ & .005 & .005 & .008 & .006 & $.005^{*}$ & $.005^{\star}$ & $.005^{\star}$ & .004 \\
\hline 7 & .008 & .005 & .006 & $.002^{*}$ & .005 & .006 & .009 & .006 & $.005^{*}$ & $.005^{\star}$ & $.005^{\star}$ & .005 \\
\hline 8 & .005 & .005 & .006 & .004 & .005 & .007 & .013 & .006 & $.005^{*}$ & $.005^{\star}$ & $.005^{*}$ & .005 \\
\hline 9 & .005 & .005 & .005 & .005 & .005 & .009 & .010 & .005 & $.005^{*}$ & $.005^{\star}$ & $.005^{*}$ & .005 \\
\hline 10 & .005 & .005 & .006 & .004 & .005 & .006 & .007 & .006 & $.005^{*}$ & $.005^{\star}$ & $.005^{\star}$ & .005 \\
\hline 11 & .007 & .005 & .006 & .004 & .004 & .007 & .010 & .006 & $.005^{*}$ & $.005^{\star}$ & $.005^{*}$ & .005 \\
\hline 12 & .009 & .005 & .007 & .004 & .005 & .007 & .013 & .006 & $.005^{*}$ & $.005^{*}$ & $.005^{*}$ & .005 \\
\hline 13 & .009 & .005 & .008 & .004 & .004 & .007 & .008 & .006 & $.005^{*}$ & $.005^{\star}$ & $.005^{*}$ & .005 \\
\hline 14 & .009 & .005 & $.002^{*}$ & .005 & .005 & .007 & .012 & .006 & $.005^{*}$ & .005 & $.005^{\star}$ & .005 \\
\hline 15 & .009 & .005 & $.002^{*}$ & .004 & .004 & .007 & .010 & .006 & $.005^{*}$ & .005 & $.005^{*}$ & .005 \\
\hline 16 & .009 & .005 & $.002^{*}$ & .004 & .004 & .007 & .006 & .006 & $.005^{*}$ & .005 & $.005^{\star}$ & .005 \\
\hline 17 & .009 & .005 & $.002^{*}$ & .004 & .005 & .007 & .005 & .006 & $.005^{*}$ & .005 & $.005^{*}$ & .005 \\
\hline 18 & .009 & .005 & $.002^{*}$ & .004 & .004 & .008 & .005 & .006 & $.005^{*}$ & .005 & $.005^{*}$ & .005 \\
\hline 19 & .009 & .005 & $.002^{*}$ & .004 & .004 & .009 & .005 & .006 & $.005^{*}$ & .005 & $.005^{\star}$ & .005 \\
\hline 20 & .007 & .006 & $.002^{*}$ & .004 & .004 & .009 & .005 & .006 & $.005^{*}$ & .005 & $.005^{\star}$ & .005 \\
\hline 21 & .006 & .005 & $.002^{*}$ & .004 & .004 & .010 & .005 & .007 & $.005^{*}$ & .005 & $.005^{*}$ & .005 \\
\hline 22 & .005 & .006 & $.002^{*}$ & .004 & .004 & .010 & .005 & .007 & $.005^{*}$ & .005 & $.005^{*}$ & .005 \\
\hline 23 & .005 & .005 & $.002^{*}$ & .004 & .004 & .012 & .005 & .007 & $.005^{*}$ & .005 & $.005^{*}$ & .005 \\
\hline 24 & .005 & .006 & $.002^{*}$ & .005 & .004 & .007 & .005 & .007 & $.005^{*}$ & .004 & $.005^{\star}$ & .005 \\
\hline 25 & .005 & .005 & $.002^{*}$ & .005 & .004 & .004 & .005 & .007 & $.005^{*}$ & .005 & $.005^{*}$ & .005 \\
\hline 26 & .005 & .005 & $.002^{*}$ & .005 & .004 & .005 & .005 & .007 & $.005^{*}$ & .005 & $.005^{\star}$ & .005 \\
\hline 27 & .005 & .006 & $.002^{*}$ & .005 & .004 & .005 & .006 & .007 & $.005^{*}$ & .004 & $.005^{\star}$ & .005 \\
\hline 28 & .005 & .005 & $.002^{*}$ & .005 & .004 & .007 & .007 & .007 & $.005^{*}$ & .005 & $.005^{\star}$ & .005 \\
\hline 29 & .005 & .005 & $.002^{*}$ & .005 & --.-- & .006 & .005 & .006 & $.005^{*}$ & .005 & $.005^{*}$ & .005 \\
\hline 30 & .006 & .005 & $.002^{*}$ & .005 & ----- & .009 & .006 & .007 & $.005^{*}$ & .005 & $.005^{*}$ & .005 \\
\hline 31 & .007 & --- & $.002^{*}$ & .005 & ---- & .012 & ----- & .006 & $-\cdots$ & .005 & $.005^{*}$ & ---- \\
\hline Total & 0.208 & 0.161 & 0.116 & 0.120 & 0.125 & 0.218 & 0.228 & 0.193 & 0.150 & 0.153 & 0.155 & 0.148 \\
\hline Mean & .007 & .005 & .004 & .004 & .004 & .007 & .008 & .006 & .005 & .005 & .005 & .005 \\
\hline Max & .011 & .007 & .008 & .005 & .005 & .012 & .013 & .007 & .005 & .005 & .005 & .005 \\
\hline Min & .004 & .005 & .002 & .002 & .004 & .004 & .005 & .005 & .005 & .004 & .005 & .004 \\
\hline Acre-Ft & .413 & .319 & .230 & .238 & .248 & .432 & .452 & .383 & .298 & .303 & .307 & .294 \\
\hline Wtr Year & 2009 & Total & 1.975 & Mean & & 005 & $\operatorname{Max}$ & .013 & Min & .002 & Acre- Ft & 3.92 \\
\hline Cal Year & 2008 & Total & 3.182 & Mean & & 009 & $\operatorname{Max}$ & .027 & Min & .002 & Acre- $\mathrm{Ft}$ & 6.31 \\
\hline
\end{tabular}




\section{S003 Martin Spring at TA-16}

Location. Lat $35^{\circ} 50^{\prime} 32^{\prime \prime}$, long $106^{\circ} 20^{\prime} 11^{\prime \prime}, 0.25 \mathrm{mi}$ south of Building 344 in LANL TA16.

Gage. Data logger with $90^{\circ}$ weir. Elevation of gage is $7,429 \mathrm{ft}$ above NGVD from survey.

Period of Record. October 1, 1996, to September 30, 2009.

Remarks. Water discharge records good. This spring is in the Water Canyon drainage.

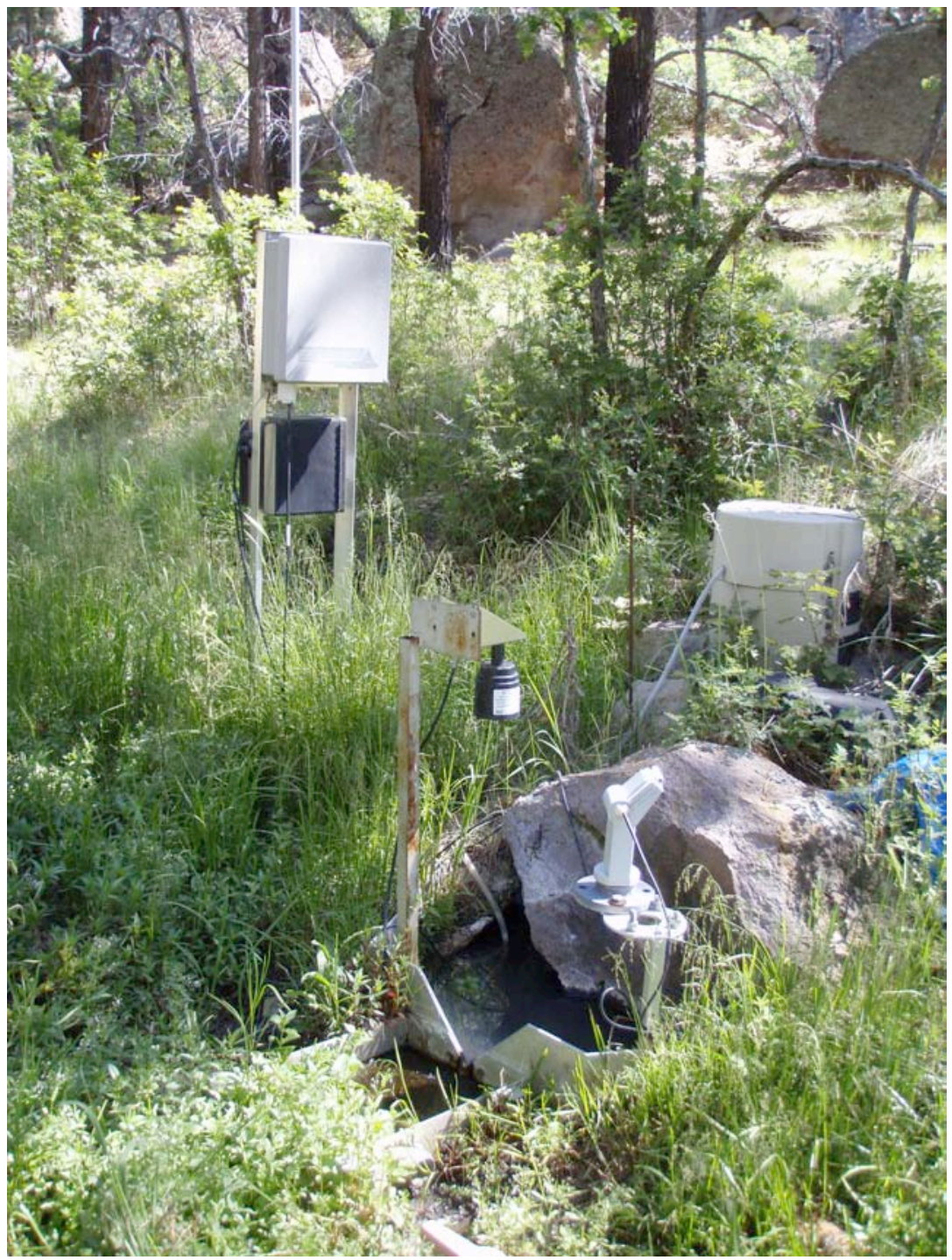


S003 Martin Spring at T A-16

Daily Mean Discharge in Cubic Feet per Second

Water Year October 2008 to September 2009

\begin{tabular}{|c|c|c|c|c|c|c|c|c|c|c|c|c|}
\hline DAY & OCT & NOV & DEC & JAN & FE B & MAR & APR & MAY & JUN & JUL & AUG & SEP \\
\hline 1 & .010 & 0 & 0 & 0 & 0 & .001 & .001 & .002 & .001 & .001 & .001 & .001 \\
\hline 2 & .011 & 0 & 0 & 0 & 0 & .001 & .001 & .002 & .001 & .001 & .001 & .001 \\
\hline 3 & .010 & 0 & 0 & 0 & 0 & .001 & .001 & .002 & .001 & .001 & .001 & .001 \\
\hline 4 & .012 & 0 & 0 & 0 & 0 & .001 & .001 & .002 & .001 & .001 & .001 & .001 \\
\hline 5 & .015 & 0 & 0 & 0 & 0 & .001 & .001 & .001 & .001 & .001 & .001 & .001 \\
\hline 6 & .006 & 0 & 0 & 0 & 0 & .001 & .001 & .001 & .001 & .001 & .001 & .001 \\
\hline 7 & .003 & 0 & 0 & 0 & 0 & .001 & .001 & .001 & .001 & .001 & .001 & .001 \\
\hline 8 & .002 & 0 & 0 & 0 & 0 & .001 & .001 & .002 & .001 & .001 & .001 & .001 \\
\hline 9 & .002 & 0 & 0 & 0 & 0 & .001 & .001 & .001 & .001 & .001 & .001 & .001 \\
\hline 10 & .002 & 0 & 0 & 0 & 0 & .001 & .001 & .001 & .001 & .001 & .001 & .001 \\
\hline 11 & .003 & 0 & 0 & 0 & 0 & .001 & .001 & .001 & .001 & .001 & .001 & .001 \\
\hline 12 & .002 & 0 & 0 & 0 & 0 & .001 & .001 & .001 & .001 & .001 & .001 & .001 \\
\hline 13 & .002 & 0 & 0 & 0 & 0 & .001 & .001 & .001 & .001 & .001 & .001 & .001 \\
\hline 14 & .002 & 0 & 0 & 0 & 0 & .001 & .001 & .001 & .001 & .001 & .001 & .001 \\
\hline 15 & .002 & 0 & 0 & 0 & 0 & .001 & .002 & .001 & .001 & .001 & .001 & .001 \\
\hline 16 & .002 & 0 & 0 & 0 & 0 & .001 & .001 & .001 & .001 & .001 & .001 & .001 \\
\hline 17 & .002 & 0 & 0 & 0 & 0 & .001 & .001 & .002 & .001 & .001 & .001 & .001 \\
\hline 18 & .001 & 0 & 0 & 0 & .001 & .001 & .001 & .002 & .001 & .001 & .001 & .001 \\
\hline 19 & .001 & 0 & 0 & 0 & .001 & .001 & .001 & .001 & .001 & .001 & .001 & .001 \\
\hline 20 & .001 & 0 & 0 & 0 & .001 & .001 & .001 & .001 & .001 & .001 & .001 & .001 \\
\hline 21 & .001 & 0 & 0 & 0 & .001 & .001 & .002 & .001 & .001 & .001 & .001 & .001 \\
\hline 22 & .001 & 0 & 0 & 0 & .001 & .001 & .001 & .001 & .001 & .001 & .001 & .001 \\
\hline 23 & .001 & 0 & 0 & 0 & .001 & .001 & .001 & .001 & .001 & .001 & .001 & .001 \\
\hline 24 & .001 & 0 & 0 & 0 & .001 & .001 & .001 & .001 & .001 & .001 & .001 & .001 \\
\hline 25 & .001 & 0 & 0 & 0 & .001 & .002 & .002 & .001 & .001 & .001 & .001 & .001 \\
\hline 26 & .001 & 0 & 0 & 0 & .001 & .002 & .002 & .001 & .001 & .001 & .001 & .001 \\
\hline 27 & 0 & 0 & 0 & 0 & .001 & .001 & .002 & .001 & .001 & .001 & .001 & .001 \\
\hline 28 & 0 & 0 & 0 & 0 & .001 & .001 & .002 & .001 & .001 & .001 & .001 & .001 \\
\hline 29 & 0 & 0 & 0 & 0 & ----- & .001 & .002 & .001 & .001 & .001 & .001 & .001 \\
\hline 30 & 0 & 0 & 0 & 0 & ----- & .001 & .002 & .001 & .001 & .001 & .001 & .001 \\
\hline 31 & 0 & ------ & 0 & 0 & ----- & .001 & ------ & .001 & ----- & .001 & .001 & ----- \\
\hline T otal & 0.097 & 0 & 0 & 0 & 0.011 & 0.033 & 0.038 & 0.038 & 0.030 & 0.031 & 0.031 & 0.030 \\
\hline Mean & .003 & 0 & 0 & 0 & 0 & .001 & .001 & .001 & .001 & .001 & .001 & .001 \\
\hline $\operatorname{Max}$ & .015 & 0 & 0 & 0 & .001 & .002 & .002 & .002 & .001 & .001 & .001 & .001 \\
\hline Min & 0 & 0 & 0 & 0 & 0 & .001 & .001 & .001 & .001 & .001 & .001 & .001 \\
\hline $\begin{array}{r}\text { Acre- } \\
\text { Ft }\end{array}$ & .192 & 0 & 0 & 0 & .022 & .065 & .075 & .075 & .059 & .061 & .061 & .059 \\
\hline Wtr Year & 2009 & Total & 0.339 & & & .001 & Max & .015 & Min & 0 & Acre-Ft & .672 \\
\hline Cal Year & 2008 & Total & 0.405 & & & .001 & Max & .015 & Min & 0 & Acre-Ft & .803 \\
\hline
\end{tabular}




\section{Gage Stations Omitted from this Publication}

For existing stations that were omitted from this publication, information was extracted from existing raw or partially reduced data files using the following procedure.

All field-collected electronic data are transferred into a commercial program referred to as "HYDSTRA". These data were accessed via the "Hydstra Data Manager's Workbench." "Raw Level" and, where available, discharge files were evaluated for relative change to the recorded stage. If visually obvious, then it was considered to be a day where some stream flow was recorded. The highest relative change was assumed to be the peak for the water year. Documented missing data or gaps in station's electronic record were tallied to estimate the days without available data. A number of these stations have been recently upgraded with equipment that should reduce the gaps in station data and provide a better record for future publication.

\begin{tabular}{|l|c|c|c|c|}
\hline Station & $\begin{array}{l}\text { Estimated } \\
\text { days with } \\
\text { flow }\end{array}$ & $\begin{array}{l}\text { Estimated } \\
\text { date of } \\
\text { peak flow }\end{array}$ & $\begin{array}{l}\text { Gap in } \\
\text { record } \\
\text { (days) }\end{array}$ & Comments \\
\hline E049 (LA Weir) & 2 & $10 / 11 / 2008$ & 28 & $\begin{array}{l}\text { Raw Stage (i.e., water level } \\
\text { behind low-head weir) }\end{array}$ \\
\hline $\begin{array}{l}\text { E070 (Bayo Canyon at } \\
\text { Pueblo Canyon) }\end{array}$ & 0 & 0 & 0 & Rating curve in development \\
\hline $\begin{array}{l}\text { E089 (Guaje Canyon } \\
\text { above Mouth of } \\
\text { Rendija Canyon) }\end{array}$ & 9 & $9 / 10 / 2009$ & 0 & $\begin{array}{l}\text { Will publish in WY 200? To } \\
\text { include previous water years }\end{array}$ \\
\hline $\begin{array}{l}\text { E124 (Sandia Canyon } \\
\text { Truck Route) }\end{array}$ & 12 & $7 / 30 / 2009$ & 0 & $\begin{array}{l}\text { Record flow above 0.62 gage } \\
\text { height. No rating curve }\end{array}$ \\
\hline $\begin{array}{l}\text { E266 (Potrillo Canyon } \\
\text { above Discharge Sink) }\end{array}$ & 0 & 0 & 0 & \begin{tabular}{l} 
Rating curve in development \\
\hline E2733(TA-39-57)
\end{tabular} \\
\hline E2737 (TA-39-6) & 4 & $7 / 30 / 2009$ & 0 & Rating curve in development \\
\hline $\begin{array}{l}\text { E338 (Chaquehui } \\
\text { Canyon South Site) }\end{array}$ & 0 & 0 & 0 & Rating curve in development \\
\hline $\begin{array}{l}\text { E340 (Chaquehui } \\
\text { Canyon Main Site) }\end{array}$ & 0 & 0 & 26 & Rating curve in development \\
\hline
\end{tabular}




\section{Monthly Precipitation (inches) \\ Los Alamos National Laboratory Meteorological Stations \\ Water Year 2009 (October 2008-September 2009)}

Data Source: LANL Weather Machine; for further documentation and information, http://weather.lanl.gov

$\begin{array}{lrrrrrr}\text { Month } & \text { TA-6 } & \text { TA-49 } & \text { TA-53 } & \text { TA-54 } & \text { NCOM }^{\mathbf{1}} & \text { PJMT }^{\mathbf{2}} \\ \text { October } & 1.43 & 1.64 & 1.34 & 1.99 & 1.10 & 0.16 \\ \text { November } & 0.60 & 0.46 & 0.44 & 0.39 & 0.63 & 0.34 \\ \text { December } & 1.63 & 1.50 & 1.49 & 1.30 & 1.07 & 0.83 \\ \text { January } & 0.26 & 0.33 & 0.20 & 0.15 & 0.39 & 0.02 \\ \text { February } & 0.02 & 0.01 & 0.03 & 0.02 & 0.06 & 0.01 \\ \text { March } & 1.18 & 1.14 & 1.10 & 0.91 & 1.21 & 0.51 \\ \text { April } & 1.31 & 1.35 & 1.27 & 0.83 & 1.66 & 0.79 \\ \text { May } & 2.14 & 1.75 & 1.94 & 1.05 & 1.67 & 0.30 \\ \text { June } & 2.67 & 1.78 & 1.86 & 1.74 & 3.02 & 1.56 \\ \text { July } & 4.01 & 3.12 & 2.40 & 2.01 & 4.13 & 1.96 \\ \text { August } & 1.66 & 1.67 & 1.26 & 0.95 & 1.80 & 1.39 \\ \text { September } & 1.95 & 3.17 & 1.42 & 1.93 & 2.00 & 1.98 \\ \text { Total } & \mathbf{1 8 . 8 6} & \mathbf{1 7 . 9 2} & \mathbf{1 4 . 7 5} & \mathbf{1 3 . 2 7} & \mathbf{1 8 . 7 4} & \mathbf{9 . 9 5}\end{array}$

${ }^{1}$ North Community

${ }^{2}$ Pajarito Mountain 
This report has been reproduced directly from the best available copy. It is available electronically on the Web (http://www.doe.gov/bridge).

Copies are available for sale to U.S. Department of Energy employees and contractors from:

Office of Scientific and Technical Information

P.O. Box 62

Oak Ridge, TN 37831

(865) 576-8401

Copies are available for sale to the public from: National Technical Information Service

U.S. Department of Commerce

5285 Port Royal Road

Springfield, VA 22161

(800) 553-6847 
- Los Alamos NATIONAL LABORATORY 